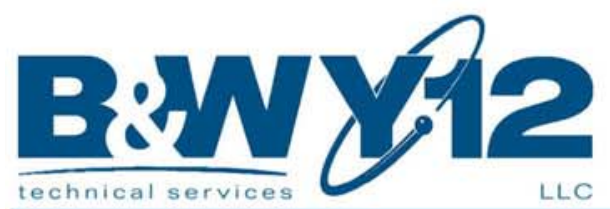

\author{
CALENDAR YEAR 2009 \\ GROUNDWATER MONITORING REPORT, \\ U.S. DEPARTMENT OF ENERGY \\ Y-12 NATIONAL SECURITY COMPLEX, \\ OAK RIDGE, TENNESSEE
}

Y-12

NATIONAL SECURITY COMPLEX
December 2010

Prepared by

Elvado Environmental LLC

Under Subcontract No. 4300073231

for the

Environmental Compliance Department Environment, Safety, and Health Division Y-12 National Security Complex

Oak Ridge, Tennessee 37831

\section{Managed by}

Babcock \& Wilcox Technical Services Y-12, LLC for the U.S. Department of Energy Under Contract No. DE-AC05-00OR22800 


\section{DISCLAIMER}

This report was prepared as an account of work sponsored by an agency of the United States Government. Neither the United States Government nor any agency thereof, nor any of their employees, makes any warranty, express or implied, or assumes any legal liability or responsibility for the accuracy, completeness, or usefulness of any information, apparatus, product, or process disclosed, or represents that its use would not infringe privately owned rights. Reference herein to any specific commercial product, process, or service by trade name, trademark, manufacturer, or otherwise, does not necessarily constitute or imply its endorsement, recommendation, or favoring by the United States Government or any agency thereof. The views and opinions of authors expressed herein do not necessarily state or reflect those of the United States Government or any agency thereof. 


\title{
CALENDAR YEAR 2009 \\ GROUNDWATER MONITORING REPORT, U.S. DEPARTMENT OF ENERGY Y-12 NATIONAL SECURITY COMPLEX, OAK RIDGE, TENNESSEE
}

December 2010

\author{
Prepared by \\ Elvado Environmental LLC \\ Under Subcontract No. 4300073231
}

\begin{abstract}
for the
Environmental Compliance Department Environment, Safety, and Health Division Y-12 National Security Complex Oak Ridge, Tennessee 37831
\end{abstract}

Managed by

Babcock \& Wilcox Technical Services Y-12, LLC for the U.S. Department of Energy Under Contract No. DE-AC05-00OR22800 



\section{CONTENTS}

$\underline{\text { Section }}$

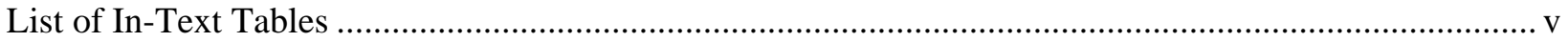

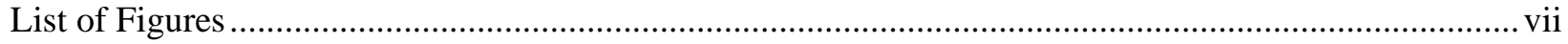

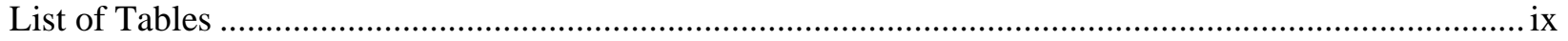

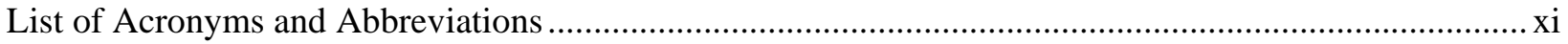

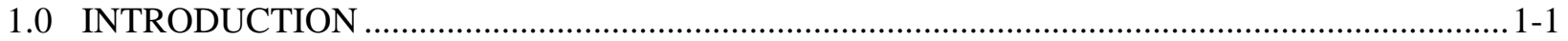

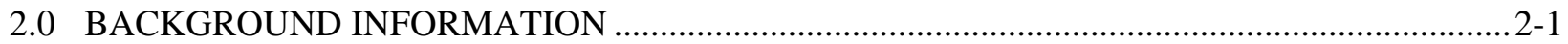

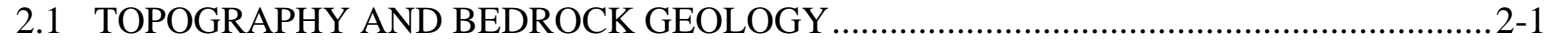

2.2 SURFACE WATER DRAINAGE

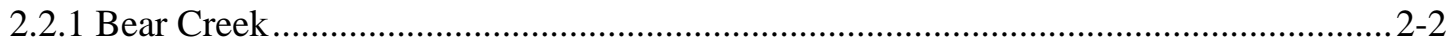

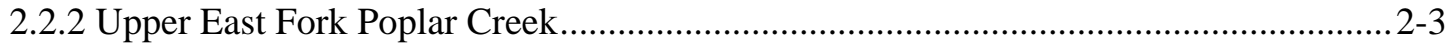

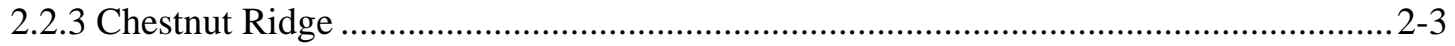

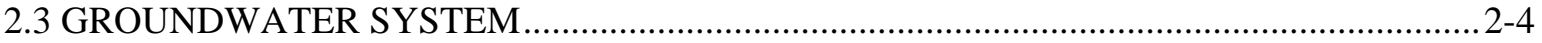

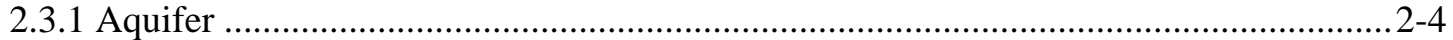

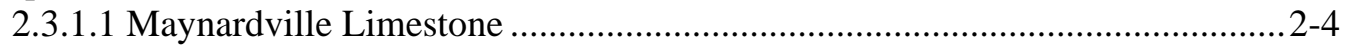

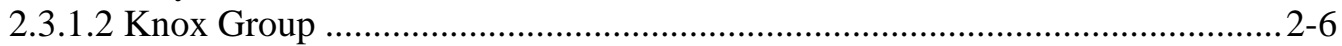

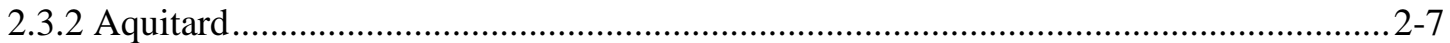

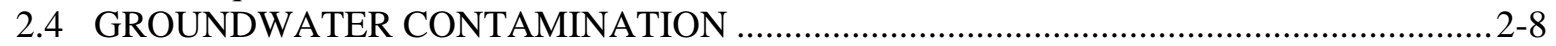

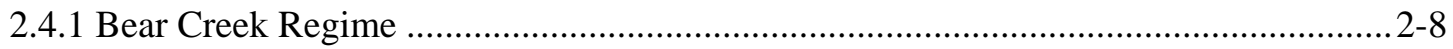

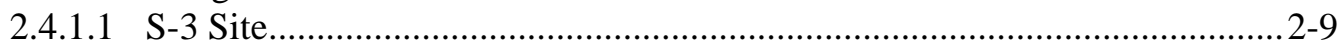

2.4.1.2 Oil Landfarm WMA .......................................................................... 2-9

2.4.1.3 Bear Creek Burial Grounds WMA …...................................................... 2-11

2.4.1.4 Maynardville Limestone Exit Pathway................................................. 2-12

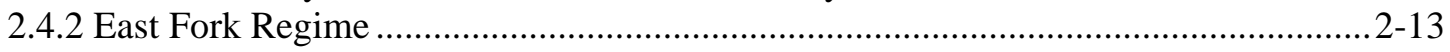

2.4.3 Chestnut Ridge Regime ................................................................................ 2 -14

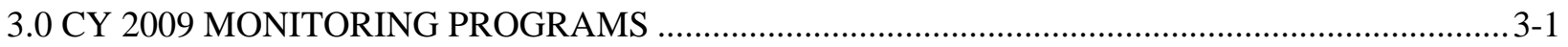

3.1 SAMPLING LOCATIONS AND FREQUENCY …..............................................

3.1.1 Bear Creek Regime .................................................................................. $3-2$

3.1.2 East Fork Regime ........................................................................................... $3-3$

3.1.3 Chestnut Ridge Regime..................................................................................... 3-4

3.2 QUALITY ASSURANCE/QUALITY CONTROL SAMPLING ….................................... $3-5$

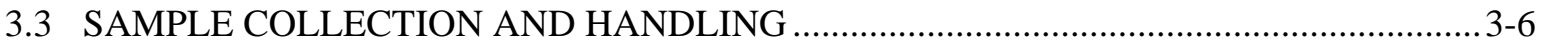

3.4 FIELD MEASUREMENTS AND LABORATORY ANALYTES .....................................

3.5 DATA MANAGEMENT AND DQO EVALUATION .....................................................

3.6 GROUNDWATER ELEVATION MONITORING ….................................................... 


\section{CONTENTS (continued)}

$\underline{\text { Section }}$

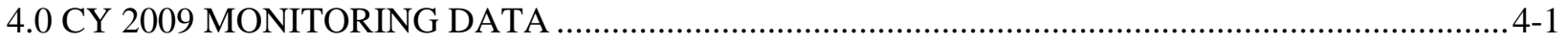

4.1 SURVEILLANCE MONITORING .............................................................................. 4

4.1.1 Bear Creek Regime ............................................................................................. 4-1

4.1.1.1 Aquitard Wells ............................................................................... 4-2

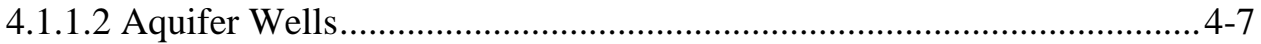

4.1.2 East Fork Regime......................................................................................... 4-11

4.1.2.1 Aquitard Wells .................................................................................. 4-11

4.1.2.2 Aquifer Wells............................................................................... 4-17

4.1.3 Chestnut Ridge Regime ….............................................................................. 4 -21

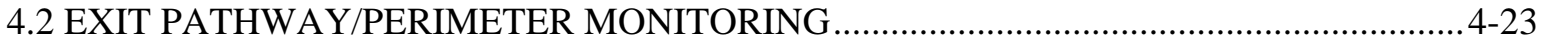

4.2.1 Bear Creek Regime ............................................................................................ 4-23

4.2.1.1 Upper Bear Creek .......................................................................... 4-24

4.2.1.2 Middle Bear Creek .................................................................. 4-25

4.2.1.3 Lower Bear Creek ........................................................................... 4-26

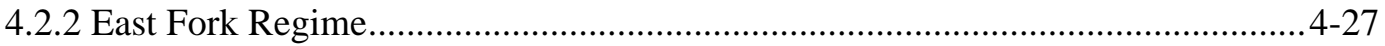

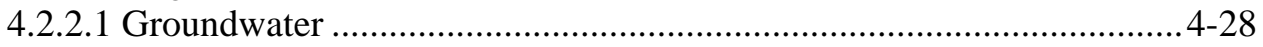

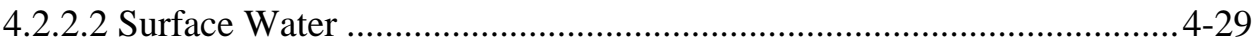

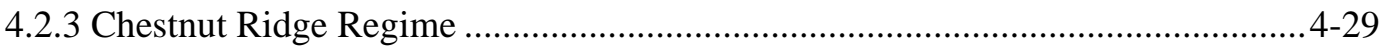

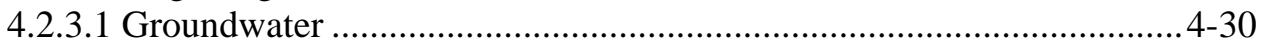

4.2.3.2 Surface Water .................................................................................... 4-30

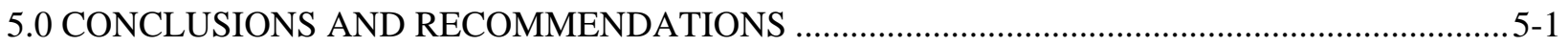

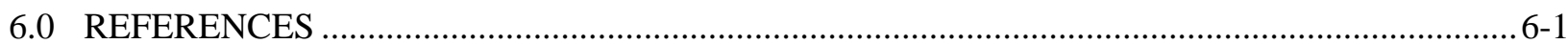

APPENDICES:

A FIGURES

B TABLES

C MONITORING WELL CONSTRUCTION DETAILS

D CY 2009 MONITORING DATA FOR THE BEAR CREEK HYDROGEOLOGIC REGIME

D.1 Field Measurements, Miscellaneous Analytes, Major Ions, and Trace Metals

D.2 Volatile Organic Compounds

D.3 Radiological Analytes

D.4 Monitoring Data for the EMWMF

E CY 2009 MONITORING DATA FOR THE UPPER EAST FORK POPLAR CREEK HYDROGEOLOGIC REGIME

E.1 Field Measurements, Miscellaneous Analytes, Major Ions, and Trace Metals

E.2 Volatile Organic Compounds

E.3 Radiological Analytes

F CY 2009 MONITORING DATA FOR THE CHESTNUT RIDGE HYDROGEOLOGIC REGIME

F.1 Field Measurements, Miscellaneous Analytes, Major Ions, and Trace Metals

F.2 Volatile Organic Compounds

F.3 Radiological Analytes

G CY 2009 QUALITY ASSURANCE/QUALITY CONTROL DATA 


\section{List of In-Text Tables}

Table

1. CY 2009 sampling locations in the Bear Creek Regime

2. CY 2009 sampling locations in the East Fork Regime, north of Pine Ridge, and in Union Valley .......3-3

3. CY 2009 sampling locations in the Chestnut Ridge Regime .......................................................... 3-4

4. QA/QC samples analyzed in CY 2009 for the Y-12 GWPP........................................................... $3-5$

5. Summary of CY 2009 groundwater elevation monitoring in the Bear Creek, East Fork, and Chestnut Ridge regimes

6. Bear Creek Regime CY 2009: elevated nitrate and uranium concentrations in surveillance monitoring aquitard wells

7. Bear Creek Regime CY 2009: maximum VOC concentrations in surveillance monitoring aquitard wells

8. Bear Creek Regime CY 2009: elevated gross alpha activity and gross beta activity in surveillance monitoring aquitard wells

9. Bear Creek Regime CY 2009: elevated nitrate and uranium concentrations in surveillance monitoring aquifer wells

10. Bear Creek Regime CY 2009: maximum VOC concentrations in surveillance monitoring aquifer wells

11. Bear Creek Regime CY 2009: elevated gross alpha activity and gross beta activity in surveillance monitoring aquifer wells

12. East Fork Regime CY 2009: elevated nitrate and uranium concentrations in surveillance monitoring aquitard wells

13. East Fork Regime CY 2009: maximum VOC concentrations in surveillance monitoring aquitard wells

14. East Fork Regime CY 2009: elevated gross alpha activity and gross beta activity in surveillance monitoring aquitard wells

15. East Fork Regime CY 2009: elevated nitrate and uranium concentrations in surveillance monitoring aquifer wells

16. East Fork Regime CY 2009: maximum VOC concentrations in surveillance monitoring aquifer wells 


\section{List of In-Text Tables (continued)}

Table

17. East Fork Regime CY 2009: elevated gross alpha activity and gross beta activity in surveillance monitoring aquifer wells

18. Chestnut Ridge Regime CY 2009: maximum VOC concentrations in surveillance monitoring wells.

19. Bear Creek Regime CY 2009: sampling locations used for exit pathway/perimeter monitoring

20. Upper Bear Creek CY 2009: maximum contaminant concentrations 4-25

21. Middle Bear Creek CY 2009: maximum contaminant concentrations $4-26$

22. Lower Bear Creek CY 2009: maximum contaminant concentrations $4-27$

23. East Fork Regime CY 2009: sampling locations for exit pathway/perimeter monitoring. $4-27$

24. East Fork Regime CY 2009: maximum VOC concentrations in exit pathway/perimeter monitoring wells

25. East Fork Regime CY 2009: maximum contaminant concentrations in exit pathway/perimeter surface water sampling locations.

26. Chestnut Ridge Regime CY 2009: sampling locations used for exit pathway/perimeter monitoring. 


\section{List of Figures}

Figure

A.1 Hydrogeologic regimes at the Y-12 National Security Complex A-1

A.2 Topography and bedrock geology at the Y-12 National Security Complex......

A.3 Fill areas and pre-construction drainage features in the Upper East Fork Poplar Creek

Hydrogeologic Regime A-3

A.4 Groundwater elevations in the Bear Creek Hydrogeologic Regime, April 2009. A-4

A.5 Groundwater elevations in the Upper East Fork Poplar Creek

Hydrogeologic Regime, April 2009.

A.6 Groundwater elevations in the Chestnut Ridge Hydrogeologic Regime, April 2009 .................. A-6

A.7 Generalized extent of nitrate in groundwater at the Y-12 National Security Complex ............... A-7

A.8 Generalized extent of volatile organic compounds in groundwater at the Y-12 National Security Complex

A.9 Generalized extent of gross alpha activity in groundwater at the Y-12 National Security Complex.

A.10 Generalized extent of gross beta activity in groundwater at the Y-12 National Security Complex.....

A.11 CY 2009 sampling locations in the Bear Creek Hydrogeologic Regime.

A.12 Westbay ${ }^{\mathrm{TM}}$ monitoring system sampling port depths in well GW-726

A.13 Components of Maynardville Limestone exit pathway pickets A, B, C, and W .

A.14 CY 2009 sampling locations in the Upper East Fork Poplar Creek Hydrogeologic Regime and in Union Valley....

A.15 CY 2009 surface water sampling locations north of Pine Ridge

A.16 Westbay ${ }^{\mathrm{TM}}$ monitoring system sampling port depths in well GW-722 .................................. A-16

A.17 CY 2009 sampling locations in the Chestnut Ridge Hydrogeologic Regime A-17 


\section{List of Figures (continued)}

Figure

Page

A.18 Bear Creek Regime CY 2009: nitrate and/or uranium concentration trends in surveillance monitoring aquitard wells GW-246, GW-276, GW-526, GW-537, and GW-615

A.19 Bear Creek Regime CY 2009: PCE concentration trends in surveillance monitoring aquitard wells GW-014, GW-046, GW-246, GW-276, GW-289, and GW-627.

A.20 Bear Creek Regime CY 2009: gross alpha and/or gross beta activity trends in surveillance monitoring aquitard wells GW-085, GW-276, and GW-537

A.21 Bear Creek Regime CY 2009: nitrate and/or uranium concentration trends in surveillance monitoring aquifer wells GW-058, GW-229, and GW-706

A.22 Bear Creek Regime CY 2009: selected VOC concentration trends in surveillance monitoring aquifer wells GW-225, GW-229, GW-704, GW-706, and GW-738.

A.23 Bear Creek Regime CY 2009: gross alpha and/or gross beta activity trends in surveillance monitoring aquifer wells GW-058, GW-229, and GW-706.

A.24 East Fork Regime CY 2009: nitrate concentration trends in surveillance monitoring aquitard wells 55-2A, 55-2B, GW-108, GW-272, GW-274, and GW-275

A.25 East Fork Regime CY 2009: summed VOC concentration trends in surveillance monitoring aquitard wells 55-3A, GW-337, GW-383, GW-656, GW-658, and GW-769 .

A.26 East Fork Regime CY 2009: gross alpha and/or gross beta activity trends in surveillance monitoring aquitard wells GW-108 and GW-204.

A.27 East Fork Regime CY 2009: nitrate and/or uranium concentration trends in surveillance monitoring aquifer wells GW-154, GW-223, GW-251, GW-253, and GW-606.

A.28 East Fork Regime CY 2009: selected VOC concentration trends in surveillance monitoring aquifer wells GW-251, GW-382, GW-605, GW-618, and GW-698.

A.29 East Fork Regime CY 2009: gross alpha and/or gross beta activity trends in surveillance monitoring aquifer wells GW-154, GW-219, and GW-605

A.30 Chestnut Ridge Regime CY 2009: VOC trends in surveillance monitoring wells GW-305, GW-322, and GW-798

A.31 East Fork Regime CY 2009: PCE concentration trends in exit pathway monitoring wells GW-151, GW-220, GW-722-14, and GW-832

A.32 East Fork Regime CY 2009: CTET concentration trend in exit pathway monitoring well GW-722-17 


\section{List of Tables}

Table

B.1 Summary of CY 2009 sampling and analysis plan addenda

B.2 CY 2009 groundwater and surface water sampling dates in the Bear Creek Hydrogeologic Regime

B.3 CY 2009 groundwater and surface water sampling dates in the Upper East Fork Poplar Creek Hydrogeologic Regime

B.4 CY 2009 groundwater and surface water sampling dates in the Chestnut Ridge Hydrogeologic Regime.

B.5 Field measurements and laboratory analytes for CY 2009 groundwater and surface water samples obtained by the Y-12 GWPP.....

B.6 Depth-to-water measurements and groundwater elevations for selected wells in the Bear Creek Hydrogeologic Regime, April 2009.

B.7 Depth-to-water measurements and groundwater elevations for selected wells in the Upper East Fork Poplar Creek Hydrogeologic Regime, April 2009.

B.8 Depth-to-water measurements and groundwater elevations for selected wells in the Chestnut Ridge Hydrogeologic Regime, April 2009

B.9 Concentration trends for the principal contaminants detected at CY 2009 sampling locations in the Bear Creek Hydrogeologic Regime

B.10 Concentration trends for the principal contaminants detected at CY 2009 sampling locations in the Upper East Fork Poplar Creek Hydrogeologic Regime

B.11 Concentration trends for contaminants detected at CY 2009 sampling locations in the Chestnut Ridge Hydrogeologic Regime. 


\section{List of Acronyms and Abbreviations}

\begin{tabular}{|c|c|}
\hline $\mathrm{ACO}$ & Analytical Chemistry Organization \\
\hline BCK & Bear Creek kilometer \\
\hline BCBG & Bear Creek Burial Grounds \\
\hline $\mathrm{BCV}$ & Bear Creek Valley \\
\hline Bear Creek Regime & Bear Creek Hydrogeologic Regime \\
\hline BG & Burial Ground \\
\hline bgs & below ground surface \\
\hline BJC & Bechtel Jacobs Company LLC \\
\hline B\&W Y-12 & Babcock \& Wilcox Technical Services Y-12, LLC \\
\hline BWXT & BWXT Y-12, L.L.C. \\
\hline BYBY & Boneyard/Burnyard \\
\hline CASI & Commodore Advanced Sciences, Inc. \\
\hline CDL & Construction/Demolition Landfill \\
\hline CERCLA & Comprehensive Environmental Response, Compensation, and Liability Act \\
\hline Chestnut Ridge Regime & Chestnut Ridge Hydrogeologic Regime \\
\hline CRSDB & Chestnut Ridge Sediment Disposal Basin \\
\hline CRSP & Chestnut Ridge Security Pits \\
\hline CTET & carbon tetrachloride \\
\hline CY & calendar year \\
\hline DNAPL & dense nonaqueous phase liquids \\
\hline DOE & U.S. Department of Energy \\
\hline DQO & data quality objective \\
\hline East Fork Regime & Upper East Fork Poplar Creek Hydrogeologic Regime \\
\hline ECRWP & East Chestnut Ridge Waste Pile \\
\hline EMWMF & Environmental Management Waste Management Facility \\
\hline ETB & ethylbenzene \\
\hline FCAP & Filled Coal Ash Pond \\
\hline $\mathrm{ft}$ & feet \\
\hline $\mathrm{ft} / \mathrm{d}$ & feet per day \\
\hline GIMS & Groundwater Information Management System \\
\hline gpm & gallons per minute \\
\hline GWPP & Groundwater Protection Program \\
\hline GWQAP & Groundwater Quality Assessment Plan \\
\hline HCDA & Hazardous Chemical Disposal Area \\
\hline ILF & Industrial Landfill \\
\hline KHQ & Kerr Hollow Quarry \\
\hline $\mathrm{MC}$ & methylene chloride \\
\hline MCL & maximum contaminant level \\
\hline MDA & minimum detectable activity \\
\hline $\mathrm{mg} / \mathrm{d}$ & million gallons per day \\
\hline $\mathrm{mg} / \mathrm{L}$ & micrograms per liter \\
\hline $\mathrm{mg} / \mathrm{L}$ & milligrams per liter \\
\hline MMES & Martin Marietta Energy Systems, Inc. \\
\hline
\end{tabular}




\section{List of Acronyms and Abbreviations (continued)}

\begin{tabular}{|c|c|}
\hline msl & mean sea level \\
\hline NHP & New Hope Pond \\
\hline NOV & Notice of Violation \\
\hline NPDES & National Pollution Discharge Elimination System \\
\hline NT & northern tributary (of Bear Creek) \\
\hline OF & outfall \\
\hline OLF & Oil Landfarm \\
\hline ORNL & Oak Ridge National Laboratory \\
\hline ORR & Oak Ridge Reservation \\
\hline PCE & tetrachloroethene \\
\hline $\mathrm{pCi} / \mathrm{L}$ & picoCuries per liter \\
\hline PDB & passive diffusion bag \\
\hline POC & point-of-compliance \\
\hline QA/QC & quality assurance/quality control \\
\hline RCRA & Resource Conservation and Recovery Act \\
\hline REDOX & oxidation-reduction potential \\
\hline ROD & record of decision (CERCLA) \\
\hline SAP & sampling and analysis plan \\
\hline SCR & south Chestnut Ridge \\
\hline SDWA & Safe Drinking Water Act \\
\hline SS & south side (of Bear Creek) \\
\hline SWDF & Solid Waste Disposal Facility \\
\hline Tc-99 & technetium-99 \\
\hline TCE & trichloroethene \\
\hline TCFM & trichlorofluoromethane \\
\hline TDEC & Tennessee Department of Environment and Conservation \\
\hline TDS & total dissolved solids \\
\hline TPU & total propagated uncertainty \\
\hline $\mathrm{U}-234$ & uranium-234 \\
\hline U-238 & uranium-238 \\
\hline UEFPC & Upper East Fork Poplar Creek \\
\hline UST & underground storage tank \\
\hline VC & vinyl chloride \\
\hline VOC & volatile organic compound \\
\hline WCPA & Waste Coolant Processing Area \\
\hline WMA & waste management area \\
\hline WRRP & Water Resources Restoration Program \\
\hline$Y-12$ & Y-12 National Security Complex \\
\hline $\mathrm{yd}^{3}$ & cubic yards \\
\hline 111TCA & 1,1,1-trichloroethane \\
\hline 11DCA & 1,1-dichloroethane \\
\hline 11DCE & 1,1-dichloroethene \\
\hline 12DCA & 1,2-dichloroethane \\
\hline 12DCE & 1,2-dichloroethene \\
\hline c12DCE & cis-1,2-dichloroethene \\
\hline t12DCE & trans-1,2-dichloroethene \\
\hline
\end{tabular}




\subsection{INTRODUCTION}

This report contains the groundwater and surface water monitoring data that were obtained during calendar year (CY) 2009 at the U.S. Department of Energy (DOE) Y-12 National Security Complex (hereafter referenced as Y-12) on the DOE Oak Ridge Reservation (ORR) in Oak Ridge, Tennessee. The CY 2009 monitoring data were obtained from wells, springs, and surface water sampling locations in three hydrogeologic regimes at Y-12 (Figure A.1). The Bear Creek Hydrogeologic Regime (Bear Creek Regime) encompasses a section of Bear Creek Valley (BCV) between the west end of Y-12 and the west end of the Bear Creek Watershed (directions are in reference to the Y-12 grid system). The Upper East Fork Poplar Creek Hydrogeologic Regime (East Fork Regime) encompasses the Y-12 industrial facilities and support structures in BCV. The Chestnut Ridge Hydrogeologic Regime (Chestnut Ridge Regime) encompasses a section of Chestnut Ridge directly south of Y-12. Section 2 of this report provides background information pertinent to groundwater and surface water quality monitoring in each hydrogeologic regime, including the topography and bedrock geology, surface water drainage, groundwater system, and extent of groundwater contamination.

The CY 2009 groundwater and surface water monitoring data in this report were obtained from sampling and analysis activities implemented under the Y-12 Groundwater Protection Program (GWPP) managed by Babcock \& Wilcox Technical Services Y-12, LLC (B\&W Y-12) and from sampling and analysis activities implemented under several monitoring programs managed by Bechtel Jacobs Company LLC (BJC). Cooperative implementation of the monitoring programs directed by the Y-12 GWPP and BJC (i.e., coordinating sample collection and sharing data) ensures that the CY 2009 monitoring results fulfill requirements of all the applicable monitoring drivers with no duplication of sampling and analysis efforts. Section 3 of this report contains a summary of information regarding the groundwater and surface water sampling and analysis activities implemented under the Y-12 GWPP including sampling locations and frequency; quality assurance (QA)/quality control (QC) sampling; sample collection and handling; field measurements and laboratory analytes; data management and data quality objective (DQO) evaluation; and groundwater elevation monitoring. However, this report does not include equivalent QA/QC or DQO evaluation information regarding the groundwater and surface water sampling and analysis activities associated with the monitoring programs implemented by BJC. Such details are deferred to the respective programmatic plans and reports issued by BJC (see Section 3.0).

Collectively, the groundwater and surface water monitoring data obtained during CY 2009 by the Y-12 GWPP and BJC address DOE Order 450.1A (Environmental Protection Program) requirements for monitoring groundwater and surface water quality in areas: (1) which are, or could be, affected by operations at Y-12 (surveillance monitoring); and (2) where contaminants from Y-12 are most likely to migrate beyond the boundaries of the ORR (exit pathway/perimeter monitoring). Section 4 of this report presents a summary evaluation of the monitoring data with regard to the respective objectives of surveillance monitoring and exit pathway/perimeter monitoring, based on the analytical results for the principal groundwater contaminants at Y-12: nitrate, uranium, volatile organic compounds (VOCs), gross alpha activity, and gross beta activity. Section 5 of this report summarizes the most pertinent findings regarding the principal contaminants, along with recommendations proposed for ongoing groundwater and surface water quality monitoring performed under the Y-12 GWPP. 
Narrative sections of this report reference several appendices. Figures (maps and diagrams) and tables (excluding data summary tables presented in the narrative sections) are in Appendix A and Appendix B, respectively. Appendix $C$ contains construction details for the wells in each regime that were sampled during CY 2009 by either the Y-12 GWPP or BJC. Field measurements recorded during collection of the groundwater and surface water samples and results of laboratory analyses of the samples are in Appendix D (Bear Creek Regime), Appendix E (East Fork Regime and surrounding areas), and Appendix F (Chestnut Ridge Regime). Appendix G contains data for the QA/QC samples associated with monitoring performed in each regime by the Y-12 GWPP. 


\subsection{BACKGROUND INFORMATION}

The following sections provide information relevant to groundwater and surface water quality monitoring in three hydrogeologic regimes at Y-12 (Figure A.1). These sections include a short description of the topography and geology in each regime; an overview of the hydrogeologic system in each regime; and a discussion of the extent of groundwater contamination in each regime.

\subsection{TOPOGRAPHY AND BEDROCK GEOLOGY}

The hydrogeologic regimes at Y-12 are located in the Valley and Ridge Physiographic Province, which is characterized by long parallel valleys and ridges formed from folding and thrust faulting that occurred during Paleozoic orogenic events. The geologic strike of the formations generally parallel the axes of the valleys and ridges.

The Bear Creek Regime and the East Fork Regime are each in BCV, which is bound to the north by Pine Ridge and to the south by Chestnut Ridge (Figure A.2). The Bear Creek Regime encompasses several miles of BCV between the western end of the Bear Creek watershed and a low topographic and hydrologic divide near the west end of Y-12. The East Fork Regime encompasses about three miles of BCV east of this topographic/hydrologic divide and west of the ORR property boundary along Scarboro Road. Ground surface elevations along the axis of BCV in each regime range from about 1,000 feet (ft) above mean sea level (msl) near the topographic/hydrologic divide to about $800 \mathrm{ft}$ above msl where Bear Creek cuts through Pine Ridge and about $900 \mathrm{ft}$ above msl where Upper East Fork Poplar Creek (UEFPC) cuts through Pine Ridge.

The Chestnut Ridge Regime is directly south of Y-12 and encompasses a portion of the ridge bordered by BCV to the north, Scarboro Road to the east, Bethel Valley Road to the south, and Dunaway Branch to the west (Figure A.2). The northern flank of the ridge forms a steep slope rising more than $200 \mathrm{ft}$ above the floor of BCV. The crest of the ridge slopes toward the east from an elevation of about 1,200 ft above msl southwest of Y-12 to about 1,060 ft above msl where Scarboro Road crosses the ridge. A series of prominent hills dominate the central part of the broad southern flank of Chestnut Ridge, which gently slopes toward Bethel Valley.

Bedrock geology in the vicinity of Y-12 is characterized by thrust-faulted sequences of southeast-dipping, clastic (primarily shale and siltstone) and carbonate (limestone and dolostone) strata of Lower Cambrian to Upper Ordovician age (Figure A.2). Geologic units in the Bear Creek Regime and the East Fork Regime are the shales and siltstones of the Rome Formation underlying Pine Ridge and the interbedded limestone and shale formations of the Conasauga Group that underlie the southern flank of Pine Ridge and BCV. Carbonates (primarily dolostone) of the Knox Group and the overlying argillaceous limestones and interbedded shales of the Chickamauga Group are the geologic units in the Chestnut Ridge Regime. Strike and dip of bedding in each hydrogeologic regime is generally $\mathrm{N} 55^{\circ} \mathrm{E}$ and $45^{\circ} \mathrm{SE}$, respectively (as referenced to true north).

In BCV, unweathered bedrock is overlain by up to $40 \mathrm{ft}$ of several unconsolidated materials, including alluvium, colluvium, fine-grained residuum, and saprolite (weathered bedrock). Where undisturbed, the saprolite often retains primary textural features of the unweathered bedrock, including fractures (Solomon et al. 1992). However, extensive areas of cut-and-fill within Y-12 have substantially altered the shallow subsurface in BCV throughout much of the East Fork Regime. Most of the fill, which contains many voids and generally consists of 5 to $25 \mathrm{ft}$ of a heterogeneous mixture of building debris and 
re-compacted soil/residuum (Sutton and Field 1995), was placed in the tributaries and main channel of UEFPC (Figure A.3).

On Chestnut Ridge, bedrock is overlain by as much as $100 \mathrm{ft}$ of red-brown to yellow-orange residuum. The residuum, which is predominantly composed of clay and hematite, contains semicontinuous relict beds of fractured chert and other lithologic heterogeneities (such as silt bodies) that provide a weakly connected network through which saturated flow can occur (Solomon et al. 1992). Also, residuum on Chestnut Ridge is thin or nonexistent near karst features such as dolines (sink holes), swallets (sinking streams), and solution pan features (Ketelle and Huff 1984).

\subsection{SURFACE WATER DRAINAGE}

The following subsections provide a brief description of surface water drainage systems in the Bear Creek Regime, East Fork Regime, and Chestnut Ridge Regime.

\subsubsection{Bear Creek}

Surface water in the Bear Creek Regime is drained by Bear Creek and its tributaries (Figure A.2). From its headwaters near the west end of Y-12, Bear Creek flows southwest for approximately 4.5 miles, where it turns northward to flow into East Fork Poplar Creek. Monitoring locations along the main channel of Bear Creek are specified by the Bear Creek kilometer (BCK) value corresponding to the distance upstream from the confluence with East Fork Poplar Creek (e.g., BCK-09.40). Sections of the main channel are referenced as upper Bear Creek (upstream of BCK-11.84), middle Bear Creek (between BCK-11.84 and BCK-09.20), and lower Bear Creek (downstream of BCK-09.20). Tributaries are designated as north tributary (NT) or south tributary along with a value representing the tributary number counted downstream from the headwaters (e.g., NT-1). Major springs along the south side (SS) of Bear Creek are numbered in ascending order downstream from the headwaters (e.g., SS-1).

Approximately half of the annual precipitation in BCV exits via surface water flow in Bear Creek, and possibly higher proportions during winter and early spring, with the remainder of the annual precipitation lost to evapotranspiration and recharge to the groundwater system (DOE 1997a). Flow in the creek increases rapidly during rainfall and afterward reflects the relative contributions of overland flow, stormflow, and groundwater discharge. Flow in the main channel and tributaries generally returns to pre-precipitation levels within one or two days. Major sections of upper and middle Bear Creek are seasonally dry, but flow is perennial in lower Bear Creek.

The main channel of Bear Creek functions as a major conduit of the shallow karst network within the Maynardville Limestone (DOE 1997a). Discharge from springs located along the Maynardville Limestone/Copper Ridge Dolomite boundary on the north slope of Chestnut Ridge dominate the hydrology of the creek, especially during droughts when springs provide most of the flow in the main channel. Additionally, the main channel contains alternating gaining and losing reaches. Each gaining reach generally correlates with a major groundwater discharge area. Losing reaches in upper and middle Bear Creek, particularly a section of the main channel directly south of Sanitary Landfill I, play an important role

in transferring contaminants from Bear Creek into the Maynardville Limestone, which directly underlies the creek throughout much of BCV. 


\subsubsection{Upper East Fork Poplar Creek}

Surface water in the East Fork Regime is drained by UEFPC, which was extensively modified during construction of Y-12 (Figure A.3). The East Fork Regime is divided into the three major areas for the purposes of this report: the western Y-12 area between Old Bear Creek Road and grid coordinate easting 55,000; the central Y-12 area between grid coordinate eastings 55,000 and 62,000; and the eastern Y-12 area between grid coordinate easting 62,000 and Scarboro Road. The headwaters and several thousand feet of the main channel in the upper reach of UEFPC, including all its northern tributaries in the western and central Y-12 areas, were filled and replaced with an extensive network of underground storm drains. For reference purposes, each buried tributary of UEFPC is designated with a value (e.g., BT-1) representing the tributary number counted downstream (west to east) from the headwaters. The storm drains direct surface runoff into the exposed portion of the UEFPC channel at several locations. Outfall (OF) 200 is at the beginning of the exposed portion of the UEFPC channel about 6,000 ft upstream of New Hope Pond (NHP)/Lake Reality (Figure A.3). Closed and capped in 1988, NHP was an unlined surface impoundment constructed in 1963 to regulate the quantity and quality of surface water exiting Y-12. Lake Reality is a lined surface impoundment that was built in 1988 to replace NHP.

During normal operations, flow in UEFPC is directed through a concrete-lined distribution channel located around the south and east side of NHP/Lake Reality (Figure A.3). Also, a gravel and perforated pipe underdrain beneath portions of the distribution channel captures shallow groundwater. Until December 1996 when flow was rerouted to bypass Lake Reality, surface flow in the UEFPC distribution channel discharged into Lake Reality (and exited through a weir in the western berm). Beginning in July 1998, flow in the UEFPC distribution channel was diverted through the Lake Reality spillway, which discharges into the mainstream of UEFPC directly north (downstream) of Lake Reality. Bypassing Lake Reality reduces mercury contributions to dry-weather flow in UEFPC.

About $70 \%$ of dry-weather flow in UEFPC is attributable to once-through non-contact cooling water, condensate, and cooling tower blowdown, and the remaining 30\% is from groundwater discharge (Shevenell 1994). Beginning in July 1996 a flow management program was implemented whereby water from the Clinch River is discharged near OF 200 to augment flow in UEFPC, which decreased from as much as 15 million gallons per day (mg/d) to about $2.5 \mathrm{mg} / \mathrm{d}$ because of reduced operations at $\mathrm{Y}-12$ in recent years. Flow management is needed to achieve the National Pollution Discharge Elimination System (NPDES) minimum daily flow requirement of $5 \mathrm{mg} / \mathrm{d}$ at Station 17, which is where UEFPC exits the ORR downstream from Lake Reality (Figure A.3). Flow management also allows compliance with NPDES toxicity requirements and helps lower the elevated water temperature in UEFPC.

\subsubsection{Chestnut Ridge}

The Chestnut Ridge Regime encompasses five primary tributary drainage basins on south Chestnut Ridge (SCR), informally numbered from west to east (SCR1 through SCR5): Dunaway Branch (SCR1) and SCR2 in the western part of the regime, McCoy Branch (SCR3) in the central part of the regime; and SCR4 and SCR5 in the eastern part of the regime (Figure A.2). These tributaries are mainly intermittent at elevations higher than $900 \mathrm{ft}$ above msl. Each receives flow via surface runoff, stormflow discharge, and groundwater baseflow, which increases with distance downstream and includes substantial contributions from springs. All of the tributaries convey surface flow south toward Bethel Valley and discharge into Melton Hill Lake (Clinch River) south of the Chestnut Ridge Regime. 


\subsection{GROUNDWATER SYSTEM}

The following overview of the groundwater system near Y-12 is based on the conceptual hydrogeologic models described in Report on the Remedial Investigation of Bear Creek Valley at the Oak Ridge Y-12 Plant, Oak Ridge, Tennessee (DOE 1997a) and Report on the Remedial Investigation of the Upper East Fork Poplar Creek Characterization Area at the Oak Ridge Y-12 Plant, Oak Ridge, Tennessee (DOE 1998), both of which incorporate the hydrogeologic framework and associated nomenclature described in Status Report - A Hydrologic Framework for the Oak Ridge Reservation (Solomon et al. 1992).

There are two basic hydrogeologic units in the vicinity of Y-12 that are defined for use in this report: the aquifer and the aquitard (Figure A.2). This nomenclature is intended only to differentiate the more permeable carbonate formations that comprise the aquifer from the less permeable formations that comprise the aquitard; no inference to the conventional connotation of each term is implied or intended. The aquifer includes the uppermost carbonate formation of the Conasauga Group (Maynardville Limestone) and the overlying formations of the Knox Group. The aquitard, which is not a true aquitard but transmits groundwater less effectively than the aquifer, consists of the remaining siliciclastic formations of the Conasauga Group (Nolichucky Shale, Maryville Limestone, Rogersville Shale, Rutledge Limestone, and Pumpkin Valley Shale) and the underlying Rome Formation. The following discussion provides a short description of each hydrogeologic unit.

\subsubsection{Aquifer}

Components of the aquifer underlie the axis of BCV (Maynardville Limestone) and form Chestnut Ridge (Knox Group). Separate overviews of the hydrologic characteristics of the Maynardville Limestone and the Knox Group are provided below.

\subsubsection{Maynardville Limestone}

Most groundwater flow in the Maynardville Limestone occurs at depths less than $100 \mathrm{ft}$ below ground surface (bgs) in an extensively interconnected network of solution conduits and cavities (karst network). Flow in the shallow karst network is relatively rapid and occurs as "quickflow" discharge to nearby surface drainage features (e.g., Bear Creek). Below the shallow karst network, fractures provide the primary flowpaths. Also, there are seven distinct stratigraphic zones (numbered from bottom to top) in the Maynardville Limestone near Y-12 (Shevenell 1995). Because of vuggy porosity related to dissolution of gypsum nodules, the uppermost stratigraphic zone (Zone 6) is the most permeable and probably transmits the bulk of the groundwater in the Maynardville Limestone (Goldstrand 1995).

Available data indicated fairly homogeneous groundwater geochemistry in the Maynardville Limestone; almost every monitoring well in this formation, regardless of depth, yields calcium-magnesium-bicarbonate groundwater. Some shallow wells monitor sulfate-enriched groundwater, which probably reflects dissolution of locally disseminated secondary minerals, including gypsum, anhydrite, and pyrite. Also, several deep wells monitor calcium-magnesium-sulfate groundwater with very high total dissolved solids (TDS).

Isopleths of groundwater elevations in the Maynardville Limestone show a low hydrologic divide in BCV near the west end of Y-12, with flow along geologic strike to the west-southwest in the Bear Creek Regime (Figure A.4) and along geologic strike to the east-southeast in the East Fork Regime (Figure A.5). In the 
Bear Creek Regime, groundwater from the deeper flow system in the Maynardville Limestone discharges along major gaining (influent) reaches of Bear Creek. These discharge areas are possibly related to large-scale structural (e.g., cross-strike faults) or stratigraphic discontinuities in the Maynardville Limestone. Also, in the East Fork Regime, shallow flow in the Maynardville Limestone in the eastern Y-12 area is primarily to the east (along geologic strike) toward Union Valley east of the ORR boundary, but the UEFPC distribution channel underdrain apparently functions as a highly permeable groundwater flow path and a constant head (recharge) boundary that strongly influence local flow directions (BJC 1998).

Results of a long-term pumping test and concurrent dye-trace test performed in July 1998 provide the most recent data regarding the hydrologic characteristics of the intermediate and deep groundwater flowpaths in the Maynardville Limestone in the East Fork Regime, and the degree of hydraulic connection between the shallow and deep flow systems in the eastern Y-12 area (BJC 1998). A stepped pump test was performed using a well (GW-845) installed in the Maynardville Limestone about $250 \mathrm{ft}$ southeast of NHP. Groundwater was pumped continuously from the well (which has an open-hole interval from 157 to $438 \mathrm{ft}$ bgs) at progressively increased discharge rates: 25 gallons per minute (gpm) for 24 hours, 50 gpm for 24 hours, and 100 gpm for seven days (pumping started on July 9, 1998 and stopped on July 18, 1998). Water level drawdown and recovery data obtained from nearby monitoring wells indicated: (1) rapid, large responses in wells located along strike to the east and across strike to the north of the pumping well, (2) more moderate responses in wells located oblique to strike near the contact with the Nolichucky Shale to the east of the pumping well, (3) responses in upgradient wells in the Maynardville Limestone to the west of the pumping well, and (4) little if any response in wells located adjacent to Lake Reality and the UEFPC distribution channel underdrain to the north and northeast of the pumping well. The maximum observed radius of influence from the pumping well encompassed the entire subcrop of the Maynardville Limestone in the eastern Y-12 area, with particularly strong anisotropies to the east (along strike) and north (up-dip) of the well and low-permeability boundary effects along the contact with the Nolichucky Shale (BJC 1998).

In conjunction with the pumping test, eosine dye was injected in a shallow (60 ft bgs) well (GW-153) located about $450 \mathrm{ft}$ southwest (upgradient) of the pumping well (GW-845). Rapid breakthrough of the dye observed in the pumping well clearly demonstrated the hydraulic connection between the shallow and intermediate/deep groundwater flowpaths along strike in the Maynardville Limestone. Additionally, confirmed detection of the dye in two shallow wells (GW-220 and GW-832) located about $600 \mathrm{ft}$ northeast (across geologic strike) of the injection well (and about $300 \mathrm{ft}$ northwest of the pumping well) suggests that the degree of hydrologic connection with the UEFPC distribution channel underdrain and groundwater movement along dip parallel or conjugate fracture flowpaths in the shallow flow system are strong enough to overcome the hydraulic capture zone created at the $100 \mathrm{gpm}$ pumping rate in the intermediate to deep flow systems (BJC 1998).

Based on the information obtained from the long-term pumping test and associated dye trace, well GW-845 was designated as the groundwater extraction point for the contaminant plume capture system required under an interim action Record of Decision (ROD) for Union Valley (DOE 1997b). Full operation of the system began in October 2000 and has involved pumping well GW-845 at a rate of $25 \mathrm{gpm}$ and treating the groundwater to remove particulates, iron, manganese, and VOCs. Monthly water level measurements in selected observation wells show that continuous operation of the system has generally maintained 15 to $17 \mathrm{ft}$ of drawdown in the immediate vicinity of well GW-845 (Figure A.5) and has established an elongated zone of influence that extends parallel with geologic strike for at least $900 \mathrm{ft}$ to the east (downgradient) and $600 \mathrm{ft}$ to the west (upgradient) of the pumping well (DOE 2010). 


\subsubsection{Knox Group}

The Knox Group formations underlying Chestnut Ridge comprise three vertically gradational hydrogeologic subsystems: (1) the stormflow zone, (2) the vadose zone, and (3) the groundwater zone. The subsystems are distinguished by groundwater flux, which decreases with depth (Solomon et al. 1992).

Investigations on Chestnut Ridge in a watershed located approximately 4,000 ft west of the Chestnut Ridge Regime show that groundwater occurs intermittently above the water table in a shallow "stormflow zone" that extends to a depth of about $8 \mathrm{ft}$ bgs (Wilson et al. 1990). Macropores and mesopores provide the primary channels for lateral flow in the stormflow zone, which lasts only a few days (5 - 10) after rainfall. Most groundwater within the stormflow zone is either lost to evapotranspiration or recharge to the water table, and the remaining water discharges at nearby seeps, springs, or streams (Moore 1989).

The vadose zone occurs between the stormflow zone and the water table, which typically occurs near the bedrock/residuum interface. Soil moisture content in the vadose zone is below the saturation limit except in the capillary fringe above the water table and within wetting fronts during periods of vertical percolation from the stormflow zone (Moore 1989). Most recharge through the vadose zone is episodic and occurs along discrete permeable fractures that become saturated, although surrounding micropores remain unsaturated (Solomon et $\underline{\text { al }}$. 1992). The residuum is hydrologically heterogeneous, with quickflow via dolines to conduits in the subsurface; residuum on Chestnut Ridge near the Oak Ridge National Laboratory (ORNL) has a mean hydraulic conductivity of about 0.006 feet per day (ft/d) (Moore 1988).

Groundwater below the vadose zone occurs within orthogonal sets of permeable, planar fractures that form water-producing zones within an essentially impermeable matrix. Dissolution of bedrock carbonates has enlarged fractures and produced an interconnected conduit-flow system characteristic of karst aquifers. Because the occurrence of solution features and the frequency, aperture, and connectivity of permeable fractures decrease with depth, the bulk hydraulic conductivity of the groundwater zone is vertically gradational. Most groundwater flux occurs within the transitional horizon between residuum and unweathered bedrock (water table interval); lower flux (and longer solute residence times) occurs at successively greater depths in the bedrock (Solomon et al. 1992).

Available data show that hydraulic conductivity in the Knox Group varies over multiple orders of magnitude, which is typical of karst aquifers. Results of straddle packer tests in core holes indicate hydraulic conductivity ranging from 0.0002 to $3.1 \mathrm{ft} / \mathrm{d}$ at depths generally less than $600 \mathrm{ft}$ bgs in the lower Knox Group (King and Haase 1988). Hydraulic conductivity values calculated from results of falling-head slug tests performed in monitoring wells completed at shallow depths (60 to $195 \mathrm{ft}$ bgs) in the middle Knox Group range from about 0.003 to $14 \mathrm{ft} / \mathrm{d}$ (Jones 1998). Also, results of a preliminary dye-tracer test at the Chestnut Ridge Security Pits (CRSP) indicate flow rates of about 100 to $300 \mathrm{ft} / \mathrm{d}$ (Martin Marietta Energy Systems, Inc. [MMES] 1990a). Although not confirmed by a second test using different tracers (MMES 1993), these findings are supported by the range of flow rates (490 to 1,250 ft/d) indicated by results of a dye-tracer test performed on Chestnut Ridge near ORNL (Ketelle and Huff 1984).

Groundwater elevations on Chestnut Ridge generally mirror surface topography (Figure A.6). Along the crest of the ridge, which is a recharge area and a flow divide, groundwater generally flows from west to east (parallel to geologic strike), with radial components of flow north into BCV and south toward tributary headwaters on the southern flank of the ridge (across geologic strike). The central part of the regime is characterized by radial flow directions from local groundwater flow divides along hilltops between tributaries. Groundwater flow directions in the southern part of the regime are generally south toward Melton Hill Lake. The overall directions of groundwater flow throughout the Chestnut Ridge Regime do 
not significantly change during seasonal groundwater flow conditions. Horizontal hydraulic gradients throughout the year are highest along the steep northern flank of Chestnut Ridge (i.e., across geologic strike) and in the upper reaches of tributaries on the southern ridge flank, and are nearly flat along the southern boundary of the regime.

Groundwater in the Knox Group has fairly homogeneous geochemistry. Most wells yield calcium-magnesium-bicarbonate groundwater with $\mathrm{pH}$ of 7.5 to 8.0; TDS above 150 milligrams per liter $(\mathrm{mg} / \mathrm{L})$; equal or nearly equal molar concentrations of calcium and magnesium; low proportions $(<5 \%)$ of chloride, sodium, sulfate, and potassium; and very low (i.e., $<1 \mathrm{mg} / \mathrm{L}$ ) carbonate alkalinity and nitrate (as N) concentrations (hereafter synonymous with "nitrate" concentrations). Some wells yield groundwater with enriched chloride and sulfate concentrations that probably reflect the geochemical influence of locally disseminated evaporates (e.g., gypsum) or sulfides (e.g., pyrite). Additionally, groundwater within low permeability (matrix) intervals in the upper Knox Group (e.g., Mascot Dolomite), as indicated by data for several wells at Kerr Hollow Quarry (KHQ), often exhibits greater proportions of sulfate and potassium and higher trace metal concentrations (e.g., strontium) than typical of the groundwater from low yield intervals within the lower Knox Group formations (e.g., Copper Ridge Dolomite). These geochemical differences potentially reflect corresponding differences between carbonate mineralogies in the upper and lower sections of the Knox Group or the proximity to and types of disseminated secondary minerals (Lockheed Martin Energy Systems, Inc. 1996).

\subsubsection{Aquitard}

The geologic formations that comprise the aquitard directly underlie the primary contaminant source areas in the Bear Creek Regime and the East Fork Regime and are hydraulically upgradient of the Maynardville Limestone throughout much of BCV. Fractures provide the primary groundwater flowpaths in the aquitard; flow through the rock matrix is negligible but nevertheless plays an important role in contaminant migration because of matrix diffusion processes. Flow directions are primarily parallel to bedding (along geologic strike and dip), which may or may not coincide with the direction of maximum horizontal hydraulic gradient inferred from groundwater elevation isopleths. Most flow occurs within the shallow bedrock interval less than $100 \mathrm{ft}$ bgs. Flow across bedding occurs primarily along permeable zones formed by cross-cutting fractures or fracture zones (and possibly small faults). Some of these cross-cutting structures may act as barriers to lateral flow, causing groundwater from deeper intervals to upwell and discharge to the shallower flow system. Others may serve as preferential pathways for migration of contaminants from the aquitard into the Maynardville Limestone.

Most groundwater flow in the aquitard occurs within a highly permeable interval near the bedrock/residuum interface. West of Y-12 in the Bear Creek Regime, flow in the aquitard above the water table occurs in response to precipitation when flowpaths in the residual soils become saturated and rapidly transmit water laterally (stormflow) down slope toward springs, seeps, streams and vertically (recharge) to the water table interval. In the East Fork Regime, however, infiltration into the subsurface and recharge to the water table interval is strongly influenced by the many buildings and other impervious surfaces that cover much of the regime as well as the extensive areas of fill and networks of subsurface storm drains, sewers, and process lines.

Recharge to the water table interval in the aquitard promotes strike-parallel groundwater flow toward nearby discharge areas, which include the subsurface drainage network in the East Fork Regime and the northern tributaries of Bear Creek in the Bear Creek Regime. Although the presence of contaminants in groundwater more than $200 \mathrm{ft}$ bgs in the Nolichucky Shale clearly indicates permeable flowpaths at depth, 
flow is most active at depths less than $100 \mathrm{ft}$ bgs, and only a small percentage of total flow ultimately recharges the deeper bedrock, where upward hydraulic gradients predominate. In the Bear Creek Regime, about $94 \%$ of the available groundwater in the aquitard discharges to Bear Creek tributaries, about 5\% flows along cross-cutting fractures into the aquifer, and about $1 \%$ flows through strike-parallel pathways in the deeper subsurface (DOE 1997a).

Decreasing groundwater flux with depth in the aquitard in BCV also is reflected by distinct changes in groundwater geochemistry. Most water table interval and shallow (i.e., $<100 \mathrm{ft}$ bgs) bedrock wells monitor calcium-magnesium-bicarbonate groundwater. A fairly abrupt change to sodium-bicarbonate groundwater, which is interpreted to be a function of longer groundwater residence time related to reduced fracture aperture or increased fracture spacing (Solomon et al. 1992), occurs at a depth of about $100 \mathrm{ft}$ bgs. Further reduced groundwater flux is indicated by the transition from sodium-bicarbonate groundwater to sodium-chloride groundwater that usually occurs at a depth of about $400 \mathrm{ft}$ bgs. The transition to the sodium-chloride groundwater is accompanied by a general increase in TDS.

Isopleths of seasonal groundwater surface elevations in the aquitard (water table interval) in the Bear Creek Regime (Figure A.4) and East Fork Regime (Figure A.5) indicate flow to the west-southwest and east-southeasterly, respectively, toward the Maynardville Limestone. In the East Fork Regime, however, the operation of basement dewatering sumps and the network of subsurface storm drains and utilities throughout much of the western and central Y-12 areas (Figure A.3) strongly influences the movement and discharge of shallow groundwater. For instance, operation of sumps to suppress the local water table below the basement floor of several buildings (9204-4, 9201-5, and 9201-4, and possibly 9204-2) have influenced local groundwater flow and contaminant transport patterns (DOE 1998). The sumps located in Building 9201-5 were shut down in CY 2005, and water consisting of steam condensate, rainwater, and groundwater has accumulated in the basement since that time.

\subsection{GROUNDWATER CONTAMINATION}

Groundwater quality monitoring data obtained from the extensive network of monitoring wells associated with Y-12 show that the most widespread groundwater contaminants are nitrate, VOCs, uranium isotopes (primarily uranium-234 [U-234] and uranium-238 [U-238]), and technetium-99 (Tc-99). Maps illustrating the generalized extent of nitrate, VOCs, uranium isotopes (as indicated by gross alpha radioactivity), and Tc-99 (as indicated by gross beta radioactivity) are provided on Figures A.7, A.8, A.9, and A.10, respectively. The following sections provide an overview of groundwater contamination in the Bear Creek Regime, East Fork Regime, and Chestnut Ridge Regime.

\subsubsection{Bear Creek Regime}

The following sections briefly describe the primary sources of groundwater contamination in the Bear Creek Regime (the S-3 Site, the Oil Landfarm (OLF) waste management area [WMA], and the Bear Creek Burial Grounds [BCBG] WMA) and the principal groundwater transport pathway in the regime (the Maynardville Limestone). 


\subsubsection{S-3 Site}

Operation of the former S-3 Ponds emplaced a large reservoir of contamination in the aquitard (Nolichucky Shale) consisting of a heterogeneous mix of inorganic, organic, and radioactive constituents. The principal contaminants are nitrate, Tc-99, uranium isotopes, trace metals (e.g., cadmium), and VOCs. Contaminant concentrations in the aquitard nearest the site have probably reached maximum levels, with the center of mass of the plume slowly moving westward. Westward, strike parallel migration of contaminants in the aquitard occurs until encountering a cross-cutting structure that promotes upward discharge into the shallow flow system or cross-strike flow into the Maynardville Limestone (DOE 1997a). Additionally, matrix diffusion and advective transport processes are slowly releasing contaminants (e.g., nitrate) from the deeper reservoir into the more active (shallow) aquitard flow system.

In the aquitard, nitrate from the former S-3 Ponds extends directly south in the water table interval into the upper reach of Bear Creek and along strike in the water table interval and the deeper bedrock for over $3,000 \mathrm{ft}$ to the west. Because it is highly mobile and chemically stable, nitrate delineates the maximum extent of groundwater transport from the S-3 Site and effectively traces the principal migration pathways in the aquitard. Nitrate concentrations within the plume exceed $10,000 \mathrm{mg} / \mathrm{L}$ in the deep bedrock directly below the S-3 Site and exceed 1,000 mg/L in the shallow groundwater near the site (Figure A.7).

Gross alpha activity and gross beta activity within the S-3 Site contaminant plume exceed 1,000 picoCuries per liter $(\mathrm{pCi} / \mathrm{L})$. Although a diverse population of radioisotopes is present in the groundwater closest to the site, elevated gross alpha and gross beta activity in the groundwater probably delineate migration of uranium isotopes (U-234 and U-238) and Tc-99, respectively, since these were the dominant radiological constituents in wastes placed into the former S-3 Ponds. Also, sludge produced by denitrification of the waste water in each pond was left in place after closure of the site. Sludge within the saturated zone may release Tc-99 and uranium isotopes to the shallow groundwater flow system in the aquitard (DOE 1997a). These contaminants then may be transported southward towards Bear Creek and westward through the water table interval toward discharge points in NT-1 (DOE 1997a).

Other components of the S-3 Site contaminant plume are trace metals and VOCs. The distribution of trace metals is less extensive than that of nitrate and radioactivity, but the most mobile metals within the plume (e.g., barium) have been transported beyond the acidic groundwater $(\mathrm{pH}<5)$ nearest the site. Acetone and tetrachloroethene (PCE) are the principal VOCs within the plume. Concentrations of PCE exceed 5,000 micrograms per liter $(\mu \mathrm{g} / \mathrm{L})$ in wells adjacent to the site, potentially indicating the presence of dense nonaqueous phase liquids (DNAPL) in the subsurface, but decrease to less than $50 \mu \mathrm{g} / \mathrm{L}$ about $500 \mathrm{ft}$ downgradient to the west of the site. This reflects the limited extent of PCE migration and suggests substantial natural attenuation in the subsurface.

\subsubsection{Oil Landfarm WMA}

The primary sources of groundwater contaminants in the OLF WMA are the Boneyard/Burnyard (BYBY), the Hazardous Chemical Disposal Area (HCDA), the OLF disposal plots, and Sanitary Landfill I. Each of these sites except the BYBY is a known or suspected source of VOCs in the shallow groundwater; the BYBY is a major source of elemental uranium and alpha radioactivity in the Bear Creek Regime.

The Boneyard was used for the disposal of magnesium chips and construction debris (e.g., concrete) in unlined shallow trenches. Filled trenches were covered with topsoil and seeded with grass. The Burnyard consisted of two unlined trenches, each about $300 \mathrm{ft}$ long by $40 \mathrm{ft}$ wide, in which various types of refuse 
(including pesticide containers, metal shavings, solvents, oils, and laboratory chemicals) were burned. Some residues may have been buried in the Boneyard. Because the BYBY is a primary source of uranium in the groundwater and surface water in BCV (DOE 1997a), this site was prioritized for Comprehensive Environmental Response, Compensation, and Liability Act (CERCLA) remedial action, which was performed in three phases. Remedial designs for the site were prepared during Phase I and remedial action field work began with Phase II. Completed in November 2001, Phase II primarily involved construction of an upgradient subsurface drain to hydraulically isolate the buried wastes at the site in order to reduce the flux of contaminants from the site and to dry the site in preparation of the Phase III field work, which began in May 2002. Phase III focused on the excavation, disposal, and consolidation of wastes from the site and the reconstruction of a section of NT-3 that drains the site. Waste removal actions were completed in October 2002 and involved the excavation of about 64,000 cubic yards $\left(\mathrm{yd}^{3}\right)$ of waste materials with the highest concentrations of uranium that were in contact with groundwater. These wastes were disposed in the Environmental Management Waste Management Facility (EMWMF). About 17,000 $\mathrm{yd}^{3}$ of other waste materials that had lower levels of uranium contamination and were not in contact with groundwater also were excavated, consolidated onsite, and covered with a low-permeability recompacted clay cap. Installation of the cap, including seeding/mulching the topsoil cover, was completed in November 2002. Field work to restore the NT-3 stream channel with natural meanders and gradients in order to reduce erosion of the bank and more efficiently transport water and sediment load through the site was completed in May 2003.

The HCDA was constructed on top of the Burnyard in 1975 and was used as an area for releasing compressed gas from cylinders with leaking or damaged valves and for disposal of reactive or explosive laboratory chemicals. The chemicals were handled to induce the expected reaction or explosion, and remaining liquids were discharged into a small unlined surface impoundment. A low permeability cap was constructed over the HCDA during closure of the OLF. In June 2002, a section of the northwest corner of the cap was excavated and removed during Phase III of the CERCLA remedial action at the BYBY. Excavated wastes were replaced with uncontaminated soil and the filled area was graded to drain, mulched, and seeded with grass.

Groundwater contaminants at the OLF are principally VOCs, and a commingled plume containing two distinct suites of VOCs are evident: one to the northeast dominated by 1,1,1-trichloroethane (111TCA), 1,1-dichloroethane (11DCA), and 1,1-dichloroethene (11DCE); and one to the south dominated by PCE, cis-1,2-dichloroethene (c12DCE), trans-1,2-dichloroethene (t12DCE), and trichloroethene (TCE) (MMES 1989). The dissolved VOC plume appears to be restricted to the shallow flow system. Summed VOC concentrations exceed $1,000 \mu \mathrm{g} / \mathrm{L}$ in the northeast part of the plume and $100 \mu \mathrm{g} / \mathrm{L}$ in the southern part of the plume (Figure A.8); maximum concentrations within the plume do not indicate the presence of DNAPL in the subsurface.

Sanitary Landfill I is a probable source of 11DCA, c12DCE, and t12DCE in the shallow groundwater (aquitard and aquifer) downgradient to the south of the site. Maximum VOC concentrations are typically less than $50 \mu \mathrm{g} / \mathrm{L}$. In the Maynardville Limestone, these constituents have intermingled with the VOC plume (primarily TCE and c12DCE) originating from upgradient sources. Sanitary Landfill I also may be a source of boron in the groundwater at several wells immediately downgradient (west) of the site. 


\subsubsection{Bear Creek Burial Grounds WMA}

Groundwater in the aquitard underlying the BCBG WMA is extensively contaminated with VOCs at both shallow (water table) and deep (bedrock) intervals. There are five primary source areas: Burial Ground (BG)-A (North and South), BG-C (East and West), and the Walk-In Pits (Figure A.8). Dissolved VOC plumes in the shallow groundwater at several of these source areas are probably related to widespread occurrence of DNAPL in the subsurface. Contamination in the deeper groundwater flow system reflects density-driven, downward migration of DNAPL.

The disposal trenches comprising BG-A (North and South) received almost two million gallons of waste oils and coolants, and DNAPL has been encountered at $260 \mathrm{ft}$ and $330 \mathrm{ft}$ bgs in monitoring wells downdip of source trenches in BG-A South. Dissolved VOC plumes in the groundwater underlying both areas are dominated by PCE, TCE, and c12DCE. Other common plume constituents are 111TCA, 11DCA, and 1,2-dichloroethane (12DCA). Summed concentrations of these plume constituents exceed 100,000 $\mu \mathrm{g} / \mathrm{L}$. Groundwater in the water table interval transports the plume constituents along strike toward discharge areas in NT-6 and NT-7. Strike-parallel migration also occurs below the water table interval, as reflected by westward (strike-parallel) transport of PCE indicated by data obtained from deeper bedrock wells west of BG-A South.

Separate plumes of dissolved VOCs apparently occur in the shallow groundwater at BG-C East and BG-C West, each plume dominated by c12DCE with lesser amounts of vinyl chloride (VC), both of which are degradation products of PCE. The concentrations of VOCs in each plume are generally less than $500 \mu \mathrm{g} / \mathrm{L}$. Groundwater containing these VOCs discharges to the NT-8 catchment on the northwest side of the BCBG WMA. Data for both source areas do not clearly indicate the presence of DNAPL in the subsurface (DOE 1997a).

Groundwater near the Walk-In Pits contains a distinct plume of dissolved VOCs dominated by PCE. Concentrations exceed 2,000 $\mu \mathrm{g} / \mathrm{L}$, which is about $1 \%$ of the maximum PCE solubility and possibly indicates DNAPL in the subsurface. Contaminants in the shallow groundwater flow system near the Walk-In Pits may not discharge extensively to surface water (DOE 1997a).

Although large quantities of uranium wastes were disposed in the BCBG WMA, few monitoring wells in the area yield radioactive groundwater samples. However, data for soil samples and surface water samples collected from NT-6, NT-7, and NT-8 indicate that uranium isotopes from BG-A South and BG-C East are probable sources of elevated alpha and beta radioactivity (DOE 1997a). Maximum gross alpha and gross beta activities in the samples from these tributaries ranged from about $20 \mathrm{pCi} / \mathrm{L}$ to more than $100 \mathrm{pCi} / \mathrm{L}$. The disparity with the groundwater sample data may be an artifact of the monitoring well network (few wells are screened within the shallowest water table interval where radioactive contamination likely occurs), but the relatively low levels of radioactivity in the groundwater also suggest that the bulk of the uranium wastes in BG-A South and BG-C East are not within the saturated zone (DOE 1997a).

Boron is the primary trace metal contaminant in the groundwater at the BCBG WMA. Elevated boron concentrations occur primarily in the shallow groundwater near BG-A South and BG-C (East and West) and probably resulted from disposal of borax wastewater from Y-12. Boron is most likely present in the groundwater as borate $\left[\mathrm{B}(\mathrm{OH})_{3}\right]$, which is chemically stable and relatively mobile, and is transported toward discharge points in Bear Creek tributaries NT-7 and NT-8. 


\subsubsection{Maynardville Limestone Exit Pathway}

Groundwater contaminants in the Maynardville Limestone originate from the S-3 Site (nitrate and Tc-99), the Rust Spoil Area (VOCs) or an unidentified source area in the Bear Creek floodplain adjacent to the Rust Spoil Area, the BYBY (uranium isotopes), Sanitary Landfill I (VOCs), and the BCBG WMA (VOCs and uranium isotopes). These contaminants enter the Maynardville Limestone through direct recharge, hydrologic communication with surface water in Bear Creek, and inflow of shallow groundwater from the aquitard. Relative contributions from the source areas and the geochemical characteristics of the contaminants have produced two primary plumes of contamination in the groundwater: one containing nitrate and radioactivity and another containing VOCs. Both plumes occur in the shallow karst network and the deeper fracture flowpaths and are commingled downgradient of the BYBY.

The nitrate plume (Figure A.7) in the aquifer essentially delineates the maximum extent of contaminant transport from the former S-3 Ponds and effectively traces the principal migration pathways in the Maynardville Limestone. The plume is continuous in the deeper bedrock from south of the S-3 Site for about 10,000 ft along strike to the west, whereas attenuation from more active recharge and groundwater flux has reduced nitrate levels and produced a more discontinuous nitrate plume in the shallow karst network. Nitrate concentrations within the plume exceed $500 \mathrm{mg} / \mathrm{L}$ south of the S-3 Site, but rapidly decrease to less than $50 \mathrm{mg} / \mathrm{L}$ south of the OLF WMA, and are typically highest in the fracture-dominated groundwater flow system at depths greater than $100 \mathrm{ft}$ bgs.

The distribution of VOCs (Figure A.8) in the Maynardville Limestone reflects the relative contributions of several source areas and commingling during downgradient transport. Plume constituents in the upper part of BCV are TCE, c12DCE, and PCE; probable source areas are Spoil Area I, the S-3 Site, and possibly the Fire Training Facility in the East Fork Regime. The major inputs to the plume occur from: (1) the Rust Spoil Area (TCE) or a nearby source in the Bear Creek floodplain, (2) the HCDA (TCE and c12DCE), Sanitary Landfill I (111TCA and 11DCA), (3) discharge from the Bear Creek tributary (NT-7) that traverses BG-A North and A South (c12DCE and 12DCA), and (4) discharge from the Bear Creek tributary (NT-8) on the west side of the BCBG WMA, including VOCs (PCE, TCE, c12DCE, VC) from BG-C East and BG-C West. The highest concentrations within the plume (i.e., $>300 \mu \mathrm{g} / \mathrm{L}$ ) occur in the deeper groundwater south (down dip) of the HCDA. These high concentrations coincide with the downward vertical hydraulic gradients in the Maynardville Limestone in this area and the major losing reach of middle Bear Creek south of Sanitary Landfill I.

Radioactivity in the groundwater in the Maynardville Limestone is primarily from uranium isotopes and Tc-99. The extent of these radionuclides is generally delineated by gross alpha activity (Figure A.9) and gross beta activity (Figure A.10), respectively. The distribution of gross beta activity mirrors that of nitrate, indicating both a common source of nitrate and Tc-99 (the S-3 Site) and migration along common flowpaths. Increased gross alpha activity in the groundwater downstream of the NT-3 catchment reflects inputs of uranium isotopes from former sources in the BYBY. Before their excavation and removal in May 2002 (see Secion. 2.4.1.2), waste materials containing high concentrations of uranium were within the saturated zone during seasonally high groundwater levels. Uranium isotopes that were leached from the wastes were transported with the shallow groundwater that discharges into NT-3 and recharges directly into the Maynardville Limestone. Prior to the removal of the wastes, gross alpha and gross beta activity exceeded 1,000 $\mathrm{pCi} / \mathrm{L}$ in the shallow groundwater along NT-3 from the northwest corner of the site to the confluence of NT-3 and Bear Creek (Figure A.9 and Figure A.10).

Most trace metal contamination in the Maynardville Limestone occurs in the shallow groundwater near the S-3 Site and the BYBY. Near the S-3 Site, the principal trace metal contaminants are barium, boron, 
cadmium, copper, lead, mercury, strontium, and uranium. Some of these metals (e.g., cadmium) were entrained in the highly acidic wastes disposed at the site, and others (e.g., barium and strontium) were dissolved from the underlying bedrock. Trace metal contamination is sporadic in the groundwater at the BYBY and the principal contaminants are beryllium, manganese, mercury, nickel, and uranium. Boron and uranium are the most common trace metal contaminants in the aquifer downgradient of the S-3 Site and the BYBY, which indicates that relatively mobile ionic species of both metals are present in the groundwater.

\subsubsection{East Fork Regime}

Sources of groundwater contamination in the East Fork Regime include hazardous and nonhazardous waste treatment, storage, or disposal sites; bulk product transfer, storage, and use areas; former petroleum-fuel underground storage tanks (USTs) and associated dispensing facilities; industrial process buildings; waste and product spill areas; and the many process pipelines, effluent drains, and utilities associated with the industrial operations at Y-12. Also, operation of the former S-3 Ponds emplaced a large reservoir of contamination in the western Y-12 area. Intermingling of contaminants from multiple source areas has produced an extensive, essentially continuous groundwater contaminant plume of varying composition that extends from the western Y-12 area through the southern part of the central and eastern Y-12 areas and into Union Valley east of the ORR (Figure A.8).

A plume of nitrate contamination originating from the former S-3 Ponds extends vertically in the aquitard at least $150 \mathrm{ft}$ bgs and laterally at least 5,000 ft into the western Y-12 area (Figure A.7). Nitrate concentrations within the plume exceed $10,000 \mathrm{mg} / \mathrm{L}$. The geometry of the nitrate plume indicates two principal migration pathways: (1) relatively rapid migration along fairly short, shallow pathways ( $<30 \mathrm{ft}$ bgs) that typically terminate in storm drains or other utilities, building sumps, and the buried tributaries and original mainstream of UEFPC; and (2) substantially slower migration along much longer strike-parallel pathways at greater depths in the bedrock toward basement sumps in Buildings 9204-4, 9201-4, and 9201-5 (DOE 1998). The S-2 Site also is a minor source of nitrate. However, because the S-2 Site directly overlies the Maynardville Limestone, the plume of nitrate contamination extends much farther from this source (>7,000 ft) than from the S-3 Site in the aquitard (Figure A.7).

The low $\mathrm{pH}$ groundwater within the contaminant plume originating from the former S-3 Ponds contains a diverse mix of metal ions and/or ion-complexes (beryllium, cadmium, cobalt, manganese, mercury, and nickel) that are usually not mobile (or are more readily attenuated) in less acidic groundwater, as well as metals that are mobile under a wider range of groundwater $\mathrm{pH}$ conditions (barium, boron, strontium, and uranium). Some of these metals were entrained in the acidic wastes disposed at the site (e.g., uranium), and others were dissolved from the underlying saprolite and bedrock (e.g., barium and strontium). Concentrations of several trace metals (e.g., barium) within the plume exceed the applicable Safe Drinking Water Act (SDWA) maximum contaminant level (MCL) for drinking water by an order-of-magnitude or more. Similarly elevated concentrations of several other trace metals (including boron, cadmium, cobalt, copper, mercury, and uranium) occur in the groundwater elsewhere in the East Fork Regime, notably the S-2 Site, but available data do not indicate that extensive plumes of metal ions and/or ion-complexes have developed in the groundwater beyond the immediate vicinity of these sites.

Volatile organic compounds are the most pervasive groundwater contaminants in the East Fork Regime (Figure A.8). The principal components of dissolved VOC plumes in the western Y-12 area and the central Y-12 area are PCE, TCE, c12DCE, 11DCE, and VC. Chloroethanes (primarily 111TCA and 11DCA) are also major components of several plumes in the central Y-12 area. In the eastern Y-12 area, 
dissolved chloromethanes, primarily carbon tetrachloride (CTET), chloroform, and methylene chloride (MC) are primary components of the VOC plume. Additionally, residual plumes of dissolved petroleum hydrocarbons (benzene, toluene, ethylbenzene (ETB), and total xylenes) occur in shallow groundwater near former petroleum fuel USTs. In the aquitard, concentrations of individual plume constituents exceed $1,000 \mu \mathrm{g} / \mathrm{L}$ in the shallow groundwater near the Waste Coolant Processing Area (WCPA), Building 9201-5, and Tank 0134-U and indicate the presence of DNAPL in the subsurface. At shallow depths ( $<100 \mathrm{ft}$ bgs) in the Maynardville Limestone, a relatively continuous plume of dissolved VOCs begins near the Fire Training Facility in the western Y-12 area, intermingles with VOC plumes from several sources in the central Y-12 area, and extends underneath NHP in the eastern Y-12 area (Figure A.8). The extent of the plume at intermediate ( $>200 \mathrm{ft}$ bgs) and deep ( $>400 \mathrm{ft}$ bgs) intervals in the Maynardville Limestone is not well defined in the western and central Y-12 areas because of very limited well coverage. However, data from the network of wells in the eastern Y-12 area show that a plume of dissolved chloromethanes (primarily CTET), which is believed to originate from several sources, including suspected DNAPL in the Maynardville Limestone west of NHP near Building 9720-6, extends vertically more than $400 \mathrm{ft}$ bgs and laterally (parallel with geologic strike) into Union Valley up to 2,000 ft east of the ORR boundary. Operation of the VOC plume capture system since CY 2000 (see Sect. 2.3.1.1) has effectively reduced VOC concentrations in groundwater downgradient of the pumping well (DOE 2010).

Groundwater with radiological contamination occurs primarily in the aquitard east of the former S-3 Ponds, at the Salvage Yard, Buildings 9204-4 and 9201-5, and Tank 0134-U (Figure A.9 and Figure A.10). In the Maynardville Limestone, radiological contamination occurs near the S-2 Site and upgradient of NHP (the Uranium Oxide Vault, wells GW-605 and GW-606, and the former Oil Skimmer Basin). The former S-3 Ponds are the principal source of uranium isotopes (primarily U-234 and U-238) and Tc-99; the migration of Tc-99 generally mirrors that of nitrate from the site. Gross alpha radioactivity levels within the plume exceed the $15 \mathrm{pCi} / \mathrm{L}$ MCL and gross beta radioactivity levels within the plume exceed the SDWA screening level ( $50 \mathrm{pCi} / \mathrm{L}$ ) for a 4 millirem per year (mrem/yr) dose equivalent (the drinking water MCL for gross beta radioactivity). Relatively limited influx of radiological contamination directly into the aquifer (or extensive dilution) in the East Fork Regime is indicated by the greatly decreased gross alpha, gross beta, and isotopic uranium activity in the groundwater downgradient of known source areas (e.g., S-2 Site and the former Oil Skimmer Basin).

\subsubsection{Chestnut Ridge Regime}

Groundwater contamination is much less extensive in the Chestnut Ridge Regime and VOCs are the most common groundwater contaminants (Figure A.8). Dissolved VOCs (primarily chloroethanes and chloroethenes) have been detected in the groundwater samples collected from monitoring wells downgradient from the CRSP and Industrial Landfill (ILF) IV. However, a clearly distinct plume of dissolved VOCs is indicated only by the data for wells at the CRSP.

The CRSP are located on the crest of Chestnut Ridge directly south of the central portion of Y-12, and consist of two areas containing a series of east-west oriented trenches that are about 8 to $10 \mathrm{ft}$ wide, 10 to $18 \mathrm{ft}$ deep, and 700 to $800 \mathrm{ft}$ long. Beginning in 1973, the trenches received hazardous wastes until December 1984 and nonhazardous wastes until the site was closed in November 1988. Data obtained from monitoring wells at the site indicate that a narrow, elongated plume of dissolved VOCs extends parallel with geologic strike for at least $700 \mathrm{ft}$ downgradient to the east, and perpendicular to geologic strike for at least $300 \mathrm{ft}$ downgradient to the north and south. The primary components of the plume include 111TCA, 11DCA, and 11DCE near the western trench area, and PCE, TCE, and 1,2-dichloroethene (12DCE) isomers near the eastern trench area. The distribution of the dissolved plume constituents relative to the respective 
source areas and elongation of the plume along the axis of Chestnut Ridge, despite steeper hydraulic gradients toward the ridge flanks, suggest primarily strike-parallel horizontal transport (west to east) in the groundwater (and possibly vapor phase transport). The maximum depth of vertical migration of the VOCs has not been conclusively determined, but is at least $150 \mathrm{ft}$ bgs in the western trench area, $250 \mathrm{ft}$ bgs near the middle of the site, and $270 \mathrm{ft}$ bgs downgradient of the eastern trench area.

Data obtained since the early 1990s show that low concentrations (many are estimated values below analytical reporting limits) of one or more VOCs are present in the groundwater at two wells hydraulically downgradient of the waste disposal trenches at the CRSP: well GW-796 $(<1 \mu \mathrm{g} / \mathrm{L})$, which is located at ILF V about $400 \mathrm{ft}$ directly south of the site, and well GW-798, which is located at Construction/ Demolition Landfill (CDL) VII about 1,600 ft south-southeast of the site (Figure A.8). Subsequent monitoring results indicate that VOC levels in both wells remain relatively low, with the more recent data showing that PCE concentrations in well GW-798 occasionally exceed the MCL (5 $\mu \mathrm{g} / \mathrm{L})$. The repeated detection of these compounds in the groundwater at both wells probably reflects southward transport from the CRSP because this site is the only known source of VOCs that is hydraulically upgradient of either well.

The ILF IV, which is located on the crest of Chestnut Ridge directly south of the west end of Y-12, has received non-hazardous solid waste since October 1989 and is a suspected source of 111TCA, 11DCA, 11DCE in groundwater downgradient of the site. These VOCs have been repeatedly detected in a well located south of the eastern portion of the site (GW-305). These results potentially indicate groundwater transport along permeable flowpaths from the unlined portion (about $150 \mathrm{ft} X 150 \mathrm{ft}$ ) at the eastern end of ILF IV. Although the source of these contaminants has not been formally confirmed, no other waste management facility is located upgradient of these wells. In response to sampling results confirming 11DCE concentrations above the MCL, the Tennessee Department of Environment and Conservation (TDEC) issued a Notice of Violation (NOV) in a letter to BJC dated November 2, 2009 (TDEC 2009). The NOV letter requested implementation of Assessment Monitoring Phase 3 at Industrial Landfill IV in accordance with an approved Groundwater Quality Assessment Plan (GWQAP). The TDEC approved the GWQAP (BJC 2009a) for Industrial Landfill IV in December 2009 and Assessment Monitoring Phase 3 subsequently began with groundwater sampling of well GW-305 for VOC analysis per the quarterly frequency specified in the plan.

Kerr Hollow Quarry is on the broad southern flank of Chestnut Ridge about 1,000 ft north of Bethel Valley Road and served as a source of stone construction material until it filled with water and was abandoned in the late 1940's. From the early 1950s until November 1988, the quarry was used for the disposal of reactive materials from Y-12 and ORNL. Wastes were removed from the quarry between mid-1990 and late 1993 to obtain certified clean-closure status from the TDEC, but the site was finally closed with some wastes remaining in place. Low levels $(<5 \mu \mathrm{g} / \mathrm{L})$ of several VOCs, primarily CTET, chloroform, and PCE, occur in the groundwater at monitoring wells located to the south (GW-144) and southeast (GW-142) of KHQ. Each of these VOCs may be present at low concentrations in the groundwater downgradient of the site, possibly as a consequence of wastes being disturbed during attempts to obtain clean closure of the site, but none of the compounds have been detected in the Resource Conservation and Recovery Act (RCRA) wells at the site since 1997. 



\subsection{CY 2009 MONITORING PROGRAMS}

The groundwater and surface water monitoring data included in this report were obtained during CY 2009 from implementation of monitoring programs directed by the Y-12 GWPP and BJC. The Y-12 GWPP implemented surveillance and exit-pathway/perimeter monitoring (hereafter referenced collectively as DOE Order monitoring) specifically to meet requirements of DOE Order 450.1A. Associated groundwater and surface water sampling and analysis activities were performed in accordance with the Y-12 GWPP sampling and analysis plan (SAP) for CY 2009 (B\&W Y-12 2008), as modified by applicable addenda (Table B.1). The following subsections provide details regarding these sampling and analysis activities, including: the respective network of sampling locations in each hydrogeologic regime; QA/QC sampling; groundwater and surface water sampling methods; field measurements and laboratory analytes; data management protocols and DQO evaluation; and groundwater elevation monitoring.

The following monitoring programs were implemented by BJC at Y-12 during CY 2009: (1) RCRA post-closure detection monitoring and RCRA post-closure corrective action monitoring (collectively referenced as RCRA monitoring); (2) CERCLA monitoring in accordance with applicable RODs or related decision documents (hereafter referenced as CERCLA ROD monitoring); (3) CERCLA baseline monitoring to evaluate pre-remediation water quality; (4) CERCLA detection monitoring at the EMWMF, an operating facility located in the Bear Creek Regime for CERCLA remediation wastes generated on the ORR; and (5) detection or assessment monitoring for several nonhazardous solid waste disposal facilities (SWDFs) located in the Chestnut Ridge Regime (referenced as SWDF monitoring). Groundwater and surface water sampling and analysis activities associated with these programs were performed in general accordance with the requirements specified in the ORR Water Resources Restoration Program (WRRP) SAP for fiscal year 2009 (BJC 2009b); the WRRP quality assurance project plan (BJC 2009c); the environmental monitoring plan for the EMWMF (BJC 2007a); and a SWDF monitoring SAP issued by the subcontractor responsible for the operations of the landfills on Chestnut Ridge (EnergySolutions 2007). The following subsections provide general information regarding the monitoring programs implemented by BJC (e.g., sampling locations), but specific details, such as QA/QC sampling information, are deferred to the applicable SAPs and related technical reports issued by BJC.

Cooperative implementation of the monitoring programs directed by the Y-12 GWPP and BJC (i.e., preparing SAPs, coordinating sample collection, and sharing data) ensures that the CY 2009 monitoring results fulfill requirements of all the applicable monitoring drivers (DOE Order, RCRA, CERCLA, and SWDF) with no duplication of sampling and analysis efforts.

\subsection{SAMPLING LOCATIONS AND FREQUENCY}

This report contains groundwater and surface water quality monitoring data obtained during CY 2009 from 235 sampling locations at Y-12, including 190 monitoring wells (complete construction details for each well are provided in Appendix C), 14 springs, and 31 surface water stations. The following subsections provide details regarding the sampling locations in each hydrogeologic regime and the corresponding sampling frequency for each applicable well, spring, and surface water station. 


\subsubsection{Bear Creek Regime}

As shown below in Table 1, a total of 66 monitoring wells, six springs, and 19 surface water stations in the Bear Creek Regime were sampled during CY 2009 for the purposes of DOE Order monitoring, RCRA monitoring, and CERCLA monitoring. Table B.2 identifies the monitoring program applicable to each well, spring, and surface water station; their locations are shown on Figure A.11.

Table 1. CY 2009 sampling locations in the Bear Creek Regime

\begin{tabular}{|c|c|c|c|}
\hline Monitoring Driver & Monitoring Wells & Springs & Surface Water Stations \\
\hline DOE Order & 38 & 2 & 4 \\
RCRA & 6 & 1 & 0 \\
CERCLA & 22 & 5 & 17 \\
\hline \multicolumn{2}{|c|}{ Totals: } & $\mathbf{6 6}$ & $\mathbf{6} *$ \\
\hline Note: $*$ = Separate samples were collected for DOE Order and CERCLA monitoring purposes at springs SS-4 \\
and SS-5 and surface water stations BCK-04.45 and NT-01 (see Table B.2). \\
\hline
\end{tabular}

Samples were collected either annually or semiannually from most of the monitoring locations during CY 2009. Of the monitoring wells, 35 were sampled annually and 19 were sampled semiannually (Table B.2). Spring and surface water samples were collected annually (13 locations), semiannually (five locations), during three quarters (two locations), or quarterly (five locations).

Thirty-three of the wells that were sampled specifically for DOE Order monitoring during CY 2009 are located near waste management facilities in BCV (Table B.2 and Figure A.11), including the primary sources of groundwater contamination in the regime (S-3 Site, OLF WMA, and BCBG WMA). One of these wells is equipped with Westbay ${ }^{\mathrm{TM}}$ multi-port sampling equipment (Westbay well GW-726), with groundwater samples collected in May 2009 from seven discrete depths intervals in the well (Figure A.12). The remaining five wells are components of two Exit Pathway Pickets in the regime: Picket B (GW-703) is located about 2,000 ft west of the Oil Landfarm and Picket C (GW-724, GW-725, GW-738, and GW-740) is located about 3,000 ft west of the S-3 Site (Figure A.13). The wells in each Exit Pathway Picket are completed at various depths along strike-normal transects of the Maynardville Limestone (MMES 1990b), which is the primary contaminant migration pathway in the Bear Creek Regime.

The springs that were sampled during CY 2009 specifically for DOE Order exit pathway/perimeter monitoring discharge into Bear Creek (Table B.2 and Figure A.11), and are located southwest (hydraulically downgradient) of the OLF (SS-4) and the BCBG WMA (SS-5). The surface water stations include three locations in Bear Creek (BCK-04.55, BCK-09.40, and BCK.11.97) and a northern tributary of Bear Creek (NT-01) about 1,500 ft west of the S-3 Site (Figure A.11).

Groundwater samples were collected from six monitoring wells and one spring to meet RCRA post-closure corrective action monitoring requirements in the Bear Creek Regime during CY 2009 (Table B.2). These wells include point-of-compliance (POC) wells located downgradient of the S-3 Site (GW-276), the OLF (GW-008), and the BCBG WMA (GW-046); three plume boundary wells (GW-712, GW-713, and GW-714) at Exit Pathway Picket W (Figure A.11 and Figure A.13). Spring SS-6 also serves as a plume boundary monitoring location (Figure A.11).

A total of 44 monitoring locations in the Bear Creek Regime were sampled to meet CERCLA monitoring requirements during CY 2009 (Table B.2 and Figure A.11). Eight wells, five springs, and 13 surface water 
stations were sampled to support CERCLA ROD monitoring requirements. Fourteen wells and five surface water stations were sampled for CERCLA detection monitoring purposes at the EMWMF. Two surface water stations located near the BCBG WMA (NT-07 and NT-08) were sampled for CERCLA baseline monitoring purposes (Figure A.11).

\subsubsection{East Fork Regime}

As shown below in Table 2, a total of 83 monitoring wells, three springs, and five surface water stations in the East Fork Regime (and surrounding areas) were sampled during CY 2009 to meet the requirements of DOE Order monitoring, RCRA monitoring, and CERCLA monitoring. Table B.3 identifies the monitoring program applicable to each well, spring, and surface water station.

Table 2. CY 2009 sampling locations in the East Fork Regime, north of Pine Ridge, and in Union Valley

\begin{tabular}{|c|c|c|c|}
\hline Monitoring Driver & Monitoring Wells & Springs & Surface Water Stations \\
\hline $\begin{array}{l}\text { DOE Order } \\
\text { RCRA } \\
\text { CERCLA }\end{array}$ & $\begin{array}{c}61 \\
5 \\
18\end{array}$ & $\begin{array}{l}1 \\
0 \\
2\end{array}$ & $\begin{array}{l}3 \\
0 \\
2\end{array}$ \\
\hline Totals: & $83 *$ & 3 & 5 \\
\hline
\end{tabular}

Most of the CY 2009 sampling locations lie within the boundaries of the East Fork Regime. However, five wells and two springs are located in Union Valley east the ORR boundary at Scarboro Road (Figure A.14), and three surface water stations are located in drainage features along the ORR boundary on the north side of Pine Ridge (Figure A.15). Samples were collected from the locations either annually (59 wells, three springs, three surface water stations) or semiannually (24 wells and three surface water stations).

Fifty-four monitoring wells in East Fork Regime, most of which are located within the western and central areas of Y-12 (Figure A.14), were sampled during CY 2009 specifically to meet DOE Order surveillance monitoring requirements (Table B.3). Seven monitoring wells, a spring (SP-17), and three surface water locations were sampled to meet DOE Order exit pathway/perimeter monitoring requirements (Table B.3). The exit pathway wells are located between UEFPC and Scarboro Road at the east end of Y-12, except for one well (GW-816) that is located next to UEFPC in the gap through Pine Ridge northeast of Y-12 (Figure A.14). One well is equipped with Westbay ${ }^{\mathrm{TM}}$ multi-port sampling equipment (Westbay well GW-722), with groundwater samples collected in July 2009 from five discrete depths intervals in the well (Figure A.16). The surface water stations are located north of Pine Ridge (Figure A.15), and samples were collected in January 2009 (Table B.3).

Groundwater samples were collected from five wells to meet RCRA post-closure corrective action monitoring requirements in the East Fork Regime during CY 2009. These wells include one POC well (GW-108) which is located in the western Y-12 area about $800 \mathrm{ft}$ southeast of the S-3 Site, and four plume delineation wells (GW-193, GW-605, GW-606, and GW-733) which are located several thousand $\mathrm{ft}$ east-southeast of the S-3 Site (Figure A.14). 
Eighteen monitoring wells, two springs, and two surface water stations were sampled during CY 2009 specifically to meet CERCLA monitoring requirements (Table B.3). Thirteen monitoring wells and two springs were sampled for CERCLA ROD monitoring purposes. Eight of these monitoring wells (GW-151, GW-154, GW-223, GW-380, GW-382, GW-722 [five discrete sampling depths], GW-762, and GW-832) are located in the eastern Y-12 area (Figure A.14). The surface water stations (200A6 and Station 8) are located in the central Y-12 area (Figure A.14). The other five monitoring wells and the springs are located in Union Valley east of the ORR boundary along Scarboro Road (Figure A.14).

\subsubsection{Chestnut Ridge Regime}

As shown below in Table 3, a total of 41 monitoring wells, five springs, and seven surface water stations in the Chestnut Ridge Regime were sampled during CY 2009 to meet the requirements of DOE Order monitoring, SWDF detection monitoring, RCRA monitoring, and CERCLA monitoring. Table B.4 identifies the monitoring program applicable to each well, spring, and surface water station; their locations are shown on Figure A.17.

Table 3. CY 2009 sampling locations in the Chestnut Ridge Regime

\begin{tabular}{|c|c|c|c|}
\hline Monitoring Driver & Monitoring Wells & Springs & Surface Water Stations \\
\hline $\begin{array}{c}\text { DOE Order } \\
\text { SWDF } \\
\text { RCRA } \\
\text { CERCLA }\end{array}$ & $\begin{array}{c}5 \\
17 \\
15 \\
4\end{array}$ & $\begin{array}{l}2 \\
1 \\
0 \\
2\end{array}$ & $\begin{array}{l}3 \\
0 \\
0 \\
4\end{array}$ \\
\hline Totals: & 41 & 5 & 7 \\
\hline
\end{tabular}

Groundwater samples were collected semiannually from most (36) of the monitoring wells, with samples collected annually from eight wells (Table B.4). Samples from the springs and surface water stations were collected annually (five locations) and semiannually (six locations).

Five monitoring wells located near the CRSP (GW-174, GW-175, GW-176, GW-180, and GW-322) were sampled specifically for DOE Order surveillance monitoring purposes during CY 2009 (Figure A.17 and Table B.4). Springs and surface water sampling locations used for DOE Order exit-pathway/perimeter monitoring are located in the southwestern portion of the regime (springs SCR2.1SP and SCR2.2SP) and along Bethel Valley Road in main channels of drainage features (surface water stations SCR1.5SW, SCR3.5SW, and S17) where surface water exits the Chestnut Ridge Regime (Figure A.17).

Seventeen monitoring wells and one spring were sampled during CY 2009 to meet SWDF monitoring requirements (Table B.4). The monitoring wells are located at four SWDFs: three wells at ILF II; five wells at ILF IV; five wells at ILF V; and four wells at CDL VII (Figure A.17). Well GW-205 at the United Nuclear Corporation Site was selected to serve as the plume delineation well for SWDF assessment monitoring at ILF IV. Spring SCR4.3SP, sampled for SWDF detection monitoring at ILF V, is located about 2,400 ft southeast of the site (Figure A.17).

Groundwater samples were collected from 15 monitoring wells to meet RCRA monitoring requirements during CY 2009 in the Chestnut Ridge Regime: three wells for RCRA post-closure corrective action monitoring and 12 wells for RCRA post-closure detective monitoring (Table B.4). RCRA post-closure corrective action monitoring at the CRSP included one POC well (GW-177) located at the west end of the 
site and two plume delineation wells: GW-301 at the former Chestnut Ridge Borrow Area Waste Pile about 3,000 ft east of the site and GW-831 at the Filled Coal Ash Pond (FCAP) about 2,000 ft southwest of the site (Figure A.17). Note that the SWDF detection monitoring results for five monitoring wells and one spring also serve the purposes of RCRA post-closure corrective action monitoring at the CRSP. The monitoring wells include one background well (GW-521) and four plume delineation wells (GW-557, GW-562, GW-799, and GW-801) (Table B.4 and Figure A.17). The spring sampling location (SCR4.3SP) is located south of CDL VII (Figure A.17). During CY 2009, RCRA post-closure detection monitoring included four wells at the Chestnut Ridge Sediment Disposal Basin (CRSDB), four wells at the East Chestnut Ridge Waste Pile (ECRWP), and four wells at KHQ (Table B.4). The RCRA monitoring well network at the CRSDB includes one well (GW-159) located hydraulically upgradient (northwest) of the site and three POC wells (GW-156, GW-731, and GW-732) to the east-southeast (hydraulically downgradient) of the site (Figure A.17). One upgradient/background well (GW-231) and three downgradient POC wells (GW-143, GW-144, and GW-145) comprise the RCRA monitoring well network at KHQ (Figure A.17). The RCRA monitoring network for CY 2009 at the ECRWP included the upgradient/background well (GW-294) and three POC wells (GW-161, GW-296, and GW-298) located hydraulically downgradient of the site (Figure A.17).

Samples were collected from four monitoring wells, two springs, and four surface water stations to meet CERCLA monitoring requirements in the Chestnut Ridge Regime during CY 2009 (Table B.4). The wells and one surface water station are located at the United Nuclear Corporation Site (Figure A.17). One spring (SCR1.25SP) is located along Dunaway Branch in the southwestern portion of the regime, and a spring (SCR3.5SP) and three surface water stations (MCK 1.4, MCK 2.0, and MCK 2.05) are located along McCoy Branch (Figure A.17).

\subsection{QUALITY ASSURANCE/QUALITY CONTROL SAMPLING}

Quality assurance/quality control sampling activities managed by the Y-12 GWPP during CY 2009 were performed to ensure that the highest level of quality in sampling provided representative groundwater results. Comparable QA/QC sampling protocols also were performed under monitoring programs managed by BJC (BJC 2009c and EnergySolutions 2007).

As shown in Table 4, the QA/QC samples associated with the groundwater and surface water monitoring performed under the Y-12 GWPP during CY 2009 included 57 trip blanks, 38 method (laboratory) blanks, two field blanks, two equipment rinsate samples, and 15 duplicate groundwater and surface water samples.

Table 4. QA/QC samples analyzed in CY 2009 for the Y-12 GWPP

\begin{tabular}{|r|c|c|c|c|c|}
\hline \multirow{2}{*}{ Sample Type } & \multicolumn{2}{|c|}{ Total Number of Samples per Quarter of CY 2009 } & \multirow{2}{*}{$\begin{array}{c}\text { Annual } \\
\text { Total }\end{array}$} \\
\cline { 2 - 5 } & First & Second & Third & Fourth & 57 \\
Trip Blank Samples & 16 & 15 & 13 & 13 & $\mathbf{5}$ \\
Method Blank Samples & 8 & 10 & 10 & 10 & $\mathbf{3 8}$ \\
Field Blank Samples & 1 & 0 & 1 & 0 & $\mathbf{2}$ \\
Equipment Rinsate Samples & 0 & 1 & 1 & 0 & $\mathbf{2}$ \\
\hline Duplicate Samples & 4 & 4 & 4 & 3 & $\mathbf{1 5}$ \\
\hline
\end{tabular}

The blanks and equipment rinsate samples were prepared and analyzed as specified in the Field Quality Control Samples operating procedure (B\&W Y-12 2009a). Analytical results for the blank samples help assess the environmental conditions in the field and laboratory under which associated groundwater and surface water samples were collected, transported, stored, and analyzed. Trip blanks were samples of 
analyte-free water prepared in the laboratory and transported to the field and then to the laboratory in coolers containing groundwater and surface water samples. Field blanks were samples of analyte-free water that were transported to the field in a sealed glass container and transferred to sample bottles at monitoring wells GW-623 (first quarter) and 56-3C (third quarter) and then transported to the laboratory in a cooler containing the other samples from the well. Method blanks were samples of analyte-free water that were prepared in the laboratory and analyzed along with one or more associated groundwater or surface water samples. The equipment rinsates are samples of the analyte-free water from the final rinse of the decontaminated portable sampling equipment after sampling was completed at Westbay wells GW-726 (second quarter) and GW-722 (third quarter).

Method blanks, trip blanks, field blanks, and equipment rinsate samples were analyzed for VOCs. Appendix $G$ provides summaries of detected results for the QA/QC blanks and equipment rinsate samples and shows the method blank and trip blank samples associated with each groundwater and surface water sample collected under management of the GWPP during CY 2009.

A total of 15 field duplicate samples were collected during CY 2009 from five wells and one surface water station in the Bear Creek Regime (Table B.2), seven wells and a spring in the East Fork Regime (Table B.3), and one well in the Chestnut Ridge Regime (Table B.4). The duplicate samples were analyzed for the same constituents and parameters specified for the sampling location from which they were collected. Analytical results for the duplicates are presented with the regular sample results in Appendices D, E, and F.

\subsection{SAMPLE COLLECTION AND HANDLING}

The following discussion pertains to the groundwater and surface water sampling activities managed by the Y-12 GWPP during CY 2009. Personnel with the Environmental Sampling Section of the Y-12 Environmental Compliance Department were responsible for collection, transportation, and chain-of-custody control of the groundwater and surface water samples during CY 2009. Sampling throughout the year was performed in accordance with the most recent version of the technical procedures approved by the Y-12 GWPP Manager (BWXT Y-12, L.L.C. [BWXT] 2002, BWXT 2007a, and BWXT 2008). All samples were collected in appropriate containers, preserved as required, labeled, logged, placed in ice-filled coolers, and transported to the designated laboratory in accordance with chain-of-custody control requirements (B\&W Y-12 2009b). Similar protocols were followed under the monitoring programs managed by BJC during CY 2009 (Commodore Advanced Sciences, Inc. [CASI] 2009).

Unfiltered samples were collected from the monitoring wells, springs, and surface water stations in each hydrogeologic regime during CY 2009. Groundwater samples were collected from most monitoring wells with dedicated bladder pumps (Well Wizard ${ }^{\mathrm{TM}}$ ). However, samples were obtained from two wells equipped with a dedicated Westbay ${ }^{\mathrm{TM}}$ multi-port sampling apparatus (wells GW-722 and GW-726).

The low-flow minimal drawdown sampling method (low-flow sampling) was used to obtain groundwater samples from the wells equipped with dedicated bladder pumps. Under this method, a representative sample is obtained without introducing stagnant water from the well casing. To obtain the sample, groundwater is pumped from the well at a flow rate which is low enough ( $<300$ milliliters per minute) to minimize drawdown of the water level in the well $(<0.1 \mathrm{ft}$ per quarter-hour). At five-minute intervals after the water-level drawdown has stabilized, field personnel record measurements of the $\mathrm{pH}$, conductivity, water temperature, oxidation-reduction potential (REDOX), and dissolved oxygen. Samples of the 
groundwater in the well are collected once the field measurements for each parameter show minimal variation over four consecutive readings.

Groundwater samples were collected from Westbay wells GW-722 and GW-726 in accordance with the most recent and approved version of the operating procedures for the multi-port sampling equipment (BWXT 2007a and BWXT 2007b). Four 250-milliliter non-vented stainless steel sample collection bottles are used to obtain groundwater samples from the sampling ports. The sample collection bottles are lowered to the designated sampling port, the sampling port valve is opened remotely, and the bottles are allowed to fill with groundwater. The filled bottles are retrieved to the surface and the contents are poured into the appropriate laboratory sample bottle(s). The sample collection bottles are lowered, filled, and retrieved as many times as needed to completely fill the laboratory sample bottles. Groundwater in the first sample collection bottle retrieved from each sampling port is used as a "formation rinse" to obtain field measurements and to condition the sample collection bottles.

Passive (no purge) sampling methods were used to evaluate groundwater quality at 34 wells during CY 2009. A passive diffusion bag (PDB) was used to evaluate VOC concentrations in groundwater in 31 of these wells, including nine wells in the Bear Creek Regime (Appendix D), 17 wells in the East Fork Regime (Appendix E), and five wells in the Chestnut Ridge Regime (Appendix F). The PDB sampling method is suitable only for monitoring for the presence and concentration of selected VOCs in groundwater. This method involves suspending a polyethylene bag (semipermeable membrane) filled with analyte-free water at a selected depth within the monitored interval of the well and leaving the PDB in place for a prescribed period (at least two weeks). The chemical concentration gradient between the uncontaminated analyte-free water in the PDB and the surrounding contaminated groundwater induces VOCs in the groundwater to diffuse through the bag into the analyte-free water until equilibrium conditions are achieved. When retrieved, the water in the PDB is decanted into VOC sample bottles (U.S. Geological Survey 2001).

A "no-purge method" was used for wells that have demonstrated a very low pumping rate $(<50 \mathrm{ml} / \mathrm{min})$ to meet the minimal drawdown requirement during purging and sample collection. During CY 2009, the no-purge method was used to collect groundwater samples from two wells (GW-065 and GW-623) in the Bear Creek Regime and one well (56-4A) in the East Fork Regime. For this method, field measurements were obtained and groundwater samples were collected after pumping the stagnant water (calculated volume) from the tubing.

\subsection{FIELD MEASUREMENTS AND LABORATORY ANALYTES}

The following discussion pertains to the field measurements and laboratory analytes associated with the CY 2009 groundwater and surface water sampling activities directed by the Y-12 GWPP. Identical or functionally equivalent field measurements and laboratory analyses were performed under monitoring programs managed by BJC during CY 2009 (BJC 2007a, BJC 2009b, BJC 2009c, and EnergySolutions 2007).

Field personnel measured the depth to the static water surface before sampling groundwater in each monitoring well (except wells GW-722 and GW-726, and all wells sampled using PDBS.) and recorded field measurements of $\mathrm{pH}$, temperature, conductivity, dissolved oxygen, and REDOX for each groundwater and surface water sampling location (Table B.5). The depth to the static water level was converted from pressure measurements for each sampling port in wells GW-722 and GW-726. Additionally, REDOX and dissolved oxygen were not recorded for wells GW-722 and GW-726 (not applicable when a well is equipped with a multiport sampling apparatus). Field measurements were obtained in accordance with the 
most recent and approved technical procedures referenced in the CY 2009 SAP for the Y-12 GWPP (B\&W Y-12 2008). The field measurements recorded for the sampling locations in each regime are presented in Appendix D (Bear Creek Regime), Appendix E (East Fork Regime), and Appendix F (Chestnut Ridge Regime).

Most of the CY 2009 groundwater samples and surface water samples were analyzed for: (1) miscellaneous laboratory analytes-total suspended solids and total dissolved solids; (2) major ions and trace metals; (3) VOCs; and (4) gross alpha and gross beta activity (Table B.5). The Y-12 GWPP implemented selective parameter monitoring during CY 2009 on samples from monitoring wells with analytical results for at least eight groundwater samples obtained since January 1991 (B\&W Y-12 2008). Historical data clearly demonstrate that the selected parameters are the contaminants of concern and provide sufficient data for the other parameters. For example, samples from 35 monitoring wells were analyzed only for VOCs, and historical data for these locations show consistently low results for inorganic and radiochemical analytes. The CY 2009 results provide the data necessary to meet requirements of the Y-12 GWPP monitoring program.

Laboratory analyses of the samples were performed by the Y-12 Analytical Chemistry Organization (ACO) laboratories in accordance with the analytical methods and procedures listed in Table B.5. Analytical results are presented in Appendix D (Bear Creek Regime), Appendix E (East Fork Regime), and Appendix F (Chestnut Ridge Regime).

The analytical method used for mercury concentrations in groundwater and surface water samples was modified during CY 2009 to achieve a significantly lower reporting limit $(0.00005 \mathrm{mg} / \mathrm{L})$. The lower reporting limit can address whether groundwater may have been an undetected contributor of mercury to UEFPC. The issue is that the previous reporting limit $(0.0002 \mathrm{mg} / \mathrm{L})$ may not have been low enough to detect concentrations of mercury possibly entrained by groundwater.

\subsection{DATA MANAGEMENT AND DQO EVALUATION}

The following discussion pertains to the data management protocols associated with the CY 2009 groundwater and surface water sampling activities directed by the Y-12 GWPP. Field measurements and results of specified laboratory analyses performed for the samples collected from each well, spring, and surface water station during CY 2009 were provided to the GWPP in electronic files and hardcopy printouts provided by the ACO. Electronic files and hardcopy printouts of $10 \%$ of the monitoring data obtained under the Y-12 GWPP were verified in accordance with the Y-12 Groundwater Protection Program Data Management Plan (BWXT 2003a). Appropriate ACO staff and personnel in the B\&W Y-12 Information Technology Department worked to resolve any incomplete data transfers, irregular parameter names or reporting units, and discrepancies between electronic and hardcopy versions of the data. All data management functions were performed using Microsoft Access to maintain the GWPP Analytical Data Management System, a component of the GWPP Groundwater Information Management System (GIMS).

The BJC data management process (BJC 2007b and BJC 2009c) is similar to the process described above for the Y-12 GWPP. Analytical results and field measurements associated with monitoring programs managed by BJC were extracted from the Project Environmental Measurements System or the Oak Ridge Environmental Information System and uploaded into the GWPP GIMS by personnel in the B\&W Y-12 Information Technology Department. Data were then extracted from GIMS and formatted for presentation in this report. 
The CY 2009 groundwater and surface water monitoring data presented in this report have been evaluated with respect to the DQO criteria defined in the Y-12 Groundwater Protection Program Data Management Plan (BWXT 2003a). Specific DQO criteria apply to analytical results for field measurements, major ions, trace metals, VOCs, radiological analytes (gross alpha, gross beta, and radionuclides), and miscellaneous laboratory analytes (e.g., total suspended solids). Monitoring results that do not meet applicable DQOs are flagged with an "R" or "Q" qualifier and described in the introductory section of the applicable data appendices (Appendix D, Appendix E, and Appendix F). Functionally equivalent DQO criteria were employed for most of the monitoring programs managed by BJC (BJC 2007b and BJC 2009c). All of the data obtained to meet RCRA and SWDF monitoring requirements have been similarly evaluated; however, portions of the data obtained to meet CERCLA monitoring requirements have not been fully evaluated. Therefore, some results obtained during 2009 from BJC that are presented in this report may not meet the GWPP DQOs.

\subsection{GROUNDWATER ELEVATION MONITORING}

As shown in Table 5, selected monitoring wells in the Bear Creek, East Fork, and Chestnut Ridge hydrogeologic regimes were used to monitor groundwater elevations during seasonally high flow conditions in CY 2009.

Table 5. Summary of CY 2009 groundwater elevation monitoring in the Bear Creek, East Fork, and Chestnut Ridge regimes

\begin{tabular}{|r|c|c|c|c|}
\hline \multirow{2}{*}{ REGIME } & \multicolumn{2}{|c|}{$\begin{array}{c}\text { DEPTH-TO-WATER } \\
\text { MEASUREMENTS }\end{array}$} & \multicolumn{2}{c|}{$\begin{array}{c}\text { GROUNDWATER } \\
\text { ELEVATIONS }\end{array}$} \\
\cline { 2 - 5 } & No. of Wells & Dates & Data & Isopleth Map \\
\hline Bear Creek & 76 & April 8-9, 2009 & Table B.6 & Figure A.4 \\
East Fork & 62 & April 7-9, 2009 & Table B.7 & Figure A.5 \\
Chestnut Ridge & 77 & April 7-8, 2009 & Table B.8 & Figure A.6 \\
\hline
\end{tabular}

Field personnel with the Environmental Sampling Section of the Y-12 Environmental Compliance Department measured the depth to the static water surface in each well in accordance with the operating procedure (BWXT 2004). 



\subsection{CY 2009 MONITORING DATA}

The monitoring data obtained in CY 2009 for compliance with the groundwater monitoring and reporting requirements of DOE Order 450.1A is presented in this section. Separate discussions of the surveillance monitoring and exit pathway/perimeter monitoring data are provided for the Bear Creek, East Fork, and Chestnut Ridge hydrogeologic regimes. Each discussion of data focuses on the analytical results for the principal groundwater contaminants at Y-12, which are nitrate, uranium, VOCs, and gross alpha activity, and gross beta activity. Elevated levels of the contaminants are defined as results that exceed the following screening levels: (1) nitrate concentrations above the MCL for drinking water (10 mg/L); (2) total uranium concentrations above the MCL (0.03 mg/L); (3) individual VOC concentrations exceeding applicable MCLs or summed VOC concentrations exceeding $5 \mu \mathrm{g} / \mathrm{L}$; (4) gross alpha activity above the MCL (15 pCi/L); and (5) gross beta radioactivity above the SDWA screening level of $50 \mathrm{pCi} / \mathrm{L}$ for a $4 \mathrm{mrem} / \mathrm{yr}$ dose equivalent (the MCL for gross beta activity).

A more detailed analysis and interpretation of the monitoring data for groundwater and surface water sampling locations is contained in the Y-12 Groundwater Protection Program Groundwater Monitoring Data Compendium (B\&W Y-12 2009c), hereafter referenced as the GWPP Compendium. For each applicable well, spring, and surface water station, the GWPP compendium provides (1) a complete sampling history, including sampling methods and distinguishing sampling characteristics; (2) an evaluation of hydrologic data (pre-sampling groundwater elevations and available aquifer test data); (3) a discussion of geochemical characteristics of the groundwater or surface water; and (4) a thorough evaluation of the available sampling results for nitrate, uranium, VOCs, gross alpha activity, and gross beta activity, including data summary tables and trend graphs.

In addition to the data evaluation in the GWPP compendium, the following technical reports issued by BJC analyze and interpret the CY 2009 monitoring results for the applicable RCRA, CERCLA, and SWDF sampling locations in the Bear Creek Regime, East Fork Regime, and Chestnut Ridge Regime: the 2010 Remediation Effectiveness Report (DOE 2010), the Calendar Year 2009 Resource Conservation and Recovery Act Annual Monitoring Report (BJC 2010a), the Annual Report for 2008 - 2009 Detection Monitoring at the Environmental Management Waste Management Facility (BJC 2010b) and each semiannual Groundwater Monitoring Report for the Oak Ridge Reservation Landfills (BJC 2009d and BJC 2009e).

\subsection{SURVEILLANCE MONITORING}

Groundwater quality monitoring data collected during CY 2009 were evaluated to determine if any changes have occurred in areas that are, or could be, affected by Y-12 operations. Due to inherent differences in their characteristics, these evaluations were done for each hydrogeologic unit (aquitard and aquifer) within each hydrogeologic regime (Bear Creek, East Fork, and Chestnut Ridge).

\subsubsection{Bear Creek Regime}

In CY 2009, groundwater samples were collected from 63 surveillance monitoring wells in the Bear Creek Regime (Table B.2). Forty-one of these wells are completed in the geologic formations comprising the aquitard in BCV (Nolichucky Shale, Maryville Limestone, Rogersville Shale, Pumpkin Valley Shale, and 
Rome Formation). Twenty-two wells are completed in the geologic formations that comprise the aquifer in BCV (Copper Ridge Dolomite and Maynardville Limestone).

\subsubsection{Aquitard Wells}

Elevated concentrations of one or more of the principal groundwater contaminants at Y-12 were reported for the groundwater samples collected during CY 2009 from 23 aquitard wells in the Bear Creek Regime (Table B.9). The presence of contaminants in the groundwater at these wells is attributable to the transport/migration of the mobile components of the groundwater contaminant plumes emplaced during historical operations of the former S-3 Ponds, the OLF WMA, and the BCBG WMA. These sites are closed former hazardous waste disposal units that are presently regulated under a RCRA post-closure permit. Additionally, the types and concentrations of contaminants detected in the groundwater samples collected from these wells during CY 2009 are generally consistent with the overall extent of nitrate (Figure A.7), total uranium, VOCs (Figure A.8), gross alpha activity (Figure A.9), and gross beta activity (Figure A.10) defined by the available data for the existing network of wells completed in the aquitard formations in BCV west of $\mathrm{Y}-12$.

\section{Nitrate and Uranium}

As shown in Table 6, elevated concentrations of nitrate ( $>10 \mathrm{mg} / \mathrm{L})$ and/or total uranium $(>0.03 \mathrm{mg} / \mathrm{L})$ were reported for at least one groundwater sample collected during CY 2009 from nine aquitard wells in the Bear Creek Regime, listed below in sequence from closest to farthest from the S-3 Site (from northeast [hydraulically upgradient] to southwest [hydraulically downgradient]), which is the source of the nitrate and uranium in the groundwater from each well.

Table 6. Bear Creek Regime CY 2009: elevated nitrate and uranium concentrations in surveillance monitoring aquitard wells

\begin{tabular}{|c|c|c|c|c|c|c|c|}
\hline \multirow{3}{*}{$\begin{array}{c}\begin{array}{c}\text { Well } \\
\text { Number }\end{array} \\
\text { GW-615 } \\
\text { GW-246 }\end{array}$} & \multirow{2}{*}{\multicolumn{2}{|c|}{$\begin{array}{c}\text { Direction - Distance } \\
\text { from S-3 Site } \\
\text { (Figure A.7) } \\
\end{array}$}} & \multirow{3}{*}{$\begin{array}{c}\begin{array}{c}\text { Total Depth } \\
\text { (ft bgs) }\end{array} \\
245 \\
76\end{array}$} & \multicolumn{2}{|c|}{ Nitrate (mg/L) } & \multicolumn{2}{|c|}{ Uranium (mg/L) } \\
\hline & & & & \multirow{2}{*}{$\begin{array}{c}\text { Jan-Feb } \\
\mathbf{2 0 0 9} \\
10,400 \\
\text { NS }\end{array}$} & \multirow{2}{*}{$\begin{array}{c}\begin{array}{c}\text { Jul-Aug } \\
\mathbf{2 0 0 9}\end{array} \\
\text { NS } \\
2,829\end{array}$} & \multirow{2}{*}{$\begin{array}{c}\text { Jan-Feb } \\
\mathbf{2 0 0 9} \\
1.33 \\
\text { NS }\end{array}$} & \multirow{2}{*}{ 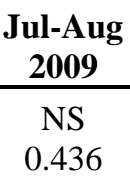 } \\
\hline & South & $\begin{array}{l}50 \mathrm{ft} \\
50 \mathrm{ft}\end{array}$ & & & & & \\
\hline GW-276 & Southeast & $200 \mathrm{ft}$ & 18.5 & 12.2 & 11 & 0.39 & 0.35 \\
\hline GW-127 & Southwest & $300 \mathrm{ft}$ & 24 & $<$ & NS & 0.0534 & NS \\
\hline GW-616 & & $400 \mathrm{ft}$ & 269 & NS & 255 & NS & NA \\
\hline GW-101 & West & $160 \mathrm{ft}$ & 17.5 & 20.1 & NS & $<$ & NS \\
\hline GW-526 & & $1,300 \mathrm{ft}$ & 114.6 & 1,560 & NS & NA & NS \\
\hline GW-537 & & $2,500 \mathrm{ft}$ & 23.3 & NS & 397 & NS & NA \\
\hline GW-085 & & $3,000 \mathrm{ft}$ & 58.8 & 97.4 & NS & NA & NS \\
\hline \multicolumn{4}{|c|}{ MCL } & \multicolumn{2}{|c|}{10} & \multicolumn{2}{|c|}{0.03} \\
\hline
\end{tabular}

These sampling results show that the highest concentrations of nitrate occur in the groundwater from wells located directly south (geologically down-dip) of the S-3 Site (GW-246 and GW-615), reflecting the density-driven vertical (dip-parallel) migration of the highly mineralized acidic wastes disposed at the site. The very high nitrate levels in the groundwater samples from well GW-526 confirm the substantial westward transport of nitrate via strike-parallel flowpaths (e.g., bedding plane fractures) at depth (>100 ft bgs) in the Nolichucky Shale. The high nitrate concentration in the shallow groundwater from 
well GW-537 (Figure A.7) is believed to reflect upwelling of nitrate-contaminated groundwater from deeper flowpaths toward discharge features along NT-2. The elevated nitrate levels in the groundwater from well GW-085 indicate continued westward transport of nitrate in the shallow flow system west of NT-2, at least 3,000 ft from the S-3 Site.

As with nitrate, the CY 2009 groundwater sampling results show that the highest concentrations of total uranium occur geologically down-dip to the south of the S-3 Site. Elevated uranium concentrations in the Nolichucky Shale occur only in the low-pH groundwater within approximately $500 \mathrm{ft}$ of the S-3 Site.

The CY 2009 sampling results for the wells listed in Table 6 support the long-term concentration trends (Table B.9), with time-series plots of the nitrate and uranium data (excluding analytical results that do not meet applicable DQOs) for these wells generally showing:

- Decreasing concentration trends for wells GW-101 (nitrate), GW-127 (uranium), GW-276 (nitrate and uranium), and GW-537 (nitrate), as illustrated by the nitrate data for wells GW-276 and GW-537 (Figure A.18). The decreasing trends reflect substantially reduced flux of nitrate and uranium in the groundwater following closure of the S-3 Ponds and installation of a low-permeability cap in 1988. Additionally, the decreasing concentrations may reflect the long-term cumulative effects of various natural attenuation processes.

- Indeterminate trends for nitrate concentrations at wells GW-085, GW-246, GW-615, and GW-616 and for uranium concentrations at well GW-246. For example, data for well GW-246 (Figure A.18) show little if any change in the uranium concentrations evident in March 1987 (0.464 mg/L) and August 2009 (0.436 mg/L). Additionally, the long-term stable trend for nitrate concentrations at well GW-246 seems unusual in light of the substantially reduced flux after the S-3 Ponds were closed and capped. The trend is probably a function of the extensive mass of nitrate and uranium emplaced in the Nolichucky Shale beneath the site and the relatively low-permeability of the hydrostratigraphic zone intercepted by the monitored interval in the well.

- Increasing trends for nitrate concentrations at well GW-526 and for uranium concentrations at well GW-615 (Figure A.18). The increasing concentrations of uranium indicated by the data for well GW-615 potentially reflect a long-term increase in the relative vertical flux of uranium down-dip of the site. This increase is somewhat conspicuous in light of the indeterminate trend for nitrate at well GW-615, which is far more mobile in groundwater than uranium.

\section{Volatile Organic Compounds}

Groundwater samples collected during CY 2009 from 16 aquitard wells in the Bear Creek Regime contained one or more dissolved VOCs at individual or summed concentrations of $5 \mu \mathrm{g} / \mathrm{L}$ or more (Table B.9). As shown in Table 7, the maximum concentration of ten VOCs reported for groundwater samples collected from 15 of these wells exceed the respective drinking water MCLs. The presence of dissolved VOCs in the groundwater at these wells reflects their transport/migration from the contaminant source areas emplaced during historical operations of the S-3 Ponds (three wells), OLF (two wells), and various waste disposal areas within the BCBG WMA (11 wells). 
Table 7. Bear Creek Regime CY 2009: maximum VOC concentrations in surveillance monitoring aquitard wells

\begin{tabular}{|c|c|c|c|c|c|c|c|c|c|c|c|}
\hline \multirow{2}{*}{$\begin{array}{c}\text { Location/ } \\
\text { Well } \\
\text { Number } \\
\text { (Figure A.8) }\end{array}$} & \multicolumn{11}{|c|}{ Concentration $(\mu \mathrm{g} / \mathrm{L})$} \\
\hline & PCE & TCE & C12 DCE & 11DCE & VC & $\begin{array}{c}111 \\
\text { TCA }\end{array}$ & $\begin{array}{c}112 \\
\text { TCA }\end{array}$ & $\begin{array}{c}12 \\
\text { DCA }\end{array}$ & 11DCA & MC & Benzene \\
\hline \\
\hline GW-246 & 97 & $<$ & . & $<$ & . & . & . & . & . & 15 & . \\
\hline GW-276 & 6.43 & . & . & . & . & . & . & . & . & & . \\
\hline GW-615 & 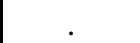 & . & . & . & . & . & . & . & . & 5 & . \\
\hline \multicolumn{12}{|l|}{ OLF } \\
\hline GW-008 & 51 & 11.3 & $<$ & $<$ & . & . & . & . & 13 & . & $<$ \\
\hline GW-098 & $\cdot$ & 7 & $<$ & $<$ & . & . & . & . & . & & . \\
\hline \multicolumn{12}{|l|}{ BCBG } \\
\hline GW-014 & 28 & 160 & 710 & 34 & 120 & . & . & . & 180 & . & $<$ \\
\hline GW-046 & 1,300 & 783 & 2,730 & 98 & 320 & 85 & . & . & 360 & & 180 \\
\hline GW-068 & $<$ & 93 & 1,900 & 180 & 320 & . & . & . & 850 & . & 110 \\
\hline GW-071 & 610 & 63 & $<$ & 78 & 3 & 200 & . & . & 2,900 & & 1,500 \\
\hline GW-082 & & $<$ & 150 & $<$ & 92 & . & . & . & 77 & & $<$ \\
\hline GW-242 & 5 & $<$ & $<$ & . & 18 & . & . & . & 4 & . & . \\
\hline GW-289 & 260 & 12 & 2 & & 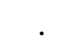 & . & . & . & . & & 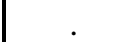 \\
\hline GW-623 & 25,000 & 19,000 & 640 & 290 & 150 & . & . & . & 3,300 & 29 & 10 \\
\hline GW-627 & 870 & 330 & 45 & 49 & 78 & 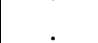 & & . & 130 & & . \\
\hline GW-629 & 180,000 & 24,000 & & 2,700 & . & 1,200 & 43 & 24 & 11,000 & & . \\
\hline GW-653 & 13 & 24 & 190 & 5 & . & . & 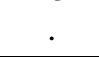 & . & 11 & . & . \\
\hline MCL & 5 & 5 & 70 & 7 & 2 & 200 & 5 & 5 & NA & 5 & 5 \\
\hline
\end{tabular}

As shown in the preceding data summary, extremely high concentrations $(>1,000 \mu \mathrm{g} / \mathrm{L})$ of VOCs, especially PCE and c12DCE, were detected in the groundwater samples collected from several wells located at the BCBG. These results primarily reflect migration/transport of dissolved VOCs at depth (>300 ft bgs) in the Nolichucky Shale directly south (down dip) and/or southwest (along strike) of BG-A South (Figure A.8).

The CY 2009 sampling results for the wells listed in Table 7 support long-term summed VOC (e.g., chloroethenes) concentration trends (Table B.9), with time-series plots of the VOC data for each well generally showing:

- Decreasing concentration trends for VOCs in groundwater from wells GW-014, GW-071, GW-098, and GW-276, as illustrated by the PCE results for wells GW-014 and GW-276 (Figure A.19). The decreasing concentration trends reflect a combination of several factors, primarily the substantially reduced flux of VOCs following closure of the former S-3 Ponds, OLF WMA, and BCBG WMA, the components of which were closed in 1986-1988 and covered by low-permeability caps in 1989. Along with reduced flux from the respective source areas, the long-term cumulative effects of various natural attenuation processes, including biologically mediated degradation, also explain the decreasing concentrations of VOCs in the groundwater at these wells. 
- Indeterminate concentration trends for summed VOC groups in groundwater from five wells located hydraulically downgradient of the BCBG WMA (GW-046, GW-068, GW-082, GW-242, GW-289, GW-623, and GW-629), as illustrated by the PCE results for wells GW-046 and GW-289 (Figure A.19). For example, PCE concentrations at well GW-046 show wide (seasonal, with peak concentrations in July) fluctuations, but similar results were reported for the groundwater samples collected from the well in August 1995 (460 $\mu \mathrm{g} / \mathrm{L})$ and July $2008(430 \mu \mathrm{g} / \mathrm{L})$. Essentially unchanged levels of VOCs, as shown by more than 20 years of sampling data for these wells suggest minimal corresponding change in the relative advective flux of VOCs via the low-permeability flowpaths monitored by each well.

- Increasing concentration trends for VOCs in groundwater from well GW-246 at the S-3 Site, well GW-008 at the OLF WMA, and wells GW-068, GW-627, GW-629, and GW-653 at the BCBG WMA. The increasing concentration trend indicated by the PCE data for well GW-246 (Figure A.19) may be of questionable significance considering the prolonged gap (January 1990 March 2004) in the sampling history for the well and the relatively low concentrations of PCE (and other VOCs) relative to other contaminants in the groundwater from this well (e.g., nitrate). Increasing concentrations of VOCs indicated by the sampling results for wells GW-627 (Figure A.19) and GW-653 potentially reflect an increase in the relative flux of VOCs via the strike-parallel flowpaths in the Nolichucky Shale west of BG-A South, following down-dip migration of dissolved VOCs in the groundwater and DNAPL in the nearby subsurface.

Divergent concentration trends for individual chloroethenes in groundwater from well GW-068 at the BCBG WMA indicate biodegradation. The CY 2009 results show that c12DCE, 11DCE, and VC are the chloroethenes with the highest concentrations (Table 7). Historic data for the well show clearly decreasing trends for concentrations of PCE and TCE (parent compounds), with clearly increasing trends for concentrations of c12DCE and VC (degradation products). For example, between March 1987 and March 2009, PCE concentrations decreased from $220 \mu \mathrm{g} / \mathrm{L}$ to $2 \mu \mathrm{g} / \mathrm{L}$ and total 12DCE concentrations increased from $420 \mu \mathrm{g} / \mathrm{L}$ to $1903 \mu \mathrm{g} / \mathrm{L}$.

\section{Gross Alpha and Gross Beta Activity}

Groundwater samples collected during CY 2009 from 11 of the aquitard wells used for surveillance monitoring in the Bear Creek Regime contained gross alpha activity and/or gross beta activity above the associated minimum detectable activity (MDA) and the corresponding total propagated uncertainty (TPU). As shown in Table 8, elevated levels of gross alpha activity ( $>15 \mathrm{pCi} / \mathrm{L})$ and/or gross beta activity $(>50 \mathrm{pCi} / \mathrm{L})$ were reported for seven of these wells. However, the elevated gross alpha activity for well GW-726-06 in May 2009 is inconsistent (much higher) with historical data for the well and does not meet DQOs of the Y-12 GWPP (see Section 3.5). This result, shown with a "Q" qualifier, is a suspected outlier (possible sampling or analytical artifact) that is excluded from further evaluation in this report. Future monitoring results will confirm or negate the elevated activity. 
Table 8. Bear Creek Regime CY 2009: elevated gross alpha activity and gross beta activity in surveillance monitoring aquitard wells

\begin{tabular}{|c|c|c|c|c|c|c|c|c|c|}
\hline \multirow{3}{*}{$\begin{array}{c}\text { Well } \\
\text { GW-085 }\end{array}$} & \multirow{3}{*}{$\begin{array}{c}\begin{array}{c}\text { Date } \\
\text { Sampled }\end{array} \\
02 / 23 / 09\end{array}$} & \multicolumn{4}{|c|}{$\begin{array}{l}\text { Gross Alpha Activity } \\
\text { (pCi/L) }\end{array}$} & \multicolumn{4}{|c|}{$\begin{array}{l}\text { Gross Beta Activity } \\
\text { (pCi/L) }\end{array}$} \\
\hline & & \multirow{2}{*}{$\frac{\text { MDA }}{2.9}$} & \multicolumn{3}{|c|}{ Activity \pm TPU } & \multirow{3}{*}{$\begin{array}{c}\text { MDA } \\
5.4 \\
4.7\end{array}$} & \multicolumn{3}{|c|}{ Activity \pm TPU } \\
\hline & & & & $<$ MDA & & & 53 & \pm & 5.1 \\
\hline GW-127 & 02/17/09 & 2.5 & 27 & \pm & 4.6 & & & $<$ & \\
\hline GW-246 & 08/05/09 & 76 & 380 & \pm & 100 & 140 & 11,000 & \pm & 360 \\
\hline GW-276 & 01/07/09 & 2.55 & 136 & \pm & 23.2 & 4.65 & 144 & \pm & 23.6 \\
\hline GW-276 & 07/06/09 & 2.42 & 107 & \pm & 18.4 & 5.01 & 148 & \pm & 24.4 \\
\hline GW-537 & 08/05/09 & 5.9 & & $<$ MDA & & 15 & 130 & \pm & 14 \\
\hline GW-615 & 02/18/09 & 93 & 400 & \pm & 250 & 170 & 57 & \pm & 190 \\
\hline GW-726-06 & 05/04/09 & 18 & $41 \mathrm{Q}$ & \pm & 21 & 30 & & $<\mathrm{MDA}$ & \\
\hline \multicolumn{2}{|c|}{ Screening Level } & \multicolumn{4}{|c|}{15} & \multicolumn{4}{|c|}{50} \\
\hline
\end{tabular}

The elevated levels of gross alpha activity and gross beta activity reflect transport/migration of uranium isotopes and Tc-99, respectively, from the groundwater contaminants (acidified wastes) emplaced at the source during historical operation of the former S-3 Ponds. As with total uranium, the relatively limited extent of elevated gross alpha activity indicated by the CY 2009 sampling results reflects the limited mobility of uranium isotopes beyond the acidic groundwater in the Nolichucky Shale within approximately $500 \mathrm{ft}$ of the site.

As shown by the CY 2009 sampling results summarized in Table 8 and shown on Figure A.10, gross beta activity remains extremely high $(>10,000 \mathrm{pCi} / \mathrm{L})$ in groundwater from the Nolichucky Shale nearest to the S-3 Site (well GW-246), and exceeds $100 \mathrm{pCi} / \mathrm{L}$ in the shallow groundwater 2,500 ft west of the site (well GW-537). Moreover, as with nitrate, the CY 2009 sampling results for well GW-085 show slightly elevated gross beta activity extending approximately 3,000 ft west of the site (Figure A.10). Historical data show that Tc-99 is the primary beta-emitting radionuclide in the groundwater at each of these wells. Considered a "signature" contaminant from the former S-3 Ponds, Tc-99 is believed to occur as an ion $\left(\mathrm{TcO}_{4}\right)$ that, like nitrate, is not readily attenuated in the subsurface and is highly mobile in the groundwater. This largely explains the similar distribution of nitrate and elevated gross beta activity in the aquitard near the site.

The gross alpha and gross beta activity reported for the groundwater samples collected during CY 2009 support the long-term trends indicated by historical data (Table B.9). Time-series plots of the gross alpha and/or gross beta activity reported for each applicable well, excluding results that do not meet applicable DQOs, generally show:

- Decreasing trends for wells GW-127 (gross alpha activity) and GW-276 (gross alpha and gross beta activity), which are located southwest and southeast, respectively, of the S-3 Site (Figure A.11). As shown by data for well GW-276, the decreasing trends for gross alpha and gross beta activity mirror the concurrently decreasing trends evident for nitrate and uranium (Figure A.18) and PCE (Figure A.20). As with the other contaminants in the groundwater from this well, the decreasing levels of gross alpha and gross beta activity likewise primarily reflect the substantially reduced flux of uranium isotopes and Tc-99 that occurred after the former S-3 Ponds were closed and capped. 
- Indeterminate gross alpha and/or gross beta activity trends for wells GW-085, GW-246, GW-537, and GW-615, which together characterize the lateral (GW-085) and vertical (GW-615) extent of radiological contamination in the aquitard (Nolichucky Shale) west of the S-3 Site. Of these wells, GW-085 and GW-537 have uninterrupted sampling histories extending back to January/February 1990. Results from these wells reflect the common source of nitrate and Tc-99 (the former S-3 Ponds) and their similar relative mobility in groundwater. The data for well GW-085 (Figure A.20) show long-term fluctuations in gross beta activity (and nitrate concentrations), suggesting temporal "pulses" in the level of gross beta activity (and nitrate) in the shallow groundwater. As noted previously, the nitrate concentrations at well GW-537 show a generally decreasing trend (Figure A.18), and the indeterminate gross beta trend appears to be generally decreasing in the groundwater samples collected from the well since August 2003.

\subsubsection{Aquifer Wells}

Elevated concentrations of one or more of the principal groundwater contaminants at Y-12 were reported for the groundwater samples collected during CY 2009 from 16 aquifer wells in the Bear Creek Regime (Table B.9). Six of these wells are components of two Exit Pathway Pickets in the Bear Creek Regime (Figure A.13): Picket B (GW-703, GW-704, and GW-706) and Picket C (GW-724, GW-738, and GW-740). The remaining wells are located near the eastern end of the regime near the S-3 Site (GW-100, GW-122, GW-236), and Rust Spoil Area (GW-307); near Bear Creek south of the OLF WMA (GW-225, GW-229, GW-365, and GW-601); and near Bear Creek south of the BCBG WMA (GW-053 and GW-058).

The presence of contaminants in the groundwater from these aquifer wells is attributable to the migration of groundwater contaminant plumes emanating from historical operations of the former S-3 Ponds, Spoil Area I, Rust Spoil Area, the OLF WMA, and the BCBG WMA and intermixing during transport in the Maynardville Limestone. The types and concentrations of contaminants detected in the groundwater samples collected from these wells during CY 2009 are generally consistent with historical data that define the overall extent of nitrate (Figure A.7), total uranium, VOCs (Figure A.8), gross alpha activity (Figure A.9), and gross beta activity (Figure A.10) in the Maynardville Limestone (and lower Knox Group) in BCV west of Y-12.

\section{Nitrate and Uranium}

Elevated concentrations of nitrate $(>10 \mathrm{mg} / \mathrm{L})$ and/or total uranium $(>0.03 \mathrm{mg} / \mathrm{L})$ were reported for at least one groundwater sample collected during CY 2009 from 10 of the aquifer wells used for surveillance monitoring in the Bear Creek Regime, listed below in Table 9 in sequence from closest to farthest from the S-3 Site. 
Table 9. Bear Creek Regime CY 2009: elevated nitrate and uranium concentrations in surveillance monitoring aquifer wells

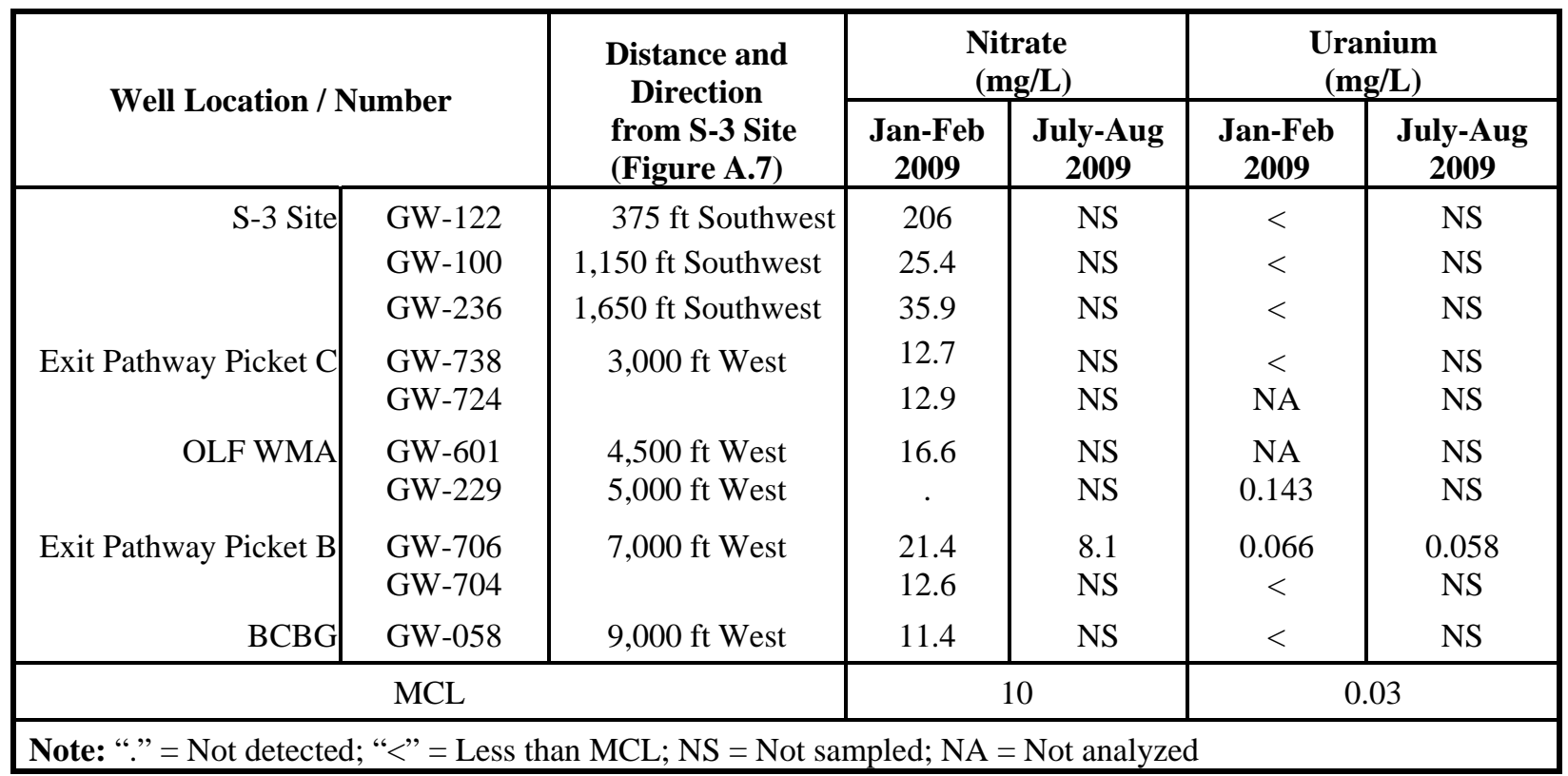

These sampling results show that the highest nitrate concentrations in the aquifer occur within approximately $500 \mathrm{ft}$ of the S-3 Site (e.g., GW-122). Elevated concentrations of total uranium were reported only for groundwater samples from wells GW-229 and GW-706, which are located hydraulically downgradient to the west of the BYBY (Figure A.9). Uranium-bearing wastes were buried at depths below the seasonally high water table at the BYBY. Carbonate dissolved from the limestone bedrock combined with uranyl cations leached from the wastes, which greatly increased the otherwise limited mobility of uranium in the neutral $\mathrm{pH}$ groundwater typical of the Maynardville Limestone (DOE 1997a). The bulk of these wastes were excavated and removed during CERCLA remedial actions completed in May 2003.

Elevated concentrations of nitrate and/or uranium in the groundwater samples collected during CY 2009 from the aquifer wells in the Bear Creek Regime support the respective long-term concentration trends indicated by historical data (Table B.9), except for the unusually low nitrate results reported for wells GW-225 and GW-725. These nitrate results are inconsistent with respect to available historical data for the locations and are flagged with a "Q" qualifier in Appendix D. The CY 2009 data for the other wells have time-series plots of the nitrate and uranium data (excluding analytical results that do not meet DQOs) generally showing:

- Decreasing concentration trends for nitrate at eight wells (GW-100, GW-122, GW-236, GW-601, GW-704, GW-706, GW-724, and GW-738) and for uranium at well GW-706, as illustrated by nitrate and uranium data for well GW-706 (Figure A.21). Decreasing concentrations of nitrate reflect a combination of substantially reduced flux of nitrate in the Maynardville Limestone after the former S-3 Ponds were closed and capped, and the cumulative effectiveness of various natural attenuation processes, including the outflow of nitrate-contaminated groundwater into Bear Creek. The sharp decrease in uranium concentrations at well GW-706 between January and July 2003 may be attributable to the CERCLA remedial actions at the BYBY that were completed in May 2003. 
- Increasing concentration trends for nitrate in well GW-058 and uranium in well GW-229 (Figure A.21). Only the two most recent samples from well GW-058 have elevated nitrate concentrations, and the significance of this trend is questionable. Available sampling results for well GW-229 show an order-of-magnitude increase in the concentrations of uranium occurred between sampling events performed in September 1995 (0.014 mg/L) and March 2002 (0.238 mg/L), with subsequent sampling results defining a generally decreasing trend through February $2009(0.143 \mathrm{mg} / \mathrm{L})$. The decreasing uranium concentrations indicated by the more recent data suggest reduced flux of uranium in response to the removal of uranium-bearing wastes during CERCLA remedial actions at the BYBY.

\section{Volatile Organic Compounds}

Groundwater samples collected during CY 2009 from 13 aquifer wells contained individual or summed VOC concentrations of $5 \mu \mathrm{g} / \mathrm{L}$ or more (Table B.9). As shown in Table 10, the maximum concentrations of TCE, c12DCE, 11DCE, VC, and benzene reported for at least one groundwater sample from one or more wells exceed the respective drinking water MCLs.

Sampling results for these wells also show that TCE is the primary VOC in the intermingled plume of contaminants in groundwater from the Maynardville Limestone west of Y-12, with input to the plume from multiple confirmed sources, including the Rust Spoil Area, the OLF WMA, and the BCBG WMA (Figure A.8). The CY 2009 sampling results show the continued persistence of TCE in the groundwater from a few of these wells without concurrent detection of TCE degradation products (e.g., c12DCE) suggesting that the geochemical characteristics of the groundwater near these wells are not especially conducive to biologically-mediated degradation processes (reductive dechlorination).

Table 10. Bear Creek Regime CY 2009: maximum VOC concentrations in surveillance monitoring aquifer wells

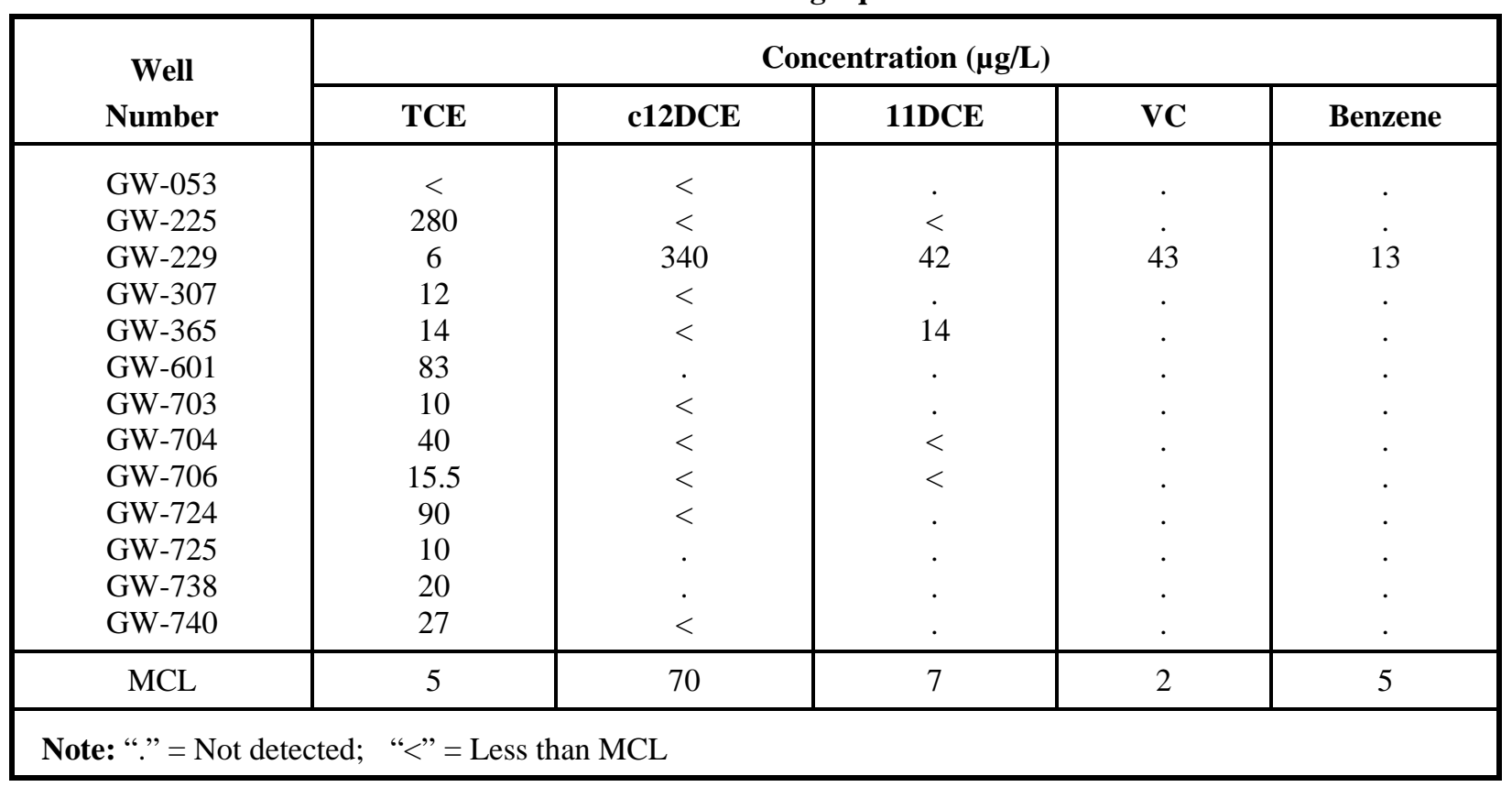

These VOC results support the long-term summed VOC (e.g., chloroethenes) concentration trends (Table B.9), with time-series plots of the VOC data for each well generally showing: 
- Variable, but generally decreasing, concentration trends for VOCs (primarily TCE) in groundwater from eight wells (GW-053, GW-307, GW-365, GW-601, GW-703, GW-704, GW-738, and GW-740), as illustrated by TCE data for wells GW-704 and GW-738 (Figure A.22). The decreasing concentration trends reflect the substantially reduced flux of VOCs following closure of principal source areas (e.g., OLF WMA), and the long-term cumulative effects of various natural attenuation processes.

- Indeterminate concentration trends for VOCs in groundwater from four wells GW-225, GW-706, GW-724, and GW-725, as illustrated by the TCE data for wells GW-225 and GW-706 (Figure A.22). The relatively unchanged levels of VOCs in the groundwater from these wells suggest there is minimal change in the advective flux of VOCs in the hydrostratigraphic zone monitored by each well.

- Generally increasing concentration trends for summed VOC groups in groundwater from well GW-229. The data for this well are clearly distinguishable from the other wells listed in Table 10 by the dominant concentrations of TCE degradation products (c12DCE, 11DCE, and VC). Concentrations of these compounds have increased over time, as illustrated by the 11DCE and 12DCE results for well GW-229 (Figure A.22). The increasing concentrations do not reflect any clear response to the CERCLA remedial actions at the BYBY. This suggests that the site is not a significant source of the VOCs in the groundwater from the well. However, Sanitary Landfill I is located upgradient and along geologic strike to the east of well GW-229, and may be the source of VOCs in groundwater at the well.

Divergent concentration trends observed for individual chloroethenes that indicate ongoing biodegradation near wells GW-229 and GW-365. For example, the low flow sampling results from March 2001 to March 2009 reported for well GW-365 show that TCE (parent compound) concentrations decreased from $54 \mu \mathrm{g} / \mathrm{L}$ to $14 \mu \mathrm{g} / \mathrm{L}$ while c12DCE (degradation product) concentrations concurrently increased from $17 \mu \mathrm{g} / \mathrm{L}$ to $40 \mu \mathrm{g} / \mathrm{L}$.

\section{Gross Alpha and Gross Beta Activity}

Groundwater samples collected during CY 2009 from 13 aquifer surveillance monitoring wells contained gross alpha and/or gross beta activity above the associated MDA and the corresponding TPU. However, as shown in Table 11, only samples from three of these wells had elevated levels of gross alpha activity $(>15 \mathrm{pCi} / \mathrm{L})$ and/or gross beta activity $(>50 \mathrm{pCi} / \mathrm{L})$.

Table 11. Bear Creek Regime CY 2009: elevated gross alpha activity and gross beta activity in surveillance monitoring aquifer wells

\begin{tabular}{|c|c|c|c|c|c|c|c|c|c|}
\hline \multirow{2}{*}{ Well } & \multirow{2}{*}{$\begin{array}{c}\text { Date } \\
\text { Sampled }\end{array}$} & \multicolumn{3}{|c|}{ Gross Alpha Activity (pCi/L) } & \multicolumn{3}{|c|}{ Gross Beta Activity (pCi/L) } \\
\cline { 3 - 10 } & & MDA & \multicolumn{2}{|c|}{ Activity \pm TPU } & MDA & \multicolumn{3}{|c|}{ Activity \pm TPU } \\
\hline GW-058 & $02 / 10 / 09$ & 3.1 & 34 & \pm & 4.6 & 5.4 & 54 & \pm & 5.3 \\
GW-229 & $02 / 26 / 09$ & 3.4 & 53 & \pm & 6.7 & 5.8 & & $<$ & \\
GW-706 & $03 / 03 / 09$ & 3.83 & 18.1 & \pm & 5.24 & 5.07 & & $<$ & \\
GW-706 & $07 / 22 / 09$ & 2.29 & 17.9 & \pm & 4.33 & 4.15 & 51 & \pm & 9.24 \\
\hline
\end{tabular}


Elevated gross alpha and gross beta activity in the groundwater at these wells reflects the transport/migration of uranium isotopes (and beta-emitting decay products of uranium) and Tc-99, the principal radiological components of the intermingled contaminant plume in the Maynardville Limestone.

The CY 2009 monitoring results show that the highest level of gross alpha activity occurs in the groundwater from aquifer well GW-229, located downgradient (west-southwest) of the former BYBY (Figure A.9 and Figure A.10, respectively). These results are consistent with historical data for the well, which show that uranium isotopes are the principal source of gross alpha activity and that beta-emitting uranium decay products (e.g., thorium-234) are the principal source of gross beta activity. Uranium-bearing wastes removed from the BYBY are considered the principal source of the uranium isotopes in the groundwater from this well. Gross beta activity is higher in the other two wells, which probably reflects a combination of the uranium decay products from the BYBY and Tc-99 from the S-3 Site.

The elevated gross alpha and gross beta activity in samples collected from aquifer wells during CY 2009 supports long-term trends indicated by respective historical data (Table B.9). Time-series plots of the gross alpha and/or gross beta activity reported for each applicable well generally show:

- An overall decreasing gross alpha and gross beta activity trend for well GW-706 (Figure A.23). The long-term trends for conventional sampling were highly variable and indeterminate. However, the trend for low flow sampling results show a generally decreasing trend with a drop in alpha activity in July 2003 that is a possible response to the CERCLA actions completed in May 2003.

- Increasing long-term trends for gross alpha and beta activity in well GW-058 and gross alpha activity in well GW-229. The monitoring history for well GW-058 spans a 14-yr sampling gap (September 1992 - June 2006) and only the recent samples have elevated radioactivity, as shown by the gross alpha activity reported for the well (Figure A.23). The trend for gross alpha activity at well GW-229 (Figure A.23) is similar to the long-term trend for total uranium (Figure A.21) which shows a significant concentration increase between September 1995 and March 2002, followed by a generally decreasing trend through February 2009. The most recent data for gross alpha activity likewise show decreasing levels between February 2003 (150 pCi/L) and February 2009 (53 pCi/L). Decreasing levels of gross alpha activity (and gross beta activity) indicated by the recent sampling results suggest a corresponding reduction in the relative flux of uranium isotopes following removal of uranium-bearing wastes from the BYBY during CERCLA remedial actions completed in May 2003.

\subsubsection{East Fork Regime}

In CY 2009, groundwater samples were collected from 73 surveillance monitoring wells in the East Fork Regime (Table B.3). Forty-five of the wells are completed in geologic formations comprising the aquitard (Nolichucky Shale, Maryville Limestone, Rogersville Shale, Pumpkin Valley Shale, and Rome Formation). The remaining 28 wells are completed in geologic formations comprising the aquifer (Copper Ridge Dolomite and Maynardville Limestone).

\subsubsection{Aquitard Wells}

Elevated concentrations of one or more of the principal groundwater contaminants at Y-12 were reported for groundwater samples collected during CY 2009 from 34 aquitard monitoring wells in the East Fork 
Regime (Table B.10). The presence of principal contaminants in the groundwater at these wells is attributable to the transport/migration of the mobile components of the groundwater contaminant plumes originating from multiple sources, including the S-3 Site (former S-3 Ponds), the S-2 Site, and the WCPA in the western Y-12 area and unidentified sources in the central and eastern Y-12 areas. Additionally, the types and concentrations of detected contaminants are generally consistent with nitrate (Figure A.7), total uranium, VOCs (Figure A.8), gross alpha activity (Figure A.9), and gross beta activity (Figure A.10) results for the existing network of wells completed in the aquitard formations in the western, central, and eastern Y-12 areas.

\section{Nitrate and Uranium}

Elevated concentrations of nitrate $(>10 \mathrm{mg} / \mathrm{L})$ or uranium $(>0.03 \mathrm{mg} / \mathrm{L})$ were detected in groundwater samples collected during CY 2009 from 11 wells in the East Fork Regime. As shown in Table 12, elevated nitrate concentrations were reported for seven aquitard wells in the western Y-12 area and four wells in the central Y-12 area. The wells listed below are sequenced from closest to farthest from the S-3 Site, the source of nitrate in the aquitard. Elevated levels of nitrate in the groundwater reflect the substantial transport of nitrate (and other similarly mobile contaminants) eastward from the former S-3 Ponds, which created a local mound in the water table that enabled the contaminants to migrate to the east of the hydrologic divide now separating the UEFPC and Bear Creek watersheds. These sampling results show that nitrate concentrations remain highest in the groundwater within approximately $1,500 \mathrm{ft}$ of the S-3 Site (Figure A.7). The results also illustrate the preferred strike- and dip-parallel flow of groundwater in the water table interval (wells 55-2A, 55-2B, GW-274, and GW-633) and the shallow bedrock (<70 ft bgs) interval (wells 55-2C, GW-108, and GW-275) in the Nolichucky Shale east and southeast of the site.

Table 12. East Fork Regime CY 2009: elevated nitrate and uranium concentrations in surveillance monitoring aquitard wells

\begin{tabular}{|c|c|c|c|c|c|c|}
\hline \multirow{2}{*}{\multicolumn{3}{|c|}{$\begin{array}{c}\text { Well Location/Number/ } \\
\text { Approx. Distance (ft) and } \\
\text { Direction from S-3 Ponds } \\
\text { (Figure A.7) }\end{array}$}} & \multicolumn{2}{|c|}{ Nitrate (mg/L) } & \multicolumn{2}{|c|}{ Uranium (mg/L) } \\
\hline & & & $\begin{array}{c}\text { Jan-May } \\
2009\end{array}$ & $\begin{array}{c}\text { Oct } \\
2009\end{array}$ & $\begin{array}{c}\text { Jan-May } \\
2009\end{array}$ & $\begin{array}{c}\text { Oct } \\
2009\end{array}$ \\
\hline $\begin{array}{r}\text { Western } \\
\text { Y-12 Area }\end{array}$ & $\begin{array}{l}\text { GW-505 } \\
\text { GW-270 } \\
\text { GW-272 } \\
\text { GW-633 } \\
\text { GW-108 } \\
\text { GW-275 } \\
\text { GW-274 }\end{array}$ & $\begin{array}{l}600 \mathrm{E} \\
700 \mathrm{E} \\
1,350 \mathrm{E} \\
720 \mathrm{SE} \\
800 \mathrm{SE} \\
1,300 \mathrm{SE} \\
1,300 \mathrm{SE}\end{array}$ & $\begin{array}{r}\text { NA } \\
107 \\
682 \\
823 \\
8,030 \\
8,960 \\
1,739\end{array}$ & $\begin{array}{l}\text { NS } \\
\text { NS } \\
\text { NS } \\
\text { NS } \\
\text { NS } \\
\text { NS } \\
\text { NS }\end{array}$ & $\begin{array}{c}0.0629 \mathrm{Q} \\
< \\
< \\
< \\
< \\
\dot{<}\end{array}$ & $\begin{array}{l}\text { NS } \\
\text { NS } \\
\text { NS } \\
\text { NS } \\
\text { NS } \\
\text { NS } \\
\text { NS }\end{array}$ \\
\hline $\begin{array}{r}\text { Central } \\
\text { Y-12 Area }\end{array}$ & $\begin{array}{c}55-2 \mathrm{~A} \\
55-2 \mathrm{~B} \\
55-2 \mathrm{C} \\
\mathrm{GW}-204\end{array}$ & $\begin{array}{r}3,000 \mathrm{SE} \\
3,000 \mathrm{SE} \\
3,000 \mathrm{SE} \\
5,100 \mathrm{SE}\end{array}$ & $\begin{array}{l}\text { NS } \\
\text { NS } \\
\text { NS } \\
\text { NA }\end{array}$ & $\begin{array}{l}212 \\
292 \\
261 \\
\text { NS }\end{array}$ & $\begin{array}{l}\text { NS } \\
\text { NS } \\
\text { NS } \\
0.0421\end{array}$ & $\begin{array}{l}\text { NS } \\
\dot{N S} \\
\text { NS }\end{array}$ \\
\hline \multicolumn{3}{|r|}{$\overline{M C L}$} & \multicolumn{2}{|c|}{10} & \multicolumn{2}{|c|}{0.03} \\
\hline \multicolumn{7}{|c|}{$\begin{array}{l}\text { Note: "NA" = Not analyzed; "NS" = Not sampled; " <" = Concentration less than MCL; " " " = Not detected } \\
\text { "Q"=inconsistent with other results for the location. }\end{array}$} \\
\hline
\end{tabular}

For the wells with elevated nitrate concentrations, the CY 2009 sampling results are consistent with historical nitrate concentration trends (Table B.10), with time-series plots for each well generally showing: 
- Decreasing nitrate concentration trends for wells GW-108, GW-270, GW-274, and GW-633, as illustrated by the nitrate data for wells GW-108 and GW-274 (Figure A.24). As noted previously, the decreasing concentrations of nitrate in the Nolichucky Shale downgradient of the S-3 Site reflect substantially reduced flux of nitrate (and other mobile contaminants) in groundwater following closure of the site and installation of the low-permeability cap and the cumulative effectiveness of natural attenuation processes.

- Indeterminate nitrate concentration trends for wells 55-2A and GW-275 (Figure A.24). The relatively unchanged nitrate levels in the groundwater from these wells seems unusual considering that the S-3 Ponds have been closed for more than 20 years. The persistently high levels of nitrate in the wells probably reflect both the extensive volume (mass) of nitrate emplaced in the Nolichucky Shale beneath the site and the relatively low-permeability of the groundwater flow pathways intercepted by each well.

- Increasing nitrate concentration trends for wells 55-2B, 55-2C, and GW-272, as illustrated by the nitrate data for wells 55-2B and GW-272 (Figure A.24). The increasing nitrate concentrations at wells 55-2B and 55-2C potentially reflect the continued eastward movement of the center of mass of the S-3 Ponds contaminant plume in the Nolichucky Shale east of the site (DOE 1998).

As shown in Table 12, elevated uranium concentrations were reported only for wells GW-204 and GW-505. The elevated uranium result reported for GW-505 in April 2009 is inconsistent (much higher) with historical data for the well and does not meet DQOs of the Y-12 GWPP (see Section 3.5). This result, shown with a "Q" qualifier, is a suspected outlier (possible sampling or analytical artifact) that is excluded from further evaluation in this report. Well GW-204, located in the central Y-12 area on the east side of Bldg. 9204-2 (Figure A.14), is installed in the pit where an underground storage tank was removed in August 1988. The source of uranium in the groundwater from this well has not been determined. Available data indicate a widely fluctuating, indeterminate long-term uranium concentration trend, with results since June 2000 ranging from $0.0316 \mathrm{mg} / \mathrm{L}$ to $0.127 \mathrm{mg} / \mathrm{L}$.

\section{Volatile Organic Compounds}

One or more dissolved VOCs were detected at individual or summed concentrations of $5 \mu \mathrm{g} / \mathrm{L}$ or more in at least one groundwater sample collected during CY 2009 from 29 aquitard wells in the East Fork Regime (Table B.10). Summarized below in Table 13, these sampling results show maximum concentrations of PCE, TCE, C12DCE, 11DCE, VC, CTET, MC, 12DCA, benzene, ETB, and toluene exceeding respective drinking water MCLs. The presence of dissolved VOCs reflects transport/migration from the contaminant plumes from several source areas, including: the former S-3 Ponds, the WCPA, former petroleum fuel dispensing facilities associated with the Rust Garage Area and the East End Fuel Facility, and other sources within the industrial areas of Y-12. Moreover, the extremely high concentrations $(>1,000 \mu \mathrm{g} / \mathrm{L})$ of VOCs in some wells suggest the likely presence of DNAPL in the aquitard underlying several areas within Y-12. For example, the CY 2009 sampling data for wells 55-3A, 55-3B, and 55-3C (located in the central Y-12 area south of Bldg. 9201-5) show the highest dissolved concentrations of chlorinated hydrocarbons in the East Fork Regime. 
Table 13. East Fork Regime CY 2009: maximum VOC concentrations in surveillance monitoring aquitard wells

\begin{tabular}{|c|c|c|c|c|c|c|c|c|c|c|c|}
\hline \multirow{2}{*}{$\begin{array}{l}\text { Y-12 Area/ } \\
\text { Well }\end{array}$} & \multicolumn{11}{|c|}{ Maximum Concentration ( $\mu \mathrm{g} / \mathrm{L}$ ) } \\
\hline & PCE & TCE & $\begin{array}{c}\text { c12 } \\
\text { DCE }\end{array}$ & $\begin{array}{c}11 \\
\text { DCE }\end{array}$ & VC & CTET & MC & $\begin{array}{c}12 \\
\text { DCA }\end{array}$ & $\begin{array}{l}\text { Ben- } \\
\text { zene }\end{array}$ & ETB & $\begin{array}{l}\text { Tol- } \\
\text { uene }\end{array}$ \\
\hline $\begin{array}{r}\text { Western } \\
\text { GW-108 } \\
\text { GW-269 } \\
\text { GW-274 } \\
\text { GW-332 } \\
\text { GW-337 } \\
\text { GW-508 } \\
\text { GW-633 }\end{array}$ & $\begin{array}{c}10.7 \\
13 \\
1,600 \\
560 \\
380 \\
\cdot \\
190\end{array}$ & $\begin{array}{c}5.7 \\
5 \\
11 \\
170 \\
450 \\
. \\
7\end{array}$ & $\begin{array}{c}< \\
< \\
< \\
740 \\
1,500 \\
\cdot \\
<\end{array}$ & $\begin{array}{c}< \\
160 \\
\cdot \\
20 \\
55 \\
\cdot \\
<\end{array}$ & $\begin{array}{c}\cdot \\
\cdot \\
3 \\
11 \\
13 \\
\cdot \\
\cdot\end{array}$ & . & $\begin{array}{c}48.8 \\
\cdot \\
29 \\
\cdot \\
\cdot \\
\cdot \\
18\end{array}$ & $\begin{array}{l}. \\
. \\
.\end{array}$ & $\begin{array}{c}< \\
\cdot \\
200 \\
\cdot \\
\cdot \\
280 \\
2,100\end{array}$ & $\begin{array}{c}\cdot \\
\cdot \\
\cdot \\
\cdot \\
\dot{\cdot} \\
\dot{\cdot}\end{array}$ & $\begin{array}{c}\cdot \\
\cdot \\
\cdot \\
\cdot \\
\cdot \\
890 \\
\cdot\end{array}$ \\
\hline $\begin{array}{c}\text { Central } \\
55-2 \mathrm{~A} \\
55-2 \mathrm{~B} \\
55-2 \mathrm{C} \\
55-3 \mathrm{~A} \\
55-3 \mathrm{~B} \\
55-3 \mathrm{C} \\
56-2 \mathrm{~A} \\
56-2 \mathrm{~B} \\
56-2 \mathrm{C} \\
56-3 \mathrm{~A} \\
56-3 \mathrm{~B} \\
56-3 \mathrm{C} \\
\text { GW-656 } \\
\text { GW-769 } \\
\text { GW-770 } \\
\text { GW-782 } \\
\text { GW-783 } \\
\text { GW-791 } \\
\end{array}$ & $\begin{array}{c}200 \\
390 \\
260 \\
17,000 \\
51,000 \\
8,300 \\
12 \\
1,000 \\
40 \\
14 \\
150 \\
520 \\
32 \\
22 \\
. \\
36 \\
< \\
22 \\
\end{array}$ & $\begin{array}{c}100 \\
170 \\
140 \\
1,700 \\
6,400 \\
1,500 \\
< \\
75 \\
170 \\
5 \\
15 \\
38 \\
2,700 \\
7 \\
\cdot \\
16 \\
< \\
. \\
\end{array}$ & $\begin{array}{c}280 \\
430 \\
450 \\
1,300 \\
1,500 \\
1,400 \\
< \\
98 \\
920 \\
< \\
< \\
< \\
150 \\
< \\
\cdot \\
< \\
< \\
< \\
. \\
\end{array}$ & $\begin{array}{c}7 \\
13 \\
15 \\
50 \\
210 \\
37 \\
\cdot \\
< \\
13 \\
\cdot \\
. \\
< \\
150 \\
< \\
. \\
9 \\
. \\
\end{array}$ & $\begin{array}{c}7 \\
14 \\
13 \\
110 \\
530 \\
160 \\
\cdot \\
\cdot \\
59 \\
\cdot \\
\cdot \\
\cdot \\
\cdot \\
\cdot \\
\cdot \\
\cdot \\
\cdot \\
\cdot \\
\end{array}$ & $\begin{array}{c}\cdot \\
\cdot \\
. \\
. \\
160 \\
12 \\
< \\
. \\
. \\
\end{array}$ & $\begin{array}{l}. \\
. \\
. \\
. \\
. \\
. \\
. \\
. \\
. \\
. \\
. \\
. \\
. \\
.\end{array}$ & $\begin{array}{l}. \\
. \\
. \\
. \\
. \\
. \\
. \\
. \\
. \\
. \\
. \\
. \\
. \\
. \\
. \\
.\end{array}$ & $\begin{array}{l}\cdot \\
. \\
. \\
\dot{<} \\
. \\
. \\
. \\
. \\
. \\
. \\
. \\
. \\
. \\
. \\
. \\
. \\
.\end{array}$ & $\begin{array}{l}. \\
. \\
. \\
. \\
. \\
. \\
. \\
. \\
. \\
. \\
. \\
. \\
. \\
. \\
.\end{array}$ & $\begin{array}{l}. \\
. \\
. \\
< \\
. \\
. \\
. \\
. \\
. \\
. \\
. \\
. \\
. \\
. \\
. \\
.\end{array}$ \\
\hline $\begin{array}{l}\text { Eastern } \\
\text { GW-383 } \\
\text { GW-658 } \\
\text { GW-762 } \\
\text { GW-763 }\end{array}$ & $\begin{array}{c}120 \\
\text { 2,460 } \\
\text {. }\end{array}$ & $\begin{array}{c}150 \\
\dot{172}\end{array}$ & $\begin{array}{c}210 \\
\dot{<} \\
<\end{array}$ & $\begin{array}{c}< \\
\dot{4} .2 \\
\dot{\cdot}\end{array}$ & $\begin{array}{c}5 \\
. \\
4.72 \\
4\end{array}$ & . & . & $\begin{array}{c}373 \\
\cdot \\
\cdot\end{array}$ & $\begin{array}{c}8,110 \\
. \\
.\end{array}$ & $\begin{array}{c}837 \\
\cdot \\
\cdot\end{array}$ & $\begin{array}{c}2,110 \\
\cdot \\
.\end{array}$ \\
\hline MCL & 5 & 5 & 70 & 7 & 2 & 5 & 5 & 5 & 5 & 700 & 1,000 \\
\hline
\end{tabular}


The CY 2009 sampling results for these wells support the long-term summed VOC (e.g., chloroethenes) concentration trends (Table B.10), with time-series plots of the VOC results generally showing:

- Decreasing concentration trends for VOCs at 12 wells, including three wells in the western Y-12 area (GW-332, GW-337, and GW-508) and nine wells in the central Y-12 area (55-2A, 55-2B, 55-2C, 56-2A, 56-2C, 56-3A, GW-656, GW-783, and GW-791). Decreasing trends are illustrated by the summed chloroethene concentrations detected in the samples from wells GW-337 and GW-656 (Figure A.25). The decreasing concentration trends reflect several factors, such the cumulative effectiveness of natural attenuation processes, including biologically mediated degradation. Decreasing VOC concentrations in samples from well 55-2B are concurrent with clearly increasing nitrate concentrations (Figure A.24), which suggest separate sources of VOCs and nitrate.

- Indeterminate concentration trends for VOCs in groundwater from eight wells, including six wells in the central Y-12 area (55-3A, 55-3B, 55-3C, 56-2B, 56-3B, and 56-3C); and two wells (GW-658 and GW-763) in the eastern Y-12 area. These trends are illustrated (Figure A.25) by concentrations of the principal VOC detected in shallow wells 55-2A (PCE) and GW-658 (benzene). Widely variable, but essentially unchanged, levels of VOCs suggest minimal changes in the advective flux of VOCs in groundwater pathways intercepted by each well. The indeterminate concentration trends also suggest that the geochemical characteristics of the groundwater in most of these wells (i.e., excluding wells with elevated c12DCE concentrations) are not especially conducive to biologically-mediated degradation processes that would reduce VOC concentrations over the long term.

- Increasing concentration trends for VOCs from three wells, including wells GW-769 and GW-770 in the central Y-12 area and well GW-383 in the eastern Y-12 area, as illustrated by the concentrations of 12DCE in well GW-383 and CTET in well GW-769 (Figure A.25). These wells yield VOC-contaminated groundwater from shallow depths ( $<60 \mathrm{ft}$ bgs) in the Nolichucky Shale. The increasing concentration trends suggest corresponding increases in the relative flux of dissolved VOCs through the hydrostratigraphic zones monitored by each well.

- A mixture of summed VOC concentration trends (Table B.10) in groundwater from six wells, including four wells in the western Y-12 area (GW-108, GW-269, GW-274, and GW-633), well GW-782 in the central Y-12 area, and well GW-762 in the eastern Y-12 area. Historical data for all of the wells except for well GW-782 show an increasing trend for summed chloroethenes with a concurrent indeterminate trend for summed chloroethanes or chloromethanes. The long term trends for well GW-782 show decreasing summed chloroethene concentrations with indeterminate summed chloroethane concentrations.

Divergent concentration trends observed for individual chloroethenes in wells 55-3A, 56-2C, and GW-383 are likely attributable to the effects of biotic and/or chemical degradation processes. Historic data for the wells show decreasing and/or indeterminate trends for concentrations of parent compounds (PCE and/or TCE), with increasing trends for concentrations of degradation products (c12DCE, 11DCE, and/or VC). For example, the 12DCE (total) concentrations reported for well GW-383 increased significantly between January $1991(41 \mu \mathrm{g} / \mathrm{L})$ and October $2009(213 \mu \mathrm{g} / \mathrm{L})$, while initial and most recent concentrations of PCE $(390 \mu \mathrm{g} / \mathrm{L}-120 \mu \mathrm{g} / \mathrm{L})$ and TCE $(150 \mu \mathrm{g} / \mathrm{L}-150 \mu \mathrm{g} / \mathrm{L})$ show decreasing and indeterminate trends, respectively. 


\section{Gross Alpha and Gross Beta Activity}

Groundwater samples collected during CY 2009 from 19 aquitard wells contained gross alpha activity and/or gross beta activity above the associated MDA and the corresponding TPU (Appendix E.3). However, as shown in Table 14, only three of these wells had elevated gross alpha activity $(>15 \mathrm{pCi} / \mathrm{L})$ and/or gross beta activity ( $>50 \mathrm{pCi} / \mathrm{L}$ ). The elevated alpha activity reported for well GW-505 in April 2009 (as with the total uranium result) is inconsistent (much higher) with historical data for the well and does not meet DQOs of the Y-12 GWPP (see Section 3.5). This result, shown with a "Q" qualifier, is a suspected outlier (possible sampling or analytical artifact) that is excluded from further evaluation in this report. Future monitoring results will confirm or negate the elevated activity. Conversely, very low gross beta results $(<5 \mathrm{pCi} / \mathrm{L})$ reported for groundwater samples collected in April 2009 from wells $\mathrm{GW}-274$ and GW-633 in the western Y-12 area also are flagged with a "Q" qualifier (see Appendix E) because gross beta activity for both of these wells typically exceeds $1,000 \mathrm{pCi} / \mathrm{L}$.

Table 14. East Fork Regime CY 2009: elevated gross alpha activity and gross beta activity in surveillance monitoring aquitard wells

\begin{tabular}{|c|c|c|c|c|c|c|c|c|c|}
\hline \multirow{2}{*}{ Location and Well } & \multirow{2}{*}{$\begin{array}{c}\text { Date } \\
\text { Sampled }\end{array}$} & \multicolumn{4}{|c|}{ Gross Alpha (pCi/L) } & \multicolumn{4}{|c|}{ Gross Beta (pCi/L) } \\
\hline & & MDA & Activity & \pm & ГPU & MDA & Activit & \pm & TPU \\
\hline $\begin{array}{c}\text { Western Y-12 Area } \\
\text { GW-108 } \\
\text { GW-108 }\end{array}$ & $\begin{array}{l}01 / 12 / 09 \\
07 / 08 / 09\end{array}$ & $\begin{array}{l}101 \\
61.2\end{array}$ & 186 & $\stackrel{ \pm}{<\mathrm{MDA}}$ & 75 & $\begin{array}{l}101 \\
108\end{array}$ & $\begin{array}{l}16,200 \\
13,400\end{array}$ & $\begin{array}{l} \pm \\
\pm\end{array}$ & $\begin{array}{l}2,600 \\
2,140\end{array}$ \\
\hline GW-505 & 04/20/09 & 2.3 & $67 \mathrm{Q}$ & \pm & 5.6 & 5.8 & & $<$ & \\
\hline $\begin{array}{c}\text { Central Y-12 Area } \\
\text { GW-204 }\end{array}$ & 05/12/09 & 3 & 35 & \pm & 4.7 & 6.4 & & $<$ & \\
\hline \multicolumn{2}{|c|}{ Screening Level } & \multicolumn{4}{|c|}{15} & \multicolumn{4}{|c|}{50} \\
\hline
\end{tabular}

Groundwater transport/migration of alpha- and beta-emitting radionuclides from the contaminant plume emplaced during historical operations of the former S-3 Ponds accounts for the elevated levels of gross alpha and/or gross beta activity in the groundwater from well GW-108. Uranium isotopes are the primary alpha-emitting radionuclides in the contaminant plume originating from this site and uranium decay products probably account for some of the gross beta activity in the groundwater. However, Tc-99 is the "signature" component of the S-3 Ponds contaminant plume in the East Fork Regime and is the principal beta-emitting radionuclide in the Nolichucky Shale east of the site. The elevated gross alpha activity reported for well GW-204 indicates groundwater transport of radiological contaminants (primarily uranium isotopes) from unspecified sources within the central Y-12 area (Figure A.9).

The elevated gross alpha and gross beta activity in groundwater samples collected from aquitard wells during CY 2009 support the long-term trends indicated by historical data (Table B.10). Time-series plots of the gross alpha and/or gross beta activity reported for each well (excluding results that do not meet applicable DQOs) show:

- Indeterminate trends for gross alpha activity in groundwater from wells GW-108 and GW-204 (Figure A.26). Widely variable and not clearly increasing or decreasing levels of gross alpha activity in the groundwater from these wells suggest minimal change in the flux of alpha-emitting radionuclides (primarily uranium isotopes) in the groundwater. 
- An increasing trend for gross beta activity in groundwater from well GW-108 (Figure A.26). The increasing beta activity reflects an increase in the flux of Tc-99 (and possibly other beta-emitting radionuclides) in the groundwater pathways intercepted by the well. The increasing gross beta activity trend contrasts with the decreasing nitrate concentration trend for the well. Considering that both contaminants share a common source (the S-3 Ponds), the increasing levels of gross beta activity suggest that Tc-99 levels remain unaffected by natural attenuation processes that reduce nitrate concentrations.

\subsubsection{Aquifer Wells}

Elevated concentrations of one or more of the principal groundwater contaminants at Y-12 were reported for groundwater samples collected during CY 2009 from 21 surveillance monitoring aquifer wells in the East Fork Regime (Table B.10), including three wells located in the western Y-12 area; nine wells located in the central Y-12 area; eight wells in the eastern Y-12 area; and one well in Union Valley east of the ORR boundary.

\section{Nitrate and Uranium}

As shown in Table 15, elevated concentrations of nitrate $(>10 \mathrm{mg} / \mathrm{L})$ or total uranium $(>0.03 \mathrm{mg} / \mathrm{L})$ were detected in the groundwater samples collected during CY 2009 from nine aquifer wells in the East Fork Regime. The S-2 Site is the source of elevated nitrate concentrations in the groundwater from wells GW-251, GW-253, GW-606, and GW-698. As in previous years, the CY 2009 sampling results show the highest nitrate concentrations in the aquifer occur in groundwater immediately downgradient to the east of the S-2 Site (GW-253) in the southwestern section of Y-12. The data for well GW-606 indicate nitrate concentrations above $10 \mathrm{mg} / \mathrm{L}$ occur at least 7,900 ft downgradient of the site (Figure A.7). The elevated uranium concentrations in groundwater reflect transport/migration from one or more unspecified upgradient of well GW-605, and from the Oil Skimmer Basin (GW-154 and GW-223). As shown below, the highest concentrations of uranium were reported for well GW-154, located near the former Oil Skimmer Basin. 
Table 15. East Fork Regime CY 2009: elevated nitrate and uranium concentrations in surveillance monitoring aquifer wells

\begin{tabular}{|c|c|c|c|c|c|}
\hline \multirow{2}{*}{\multicolumn{2}{|c|}{ Well Location/Number }} & \multicolumn{2}{|c|}{ Nitrate (mg/L) } & \multicolumn{2}{|c|}{ Uranium (mg/L) } \\
\hline & & $\begin{array}{c}\text { Jan-May } \\
2009 \\
\end{array}$ & $\begin{array}{c}\text { July-Oct } \\
2009 \\
\end{array}$ & $\begin{array}{c}\text { Jan-May } \\
2009 \\
\end{array}$ & $\begin{array}{c}\text { July-Oct } \\
2009\end{array}$ \\
\hline Western Y-12 Area & $\begin{array}{l}\text { GW-253 } \\
\text { GW-251 }\end{array}$ & $\begin{array}{c}744 \\
38.7\end{array}$ & $\begin{array}{l}\text { NS } \\
\text { NS }\end{array}$ & $\begin{array}{l}< \\
<\end{array}$ & $\begin{array}{l}\text { NS } \\
\text { NS }\end{array}$ \\
\hline Central Y-12 Area & $\begin{array}{l}\text { GW-219 } \\
\text { GW-698 }\end{array}$ & $\begin{array}{l}\text { NA } \\
90.1\end{array}$ & $\begin{array}{l}\text { NA } \\
12.1\end{array}$ & $\begin{array}{c}0.555 \\
\text { NA }\end{array}$ & $\begin{array}{l}\text { NS } \\
\text { NA }\end{array}$ \\
\hline Eastern Y-12 Area & $\begin{array}{l}\text { GW-154 } \\
\text { GW-222 } \\
\text { GW-223 } \\
\text { GW-605 } \\
\text { GW-606 }\end{array}$ & $\begin{array}{c}\text { NA } \\
< \\
\dot{<} \\
< \\
12.8\end{array}$ & $\begin{array}{c}\text { NA } \\
< \\
\cdot \\
< \\
16\end{array}$ & $\begin{array}{c}0.6 \\
0.228 \\
0.04 \\
0.13 \\
<\end{array}$ & $\begin{array}{c}0.56 \\
0.228 \\
0.046 \\
0.1 \\
<\end{array}$ \\
\hline & MCL & \multicolumn{2}{|c|}{10} & \multicolumn{2}{|c|}{0.03} \\
\hline
\end{tabular}

The CY 2009 sampling results support the historical long-term concentration trends (Table B.10), with time-series plots of the nitrate and uranium data generally showing:

- A decreasing nitrate concentration trend for well GW-251 dominated by wide seasonal fluctuations (Figure A.27), with the highest concentrations typically evident during seasonally high-flow conditions (April and May). The relationship with seasonal flow conditions suggests that the nitrate concentrations are influenced by local inflow of nitrate-contaminated seasonal recharge and that the well intercepts active groundwater pathways. Also, the overall decrease in nitrate levels in the groundwater from this well probably reflects continued reduced flux of nitrate in the Maynardville Limestone west of the S-2 Site (closed in 1951) and the long-term effectiveness of natural attenuation processes.

- Indeterminate concentration trends for nitrate in wells GW-253 and GW-698 and for uranium in wells GW-154, GW-219, GW-222, and GW-605. These trends are illustrated by the historical data for wells GW-253 and GW-154 (Figure A.27). The relatively unchanged nitrate levels at well GW-253 suggest minimal long-term change in the flux of nitrate in the groundwater pathways monitored by the well. Such minimal changes in the rate of nitrate flux seem unusual considering that the S-2 Site closed more than 50 years ago and nitrate is highly mobile in groundwater. The uranium data obtained since 1991 for well GW-154 (Figure A.27) is dominated by conspicuous "peak" concentrations evident in January 1991 (0.81 mg/L) and July 2001 (1.37 mg/L). The latter result corresponds with a sharp spike in the groundwater elevation in the well. This relationship suggests wide temporal changes in the advective flux of uranium in the shallow groundwater flow system near this well.

- Increasing concentration trends for uranium in well GW-223 and for nitrate in well GW-606 (Figure A.27). The uranium levels indicated by the most recent sampling results for well GW-223 show concentrations that are an order-of-magnitude higher than the uranium data for samples collected in the late 1980s and early 1990s. The long-term increase in uranium concentrations reflects a corresponding increase in the flux of uranium in the groundwater flowpaths intercepted by the well. The Oil Skimmer Basin, closed along with New Hope Pond in 1988, is the suspected 
source of the uranium. The increasing trend in nitrate concentrations at well GW-606 generally began with the change from conventional to low flow sampling (October 1997). Therefore, it is uncertain that the higher nitrate concentrations reflect an increase in the flux of nitrate from the S-2 Site along groundwater flowpaths monitored by the well.

\section{Volatile Organic Compounds}

Groundwater samples collected during CY 2009 from 19 aquifer wells in the East Fork Regime contained one or more dissolved VOCs at individual or summed concentrations of $5 \mu \mathrm{g} / \mathrm{L}$ or more (Table B.10). As shown in Table 16, the maximum concentrations of PCE, TCE, c12DCE, VC, CTET, and/or chloroform exceed drinking water MCLs. The presence of VOCs reflects transport/migration of the intermingled plume(s) of dissolved VOCs in the Maynardville Limestone (Figure A.8). The summed concentration of chloroethenes (c12DCE and VC) in the CY 2009 groundwater sample from aquifer well GW-230 $(10.72 \mu \mathrm{g} / \mathrm{L})$ represent concentrations within the plume of dissolved VOCs that extends eastward from Y-12 (parallel with geologic strike in the Maynardville Limestone) into Union Valley east of the ORR boundary along Scarboro Road (Figure A.8). None of the CY 2009 sampling results for the wells in Union Valley exceeds the applicable drinking water MCLs.

Table 16. East Fork Regime CY 2009: maximum VOC concentrations in surveillance monitoring aquifer wells

\begin{tabular}{|c|c|c|c|c|c|c|}
\hline \multirow{2}{*}{ Location and Well } & \multicolumn{6}{|c|}{ Maximum Concentration $(\mu \mathrm{g} / \mathrm{L})$} \\
\hline & PCE & TCE & c12DCE & VC & CTET & Chloroform \\
\hline $\begin{array}{c}\text { Western Y-12 Area } \\
\text { GW-251 } \\
\text { GW-253 } \\
\text { GW-618 }\end{array}$ & $\begin{array}{c}230 \\
766 \\
<\end{array}$ & $\begin{array}{l}110 \\
812 \\
7.81\end{array}$ & $\begin{array}{c}< \\
257 \\
<\end{array}$ & $\begin{array}{c}75.6 \\
.\end{array}$ & $\begin{array}{c}< \\
42.4 \mathrm{~J} \\
.\end{array}$ & $\begin{array}{l}< \\
< \\
.\end{array}$ \\
\hline $\begin{array}{c}\text { Central Y-12 Area } \\
\text { GW-686 } \\
\text { GW-690 } \\
\text { GW-691 } \\
\text { GW-692 } \\
\text { GW-698 } \\
\text { GW-700 } \\
\text { GW-820 } \\
\text { GW-959 }\end{array}$ & $\begin{array}{c}6 \\
65 \\
14 \mathrm{Q} \\
7 \\
100 \\
17 \\
870 \\
.\end{array}$ & $\begin{array}{c}< \\
< \\
< \\
< \\
280 \\
10 \\
350 \\
\cdot\end{array}$ & $\begin{array}{c}< \\
< \\
\cdot \\
< \\
< \\
< \\
490 \\
<\end{array}$ & $\begin{array}{l}\dot{.} \\
\dot{.} \\
\dot{.} \\
. \\
.\end{array}$ & $\begin{array}{l}\dot{\cdot} \\
\dot{.} \\
\dot{<} \\
\dot{.} \\
\dot{.} \\
\dot{.}\end{array}$ & $\begin{array}{l}\dot{\cdot} \\
< \\
< \\
< \\
\dot{\cdot} \\
\dot{\cdot}\end{array}$ \\
\hline $\begin{array}{c}\text { Eastern Y-12 Area } \\
\text { GW-153 } \\
\text { GW-222 } \\
\text { GW-223 } \\
\text { GW-381 } \\
\text { GW-382 } \\
\text { GW-605 } \\
\text { GW-606 }\end{array}$ & $\begin{array}{c}13 \\
21.8 \\
< \\
25.5 \\
110 \\
6\end{array}$ & $\begin{array}{c}\dot{<} \\
13.4 \\
\cdot \\
\dot{1} \\
< \\
<\end{array}$ & $\begin{array}{c}\dot{<} \\
<0.2 \\
< \\
< \\
160\end{array}$ & $\begin{array}{l}\cdot \\
\dot{5.04} \\
\dot{\cdot} \\
\dot{<} \\
\dot{ }\end{array}$ & $\begin{array}{c}68 \\
\cdot \\
\cdot \\
430 \\
81 \\
61\end{array}$ & $\begin{array}{l}< \\
\cdot \\
\cdot \\
< \\
120 \\
< \\
<\end{array}$ \\
\hline $\begin{array}{c}\text { Union Valley } \\
\text { GW-230 }\end{array}$ & . & . & $<$ & $<$ & . & . \\
\hline MCL & 5 & 5 & 70 & 2 & 5 & $80 *$ \\
\hline
\end{tabular}


The CY 2009 VOC results for the aquifer wells support the long-term summed VOC (e.g., chloroethenes) concentration trends (Table B.10), and time-series plots of the VOC data generally show:

- Variable but generally decreasing trends for chloroethene and/or chloromethane concentrations for eight wells (GW-153, GW-223, GW-230, GW-382, GW-618, GW-690, GW-700, and GW-959), as illustrated by the summed concentration of chloromethanes detected in well GW-382 and chloroethenes in well GW-618 (Figure A.28). The decreasing concentration trends reflect reduced flux of VOCs from the applicable source areas and the long-term effects of natural attenuation processes. The decrease in VOC concentrations at well GW-382 between May 1995 and September 1999 may reflect a sampling method bias with higher concentrations in samples obtained with the conventional method.

- Indeterminate concentration trends for chloroethenes and/or chloromethanes (Table B.10) in groundwater from seven wells (GW-222, GW-251, GW-253, GW-686, GW-691, GW-698, and GW-820). These trends are illustrated by the summed chloroethene concentrations detected in the groundwater samples from wells GW-251 and GW-698 (Figure A.28). The summed VOC concentrations at well GW-251 show clearly seasonal fluctuations, with high concentrations evident in samples collected during seasonally high flow conditions (April and May). As noted previously regarding nitrate levels in well GW-251, this relationship suggests seasonal inflow of contaminated recharge in groundwater flowpaths intercepted by the well. The VOC concentrations at well GW-698 generally show seasonal fluctuations that are opposite of the relationship shown at well GW-251. Higher VOC concentrations evident during seasonally low flow conditions (October/November) suggest recharge of less contaminated groundwater that dilute the VOC concentrations during high flow conditions.

- An increasing concentration trend for summed chloroethenes and chloromethanes in the groundwater samples collected with low flow sampling from well GW-605 (Figure A.28). The VOC concentrations show seasonal fluctuations, with high concentrations typically evident in samples collected during seasonally low flow conditions (July). This relationship suggests seasonal inflow of uncontaminated recharge via the groundwater flowpaths intercepted by the monitored interval in the well. The increasing VOC concentration trends probably reflect increased flux in the groundwater flowpaths monitored by the well.

- A combination of indeterminate trends for summed chloroethenes and decreasing trends for summed chloromethanes in groundwater from wells GW-381, GW-606, and GW-692 (Table B.10). The divergent trends suggest different source areas and/or flowpaths for the different types of VOCs detected at these wells.

Divergent concentration trends for individual chloroethenes may reflect biologically mediated degradation at wells GW-223 and GW-253. For instance, while the 12DCE concentrations reported for well GW-223

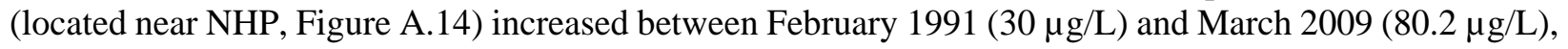
significant concentration decreases were reported for this same time period for concentrations of PCE $(190 \mu \mathrm{g} / \mathrm{L}-21.8 \mu \mathrm{g} / \mathrm{L})$ and TCE $(42 \mu \mathrm{g} / \mathrm{L}-13.4 \mu \mathrm{g} / \mathrm{L})$. Similarly at well GW-253, the concentrations of PCE and TCE have remained fairly stable (indeterminate trend) while concentrations of VC have increased from not detected in CY 1991 to $75.6 \mu \mathrm{g} / \mathrm{L}$ in March 2009. 


\section{Gross Alpha and Gross Beta}

Groundwater samples collected during CY 2009 from 12 aquifer wells in the East Fork Regime contained gross alpha activity and/or gross beta activity above the MDA and corresponding TPU (Appendix E.3). As shown in Table 17, only five of these wells had elevated gross alpha activity ( $>15 \mathrm{pCi} / \mathrm{L}$ ) or gross beta activity $(>50 \mathrm{pCi} / \mathrm{L})$. Elevated gross alpha and gross beta activity at these aquifer wells reflect the transport/migration of radiological contaminants (primarily uranium isotopes) from the S-2 Site (GW-253), one or more sources upgradient of well GW-605, and the Oil Skimmer Basin (GW-154).

Table 17. East Fork Regime CY 2009: elevated gross alpha activity and gross beta activity in surveillance monitoring aquifer wells

\begin{tabular}{|c|c|c|c|c|c|c|c|c|c|}
\hline \multirow{3}{*}{$\begin{array}{c}\text { Well } \\
\begin{array}{c}\text { Western Y-12 Area } \\
\text { GW-253 }\end{array}\end{array}$} & \multirow{3}{*}{$\begin{array}{c}\begin{array}{c}\text { Date } \\
\text { Sampled }\end{array} \\
03 / 04 / 09\end{array}$} & \multicolumn{4}{|c|}{ Gross Alpha (pCi/L) } & \multicolumn{4}{|c|}{ Gross Beta (pCi/L) } \\
\hline & & \multirow{2}{*}{$\begin{array}{c}\text { MDA } \\
4.65\end{array}$} & \multicolumn{3}{|c|}{ Activity \pm TPU } & \multirow{2}{*}{$\begin{array}{c}\text { MDA } \\
7.0\end{array}$} & \multicolumn{3}{|c|}{ Activity \pm TPU } \\
\hline & & & 23.7 & \pm & 5.6 & & & $<$ & \\
\hline $\begin{array}{c}\text { Central Y-12 Area } \\
\text { GW-219 }\end{array}$ & 05/11/09 & 2.9 & 140 & \pm & 9.4 & 7 & 82 & \pm & 8.1 \\
\hline Eastern Y-12 Area & & & & & & & & & \\
\hline GW-154 & 03/03/09 & 3.17 & 433 & \pm & 70.7 & 7.34 & 133 & \pm & 22.2 \\
\hline GW-154 & 07/23/09 & 3.55 & 354 & \pm & 59.5 & 8.9 & 67.6 & \pm & 12.8 \\
\hline GW-222 & 04/30/09 & 3.1 & 70 & \pm & 6.7 & 7.5 & & $<$ & \\
\hline GW-605 & 01/08/09 & 2.47 & 71 & \pm & 12.8 & 4.76 & & $<$ & \\
\hline GW-605 & 07/07/09 & 2.34 & 51.8 & & 9.74 & 4.65 & & $<$ & \\
\hline \multicolumn{2}{|c|}{ Screening Level } & \multicolumn{4}{|c|}{15} & \multicolumn{4}{|c|}{50} \\
\hline
\end{tabular}

The gross alpha and gross beta activity reported for the samples collected during CY 2009 support the long-term trends indicated by historical data (Table B.10). Time-series plots of the gross alpha and/or gross beta activity reported for each applicable well generally show:

- Widely variable, indeterminate long-term trends for gross alpha activity in groundwater from wells GW-154, GW-219, GW-222, GW-253, and GW-605 and for gross beta activity at wells GW-154 and GW-219. These trends, illustrated by the data for wells GW-154, GW-219, and GW-605 (Figure A.29), suggest minimal relative change in the flux of uranium isotopes in hydrostratigraphic intervals monitored by the wells. These indeterminate trends are consistent with the indeterminate long-term total uranium concentration trends evident for these wells (Table B.10).

\subsubsection{Chestnut Ridge Regime}

The CY 2009 groundwater sampling results for 41 wells on Chestnut Ridge meet the requirements of surveillance monitoring in the Chestnut Ridge Regime. Most of these wells continue to yield uncontaminated groundwater. Data for a few wells suggest artifacts of well installation/construction, including elevated nickel from corrosion of the stainless steel well screen (GW-305) and the geochemical influence of cement grout, such as strongly basic $\mathrm{pH}$ and unusually high potassium concentrations (wells GW-205 and GW-757). Aside from these artifacts, VOCs were the contaminants most frequently detected 
in the groundwater samples collected during CY 2009, with at least one principal compound detected $(>1 \mu \mathrm{g} / \mathrm{L})$ in samples from nine wells (Table 18). The TCE and c12DCE results for well GW-217 are inconsistent with historic and subsequent results (see Appendix F) from the well, are considered to be analytical artifacts, and are excluded from further discussion in this report.

Table 18. Chestnut Ridge Regime CY 2009: maximum VOC concentrations in surveillance monitoring wells

\begin{tabular}{|c|c|c|c|c|c|c|c|c|}
\hline \multirow{2}{*}{ Well } & \multicolumn{8}{|c|}{ Maximum Concentration ( $\mu \mathrm{g} / \mathrm{L}$ ) } \\
\hline & PCE & TCE & c12DCE & 11DCE & 111TCA & 11DCA & TCFM & F113 \\
\hline $\begin{array}{r}\text { Near CRSP: } \\
\text { GW-174 } \\
\text { GW-175 } \\
\text { GW-176 } \\
\text { GW-177 } \\
\text { GW-180 } \\
\text { GW-322 } \\
\text { GW-798 } \\
\text { IL IV: } \\
\text { GW-217 } \\
\text { GW-305 }\end{array}$ & $\begin{array}{l}\dot{4} \mathrm{~J} \\
\dot{4} \\
\dot{4} \mathrm{~J} \\
4 \mathrm{~J} \\
15\end{array}$ & $\begin{array}{c}\cdot \\
\cdot \\
\cdot \\
\cdot \\
\cdot \\
1.3 \mathrm{~J} \\
6.8 \mathrm{Q} \\
\cdot\end{array}$ & $\begin{array}{c}1 \mathrm{~J} \\
\dot{13} \\
2.6 \mathrm{Q}\end{array}$ & $\begin{array}{c}\cdot \\
\dot{2} \\
8.09 \\
\cdot \\
53 \\
8.7 \\
\\
\dot{9} \\
9.1\end{array}$ & $\begin{array}{c}\cdot \\
\dot{20} \\
7.75 \\
\dot{16} \\
2.9 \mathrm{~J} \\
\\
\dot{18}\end{array}$ & $\begin{array}{c}\cdot \\
\dot{4} 6 \\
39 \\
. \\
75 \\
4.7 \mathrm{~J} \\
\\
\\
\dot{40}\end{array}$ & $\begin{array}{l}10 \\
3 \mathrm{~J} \\
2 \mathrm{~J} \\
\mathrm{NR} \\
5 \mathrm{~J} \\
32 \\
22\end{array}$ & $\begin{array}{c}3 \mathrm{~J} \\
\cdot \\
\cdot \\
\mathrm{NR} \\
2 \mathrm{~J} \\
3 \mathrm{~J} \\
\cdot\end{array}$ \\
\hline MCL & 5 & 5 & 70 & 7 & 200 & NA & NA & NA \\
\hline
\end{tabular}

The CRSP are the source of the VOCs in the groundwater at seven of these wells (GW-174, GW-175, GW-176, GW-177, GW-180, GW-322, and GW-798). Historical operation of the eastern and western waste disposal trench areas at the CRSP emplaced an elongated plume of dissolved VOCs in the groundwater that currently extends more than $700 \mathrm{ft}$ east-northeast along the ridge crest (parallel with geologic strike) and at least $300 \mathrm{ft}$ to the north and south down the ridge flanks (Figure A.8). As shown in Table 18, PCE, 11DCE, 111TCA, 11DCA, and trichlorofluoromethane (TCFM) are the VOCs detected most frequently in samples from CRSP monitoring wells. The maximum concentration of PCE and/or 11DCE reported for wells GW-176, GW-177, GW-322, and GW-798 exceed respective drinking water MCLs.

Historic data show that 111TCA, 11DCA, and 11DCE are the primary VOCs near the western disposal trench area and PCE and 12DCE are the principal VOCs near the eastern disposal trench area. Elongation of the VOC plume along the axis of the ridge and the distribution of plume constituents relative to source trenches indicate primarily west-to-east groundwater flow/contaminant transport in strike-parallel flowpaths (e.g., bedding-plane fractures). However, detection of VOCs in groundwater from wells located south and southeast of the site (down dip and perpendicular to strike) suggests that conduit transport from the site also occurs.

Over time, the concentrations of the primary components of the plume (PCE and 111TCA) have decreased while the concentrations of 111TCA degradation products (11DCE and 11DCA) have increased or remained stable, which suggests active biotic and/or chemical degradation processes. The concentration 
of degradation products (11DCE and 11DCA) is currently higher than the parent compound (111TCA) at wells GW-176, GW-177, GW-322, and GW-798.

The CY 2009 sampling results generally continue the long-term concentration trends indicated by historical VOC data (Table B.11), as illustrated the VOC data for wells GW-322 and GW-798 (Figure A.30). The 111TCA concentrations at well GW-322 show a steadily decreasing trend, with the summed concentration of degradation products (11DCA and 11DCE) increasing from March 1988 through January 1998 then decreasing concurrently with 111TCA (Figure A.30). The VOC data for well GW-798 shows an overall indeterminate trend characterized by peak concentrations in January 2003, January 2007, and February 2009 (Figure A.30).

The groundwater samples collected from well GW-305 during CY 2009 contained 11DCE, 11DCA, and 111TCA (Table 18). The source of the VOCs in the groundwater from the well is unconfirmed. Along with the historical data, the CY 2009 monitoring results continue the concentration trends evident after the sequential detection of 111TCA, 11DCA, and 11DCE beginning in January 1992 (Figure A.30). The data show the arrival of the parent compound (111TCA) followed four years later by the related degradation products (11DCA and 11DCE). From January 2001 to December 2009, 111TCA concentrations have decreased $(20 \mu \mathrm{g} / \mathrm{L}-14 \mu \mathrm{g} / \mathrm{L}), 11 \mathrm{DCE}$ concentrations have remained fairly stable $(4.1 \mu \mathrm{g} / \mathrm{L}-7.9 \mu \mathrm{g} / \mathrm{L})$, and 11DCA concentrations have increased $(12 \mu \mathrm{g} / \mathrm{L}-35.7 \mu \mathrm{g} / \mathrm{L})$.

\subsection{EXIT PATHWAY/PERIMETER MONITORING}

This section describes results of groundwater and surface water quality monitoring performed during CY 2009 in areas where contaminants associated with Y-12 are most likely to be transported beyond the boundary of the DOE ORR. Separate discussions of the monitoring data obtained from respective networks of exit pathway/perimeter sampling locations in the Bear Creek, East Fork, and Chestnut Ridge hydrogeologic regimes are provided.

\subsubsection{Bear Creek Regime}

The CY 2009 monitoring results and historical data for the monitoring wells, springs, and surface water sampling locations listed from upstream to downstream in Table 19 meet exit pathway/perimeter monitoring requirements. These locations are (1) three monitoring wells that are located in a perimeter region (Exit Pathway Picket W, Figure A.13), (2) six springs that represent natural groundwater discharge locations, and (3) 19 surface water stations that measure water quality in strategic locations along Bear Creek. For this report, these sampling locations are assigned to three areas: Upper, Middle, and Lower Bear Creek. Upper Bear Creek encompasses the surface water sampling locations upstream (east) of the confluence of NT-2 with Bear Creek (Figure A.11), including two sampling locations in Bear Creek (BCK-11.97 and BCK-12.34) and sampling locations in NT-1 (NT-01) and NT-2 (S07). Middle Bear Creek encompasses the surface water sampling stations and springs that are located along Bear Creek between NT-2 and NT-9 (Figure A.11), including two springs (SS-4 and SS-5), four sampling location in Bear Creek (BCK-09.20, BCK-09.40, BCK-11.54, and BCK-11.84), and sampling locations in NT-3 (EMWNT-03A and NT-03), NT-4 (NT-04 and EMW-VWUNDER), NT-5 (EMWNT-05 and EMW-VWEIR), NT-7 (NT-07), and NT-8 (NT-08). The lower Bear Creek sampling locations (downstream of NT-9) include the monitoring wells listed in Table 19, four springs (SS-6, SS-6.6, SS-7, 
and SS-8), and three surface water stations in Bear Creek (BCK.03.30, BCK-04.55, and BCK-07.87) (Figure A.11).

Table 19. Bear Creek Regime CY 2009: sampling locations used for exit pathway/perimeter monitoring

\begin{tabular}{|c|c|c|c|c|c|}
\hline \multirow[b]{2}{*}{$\begin{array}{c}\text { Bear Creek } \\
\text { Area }\end{array}$} & \multicolumn{2}{|c|}{ Monitoring Wells } & \multirow{2}{*}{ Springs } & \multicolumn{2}{|c|}{ Surface Water Stations } \\
\hline & $\begin{array}{c}\text { Well } \\
\text { Number }\end{array}$ & $\begin{array}{l}\text { Monitored Interval } \\
\text { Depth (ft bgs) }\end{array}$ & & $\begin{array}{c}\text { Bear Creek } \\
\text { Main Channel }\end{array}$ & $\begin{array}{l}\text { Bear Creek } \\
\text { Tributaries }\end{array}$ \\
\hline Upper & - & & - & $\begin{array}{l}\text { BCK-12.34 } \\
\text { BCK-11.97 }\end{array}$ & $\begin{array}{c}\text { NT-01 } \\
\text { NT-02 (S07) }\end{array}$ \\
\hline Middle & - & & $\begin{array}{l}\text { SS-4 } \\
\text { SS-5 }\end{array}$ & $\begin{array}{l}\text { BCK-11.84 } \\
\text { BCK.11.54 } \\
\text { BCK-09.40 } \\
\text { BCK-09.20 }\end{array}$ & $\begin{array}{c}\text { EMWNT-03A } \\
\text { NT-03 } \\
\text { NT-04 } \\
\text { EMW-VWUNDER (NT-4) } \\
\text { EMWNT-05 } \\
\text { EMW-VWEIR (NT-5) } \\
\text { NT-07 } \\
\text { NT-08 }\end{array}$ \\
\hline Lower & $\begin{array}{l}\text { GW-712 } \\
\text { GW-713 } \\
\text { GW-714 }\end{array}$ & $\begin{array}{l}441.5-457.5 \\
305.0-315.2 \\
115.1-145.0\end{array}$ & $\begin{array}{l}\text { SS-6 } \\
\text { SS-6.6 } \\
\text { SS-7 } \\
\text { SS-8 } \\
\end{array}$ & $\begin{array}{l}\text { BCK-07.87 } \\
\text { BCK-04.55 } \\
\text { BCK-03.30 }\end{array}$ & - \\
\hline
\end{tabular}

\subsubsection{Upper Bear Creek}

The chemical quality of surface water in Upper Bear Creek is primarily controlled by inflow of groundwater containing the principal components of the contaminant plume emplaced during historical operations of the S-3 Ponds. To the west of this site, contaminated groundwater discharges from the aquitard (Nolichucky Shale) as base flow into NT-1, which enters Bear Creek about 2,500 ft downstream of the site. The highly contaminated groundwater in the Nolichucky Shale extends west of NT-1 where it upwells into the shallow flow system and ultimately discharges into NT-2, which enters the main channel of Bear Creek about 1,400 ft downstream of its confluence with NT-1 (Figure A.11). In addition to the influx of contaminants from the NT-1 and NT-2 catchments, contaminated groundwater in the Maynardville Limestone discharges into Bear Creek via seeps and springs along the main channel of the creek.

As shown in Table 20, monitoring results obtained during CY 2009 show that nitrate, uranium, and PCE concentrations in Upper Bear Creek remain above respective screening levels, with the highest levels of nitrate and gross beta activity in NT-01 and highest uranium and gross alpha activity in the main channel of Bear Creek. 
Table 20. Upper Bear Creek CY 2009: maximum contaminant concentrations

\begin{tabular}{|c|c|c|c|c|c|}
\hline \multirow{2}{*}{$\begin{array}{l}\text { Sampling } \\
\text { Point }\end{array}$} & \multirow{2}{*}{$\begin{array}{l}\text { Nitrate } \\
\text { (mg/L) }\end{array}$} & \multirow{2}{*}{$\begin{array}{c}\text { Uranium } \\
\text { (mg/L) }\end{array}$} & \multirow{2}{*}{$\begin{array}{c}\text { PCE } \\
(\mu \mathrm{g} / \mathrm{L})\end{array}$} & \multicolumn{2}{|c|}{ Radioactivity (pCi/) } \\
\hline & & & & Alpha & Beta \\
\hline NT-01 & 122 & 0.0213 & 26 & 5.8 & 310 \\
\hline S07 & NA & & & NA & NA \\
\hline BCK-12.34 & 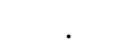 & 0.11 & 7.5 & NA & NA \\
\hline BCK-11.97 & 28.5 & 0.158 & & 64 & 84 \\
\hline Screening Level & 10 & 0.03 & 5 & 15 & 50 \\
\hline
\end{tabular}

These results are generally consistent with historical data and show that contaminants associated with historical operations at Y-12 continue to substantially impact the quality of surface water in Upper Bear Creek.

\subsubsection{Middle Bear Creek}

Surface water quality in Middle Bear Creek is impacted by contaminants from the S-3 Site (nitrate, uranium, and radioactivity), the BYBY/HCDA (uranium and VOCs), and the BCBG WMA (uranium, VOCs, and radioactivity). Also, results of a study by the U.S. Geological Survey show that much of Middle Bear Creek loses flow to the Maynardville Limestone, particularly the section of the channel immediately south of the OLF WMA. This section of the main channel of Bear Creek plays an important role in transferring contaminants from the creek into the groundwater flow system (DOE 1997a) which discharges from springs SS-4 and SS-5 located downgradient of this losing reach of Bear Creek.

As shown in Table 21, elevated concentrations (i.e., >screening level) of one or more of the principal contaminants in the Bear Creek Regime were reported for five of the exit pathway sampling locations in Middle Bear Creek. The highest nitrate concentrations were reported for surface water stations located in the main Channel of Bear Creek nearest to the S-3 Site (BCK-11.84 and BCK-11.54). The highest uranium levels were reported for the sampling location in NT-8, west of the BCBG WMA (Figure A.11). The uranium concentration reported for station BCK-09.40 is similar to the uranium concentration at station BCK-11.84, which reflects contributions of uranium to Bear Creek from spring SS-4 and NT-08. The highest VOC concentrations were reported for surface water stations at the BCBG (NT-07 and NT-08). 
Table 21. Middle Bear Creek CY 2009: maximum contaminant concentrations

\begin{tabular}{|c|c|c|c|c|c|c|c|c|c|}
\hline \multirow{2}{*}{$\begin{array}{l}\text { Sampling } \\
\text { Point }\end{array}$} & \multirow{2}{*}{$\begin{array}{l}\text { Nitrate } \\
\text { (mg/L) }\end{array}$} & \multirow{2}{*}{$\begin{array}{l}\text { Uranium } \\
\text { (mg/L) }\end{array}$} & \multicolumn{5}{|c|}{ Chloroethenes $(\mu \mathrm{g} / \mathrm{L})$} & \multicolumn{2}{|c|}{ Radioactivity (pCi/L) } \\
\hline & & & PCE & TCE & C12DCE & 11DCE & VC & Alpha & Beta \\
\hline BCK-11.84 & 31 & 0.0816 & . & . & . & . & • & NA & NA \\
\hline EMWNT-03 & NA & & . & . & . & $\cdot$ & • & NA & NA \\
\hline NT-03 & 0.017 & 0.0303 & . & . & . & $\cdot$ & . & NA & NA \\
\hline BCK-11.54 & 19 & 0.0545 & . & . & . & $\cdot$ & r. & NA & NA \\
\hline EMW-VWUNDER & NA & . & . & . & & . & . & NA & NA \\
\hline NT-04 & NA & 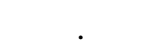 & . & . & 5.83 & 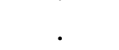 & . & NA & NA \\
\hline EMWNT-05 & NA & & . & . & . & . & 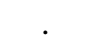 & NA & NA \\
\hline EMW-VWWEIR & NA & 0.0084 & . & & & . & . & NA & NA \\
\hline SS-4 & 15.3 & 0.0801 & 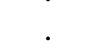 & $3 \mathrm{~J}$ & $3 \mathrm{~J}$ & 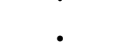 & . & 42 & 33 \\
\hline NT-07 & 0.61 & 0.031 & 36.5 & 34.1 & 186 & 7.33 & 3.41 & NA & NA \\
\hline NT-08 & 0.04 & 0.42 & 24 & 28 & 150 & 4.7 & 4.8 & NA & NA \\
\hline BCK-09.40 & 5.86 & 0.0812 & . & $3 \mathrm{~J}$ & . & . & . & 36 & 22 \\
\hline SS-5 & 2.78 & 0.0242 & 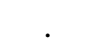 & & & 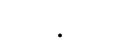 & . & 17 & 13 \\
\hline BCK-09.20 & . & 0.044 & 1.3 & 1.5 & 7 & . & . & NA & NA \\
\hline Screening Level & 10 & 0.03 & 5 & 5 & 70 & 7 & 2 & 15 & 50 \\
\hline
\end{tabular}

These monitoring results are generally consistent with historical data and show that contaminants associated with Y-12, particularly total uranium (and gross alpha activity) and VOCs, continue to impact the quality of surface water in Middle Bear Creek. Recent data suggest a possible increase in VOC and uranium concentration in samples from stations NT-07 and NT-08 at the BCBG, although results are still within the historical range of contaminants at each location.

\subsubsection{Lower Bear Creek}

The quality of groundwater and surface water in Lower Bear Creek is substantially less impacted by contaminants present in upstream areas of BCV. As shown by the CY 2009 monitoring results summarized in Table 22, the concentrations of all principal contaminants were below applicable screening levels at BCK-04.55. The only result reported above a respective screening level was the uranium concentration at surface water station BCK-07.87. 
Table 22. Lower Bear Creek CY 2009: maximum contaminant concentrations

\begin{tabular}{|c|c|c|c|c|c|}
\hline \multirow{2}{*}{ Sampling Point } & \multirow{2}{*}{$\begin{array}{l}\text { Nitrate } \\
(\mathrm{mg} / \mathrm{L})\end{array}$} & \multirow{2}{*}{$\begin{array}{c}\text { Uranium } \\
(\mathrm{mg} / \mathrm{L})\end{array}$} & \multirow{2}{*}{$\begin{array}{c}\text { Summed VOCs } \\
(\mu \mathrm{g} / \mathrm{L})\end{array}$} & \multicolumn{2}{|c|}{ Radioactivity (pCi/L) } \\
\hline & & & & Gross Alpha & Gross Beta \\
\hline \multicolumn{6}{|l|}{ Monitoring Wells } \\
\hline GW-712 & 0.052 & $\cdot$ & • & • & 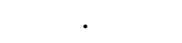 \\
\hline GW-713 & 0.028 & . & . & . & . \\
\hline GW-714 & 0.34 & . & . & . & 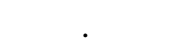 \\
\hline \multicolumn{6}{|l|}{ Springs } \\
\hline SS-6 & 0.68 & 0.0065 & . & 3.19 & 4.2 \\
\hline SS-6.6 & 0.1 & . & . & NA & NA \\
\hline SS-7 & 0.064 & . & . & NA & NA \\
\hline SS-8 & 0.19 & . & . & NA & NA \\
\hline \multicolumn{6}{|l|}{ Surface Water } \\
\hline BCK-07.87 & 4.2 & 0.0396 & 1.2 & NA & NA \\
\hline BCK-04.55 & 1.56 & 0.0283 & $2 \mathrm{~J}$ & 12 & 14 \\
\hline BCK-03.30 & 0.81 & 0.0127 & 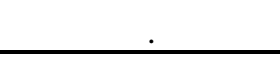 & NA & NA \\
\hline Screening Level & 10 & 0.03 & MCL or $>5 \mu \mathrm{g} / \mathrm{L}$ & 15 & 50 \\
\hline
\end{tabular}

The CY 2009 monitoring results are generally consistent with respective historical data and show that contaminants associated with Y-12 continue to impact the quality of surface water in Lower Bear Creek. Sampling results for the exit pathway monitoring wells indicate no significant impact on groundwater quality.

\subsubsection{East Fork Regime}

The CY 2009 monitoring results and respective historical data for the monitoring wells, springs, and surface water sampling locations listed in Table 23 meet the requirements of exit pathway/perimeter monitoring for the East Fork Regime. The monitoring wells are located near the eastern end of Y-12 and are hydraulically downgradient of NHP/Lake Reality and all but three of the wells (GW-151, GW-220, and GW-832) are within $500 \mathrm{ft}$ of the ORR boundary along Scarboro Road (Figure A.14). Spring SP-17 is located on the south side of UEFPC about 1,700 ft upstream of NHP, and the two surface water stations located in the East Fork (200A6 and Station 8) are in the south-central part of Y-12 (Figure A.14).

Table 23. East Fork Regime CY 2009: sampling locations for exit pathway/perimeter monitoring

\begin{tabular}{|c|c|c|c|c|c|c|}
\hline \multicolumn{4}{|c|}{ Monitoring Wells/ Monitored Interval Depth } & \multirow{2}{*}{ Springs } & \multicolumn{2}{|c|}{ Surface Water Stations } \\
\hline $\begin{array}{c}\text { Well } \\
\text { Number }\end{array}$ & Depth (ft bgs) & $\begin{array}{c}\text { Well } \\
\text { Number }\end{array}$ & Depth (ft bgs) & & UEFPC & $\begin{array}{l}\text { North of } \\
\text { Pine Ridge }\end{array}$ \\
\hline $\begin{array}{l}\text { GW-151 } \\
\text { GW-220 } \\
\text { GW-722 } \\
\text { GW-733 }\end{array}$ & $\begin{aligned} 85.0 & -110.0 \\
31.0 & -45.2 \\
75.0 & -644.3 \\
240.1 & -256.5\end{aligned}$ & $\begin{array}{l}\text { GW-744 } \\
\text { GW-747 } \\
\text { GW-750 } \\
\text { GW-816 } \\
\text { GW-832 }\end{array}$ & $\begin{array}{r}55.0-69.5 \\
60.8-73.0 \\
61.2-72.2 \\
2.9-15.8 \\
4.0-11.8\end{array}$ & $\begin{array}{c}\text { SP-17 } \\
\text { Union Valley } \\
\text { SCR7.1SP } \\
\text { SCR7.8SP }\end{array}$ & $\begin{array}{c}200 \mathrm{~A} 6 \\
\text { Station } 8\end{array}$ & $\begin{array}{c}\text { GHK2.51WSW } \\
\text { NPR12.0SW } \\
\text { NPR23.0SW }\end{array}$ \\
\hline
\end{tabular}


In addition to the surface water and spring sampling locations within the East Fork Regime, two springs located along South Illinois Avenue east of Y-12 (Figure A.14) and three sampling stations (GHK2.51WSW, NPR12.0SW, and NPR23.0SW) located in drainage features along the ORR boundary north of Pine Ridge (Figure A.15) also serve as exit pathway/perimeter monitoring locations. Sampling results for these locations showed principal contaminant concentrations below screening levels.

\subsubsection{Groundwater}

At least one of the groundwater samples collected during CY 2009 from the five exit pathway wells located in the Maynardville Limestone (GW-151, GW-220, GW-722, GW-733, and GW-832) had summed concentrations of dissolved VOCs of at least $5 \mu \mathrm{g} / \mathrm{L}$. Each of these wells are located within 1,000 ft of the groundwater extraction well (GW-845) being used to capture the VOC plume in the groundwater extending from the eastern end of Y-12 into Union Valley east of the ORR boundary along Scarboro Road (see Section 2.3.1.1 and Figure A.14). As shown in Table 24, the groundwater samples from each of these wells contained concentrations of CTET and /or PCE and TCE that exceed drinking water MCLs.

Table 24. East Fork Regime CY 2009: maximum VOC concentrations in exit pathway/perimeter monitoring wells

\begin{tabular}{|c|c|c|c|c|c|}
\hline \multirow{2}{*}{ Well } & \multicolumn{5}{|c|}{ Maximum Concentration $(\mu \mathrm{g} / \mathrm{L})$} \\
\hline & PCE & TCE & c12DCE & CTET & Chloroform \\
\hline GW-151 & 731 & $115 \mathrm{~J}$ & $61.4 \mathrm{~J}$ & 1,340 & $74.5 \mathrm{~J}$ \\
\hline GW-220 & 210 & 100 & 65 & 690 & 71 \\
\hline GW-722-22 & 3 & $1.26 \mathrm{~J}$ & . & 21.8 & $2.06 \mathrm{~J}$ \\
\hline GW-722-20 & 8 & $1.72 \mathrm{~J}$ & . & 51.2 & 7.19 \\
\hline GW-722-17 & 4 & & . & 23 & $4.96 \mathrm{~J}$ \\
\hline GW-722-14 & $4 \mathrm{~J}$ & $1.04 \mathrm{~J}$ & . & 26 & $2.16 \mathrm{~J}$ \\
\hline GW-733 & 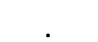 & & $\cdot$ & 7.3 & $1 \mathrm{~J}$ \\
\hline GW-832 & 7 & $1 \mathrm{~J}$ & $0.8 \mathrm{~J}$ & 6.77 & $1.49 \mathrm{~J}$ \\
\hline$\overline{\mathrm{MCL}}$ & 5 & 5 & 70 & 5 & NA \\
\hline
\end{tabular}

These results are consistent with historical data and illustrate the range of VOC concentrations within in the shallow karst network (GW-151, GW-220, and GW-832) and deeper bedrock intervals (GW-722 and GW-733) in the Maynardville Limestone at the east end of Y-12. The CY 2009 monitoring results continue the long-term concentration trends indicated by historical VOC data for these wells (Table B.10), as illustrated by the decreasing PCE trends for sampling ports in Westbay well GW-722 (e.g., GW-722-14), the indeterminate PCE trend for well GW-832, and the increasing PCE trends for wells GW-151 and GW-220 (Figure A.31). The VOC concentration trends evident for some wells, particularly CTET at Westbay well GW-722, suggest a direct response to the long-term operation of groundwater extraction well GW-845 (Figure A.32).

The CY 2009 monitoring results for spring SP-17 show that the nitrate concentration $(9.08 \mathrm{mg} / \mathrm{L})$ at this location is just below the drinking water MCL for nitrate $(10 \mathrm{mg} / \mathrm{L})$. The S-2 Site is the suspected source of nitrate in the groundwater at this spring (Figure A.7). Samples from springs SCR7.1SP and SCR7.8SP in Union Valley were analyzed for VOCs and none were detected. 


\subsubsection{Surface Water}

Maximum concentrations reported for CY 2009 samples, summarized in Table 25 (sampling stations are listed from upstream to downstream along UEFPC), show that nitrate, uranium, or gross alpha activity was detected at three of the surface water sampling stations used for exit pathway/perimeter monitoring.

Table 25. East Fork Regime CY 2009: maximum contaminant concentrations in exit pathway/perimeter surface water sampling locations

\begin{tabular}{|c|c|c|c|c|c|}
\hline \multirow{2}{*}{ Sampling Point } & \multirow{2}{*}{$\begin{array}{l}\text { Nitrate } \\
(\mathrm{mg} / \mathrm{L})\end{array}$} & \multirow{2}{*}{$\begin{array}{l}\text { Uranium } \\
\text { (mg/L) }\end{array}$} & \multirow{2}{*}{$\begin{array}{c}\text { Summed VOCs } \\
(\mu \mathrm{g} / \mathrm{L})\end{array}$} & \multicolumn{2}{|c|}{ Radioactivity (pCi/L) } \\
\hline & & & & Alpha & Beta \\
\hline \multicolumn{6}{|l|}{ UEFPC } \\
\hline $200 \mathrm{~A} 6$ & NA & 0.088 & NA & NA & NA \\
\hline Station 8 & NA & 0.036 & NA & 12.9 & 8.99 \\
\hline \multicolumn{6}{|l|}{ North of Pine Ridge } \\
\hline GHK2.51WSW & 0.21 & $\cdot$ & . & . & \\
\hline NPR12.0SW & 0.172 & . & . & . & 5.8 \\
\hline NPR23.0SW & 0.177 & . & . & . & 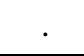 \\
\hline Screening Level & 10 & 0.03 & 5 & 15 & 50 \\
\hline
\end{tabular}

The CY 2009 uranium concentrations for surface water stations 200A6 and Station 8 exceed the drinking water MCL $(0.03 \mathrm{mg} / \mathrm{L})$ and continue the indeterminate long-term concentration trend indicated by historical uranium results (Table B.10). Principal groundwater contaminant concentrations evident at these locations during CY 2009 reflect the continued impact of legacy Y-12 operations on the quality of surface water in UEFPC upstream of the ORR boundary.

Although not a principal groundwater contaminant because of very low solubility, mercury is a primary contaminant of soils and surface water in the East Fork Regime as a legacy of historical operations at Y-12. Extensive surface water sampling (flow proportionate and grab samples) is performed by other monitoring programs (e.g., NPDES and CERCLA) and the annual monitoring results are not addressed in this document. However for information purposes, the mercury concentration reported for over 200 surface water samples collected during CY 2009 from Station 17 ranged from $0.000021 \mathrm{mg} / \mathrm{L}$ (August 2009) to $0.005511 \mathrm{mg} / \mathrm{L}$ (January 2009), which exceeds the drinking water MCL (0.002 mg/L). Station 17 is located in UEFPC on the south side of Bear Creek Road (Figure A.13) downstream (north) of Lake Reality. As noted in the explanation notes for Appendix E (page iii), total and dissolved mercury concentrations were analyzed in samples collected by BJC in June and December 2009. The total (unfiltered) mercury concentrations in both samples $(0.0002895 \mathrm{mg} / \mathrm{L}$ and $0.0002849 \mathrm{mg} / \mathrm{L}$, respectively) were an order of magnitude below the MCL for mercury.

\subsubsection{Chestnut Ridge Regime}

The CY 2009 monitoring results reported for the springs and surface water sampling stations listed in Table 26 serve as the exit pathway/perimeter monitoring locations in the Chestnut Ridge Regime. 
Table 26. Chestnut Ridge Regime CY 2009: sampling locations used for exit pathway/perimeter monitoring

\begin{tabular}{|c|c|c|c|}
\hline \multicolumn{2}{|c|}{ Groundwater } & \multicolumn{2}{c|}{ Surface Water } \\
\hline SCR1.25SP & SCR3.5SP & SCR1.5SW & MCK 1.4 \\
SCR2.1SP & SCR4.3SP & SCR3.5SW & MCK 2.0 \\
SCR2.2SP & & S17 & MCK 2.05 \\
& & & UNC SW-1 \\
\hline
\end{tabular}

\subsubsection{Groundwater}

The springs used for exit pathway/perimeter monitoring in the Chestnut Ridge Regime are located in four of the primary surface drainage features that traverse the southern flank of Chestnut Ridge, exit the ORR, and discharge into the Melton Hill Lake south of Bethel Valley Road (Figure A.17). The CY 2009 monitoring results for these springs are consistent with respective historical data and show that the springs discharge uncontaminated calcium-magnesium-bicarbonate groundwater characterized by: (1) a wide range of calcium:magnesium ratios; (2) variable but generally low molar proportions $(<5 \%)$ of chloride, potassium, and sodium; (3) slightly elevated sulfate concentrations at spring SCR4.3SP that probably reflect dissolution of locally disseminated sulfides; and (4) low concentrations of several trace metals, notably barium, iron, manganese, and strontium. Results for nitrate and uranium are either non-detect values or within the range of background levels in the Chestnut Ridge Regime. Excluding a trace level $(1 \mu \mathrm{g} / \mathrm{L})$ of chloromethane detected at SCR-4.3SP (suspected analytical artifact), VOCs were not detected in the groundwater samples collected from the springs. Gross alpha or gross beta activity above the associated MDA was reported for only one semiannual sample from two of the springs, and these gross beta results (3.18 pCi/L at spring SCR3.5SP and $4.55 \mathrm{pCi} / \mathrm{L}$ at spring SCR4.3SP) indicate natural background radiation. These results suggest that operations at $\mathrm{Y}-12$ have not impacted the quality of groundwater discharged from natural springs located in the surface drainage features that traverse the Chestnut Ridge Regime.

\subsubsection{Surface Water}

The surface water sampling stations used for exit pathway/perimeter monitoring in the Chestnut Ridge Regime during CY 2009 are located in Dunaway Branch (SCR1.5SW) at the western boundary of the regime; near the headwaters of SCR2 (UNC SW-1); in McCoy Branch downstream of the FCAP (MCK 2.05 and MCK 2.0), upstream of Rogers Quarry (SCR3.5SW), and near the confluence with the Clinch River (MCK 1.4); and in tributary SCR5 downstream of KHQ (S17) near the southeastern boundary of the regime (Figure A.17).

Analytical results for the surface water samples collected from McCoy Branch during CY 2009 indicate contamination immediately downstream of the FCAP at MCK 2.0 and MCK 2.05. These surface water sampling stations are located upstream (MCK 2.05) and downstream (MCK 2.0) of the FCAP Discharge Treatment Wetland, which was constructed as part of the CERCLA remedial action specified in the ROD for the site (DOE 1996). Samples from MCK 2.05 are representative of FCAP "influent" to the wetland and samples from MCK 2.0 are representative of "effluent" from the wetland (DOE 2010). Historical data show that the surface water samples from both locations are distinguished by elevated concentrations of sulfate and arsenic. The sulfate concentrations in the samples collected in March and September 2009 from MCK 2.05 (27.7mg/L and $41.5 \mathrm{mg} / \mathrm{L}$, respectively) and MCK 2.0 (31.2 mg/L and $29.7 \mathrm{mg} / \mathrm{L}$, respectively) exceed background levels. The monitoring results obtained during CY 2009 show that the 
maximum arsenic concentrations at MCK $2.05(0.101 \mathrm{mg} / \mathrm{L})$ and MCK $2.0(0.0159 \mathrm{mg} / \mathrm{L})$ are above the drinking water MCL $(0.01 \mathrm{mg} / \mathrm{L})$. At station MCK 1.4, located about 4,000 ft downstream from MCK 2.0, much lower arsenic concentrations were reported in the CY 2009 samples collected in March $(0.005 \mathrm{mg} / \mathrm{L})$ and September $(0.00604 \mathrm{mg} / \mathrm{L})$. Nevertheless, the elevated arsenic and sulfate levels reported for samples from MCK 2.0 and MCK 2.05 show continued impacts on surface water quality in upper McCoy Branch near the FCAP.

The CY 2009 monitoring results for surface water stations located in the other drainage features in the Chestnut Ridge Regime show non-detect values or background levels of nitrate, except for nitrate concentration $(6.94 \mathrm{mg} / \mathrm{L})$ in the October 2009 sample from station S17. The CY 2009 nitrate result is higher than previous measurements (e.g., $2.17 \mathrm{mg} / \mathrm{L}$ in April 2008). Future monitoring results will determine if the result is an outlier or indicates an increasing trend. Uranium and VOCs were not detected in the samples collected from these surface water stations. Gross alpha activity and gross beta activity were below the associated MDAs in all but one surface water sample: gross alpha ( $5 \mathrm{pCi} / \mathrm{L})$ in the October 2009 sample from station SCR3.5SW. Alpha activity was not detected in the April 2009 sample and the low activity level is indicative of natural background radiation and/or analytical variability. Historical and current waste management operations do not appear to have significantly affected surface-water quality in these drainage features. 



\subsection{CONCLUSIONS AND RECOMMENDATIONS}

The groundwater and surface water quality data obtained during CY 2009 are generally consistent with: (1) the presence of the principal Y-12 groundwater contaminants from known and suspected source areas in the Bear Creek Regime, East Fork Regime, and Chestnut Ridge Regime; (2) the types of contaminants from respective source areas in each regime and the overall pattern and extent of contaminant transport in each regime; and (3) the long-term contaminant concentration trends evident for the respective groundwater and surface water sampling locations in each regime. This report includes monitoring results for 236 sampling locations: 204 monitoring wells, 10 springs, and 22 surface water stations.

The CY 2009 monitoring results reported for 66 wells (38 aquitard wells and 28 aquifer wells) meet surveillance monitoring requirements in the Bear Creek Regime. Groundwater samples from 23 of the aquitard wells and 24 of the aquifer wells had elevated concentrations of one or more of the principal contaminants at Y-12, with the highest concentrations reported for samples from wells located near the former S-3 Ponds, the former BYBY/HCDA, and the BCBG WMA. Analytical results for most these wells do not indicate any significant change in the overall extent of groundwater contamination in the Bear Creek Regime or the relative distribution of contaminants from the primary source areas. Chloroethenes (PCE, TCE, 12DCE, 11DCE, and VC) are the most widespread groundwater contaminants, with elevated concentrations of one or more of these VOCs reported for 28 wells.

The CY 2009 exit pathway/perimeter monitoring in the Bear Creek Regime is reported for 19 surface water stations along Bear Creek (including six northern tributaries), six springs that discharge into Bear Creek, and three aquifer wells at the westernmost Exit Pathway Picket (Picket W). None of the groundwater samples from the Picket $\mathrm{W}$ wells had elevated concentrations of the principal groundwater contaminants at Y-12, but elevated concentrations of one or more of the contaminants were detected in surface water samples from seven sampling stations in Bear Creek (BCK-12.34, BCK-11.97, BCK-11.84, BCK-11.54, BCK-09.40, BCK-09.20, and BCK-07.87), five tributaries (NT-1, NT-2, NT-3, NT-7, and NT-8), and two springs (SS-4 and SS-5). These results are generally consistent with historical data and show that contaminant concentrations in Bear Creek decrease with distance from each of the principal source areas (the S-3 Site, BYBY/HCDA, and BCBG WMA), including inflow of contaminated water from the northern tributaries of the creek that drain these sites. At station BCK-04.55, which is located where Bear Creek turns north at the westernmost extent of the Bear Creek Regime, the CY 2009 concentrations of all principal contaminants were below applicable screening levels.

The CY 2009 monitoring results for applicable surveillance and exit-pathway/perimeter sampling locations in the Bear Creek Regime continue the long-term contaminant concentration trends indicated by historical data for each applicable sampling location. Increasing concentrations are evident for at least one principal contaminant detected in samples from ten monitoring wells (eight aquitard wells and two aquifer wells). These monitoring locations are near the S-3 Site (three wells), the OLF WMA (two wells), and the BCBG WMA (five wells). Decreasing or indeterminate (not increasing or decreasing) trends are evident for at least one contaminant detected in samples from 33 wells, 12 surface water stations, and two springs. Monitoring wells with elevated concentrations of more than one principal contaminant that have different trends for each contaminant (e.g., increasing nitrate trend and decreasing or indeterminate VOC trend), reflect different sources and/or transport flowpaths for the different contaminants. Divergent concentration trends for individual chloroethenes at wells GW-068, GW-229, and GW-365 are likely attributable to the effects of biotic and/or chemical degradation processes. 
The CY 2009 monitoring results reported for 45 aquitard wells and 28 aquifer wells (including five wells located in Union Valley east of the ORR boundary along Scarboro Road) meet the requirements of surveillance monitoring in the East Fork Regime. Groundwater samples from 33 of the aquitard wells and 21 of the aquifer wells had elevated concentrations of one or more of the principal contaminants at Y-12. Aquitard wells with the highest inorganic and radiological contaminant concentrations are located in a portion of the western Y-12 area impacted by the contaminant plume emplaced during historical operations of the former S-3 Ponds. Extremely high $(>20,000 \mu \mathrm{g} / \mathrm{L})$ VOC concentrations were reported for the groundwater near Building 9201-5 and very high $(>1,000 \mu \mathrm{g} / \mathrm{L})$ VOC concentrations were reported for wells near the Y-12 Salvage Yard, the WCPA, and former UST locations (Rust Garage and East End Garage). Aquifer wells with the highest contaminant concentrations are located immediately downgradient (east) of the former S-2 Ponds in the western Y-12 area, within the co-mingled VOC plume from multiple sources in the central Y-12 area, and in the eastern Y-12 area near NHP/Lake Reality and Oil Skimmer Basin. Analytical results for these wells do not indicate any significant change in the overall extent of groundwater contamination in the East Fork Regime or the relative distribution of contaminants from the primary source areas.

The CY 2009 monitoring results reported for 18 sampling locations, including ten monitoring wells, three springs and five surface water stations meet the requirements of exit-pathway/perimeter monitoring for the East Fork Regime. Elevated concentrations of one or more of the principal groundwater contaminants at Y-12 were reported for at least one of the samples from five of the wells (VOCs) and two of the surface water sampling stations (uranium). Sampling results for some of the wells exhibit a direct response (i.e., lower VOC concentrations) to the operation of the groundwater extraction well used to help capture the plume and deter continued migration of VOCs into Union Valley. Uranium concentrations reported for the surface water sampling stations suggest the continued impact of legacy Y-12 operations on the quality of surface water in UEFPC upstream of the ORR boundary. Note that mercury is a primary concern in the surface water of the East Fork Regime and results of flow-proportionate sampling performed under other monitoring programs are not directly addressed in this report. Because of low solubility, mercury is consistently detected only in groundwater samples very near source areas, and is not considered to be a principal groundwater contaminant.

The CY 2009 monitoring results for applicable surveillance and exit-pathway/perimeter sampling locations in the East Fork Regime continue the long-term contaminant concentration trends indicated by historical data for each applicable sampling location. Increasing concentrations are evident for at least one of the principal contaminants detected in samples from 16 wells, and decreasing or indeterminate (not increasing or decreasing) concentration trends are evident for at least one contaminant detected in samples from 53 wells and two surface water stations. Monitoring wells with elevated concentrations of more than one principal contaminant commonly have different trends for each contaminant (e.g., increasing nitrate trend and decreasing or indeterminate VOC trend), which reflects different sources, transport flowpaths, and/or geochemical attenuation characteristics for the different contaminants. The effects of biotic and/or chemical degradation processes are the likely cause of divergent concentration trends for individual chloroethenes at wells 55-3A, 56-2C, GW-223, GW-253, and GW-383. Historic data for the wells show decreasing and/or indeterminate trends for concentrations of parent compounds (PCE and/or TCE), with increasing trends for concentrations of degradation products (c12DCE, 11DCE, and/or VC).

The CY 2009 sampling results for 41 wells located on Chestnut Ridge meet the requirements of surveillance monitoring in the Chestnut Ridge Regime, and results for eight wells indicate former operations at Y-12 have impacted groundwater quality. One or more VOCs were detected in groundwater samples from well GW-305 at Industrial Landfill IV and seven wells near the CRSP. Concentrations 
above applicable drinking water MCLs were reported for 11DCE (GW-305, GW-176, GW-177, GW-322, and GW-798) and PCE (GW-798). Analytical results for these wells do not indicate any significant change in the overall extent of VOC-contaminated groundwater in the regime or the relative distribution of contaminants. Additionally, the CY 2009 sampling results continue the VOC concentration trends indicated by historical data for the wells at the CRSP, and are consistent with the recent trends evident since the initial detection of VOCs in well GW-305.

The CY 2009 monitoring results reported for five natural springs and seven sampling stations located in major drainage features that traverse the southern flank of Chestnut Ridge meet the requirements of exit-pathway/perimeter monitoring in the Chestnut Ridge Regime. The principal groundwater contaminants at Y-12 were either not detected in the samples from each spring and surface water station, or were detected at concentrations within the range of background levels in the regime. However, the CY 2009 sampling results for sampling stations in McCoy Branch show elevated concentrations of arsenic $(>0.01 \mathrm{mg} / \mathrm{L})$ and sulfate $(>20 \mathrm{mg} / \mathrm{L})$ immediately downstream of the FCAP, but not farther downstream where this drainage feature exits the ORR.

Based on groundwater and surface water monitoring data obtained during CY 2009, the following observations were noted and/or actions are recommended:

- $\quad$ Results of mercury analyses for samples collected during CY 2009 using the revised analytical method with a lower reporting limit are generally consistent with historic results. Mercury was detected in samples from six locations, including one well in the Bear Creek Regime (GW-246), and five wells in the East Fork Regime (56-1A, 56-3B, GW-274, GW-692, and GW-698). All but two of these results are greater than the historic reporting limit $(0.0002 \mathrm{mg} / \mathrm{L})$, and all results are below the drinking water MCL for mercury $(0.002 \mathrm{mg} / \mathrm{L})$. There were no locations where mercury was detected for the first time. The lowest results were reported for wells 56-1A (0.0000835 mg/L) and 56-3B $(0.0000517 \mathrm{mg} / \mathrm{L})$ located in the central Y-12 Area, and mercury was detected at each of these locations in CY 2006.

- $\quad$ Some VOC results obtained using PDB samplers were lower than results obtained using the low-flow method. For example, PCE results were much lower than expected at wells GW-289 and GW-315 in the Bear Creek Regime, wells GW-174 and GW-180 in the Chestnut Ridge Regime, and wells 56-2C, GW-220, GW-337, GW-383, GW-700, and GW-820 in the East Fork Regime. Studies have indicated that the PDB sampling method is appropriate for analysis for PCE concentrations. However, these results indicate that low-flow sampling may be the more conservative method for VOC analyses at these wells. The current procedure for PDB sampling is to install and leave the PDB for at least two weeks before collecting samples. It is recommended to install the PDB at least four weeks before collecting samples to allow twice the amount of time for VOCs to diffuse into the PDB sampler.

- A significant decrease in contaminant concentrations observed in groundwater samples from a few monitoring wells since implementation of low flow sampling has been interpreted to reflect a sampling method bias. However, this drop in concentrations also may reflect bio-fouling of the well screen and/or filter pack. The pumping rates to purge and sample monitoring wells have been maintained electronically by the Y-12 GWPP 
since CY 2000. It is suggested that review of this data should be used to identify wells (if any) with a decreasing trend in the pumping rate used to collect groundwater samples, which would suggest decreased performance of the well (permeability of the filter pack and/or well screen). These wells would be candidates for rehabilitation (e.g., surging or swabbing) using a workover rig, with subsequent monitoring results used to evaluate the effectiveness of rehabilitation methods. 


\subsection{REFERENCES}

Babcock \& Wilcox Technical Services (B\&W) Y-12. 2008. Y-12 Groundwater Protection Program Groundwater and Surface Water Sampling and Analysis Plan for Calendar Year 2009. Prepared by Elvado Environmental LLC. (Y/SUB/08-063119/2).

B\&W Y-12. 2009a. Field Quality Control Samples. B\&W Y-12 Management Requirement prepared by the Environment, Safety, and Health Organization (Y71-66-EC-003, Rev 09/16/09).

B\&W Y-12. 2009b. Sample Chain of Custody. B\&W Y-12 Management Requirement prepared by the Environment, Safety, and Health Organization (Y71-66-EC-004, Rev 09/16/09).

B\&W Y-12. 2009c. Y-12 Groundwater Protection Program Groundwater Monitoring Data Compendium. Prepared by Elvado Environmental LLC (Y/TS-1983/R3).

Bechtel Jacobs Company LLC (BJC). 1998. East End VOC Plume Pump and Tracer Test Technical Memorandum. (BJC/OR-103).

BJC. 2007a. Environmental Monitoring Plan for the Environmental Management Waste Management Facility. (BJC/OR-2712).

BJC. 2007b. Data Management Implementation Plan for the Water Resources Restoration Program, U.S. Department of Energy, Oak Ridge Reservation, Oak Ridge, Tennessee. (BJC/OR-754/R2).

BJC (Bechtel Jacobs Company LLC). 2009a. Groundwater Quality Assessment Plan for Assessment Monitoring Phase 3 at Industrial Landfill IV at the Y-2 National Security Complex, Oak Ridge, Tennessee, BJC/OR-3566, Bechtel Jacobs Company LLC, Oak Ridge, Tennessee.

BJC. 2009b. Sampling and Analysis Plan for the Water Resources Restoration Program for Fiscal Year 2009 Oak Ridge Reservation, Oak Ridge, Tennessee. (BJC/OR-3121/A3).

BJC. 2009c. Quality Assurance Project Plan for the Water Resources Restoration Program, U.S. Department of Energy, Oak Ridge Reservation, Oak Ridge, Tennessee. (BJC/OR-235/R2/A2).

BJC. 2009d. Groundwater Monitoring Report for the Oak Ridge Reservation Landfills; First 180-day Reporting Period of Calendar Year 2009, Oak Ridge Y-12 Plant, Anderson County, Tennessee. Prepared by Elvado Environmental LLC (TD-2009-00xx).

BJC. 2009e. Groundwater Monitoring Report for the Oak Ridge Reservation Landfills; Second 180-day Reporting Period of Calendar Year 2009, Oak Ridge Y-12 Plant, Anderson County, Tennessee. Prepared by Elvado Environmental LLC (BJC/OR-3296).

BJC. 2010a. CY 2009 Resource Conservation and Recovery Act Annual Monitoring Report for the U.S. Department of Energy Y-12 National Security Complex, Oak Ridge, Tennessee. Prepared by Elvado Environmental LLC (BJC/OR-3366). 
BJC. 2010b. Annual Report for 2008 - 2009 Detection Monitoring at the Environmental Management Waste Management Facility, Oak Ridge, Tennessee. Prepared by Elvado Environmental LLC and Professional Project Services, Inc (BJC/OR-3385).

BWXT Y-12, L.L.C. (BWXT). 2002. Liquid Grab Sampling. BWXT Y-12, L.L.C. management requirement prepared by the Environment, Safety, and Health Organization (Y50-71-005, currently in revision).

BWXT. 2003a. Y-12 Groundwater Protection Program Data Management Plan. Prepared by Science Applications International Corporation (Y/SUB/03-013288/1).

BWXT. 2003b. Updated Subsurface Data Base for Bear Creek Valley, Chestnut Ridge, and Parts of Bethel Valley on the U.S. Department of Energy Oak Ridge Reservation. (Y/TS-881/R5). (referenced in Appendix C).

BWXT. 2004. Measurement of Static Water Level Elevation. BWXT Y-12, L.L.C. Management Requirement prepared by the Environment, Safety, and Health Organization (Y50-71-015, Rev 1.0).

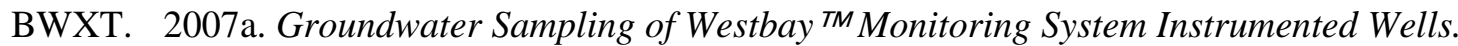
BWXT Y-12, L.L.C. management requirement prepared by the Environment, Safety, and Health Organization (Y50-71-018, Rev. 2.1).

BWXT. 2007b. Pressure Profiling of Wells Equipped with Westbay ${ }^{T M}$ Monitoring System Instrumentation. BWXT Y-12, L.L.C. management requirement prepared by the Environment, Safety, and Health Organization (Y50-71-019, Rev 1.1).

BWXT. 2008. Groundwater Sampling. Oak Ridge Y-12 National Security Complex Procedure prepared by the Environment, Safety, and Health Organization (Y50-71-016, Rev. 2.0).

Commodore Advanced Sciences, Inc. (CASI). 2009. Environmental Data Acquisition and Management Technical Procedures. R15.

EnergySolutions. 2007. Sampling and Analysis Plan for Environmental Monitoring at the Nonhazardous Solid Waste Landfills on Chestnut Ridge South of the U.S. Department of Energy Y-12 National Security Complex, Oak Ridge, Tennessee. Prepared by Elvado Environmental LLC. (ORR-LF-SAP, Rev. 1).

Goldstrand, P.M. 1995. Stratigraphic Variations and Secondary Porosity Within the Maynardville Limestone in Bear Creek Valley, Y-12 Plant, Oak Ridge, Tennessee. (Y/TS-1093).

Hatcher, R.D., Jr., P.J. Lemiszki, R.B. Dreier, R.H. Ketelle, R.R. Lee, D.A. Leitzke, W.M. McMaster, J.L. Foreman, and S.Y. Lee. 1992. Status Report on the Geology of the Oak Ridge Reservation. (ORNL/TM-12074) [referenced on Figure A.2].

Jones, S.B. 1998. Hydraulic Conductivity Estimates from Landfills in the Chestnut Ridge Hydrogeologic Regime at the Y-12 Plant, 1994-1997. Letter to AJA Technical Services, Inc. February 12, 1998. 
Ketelle, R.H. and D.D. Huff. 1984. Site Characterization of the West Chestnut Ridge Site. Oak Ridge National Laboratory. (ORNL/TM-9229).

King, H.L. and C.S. Haase. 1987. Subsurface-Controlled Geological Maps for the Y-12 Plant and Adjacent Areas of Bear Creek Valley. (ORNL/TM-10112).

King, H.L. and C.S. Haase. 1988. Summary of Results and Preliminary Interpretation of Hydrogeologic Packer Testing in Core Holes GW-131 Through GW-135 and CH-157, Oak Ridge Y-12 Plant. (Y/TS-495).

Lockheed Martin Energy Systems, Inc. 1996. Calendar Year 2001 Groundwater Quality Report for the Chestnut Ridge Hydrogeologic Regime, Y-12 Plant, Oak Ridge, Tennessee; Part 2: 1995 Groundwater Quality Data Interpretations and Proposed Program Modifications. (Y/SUB/96-KDS15V/2).

Martin Marietta Energy Systems, Inc. (MMES). 1989. Groundwater Quality Assessment Report for the Oil Landfarm, 1988. (Y/SUB/89-00206C/3).

MMES. 1990a. Study of Ground-Water Flow from Chestnut Ridge Security Pits Using a Fluorescent Dye Tracer. (Y/SUB/90-00206C/6).

MMES. 1990b. Comprehensive Groundwater Monitoring Plan for the Oak Ridge Y-12 Plant. Prepared by Geraghty and Miller, Inc. (Y/SUB/90-00206CI5).

MMES. 1993. Final Report of the Second Dye-Trace Test at the Chestnut Ridge Security Pits, Y-12 Plant, Oak Ridge, Tennessee. (Y/SUB/93-99928C/Y10/1).

Moore, G.K. 1988. Concepts of Groundwater Occurrence and Flow Near Oak Ridge National Laboratory. Oak Ridge National Laboratory (ORNL/TM-10969).

Moore, G.K. 1989. Groundwater Parameters and Flow System Near Oak Ridge National Laboratory. (ORNL/TM-11368).

Shevenell, L.A. 1994. Chemical Characteristics of Water in Karst Formations at the Oak Ridge Y-12 Plant. (Y/TS/1001).

Shevenell, L.A. 1995. Evaluation of Cross Borehole Tests at Selected Wells in the Maynardville Limestone and Copper Ridge Dolomite at the Oak Ridge Y-12 Plant. (Y/TS-1166).

Solomon, D.K., G.K. Moore, L.E. Toran, R.B. Dreier, and W.M. McMaster. 1992. Status Report - A Hydrologic Framework for the Oak Ridge Reservation. Oak Ridge National Laboratory (ORNL/TM-12053).

Sutton, G.E., and S.M. Field. 1995. Distribution of Anthropogenic Fill Material within the Y-12 Plant Area, Oak Ridge, Tennessee. (Y/TS-1387). 
Tennessee Department of Environment and Conservation (TDEC). 2009. Notice of Violation Groundwater Protection Standard Industrial Landfill IV (SNL 01-0075). Letter to Bechtel Jacobs Company LLC, November 2, 2009.

U.S. Department of Energy (DOE). 1996. Record of Decision for Chestnut Ridge Operable Unit 2 (Filled Coal Ash Pond Vicinity) Oak Ridge, Tennessee. (DOE/OR/02-1410\&D3).

DOE. 1997a. Report on the Remedial Investigation of Bear Creek Valley at the Oak Ridge Y-12 Plant, Oak Ridge, Tennessee. Volume 1. (DOE/OR/01-1455/V1\&D2).

DOE. 1997b. Record of Decision for an Interim Action for Union Valley, East Fork Poplar Creek Characterizations Area, Oak Ridge, Tennessee. (DOE/OR/02-1545\&D2).

DOE. 1998. Report on the Remedial Investigation of the Upper East Fork Poplar Creek Characterization Area at the Oak Ridge Y-12 Plant, Oak Ridge, Tennessee. (DOE/OR/01-164/V3\&D1).

DOE. 2010. 2010 Remediation Effectiveness Report for the U.S. Department of Energy Oak Ridge Reservation, Oak Ridge, Tennessee. Volume 2: Data Evaluations (DOE/OR/01-2437\&D1/V2).

U.S. Environmental Protection Agency. 1983. Methods for Chemical Analysis of Water and Wastes. (referenced in Table B.5).

U.S. Environmental Protection Agency. 1996. Test Methods for Evaluating Solid Waste Physical/Chemical Methods.(referenced in Table B.5).

U. S. Environmental Protection Agency. 2001. Controlling Disinfection By-Products and Microbial Contamination in Drinking Water, EPA/600/R-01/110, U. S. Environmental Protection Agency, Office of Research and Development, Washington, DC.

U. S. Geological Survey. 2001. Users Guide for Polyethylene-Based Passive Diffusion Bag Samplers to Obtain Volatile Organic Compound Concentrations in Wells, Water Resources Investigations Report 01-4060.

Wilson, G.V., P.M. Jardine, R.J. Luxmoore, and J.R. Jones. 1990. Hydrology of a Forested Hillslope During Storm Events. Geoderma, v. 46, p. 119-138. 
APPENDIX A

FIGURES 


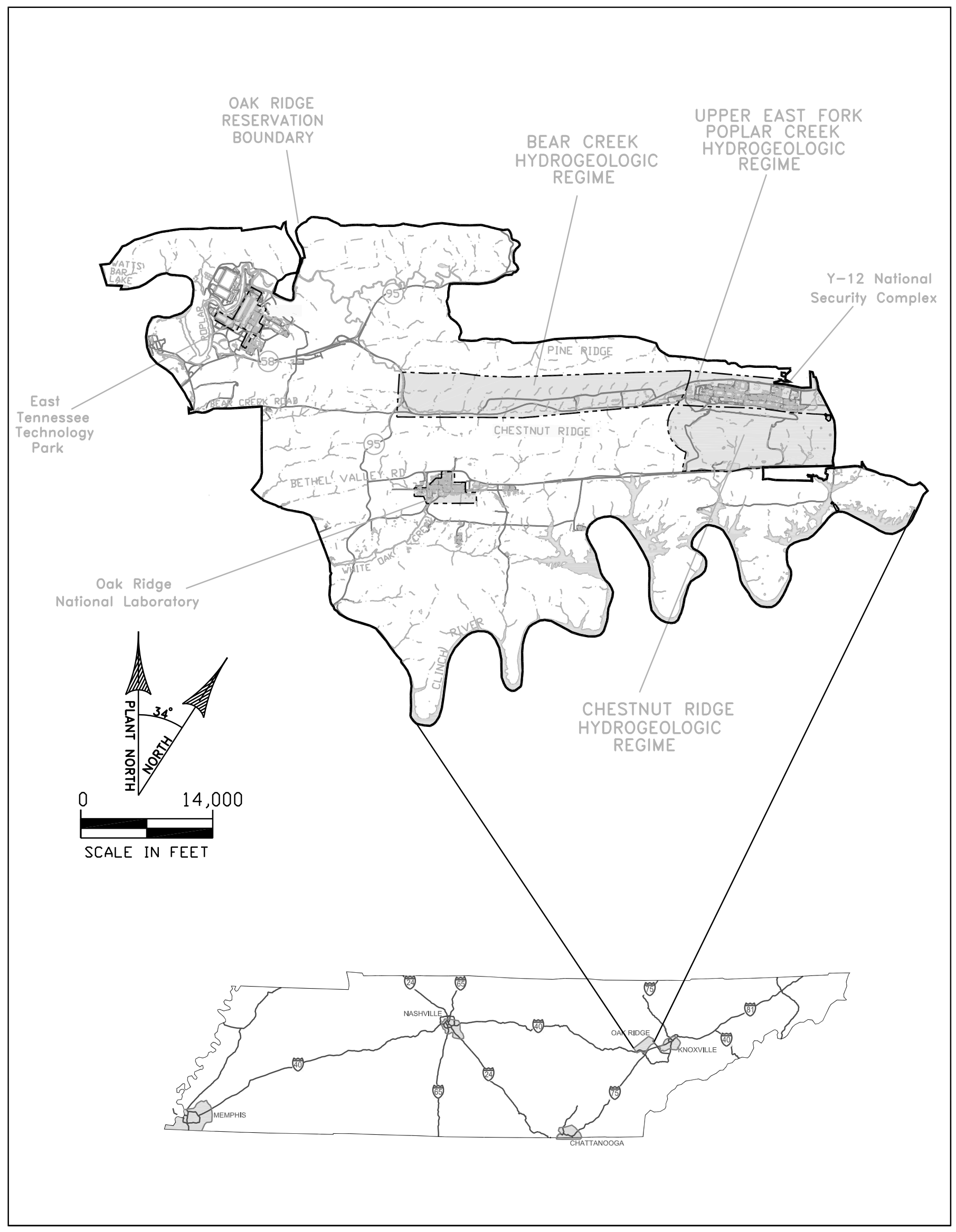

GWPP Fig1 09/23/08

Fig. A.1. Hydrogeologic regimes at the Y-12 National Security Complex. 


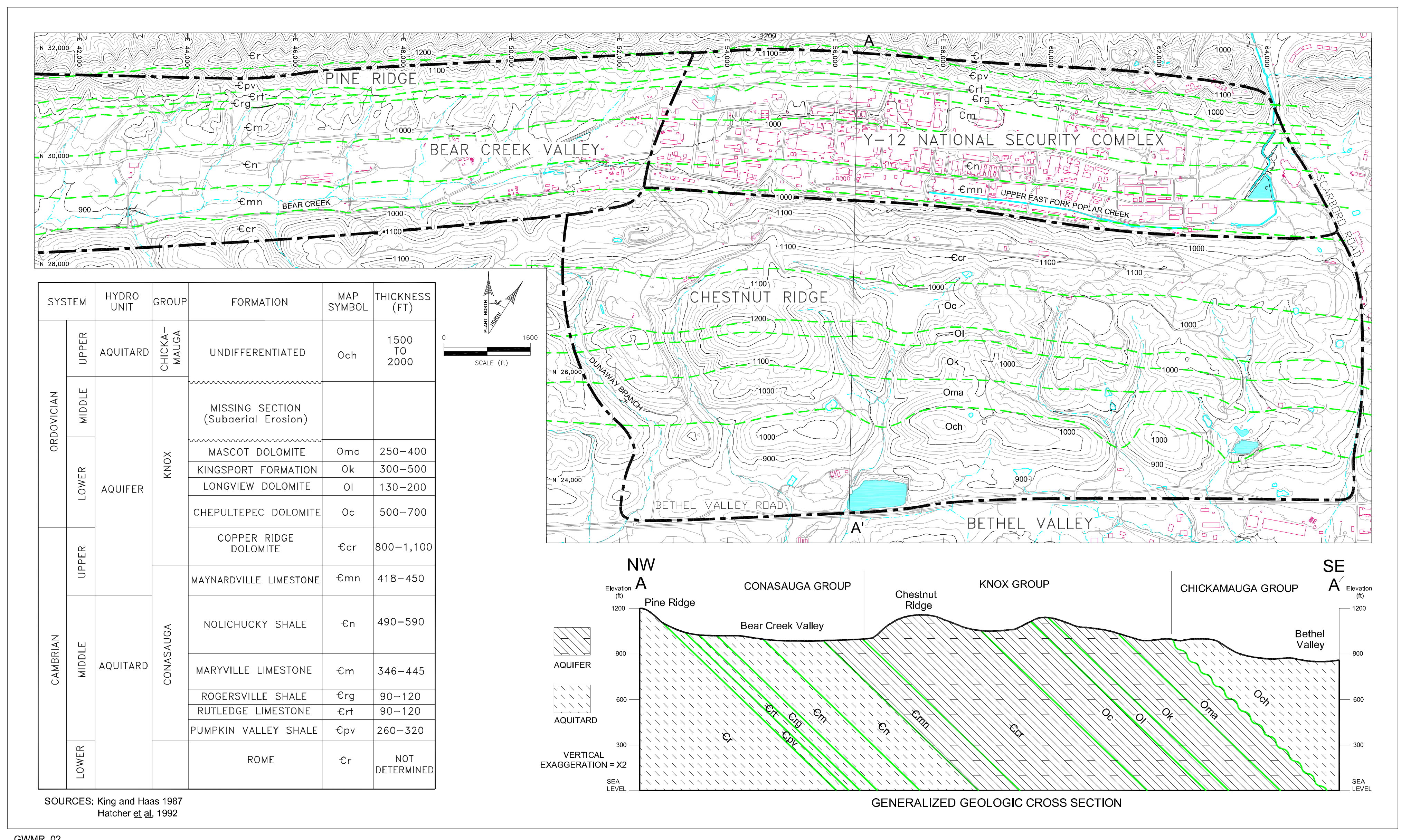

GWMR_02 


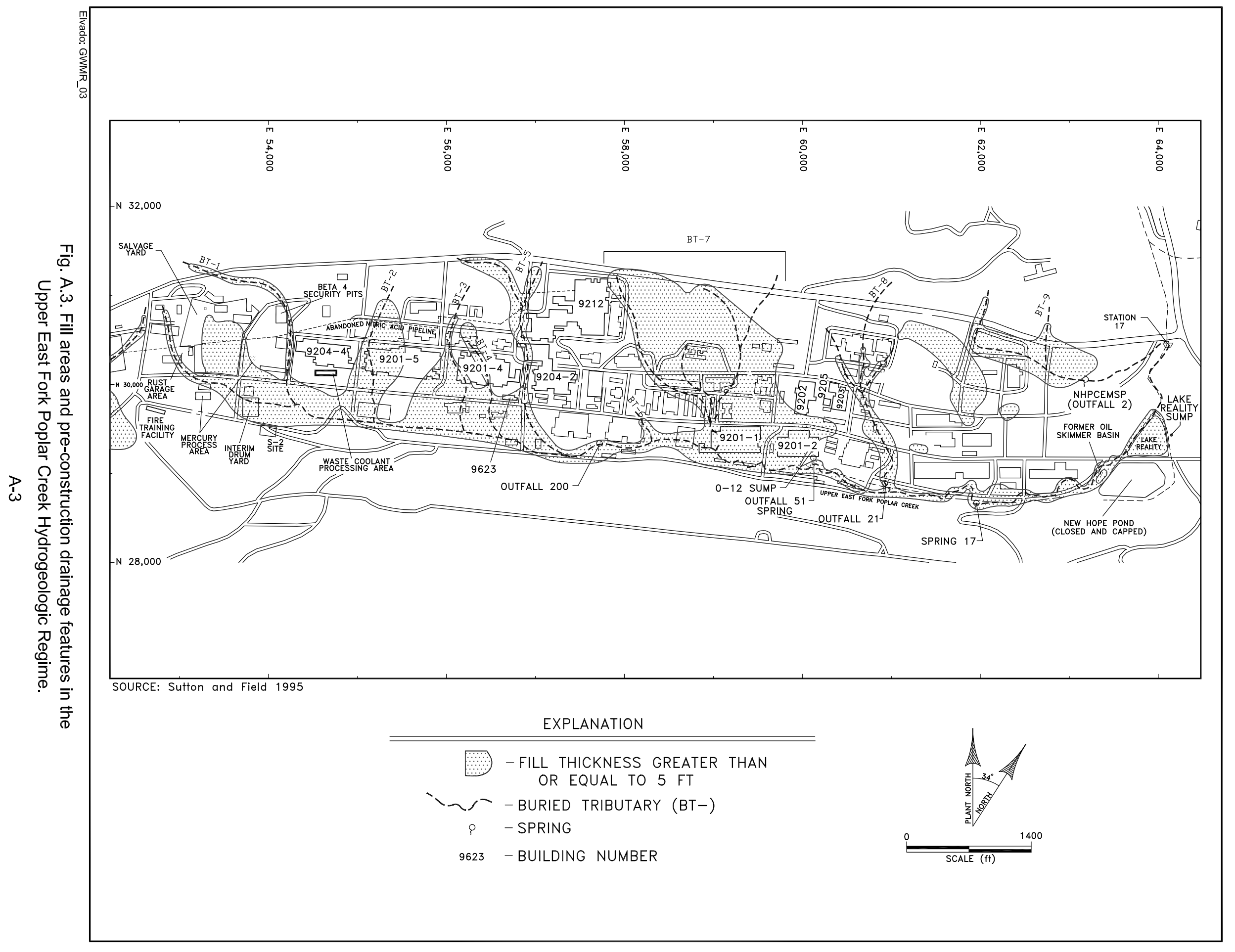




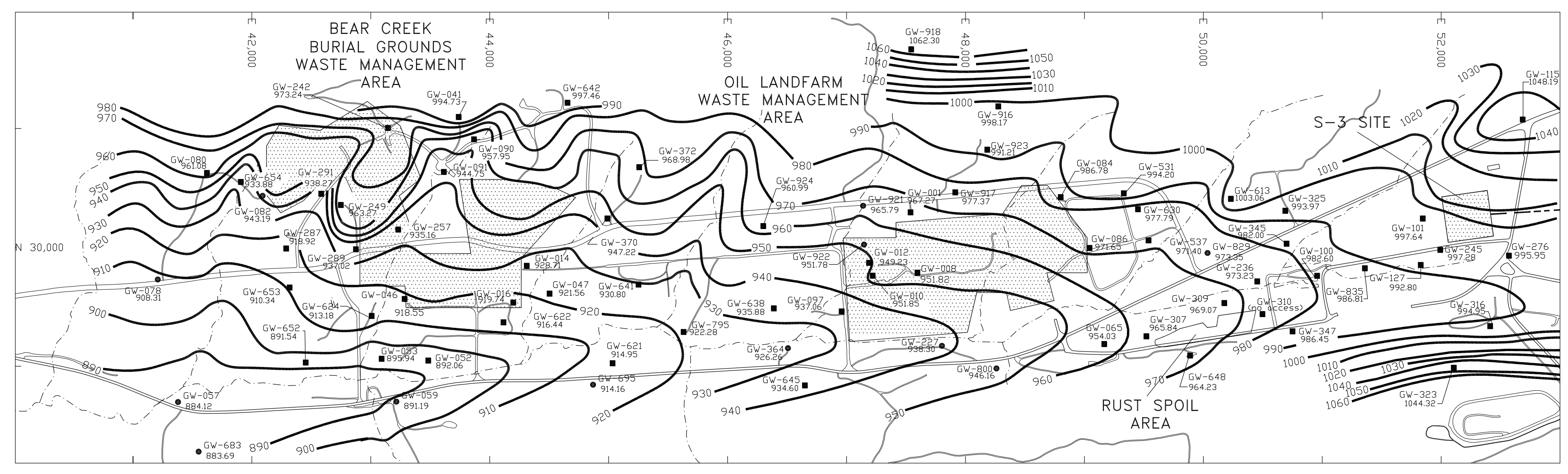

GROUNDWATER ELEVATIONS APRIL 8-9, 2009

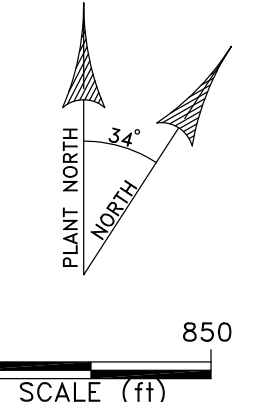

EXPLANATION 

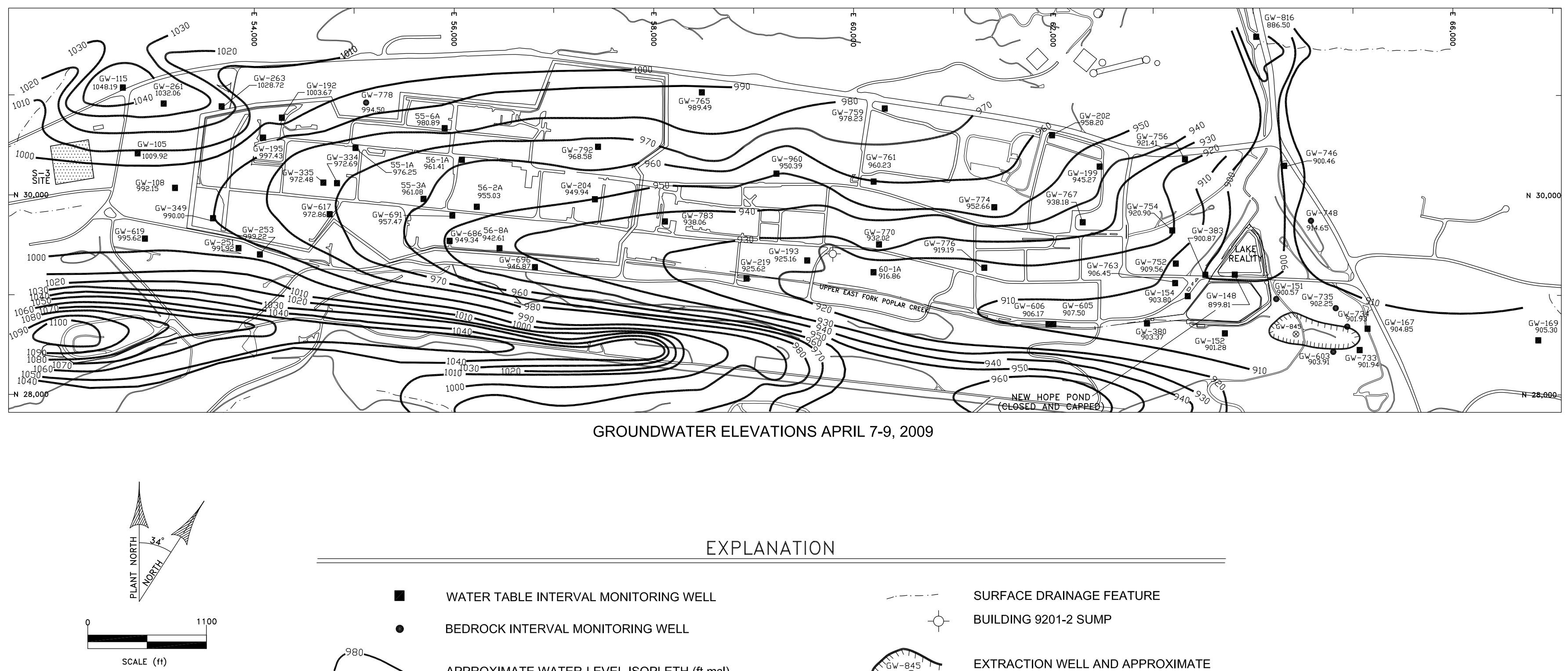

EXPLANATION

WATER TABLE INTERVAL MONITORING WEL

- BEDROCK INTERVAL MONITORING WELL

$\nearrow^{980}$ APPROXIMATE WATER-LEVEL ISOPLETH (ft mII)

SURFACE DRAINAGE FEATURE

-

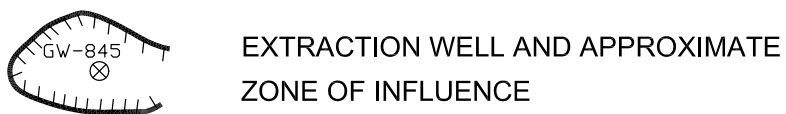




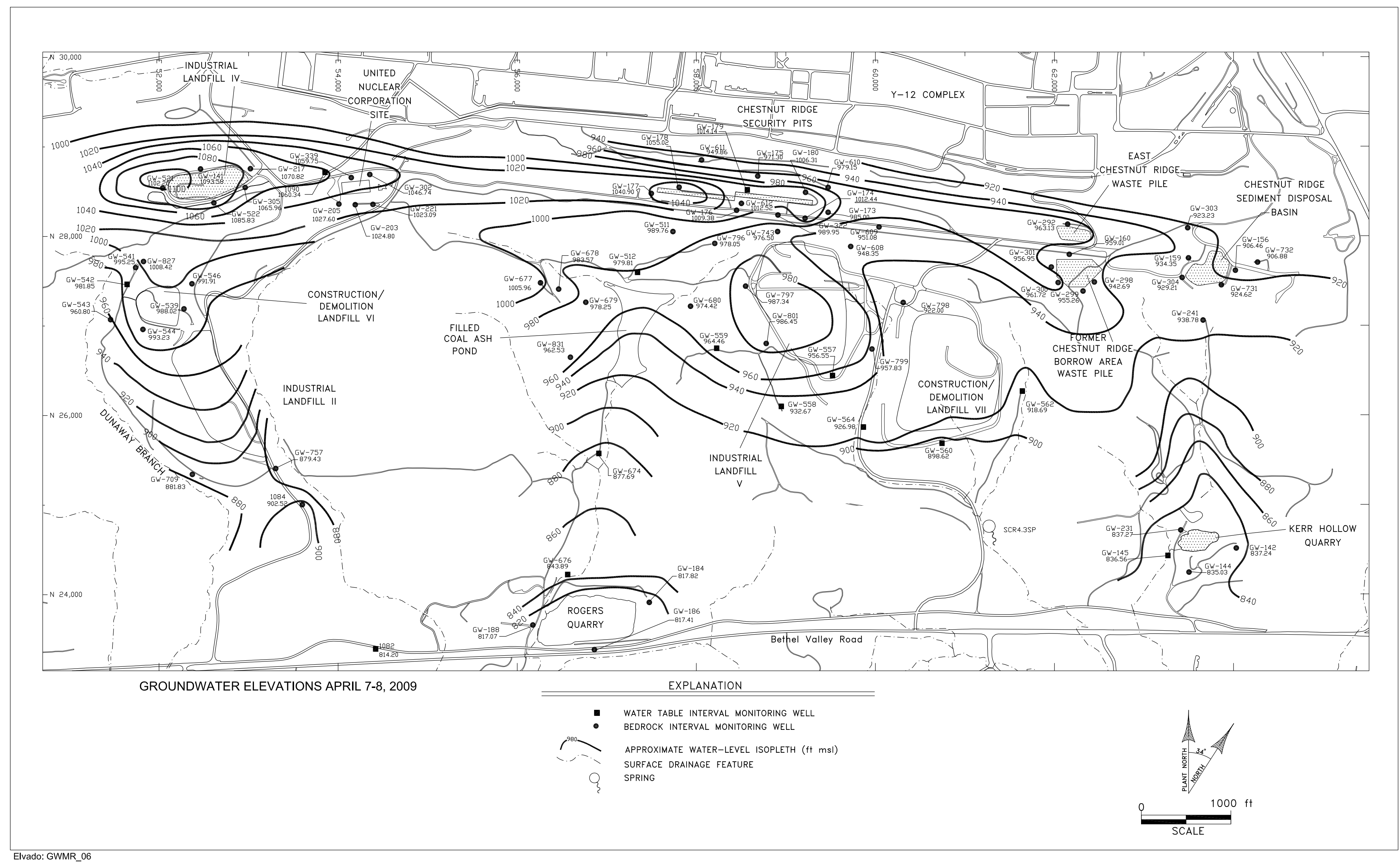




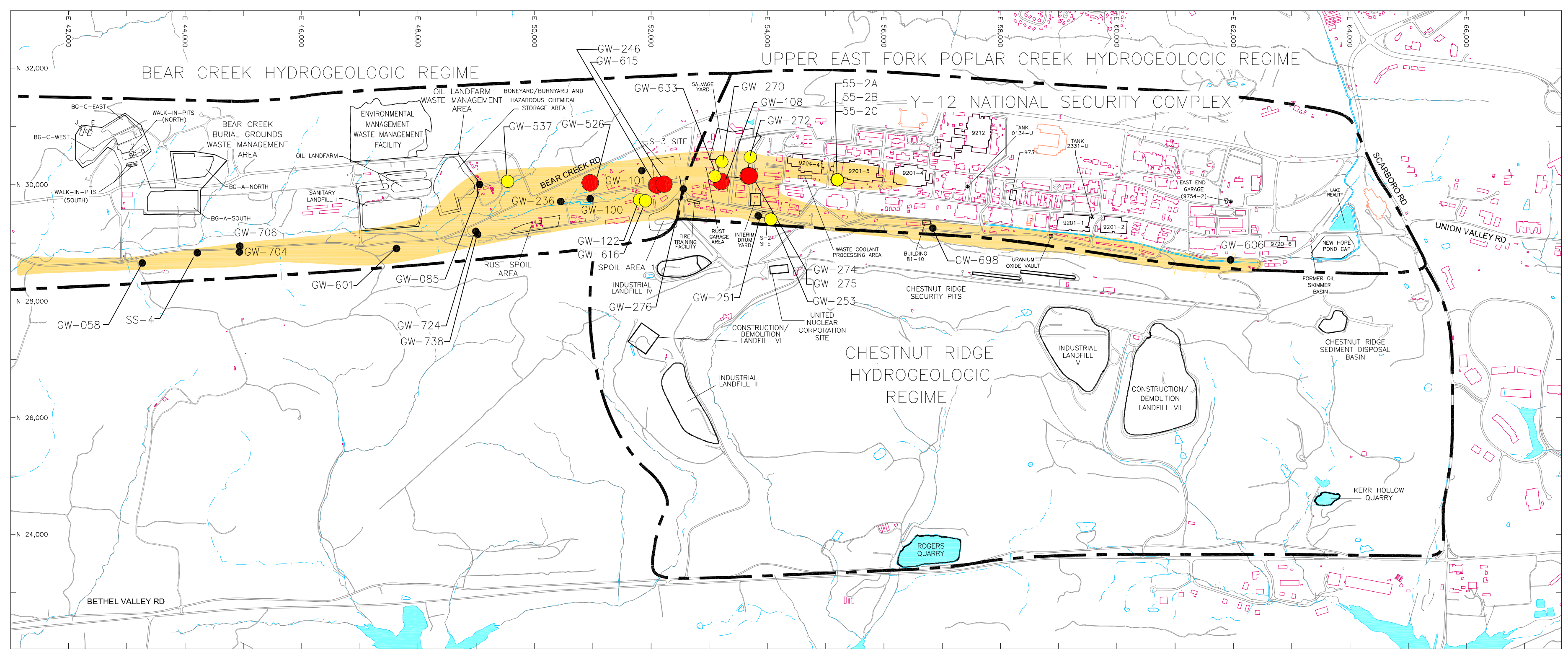

SOURCES: U.S. Department of Energy 1997a
U.S. Department of Energy 1998

EXPLANATION

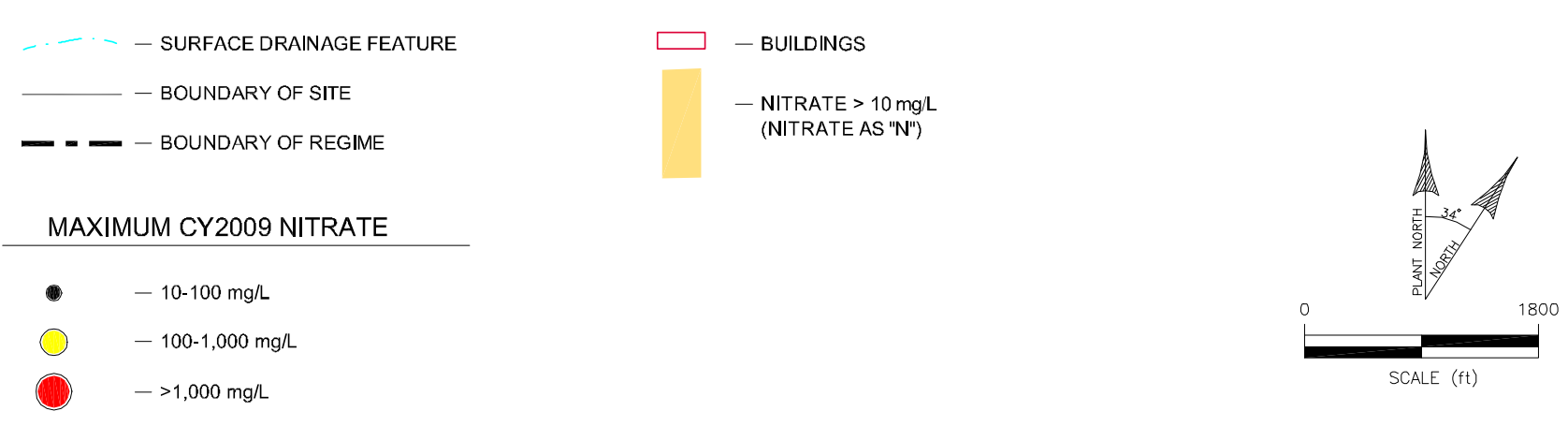




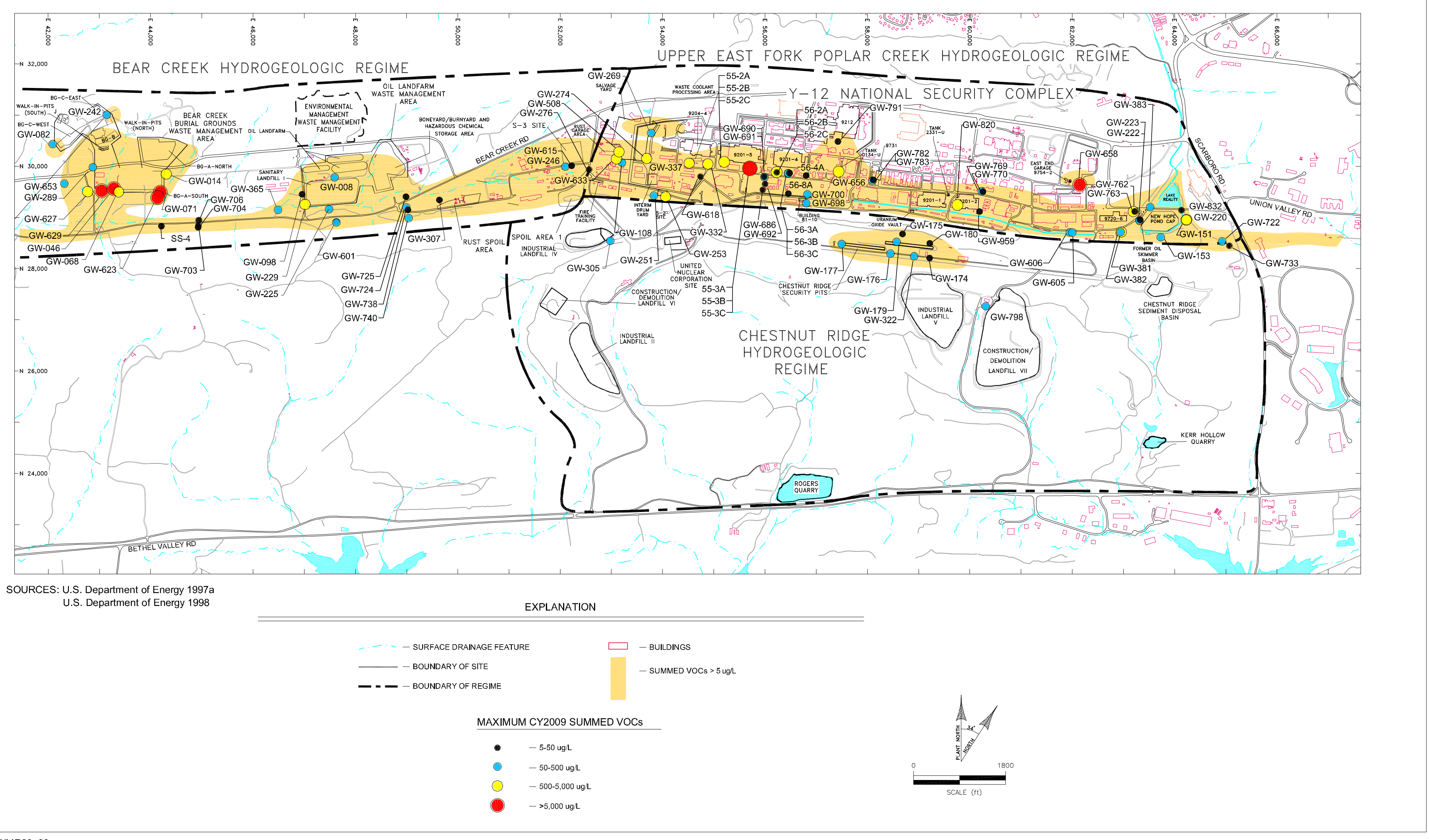




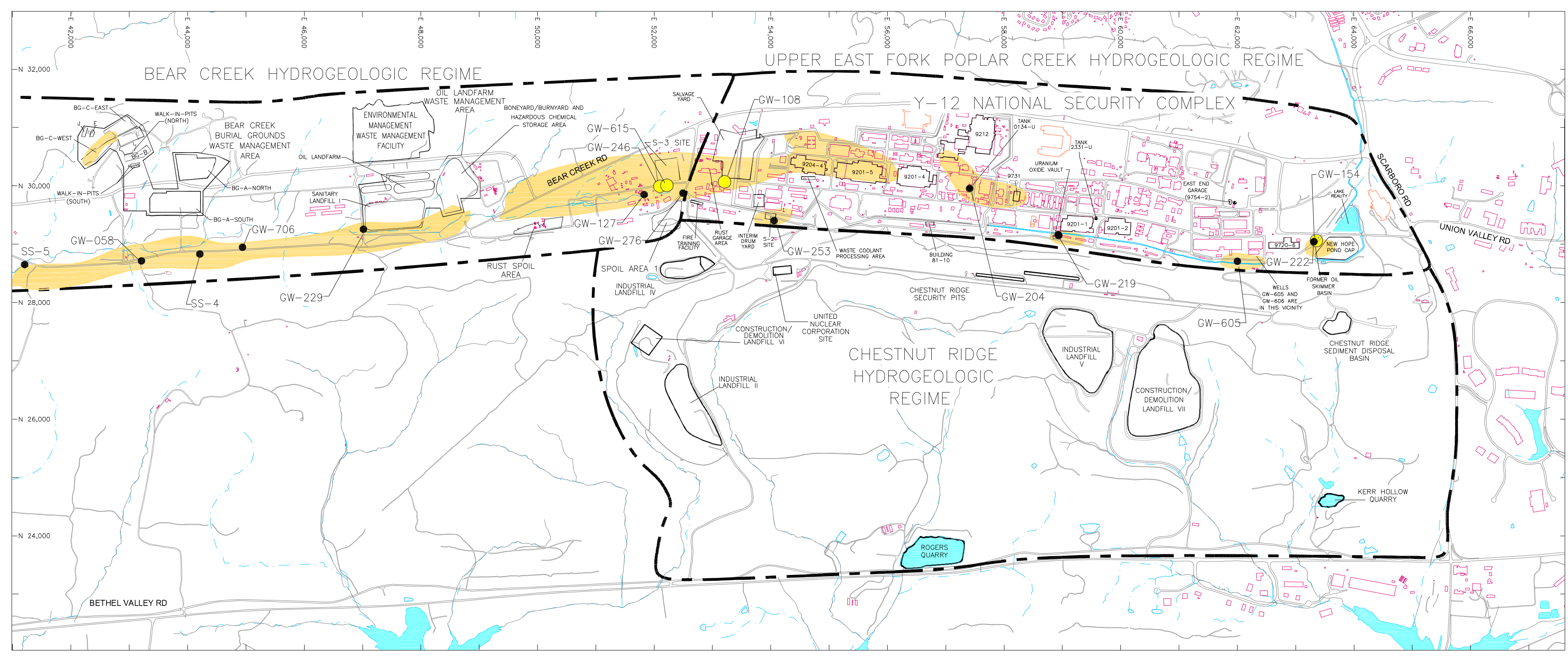

SOURCES: U.S. Department of Energy 1997 a
U.S. Department of Energy 1998

EXPLANATION

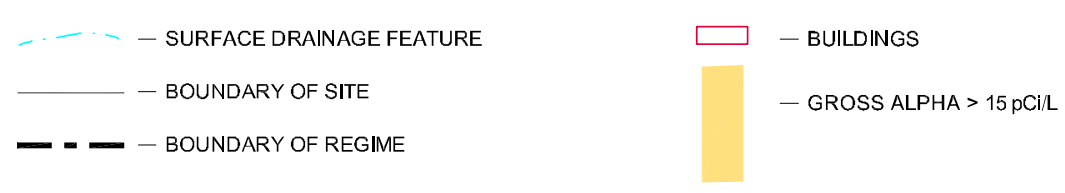

MAXIMUM CY2009 GROSS ALPHA

- $\quad-15-150 \mathrm{pcin}$

$-150-1,500 \mathrm{pCl}$

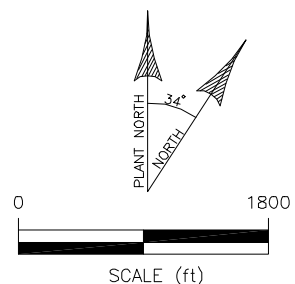




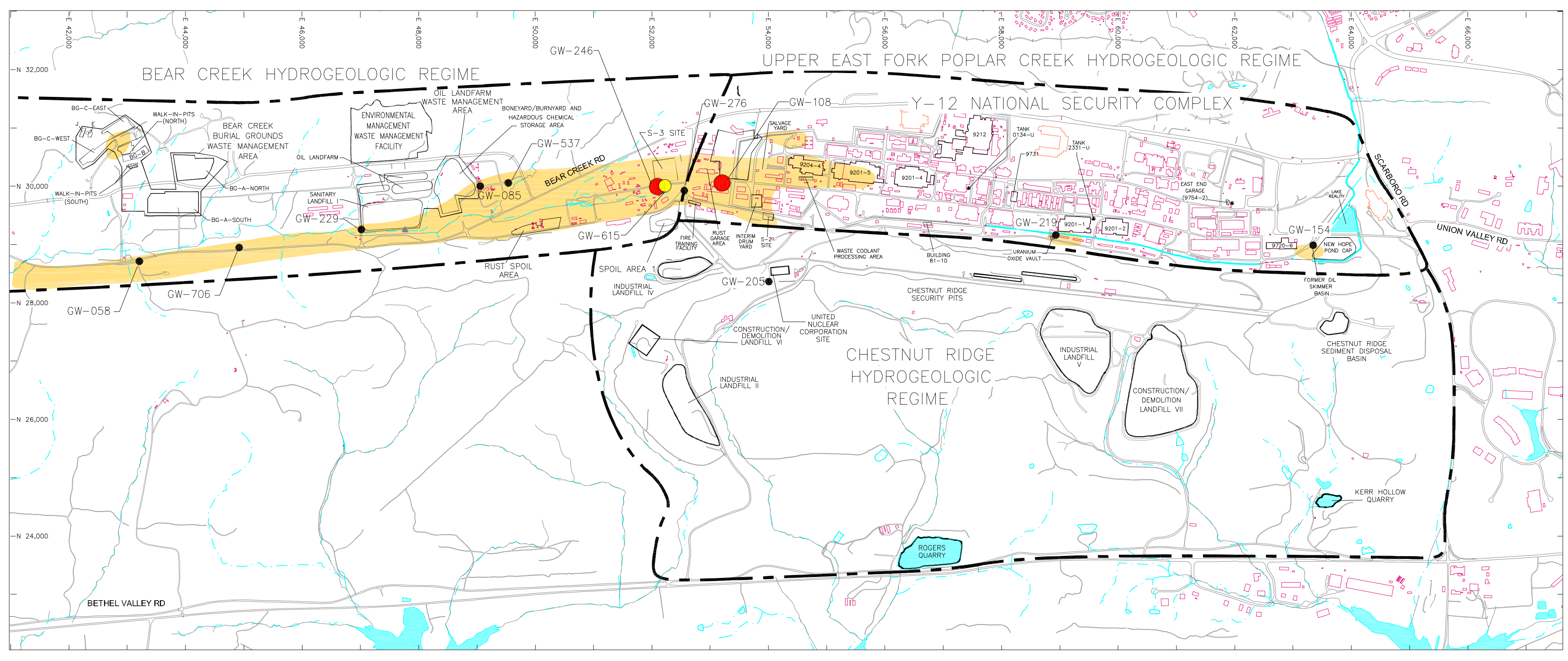

SOURCES: U.S. Department of Energy 1997 a
U.S. Department of Energy 1998

EXPLANATION

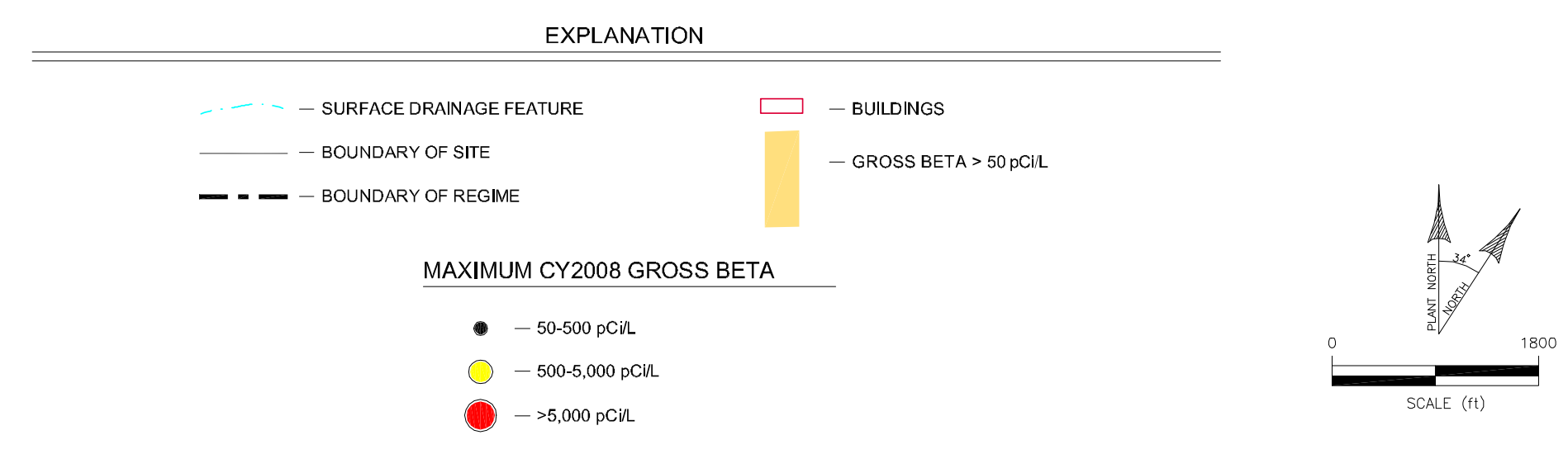




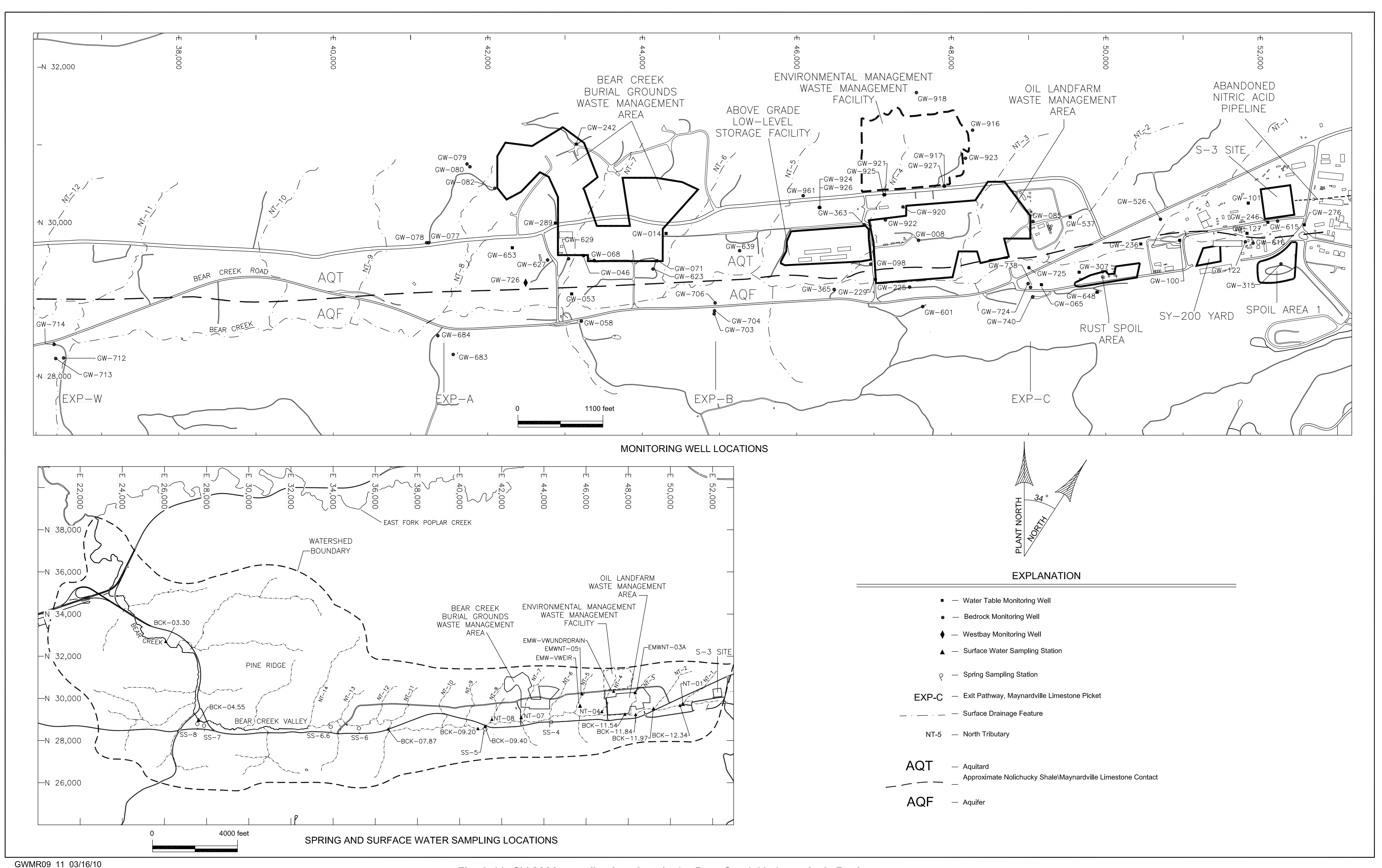




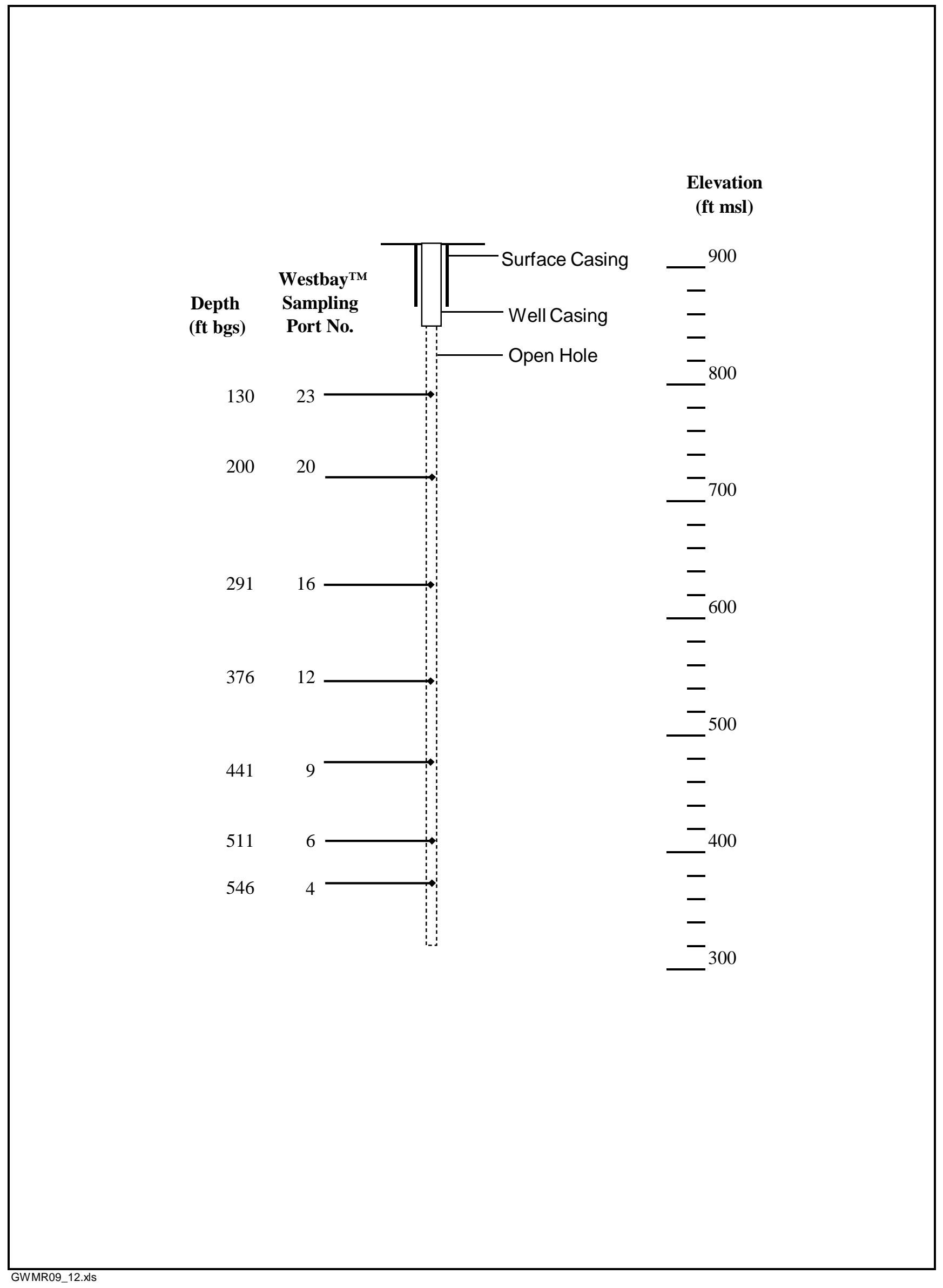

Fig. A.12. Westbay ${ }^{\mathrm{TM}}$ monitoring system sampling port depths in well GW-726. 

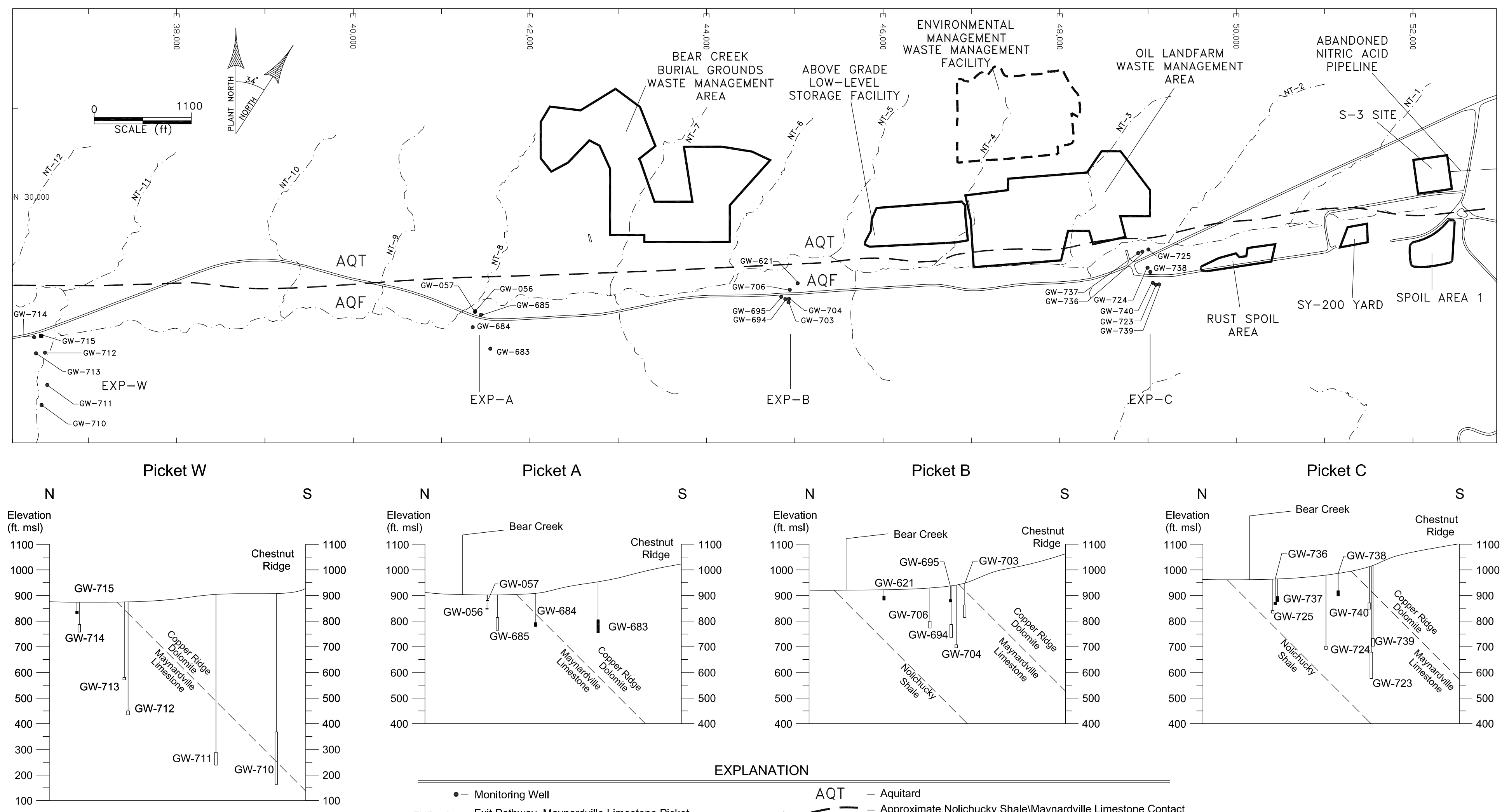

\begin{tabular}{|c|c|c|}
\hline \multicolumn{3}{|c|}{ EXPLANATION } \\
\hline - - Monitoring Well & AQT & - Aquitard \\
\hline EXP-C - Exit Pathway, Maynardville Limestone Picket & --1 & - Approximate Nolichucky ShalelMaynardville Limestone Contac \\
\hline _._. - Surface Drainage Feature & $\mathrm{AQF}$ & - Aquifer \\
\hline NT-5 - North Tributary & . & - Screened Well Construction \\
\hline & b & - Open-Hole Well Construction \\
\hline
\end{tabular}




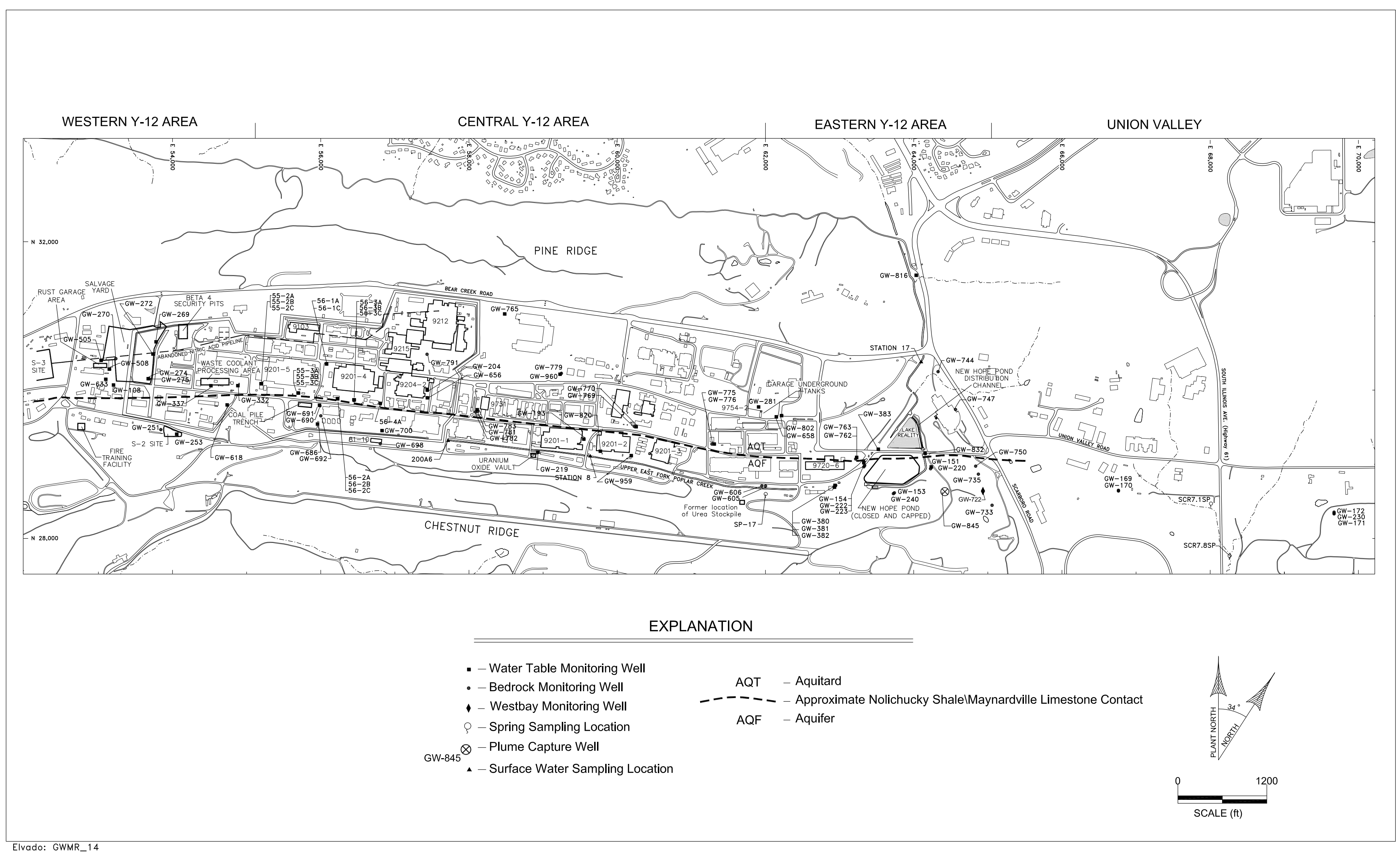




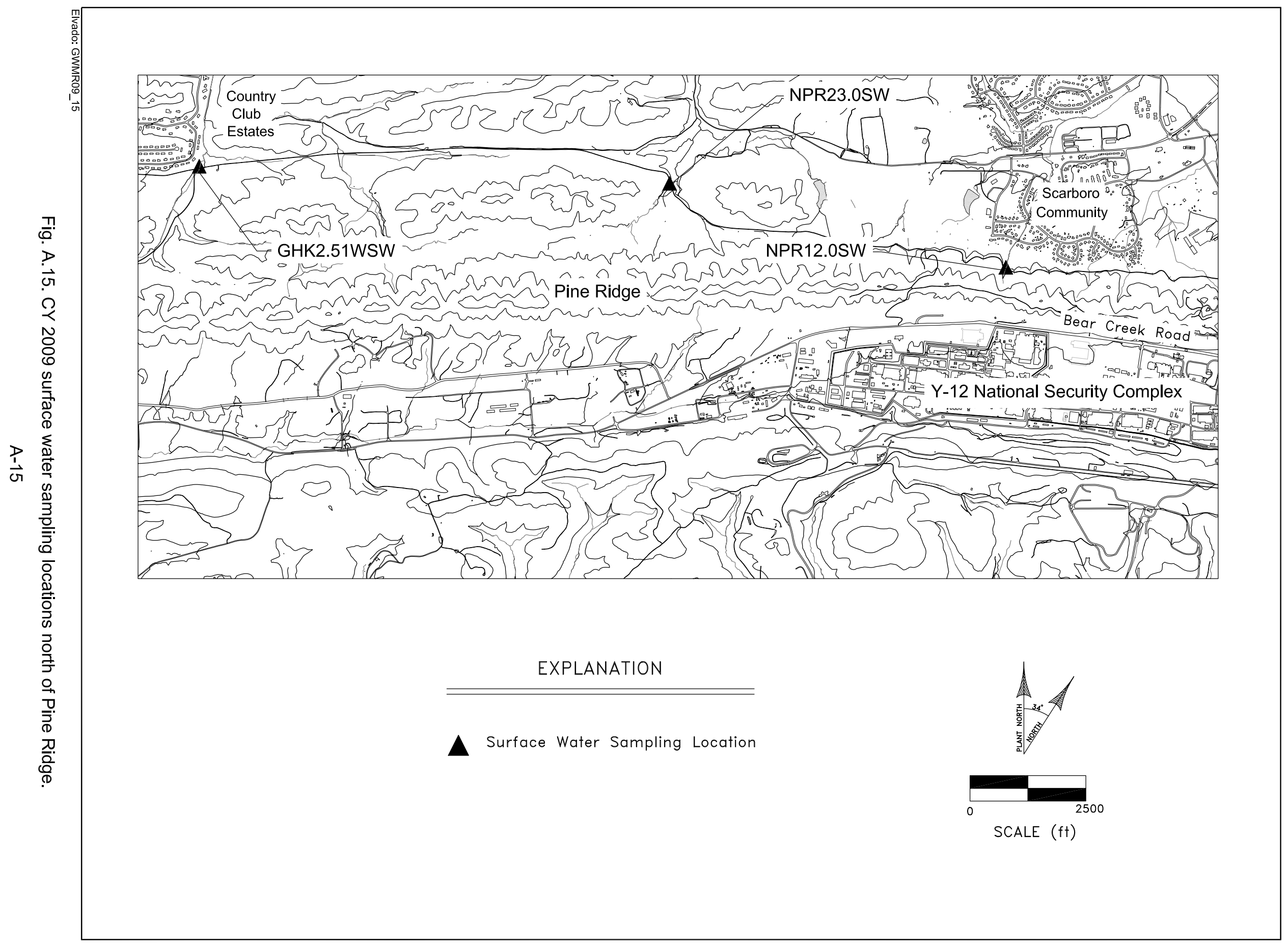




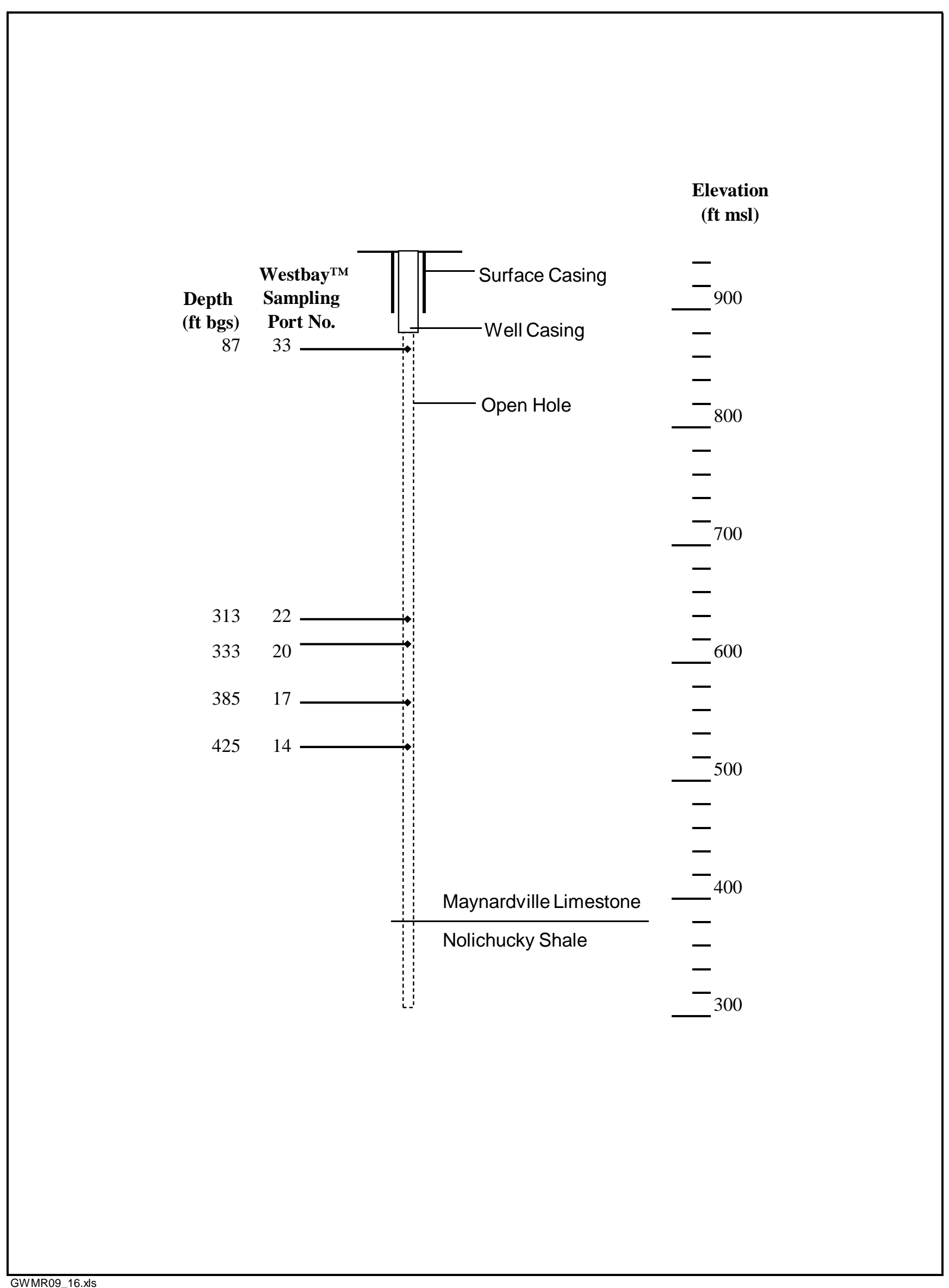

Fig. A.16. Westbay ${ }^{\mathrm{TM}}$ monitoring system sampling port depths in well GW-722.

A-16 


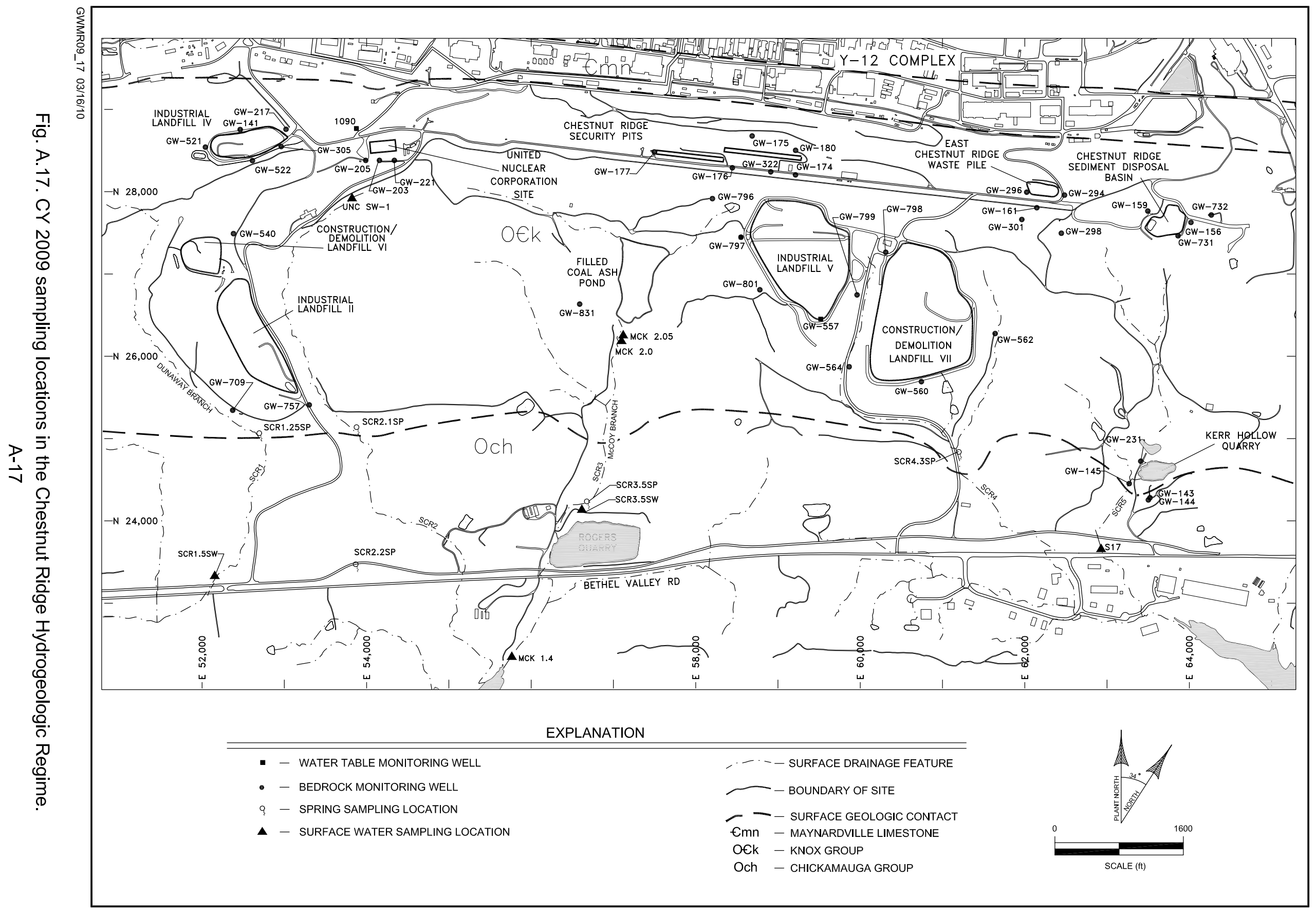



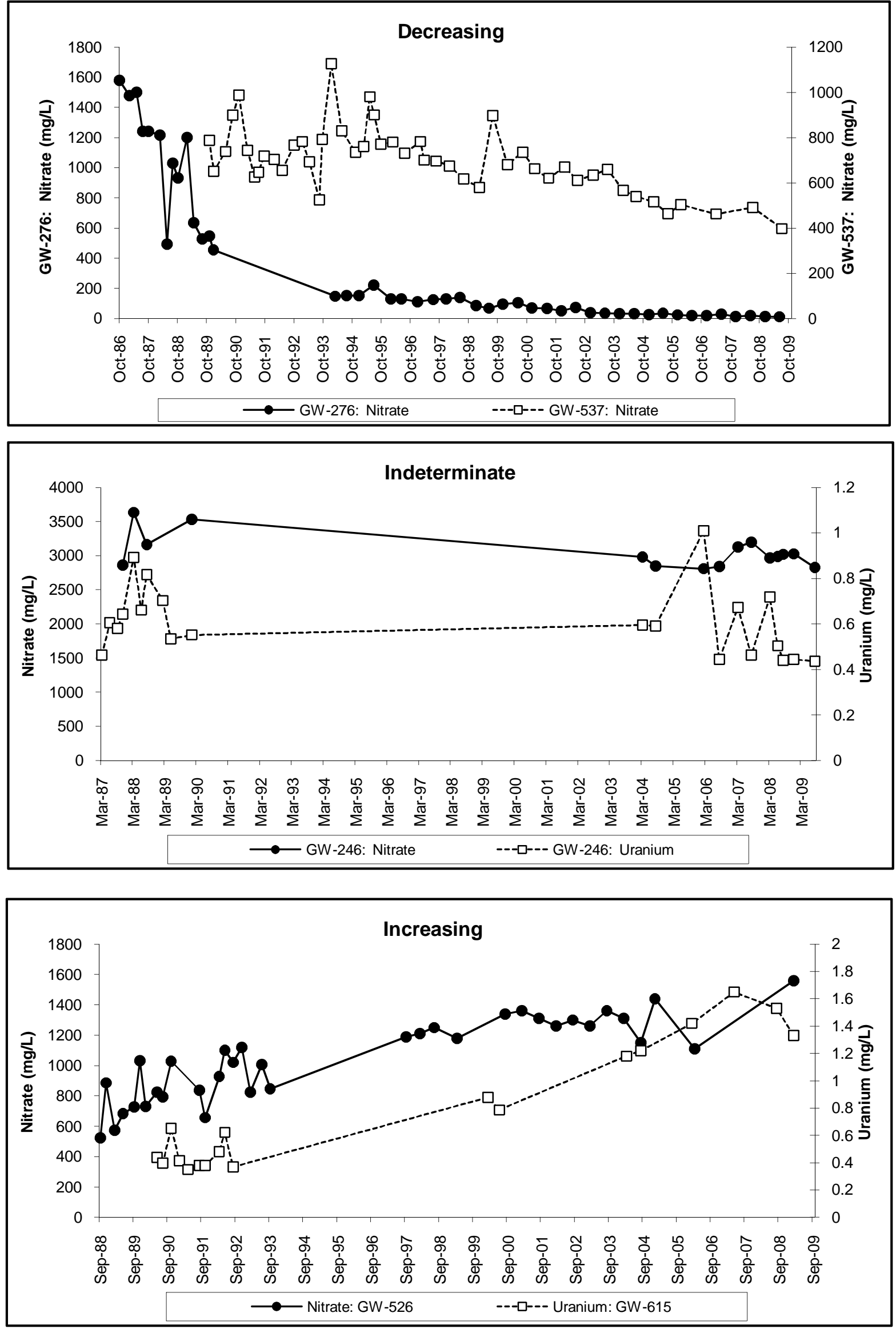

GWMR09 07/15/09

Fig. A.18. Bear Creek Regime CY 2009: nitrate and/or uranium concentration trends in surveillance monitoring aquitard wells GW-246, GW-276, GW-526, GW-537, and GW-615. 

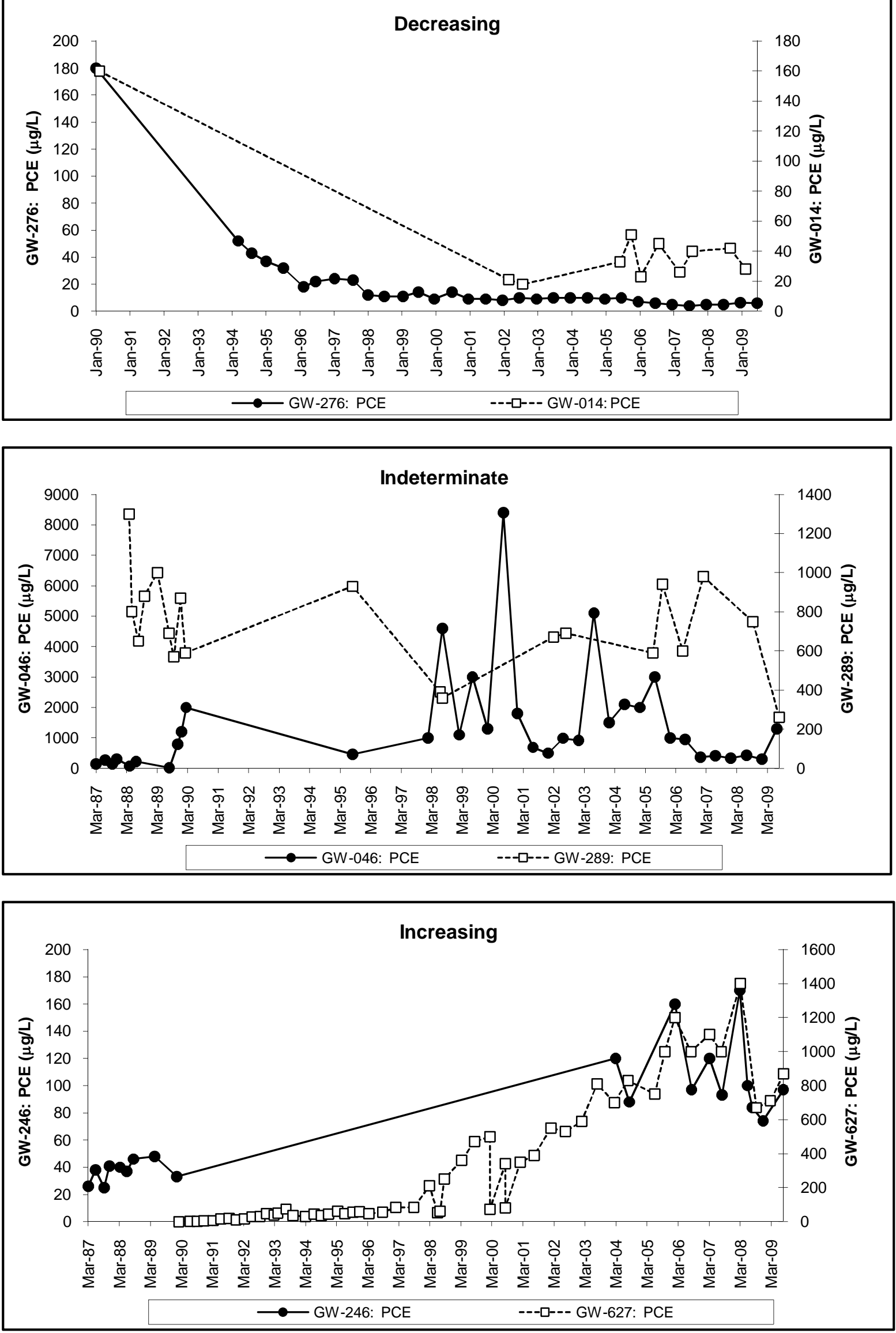

Fig. A.19. Bear Creek Regime CY 2009: PCE concentration trends in surveillance monitoring aquitard wells GW-014, GW-046, GW-246, GW-276, GW-289, and GW-627. 

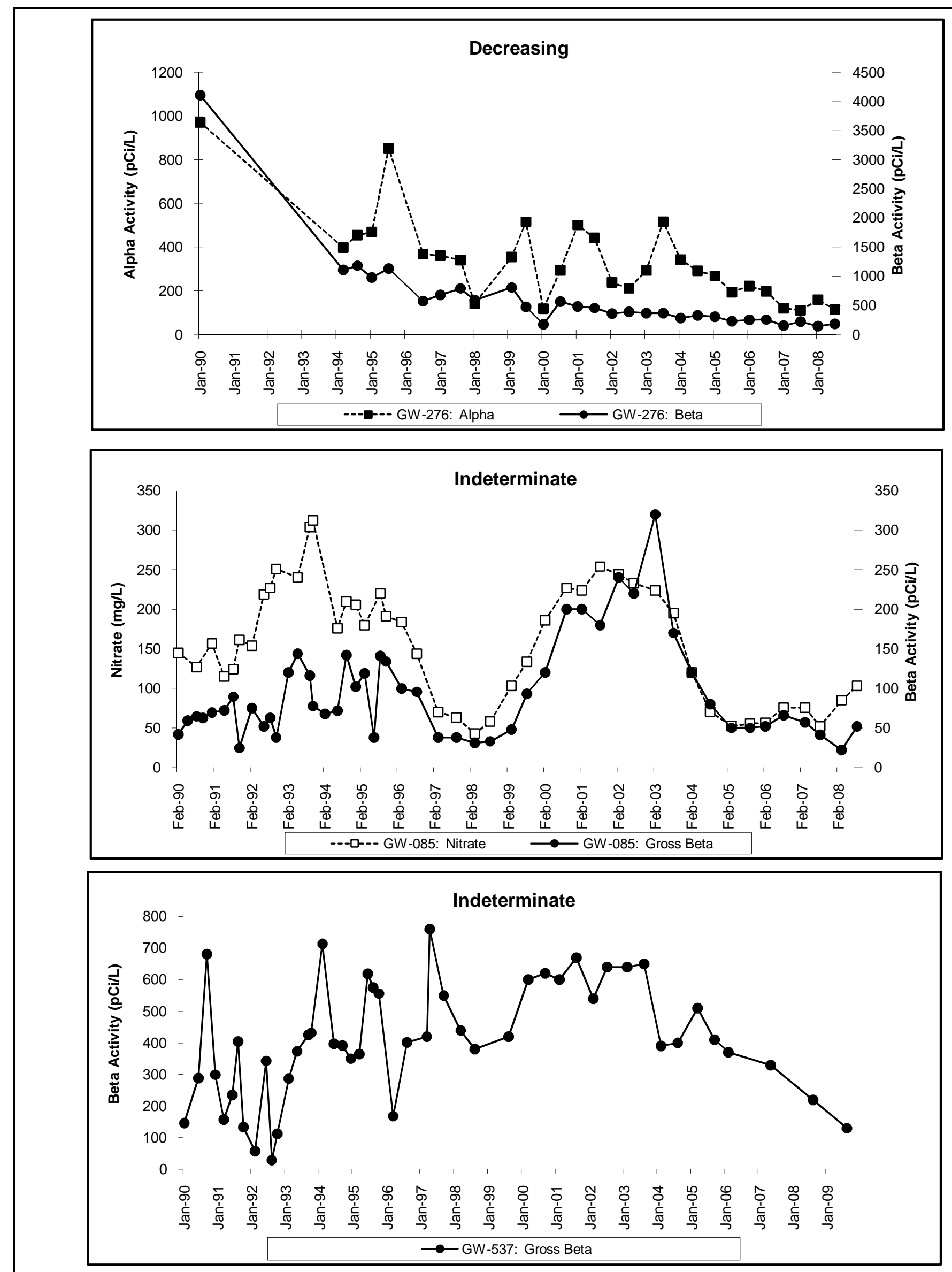

Fig. A.20. Bear Creek Regime CY 2009: gross alpha and/or gross beta activity trends in surveillance monitoring aquitard wells GW-085, GW-276, and GW-537. 

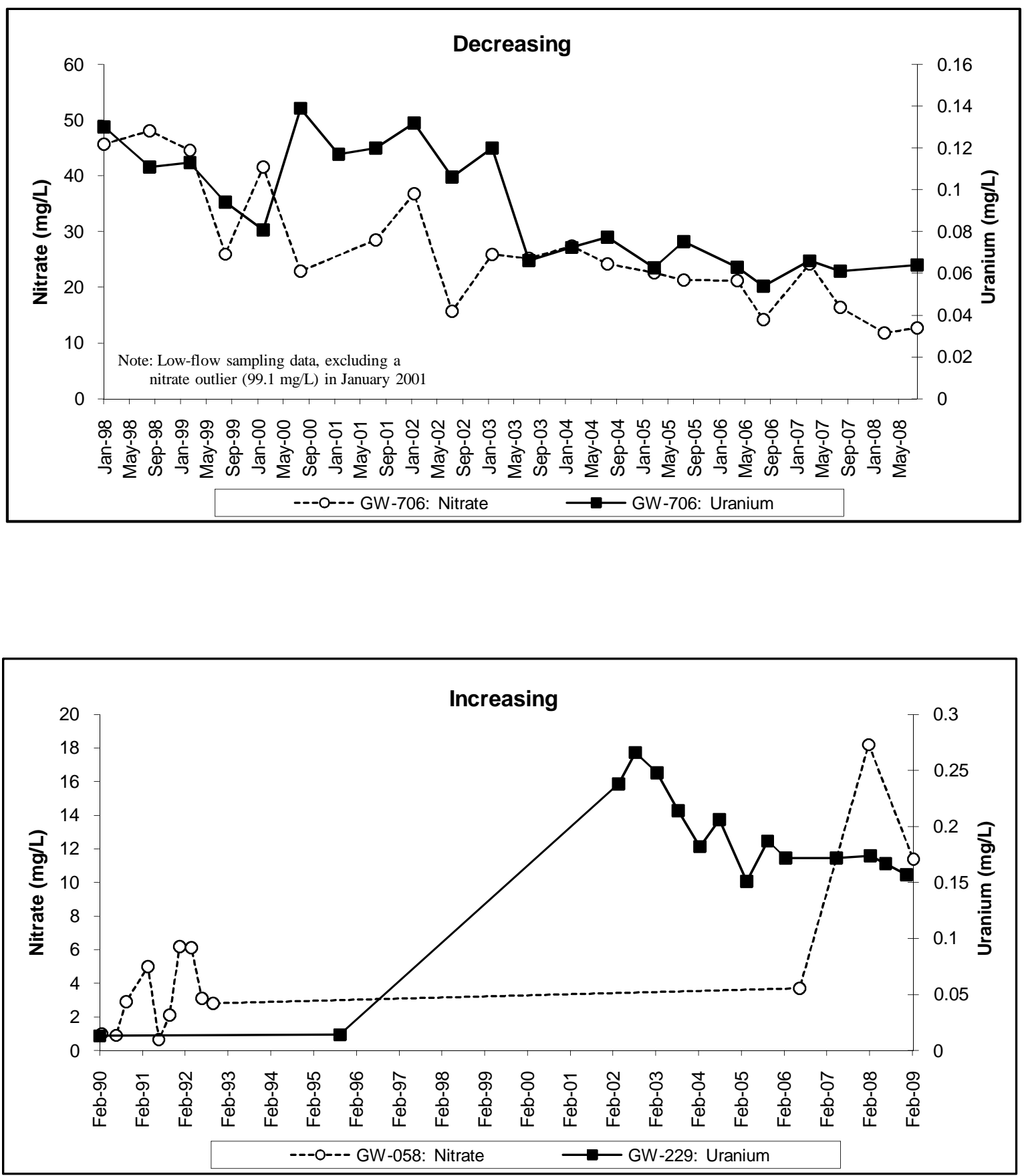

Fig. A.21. Bear Creek Regime CY 2009: nitrate and/or uranium concentration trends in surveillance monitoring aquifer wells GW-058, GW-229, and GW-706. 


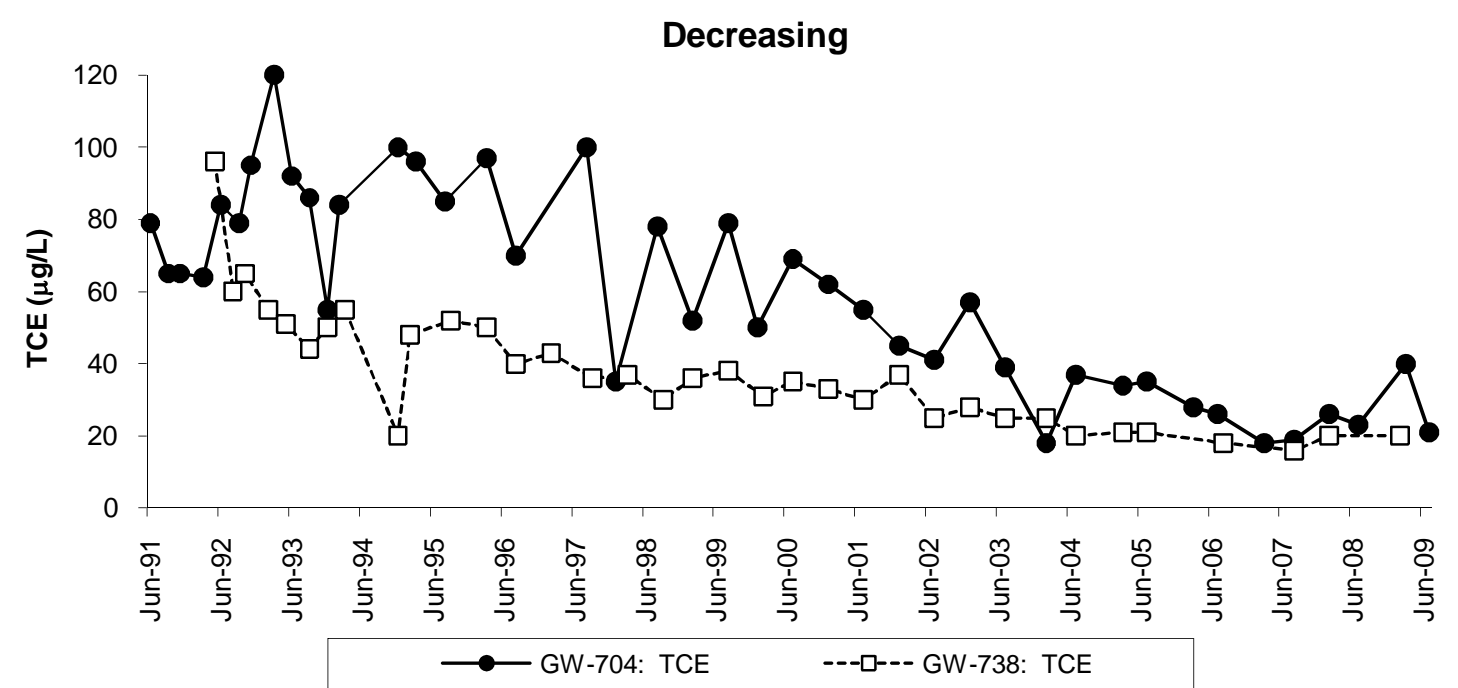

\section{Indeterminate}

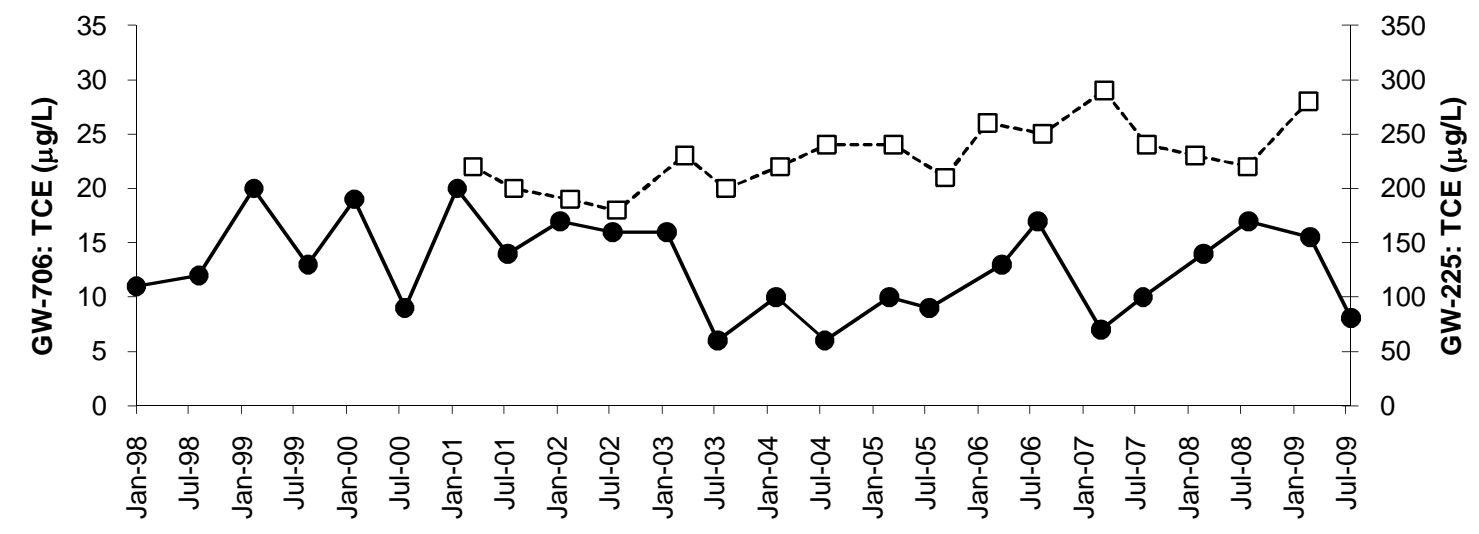

\section{$\longrightarrow$ GW-706: TCE ---口-- GW-225: TCE}

Increasing

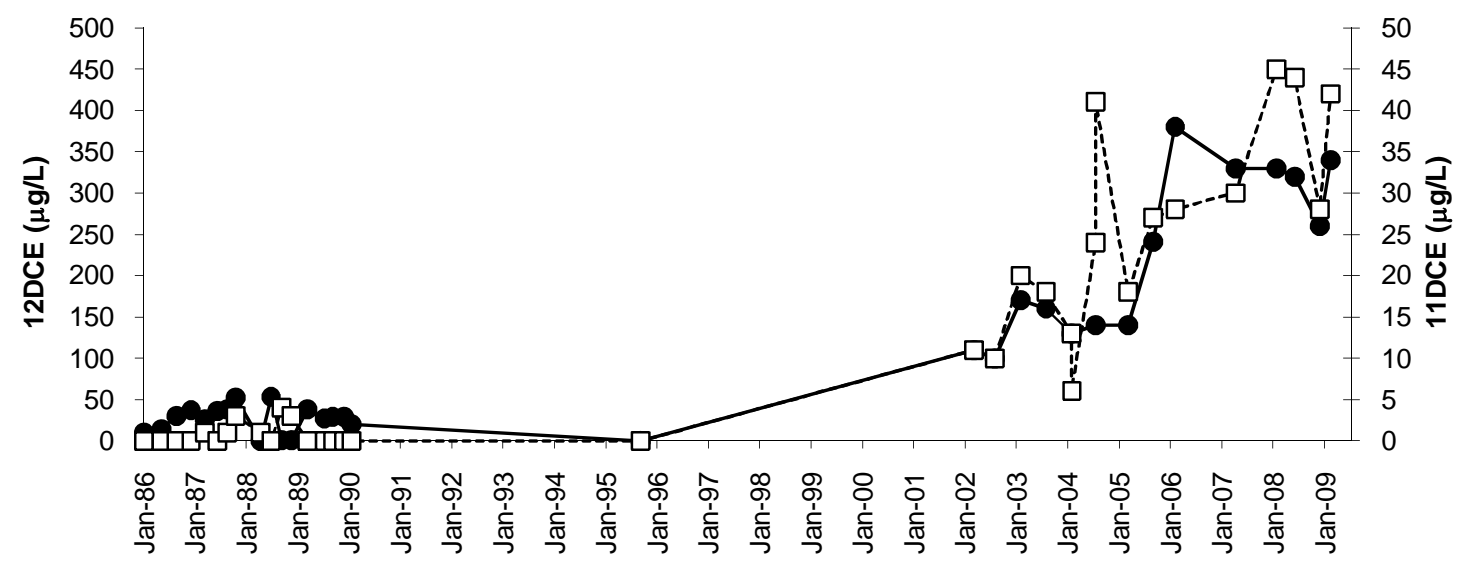



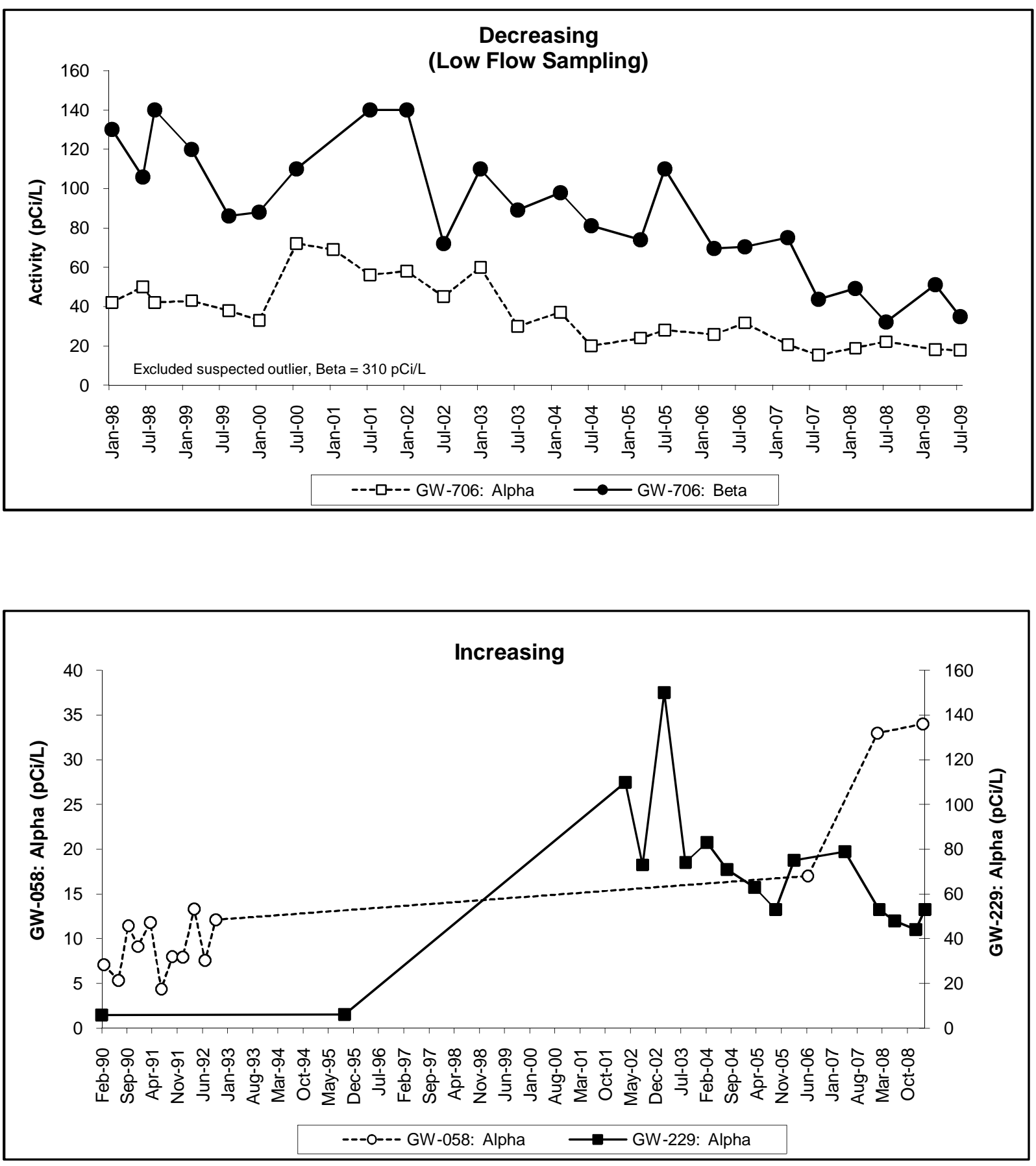

Fig. A.23. Bear Creek Regime CY 2009: gross alpha and/or gross beta activity trends in surveillance monitoring aquifer wells GW-058, GW-229, and GW-706. 

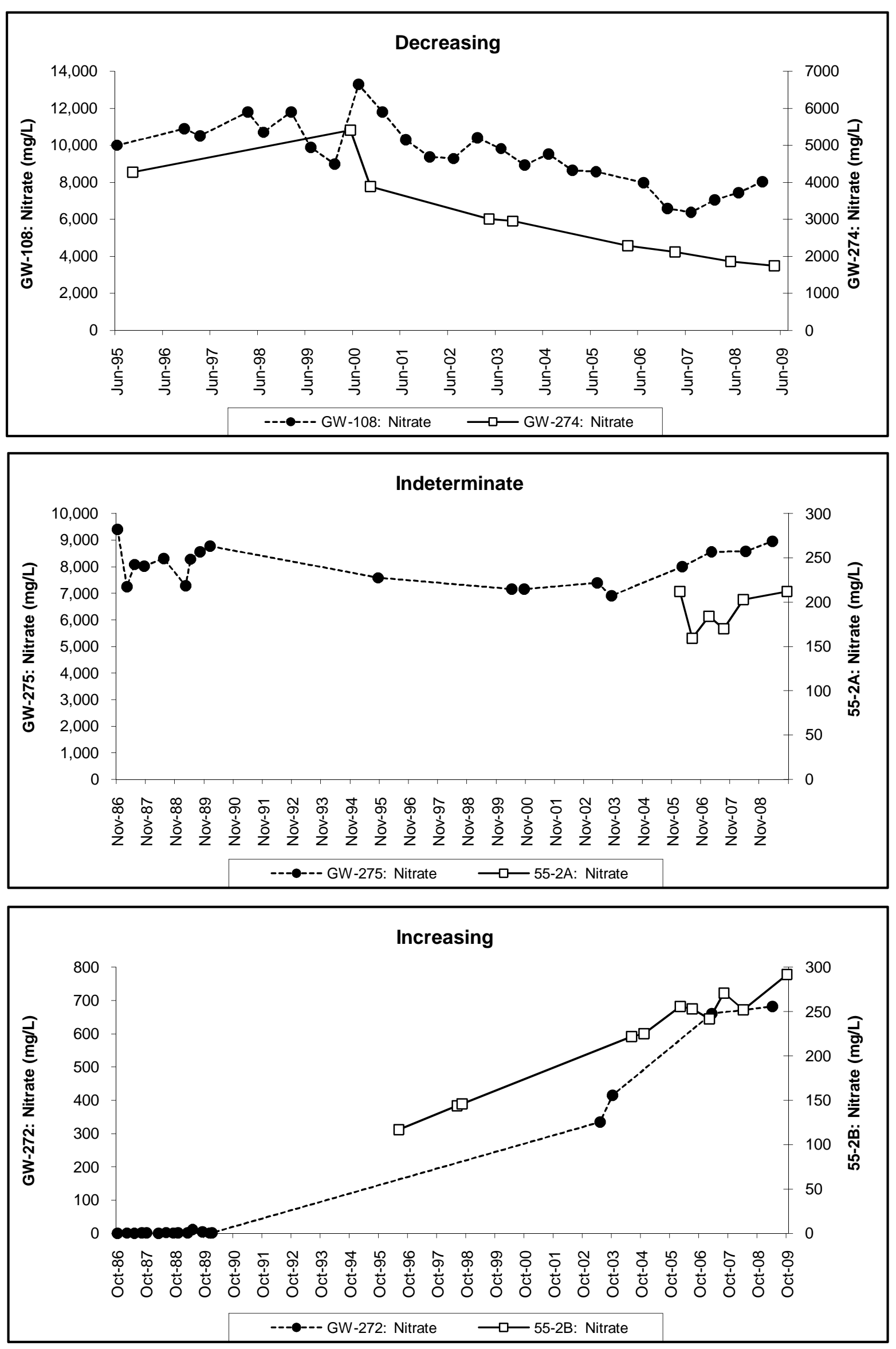

Fig. A.24. East Fork Regime $C Y$ 2009: nitrate concentration trends in surveillance monitoring aquitard wells 55-2A, 55-2B, GW-108, GW-272, GW-274, and GW-275. 


\section{Decreasing}

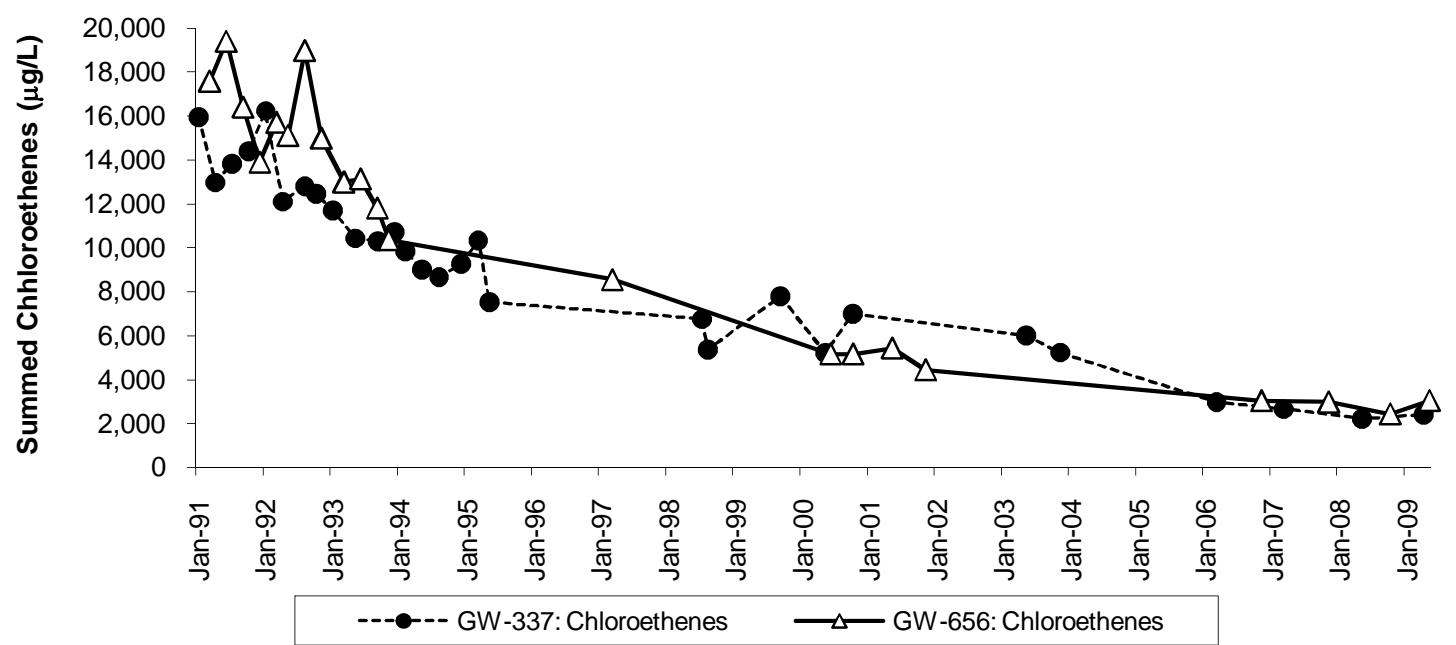

Indeterminate

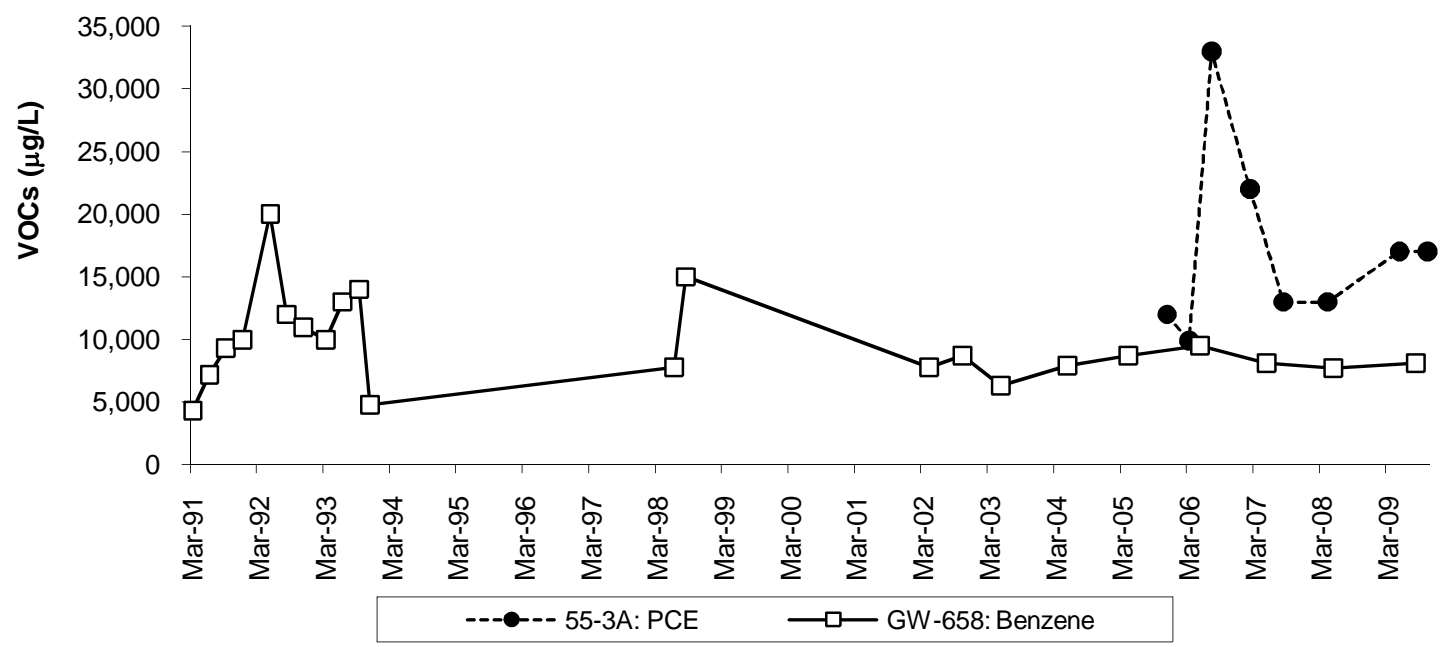

Increasing

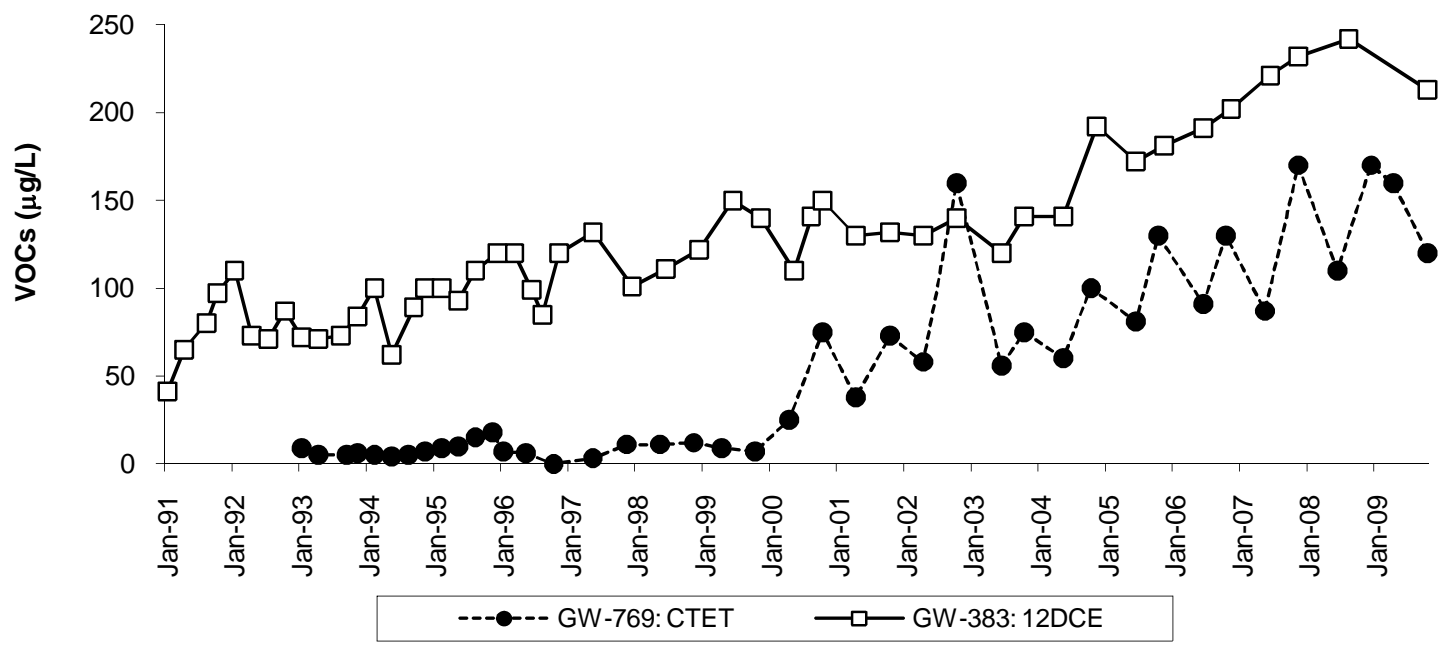

Fig. A.25. East Fork Regime CY 2009: summed VOC concentration trends in surveillance monitoring aquitard wells 55-3A, GW-337, GW-383, GW-656, GW-658, and GW-769. 

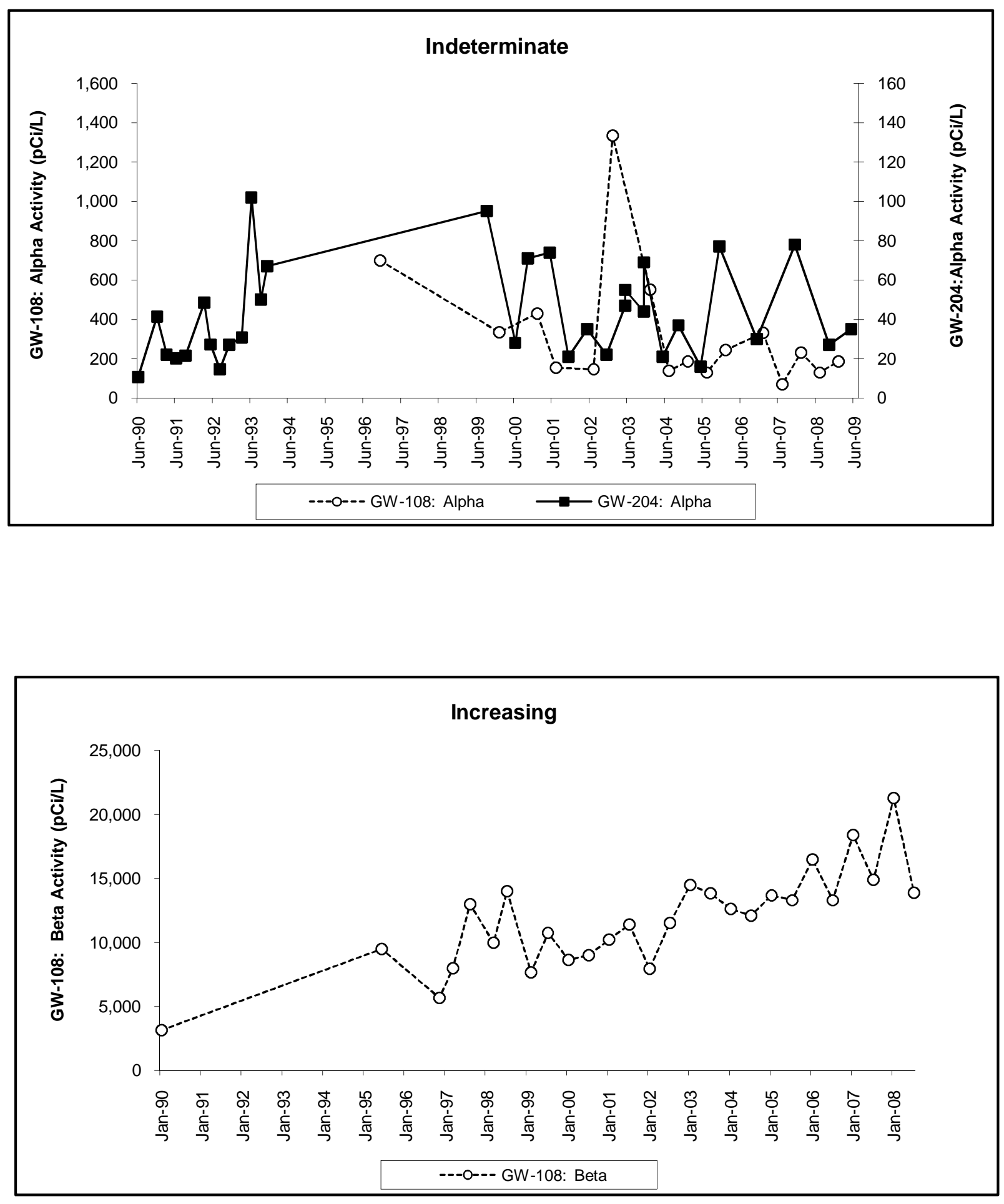

Fig. A.26. East Fork Regime CY 2009: gross alpha and/or gross beta activity trends in surveillance monitoring aquitard wells GW-108 and GW-204. 

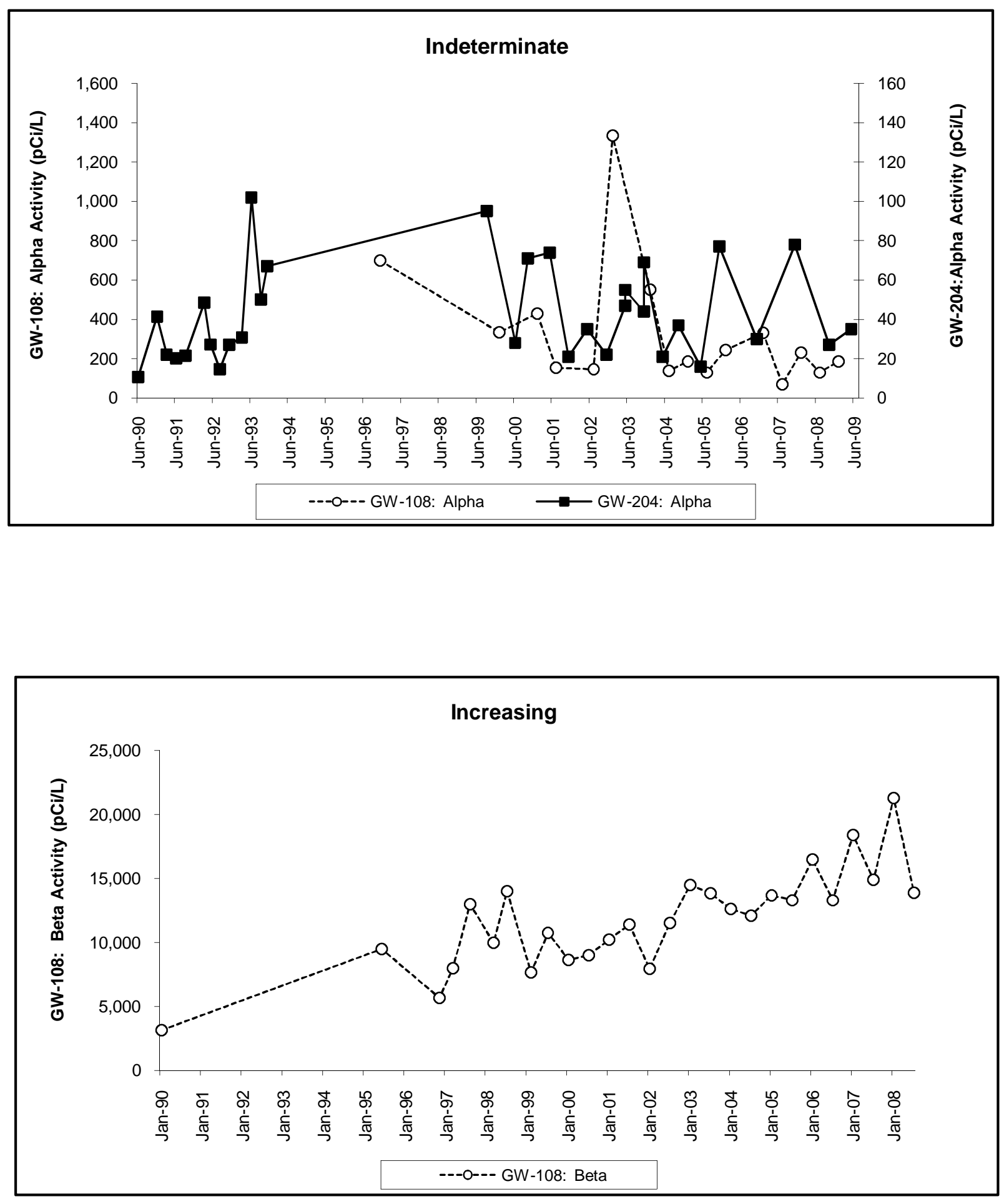

Fig. A.26. East Fork Regime CY 2009: gross alpha and/or gross beta activity trends in surveillance monitoring aquitard wells GW-108 and GW-204. 

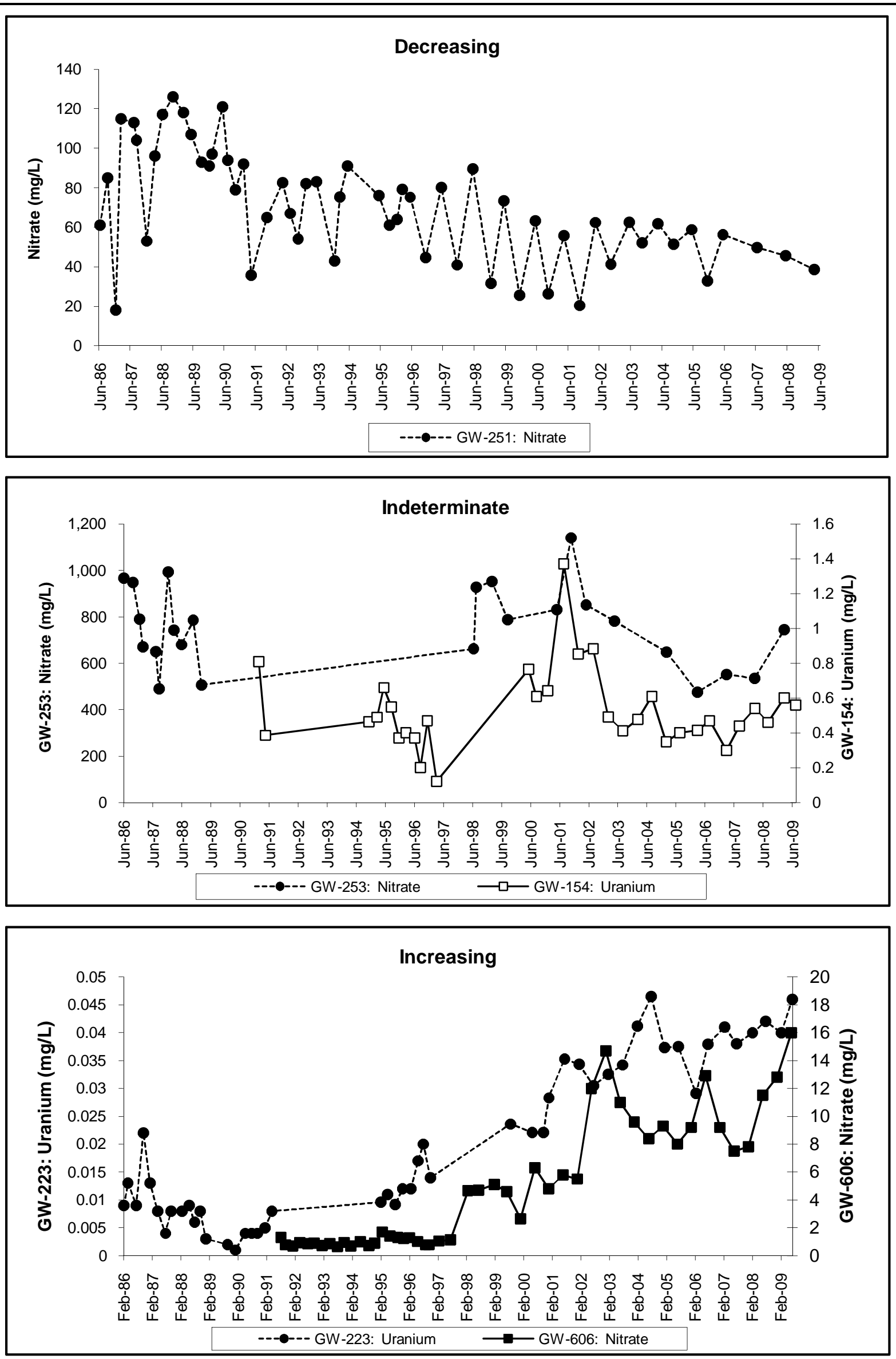

Fig. A.27. East Fork Regime CY 2009: nitrate and/or uranium concentration trends in surveillance monitoring aquifer wells GW-154, GW-223, GW-251, GW-253, and GW-606. 

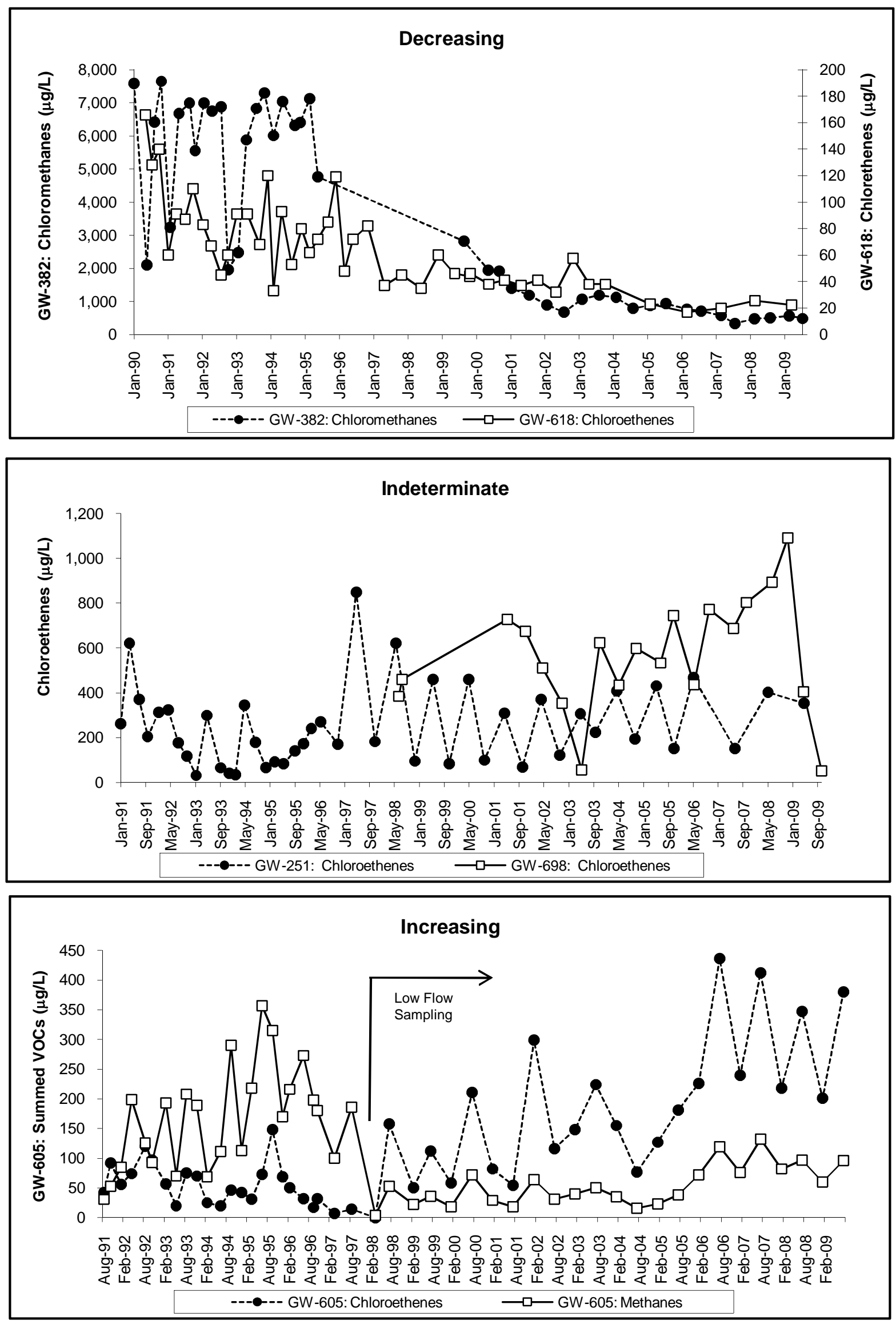

GWMR09 09/07/10

Fig. A.28. East Fork Regime CY 2009: selected VOC concentration trends in surveillance monitoring aquifer wells GW-251, GW-382, GW-605, GW-618, and GW-698. 

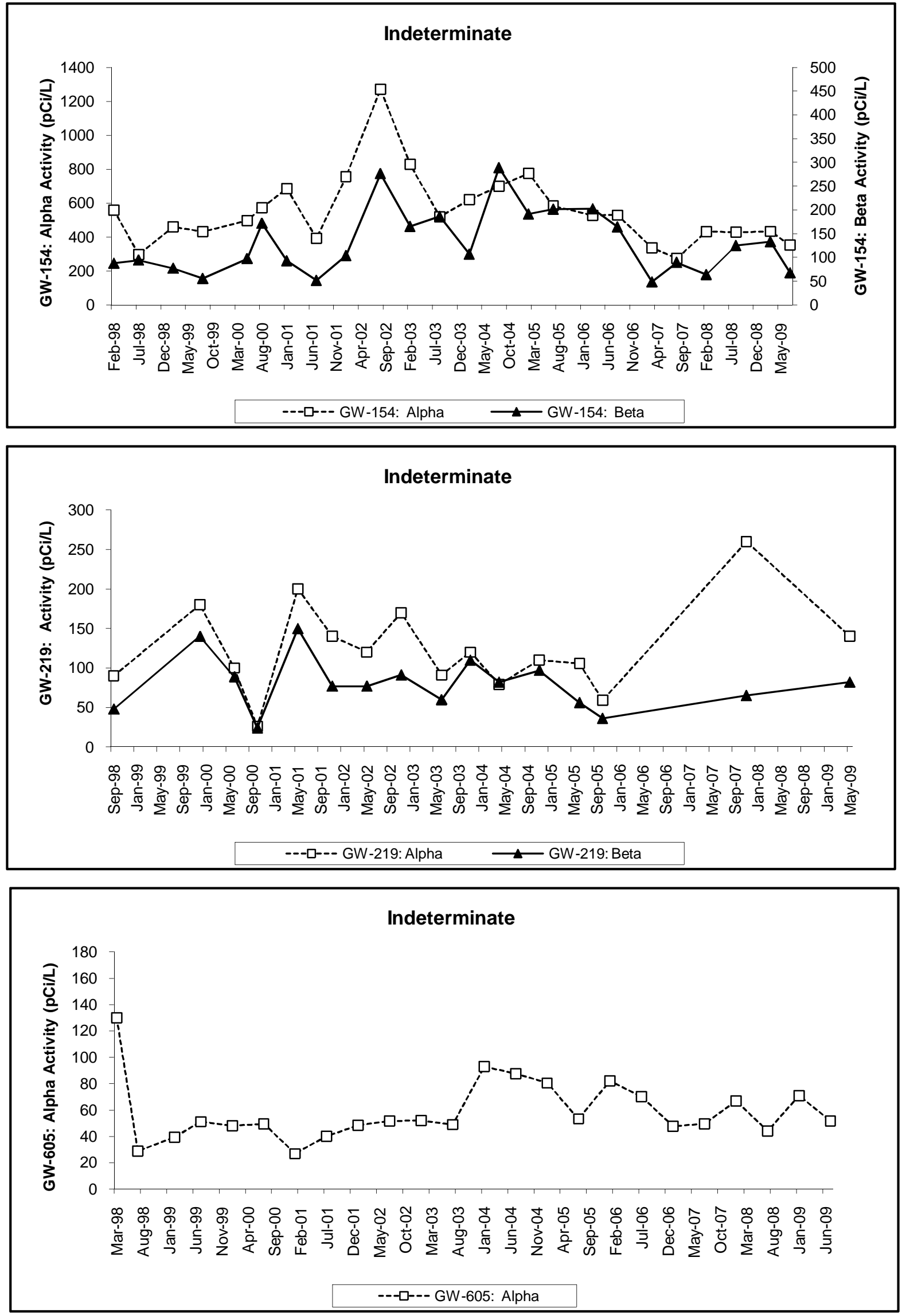

Fig. A.29. East Fork Regime CY 2009: gross alpha and/or gross beta activity trends in surveillance monitoring aquifer wells GW-154, GW-219, and GW-605. 

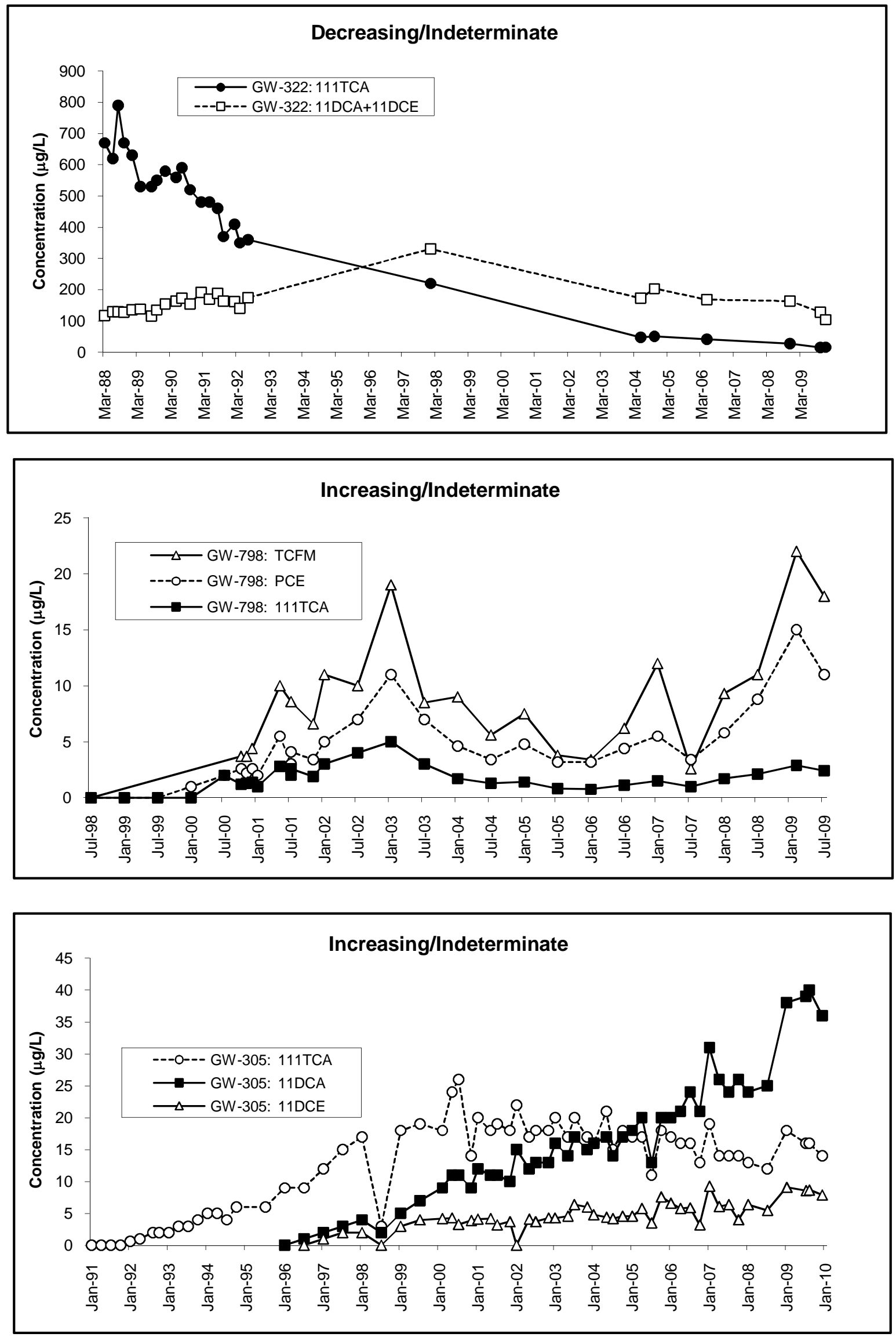

Fig. A.30. Chestnut Ridge Regime CY 2009: VOC trends in surveillance monitoring wells GW-305, GW-322, and GW-798. 

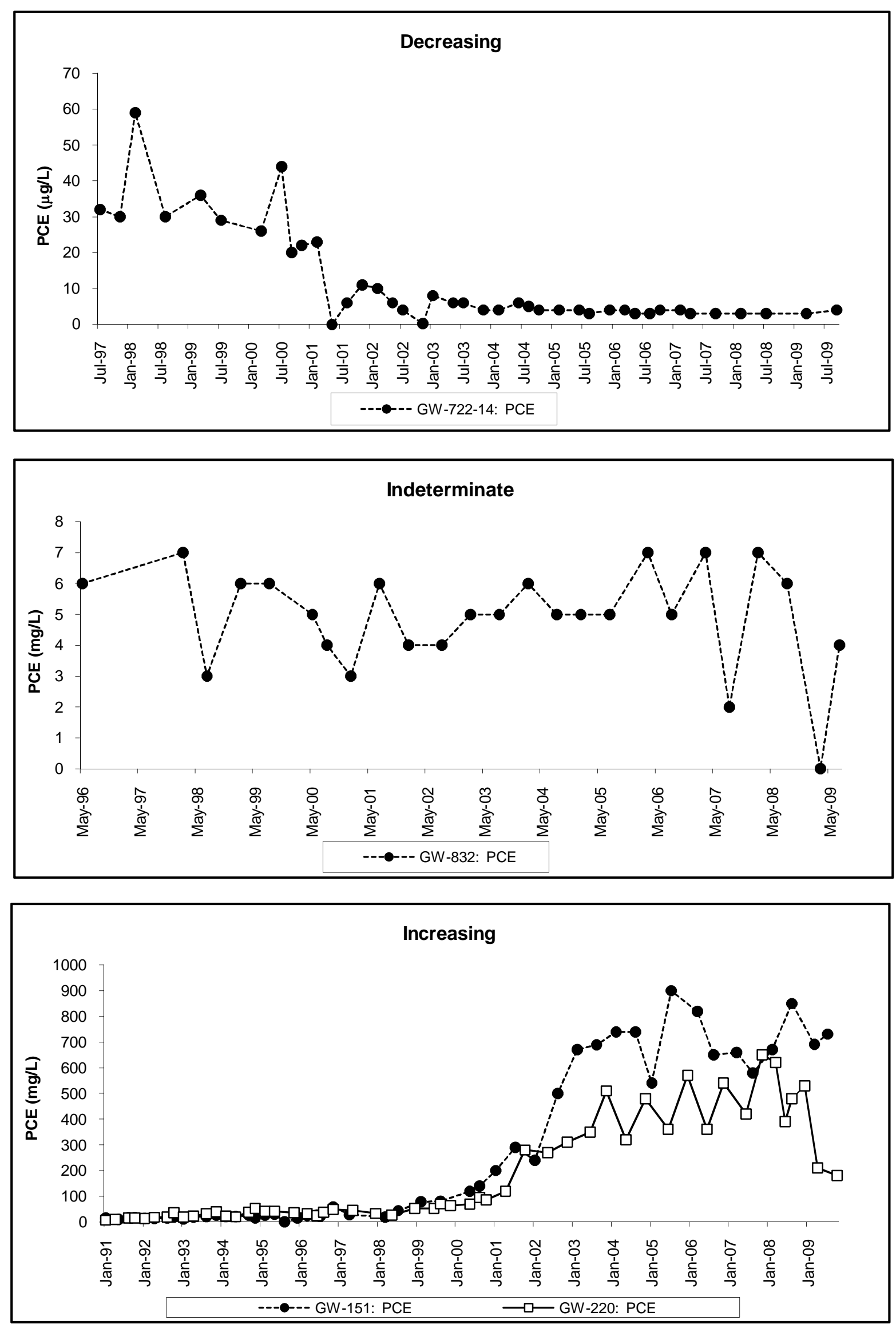

Fig. A.31. East Fork Regime CY 2009: PCE concentration trends in exit pathway monitoring wells GW-151, GW-220, GW-722-14, and GW-832. 


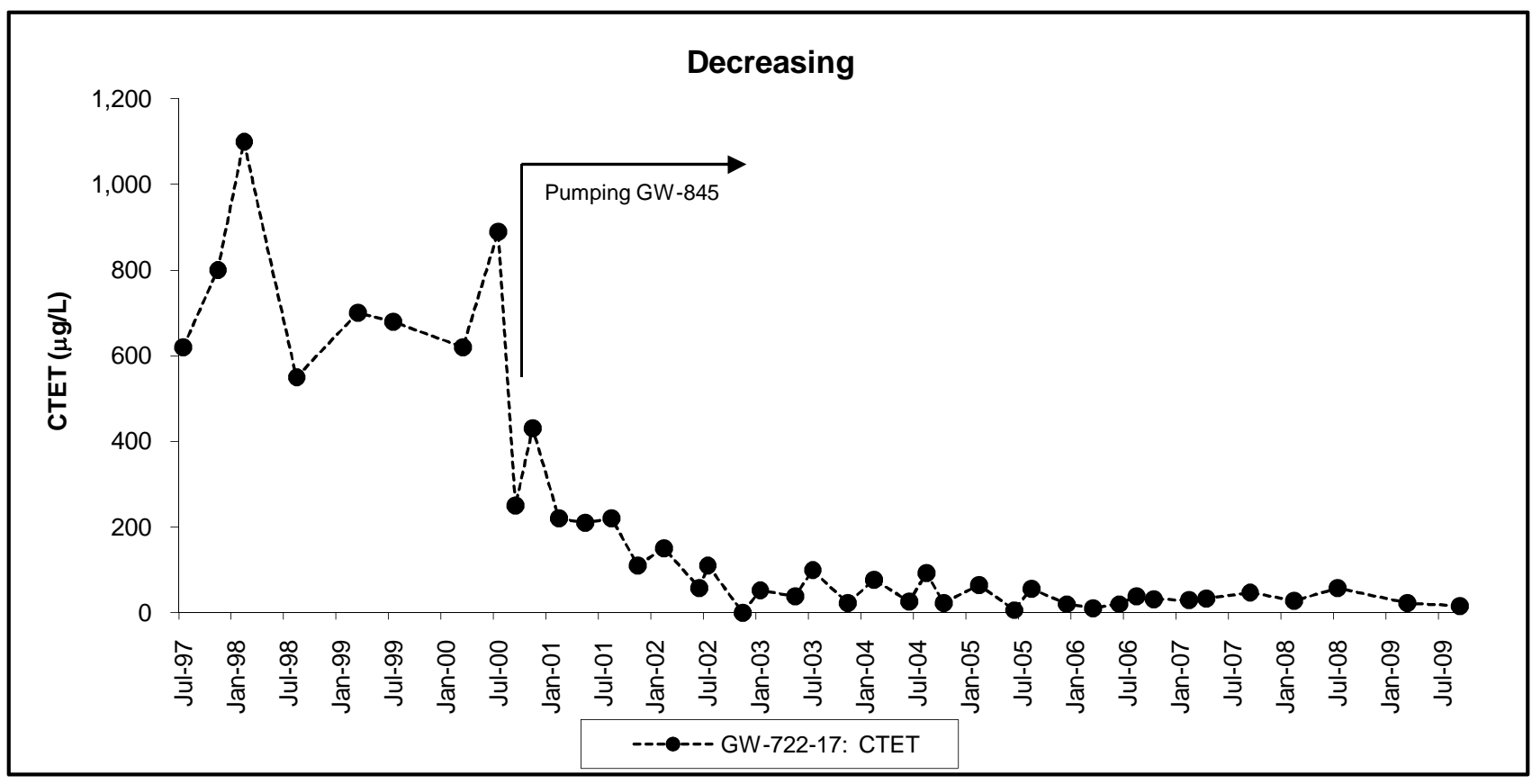

Fig. A.32. East Fork Regime CY 2009: CTET concentration trend in exit pathway monitoring well GW-722-17. 
APPENDIX B

TABLES 



\section{Table B.1. Summary of CY 2009 sampling and analysis plan addenda}

\begin{tabular}{|c|c|l|}
\hline $\begin{array}{c}\text { Addendum } \\
\text { No. }\end{array}$ & $\begin{array}{c}\text { Effective } \\
\text { Date }\end{array}$ & \multicolumn{1}{|c|}{ Modification to the CY 2009 Sampling and Analysis Plan ${ }^{1}$} \\
\hline $2009-01$ & $09 / 09 / 09$ & $\begin{array}{l}\text { Add collection of a groundwater sample, using a bailer, from well GW-629 to evaluate } \\
\text { the the composition of the oil observed on the passive diffusion bag when retrieved from } \\
\text { the well on August 6, 2009. }\end{array}$ \\
\hline $2009-02$ & $12-16-09$ & $\begin{array}{l}\text { Add collection of groundwater samples using the low-flow method at wells GW-175 and } \\
\text { GW-305 (YGW112-CR) during the fourth quarter. Samples were collected using } \\
\text { passive diffusion bags and analytical results were significantly lower than expected. }\end{array}$ \\
\hline $2009-03$ & $07 / 29 / 09$ & $\begin{array}{l}\text { Documents the sample results by the SW846-6020 method (ICPMS) for the third and } \\
\text { fourth quarter sampling events have elevated detection limits caused by dilution used } \\
\text { during analyses to accommodate interference issues. }\end{array}$ \\
\hline $2009-04$ & $01 / 08 / 09$ & $\begin{array}{l}\text { Changes the lab test code used on the bottle list for volatile organic analysis of samples } \\
\text { collected using a passive diffusion bag sampler. }\end{array}$ \\
\hline
\end{tabular}

Note:

1 Modification to the Y-12 Groundwater Protection Program Groundwater and Surface Water Sampling and Analysis Plan for Calendar Year 2009 (B\&W Y-12 2008). 
B-2 
Table B.2. CY 2009 groundwater and surface water sampling dates in the Bear Creek Hydrogeologic Regime

\begin{tabular}{|c|c|c|c|c|c|c|c|c|}
\hline \multirow{2}{*}{\multicolumn{2}{|c|}{$\mathrm{BJC}^{1}$}} & \multirow{2}{*}{\multicolumn{7}{|c|}{\begin{tabular}{c|} 
CERCLA ROD (•), Detection ( $\square$ ), and Baseline ( $\circ$ ) Monitoring \\
RCRA Post-Closure Corrective Action Monitoring
\end{tabular}}} \\
\hline & & & & & & & & \\
\hline \multirow{2}{*}{\multicolumn{2}{|c|}{ GWPP $^{2}$}} & \multicolumn{6}{|c|}{ DOE Order Exit Pathway/Perimeter Monitoring } & \\
\hline & & \multicolumn{7}{|c|}{ DOE Order Surveillance Monitoring } \\
\hline \multirow{2}{*}{$\begin{array}{l}\text { Sampling } \\
\text { Point }^{3}\end{array}$} & \multirow{2}{*}{$\begin{array}{l}\text { Functional } \\
\text { Area }^{4}\end{array}$} & \multicolumn{4}{|c|}{ CY 2009 Sampling Date ${ }^{5}$} & & & \\
\hline & & 1st Quarter & 2nd Quarter & 3rd Quarter & 4th Quarter & & & \\
\hline GW-008 & OLF & $01 / 06 / 09$ & . & $07 / 06 / 09$ & . & $\mathbf{x}$ & & \\
\hline GW-014 & BG & $03 / 04 / 09$ & . & & . & $\bullet$ & & \\
\hline GW-046 & BG & 01/07/09 & . & 07/06/09 & . & $\mathbf{x}$ & & \\
\hline GW-053 & BG & 03/03/09 D & . & - & . & $\bullet$ & & \\
\hline GW-058 & BG & $02 / 10 / 09$ & . & & . & $\bullet$ & & \\
\hline GW-065 & OLF & $02 / 25 / 09$ & . & 08/06/09 & . & $\bullet$ & & \\
\hline GW-068 & BG & $03 / 03 / 09$ & . & & . & $\bullet$ & & \\
\hline GW-071 & $\mathrm{BG}$ & $03 / 04 / 09$ & . & $08 / 10 / 09$ & . & $\bullet$ & & \\
\hline GW-077 & BG & $03 / 02 / 09$ & . & $07 / 21 / 09$ & . & $\mathbf{x}$ & & $\bullet$ \\
\hline GW-078 & $\mathrm{BG}$ & $03 / 02 / 09$ & . & $07 / 21 / 09$ & . & $\mathbf{x}$ & & $\bullet$ \\
\hline GW-079 & BG & $03 / 02 / 09$ & . & $07 / 22 / 09$ & . & $\mathbf{x}$ & & $\bullet$ \\
\hline GW-080 & $\mathrm{BG}$ & 03/02/09 D & . & 07/22/09 D & . & $\mathbf{x}$ & & $\bullet$ \\
\hline GW-082 & BG & & . & $08 / 10 / 09$ & . & $\bullet$ & & \\
\hline GW-085 & OLF & 02/23/09 D & . & . & . & $\bullet$ & & \\
\hline GW-098 & OLF & $02 / 25 / 09$ & . & . & . & $\bullet$ & & \\
\hline GW-100 & S3 & $02 / 19 / 09$ & . & . & . & $\bullet$ & & \\
\hline GW-101 & S3 & $02 / 19 / 09$ & . & . & . & $\bullet$ & & \\
\hline GW-122 & S3 & $02 / 17 / 09$ & . & . & . & $\bullet$ & & \\
\hline GW-127 & S3 & $02 / 17 / 09$ & . & . & . & $\bullet$ & & \\
\hline GW-225 & OLF & $02 / 26 / 09$ & . & . & . & $\bullet$ & & \\
\hline GW-229 & OLF & $02 / 26 / 09$ & . & . & . & $\bullet$ & & \\
\hline GW-236 & S3 & $02 / 23 / 09$ & . & . & . & $\bullet$ & & \\
\hline GW-242 & $\mathrm{BG}$ & $03 / 05 / 09$ & . & . & . & $\bullet$ & & \\
\hline GW-246 & S3 & . & . & $08 / 05 / 09$ & . & $\bullet$ & & \\
\hline GW-276 & S3 & $01 / 07 / 09$ & . & $07 / 06 / 09$ & . & $\mathbf{x}$ & & \\
\hline GW-289 & BG & & . & 08/06/09 D & . & $\bullet$ & & \\
\hline GW-307 & RS & 02/10/09 D & . & . & . & $\bullet$ & & \\
\hline GW-315 & SPI & $02 / 17 / 09$ & . & . & . & $\bullet$ & & \\
\hline GW-363* & EMWMF & $02 / 17 / 09$ & $04 / 22 / 09$ & $08 / 19 / 09$ & $11 / 19 / 09$ & $\mathbf{x}$ & & $\square$ \\
\hline GW-363 & EMWMF & $02 / 18 / 09$ & $04 / 23 / 09$ & $08 / 20 / 09$ & & $\mathbf{x}$ & & $\square$ \\
\hline GW-365 & OLF & $03 / 02 / 09$ & . & . & . & $\bullet$ & & \\
\hline GW-526 & S3 & $02 / 24 / 09$ & . & . & . & $\bullet$ & & \\
\hline GW-537 & OLF & . & . & 08/05/09 & . & $\bullet$ & & \\
\hline GW-601 & OLF & 03/02/09 & . & . & . & $\bullet$ & & \\
\hline
\end{tabular}


Table B.2 (continued)

\begin{tabular}{|c|c|c|c|c|c|c|c|c|c|}
\hline \multirow{2}{*}{\multicolumn{2}{|c|}{ BJC $^{1}$}} & \multicolumn{8}{|c|}{ CERCLA ROD (•), Detection ( $\square$ ), and Baseline ( $\odot$ ) Monitoring } \\
\hline & & \multicolumn{8}{|c|}{ RCRA Post-Closure Corrective Action Monitoring } \\
\hline \multirow{2}{*}{\multicolumn{2}{|c|}{ GWPP $^{2}$}} & \multicolumn{8}{|c|}{ DOE Order Exit Pathway/Perimeter Monitoring } \\
\hline & & \multicolumn{8}{|c|}{ DOE Order Surveillance Monitoring } \\
\hline \multirow{2}{*}{$\begin{array}{c}\text { Sampling } \\
\text { Point }^{3}\end{array}$} & \multirow{2}{*}{$\begin{array}{c}\text { Functional } \\
\text { Area }^{4}\end{array}$} & \multicolumn{4}{|c|}{ CY 2009 Sampling Date ${ }^{5}$} & & & & \\
\hline & & 1st Quarter & 2nd Quarter & 3rd Quarter & 4th Quarter & & & & \\
\hline GW-615 & S3 & 02/18/09 & & & . & $\bullet$ & & & \\
\hline GW-616 & S3 & (2) & $\dot{\square}$ & $08 / 05 / 09$ & . & $\bullet$ & & & \\
\hline GW-623 & BG & 03/03/09 & & & . & $\bullet$ & & & \\
\hline GW-627 & BG & $03 / 05 / 09$ & 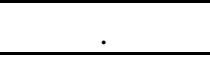 & $08 / 06 / 09$ & . & $\bullet$ & & & \\
\hline GW-629 & BG & 03/05/09 & . & 08/06/09 & . & $\bullet$ & & & \\
\hline GW-629 & $\mathrm{BG}$ & & & 09/09/09 B & . & $\bullet$ & & & \\
\hline GW-639* & EMWMF & 02/17/09 & $04 / 22 / 09$ & 08/18/09 & $11 / 18 / 09$ & $\mathbf{x}$ & & & $\square$ \\
\hline GW-639 & EMWMF & $02 / 18 / 09$ & $04 / 23 / 09$ & $08 / 19 / 09$ & & $\mathbf{x}$ & & & $\square$ \\
\hline GW-648 & RS & 02/09/09 D & & 08/05/09 & $\dot{-}$ & $\bullet$ & & & \\
\hline GW-653 & $\mathrm{BG}$ & $03 / 05 / 09$ & . & . & . & $\bullet$ & & & \\
\hline GW-683 & EXP-A & $03 / 04 / 09$ & & $07 / 21 / 09$ &. & $\mathbf{x}$ & & & $\bullet$ \\
\hline GW-684 & EXP-A & 03/03/09 & . & 07/20/09 & . & $\mathbf{x}$ & & & $\bullet$ \\
\hline GW-703 & EXP-B & 02/26/09 & . & . & . & $\bullet$ & & & \\
\hline GW-704 & EXP-B & 03/03/09 & . & 07/21/09 & . & $\mathbf{x}$ & & & $\bullet$ \\
\hline GW-706 & EXP-B & 03/03/09 & . & $07 / 22 / 09$ & . & $\mathbf{x}$ & & & $\bullet$ \\
\hline GW-712 & EXP-W & 01/07/09 & & 07/06/09 & . & & $\mathbf{x}$ & $\bullet$ & \\
\hline GW-713 & EXP-W & 01/07/09 D & . & 07/07/09 D & . & & $\mathbf{x}$ & $\bullet$ & \\
\hline GW-714 & EXP-W & 01/06/09 & & 07/06/09 & . & & $\mathbf{x}$ & $\bullet$ & \\
\hline GW-724 & EXP-C & 02/25/09 & & . & . & $\bullet$ & & & \\
\hline GW-725 & EXP-C & 02/25/09 & & . & . & $\bullet$ & & & \\
\hline GW-726-04 & $\mathrm{BG}$ & 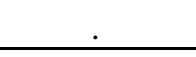 & 05/04/09 & . & . & $\bullet$ & & & \\
\hline GW-726-06 & $\mathrm{BG}$ &. & $05 / 04 / 09$ & . &. & $\bullet$ & & & \\
\hline GW-726-09 & BG & . & 05/05/09 & . & . & $\bullet$ & & & \\
\hline GW-726-12 & BG & . & 05/05/09 & . & . & $\bullet$ & & & \\
\hline GW-726-16 & $\mathrm{BG}$ & . & 05/06/09 & . & . & $\bullet$ & & & \\
\hline GW-726-20 & BG & & 05/06/09 & . & . & $\bullet$ & & & \\
\hline GW-726-23 & $\mathrm{BG}$ & 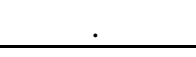 & 05/06/09 & . & . & $\bullet$ & & & \\
\hline GW-738 & EXP-C & 02/25/09 & . & . & . & $\bullet$ & & & \\
\hline GW-740 & EXP-C & $02 / 24 / 09$ & & & . & $\bullet$ & & & \\
\hline GW-916 & EMWMF & 02/12/09 & 04/15/09 & 08/11/09 & $11 / 11 / 09$ & $\mathbf{x}$ & & & $\square$ \\
\hline GW-917 & EMWMF & 02/09/09 & $04 / 14 / 09$ & 08/12/09 & $11 / 09 / 09$ & $\mathbf{x}$ & & & $\square$ \\
\hline GW-918 & EMWMF & 02/10/09 & $04 / 15 / 09$ & 08/12/09 & $11 / 12 / 09$ & $\mathbf{x}$ & & & $\square$ \\
\hline GW-920 & EMWMF & 02/10/09 & 04/16/09 & 08/11/09 & $11 / 12 / 09$ & $\mathbf{x}$ & & & $\square$ \\
\hline GW-921 & EMWMF & 02/11/09 & $04 / 14 / 09$ & 08/13/09 & $11 / 10 / 09$ & $\mathbf{x}$ & & & $\square$ \\
\hline GW-922 & EMWMF & 02/10/09 & 04/16/09 & 08/10/09 & 11/11/09 & $\mathbf{x}$ & & & $\square$ \\
\hline
\end{tabular}

B-4 
Table B.2 (continued)

\begin{tabular}{|c|c|c|c|c|c|c|c|c|}
\hline \multirow{2}{*}{\multicolumn{2}{|c|}{ BJC $^{1}$}} & \multicolumn{7}{|c|}{ CERCLA ROD (•), Detection ( $\square$ ), and Baseline ( $\odot$ ) Monitoring } \\
\hline & & \multicolumn{7}{|c|}{ RCRA Post-Closure Corrective Action Monitoring } \\
\hline \multirow{2}{*}{\multicolumn{2}{|c|}{$\mathbf{G W P P}^{2}$}} & \multicolumn{7}{|c|}{ DOE Order Exit Pathway/Perimeter Monitoring } \\
\hline & & \multicolumn{7}{|c|}{ DOE Order Surveillance Monitoring } \\
\hline \multirow{2}{*}{$\begin{array}{c}\text { Sampling } \\
\text { Point }^{3}\end{array}$} & \multirow{2}{*}{$\begin{array}{c}\text { Functional } \\
\text { Area }^{4}\end{array}$} & \multicolumn{4}{|c|}{ CY 2009 Sampling Date ${ }^{5}$} & & & \\
\hline & & 1st Quarter & 2nd Quarter & 3rd Quarter & 4th Quarter & & & \\
\hline GW-923* & EMWMF & $02 / 17 / 09$ & $04 / 20 / 09$ & $08 / 11 / 09$ & $11 / 11 / 09$ & $\mathbf{x}$ & & $\square$ \\
\hline GW-923 & EMWMF & $02 / 18 / 09$ & $04 / 21 / 09$ & 08/12/09 & - & $\mathbf{x}$ & & $\square$ \\
\hline GW-923 & EMWMF & & $04 / 22 / 09$ & $08 / 13 / 09$ & . & $\mathbf{x}$ & & $\square$ \\
\hline GW-924 & EMWMF & 02/11/09 D & 04/20/09 D & 08/17/09 D & $11 / 16 / 09$ & $\mathbf{x}$ & & $\square$ \\
\hline GW-925* & EMWMF & 02/11/09 & 04/14/09 & $08 / 17 / 09$ & $11 / 11 / 09$ & $\mathbf{x}$ & & $\square$ \\
\hline GW-925 & EMWMF & 02/12/09 & 04/15/09 & 08/18/09 & . & $\mathbf{x}$ & & $\square$ \\
\hline GW-926 & EMWMF & 02/10/09 & 04/20/09 & 08/17/09 & $11 / 17 / 09$ & $\mathbf{x}$ & & $\square$ \\
\hline GW-927 & EMWMF & 02/09/09 & $04 / 14 / 09$ & $08 / 12 / 09$ & $11 / 10 / 09$ & $\mathbf{x}$ & & $\square$ \\
\hline GW-961 & EMWMF & . & . & . & $11 / 23 / 09$ & $\mathbf{x}$ & & $\square$ \\
\hline BCK-03.30 & EXP-SW & . & . & . & $12 / 07 / 09$ & & $\mathbf{x}$ & $\bullet$ \\
\hline BCK-04.55 & EXP-SW & . & . & . & $12 / 07 / 09$ & & $\mathbf{x}$ & $\bullet$ \\
\hline BCK-04.55 & EXP-SW & . & . & 08/03/09 & . & & $\bullet$ & \\
\hline BCK-07.87 & EXP-SW & . & . & . & $12 / 07 / 09$ & & $\mathbf{x}$ & $\bullet$ \\
\hline BCK-09.20 & EXP-SW & . & . & . & $12 / 07 / 09$ & & $\mathbf{x}$ & $\bullet$ \\
\hline BCK-09.40 & EXP-SW & . & . & 08/03/09 D & . & & $\bullet$ & \\
\hline BCK-11.54 & EXP-SW & . & . & . & $12 / 07 / 09$ & & $\mathbf{x}$ & $\bullet$ \\
\hline BCK-11.84 & EXP-SW & . & . & . & $12 / 07 / 09$ & & $\mathbf{x}$ & $\bullet$ \\
\hline BCK-11.97 & EXP-SW & . & . & 08/03/09 & . & & $\bullet$ & \\
\hline BCK-12.34 & EXP-SW & . & . & . & $12 / 07 / 09$ & & $\mathbf{x}$ & $\bullet$ \\
\hline EMWNT-03A & EXP-SW & 02/09/09 & 04/13/09 & 08/10/09 & 11/09/09 & & $\mathbf{x}$ & $\square$ \\
\hline EMWNT-05 & EXP-SW & 02/09/09 & 04/13/09 & 08/10/09 & 11/09/09 & & $\mathbf{x}$ & $\square$ \\
\hline EMW-VWEIR & EXP-SW & 02/09/09 D & $04 / 13 / 09$ & 08/10/09 & 11/09/09 D & & $\mathbf{x}$ & $\square$ \\
\hline EMW-VWUND & EXP-SW & 02/12/09 & 04/16/09 & 08/11/09 & 11/12/09 D & & $\mathbf{x}$ & $\square$ \\
\hline NT-01 & EXP-SW & . & . & 08/03/09 & . & & $\bullet$ & \\
\hline NT-01 & EXP-SW & . & 06/25/09 D & 07/20/09 D & 11/17/09 D & & $\mathbf{x}$ & $\bullet$ \\
\hline NT-01 & EXP-SW & . & . & . & $12 / 07 / 09$ & & $\mathbf{x}$ & $\bullet$ \\
\hline NT-03 & EXP-SW & . & . & . & $12 / 07 / 09$ & & $\mathbf{x}$ & $\bullet$ \\
\hline NT-04 & EXP-SW & 02/09/09 & 04/13/09 & 08/10/09 & 11/09/09 & & $\mathbf{x}$ & $\square$ \\
\hline NT-07 & EXP-SW & 02/10/09 & . & $08 / 04 / 09$ & . & & $\mathbf{x}$ & 0 \\
\hline NT-08 & EXP-SW & 02/10/09 & . & 08/04/09 & . & & $\mathbf{x}$ & o \\
\hline NT-08 & EXP-SW & . & . & . & 12/07/09 D & & $\mathbf{x}$ & $\bullet$ \\
\hline S07 (NT-02) & EXP-SW & . & . & . & $12 / 07 / 09$ & & $\mathbf{x}$ & $\bullet$ \\
\hline SS-4 & EXP-SW & . & . & 08/03/09 & . & & $\bullet$ & \\
\hline SS-4 & EXP-SW & $02 / 23 / 09$ & . & $07 / 20 / 09$ & . & & $\mathbf{x}$ & $\bullet$ \\
\hline SS-5 & EXP-SW & . & . & $08 / 03 / 09$ & . & & - & \\
\hline
\end{tabular}

B-5 
Table B.2 (continued)

\begin{tabular}{|c|c|c|c|c|c|c|c|c|}
\hline \multirow{2}{*}{\multicolumn{2}{|c|}{ BJC $^{1}$}} & \multicolumn{7}{|c|}{ CERCLA ROD ( $\bullet$ ), Detection ( $\square$ ), and Baseline $(\circ)$ Monitoring } \\
\hline & & \multicolumn{6}{|c|}{ RCRA Post-Closure Corrective Action Monitoring } & \\
\hline \multirow{2}{*}{\multicolumn{2}{|c|}{ GWPP $^{2}$}} & \multicolumn{6}{|c|}{ DOE Order Exit Pathway/Perimeter Monitoring } & \\
\hline & & \multicolumn{7}{|c|}{ DOE Order Surveillance Monitoring } \\
\hline \multirow{2}{*}{$\begin{array}{c}\text { Sampling } \\
\text { Point }^{3}\end{array}$} & \multirow{2}{*}{$\begin{array}{c}\text { Functional } \\
\text { Area }^{4}\end{array}$} & \multicolumn{4}{|c|}{ CY 2009 Sampling Date ${ }^{5}$} & & & \\
\hline & & 1st Quarter & 2nd Quarter & 3rd Quarter & 4th Quarter & & & \\
\hline SS-5 & EXP-SW & . & . & . & $12 / 07 / 09$ & & & $\bullet$ \\
\hline SS-6 & EXP-SW & $01 / 05 / 09$ & . & $07 / 06 / 09$ & . & & & \\
\hline SS-6.6 & EXP-SW & . & . & . & $12 / 07 / 09$ & & & $\bullet$ \\
\hline SS-7 & EXP-SW & . & . & . & $12 / 07 / 09$ & & & $\bullet$ \\
\hline SS-8 & EXP-SW & . & . & . & 12/07/09 D & & & $\bullet$ \\
\hline
\end{tabular}

Notes:

1 Groundwater and surface water sampling performed for monitoring programs managed by Bechtel Jacobs Company LLC (BJC).

2 Groundwater and surface water sampling performed for the Y-12 Groundwater Protection Program (GWPP), managed by Babcock \& Wilcox Technical Services Y-12, LLC.

$\mathbf{x} \quad$ - Denotes the DOE Order monitoring category (surveillance or exit pathway/perimeter) fulfilled by samples collected under programs managed by BJC. Although the CY 2009 samples were collected for various monitoring purposes, all of the data meet DOE Order monitoring requirements. Surveillance and exit pathway/perimeter monitoring data evaluations are provided in Section 4.

3 BCK - Bear Creek Kilometer

EMW-VWUND - EMW-VWUNDRDRAIN; outfall for an underdrain installed to lower the water table and relieve hydrostatic pressure beneath the EMWMF liners.

GW - Groundwater Monitoring Well

NT - Northern Tributary (to Bear Creek)

SS - Spring sampling location (south side of Bear Creek)

4

BG - Bear Creek Burial Grounds Waste Management Area

EMWMF - Environmental Management Waste Management Facility

EXP-A - Exit Pathway (Maynardville Limestone) Picket A

EXP-B - Exit Pathway Picket B

EXP-C - Exit Pathway Picket C

EXP-SW - Exit Pathway (Bear Creek) Surface Water

EXP-W - Exit Pathway Picket W

OLF - Oil Landfarm Waste Management Area

RS - Rust Spoil Area

S3 - S-3 Site

SPI - Spoil Area I 
Table B.3. CY 2009 groundwater and surface water sampling dates in the Upper East Fork Poplar Creek Hydrogeologic Regime

\begin{tabular}{|c|c|c|c|c|c|c|c|c|c|}
\hline \multirow{2}{*}{\multicolumn{2}{|c|}{ BJC $^{1}$}} & \multicolumn{8}{|c|}{ CERCLA ROD Monitoring } \\
\hline & & \multicolumn{7}{|c|}{ RCRA Post-Closure Corrective Action Monitoring } & \\
\hline \multirow{2}{*}{\multicolumn{2}{|c|}{$\mathbf{G W P P}^{2}$}} & \multicolumn{7}{|c|}{ DOE Order Exit Pathway/Perimeter Monitoring } & \\
\hline & & \multicolumn{7}{|c|}{ DOE Order Surveillance Monitoring } & \\
\hline \multirow{2}{*}{$\begin{array}{c}\text { Sampling } \\
\text { Point }^{3}\end{array}$} & \multirow{2}{*}{$\begin{array}{c}\text { Functional } \\
\text { Area }^{4}\end{array}$} & \multicolumn{4}{|c|}{ CY 2009 Sampling Date ${ }^{5}$} & & & & \\
\hline & & 1st Quarter & 2nd Quarter & 3rd Quarter & 4th Quarter & & & & \\
\hline $55-2 \mathrm{~A}$ & GRID B3 & . & . & . & $10 / 27 / 09$ & $\bullet$ & & & \\
\hline $55-2 B$ & GRID B3 & . & . & . & $10 / 26 / 09$ & $\bullet$ & & & \\
\hline $55-2 \mathrm{C}$ & GRID B3 & . & . & . & $10 / 26 / 09$ & $\bullet$ & & & \\
\hline $55-3 \mathrm{~A}$ & B9201-5 & . & $05 / 14 / 09$ & . & $10 / 20 / 09$ & $\bullet$ & & & \\
\hline $55-3 \mathrm{~B}$ & B9201-5 & . & $05 / 14 / 09$ & . & $10 / 21 / 09$ & $\bullet$ & & & \\
\hline $55-3 C$ & B9201-5 & . & 05/13/09 & . & $10 / 21 / 09$ & $\bullet$ & & & \\
\hline 56-1A & Y12 & . & . & $07 / 28 / 09$ & $\dot{-}$ & $\bullet$ & & & \\
\hline $56-1 \mathrm{C}$ & Y12 & . & . & 07/28/09 D & . & $\bullet$ & & & \\
\hline 56-2A & GRID C3 & . & . & $07 / 29 / 09$ & . & $\bullet$ & & & \\
\hline $56-2 B$ & GRID C3 & . & . & $07 / 29 / 09$ & . & $\bullet$ & & & \\
\hline $56-2 C$ & GRID C3 & . & . & $07 / 28 / 09$ & . & $\bullet$ & & & \\
\hline 56-3A & Y12 & . & . & $07 / 30 / 09$ & . & $\bullet$ & & & \\
\hline 56-3B & Y12 & . & . & $07 / 29 / 09$ & . & $\bullet$ & & & \\
\hline $56-3 \mathrm{C}$ & Y12 & $\dot{\bullet}$ & . & $07 / 30 / 09$ & . & $\bullet$ & & & \\
\hline 56-4A & Y12 & & $05 / 12 / 09$ & &. & $\bullet$ & & & \\
\hline GW-108 & S3 & $01 / 12 / 09$ & . & $07 / 08 / 09$ & . & $\mathbf{x}$ & & $\bullet$ & \\
\hline GW-151 & NHP & $03 / 03 / 09$ & . & $07 / 23 / 09$ & 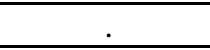 & 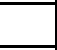 & $\mathbf{x}$ & & $\bullet$ \\
\hline GW-153 & NHP & . & . & . & 10/14/09 D & $\bullet$ & & & \\
\hline GW-154 & NHP & $03 / 03 / 09$ & . & $07 / 23 / 09$ & . & $\mathbf{x}$ & & & $\bullet$ \\
\hline GW-169 & EXP-UV & $03 / 04 / 09$ & . & $07 / 23 / 09$ &. & $\mathbf{x}$ & & & $\bullet$ \\
\hline GW-170 & EXP-UV & 03/04/09 D & . & 07/23/09 D & . & $\mathbf{x}$ & & & $\bullet$ \\
\hline GW-171 & EXP-UV & $03 / 05 / 09$ & . & . & . & $\mathbf{x}$ & & & $\bullet$ \\
\hline GW-172 & EXP-UV & $03 / 05 / 09$ & . & & . & $\mathbf{x}$ & & & $\bullet$ \\
\hline GW-193 & T2331 & $01 / 13 / 09$ & . & $07 / 07 / 09$ & . & $\mathbf{x}$ & & $\bullet$ & \\
\hline GW-204 & T0134 & . & $05 / 12 / 09$ & . & . & $\bullet$ & & & \\
\hline GW-219 & UOV & . & $05 / 11 / 09$ & . & . & $\bullet$ & & & \\
\hline GW-220 & NHP & . & 04/29/09 & . & $10 / 14 / 09$ & & $\bullet$ & & \\
\hline GW-222 & NHP & . & 04/30/09 D & . & . & $\bullet$ & & & \\
\hline GW-223 & NHP & 03/03/09 & . & $07 / 22 / 09$ & . & $\mathbf{x}$ & & & $\bullet$ \\
\hline GW-230 & EXP-UV & $03 / 05 / 09$ & . & . & . & $\mathbf{x}$ & & & $\bullet$ \\
\hline GW-240 & NHP & . & . & . & $10 / 14 / 09$ & $\bullet$ & & & \\
\hline GW-251 & $\mathrm{S} 2$ & 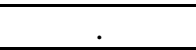 & $04 / 30 / 09$ & . & . & $\bullet$ & & & \\
\hline GW-253 & S2 & $03 / 04 / 09$ & . & . & . & $\mathbf{x}$ & & & $\bullet$ \\
\hline GW-269 & SY & . & $04 / 21 / 09$ & . &. & $\bullet$ & & & \\
\hline GW-270 & SY & 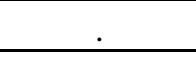 & $04 / 28 / 09$ & . & . & $\bullet$ & & & \\
\hline GW-272 & SY & 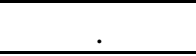 & $04 / 21 / 09$ & 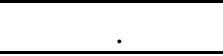 & . & $\bullet$ & & & \\
\hline GW-274 & SY & . & 04/21/09 & . & . & $\bullet$ & & & \\
\hline
\end{tabular}

B-7 
Table B.3 (continued)

\begin{tabular}{|c|c|c|c|c|c|c|c|c|c|}
\hline \multirow{2}{*}{\multicolumn{2}{|c|}{ BJC $^{1}$}} & & & & \multicolumn{5}{|c|}{ CERCLA ROD Monitoring } \\
\hline & & \multicolumn{8}{|c|}{ RCRA Post-Closure Corrective Action Monitoring } \\
\hline \multirow{2}{*}{\multicolumn{2}{|c|}{$\mathbf{G W P P}^{2}$}} & \multicolumn{8}{|c|}{ DOE Order Exit Pathway/Perimeter Monitoring } \\
\hline & & \multicolumn{8}{|c|}{ DOE Order Surveillance Monitoring } \\
\hline \multirow{2}{*}{$\begin{array}{c}\text { Sampling } \\
\text { Point }^{3}\end{array}$} & \multirow{2}{*}{$\begin{array}{c}\text { Functional } \\
\text { Area }^{4}\end{array}$} & \multicolumn{4}{|c|}{ CY 2009 Sampling Date ${ }^{5}$} & & & & \\
\hline & & 1st Quarter & 2nd Quarter & 3rd Quarter & 4th Quarter & & & & \\
\hline GW-275 & SY & . & 04/27/09 & . & . & $\bullet$ & & & \\
\hline GW-281 & FF & . & . & 08/13/09 & . & $\mathbf{x}$ & & & $\bullet$ \\
\hline GW-332 & WCPA & . & $04 / 28 / 09$ & . & . & $\bullet$ & & & \\
\hline GW-337 & WCPA & . & 04/28/09 & . & . & $\bullet$ & & & \\
\hline GW-380 & NHP & 03/04/09 & . & 07/23/09 & . & $\mathbf{x}$ & & & $\bullet$ \\
\hline GW-381 & NHP & . & . & . & $10 / 19 / 09$ & $\bullet$ & & & \\
\hline GW-382 & NHP & 03/04/09 & . & 07/23/09 & . & $\mathbf{x}$ & & & $\bullet$ \\
\hline GW-383 & NHP & . & . & . & $10 / 14 / 09$ & $\bullet$ & & & \\
\hline GW-505 & RG & . & 04/20/09 D & . & . & $\bullet$ & & & \\
\hline GW-508 & RG & . & 04/20/09 & . & . & $\bullet$ & & & \\
\hline GW-605 & EXP-I & 01/08/09 D & . & 07/07/09 D & . & $\mathbf{x}$ & & $\bullet$ & \\
\hline GW-606 & EXP-I & $01 / 08 / 09$ & . & $07 / 07 / 09$ & . & $\mathbf{x}$ & & $\bullet$ & \\
\hline GW-618 & EXP-E & $03 / 30 / 09$ & . & . & . & $\mathbf{x}$ & & & $\bullet$ \\
\hline GW-633 & RG & . & 04/28/09 & . & . & $\bullet$ & & & \\
\hline GW-656 & T0134 & . & 05/12/09 & . & . & $\bullet$ & & & \\
\hline GW-658 & $\mathrm{FF}$ & . & . & 08/13/09 & . & $\mathbf{x}$ & & & $\bullet$ \\
\hline GW-686 & $\mathrm{CPT}$ & . & $05 / 13 / 09$ & . & . & $\bullet$ & & & \\
\hline GW-690 & $\mathrm{CPT}$ & . & 05/13/09 & . &. & $\bullet$ & & & \\
\hline GW-691 & $\mathrm{CPT}$ & . & $05 / 12 / 09$ & . & 10/20/09 D & $\bullet$ & & & \\
\hline GW-692 & $\mathrm{CPT}$ & . & $05 / 12 / 09$ & - & . & $\bullet$ & & & \\
\hline GW-698 & B8110 & . & 04/29/09 D & . & $10 / 21 / 09$ & $\bullet$ & & & \\
\hline GW-700 & B8110 & 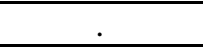 & . & $07 / 28 / 09$ & 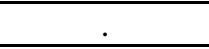 & $\bullet$ & & & \\
\hline GW-722-14 & EXP-J & 03/02/09 & . & . & . & & $x$ & & $\bullet$ \\
\hline GW-722-14 & EXP-J & . & . & $09 / 02 / 09$ & . & & $\bullet$ & & \\
\hline GW-722-17 & EXP-J & 03/02/09 & . & . & . & & $x$ & & $\bullet$ \\
\hline GW-722-17 & EXP-J & - & . & $09 / 02 / 09$ & . & & $\bullet$ & & \\
\hline GW-722-20 & EXP-J & 03/02/09 & . & . & . & & $\mathbf{x}$ & & $\bullet$ \\
\hline GW-722-20 & EXP-J & . & . & 09/02/09 & . & & $\bullet$ & & \\
\hline GW-722-22 & EXP-J & 03/02/09 & . & . & . & & $\mathbf{x}$ & & $\bullet$ \\
\hline GW-722-22 & EXP-J & . & . & 09/02/09 & . & & $\bullet$ & & \\
\hline GW-722-33 & EXP-J & 03/02/09 & . & . & . & & $x$ & & $\bullet$ \\
\hline GW-722-33 & EXP-J & . & . & 09/03/09 & . & & $\bullet$ & & \\
\hline GW-733 & EXP-J & 01/12/09 & . & 07/07/09 & . & & $x$ & $\bullet$ & \\
\hline GW-735 & EXP-J & . & . & 08/26/09 & . & & $\bullet$ & & \\
\hline GW-744 & GRID K1 & & . & 08/26/09 & 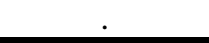 & & $\bullet$ & & \\
\hline
\end{tabular}


Table B.3 (continued)

\begin{tabular}{|c|c|c|c|c|c|c|c|c|}
\hline \multirow{2}{*}{\multicolumn{2}{|c|}{ BJC $^{1}$}} & \multicolumn{7}{|c|}{ CERCLA ROD Monitoring } \\
\hline & & \multicolumn{7}{|c|}{ RCRA Post-Closure Corrective Action Monitoring } \\
\hline \multirow{2}{*}{\multicolumn{2}{|c|}{ GWPP $^{2}$}} & \multicolumn{6}{|c|}{ DOE Order Exit Pathway/Perimeter Monitoring } & \\
\hline & & \multicolumn{5}{|c|}{ DOE Order Surveillance Monitoring } & & \\
\hline \multirow{2}{*}{$\begin{array}{c}\text { Sampling } \\
\text { Point }^{3}\end{array}$} & \multirow{2}{*}{$\begin{array}{c}\text { Functional } \\
\text { Area }^{4}\end{array}$} & \multicolumn{4}{|c|}{ CY 2009 Sampling Date ${ }^{5}$} & & & \\
\hline & & 1st Quarter & 2nd Quarter & 3rd Quarter & 4th Quarter & & & \\
\hline GW-747 & GRID K2 & . & & 08/31/09 & . & & $\bullet$ & \\
\hline GW-750 & EXP-J & . & 04/29/09 & . & . & & $\bullet$ & \\
\hline GW-762 & GRID J3 & 03/04/09 D & . & 07/23/09 D & . & $\mathbf{x}$ & & $\bullet$ \\
\hline GW-763 & GRID J3 & . & & . & $10 / 14 / 09$ & $\bullet$ & & \\
\hline GW-765 & GRID E1 & . & 05/07/09 & . & & $\bullet$ & & \\
\hline GW-769 & GRID G3 & . & $04 / 29 / 09$ & . & $10 / 13 / 09$ & $\bullet$ & & \\
\hline GW-770 & GRID G3 & . & . & . & $10 / 13 / 09$ & $\bullet$ & & \\
\hline GW-775 & GRID H3 & . & . & $08 / 27 / 09$ & 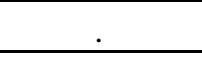 & $\bullet$ & & \\
\hline GW-776 & GRID H3 & . & . & $09 / 01 / 09$ & . & $\bullet$ & & \\
\hline GW-779 & GRID F2 & . & . & 08/31/09 & & $\bullet$ & & \\
\hline GW-781 & GRID E3 & . & . & 08/27/09 & . & $\bullet$ & & \\
\hline GW-782 & GRID E3 & . & . & $08 / 27 / 09$ & . & $\bullet$ & & \\
\hline GW-783 & GRID E3 & . & . & $08 / 27 / 09$ & . & $\bullet$ & & \\
\hline GW-791 & GRID D2 & . & . & 08/27/09 & $\dot{-}$ & $\bullet$ & & \\
\hline GW-802 & $\mathrm{FF}$ & . & . & 08/13/09 & . & $\mathbf{x}$ & & $\bullet$ \\
\hline GW-816 & EXP-SR & . & . & $08 / 26 / 09$ & 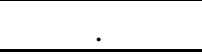 & & $\bullet$ & \\
\hline GW-820 & B9201-2 & . & $04 / 29 / 09$ & . & . & $\bullet$ & & \\
\hline GW-832 & NHP & 03/03/09 & & 07/23/09 & . & & $\mathbf{x}$ & $\bullet$ \\
\hline GW-959 & B9201-2 & . & 05/06/09 & . & . & $\bullet$ & & \\
\hline GW-960 & GRID F2 & . & 05/07/09 & . & . & $\bullet$ & & \\
\hline GHK2.51WSW & EXP-SW & $01 / 29 / 09$ & . & . & . & & $\bullet$ & \\
\hline NPR12.0SW & EXP-SW & $01 / 29 / 09$ & 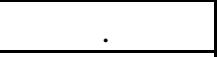 & . & . & & $\bullet$ & \\
\hline NPR23.0SW & EXP-SW & 01/29/09 & & . & & & $\bullet$ & \\
\hline SCR7.1SP & EXP-SW & 02/05/09 & . & . & . & & $\mathbf{x}$ & $\bullet$ \\
\hline SCR7.8SP & EXP-SW & $02 / 05 / 09$ & & . & 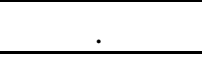 & & $\mathbf{x}$ & $\bullet$ \\
\hline SP-17 & EXP-SW & . & 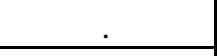 & 08/03/09 D & . & & $\bullet$ & \\
\hline 200A6* & EXP-SW & $01 / 06 / 09$ & . & $08 / 19 / 09$ & . & & $\mathbf{x}$ & $\bullet$ \\
\hline $200 A 6$ & EXP-SW & $01 / 22 / 09$ & . & $09 / 10 / 09$ & . & & $\mathbf{x}$ & $\bullet$ \\
\hline STATION 8* & EXP-SW & 01/06/09 & . & 08/19/09 & . & & $\mathbf{x}$ & $\bullet$ \\
\hline STATION 8 & EXP-SW & $01 / 22 / 09$ & . & 09/10/09 & . & & $\mathbf{x}$ & $\bullet$ \\
\hline
\end{tabular}

\section{Notes:}

1 Groundwater and surface water sampling performed for monitoring programs managed by Bechtel Jacobs Company LLC (BJC). 


\section{Table B.3 (continued)}

Notes: (continued)

2 Groundwater and surface water sampling performed for the Y-12 Groundwater Protection Program (GWPP), managed by Babcock \& Wilcox Technical Services Y-12, LLC.

$\mathbf{x} \quad$ - Denotes the DOE Order monitoring category (surveillance or exit pathway/perimeter) fulfilled by samples collected under programs managed by BJC. Although the CY 2009 samples were collected for various monitoring purposes, all of the data meet DOE Order monitoring requirements. Surveillance and exit pathway/perimeter monitoring data evaluations are provided in Section 4.

GHK - Gum Hollow Branch Kilometer (surface water sampling station)

GW - Groundwater Monitoring Well (also locations beginning with number 5 or 6 )

NPR - North of Pine Ridge near the Scarboro Community (surface water sampling station)

200A6 - Storm drain outfall (surface water sampling station)

SCR - Spring sampling location in Union Valley (prefix)

SP - Spring sampling location (prefix or suffix)

STATION 8 - $\quad$ Surface water sampling location in Upper East Fork Poplar Creek, central Y-12

STATION 17 - Surface water sampling location in Upper East Fork Poplar Creek, eastern Y-12

SW - Surface water sampling location (suffix)

B8110 - Building 81-10

B9201-2 - Building 9201-2

B9201-5 - Building 9201-5

CPT - Coal Pile Trench

EXP-E - Exit Pathway Picket E

EXP-I - Exit Pathway Picket I

EXP-J - Exit Pathway Picket J

EXP-SR - Along Scarboro Road in the gap through Pine Ridge

EXP-SW - Surface water or spring sampling station

EXP-UV - East of the Oak Ridge Reservation boundary in Union Valley

FF - Fuel Facility (Building 9754-2)

GRID - Comprehensive Groundwater Monitoring Plan Grid Location

NHP - New Hope Pond

RG - Rust Garage Area

S2 - S-2 Site

S3 - S-3 Site

SY - Y-12 Salvage Yard

T0134 - Tank 0134-U

T2331 - Tank 2331-U

UOV - Uranium Oxide Vault

WCPA - Waste Coolant Processing Area

Y12 - Y-12 Complex

- - Not sampled.

D - Duplicate sample collected on specified date (shown in bold typeface).

* - Two sets of surface water samples collected; a stormflow sample on the first date shown and a base flow sample collected later during the first and third quarters. 
Table B.4. CY 2009 groundwater and surface water sampling dates in the Chestnut Ridge Hydrogeologic Regime

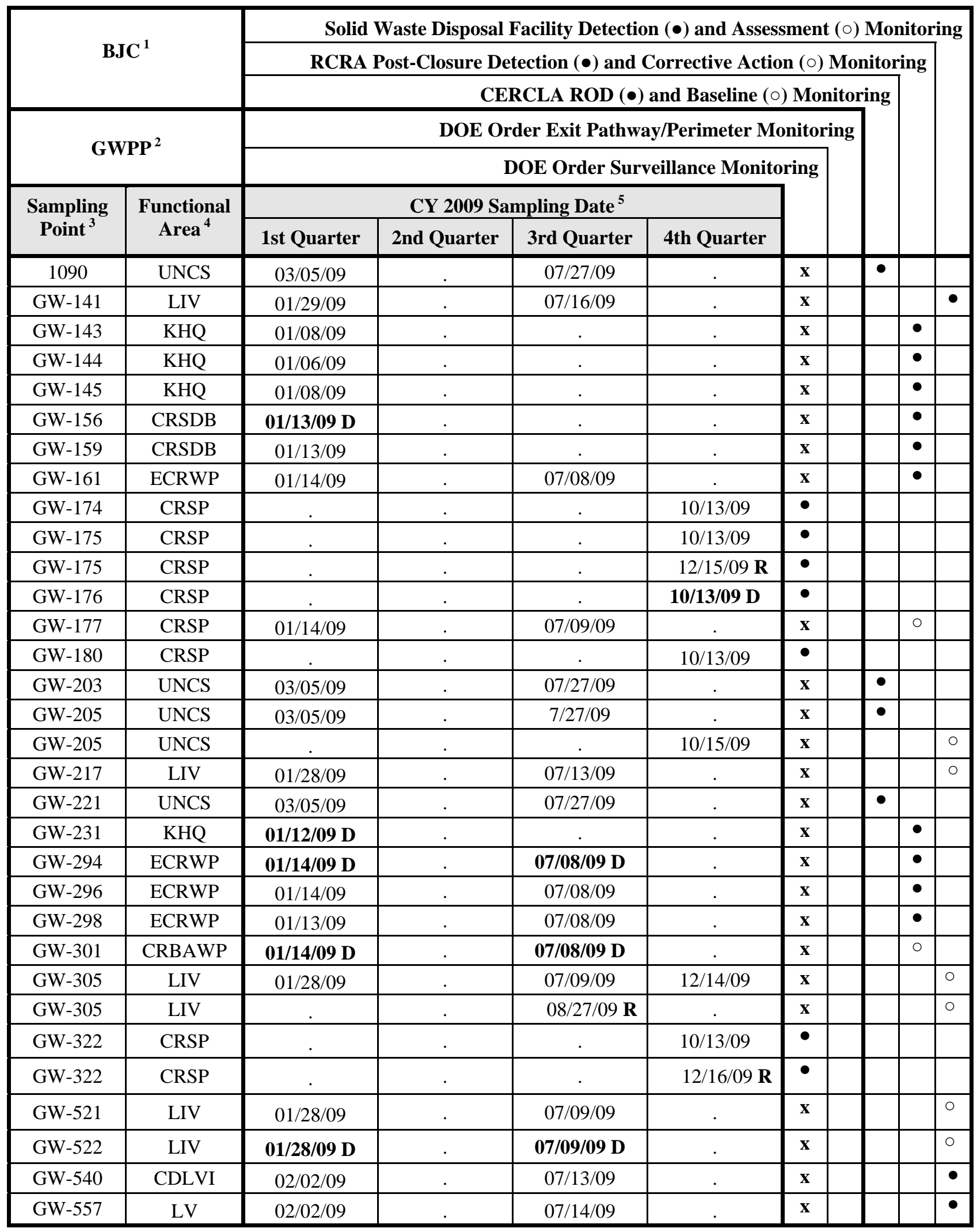


Table B.4 (continued)

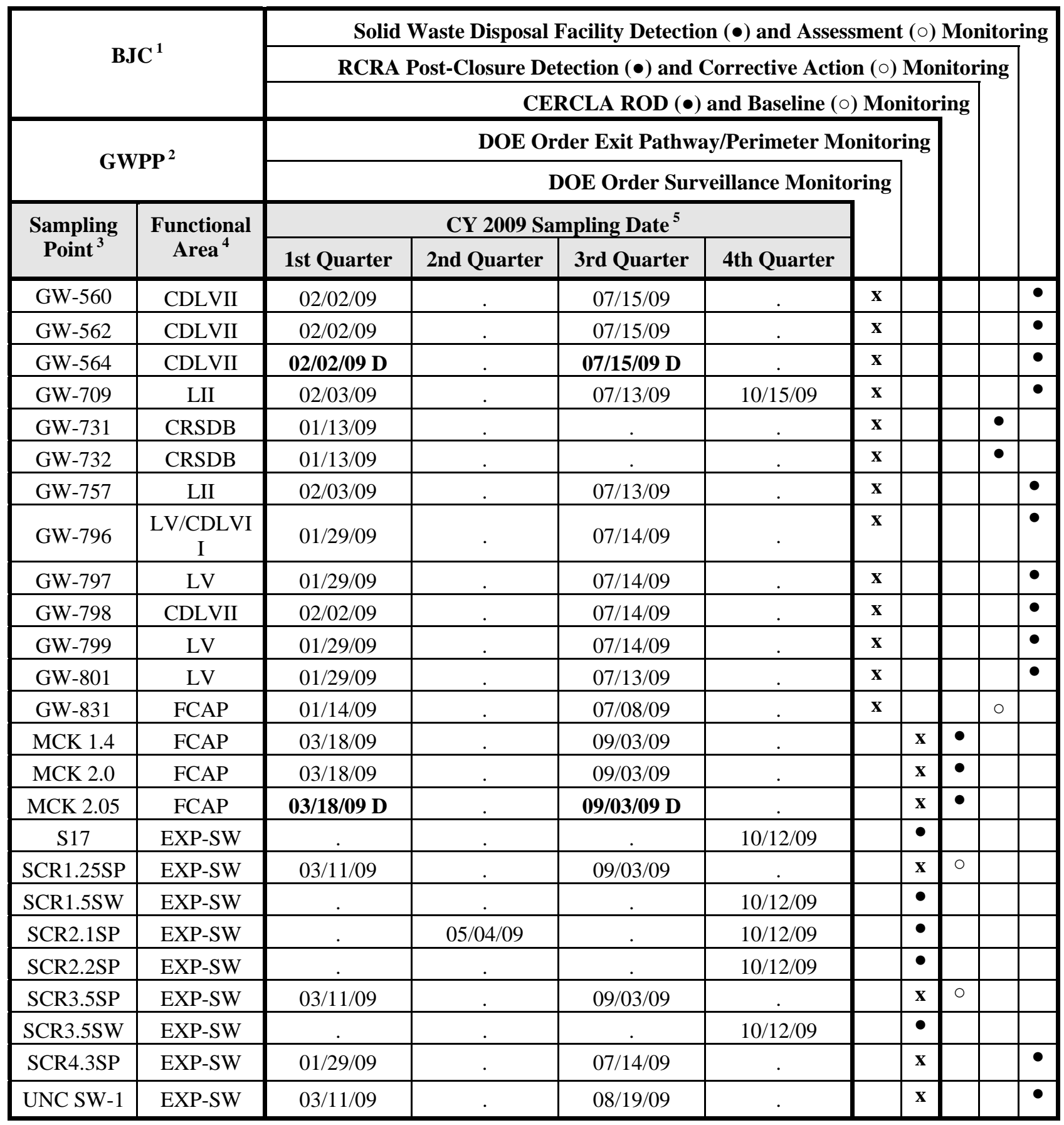

Notes:

1 Groundwater and surface water sampling performed under monitoring programs managed by Bechtel Jacobs Company LLC (BJC). 


\section{Table B.4 (continued)}

\section{Notes: (continued)}

2 Surface water sampling performed under the Y-12 Groundwater Protection Program (GWPP) managed by Babcock \& Wilcox Technical Services Y-12, LLC.

$\mathbf{x}$ - Denotes the DOE Order monitoring category (site surveillance or exit pathway/perimeter) fulfilled by samples collected under programs managed by BJC. Although the CY 2009 samples were collected for various monitoring purposes, all of the data meet DOE Order monitoring requirements. Surveillance and exit pathway/perimeter monitoring data evaluations are provided in Section 4.

3

GW - Groundwater monitoring well (also 1090)

MCK - McCoy Branch Kilometer

SCR - South Chestnut Ridge (tributary prefix)

SP - Spring sampling location (suffix)

SW - Surface water sampling location (suffix)

4

CDLVII - Construction/Demolition Landfill VII

CRBAWP - Chestnut Ridge Borrow Area Waste Pile (formerly)

CRSDB - Chestnut Ridge Sediment Disposal Basin

CRSP - Chestnut Ridge Security Pits

ECRWP - East Chestnut Ridge Waste Pile

EXP-SW - Exit Pathway (spring or surface water sampling location)

FCAP - Filled Coal Ash Pond

KHQ - Kerr Hollow Quarry

LII - Industrial Landfill II

LIV - Industrial Landfill IV

LV - Industrial Landfill V

UNCS - United Nuclear Corporation Site

- - Not Sampled.

D - Duplicate sample collected on specified date (shown in bold typeface).

$\mathbf{R}$ - Resample collected during the same quarterly event. 
B-14 
Table B.5. Field measurements and laboratory analytes for CY 2009 groundwater and surface water samples obtained by the Y-12 GWPP

\begin{tabular}{|c|c|c|c|}
\hline Field Measurements & Analytical Method ${ }^{1}$ & Reporting Limit $^{2}$ & Units $^{3}$ \\
\hline Depth to Water & NA & NA & $\mathrm{ft}$ \\
\hline Water Temperature & NA & NA & Celsius \\
\hline $\mathrm{pH}$ & NA & NA & $\mathrm{pH}$ units \\
\hline Conductivity & NA & NA & $\mu \mathrm{mho} / \mathrm{cm}$ \\
\hline Dissolved Oxygen & NA & NA & $\mathrm{ppm}$ \\
\hline Oxidation-Reduction Potential & NA & NA & $\mathrm{mV}$ \\
\hline \multicolumn{4}{|l|}{ Miscellaneous Laboratory Analytes } \\
\hline Total Dissolved Solids & SM 2540C 18 & 1 & $\mathrm{mg} / \mathrm{L}$ \\
\hline Total Suspended Solids & SM 2540D 18 & 1 & $\mathrm{mg} / \mathrm{L}$ \\
\hline \multicolumn{4}{|l|}{ Anions } \\
\hline Carbonate & SM 2320B 18 & 1 & $\mathrm{mg} / \mathrm{L}$ \\
\hline Bicarbonate & SM 2320B 18 & 1 & $\mathrm{mg} / \mathrm{L}$ \\
\hline Chloride & EPA-300.0 & 0.2 & $\mathrm{mg} / \mathrm{L}$ \\
\hline Fluoride & SM 4500F 18 & 0.1 & $\mathrm{mg} / \mathrm{L}$ \\
\hline Nitrate (as Nitrogen) & EPA-300.0 & 0.05 & $\mathrm{mg} / \mathrm{L}$ \\
\hline Sulfate & EPA-300.0 & 0.25 & $\mathrm{mg} / \mathrm{L}$ \\
\hline \multicolumn{4}{|l|}{ Metals/Cations } \\
\hline Aluminum & SW846-6010B & 0.2 & $\mathrm{mg} / \mathrm{L}$ \\
\hline Antimony & SW846-6020 & 0.0025 & $\mathrm{mg} / \mathrm{L}$ \\
\hline Arsenic & SW846-6020 & 0.005 & $\mathrm{mg} / \mathrm{L}$ \\
\hline Barium & SW846-6010B & 0.004 & $\mathrm{mg} / \mathrm{L}$ \\
\hline Beryllium & SW846-6010B & 0.0005 & $\mathrm{mg} / \mathrm{L}$ \\
\hline Boron & SW846-6010B & 0.1 & $\mathrm{mg} / \mathrm{L}$ \\
\hline Cadmium & SW846-6020 & 0.0025 & $\mathrm{mg} / \mathrm{L}$ \\
\hline Calcium & SW846-6010B & 0.2 & $\mathrm{mg} / \mathrm{L}$ \\
\hline Chromium & SW846-6020 & 0.01 & $\mathrm{mg} / \mathrm{L}$ \\
\hline Cobalt & SW846-6010B & 0.02 & $\mathrm{mg} / \mathrm{L}$ \\
\hline Copper & SW846-6010B & 0.02 & $\mathrm{mg} / \mathrm{L}$ \\
\hline Iron & SW846-6010B & 0.05 & $\mathrm{mg} / \mathrm{L}$ \\
\hline Lead & SW846-6020 & 0.0005 & $\mathrm{mg} / \mathrm{L}$ \\
\hline Lithium & SW846-6010B & 0.01 & $\mathrm{mg} / \mathrm{L}$ \\
\hline Magnesium & SW846-6010B & 0.2 & $\mathrm{mg} / \mathrm{L}$ \\
\hline Manganese & SW846-6010B & 0.005 & $\mathrm{mg} / \mathrm{L}$ \\
\hline Mercury & SW846-7470/A & 0.00005 & $\mathrm{mg} / \mathrm{L}$ \\
\hline Molybdenum & SW846-6010B & 0.05 & $\mathrm{mg} / \mathrm{L}$ \\
\hline Nickel & SW846-6020 & 0.005 & $\mathrm{mg} / \mathrm{L}$ \\
\hline Potassium & SW846-6010B & 2 & $\mathrm{mg} / \mathrm{L}$ \\
\hline Selenium & SW846-6020 & 0.01 & $\mathrm{mg} / \mathrm{L}$ \\
\hline Silver & SW846-6010B & 0.02 & $\mathrm{mg} / \mathrm{L}$ \\
\hline
\end{tabular}


Table B.5 (continued)

\begin{tabular}{|c|c|c|c|}
\hline Metals/Cations (continued) & Analytical Method $^{1}$ & Reporting Limit $^{2}$ & Units $^{3}$ \\
\hline Sodium & SW846-6010B & 0.2 & $\mathrm{mg} / \mathrm{L}$ \\
\hline Strontium & SW846-6010B & 0.005 & $\mathrm{mg} / \mathrm{L}$ \\
\hline Thallium & SW846-6020 & 0.0005 & $\mathrm{mg} / \mathrm{L}$ \\
\hline Thorium & SW846-6010B & 0.2 & $\mathrm{mg} / \mathrm{L}$ \\
\hline Uranium & SW846-6020 & 0.0005 & $\mathrm{mg} / \mathrm{L}$ \\
\hline Vanadium & SW846-6010B & 0.02 & $\mathrm{mg} / \mathrm{L}$ \\
\hline Zinc & SW846-6010B & 0.05 & $\mathrm{mg} / \mathrm{L}$ \\
\hline Volatile Organic Compounds & & $\mathrm{CRQL}^{4}$ & \\
\hline Acetone & SW846-8260B UP & 10 & $\mu \mathrm{g} / \mathrm{L}$ \\
\hline Acetonitrile & SW846-8260B UP & 10 & $\mu \mathrm{g} / \mathrm{L}$ \\
\hline Acrolein & SW846-8260B UP & 10 & $\mu \mathrm{g} / \mathrm{L}$ \\
\hline Acrylonitrile & SW846-8260B UP & 5 & $\mu \mathrm{g} / \mathrm{L}$ \\
\hline Benzene & SW846-8260B UP & 5 & $\mu \mathrm{g} / \mathrm{L}$ \\
\hline Bromochloromethane & SW846-8260B UP & 5 & $\mu \mathrm{g} / \mathrm{L}$ \\
\hline Bromodichloromethane & SW846-8260B UP & 5 & $\mu \mathrm{g} / \mathrm{L}$ \\
\hline Bromoform & SW846-8260B UP & 5 & $\mu \mathrm{g} / \mathrm{L}$ \\
\hline Bromomethane & SW846-8260B UP & 5 & $\mu \mathrm{g} / \mathrm{L}$ \\
\hline 2-Butanone & SW846-8260B UP & 5 & $\mu \mathrm{g} / \mathrm{L}$ \\
\hline Carbon disulfide & SW846-8260B UP & 5 & $\mu \mathrm{g} / \mathrm{L}$ \\
\hline Carbon tetrachloride & SW846-8260B UP & 5 & $\mu \mathrm{g} / \mathrm{L}$ \\
\hline Chlorobenzene & SW846-8260B UP & 5 & $\mu \mathrm{g} / \mathrm{L}$ \\
\hline Chloroethane & SW846-8260B UP & 5 & $\mu \mathrm{g} / \mathrm{L}$ \\
\hline 2-Chloroethyl vinyl ether & SW846-8260B UP & 10 & $\mu \mathrm{g} / \mathrm{L}$ \\
\hline Chloroform & SW846-8260B UP & 5 & $\mu \mathrm{g} / \mathrm{L}$ \\
\hline Chloromethane & SW846-8260B UP & 5 & $\mu \mathrm{g} / \mathrm{L}$ \\
\hline Dibromochloromethane & SW846-8260B UP & 5 & $\mu \mathrm{g} / \mathrm{L}$ \\
\hline 1,2-Dibromo-3-chloropropane & SW846-8260B UP & 10 & $\mu \mathrm{g} / \mathrm{L}$ \\
\hline 1,2-Dibromoethane & SW846-8260B UP & 5 & $\mu \mathrm{g} / \mathrm{L}$ \\
\hline Dibromomethane & SW846-8260B UP & 5 & $\mu g / L$ \\
\hline 1,2-Dichlorobenzene & SW846-8260B UP & 5 & $\mu \mathrm{g} / \mathrm{L}$ \\
\hline 1,4-Dichlorobenzene & SW846-8260B UP & 5 & $\mu g / L$ \\
\hline 1,4-Dichloro-2-butene & SW846-8260B UP & 5 & $\mu \mathrm{g} / \mathrm{L}$ \\
\hline trans-1,4-Dichloro-2-butene & SW846-8260B UP & 5 & $\mu \mathrm{g} / \mathrm{L}$ \\
\hline Dichlorodifluoromethane & SW846-8260B UP & 5 & $\mu g / L$ \\
\hline 1,1-Dichloroethane & SW846-8260B UP & 5 & $\mu \mathrm{g} / \mathrm{L}$ \\
\hline 1,2-Dichloroethane & SW846-8260B UP & 5 & $\mu \mathrm{g} / \mathrm{L}$ \\
\hline 1,1-Dichloroethene & SW846-8260B UP & 5 & $\mu \mathrm{g} / \mathrm{L}$ \\
\hline cis-1,2-Dichloroethene & SW846-8260B UP & 5 & $\mu \mathrm{g} / \mathrm{L}$ \\
\hline trans-1,2-Dichloroethene & SW846-8260B UP & 5 & $\mu \mathrm{g} / \mathrm{L}$ \\
\hline 1,2-Dichloropropane & SW846-8260B UP & 5 & $\mu \mathrm{g} / \mathrm{L}$ \\
\hline cis-1,3-Dichloropropene & SW846-8260B UP & 5 & $\mu \mathrm{g} / \mathrm{L}$ \\
\hline trans-1,3-Dichloropropene & SW846-8260B UP & 5 & $\mu \mathrm{g} / \mathrm{L}$ \\
\hline
\end{tabular}


Table B.5 (continued)

\begin{tabular}{|c|c|c|c|}
\hline Volatile Organic Compounds (cont'd) & Analytical Method $^{1}$ & $\mathrm{CRQL}^{4}$ & Units $^{3}$ \\
\hline Ethanol & SW846-8260B UP & 200 & $\mu \mathrm{g} / \mathrm{L}$ \\
\hline Ethylbenzene & SW846-8260B UP & 5 & $\mu \mathrm{g} / \mathrm{L}$ \\
\hline Ethyl methacrylate & SW846-8260B UP & 5 & $\mu \mathrm{g} / \mathrm{L}$ \\
\hline 2-Hexanone & SW846-8260B UP & 5 & $\mu \mathrm{g} / \mathrm{L}$ \\
\hline Iodomethane & SW846-8260B UP & 5 & $\mu \mathrm{g} / \mathrm{L}$ \\
\hline 4-Methyl-2-pentanone & SW846-8260B UP & 5 & $\mu \mathrm{g} / \mathrm{L}$ \\
\hline Methylene chloride & SW846-8260B UP & 5 & $\mu \mathrm{g} / \mathrm{L}$ \\
\hline Styrene & SW846-8260B UP & 5 & $\mu \mathrm{g} / \mathrm{L}$ \\
\hline 1,1,1,2-Tetrachloroethane & SW846-8260B UP & 5 & $\mu \mathrm{g} / \mathrm{L}$ \\
\hline 1,1,2,2-Tetrachloroethane & SW846-8260B UP & 5 & $\mu \mathrm{g} / \mathrm{L}$ \\
\hline Tetrachloroethene & SW846-8260B UP & 5 & $\mu \mathrm{g} / \mathrm{L}$ \\
\hline Toluene & SW846-8260B UP & 5 & $\mu \mathrm{g} / \mathrm{L}$ \\
\hline 1,1,1-Trichloroethane & SW846-8260B UP & 5 & $\mu \mathrm{g} / \mathrm{L}$ \\
\hline 1,1,2-Trichloroethane & SW846-8260B UP & 5 & $\mu \mathrm{g} / \mathrm{L}$ \\
\hline Trichloroethene & SW846-8260B UP & 5 & $\mu \mathrm{g} / \mathrm{L}$ \\
\hline Trichlorofluoromethane & SW846-8260B UP & 5 & $\mu \mathrm{g} / \mathrm{L}$ \\
\hline 1,1,2-Trichloro-1,2,2-trifluoroethane & SW846-8260B UP & 5 & $\mu \mathrm{g} / \mathrm{L}$ \\
\hline 1,2,3-Trichloropropane & SW846-8260B UP & 10 & $\mu \mathrm{g} / \mathrm{L}$ \\
\hline Vinyl acetate & SW846-8260B UP & 10 & $\mu \mathrm{g} / \mathrm{L}$ \\
\hline Vinyl chloride & SW846-8260B UP & 2 & $\mu \mathrm{g} / \mathrm{L}$ \\
\hline Total Xylene & SW846-8260B UP & 5 & $\mu \mathrm{g} / \mathrm{L}$ \\
\hline Radiological Analytes & & Target MDA $^{5}$ & \\
\hline Gross Alpha Activity & EPA-900.0 & 5 & $\mathrm{pCi} / \mathrm{L}$ \\
\hline Gross Beta Activity & EPA-900.0 & 10 & $\mathrm{pCi} / \mathrm{L}$ \\
\hline Technetium-99 & $\mathrm{Y} / \mathrm{P} 65-7060$ & 15 & $\mathrm{pCi} / \mathrm{L}$ \\
\hline Uranium-234, 235, \& 238 & Y/P65-7061 & 0.4 & $\mathrm{pCi} / \mathrm{L}$ \\
\hline
\end{tabular}

Notes:

$1 \quad$ NA - not applicable

Analytical methods from:

- Test Methods for Evaluating Solid Waste Physical/Chemical Methods (U.S. Environmental Protection Agency 1996)

- Methods for Chemical Analysis of Water and Wastes (U.S. Environmental Protection Agency 1983)

- BWXT Y-12 Analytical Chemistry Organization Control Procedures: (Y/P65-7060 and Y/P65-7061)

2 The lowest concentration reported.

NA - not applicable 
Table B.5 (continued)

Notes: (continued)

3

$\mathrm{ft}$ - feet

$\mu \mathrm{g} / \mathrm{L}$ - micrograms per liter

$\mu \mathrm{mho} / \mathrm{cm}$ - micromhos per centimeter

$\mathrm{mg} / \mathrm{L}$ - milligrams per liter

$\mathrm{mV}$ - millivolts

NTU - nephelometric turbidity units

ppm - parts per million

$\mathrm{pCi} / \mathrm{L}$ - picoCuries per liter

4 CRQL - contract-required quantitation limit; estimated values are reported below this level and above the instrument detection limit. Results below the instrument detection limit are reported as not detected at the CRQL.

5 MDA - minimum detectable activity. The target MDA may be obtained under optimal analytical conditions; actual MDAs are sample-specific and, in some cases, may vary significantly from the target value. 
Table B.6. Depth-to-water measurements and groundwater elevations for selected wells in the Bear Creek Hydrogeologic Regime, April 2009

\begin{tabular}{|c|c|c|c|c|c|c|c|}
\hline \multirow{2}{*}{$\begin{array}{c}\text { Well } \\
\text { Number }\end{array}$} & \multirow{2}{*}{ Location $^{1}$} & \multicolumn{2}{|c|}{ Hydrogeologic Unit } & \multirow{2}{*}{$\begin{array}{c}\text { Measuring } \\
\text { Point }^{2}\end{array}$} & \multirow{2}{*}{$\begin{array}{c}\text { Date } \\
\text { Measured }\end{array}$} & \multirow{2}{*}{$\begin{array}{l}\text { Depth to } \\
\text { Water }^{3}\end{array}$} & \multirow{2}{*}{$\begin{array}{c}\text { Groundwate } \\
\text { Elevation }^{4}\end{array}$} \\
\hline & & Aquifer & Aquitard & & & & \\
\hline GW-001 & OLF & & $\bullet$ & 981.00 & 04/09/09 & 13.73 & 967.27 \\
\hline GW-008 & OLF & & $\bullet$ & 965.39 & 04/09/09 & 13.57 & 951.82 \\
\hline GW-010 & OLF & & $\bullet$ & 952.70 & 04/09/09 & 0.85 & 951.85 \\
\hline GW-012 & OLF & & $\bullet$ & 955.57 & 04/09/09 & 6.34 & 949.23 \\
\hline GW-014 & BG & & $\bullet$ & 934.50 & 04/08/09 & 5.79 & 928.71 \\
\hline GW-016 & BG & & $\bullet$ & 928.81 & 04/08/09 & 9.07 & 919.74 \\
\hline GW-041 & BG & & $\bullet$ & 1008.10 & 04/09/09 & 13.37 & 994.73 \\
\hline GW-046 & $\mathrm{BG}$ & & $\bullet$ & 921.17 & 04/08/09 & 2.62 & 918.55 \\
\hline GW-047 & BG & & $\bullet$ & 929.00 & $04 / 08 / 09$ & 7.44 & 921.56 \\
\hline GW-052 & BG & $\bullet$ & & 905.70 & $04 / 08 / 09$ & 13.64 & 892.06 \\
\hline GW-053 & BG & $\bullet$ & & 903.42 & $04 / 08 / 09$ & 7.48 & 895.94 \\
\hline GW-057 & EXP-A & $\bullet$ & & 890.20 & $04 / 08 / 09$ & 6.08 & 884.12 \\
\hline GW-059 & BG & $\bullet$ & & 912.70 & $04 / 08 / 09$ & 21.51 & 891.19 \\
\hline GW-065 & OLF & $\bullet$ & & 982.50 & $04 / 08 / 09$ & 28.47 & 954.03 \\
\hline GW-078 & BG & & $\bullet$ & 918.10 & $04 / 09 / 09$ & 9.79 & 908.31 \\
\hline GW-080 & BG & & $\bullet$ & 981.00 & $04 / 09 / 09$ & 19.92 & 961.08 \\
\hline GW-082 & BG & & $\bullet$ & 964.00 & $04 / 09 / 09$ & 20.81 & 943.19 \\
\hline GW-084 & OLF & & $\bullet$ & 997.18 & $04 / 08 / 09$ & 10.40 & 986.78 \\
\hline GW-086 & OLF & & $\bullet$ & 982.80 & $04 / 08 / 09$ & 11.15 & 971.65 \\
\hline GW-090 & $\mathrm{BG}$ & & $\bullet$ & 961.88 & $04 / 09 / 09$ & 3.93 & 957.95 \\
\hline GW-091 & BG & & $\bullet$ & 952.62 & $04 / 09 / 09$ & 7.87 & 944.75 \\
\hline GW-097 & OLF & & $\bullet$ & 945.41 & 04/09/09 & 8.35 & 937.06 \\
\hline GW-100 & S3 & $\bullet$ & & 987.40 & 04/09/09 & 4.80 & 982.60 \\
\hline GW-101 & S3 & & - & 1007.40 & $04 / 09 / 09$ & 9.76 & 997.64 \\
\hline GW-115 & S3 & & $\bullet$ & 1055.01 & 04/09/09 & 6.82 & 1048.19 \\
\hline GW-127 & S3 & & $\bullet$ & 1005.90 & $04 / 09 / 09$ & 13.10 & 992.80 \\
\hline GW-227 & OLF & $\bullet$ & & 946.46 & $04 / 09 / 09$ & 8.16 & 938.30 \\
\hline GW-236 & S3 & $\bullet$ & & 983.21 & $04 / 08 / 09$ & 9.98 & 973.23 \\
\hline GW-242 & BG & & $\bullet$ & 978.69 & $04 / 09 / 09$ & 5.45 & 973.24 \\
\hline GW-245 & S3 & & $\bullet$ & 1009.08 & 04/09/09 & 11.80 & 997.28 \\
\hline GW-249 & $\mathrm{BG}$ & & $\bullet$ & 991.15 & $04 / 09 / 09$ & 27.88 & 963.27 \\
\hline GW-257 & BG & & $\bullet$ & 961.68 & 04/09/09 & 26.52 & 935.16 \\
\hline GW-276 & S3 & & $\bullet$ & 1001.57 & $04 / 08 / 09$ & 5.62 & 995.95 \\
\hline GW-287 & $\mathrm{BG}$ & & $\bullet$ & 927.04 & $04 / 09 / 09$ & 8.12 & 918.92 \\
\hline GW-289 & $\mathrm{BG}$ & & $\bullet$ & 948.73 & $04 / 09 / 09$ & 11.71 & 937.02 \\
\hline GW-291 & BG & & $\bullet$ & 948.66 & 04/09/09 & 10.39 & 938.27 \\
\hline GW-307 & $\mathrm{RS}$ & $\bullet$ & & 993.14 & 04/09/09 & 27.30 & 965.84 \\
\hline GW-309 & $\mathrm{RS}$ & $\bullet$ & & 988.17 & $04 / 09 / 09$ & 19.10 & 969.07 \\
\hline GW-316 & SPI & $\bullet$ & & 1047.17 & 04/08/09 & 52.22 & 994.95 \\
\hline
\end{tabular}


Table B.6 (continued)

\begin{tabular}{|c|c|c|c|c|c|c|c|}
\hline \multirow{2}{*}{$\begin{array}{c}\text { Well } \\
\text { Number }\end{array}$} & \multirow{2}{*}{ Location $^{1}$} & \multicolumn{2}{|c|}{ Hydrogeologic Unit } & \multirow{2}{*}{$\begin{array}{c}\text { Measuring } \\
\text { Point }^{2}\end{array}$} & \multirow{2}{*}{$\begin{array}{c}\text { Date } \\
\text { Measured }\end{array}$} & \multirow{2}{*}{$\begin{array}{l}\text { Depth to } \\
\text { Water }^{3}\end{array}$} & \multirow{2}{*}{$\begin{array}{c}\text { Groundwater } \\
\text { Elevation }\end{array}$} \\
\hline & & Aquifer & Aquitard & & & & \\
\hline GW-323 & SPI & $\bullet$ & & 1130.11 & $04 / 08 / 09$ & 85.79 & 1044.32 \\
\hline GW-325 & S3 & & $\bullet$ & 1003.00 & 04/08/09 & 9.03 & 993.97 \\
\hline GW-345 & S3 & & $\bullet$ & 999.63 & 04/08/09 & 17.63 & 982.00 \\
\hline GW-347 & S3 & $\bullet$ & & 1001.05 & $04 / 09 / 09$ & 14.60 & 986.45 \\
\hline GW-364 & OLF & $\bullet$ & & 936.16 & $04 / 09 / 09$ & 9.90 & 926.26 \\
\hline GW-370 & BG & & $\bullet$ & 960.81 & $04 / 09 / 09$ & 13.59 & 947.22 \\
\hline GW-372 & BG & & $\bullet$ & 983.16 & $04 / 09 / 09$ & 14.18 & 968.98 \\
\hline GW-531 & LD & & $\bullet$ & 1004.61 & 04/08/09 & 10.41 & 994.20 \\
\hline GW-537 & OLF & & $\bullet$ & 976.65 & $04 / 08 / 09$ & 5.25 & 971.40 \\
\hline GW-613 & S3 & & $\bullet$ & 1013.58 & $04 / 08 / 09$ & 10.52 & 1003.06 \\
\hline GW-621 & EXP-B & $\bullet$ & & 925.45 & 04/09/09 & 10.50 & 914.95 \\
\hline GW-622 & $\mathrm{BG}$ & & $\bullet$ & 924.16 & $04 / 09 / 09$ & 7.72 & 916.44 \\
\hline GW-624 & BG & & $\bullet$ & 922.15 & $04 / 08 / 09$ & 8.97 & 913.18 \\
\hline GW-630 & LD & & $\bullet$ & 986.65 & 04/08/09 & 8.86 & 977.79 \\
\hline GW-638 & OLF & & $\bullet$ & 941.77 & $04 / 09 / 09$ & 5.89 & 935.88 \\
\hline GW-641 & BG & & $\bullet$ & 946.66 & 04/09/09 & 15.86 & 930.80 \\
\hline GW-642 & BG & & $\bullet$ & 1014.95 & 04/09/09 & 17.49 & 997.46 \\
\hline GW-645 & OLF & $\bullet$ & & 1006.40 & $04 / 09 / 09$ & 71.80 & 934.60 \\
\hline GW-648 & RS & $\bullet$ & & 1029.20 & 04/09/09 & 64.97 & 964.23 \\
\hline GW-652 & BG & $\bullet$ & & 900.83 & $04 / 08 / 09$ & 9.29 & 891.54 \\
\hline GW-653 & BG & & $\bullet$ & 931.84 & $04 / 09 / 09$ & 21.50 & 910.34 \\
\hline GW-654 & BG & & $\bullet$ & 940.79 & 04/09/09 & 6.91 & 933.88 \\
\hline GW-683 & EXP-A & $\bullet$ & & 972.23 & $04 / 08 / 09$ & 88.54 & 883.69 \\
\hline GW-695 & EXP-B & $\bullet$ & & 939.54 & $04 / 09 / 09$ & 25.38 & 914.16 \\
\hline GW-795 & AGLLSF & & $\bullet$ & 926.18 & 04/09/09 & 3.90 & 922.28 \\
\hline GW-800 & OLF & $\bullet$ & & 964.36 & $04 / 09 / 09$ & 18.20 & 946.16 \\
\hline GW-829 & OLF & & $\bullet$ & 985.95 & 04/08/09 & 12.60 & 973.35 \\
\hline GW-835 & S3 & $\bullet$ & & 1000.91 & 04/09/09 & 14.10 & 986.81 \\
\hline GW-916 & EMWMF & & $\bullet$ & 1002.85 & $04 / 09 / 09$ & 4.68 & 998.17 \\
\hline GW-917 & EMWMF & & $\bullet$ & 997.10 & $04 / 09 / 09$ & 19.73 & 977.37 \\
\hline GW-918 & EMWMF & & $\bullet$ & 1067.96 & 04/09/09 & 5.66 & 1062.30 \\
\hline GW-921 & EMWMF & & $\bullet$ & 971.29 & $04 / 09 / 09$ & 5.50 & 965.79 \\
\hline GW-922 & EMWMF & & $\bullet$ & 956.91 & $04 / 09 / 09$ & 5.13 & 951.78 \\
\hline GW-923 & EMWMF & & $\bullet$ & 1016.73 & 04/09/09 & 25.52 & 991.21 \\
\hline GW-924 & EMWMF & & - & 968.90 & $04 / 09 / 09$ & 7.91 & 960.99 \\
\hline
\end{tabular}




\section{Table B.6 (continued)}

Notes:

1 AGLLSF - Above Grade Low-Level Storage Facility

\begin{tabular}{|c|c|}
\hline BG & - Bear Creek Burial Grounds Waste Management Area \\
\hline EMWMF & - Environmental Management Waste Management Facility \\
\hline EXP-A & - Exit Pathway (Maynardville Limestone) Picket A \\
\hline EXP-B & - Exit Pathway (Maynardville Limestone) Picket B \\
\hline LD & - Lysimeter Demonstration Site \\
\hline OLF & - Oil Landfarm Waste Management Area \\
\hline RS & - Rust Spoil Area \\
\hline S3 & - S-3 Site \\
\hline SPI & - Spoil Area I \\
\hline
\end{tabular}

2 The measuring point is the surveyed elevation of a mark on either the top of the innermost well casing or the top of dedicated sampling equipment, in feet above mean sea level.

3 The depth to water is in feet below the measuring point.

4 The groundwater elevation (measuring point depth to water) is in feet above mean sea level. 


\section{B-22}


Table B.7. Depth-to-water measurements and groundwater elevations for selected wells in the Upper East Fork Poplar Creek Hydrogeologic Regime, April 2009

\begin{tabular}{|c|c|c|c|c|c|c|c|}
\hline \multirow{2}{*}{$\begin{array}{c}\text { Well } \\
\text { Number }\end{array}$} & \multirow{2}{*}{ Location $^{1}$} & \multicolumn{2}{|c|}{ Hydrogeologic Unit } & \multirow{2}{*}{$\begin{array}{c}\text { Measuring } \\
\text { Point }^{2}\end{array}$} & \multirow{2}{*}{$\begin{array}{c}\text { Date } \\
\text { Measured }\end{array}$} & \multirow{2}{*}{$\begin{array}{l}\text { Depth to } \\
\text { Water }^{3}\end{array}$} & \multirow{2}{*}{$\begin{array}{c}\text { Groundwate } \\
\text { Elevation }^{4} \\
\end{array}$} \\
\hline & & Aquifer & Aquitard & & & & \\
\hline $55-1 \mathrm{~A}$ & GRIDB2 & & - & 986.91 & $04 / 07 / 09$ & 10.66 & 976.25 \\
\hline $55-3 \mathrm{~A}$ & B9201-5 & & $\bullet$ & 972.46 & $04 / 07 / 09$ & 11.38 & 961.08 \\
\hline $55-6 \mathrm{~A}$ & B9103 & & - & 989.29 & $04 / 07 / 09$ & 8.40 & 980.89 \\
\hline $56-1 \mathrm{~A}$ & $\mathrm{Y} 12$ & & $\bullet$ & 969.25 & $04 / 07 / 09$ & 7.84 & 961.41 \\
\hline $56-2 \mathrm{~A}$ & GRIDC3 & & $\bullet$ & 963.53 & $04 / 07 / 09$ & 8.50 & 955.03 \\
\hline $56-8 \mathrm{~A}$ & Y12 & $\bullet$ & & 962.46 & $04 / 07 / 09$ & 19.85 & 942.61 \\
\hline $60-1 \mathrm{~A}$ & $\mathrm{Y} 12$ & $\bullet$ & & 929.66 & $04 / 07 / 09$ & 12.80 & 916.86 \\
\hline GW-105 & $\mathrm{S} 3$ & & $\bullet$ & 1018.20 & $04 / 08 / 09$ & 8.28 & 1009.92 \\
\hline GW-108 & $\mathrm{S} 3$ & & $\bullet$ & 999.00 & $04 / 08 / 09$ & 6.85 & 992.15 \\
\hline GW-115 & S3 & & 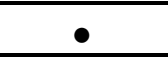 & 1055.01 & $04 / 09 / 09$ & 6.82 & 1048.19 \\
\hline GW-148 & NHP & $\bullet$ & & 907.76 & $04 / 08 / 09$ & 7.95 & 899.81 \\
\hline GW-152 & NHP & $\bullet$ & & 921.18 & $04 / 07 / 09$ & 19.90 & 901.28 \\
\hline GW-154 & NHP & $\bullet$ & & 911.70 & $04 / 08 / 09$ & 7.90 & 903.80 \\
\hline GW-167 & EXP & $\bullet$ & & 931.95 & $04 / 07 / 09$ & 27.10 & 904.85 \\
\hline GW-169 & EXP-UV & $\bullet$ & & 932.12 & $04 / 07 / 09$ & 26.82 & 905.30 \\
\hline GW-192 & B4 & & $\bullet$ & 1008.83 & $04 / 07 / 09$ & 5.16 & 1003.67 \\
\hline GW-193 & T2331 & $\bullet$ & & 934.17 & $04 / 08 / 09$ & 9.01 & 925.16 \\
\hline GW-195 & B4 & & - & 1002.90 & $04 / 07 / 09$ & 5.47 & 997.43 \\
\hline GW-199 & GRIDI1 & & $\bullet$ & 961.08 & $04 / 07 / 09$ & 15.81 & 945.27 \\
\hline GW-202 & RDS & & $\bullet$ & 968.02 & 04/07/09 & 9.82 & 958.20 \\
\hline GW-204 & T0134 & & $\bullet$ & 958.74 & $04 / 08 / 09$ & 8.80 & 949.94 \\
\hline GW-219 & UOV & $\bullet$ & & 935.83 & $04 / 08 / 09$ & 10.21 & 925.62 \\
\hline GW-251 & $\mathrm{S} 2$ & $\bullet$ & & 1003.80 & $04 / 08 / 09$ & 11.88 & 991.92 \\
\hline GW-253 & $\mathrm{S} 2$ & $\bullet$ & & 1004.24 & $04 / 08 / 09$ & 5.02 & 999.22 \\
\hline GW-261 & SY & & $\bullet$ & 1049.99 & $04 / 08 / 09$ & 17.93 & 1032.06 \\
\hline GW-263 & SY & & $\bullet$ & 1057.73 & $04 / 08 / 09$ & 29.01 & 1028.72 \\
\hline GW-334 & $\mathrm{WC}$ & & $\bullet$ & 983.73 & $04 / 07 / 09$ & 11.04 & 972.69 \\
\hline GW-335 & WC & & $\bullet$ & 981.88 & $04 / 07 / 09$ & 9.40 & 972.48 \\
\hline GW-349 & $\mathrm{S} 2$ & $\bullet$ & & 993.50 & $04 / 07 / 09$ & 3.50 & 990.00 \\
\hline GW-380 & NHP & $\bullet$ & & 913.55 & $04 / 07 / 09$ & 10.18 & 903.37 \\
\hline GW-383 & NHP & & $\bullet$ & 908.77 & $04 / 08 / 09$ & 7.90 & 900.87 \\
\hline GW-603 & EXP-J & $\bullet$ & & 961.32 & $04 / 07 / 09$ & 57.41 & 903.91 \\
\hline GW-605 & EXP-I & $\bullet$ & & 919.06 & $04 / 07 / 09$ & 11.56 & 907.50 \\
\hline GW-606 & EXP-I & $\bullet$ & & 919.59 & 04/07/09 & 13.42 & 906.17 \\
\hline GW-617 & EXP-E & $\bullet$ & & 985.28 & $04 / 07 / 09$ & 12.42 & 972.86 \\
\hline GW-619 & FTF & $\bullet$ & & 1015.42 & $04 / 08 / 09$ & 19.80 & 995.62 \\
\hline
\end{tabular}


Table B.7 (continued)

\begin{tabular}{|c|c|c|c|c|c|c|c|}
\hline \multirow{2}{*}{$\begin{array}{c}\text { Well } \\
\text { Number }\end{array}$} & \multirow{2}{*}{ Location $^{1}$} & \multicolumn{2}{|c|}{ Hydrogeologic Unit } & \multirow{2}{*}{$\begin{array}{c}\text { Measuring } \\
\text { Point }^{2} \\
\end{array}$} & \multirow{2}{*}{$\begin{array}{c}\text { Date } \\
\text { Measured }\end{array}$} & \multirow{2}{*}{$\begin{array}{l}\text { Depth to } \\
\text { Water }^{3}\end{array}$} & \multirow{2}{*}{\begin{tabular}{|c} 
Groundwater \\
Elevation
\end{tabular}} \\
\hline & & Aquifer & Aquitard & & & & \\
\hline GW-686 & $\mathrm{CPT}$ & $\bullet$ & & 963.76 & $04 / 07 / 09$ & 14.42 & 949.34 \\
\hline GW-691 & $\mathrm{CPT}$ & $\bullet$ & & 968.59 & $04 / 07 / 09$ & 11.12 & 957.47 \\
\hline GW-696 & B8110 & $\bullet$ & & 969.78 & $04 / 08 / 09$ & 22.91 & 946.87 \\
\hline GW-733 & EXP-J & $\bullet$ & & 959.84 & $04 / 08 / 09$ & 57.90 & 901.94 \\
\hline GW-734 & EXP-J & $\bullet$ & & 939.93 & $04 / 08 / 09$ & 38.00 & 901.93 \\
\hline GW-735 & EXP-J & & $\bullet$ & 924.46 & $04 / 08 / 09$ & 22.21 & 902.25 \\
\hline GW-746 & GRIDK1 & & $\bullet$ & 906.88 & $04 / 07 / 09$ & 6.42 & 900.46 \\
\hline GW-748 & GRIDK2 & & $\bullet$ & 921.17 & $04 / 08 / 09$ & 6.52 & 914.65 \\
\hline GW-752 & GRIDJ3 & & $\bullet$ & 912.78 & 04/08/09 & 3.22 & 909.56 \\
\hline GW-754 & GRIDJ2 & & $\bullet$ & 928.78 & $04 / 08 / 09$ & 7.88 & 920.90 \\
\hline GW-756 & GRIDJ1 & & $\bullet$ & 928.11 & $04 / 07 / 09$ & 6.70 & 921.41 \\
\hline GW-759 & GRIDG1 & & $\bullet$ & 994.01 & $04 / 07 / 09$ & 15.78 & 978.23 \\
\hline GW-761 & GRIDG2 & & $\bullet$ & 968.23 & $04 / 07 / 09$ & 8.00 & 960.23 \\
\hline GW-763 & GRIDJ3 & & $\bullet$ & 915.03 & $04 / 07 / 09$ & 8.58 & 906.45 \\
\hline GW-765 & GRIDE1 & & $\bullet$ & 1008.54 & $04 / 09 / 09$ & 19.05 & 989.49 \\
\hline GW-767 & GRIDI2 & & $\bullet$ & 948.54 & $04 / 07 / 09$ & 10.36 & 938.18 \\
\hline GW-770 & GRIDG3 & & $\bullet$ & 944.72 & $04 / 07 / 09$ & 12.70 & 932.02 \\
\hline GW-774 & GRIDH2 & & $\bullet$ & 963.16 & $04 / 07 / 09$ & 10.50 & 952.66 \\
\hline GW-776 & GRIDH3 & & $\bullet$ & 931.25 & $04 / 07 / 09$ & 12.06 & 919.19 \\
\hline GW-778 & GRIDB2 & & $\bullet$ & 1001.84 & $04 / 09 / 09$ & 7.34 & 994.50 \\
\hline GW-783 & GRIDE3 & & $\bullet$ & 948.49 & $04 / 07 / 09$ & 10.43 & 938.06 \\
\hline GW-792 & GRIDD2 & & $\bullet$ & 992.74 & $04 / 07 / 09$ & 24.16 & 968.58 \\
\hline GW-816 & EXP-SR & & $\bullet$ & 898.42 & $04 / 07 / 09$ & 11.92 & 886.50 \\
\hline GW-960 & GRID F2 & & - & 963.26 & $04 / 07 / 09$ & 12.87 & 950.39 \\
\hline
\end{tabular}




\section{Table B.7 (continued)}

\section{Notes:}

1 B4 - Beta-4 Security Pits

B8110 - Building 81-10

B9103 - Building 9103

B9201-2 - Building 9201-2

CPT - Coal Pile Trench

EXP - Exit Pathway (Maynardville Limestone) monitoring well -E, -I, or -J: Maynardville Limestone Picket

-SR: Along Scarboro Road in the gap through Pine Ridge -UV: Offsite in Union Valley

FTF - Fire Training Facility

GRID - Comprehensive Groundwater Monitoring Plan Grid Location

NHP - New Hope Pond

RDS - Ravine Disposal Site

S2 - S-2 Site

S3 - S-3 Site

SY - Y-12 Plant Salvage Yard

T0134 - Tank 0134-U

T2331 - Tank 2331-U

UOV - Uranium Oxide Vault

WC - Waste Coolant Processing Area

Y12 - Y-12 Complex

2 The measuring point is the surveyed elevation of a mark on either the top of the innermost well casing or the top of dedicated sampling equipment, in feet above mean sea level.

3 The depth to water is in feet below the measuring point.

4 The groundwater elevation (measuring point depth to water) is in feet above mean sea level. 


\section{B-26}


Table B.8. Depth-to-water measurements and groundwater elevations for selected wells in the Chestnut Ridge Hydrogeologic Regime, April 2009

\begin{tabular}{|c|c|c|c|c|c|}
\hline $\begin{array}{c}\text { Well } \\
\text { Number }\end{array}$ & Location $^{1}$ & $\begin{array}{c}\text { Measuring } \\
\text { Point }{ }^{2}\end{array}$ & $\begin{array}{c}\text { Date } \\
\text { Measured }\end{array}$ & $\begin{array}{l}\text { Depth to } \\
\text { Water }^{3}\end{array}$ & $\begin{array}{c}\text { Groundwater } \\
\text { Elevation }^{4}\end{array}$ \\
\hline 1082 & ORSF & 837.28 & 04/07/09 & 23.08 & 814.20 \\
\hline 1084 & ORSF & 965.40 & $04 / 08 / 09$ & 62.88 & 902.52 \\
\hline 1090 & UNCS & 1104.48 & 04/08/09 & 44.14 & 1060.34 \\
\hline GW-141 & LIV & 1186.23 & 04/08/09 & 92.65 & 1093.58 \\
\hline GW-142 & KHQ & 971.15 & 04/08/09 & 133.91 & 837.24 \\
\hline GW-144 & KHQ & 913.54 & $04 / 08 / 09$ & 78.51 & 835.03 \\
\hline GW-145 & KHQ & 840.24 & 04/08/09 & 3.68 & 836.56 \\
\hline GW-156 & CRSDB & 1049.28 & 04/07/09 & 142.82 & 906.46 \\
\hline GW-159 & CRSDB & 1051.38 & 04/07/09 & 117.03 & 934.35 \\
\hline GW-160 & CRBAWP & 1093.09 & $04 / 07 / 09$ & 134.08 & 959.01 \\
\hline GW-173 & CRSP & 1115.00 & $04 / 07 / 09$ & 130.00 & 985.00 \\
\hline GW-174 & CRSP & 1116.66 & 04/07/09 & 104.22 & 1012.44 \\
\hline GW-175 & CRSP & 1084.19 & $04 / 08 / 09$ & 112.89 & 971.30 \\
\hline GW-176 & CRSP & 1125.30 & $04 / 07 / 09$ & 115.92 & 1009.38 \\
\hline GW-177 & CRSP & 1158.20 & $04 / 07 / 09$ & 117.30 & 1040.90 \\
\hline GW-178 & CRSP & 1143.49 & 04/07/09 & 88.47 & 1055.02 \\
\hline GW-179 & CRSP & 1128.00 & $04 / 07 / 09$ & 113.86 & 1014.14 \\
\hline GW-180 & CRSP & 1104.14 & $04 / 07 / 09$ & 97.83 & 1006.31 \\
\hline GW-184 & RQ & 927.63 & $04 / 07 / 09$ & 109.81 & 817.82 \\
\hline GW-186 & $\mathrm{RQ}$ & 831.32 & $04 / 07 / 09$ & 13.91 & 817.41 \\
\hline GW-188 & $\mathrm{RQ}$ & 837.09 & $04 / 07 / 09$ & 20.02 & 817.07 \\
\hline GW-203 & UNCS & 1105.45 & $04 / 07 / 09$ & 80.65 & 1024.80 \\
\hline GW-205 & UNCS & 1104.14 & $04 / 07 / 09$ & 76.54 & 1027.60 \\
\hline GW-217 & LIV & 1177.03 & $04 / 08 / 09$ & 106.21 & 1070.82 \\
\hline GW-221 & UNCS & 1106.16 & $04 / 07 / 09$ & 83.07 & 1023.09 \\
\hline GW-231 & KHQ & 849.67 & $04 / 08 / 09$ & 12.40 & 837.27 \\
\hline GW-241 & CRSDB & 982.84 & $04 / 07 / 09$ & 44.06 & 938.78 \\
\hline GW-292 & ECRWP & 1073.00 & $04 / 07 / 09$ & 109.87 & 963.13 \\
\hline GW-298 & CRBAWP & 1049.01 & $04 / 07 / 09$ & 106.32 & 942.69 \\
\hline GW-299 & CRBAWP & 1053.86 & $04 / 07 / 09$ & 98.60 & 955.26 \\
\hline GW-300 & CRBAWP & 1073.12 & $04 / 07 / 09$ & 111.40 & 961.72 \\
\hline GW-301 & CRBAWP & 1086.55 & $04 / 07 / 09$ & 129.60 & 956.95 \\
\hline GW-302 & UNCS & 1141.84 & $04 / 07 / 09$ & 95.10 & 1046.74 \\
\hline GW-303 & CRSDB & 1007.16 & $04 / 07 / 09$ & 83.93 & 923.23 \\
\hline GW-304 & CRSDB & 1045.49 & $04 / 07 / 09$ & 116.28 & 929.21 \\
\hline GW-305 & LIV & 1183.72 & $04 / 08 / 09$ & 117.76 & 1065.96 \\
\hline GW-322 & CRSP & 1134.98 & $04 / 07 / 09$ & 145.03 & 989.95 \\
\hline GW-339 & UNCS & 1124.83 & $04 / 07 / 09$ & 65.08 & 1059.75 \\
\hline
\end{tabular}


Table B.8 (continued)

\begin{tabular}{|c|c|c|c|c|c|}
\hline $\begin{array}{c}\text { Well } \\
\text { Number }\end{array}$ & Location $^{1}$ & $\begin{array}{l}\text { Measuring } \\
\text { Point }^{2}\end{array}$ & $\begin{array}{c}\text { Date } \\
\text { Measured }\end{array}$ & $\begin{array}{l}\text { Depth to } \\
\text { Water }^{3}\end{array}$ & $\begin{array}{c}\text { Groundwater } \\
\text { Elevation }{ }^{4}\end{array}$ \\
\hline GW-511 & CRSP & 1093.21 & $04 / 07 / 09$ & 103.45 & 989.76 \\
\hline GW-512 & FCAP & 1001.54 & $04 / 07 / 09$ & 21.73 & 979.81 \\
\hline GW-521 & LIV & 1182.88 & $04 / 08 / 09$ & 80.68 & 1102.20 \\
\hline GW-522 & LIV & 1175.48 & $04 / 08 / 09$ & 89.65 & 1085.83 \\
\hline GW-539 & LII & 1093.20 & $04 / 08 / 09$ & 105.18 & 988.02 \\
\hline GW-541 & CDLVI & 1058.40 & $04 / 08 / 09$ & 63.15 & 995.25 \\
\hline GW-542 & CDLVI & 1051.81 & $04 / 08 / 09$ & 69.96 & 981.85 \\
\hline GW-543 & CDLVI & 1024.01 & $04 / 08 / 09$ & 63.21 & 960.80 \\
\hline GW-544 & CDLVI & 1045.19 & $04 / 08 / 09$ & 51.96 & 993.23 \\
\hline GW-546 & CDLVI & 1072.21 & 04/08/09 & 80.30 & 991.91 \\
\hline GW-557 & $\mathrm{LV}$ & 1081.36 & $04 / 07 / 09$ & 124.81 & 956.55 \\
\hline GW-558 & SSCR & 981.42 & $04 / 07 / 09$ & 48.75 & 932.67 \\
\hline GW-559 & SSCR & 1102.79 & $04 / 07 / 09$ & 138.33 & 964.46 \\
\hline GW-560 & CDLVII & 949.05 & 04/07/09 & 50.43 & 898.62 \\
\hline GW-562 & CDLVII & 934.69 & $04 / 07 / 09$ & 16.00 & 918.69 \\
\hline GW-564 & CDLVII & 938.07 & $04 / 07 / 09$ & 11.09 & 926.98 \\
\hline GW-608 & CRSP & 1075.38 & $04 / 07 / 09$ & 127.03 & 948.35 \\
\hline GW-609 & CRSP & 1112.31 & $04 / 07 / 09$ & 161.23 & 951.08 \\
\hline GW-610 & CRSP & 1059.44 & $04 / 08 / 09$ & 80.29 & 979.15 \\
\hline GW-611 & CRSP & 1048.38 & $04 / 08 / 09$ & 98.52 & 949.86 \\
\hline GW-612 & CRSP & 1131.03 & $04 / 07 / 09$ & 118.51 & 1012.52 \\
\hline GW-674 & FCAP & 883.79 & $04 / 07 / 09$ & 6.10 & 877.69 \\
\hline GW-676 & FCAP & 846.50 & $04 / 07 / 09$ & 2.61 & 843.89 \\
\hline GW-677 & FCAP & 1030.40 & $04 / 07 / 09$ & 24.44 & 1005.96 \\
\hline GW-678 & FCAP & 1000.70 & $04 / 07 / 09$ & 17.13 & 983.57 \\
\hline GW-679 & FCAP & 1026.90 & $04 / 07 / 09$ & 48.65 & 978.25 \\
\hline GW-680 & FCAP & 1001.50 & $04 / 07 / 09$ & 27.08 & 974.42 \\
\hline GW-709 & LII & 906.81 & $04 / 08 / 09$ & 24.98 & 881.83 \\
\hline GW-731 & CRSDB & 1049.38 & $04 / 07 / 09$ & 124.76 & 924.62 \\
\hline GW-732 & CRSDB & 1064.29 & $04 / 07 / 09$ & 157.41 & 906.88 \\
\hline GW-743 & CRSP & 1100.36 & $04 / 07 / 09$ & 123.86 & 976.50 \\
\hline GW-757 & LII & 961.64 & 04/08/09 & 82.21 & 879.43 \\
\hline GW-796 & $\mathrm{LV}$ & 1052.62 & $04 / 07 / 09$ & 74.57 & 978.05 \\
\hline GW-797 & $\mathrm{LV}$ & 1060.00 & $04 / 07 / 09$ & 72.66 & 987.34 \\
\hline GW-798 & CDLVII & 1006.00 & $04 / 07 / 09$ & 84.00 & 922.00 \\
\hline GW-799 & $\mathrm{LV}$ & 981.29 & $04 / 07 / 09$ & 23.46 & 957.83 \\
\hline GW-801 & $\mathrm{LV}$ & 1097.16 & $04 / 07 / 09$ & 110.71 & 986.45 \\
\hline GW-827 & CDLVI & 1051.60 & 04/08/09 & 43.18 & 1008.42 \\
\hline GW-831 & FCAP & 1091.29 & $04 / 07 / 09$ & 128.76 & 962.53 \\
\hline
\end{tabular}




\section{Table B.8 (continued)}

\section{Notes:}

1 CDLVI - Construction/Demolition Landfill VI

CDLVII - Construction/Demolition Landfill VII

CRBAWP - Chestnut Ridge Borrow Area Waste Pile

CRSDB - Chestnut Ridge Sediment Disposal Basin

CRSP - Chestnut Ridge Security Pits

ECRWP - East Chestnut Ridge Waste Pile

FCAP - Filled Coal Ash Pond

KHQ - Kerr Hollow Quarry

LII - Industrial Landfill II

LIV - Industrial Landfill IV

LV - Industrial Landfill V

ORSF - Oak Ridge Sludge Farm

RQ - Rogers Quarry

SSCR - South Side Chestnut Ridge

UNCS - United Nuclear Corporation Site

2 The measuring point is the surveyed elevation of a mark on either the top of the innermost well casing or the top of dedicated sampling equipment, in feet above mean sea level.

3 The depth to water is in feet below the measuring point.

4 The groundwater elevation (measuring point - depth to water) is in feet above mean sea level. 
B-30 
Table B.9 Concentration trends for the principal contaminants detected at CY 2009 sampling locations in the Bear Creek Hydrogeologic Regime

\begin{tabular}{|c|c|c|c|c|c|c|c|c|c|c|}
\hline \multirow{3}{*}{$\begin{array}{l}\text { Sampling } \\
\text { Location }^{1}\end{array}$} & \multicolumn{2}{|c|}{$\begin{array}{l}\text { Hydro. } \\
\text { Unit }^{2}\end{array}$} & \multicolumn{8}{|c|}{$\begin{array}{c}\text { Contaminant Type and Long-Term Trend }{ }^{3} \\
\text { ( } \mathrm{=} \text { indeterminate, }+=\text { increasing, } \nabla=\text { decreasing) }^{-}\end{array}$} \\
\hline & \multirow{2}{*}{$\begin{array}{l}\mathbf{A} \\
\mathbf{Q} \\
\mathbf{T}\end{array}$} & \multirow{2}{*}{$\begin{array}{l}\mathbf{A} \\
\mathbf{Q} \\
\mathbf{F}\end{array}$} & \multicolumn{2}{|c|}{ Inorganics $^{4}$} & \multicolumn{4}{|c|}{ VOCs $^{5}$} & \multicolumn{2}{|c|}{ Radioactivity $^{6}$} \\
\hline & & & $\mathrm{NO}^{3}$ & $\mathbf{U}$ & Ethenes & Ethanes & Methanes & Petrol. & Alpha & Beta \\
\hline GW-008 & $\bullet$ & & NA & . & + & + & . & . & . & . \\
\hline GW-014 & $\bullet$ & & . & . & $\boldsymbol{\nabla}$ & $\bar{\nabla}$ & . & . & . & . \\
\hline GW-046 & $\bullet$ & & NA & . & 0 & $\circ$ & . & 0 & . & . \\
\hline GW-053 & & $\bullet$ & & . & $\nabla$ & . & . & . & . & . \\
\hline GW-058 & & $\bullet$ & + & . & . & . & . & . & . & . \\
\hline GW-065 & & $\bullet$ & . & . & . & . & . & . & + & + \\
\hline GW-068 & $\bullet$ & & . & . & + & O & . & + & . & . \\
\hline GW-071 & $\bullet$ & & . & . & $\nabla$ & $\bar{\nabla}$ & . & $\nabla$ & . & . \\
\hline GW-077 & $\bullet$ & & NA & . & . & . & . & . & NA & NA \\
\hline GW-078 & $\bullet$ & & NA & . & . & . & . & . & NA & $\mathrm{NA}$ \\
\hline GW-079 & $\bullet$ & & NA & . & . & . & . & . & NA & NA \\
\hline GW-080 & $\bullet$ & & NA & . & . & . & . & . & NA & NA \\
\hline GW-082 & $\bullet$ & & . & . & 0 & 0 & . & . & . & . \\
\hline GW-085 & $\bullet$ & & 0 & . & . & . & . & . & . & . \\
\hline GW-098 & $\bullet$ & & . & . & $\bar{\nabla}$ & . & . & . & . & . \\
\hline GW-100 & & $\bullet$ & $\nabla$ & . & . & . & . & . & . & . \\
\hline GW-101 & $\bullet$ & & $\nabla$ & . & . & . & . & . & . & . \\
\hline GW-122 & & $\bullet$ & $\nabla$ & . & $\dot{.}$ & $\dot{.}$ & $\dot{.}$ & $\dot{.}$ & $\dot{.}$ & $\dot{.}$ \\
\hline GW-127 & $\bullet$ & & . & $\boldsymbol{\nabla}$ & . & . & . & . & $\nabla$ & . \\
\hline GW-225 & & $\bullet$ & . & 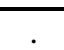 & . & . & 0 & . & . & . \\
\hline GW-229 & & $\bullet$ & . & + & + & 4 & . & + & + & . \\
\hline GW-236 & & $\bullet$ & $\nabla$ & . & . & . & . & . & . & . \\
\hline GW-242 & $\bullet$ & & . & . & 0 & . & . & . & . & . \\
\hline GW-246 & $\bullet$ & & 0 & 0 & + & . & + & . & 0 & 0 \\
\hline GW-276 & $\bullet$ & & $\bar{\nabla}$ & $\boldsymbol{\nabla}$ & $\nabla$ & . & . & . & $\bar{\nabla}$ & $\nabla$ \\
\hline GW-289 & $\bullet$ & & . & . & 0 & . & . & . & . & . \\
\hline GW-307 & & $\bullet$ & . & . & $\nabla$ & . & . & . & . & . \\
\hline GW-315 & & $\bullet$ & . & . & . & . & . & . & . & . \\
\hline GW-363 & $\bullet$ & & NA & . & . & NA & . & . & NA & NA \\
\hline GW-365 & & $\bullet$ & . & . & $\nabla$ & . & . & . & . & . \\
\hline GW-526 & $\bullet$ & & + & . & . & . & . & . & . & . \\
\hline GW-537 & $\bullet$ & & . & . & . & . & . & . & . & $\circ$ \\
\hline GW-601 & & $\bullet$ & $\bar{\nabla}$ & - & $\bar{\nabla}$ & . & . & . & . & . \\
\hline GW-615 & $\bullet$ & & 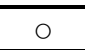 & + & . & . & 0 & . & 0 & 0 \\
\hline GW-616 & $\bullet$ & & 0 & . & . & . & . & . & . & . \\
\hline GW-623 & $\bullet$ & & . & . & 0 & 0 & 0 & 0 & . & . \\
\hline GW-627 & $\bullet$ & & . & . & + & + & . & . & . & . \\
\hline GW-629 & $\bullet$ & & . & . & + & + & 0 & + & . & . \\
\hline GW-639 & $\bullet$ & & NA &. & . & NA & . & . & NA & NA \\
\hline GW-648 & & $\bullet$ & . & . & . & - & . & . & . & . \\
\hline GW-653 & $\bullet$ & & . & . & + & + & . & . & . & . \\
\hline GW-683 & & $\bullet$ & $\dot{x}$ & . & . & . & . & . & . & . \\
\hline
\end{tabular}


Table B.9 (continued)

\begin{tabular}{|c|c|c|c|c|c|c|c|c|c|c|}
\hline \multirow{3}{*}{$\begin{array}{l}\text { Sampling } \\
\text { Location }\end{array}$} & \multicolumn{2}{|c|}{$\begin{array}{l}\text { Hydro. } \\
\text { Unit }^{2}\end{array}$} & \multicolumn{8}{|c|}{$\begin{array}{c}\text { Contaminant Type and Long-Term Trend }{ }^{3} \\
\left(\mathrm{o}=\text { indeterminate, } \$=\text { increasing, } \nabla=\text { decreasing) }^{\text {ind }}\right.\end{array}$} \\
\hline & \multirow{2}{*}{$\begin{array}{l}\mathbf{A} \\
\mathbf{Q} \\
\mathbf{T}\end{array}$} & \multirow{2}{*}{$\begin{array}{l}\mathbf{A} \\
\mathbf{Q} \\
\mathbf{F}\end{array}$} & \multicolumn{2}{|c|}{ Inorganics ${ }^{4}$} & \multicolumn{4}{|c|}{ VOCs $^{5}$} & \multicolumn{2}{|c|}{ Radioactivity $^{6}$} \\
\hline & & & $\mathrm{NO}^{3}$ & $\mathbf{U}$ & Ethenes & Ethanes & Methanes & Petrol. & Alpha & Beta \\
\hline GW-684 & & $\bullet$ & . & . & 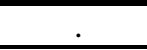 & . & . & . & . & . \\
\hline GW-703 & & $\bullet$ & . & . & $\nabla$ & . & . & . & . & . \\
\hline GW-704 & & $\bullet$ & $\bar{\nabla}$ & . & $\nabla$ & . & . & . & . & . \\
\hline GW-706 & & $\bullet$ & $\bar{\nabla}$ & $\nabla$ & $\circ$ & . & . & . & $\nabla$ & $\nabla$ \\
\hline GW-712 & & $\bullet$ & . & . & . & . & . & . & . & . \\
\hline GW-713 & & $\bullet$ & . & . & . & . & . & . & . & . \\
\hline GW-714 & & $\bullet$ & . & . & . & . & . & . & . & . \\
\hline GW-724 & & $\bullet$ & $\nabla$ & . & 0 & . & . & . & . & . \\
\hline GW-725 & & - & . & . & . & . & . & . & . & . \\
\hline GW-726-04 & $\bullet$ & & . & . & . & . & . & . & . & . \\
\hline GW-726-06 & $\bullet$ & & . & . & . & . & . & . & $\mathrm{Q}$ & . \\
\hline GW-726-09 & $\bullet$ & & . & . & . & . & . & . & . & . \\
\hline GW-726-12 & - & & . & . & . & . & . & . & . & . \\
\hline GW-726-16 & $\bullet$ & & . & . & . & . & . & . & . & . \\
\hline GW-726-20 & $\bullet$ & & . & . & . & . & . & . & . & . \\
\hline GW-726-23 & $\bullet$ & & . & . & . & . & . & . & . & . \\
\hline GW-738 & & - & $\nabla$ & . & $\nabla$ & . & . & . & . & . \\
\hline GW-740 & & $\bullet$ & . & . & $\nabla$ & 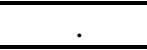 & . & . & . & . \\
\hline GW-916 & $\bullet$ & & NA & . & . & NA & . & . & NA & NA \\
\hline GW-917 & $\bullet$ & & NA & . & . & NA & . & . & NA & NA \\
\hline GW-918 & - & & NA & . & . & NA & . & . & NA & NA \\
\hline GW-920 & $\bullet$ & & NA & . & . & NA & . & . & NA & NA \\
\hline GW-921 & $\bullet$ & & NA & . & . & NA & . & . & NA & NA \\
\hline GW-922 & $\bullet$ & & NA & . & . & NA & . & . & NA & NA \\
\hline GW-923 & $\bullet$ & & NA & . & . & NA & . & . & NA & NA \\
\hline GW-924 & $\bullet$ & & NA & . & . & NA & . & . & NA & NA \\
\hline GW-925 & $\bullet$ & & NA & . & . & NA & . & . & NA & NA \\
\hline GW-926 & $\bullet$ & & NA & . & . & NA & . & . & NA & NA \\
\hline GW-927 & $\bullet$ & & NA & . & . & NA & . & . & NA & NA \\
\hline GW-961 & $\bullet$ & & NA & . & . & NA & . & . & NA & NA \\
\hline BCK-03.30 & $\dot{-}$ & & . & . &. & . & . & . & $\mathrm{NA}$ & NA \\
\hline BCK-04.55 & . & . & . & . & . & . & . & . & . & . \\
\hline BCK-07.87 & - & 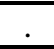 &. & 0 & . & . &. & . & $\mathrm{NA}$ & NA \\
\hline BCK-09.20 & . & . & . & $\circ$ & 0 & . & . & . & NA & NA \\
\hline BCK-09.40 & . & . & . & 0 & . & . & . & . & o & . \\
\hline BCK-11.54 & . & . & o & 0 & . & . & . & . & NA & NA \\
\hline BCK-11.84 & . & . & $\circ$ & 0 & . & . & . & . & NA & NA \\
\hline BCK-11.97 & . & . & $\circ$ & 0 & . & . & . & . & $\circ$ & $\circ$ \\
\hline BCK-12.34 & . & . & & 0 & o & . & . & . & NA & NA \\
\hline EMWNT-03A & . & . & NA & . & . & . & . & . & . & . \\
\hline EMWNT-05 & - & . & NA & . & . & . & . & . & . & . \\
\hline EMW-VWEIR & & . & NA & . & . & . & . & . & NA & NA \\
\hline EMW-VWUND & & & NA & . &. & $\mathrm{NA}$ &. &. & NA & NA \\
\hline NT-01 & - & . & o & 0 & o & . & . & . & . & . \\
\hline NT-02 (S07) & . & . & . & . & . & . & . & . & NA & NA \\
\hline NT-03 & $\cdot$ & & 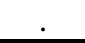 & . & . & 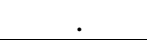 & . & . & NA & NA \\
\hline
\end{tabular}


Table B.9 (continued)

\begin{tabular}{|c|c|c|c|c|c|c|c|c|c|c|}
\hline \multirow{3}{*}{$\begin{array}{l}\text { Sampling } \\
\text { Location }^{1}\end{array}$} & \multicolumn{2}{|c|}{$\begin{array}{l}\text { Hydro. } \\
\text { Unit }^{2}\end{array}$} & \multicolumn{8}{|c|}{$\begin{array}{c}\text { Contaminant Type and Long-Term Trend }{ }^{3} \\
\left(\mathrm{O}=\text { indeterminate, }+=\text { increasing, } \nabla=\text { decreasing }^{-}\right.\end{array}$} \\
\hline & \multirow{2}{*}{$\begin{array}{l}\mathbf{A} \\
\mathbf{Q} \\
\mathbf{T}\end{array}$} & \multirow{2}{*}{$\begin{array}{l}\mathbf{A} \\
\mathbf{Q} \\
\mathbf{F}\end{array}$} & \multicolumn{2}{|c|}{ Inorganics $^{4}$} & \multicolumn{4}{|c|}{ VOCs $^{5}$} & \multicolumn{2}{|c|}{ Radioactivity $^{6}$} \\
\hline & & & $\mathbf{N O}^{3}$ & $\mathbf{U}$ & Ethenes & Ethanes & Methanes & Petrol. & Alpha & Beta \\
\hline NT-04 & . & . & NA & . & . & $\mathrm{NA}$ & . & $\dot{\square}$ & NA & NA \\
\hline NT-07 & . & . & . & - & $\bar{\nabla}$ & $\bar{\nabla}$ & . & . & NA & NA \\
\hline NT-08 & . & . & . & $\nabla$ & $\nabla$ & $\nabla$ & . & . & NA & NA \\
\hline SS-4 & . & . & $\circ$ & 0 & 0 & $\dot{\bullet}$ & . & . & . & . \\
\hline SS-5 & . & . & . & . & . & . & . & . & . & . \\
\hline SS-6 & . & . & . & . & . & 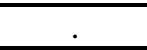 & . & . & . & \\
\hline SS-6.6 & . & . & . & . & . & . & . & . & NA & NA \\
\hline SS-7 & . &. & . & . & . & . & . & . & NA & NA \\
\hline SS-8 & . & . & . & . & . & 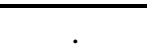 & . & 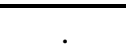 & NA & NA \\
\hline
\end{tabular}

Notes:

1 The exit pathway/perimeter monitoring locations are in bold typeface.

2 Hydrostratigraphic Unit

AQF - Monitored interval in the formations comprising the aquifer

AQT - Monitoring interval in the formations comprising the aquitard

3 Trend types were interpreted from data tables or plots of concentration changes over time.

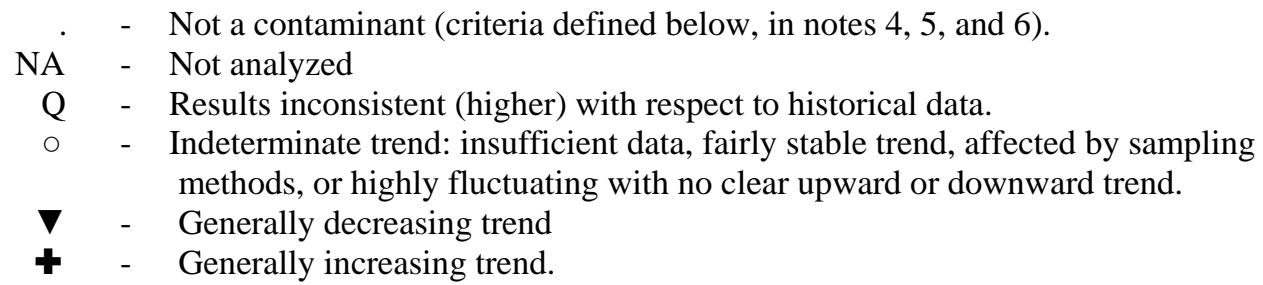

$4 \quad$ CY 2009 nitrate $\left(\mathrm{NO}^{3}\right)$ concentration greater than or equal to $10 \mathrm{mg} / \mathrm{L}$.

Total uranium (U) concentration greater than or equal to $0.03 \mathrm{mg} / \mathrm{L}$.

5 Summed CY 2009 concentration of a VOC group (see below) greater than or equal to 5 $\mu \mathrm{g} / \mathrm{L}$.

Ethenes = Summed chloroethenes (PCE, TCE, 12DCE, 11DCE, vinyl chloride

Ethanes = Summed chloroethanes (111TCA, 11DCE, chloroethane)

Methanes $=$ Summed chloromethanes (carbon tetrachloride, chloroform, methylene chloride)

Petrol = Summed petroleum hydrocarbons (benzene, toluene, ethylbenzene, xylene)

6 Maximum CY 2009 gross alpha activity greater than or equal to $15 \mathrm{pCi} / \mathrm{L}$

Maximum CY 2009 gross beta activity greater than or equal to $50 \mathrm{pCi} / \mathrm{L}$ 
B-34 
Table B.10 Concentration trends for the principal contaminants detected at CY 2009 sampling locations in the Upper East Fork Poplar Creek Hydrogeologic Regime

\begin{tabular}{|c|c|c|c|c|c|c|c|c|c|c|}
\hline \multirow{3}{*}{$\begin{array}{l}\text { Sampling } \\
\text { Location } 1\end{array}$} & \multicolumn{2}{|c|}{$\begin{array}{l}\text { Hydro. } \\
\text { Unit }^{2}\end{array}$} & \multicolumn{8}{|c|}{$\begin{array}{c}\text { Contaminant Type and Long-Term Trend }{ }^{3} \\
\left(\mathrm{O}=\text { indeterminate, }+=\text { increasing, } \nabla=\text { decreasing }^{-}\right.\end{array}$} \\
\hline & \multirow{2}{*}{$\begin{array}{l}\mathbf{A} \\
\mathbf{Q} \\
\mathbf{T}\end{array}$} & \multirow{2}{*}{$\begin{array}{l}\mathbf{A} \\
\mathbf{Q} \\
\mathbf{F}\end{array}$} & \multicolumn{2}{|c|}{ Inorganics $^{4}$} & \multicolumn{4}{|c|}{ VOCs $^{5}$} & \multicolumn{2}{|c|}{ Radioactivity $^{6}$} \\
\hline & & & $\mathrm{NO}^{3}$ & $\mathbf{U}$ & Ethenes & Ethanes & Methanes & Petrol. & Alpha & Beta \\
\hline $55-2 \mathrm{~A}$ & $\bullet$ & & $\overline{0}$ & NA & $\bar{\nabla}$ & $\bar{\nabla}$ & . & . & $\overline{N A}$ & $\overline{\mathrm{NA}}$ \\
\hline $55-2 B$ & $\bullet$ & & 4 & & $\nabla$ & $\nabla$ & . & . & NA & NA \\
\hline $55-2 \mathrm{C}$ & $\bullet$ & & + & NA & $\nabla$ & $\nabla$ & . & . & . & . \\
\hline $55-3 A$ & $\bullet$ & & . & . & 0 & 0 & . & . & . & . \\
\hline $55-3 B$ & $\bullet$ & & . & . & 0 & 0 & . & 0 & . & . \\
\hline $55-3 \mathrm{C}$ & $\bullet$ & & . & . & 0 & o & . & . & . & . \\
\hline $56-1 \mathrm{~A}$ & $\bullet$ & & . & . & . & . & . & . & . & . \\
\hline $56-1 \mathrm{C}$ & $\bullet$ & & . & . & . & . & . & . & . & . \\
\hline $56-2 \mathrm{~A}$ & $\bullet$ & & . & . & $\nabla$ & . & . & . & . & . \\
\hline $56-2 B$ & $\bullet$ & & . & 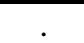 & 0 & . & . & . & . & 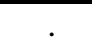 \\
\hline $56-2 \mathrm{C}$ & $\bullet$ & & NA & NA & $\nabla$ & . & . & . & NA & NA \\
\hline $56-3 \mathrm{~A}$ & $\bullet$ & & . & . & $\nabla$ & . & . & . & . & . \\
\hline 56-3B & $\bullet$ & & . & . & 0 & . & . & . & . & . \\
\hline $56-3 \mathrm{C}$ & $\bullet$ & & . & . & $\circ$ & . & . & . & . & . \\
\hline $56-4 \mathrm{~A}$ & $\bullet$ & & . & . & . & . & . & . & . & . \\
\hline GW-108 & $\bullet$ & & $\nabla$ & . & + & . & 0 & . & 0 & + \\
\hline GW-151 & & $\bullet$ & . & . & + & . & + & . & . & . \\
\hline GW-153 & & $\bullet$ & & 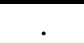 & . & . & $\nabla$ & . & . & . \\
\hline GW-154 & & $\bullet$ & NA & o & . & . & . & . & o & o \\
\hline GW-169 & & $\bullet$ & . & NA & . & . & . & . & . & . \\
\hline GW-170 & & $\bullet$ & . & NA & . & . & . & . & . & . \\
\hline GW-171 & & $\bullet$ & NA & NA & . & . & . & . & NA & NA \\
\hline GW-172 & & $\bullet$ & NA & NA & . & . & . & 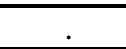 & NA & NA \\
\hline GW-193 & & $\bullet$ & NA & NA & $\overline{N A}$ & $\overline{\mathrm{NA}}$ & $\overline{N A}$ & NA & $\overline{N A}$ & NA \\
\hline GW-204 & $\bullet$ & & NA & 0 & NA & NA & NA & NA & 0 & . \\
\hline GW-219 & & $\bullet$ & NA & o & NA & NA & NA & NA & $\circ$ & $\circ$ \\
\hline GW-220 & & $\bullet$ & NA & NA & + & . & + & . & NA & NA \\
\hline GW-222 & & $\bullet$ & . & o & 0 & . & . & . & 0 & . \\
\hline GW-223 & & $\bullet$ & . & + & $\nabla$ & . & . & . & . & . \\
\hline GW-230 & & $\bullet$ & NA & NA & $\nabla$ & . & . & . & NA & NA \\
\hline GW-240 & & $\bullet$ & NA & NA & . & . & . & . & NA & NA \\
\hline GW-251 & & $\bullet$ & $\nabla$ & . & 0 & . & 0 & . & . & . \\
\hline GW-253 & & $\bullet$ & $\overline{0}$ & . & 0 & . & 0 & . & 0 & . \\
\hline GW-269 & $\bullet$ & & NA & NA & 4 & o & . & . & NA & NA \\
\hline GW-270 & $\bullet$ & & $\boldsymbol{\nabla}$ & . & . & . & . & . & . & . \\
\hline GW-272 & $\bullet$ & & + & . & 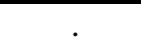 & . & . & 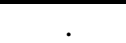 & . & . \\
\hline GW-274 & $\bullet$ & & $\nabla$ & - & + & . & 0 & + & . & . \\
\hline GW-275 & $\bullet$ & & 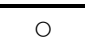 & . & . & . & . & . & . & . \\
\hline GW-281 & $\bullet$ & & NA & NA & . & . & . & . & $\overline{N A}$ & NA \\
\hline GW-332 & $\bullet$ & & NA & NA & $\bar{\nabla}$ & $\bar{\nabla}$ & . & . & NA & NA \\
\hline GW-337 & $\bullet$ & & NA & NA & $\bar{\nabla}$ & $\bar{\nabla}$ & . & . & NA & NA \\
\hline GW-380 & & $\bullet$ & . & 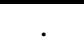 & . & . & . & 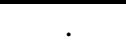 & . & . \\
\hline
\end{tabular}


Table B.10 (continued)

\begin{tabular}{|c|c|c|c|c|c|c|c|c|c|c|}
\hline \multirow{3}{*}{$\begin{array}{l}\text { Sampling } \\
\text { Location }^{1}\end{array}$} & \multicolumn{2}{|c|}{$\begin{array}{l}\text { Hydro. } \\
\text { Unit }^{2}\end{array}$} & \multicolumn{8}{|c|}{ 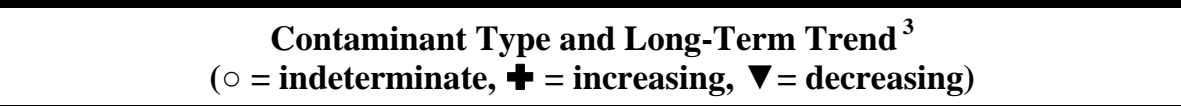 } \\
\hline & \multirow{2}{*}{$\begin{array}{l}\mathbf{A} \\
\mathbf{Q} \\
\mathbf{T}\end{array}$} & \multirow{2}{*}{$\begin{array}{l}\mathbf{A} \\
\mathbf{Q} \\
\mathbf{F}\end{array}$} & \multicolumn{2}{|c|}{ Inorganics ${ }^{4}$} & \multicolumn{4}{|c|}{ VOCs $^{5}$} & \multicolumn{2}{|c|}{ Radioactivity $^{6}$} \\
\hline & & & $\mathrm{NO}^{3}$ & $\mathbf{U}$ & Ethenes & Ethanes & Methanes & Petrol. & Alpha & Beta \\
\hline GW-381 & & $\bullet$ & $\overline{\mathrm{NA}}$ & NA & $\overline{0}$ & . & $\bar{\nabla}$ & . & NA & $\mathrm{NA}$ \\
\hline GW-382 & & $\bullet$ & . &. & $\nabla$ & . & $\nabla$ & . & . &. \\
\hline GW-383 & $\bullet$ & & . & . & + & . & . & . & . & . \\
\hline GW-505 & $\bullet$ & & NA & $\mathrm{Q}$ & NA & NA & NA & $\mathrm{NA}$ & $\mathrm{Q}$ & . \\
\hline GW-508 & $\bullet$ & & NA & NA & . & . & . & $\boldsymbol{\nabla}$ & NA & NA \\
\hline GW-605 & & $\bullet$ & . & 0 & + &. & + & . & $\circ$ &. \\
\hline GW-606 & & $\bullet$ & + & . & 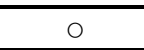 & . & $\nabla$ & . & . & . \\
\hline GW-618 & & $\bullet$ & . & . & $\bar{\nabla}$ & . & . & 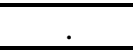 & . & . \\
\hline GW-633 & $\bullet$ & & $\bar{\nabla}$ & . & + & . & 0 & + & . & 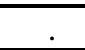 \\
\hline GW-656 & $\bullet$ & & NA & NA & $\nabla$ & $\nabla$ & . & . & NA & NA \\
\hline GW-658 & $\bullet$ & & NA & NA & . & o & . & 0 & $\mathrm{NA}$ & $\mathrm{NA}$ \\
\hline GW-686 & & $\bullet$ & . & NA & $\circ$ & . & . & . & NA & $\mathrm{NA}$ \\
\hline GW-690 & & $\bullet$ & . & NA & $\bar{\nabla}$ & . & . & . & NA & $\mathrm{NA}$ \\
\hline GW-691 & & $\bullet$ & . & NA & $\circ$ & . & $\mathrm{Q}$ & . & NA & $\mathrm{NA}$ \\
\hline GW-692 & & $\bullet$ & . & NA & 0 & . & $\nabla$ & . & NA & NA \\
\hline GW-698 & & $\bullet$ & 0 & NA & 0 & . & $\circ$ & . & NA & NA \\
\hline GW-700 & & $\bullet$ & NA & NA & $\nabla$ & . & . & . & NA & $\mathrm{NA}$ \\
\hline GW-722-14 & & $\bullet$ & . & . & $\bar{\nabla}$ & . & $\bar{\nabla}$ & . & . & . \\
\hline GW-722-17 & & $\bullet$ &. &. & . & . & $\nabla$ & . &. & . \\
\hline GW-722-20 & & $\bullet$ & . & . & $\nabla$ & . & $\nabla$ & . & . & . \\
\hline GW-722-22 & & $\bullet$ & . & . & . & . & $\nabla$ & . & . & . \\
\hline GW-722-33 & & $\bullet$ & - & - & . & . & . & . & . & . \\
\hline GW-733 & & $\bullet$ & NA & NA & . & . & $\bar{\nabla}$ & . & . & . \\
\hline GW-735 & & $\bullet$ & . & . & . & . & . & . & . & . \\
\hline GW-744 & $\bullet$ & & . & . & . & . & . & . & . & . \\
\hline GW-747 & $\bullet$ & & . & . & . & . & . & . & . & . \\
\hline GW-750 & $\bullet$ & & . & . & . & . & . & . & . & . \\
\hline GW-762 & $\bullet$ & & . & & 4 & 0 & . & . & . & . \\
\hline GW-763 & $\bullet$ & & NA & NA & $\circ$ & . & . & . & NA & $\mathrm{NA}$ \\
\hline GW-765 & $\bullet$ & & . & 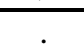 & 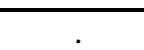 & . & 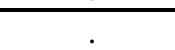 &. & . &. \\
\hline GW-769 & $\bullet$ & & NA & NA & + & . & + & . & NA & NA \\
\hline GW-770 & $\bullet$ & & NA & NA & . & . & 4 & . & NA & NA \\
\hline GW-775 & $\bullet$ & & NA & NA & . & . & . & . & NA & NA \\
\hline GW-776 & $\bullet$ & & . & . & . & . & . & . & . & . \\
\hline GW-779 & $\bullet$ & & . & . & . & . & . & . & . & . \\
\hline GW-781 & $\bullet$ & & . & - & . & . & . & . & . & . \\
\hline GW-782 & $\bullet$ & & & & $\nabla$ & 0 & . & . & . & . \\
\hline GW-783 & $\bullet$ & & NA & NA & $\nabla$ &. & . & . & NA & $\mathrm{NA}$ \\
\hline GW-791 & $\bullet$ & & - & & $\nabla$ & . & . & . & . & . \\
\hline GW-802 & $\bullet$ & & NA & NA & . & . & . & . & $\mathrm{NA}$ & $\mathrm{NA}$ \\
\hline GW-816 & $\bullet$ & & . & & . & . & . & . & 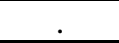 & . \\
\hline GW-820 & & $\bullet$ & NA & NA & 0 & . & . & . & NA & NA \\
\hline GW-832 & & $\bullet$ & . & . & . & . & $\bar{\nabla}$ & . & . & . \\
\hline GW-959 & & $\bullet$ & . & - & $\nabla$ & . & . & . & . & . \\
\hline GW-960 & $\bullet$ & & & & & & $\cdot$ & & & \\
\hline
\end{tabular}


Table B.10 (continued)

\begin{tabular}{|c|c|c|c|c|c|c|c|c|c|c|}
\hline \multirow{3}{*}{$\begin{array}{l}\text { Sampling } \\
\text { Location }\end{array}$} & \multicolumn{2}{|c|}{$\begin{array}{c}\text { Hydro. } \\
\text { Unit }^{2}\end{array}$} & \multicolumn{8}{|c|}{$\begin{array}{c}\text { Contaminant Type and Long-Term Trend } \\
\text { ( }{ }^{3}=\text { indeterminate, } \$=\text { increasing, } \nabla=\text { decreasing) }^{-}\end{array}$} \\
\hline & \multirow{2}{*}{$\begin{array}{l}\mathbf{A} \\
\mathbf{Q} \\
\mathbf{T}\end{array}$} & \multirow{2}{*}{$\begin{array}{l}\mathbf{A} \\
\mathbf{Q} \\
\mathbf{F}\end{array}$} & \multicolumn{2}{|c|}{ Inorganics $^{4}$} & \multicolumn{4}{|c|}{ VOCs $^{5}$} & \multicolumn{2}{|c|}{ Radioactivity $^{6}$} \\
\hline & & & $\mathrm{NO}^{3}$ & $\mathbf{U}$ & Ethenes & Ethanes & Methanes & Petrol. & Alpha & Beta \\
\hline 200A6 & . & . & NA & 0 & NA & NA & NA & NA & NA & NA \\
\hline GHK2.51WSW & $\cdot$ & $\cdot$ & $\dot{-}$ & . &. &. & 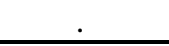 & . & . & . \\
\hline NPR12.0SW & . & . & $\cdot$ & . & . & . & . & . & . & . \\
\hline NPR23.0SW & . & . & . & . & . & . & . & . & . & . \\
\hline SCR7.1SP & . & . & NA & NA &. & . &. &. & NA & NA \\
\hline SCR7.8SP & . & . & NA & NA & . & . & . & . & NA & NA \\
\hline SP-17 & . & . & . & . & . & . & . & . & . & . \\
\hline STATION 8 & . & . & NA & 0 & NA & NA & NA & NA & . & . \\
\hline
\end{tabular}

\section{Notes:}

1 The exit pathway/perimeter monitoring locations are in bold typeface.

$2 \quad$ Hydrostratigraphic Unit

AQF - Monitored interval in the formations comprising the aquifer

AQT - Monitored interval in the formations comprising the aquitard

3 Trend types were interpreted from data tables or plots of concentration changes over time.

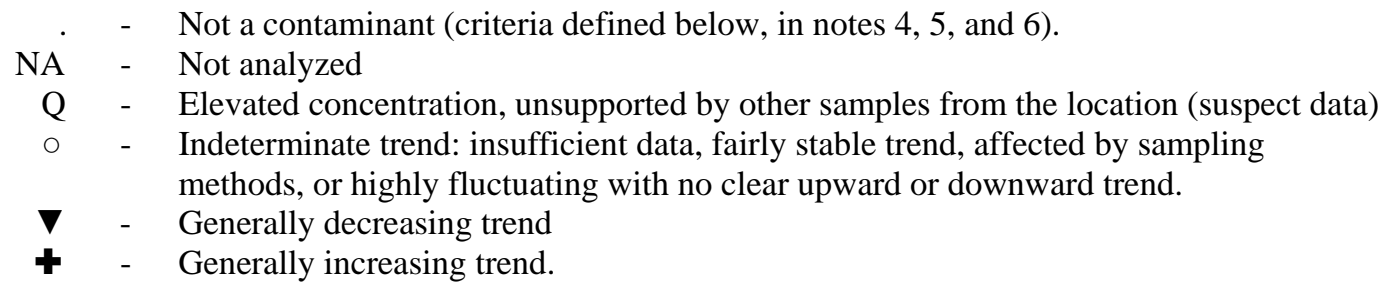

$4 \quad$ CY 2009 nitrate $\left(\mathrm{NO}^{3}\right)$ concentration greater than or equal to $10 \mathrm{mg} / \mathrm{L}$.

Total uranium $(\mathrm{U})$ concentration greater than or equal to $0.03 \mathrm{mg} / \mathrm{L}$.

5 Summed CY 2009 concentration of a solvent group (see below) greater than or equal to $5 \mu \mathrm{g} / \mathrm{L}$.

Ethenes $=$ Summed chloroethenes (PCE, TCE, 12DCE, 11DCE, vinyl chloride)

Ethanes = Summed chloroethanes (111TCA, 11DCE, chloroethane)

Methanes $=$ Summed chloromethanes (carbon tetrachloride, chloroform, methylene chloride)

Petrol = Summed petroleum hydrocarbons (benzene, ethylbenzene, toluene, and total xylene)

6 Maximum CY 2009 gross alpha activity greater than or equal to $15 \mathrm{pCi} / \mathrm{L}$

Maximum CY 2009 gross beta activity greater than or equal to $50 \mathrm{pCi} / \mathrm{L}$ 
B-38 
Table B.11 Concentration trends for contaminants detected at CY 2009 sampling locations in the Chestnut Ridge Hydrogeologic Regime

\begin{tabular}{|c|c|c|c|c|c|c|}
\hline \multirow{3}{*}{$\begin{array}{l}\text { Sampling } \\
\text { Location }^{1}\end{array}$} & \multicolumn{6}{|c|}{ 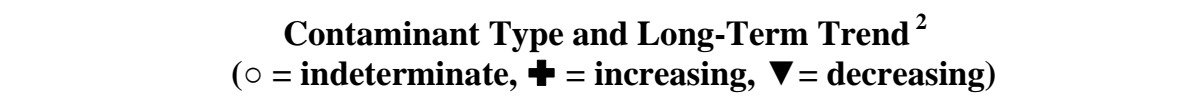 } \\
\hline & \multicolumn{4}{|c|}{ VOCs $^{3}$} & \multicolumn{2}{|c|}{ Radioactivity $^{4}$} \\
\hline & Ethenes & Ethanes & Methanes & Freons & Alpha & Beta \\
\hline 1090 & NA & NA & NA & NA & NA & NA \\
\hline GW-141 & . & . & . & & . & . \\
\hline GW-143 & . & . & . & $\mathrm{NA}$ & . & . \\
\hline GW-144 & . & . & . & NA & . & . \\
\hline GW-145 & & & 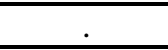 & $\mathrm{NA}$ & 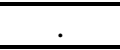 & 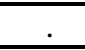 \\
\hline GW-156 & NA & NA & NA & $\mathrm{NA}$ & NA & NA \\
\hline GW-159 & NA & NA & NA & NA & NA & NA \\
\hline GW-161 & . & . & . & NA & . & . \\
\hline GW-174 & . & . & . & $\circ$ & . & . \\
\hline GW-175 & . & & . & 0 & . & . \\
\hline GW-176 & 0 & $\nabla$ & . & o & . & . \\
\hline GW-177 & 0 & $\boldsymbol{\nabla}$ & . & NA & . & . \\
\hline GW-180 & $\nabla$ & & . & $\circ$ & . & . \\
\hline GW-203 & NA & NA & NA & NA & . & . \\
\hline GW-205 & NA & NA & NA & NA & . & 0 \\
\hline GW-217 & $\mathrm{Q}$ & $\cdot$ & . & • & . & . \\
\hline GW-221 & $\mathrm{NA}$ & NA & NA & NA & . & . \\
\hline GW-231 & . & . & . & $\mathrm{NA}$ &. & . \\
\hline GW-294 & . & . & . & NA & . & . \\
\hline GW-296 & . & . & . & $\mathrm{NA}$ & . & . \\
\hline GW-298 & . & . & . & NA & . & . \\
\hline GW-301 & . & . & . & NA & NA & NA \\
\hline GW-305 & 0 & 0 & . & . & . & . \\
\hline GW-322 & 0 & $\bar{\nabla}$ & . & $\bar{\nabla}$ & . & . \\
\hline GW-521 & . & . & . & . & . & . \\
\hline GW-522 & . & . & . & . & . & . \\
\hline GW-540 & . & . &. & . & . & . \\
\hline GW-557 & . & . & . & . & . & . \\
\hline GW-560 & . & . & . & . & . & . \\
\hline GW-562 & . & . & . & . & . & . \\
\hline GW-564 & . & . &. & . & . & . \\
\hline GW-709 & . & . & . & . & . & . \\
\hline GW-731 & NA & NA & NA & NA & NA & $\mathrm{NA}$ \\
\hline GW-732 & NA & NA & NA & NA & NA & NA \\
\hline GW-757 &. & . &. &. & . & . \\
\hline GW-796 & . &. & . & . & . & . \\
\hline GW-797 & 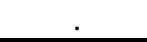 & 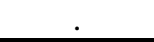 & . & . & . & . \\
\hline GW-798 & 0 & $\circ$ & 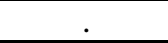 & 0 & . & . \\
\hline GW-799 &. &. & . & . & . &. \\
\hline GW-801 & & & & . & . & . \\
\hline GW-831 & . & & - & NA & NA & NA \\
\hline
\end{tabular}


Table B.11 (continued)

\begin{tabular}{|c|c|c|c|c|c|c|}
\hline \multirow{3}{*}{$\begin{array}{l}\text { Sampling } \\
\text { Location }^{1}\end{array}$} & \multicolumn{6}{|c|}{ 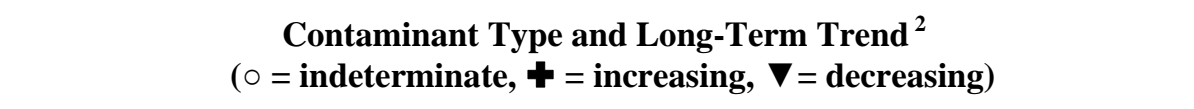 } \\
\hline & \multicolumn{4}{|c|}{ VOCs $^{3}$} & \multicolumn{2}{|c|}{ Radioactivity $^{4}$} \\
\hline & Ethenes & Ethanes & Methanes & Freons & Alpha & Beta \\
\hline MCK 1.4 & NA & NA & NA & NA & . & . \\
\hline MCK 2.0 & NA & NA & NA & NA & . & . \\
\hline MCK 2.05 & NA & NA & NA & NA & . & . \\
\hline S17 & $\cdot$ & . & - & & . & . \\
\hline SCR1.25SP & . & . & . & NA & . & . \\
\hline SCR1.5SW & . & . & . & . & . & . \\
\hline SCR2.1SP & . & . & . & . & . & . \\
\hline SCR2.2SP & . & . & . & . & . & . \\
\hline SCR3.5SP &. &. & . & NA &. &. \\
\hline SCR3.5SW & . & . & . & . & . & . \\
\hline SCR4.3SP & & & & & . & . \\
\hline UNC SW-1 & NA & NA & NA & NA & . & . \\
\hline
\end{tabular}

Notes:

1 The exit pathway/perimeter monitoring locations are in bold typeface.

2 Trend types were interpreted from data tables or plots of concentration changes over time.

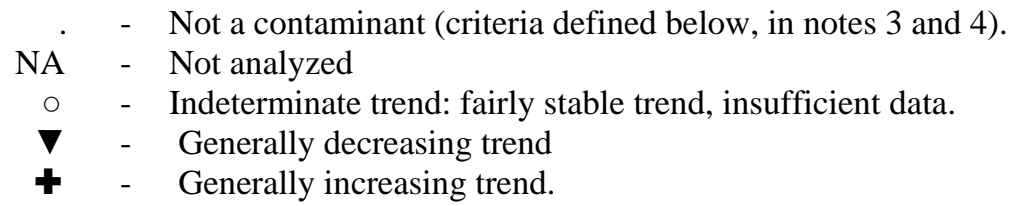

3 Summed CY 2009 concentration of a VOC group (see below) greater than or equal to $1 \mu \mathrm{g} / \mathrm{L}$. (excluding trace levels of common laboratory reagents or suspected artifacts).

Ethenes = Summed chloroethenes (PCE, TCE, 12DCE, 11DCE, vinyl chloride)

Ethanes $=$ Summed chloroethanes (111TCA, 11DCE, chloroethane)

Methanes $=$ Summed chloromethanes (carbon tetrachloride, chloroform, methylene chloride)

Freons $=$ Summed chlorofluorocarbons (1,1,2-trifluoroethane and trichlorofluoromethane)

Note that individual compounds have different long-term concentration trends at wells GW-177, GW-178, GW-305 and GW-322.

4 Maximum CY 2009 gross alpha activity greater than or equal to $15 \mathrm{pCi} / \mathrm{L}$

Maximum CY 2009 gross beta activity greater than or equal to $50 \mathrm{pCi} / \mathrm{L}$ 
APPENDIX C

MONITORING WELL CONSTRUCTION DETAILS 



\section{EXPLANATION}

\section{Hydrogeologic Regime:}

BC

CR

EF

\section{Location:}

B8110

B9201-2

B9201-5

BG

CDLVII

CPT

CRBAWP

CRSDB

CRSP

ECRWP

EMWMF

EXP

FCAP

FF

GRID

KHQ

LII

LIV

LV

NHP

OLF

RG

RS

S2

S3

SPI

SY

T0134

T2331

UNCS

WCPA

Y12
- $\quad$ Bear Creek Hydrogeologic Regime

- $\quad$ Chestnut Ridge Hydrogeologic Regime

- $\quad$ Upper East Fork Poplar Creek Hydrogeologic Regime
- $\quad$ Building 81-10

- $\quad$ Building 9201-2

- $\quad$ Building 9201-5

- $\quad$ Bear Creek Burial Grounds WMA

- $\quad$ Construction/Demolition Landfill VII

- $\quad$ Coal Pile Trench

- $\quad$ Chestnut Ridge Borrow Area Waste Pile (former site)

- $\quad$ Chestnut Ridge Sediment Disposal Basin

- $\quad$ Chestnut Ridge Security Pits

- $\quad$ East Chestnut Ridge Waste Pile

- $\quad$ Environmental Management Waste Management Facility

- $\quad$ Exit Pathway Monitoring Location:

Maynardville Limestone Picket (-A, -B, -C, -E, -I, -J, and -W)

Along Scarboro Road in the gap through Pine Ridge (-SR)

East of Scarboro Road in Union Valley (-UV)

- $\quad$ Filled Coal Ash Pond

- $\quad$ Fuel Facility (Building 9754-2)

- $\quad$ Comprehensive Groundwater Monitoring Plan Grid Location (MMES 1990b)

- $\quad$ Kerr Hollow Quarry

- $\quad$ Industrial Landfill II

- $\quad$ Industrial Landfill IV

- $\quad$ Industrial Landfill V

- $\quad$ New Hope Pond

- $\quad$ Oil Landfarm WMA

- $\quad$ Rust Garage Area

- $\quad$ Rust Spoil Area

- $\quad$ S-2 Site

- $\quad$ S-3 Site

- $\quad$ Spoil Area I

- $\quad$ Y-12 Salvage Yard

- $\quad$ Tank 0134-U

- $\quad$ Tank 2331-U, near Building 9201-1

- $\quad$ United Nuclear Corporation Site

- Waste Coolant Processing Area

- $\quad$ Y-12 Complex 


\section{EXPLANATION (continued)}

\section{General Information:}

Depth

Coordinates

Measuring Point

Elevation

Tag Depth
- $\quad$ Feet below ground surface (rounded to nearest $0.1 \mathrm{ft}$ )

- Y-12 grid system (rounded to nearest foot)

- $\quad$ Top of well casing (TOC) or top of Well Wizard ${ }^{\mathrm{TM}}$ (TOWW)

- Feet above mean sea level (rounded to nearest $0.01 \mathrm{ft}$ )

- Depth to the bottom of the well (feet below the TOC), taken from the CY 2003 comprehensive well inspection program

- Not Applicable or not available

\section{Geologic Information (regarding the monitored interval):}

\section{Hydrostratigraphic Unit:}

AQF

AQT

Geologic Formation:

OCk

Cc

$\mathrm{Cm}$

$\mathrm{Cn}$

Cmn

$\mathrm{Cpv}$

Crg

$\mathrm{Cr}$

\section{Aquifer Zone:}

BDR

WT

Depth
- Aquifer (Maynardville Limestone and Knox Group)

- Aquitard (other formations of the Conasauga Group)

- Knox Group, undifferentiated

- Conasauga Group, undifferentiated

- Maryville Limestone

- Nolichucky Shale

- Maynardville Limestone

- $\quad$ Pumpkin Valley Shale

- Rogersville Shale

- Rome Formation

- Bedrock interval (monitored interval top is in fresh rock)

- Water table interval (monitored interval top is above fresh rock)

- $\quad$ Feet below ground surface (rounded to nearest $0.1 \mathrm{ft}$ )

\section{Conductor (Surface) Casing and Well Casing:}

Depth

Diameter

PVC40

SS304

STL

S/gal

SF25/SJ55
- Feet below ground surface (rounded to nearest $0.1 \mathrm{ft}$ )

- Outside or inside dimensions, in inches

- Polyvinyl chloride, schedule 40

- $\quad$ Stainless steel, schedule 304

- Carbon steel

- Galvanized steel

- Steel; American Petroleum Institute Grade 


\section{EXPLANATION (continued)}

\section{Monitored Interval:}

Top

Bottom

Screen Material:

$\mathrm{PVC} / \mathrm{sl}$

SS/ppk

$\mathrm{SS} / \mathrm{sl}$

$\mathrm{SS} / \mathrm{sw}$

Slot Size
- Depth to top of filter pack or open-hole (feet below ground surface)

- Depth to bottom of filter pack or open-hole (feet below ground surface)

- PVC, slotted

- $\quad$ Stainless steel prepack screen, spiral wound

- Stainless steel, slotted

- $\quad$ Stainless steel, spiral wound

- $\quad$ size of screen or slot openings, in inches

\section{NOTE:}

Data compiled from the Updated Subsurface Data Base for Bear Creek Valley, Chestnut Ridge, and parts of Bethel Valley on the U.S. Department of Energy Oak Ridge Reservation (BWXT 2003b) and subsequent updates maintained electronically. 

APPENDIX C: MONITORING WELL CONSTRUCTION DETAILS, CY 2009

\begin{tabular}{|c|c|c|c|c|c|c|c|c|c|c|}
\hline $\begin{array}{r}\text { Well Number } \\
\text { Hydrogeologic Regime } \\
\text { Functional Area }\end{array}$ & $\begin{array}{c}1090 \\
\text { CR } \\
\text { UNCS }\end{array}$ & $\begin{array}{c}\text { 55-2A } \\
\text { EF } \\
\text { GRIDB3 }\end{array}$ & $\begin{array}{c}\text { 55-2B } \\
\text { EF } \\
\text { GRIDB3 }\end{array}$ & $\begin{array}{c}55-2 C \\
\text { EF } \\
\text { GRIDB3 }\end{array}$ & $\begin{array}{c}55-3 A \\
E F \\
B 9201-5\end{array}$ & $\begin{array}{c}55-3 B \\
E F \\
B 9201-5\end{array}$ & $\begin{array}{c}55-3 C \\
E F \\
B 9201-5\end{array}$ & $\begin{array}{l}56-1 A \\
\text { EF } \\
\text { Y12 }\end{array}$ & $\begin{array}{c}56-1 C \\
\text { EF } \\
\text { Y12 }\end{array}$ & $\begin{array}{c}\text { 56-2A } \\
\text { EF } \\
\text { GRIDC3 }\end{array}$ \\
\hline \multicolumn{11}{|l|}{ General Information } \\
\hline Date Installed & 1982 & 08/08/83 & 1983 & $08 / 22 / 83$ & 1983 & 1983 & 1983 & 1983 & $08 / 25 / 83$ & 1983 \\
\hline Total Depth Drilled & 96.7 & 14.1 & 27.6 & 75.9 & 14.3 & 38.1 & 77.5 & 19.0 & 75.3 & 15.1 \\
\hline East Coordinate & 53,853 & 55,195 & 55,199 & 55,203 & 55,695 & 55,699 & 55,703 & 56,079 & 56,077 & 56,229 \\
\hline North Coordinate & 28,718 & 30,085 & 30,085 & 30,085 & 29,959 & 29,959 & 29,959 & 30,351 & 30,355 & 29,881 \\
\hline Measuring Point & TOWW & TOWW & TOWW & Toww & TOWW & TOWW & TOWW & TOWW & TOC & TOWW \\
\hline Measuring Point Elevation & $1,104.48$ & 976.74 & 977.42 & 977.02 & 972.46 & 973.32 & 974.34 & 969.25 & 969.49 & 963.53 \\
\hline Ground Surface Elevation & $1,101.58$ & 976.17 & 976.17 & 976.07 & 971.59 & 971.57 & 971.76 & 968.72 & 968.89 & 962.52 \\
\hline Tag Depth-(TOC) & 98.02 & 13.98 & 27.69 & 76.00 & 14.25 & 37.98 & 77.43 & 18.95 & 73.45 & 15.03 \\
\hline \multicolumn{11}{|l|}{ Geologic Information } \\
\hline Hydrostratigraphic Unit & AQF & AQT & AQT & AQT & AQT & AQT & AQT & AQT & AQT & AQT \\
\hline Geologic Formation & oCk & $\mathrm{Cn}$ & $\mathrm{Cn}$ & $\mathrm{Cn}$ & $\mathrm{Cn}$ & $\mathrm{Cn}$ & $\mathrm{Cn}$ & $\mathrm{Cn}$ & $\mathrm{Cn}$ & $\mathrm{Cn}$ \\
\hline Aquifer Zone & WT & WT & WT & BDR & WT & WT & $\mathrm{BDR}$ & WT & $\mathrm{BDR}$ & WT \\
\hline Weathered Rock-Depth & & 11.5 & 10.0 & 14.5 & 7.0 & 5.0 & 7.0 & 2.0 & 6.0 & \\
\hline Fresh Rock-Depth & & & & 47.2 & & & & & 10.0 & \\
\hline \multicolumn{11}{|l|}{ Conductor Casing } \\
\hline Casing Depth & & & & 15.5 & & & & & 7.0 & \\
\hline Outside Diameter & & & & 4.5 & & & & & 4.5 & \\
\hline $\begin{array}{l}\text { Inside Diameter } \\
\text { Casing Material }\end{array}$ & & & & $\mathrm{STL}$ & & & & & $\mathrm{STL}$ & \\
\hline \multicolumn{11}{|l|}{ Well Casing } \\
\hline Borehole Depth & 96.7 & 14.1 & 27.6 & 75.9 & 14.3 & 38.1 & 77.5 & 19.0 & 75.3 & 15.1 \\
\hline Borehole Diameter & 8 & 6 & 6 & 6 & 6 & 6 & 6 & 6 & 6 & 6 \\
\hline Casing Depth & & 9.1 & 22.6 & 70.9 & 9.3 & 33.1 & 72.5 & 14.0 & 70.3 & 10.1 \\
\hline Outside Diameter & 6.5 & 4.5 & 4.5 & 4.5 & 4.5 & 4.5 & 4.5 & 4.5 & 4.5 & 4.5 \\
\hline Inside Diameter & & 4 & & 4 & 4 & 4 & 4 & 4 & 4 & 4 \\
\hline Casing Material & PVC40 & PVC40 & PVC40 & PVC40 & PVC40 & PVC40 & PVC40 & PVC40 & PVC40 & PVC40 \\
\hline \multicolumn{11}{|l|}{ Monitored Interval } \\
\hline Top-Depth & & 6.1 & 19.6 & 67.9 & 6.3 & 30.1 & 69.5 & 11.0 & 67.3 & 7.1 \\
\hline Midpoint-Depth & & 10.1 & 23.6 & 71.9 & 10.3 & 34.1 & 73.5 & 15.0 & 71.3 & 11.1 \\
\hline Pump Intake-Depth & 84.80 & 11.43 & 25.00 & 73.30 & 12.13 & 33.75 & 72.42 & 15.97 & & 12.00 \\
\hline Bottom of Screen-Depth & & 14.1 & 27.6 & 75.9 & 14.3 & 38.1 & 77.5 & 19.0 & 75.3 & 15.1 \\
\hline Bottom-Depth & 96.7 & 14.1 & 27.6 & 75.9 & 14.3 & 38.1 & 77.5 & 19.0 & 75.3 & 15.1 \\
\hline Top-Elevation & & 970.07 & 956.57 & 908.17 & 965.29 & 941.47 & 902.26 & 957.72 & 901.59 & 955.42 \\
\hline Midpoint-Elevation & & 966.07 & 952.57 & 904.17 & 961.29 & 937.47 & 898.26 & 953.72 & 897.59 & 951.42 \\
\hline Pump Intake-Elevation & 1016.78 & 964.74 & 951.22 & 902.82 & 959.46 & 937.82 & 899.34 & 952.75 & & 950.53 \\
\hline Bottom-Elevation & $1,004.88$ & 962.07 & 948.57 & 900.17 & 957.29 & 933.47 & 894.26 & 949.72 & 893.59 & 947.42 \\
\hline Screen Length & & & & & & & & 5 & 5 & 5 \\
\hline Screen Material & $\mathrm{PVC} / \mathrm{sl}$ & SS/sw & SS/sw & $\mathrm{SS} / \mathrm{sw}$ & $\mathrm{SS} / \mathrm{sw}$ & SS/sw & $\mathrm{SS} / \mathrm{sw}$ & SS/sw & $\mathrm{SS} / \mathrm{sw}$ & $\mathrm{SS} / \mathrm{sw}$ \\
\hline Slot Size & & 0.01 & 0.01 & 0.01 & 0.01 & 0.01 & 0.01 & 0.01 & 0.01 & 0.01 \\
\hline Open-Hole Length & & & & & & & & & & \\
\hline Open-Hole Diameter & & & & & & & & & & \\
\hline
\end{tabular}


APPENDIX C: MONITORING WELL CONSTRUCTION DETAILS, CY 2009

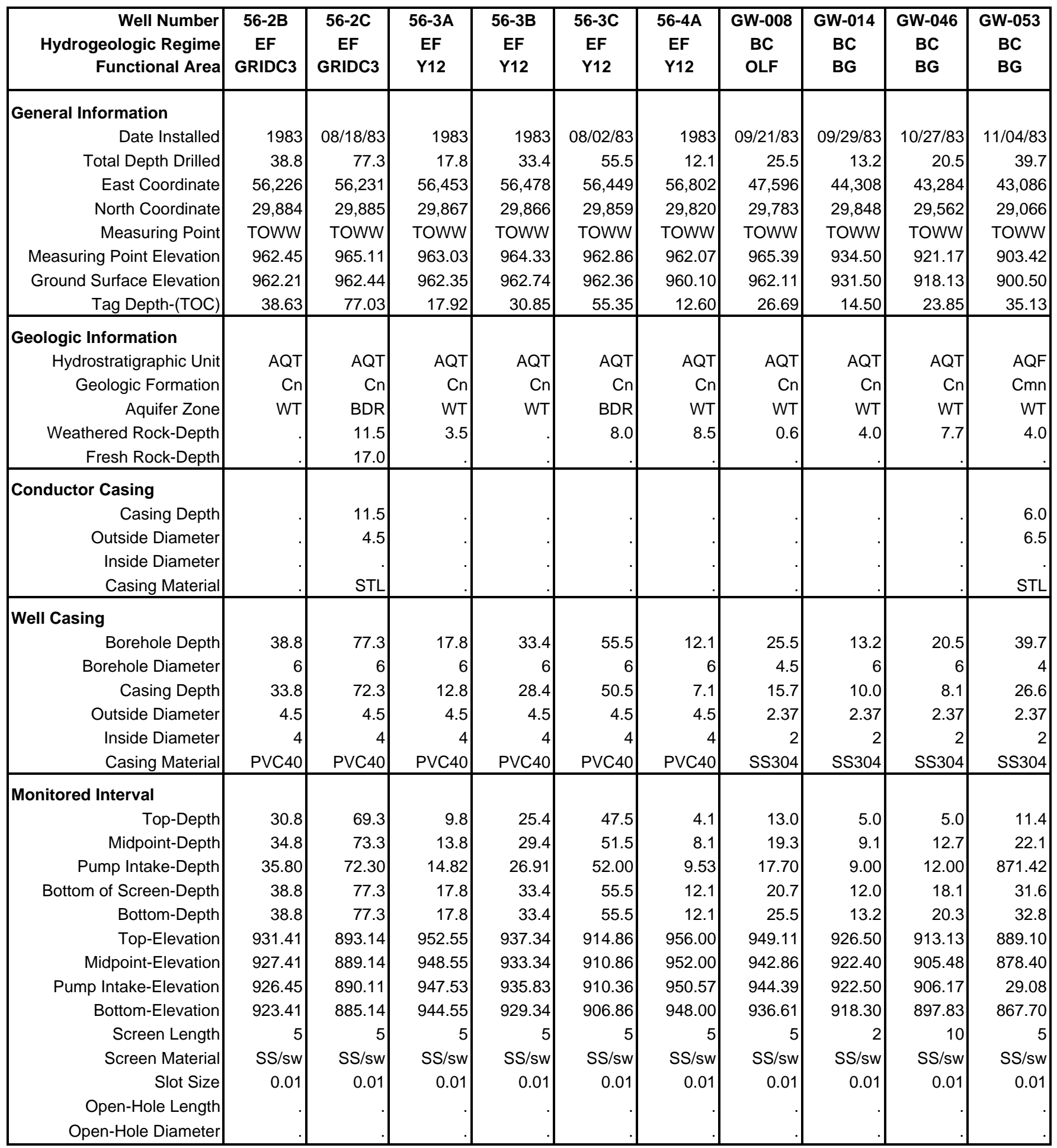


APPENDIX C: MONITORING WELL CONSTRUCTION DETAILS, CY 2009

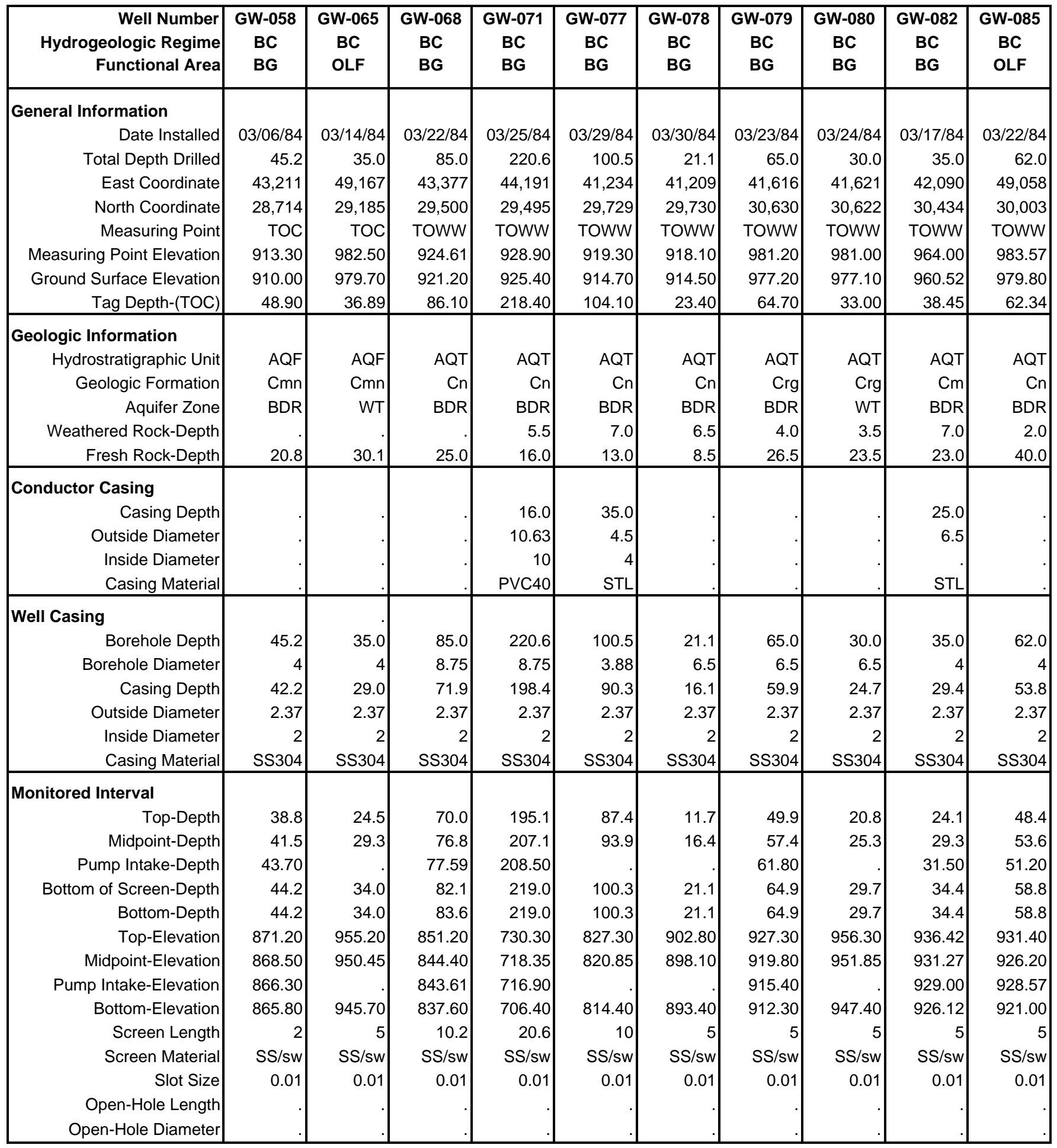


APPENDIX C: MONITORING WELL CONSTRUCTION DETAILS, CY 2009

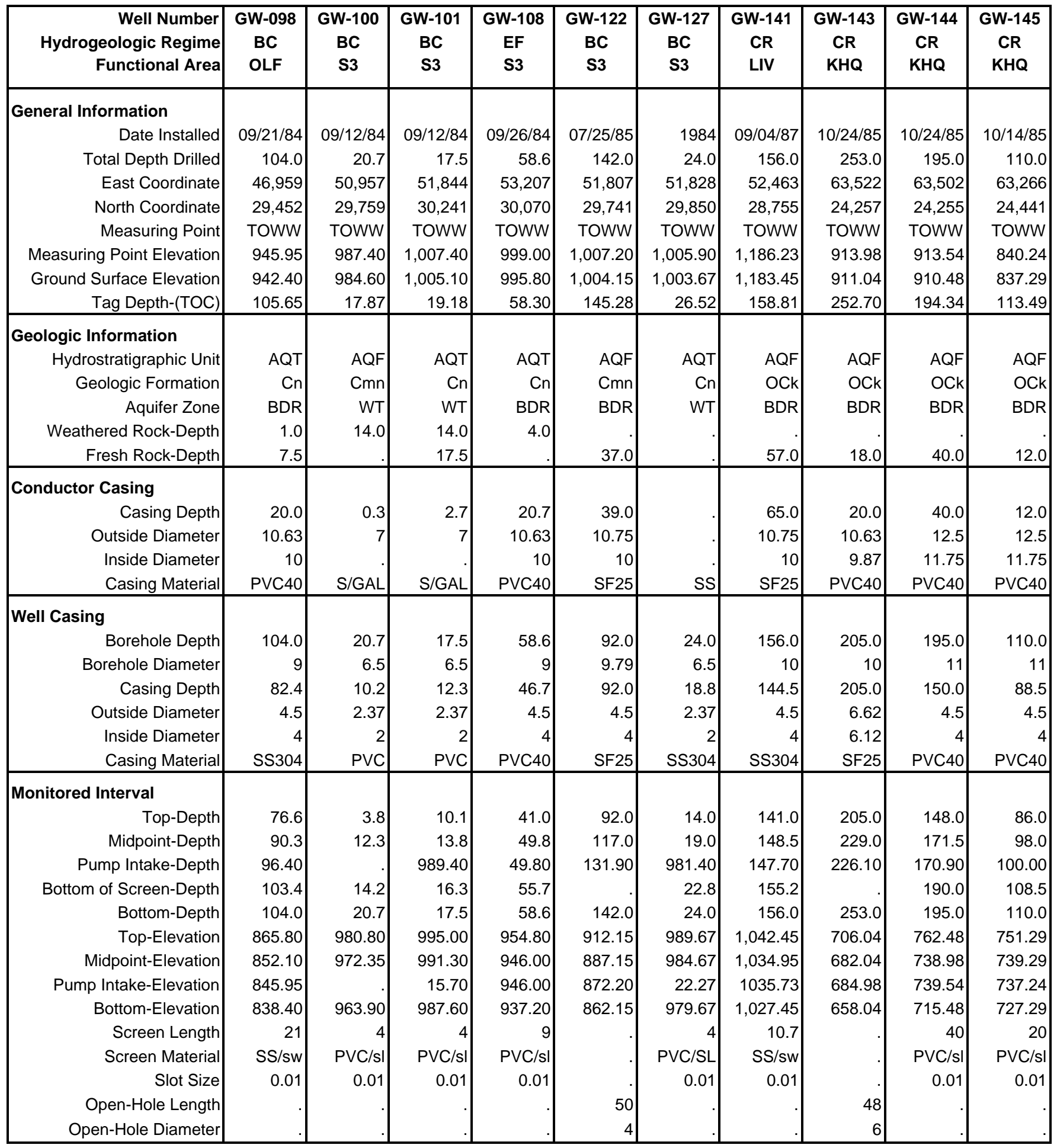


APPENDIX C: MONITORING WELL CONSTRUCTION DETAILS, CY 2009

\begin{tabular}{|c|c|c|c|c|c|c|c|c|c|c|}
\hline $\begin{array}{r}\text { Well Number } \\
\text { Hydrogeologic Regime } \\
\text { Functional Area }\end{array}$ & $\begin{array}{c}\text { GW-151 } \\
\text { EF } \\
\text { NHP }\end{array}$ & $\begin{array}{c}\text { GW-153 } \\
\text { EF } \\
\text { NHP }\end{array}$ & $\begin{array}{c}\text { GW-154 } \\
\text { EF } \\
\text { NHP }\end{array}$ & $\begin{array}{c}\text { GW-156 } \\
\text { CR } \\
\text { CRSDB }\end{array}$ & $\begin{array}{c}\text { GW-159 } \\
\text { CR } \\
\text { CRSDB }\end{array}$ & $\begin{array}{c}\text { GW-161 } \\
\text { CR } \\
\text { ECRWP }\end{array}$ & $\begin{array}{l}\text { GW-169 } \\
\text { EF } \\
\text { EXP-UV }\end{array}$ & $\begin{array}{c}\text { GW-170 } \\
\text { EF } \\
\text { EXP-UV }\end{array}$ & $\begin{array}{c}\text { GW-171 } \\
\text { EF } \\
\text { EXP-UV }\end{array}$ & $\begin{array}{l}\text { GW-172 } \\
\text { EF } \\
\text { EXP-UV }\end{array}$ \\
\hline \multicolumn{11}{|l|}{ General Information } \\
\hline Date Installed & $08 / 14 / 85$ & $10 / 31 / 85$ & $07 / 30 / 85$ & $10 / 18 / 85$ & $10 / 18 / 85$ & $07 / 07 / 87$ & $09 / 16 / 86$ & $04 / 01 / 86$ & $02 / 26 / 86$ & $05 / 05 / 86$ \\
\hline Total Depth Drilled & 96.5 & 60.0 & 11.2 & 157.6 & 157.0 & 400.0 & 34.8 & 156.9 & 31.2 & 133.9 \\
\hline East Coordinate & 64,232 & 63,728 & 63,346 & 64,020 & 63,496 & 62,146 & 66,854 & 66,843 & 69,654 & 69,579 \\
\hline North Coordinate & 28,958 & 28,613 & 28,987 & 27,626 & 27,764 & 27,805 & 28,545 & 28,545 & 28,403 & 28,358 \\
\hline Measuring Point & TOWW & TOWW & TOWW & TOWW & TOWW & TOC & TOWW & TOWW & TOWW & TOWW \\
\hline Measuring Point Elevation & 916.17 & 921.68 & 911.70 & $1,049.28$ & $1,051.38$ & $1,093.54$ & 932.12 & 932.64 & 920.72 & 926.69 \\
\hline Ground Surface Elevation & 913.06 & 918.53 & 908.60 & $1,046.94$ & $1,048.79$ & $1,090.91$ & 929.95 & 930.70 & 918.55 & 922.85 \\
\hline Tag Depth-(TOC) & 99.63 & 60.84 & 13.35 & 157.65 & 155.87 & 402.88 & 36.23 & 156.16 & 32.64 & 137.50 \\
\hline \multicolumn{11}{|l|}{ Geologic Information } \\
\hline Hydrostratigraphic Unit & $\mathrm{AQF}$ & AQF & AQF & AQF & AQF & AQF & AQF & AQF & AQF & $\mathrm{AQF}$ \\
\hline Geologic Formation & $\mathrm{Cmn}$ & $\mathrm{Cmn}$ & $\mathrm{Cmn}$ & ock & OCk & ock & $\mathrm{Cmn}$ & $\mathrm{Cmn}$ & $\mathrm{Cmn}$ & $\mathrm{Cmn}$ \\
\hline Aquifer Zone & BDR & BDR & WT & $\mathrm{BDR}$ & BDR & BDR & WT & $\mathrm{BDR}$ & WT & BDR \\
\hline Weathered Rock-Depth & & & 11.2 & 84.0 & & 65.0 & & & & 15.0 \\
\hline Fresh Rock-Depth & 12.0 & 14.0 & & 93.0 & 100.0 & 95.5 & & 30.0 & & 19.0 \\
\hline \multicolumn{11}{|l|}{ Conductor Casing } \\
\hline Casing Depth & 12.0 & 29.0 & & 94.0 & 123.0 & 108.0 & & 30.0 & & 35.0 \\
\hline Outside Diameter & 12.5 & 10.63 & & 10.75 & 10.75 & 12.5 & & 8.63 & & 8.63 \\
\hline Inside Diameter & 11.75 & 9.88 & & & 10 & & & & & \\
\hline Casing Material & PVC40 & PVC40 & & SF25 & SF25 & SF25 & & PVC40 & & SF25 \\
\hline \multicolumn{11}{|l|}{ Well Casing } \\
\hline Borehole Depth & 96.5 & 60.0 & 11.2 & 157.0 & 157.0 & 350.0 & 42.0 & 104.0 & 31.2 & 105.0 \\
\hline Borehole Diameter & 11 & 11 & 8 & 8.5 & 8.5 & 11 & 8 & 6.62 & 8 & 6.62 \\
\hline Casing Depth & 86.0 & 49.5 & 5.7 & 147.0 & 147.0 & 350.0 & 29.7 & 104.0 & 26.8 & 105.0 \\
\hline Outside Diameter & 4.5 & 4.5 & 4.5 & 4.5 & 4.5 & 6.62 & 2.37 & 4.38 & 2.37 & 4.38 \\
\hline Inside Diameter & & 4 & 4 & 4 & 4 & & 2 & 4 & 2 & \\
\hline Casing Material & PVC40 & PVC40 & PVC40 & PVC40 & PVC40 & SF25 & PVC40 & STL & PVC40 & STL \\
\hline \multicolumn{11}{|l|}{ Monitored Interval } \\
\hline Top-Depth & 85.0 & 45.0 & 4.7 & 145.0 & 145.0 & 350.0 & 28.7 & 104.0 & 25.8 & 105.0 \\
\hline Midpoint-Depth & 90.8 & 52.5 & 8.0 & 151.3 & 151.0 & 375.0 & 31.8 & 130.5 & 28.5 & 119.4 \\
\hline Pump Intake-Depth & 90.80 & 52.90 & 8.40 & 150.70 & 148.40 & & & 124.10 & & 123.20 \\
\hline Bottom of Screen-Depth & 96.0 & 59.5 & 10.7 & 157.0 & 157.0 & & 34.7 & & 31.2 & \\
\hline Bottom-Depth & 96.5 & 60.0 & 11.2 & 157.6 & 157.0 & 400.0 & 34.8 & 156.9 & 31.2 & 133.8 \\
\hline Top-Elevation & 828.06 & 873.53 & 903.90 & 901.94 & 903.79 & 740.91 & 901.25 & 826.70 & 892.75 & 817.85 \\
\hline Midpoint-Elevation & 822.31 & 866.03 & 900.65 & 895.64 & 897.79 & 715.91 & 898.20 & 800.25 & 890.05 & 803.45 \\
\hline Pump Intake-Elevation & 822.27 & 865.68 & 900.20 & 896.28 & 900.38 & & & 806.64 & & 799.69 \\
\hline Bottom-Elevation & 816.56 & 858.53 & 897.40 & 889.34 & 891.79 & 690.91 & 895.15 & 773.80 & 887.35 & 789.05 \\
\hline Screen Length & & & & & 10 & & & & 4.4 & \\
\hline Screen Material & $\mathrm{PVC} / \mathrm{sl}$ & $\mathrm{PVC} / \mathrm{sl}$ & $\mathrm{PVC} / \mathrm{sl}$ & $\mathrm{PVC} / \mathrm{sl}$ & $\mathrm{PVC} / \mathrm{sl}$ & & PVC/sl & & $\mathrm{PVC} / \mathrm{sl}$ & \\
\hline Slot Size & 0.01 & 0.01 & 0.01 & 0.01 & 0.01 & & 0.01 & & 0.01 & \\
\hline Open-Hole Length & & & & & & 50 & & 52.9 & & 28.8 \\
\hline Open-Hole Diameter & & & & & & 11 & & 3.88 & & 3.63 \\
\hline
\end{tabular}


APPENDIX C: MONITORING WELL CONSTRUCTION DETAILS, CY 2009

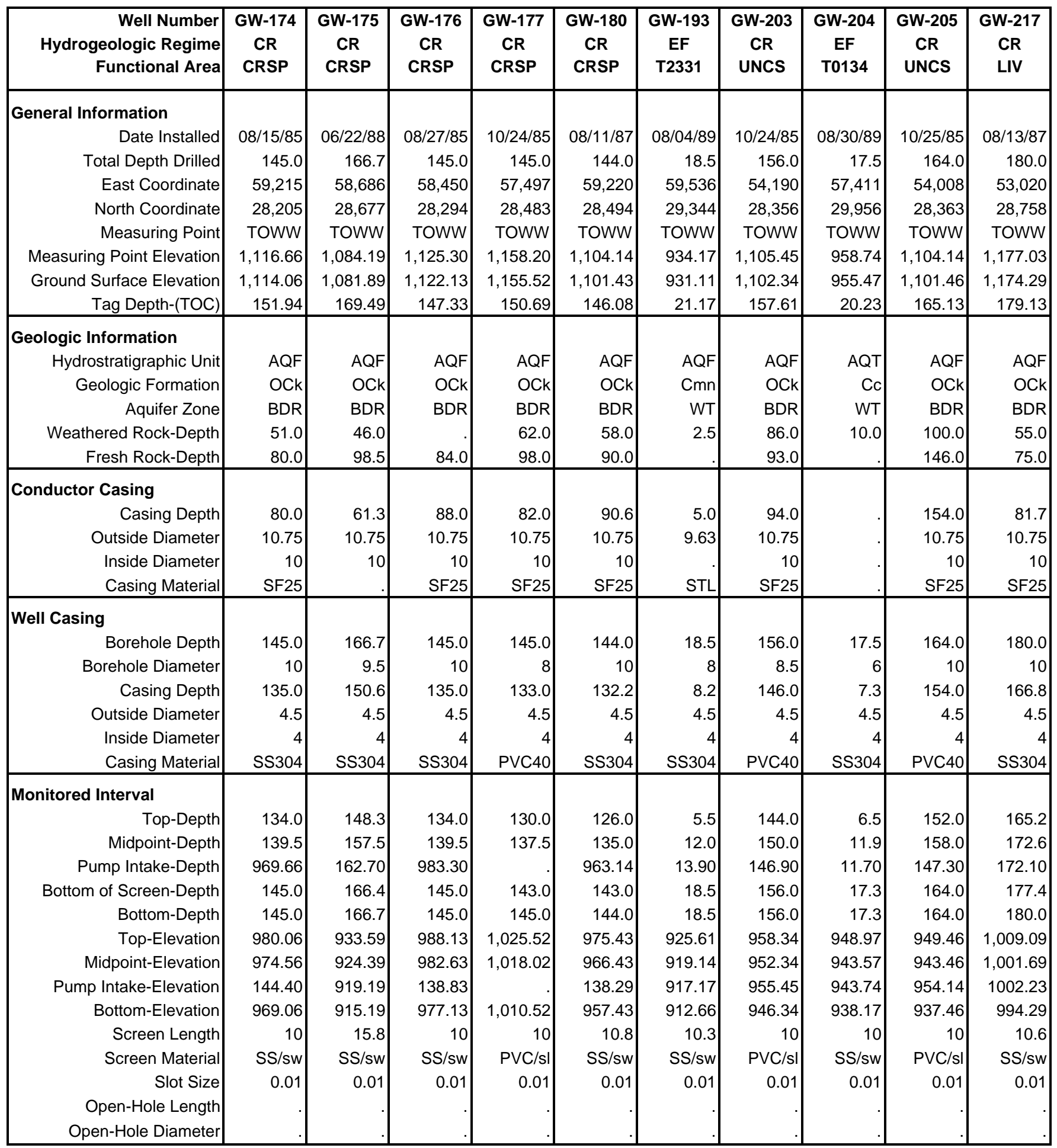


APPENDIX C: MONITORING WELL CONSTRUCTION DETAILS, CY 2009

\begin{tabular}{|c|c|c|c|c|c|c|c|c|c|c|}
\hline $\begin{array}{r}\text { Well Number } \\
\text { Hydrogeologic Regime } \\
\text { Functional Area }\end{array}$ & $\begin{array}{c}\text { GW-219 } \\
\text { EF } \\
\text { UOV }\end{array}$ & $\begin{array}{c}\text { GW-220 } \\
\text { EF } \\
\text { NHP }\end{array}$ & $\begin{array}{c}\text { GW-221 } \\
\text { CR } \\
\text { UNCS }\end{array}$ & $\begin{array}{c}\text { GW-222 } \\
\text { EF } \\
\text { NHP }\end{array}$ & $\begin{array}{c}\text { GW-223 } \\
\text { EF } \\
\text { NHP }\end{array}$ & $\begin{array}{c}\text { GW-225 } \\
\text { BC } \\
\text { OLF }\end{array}$ & $\begin{array}{c}\text { GW-229 } \\
\text { BC } \\
\text { OLF }\end{array}$ & $\begin{array}{c}\text { GW-230 } \\
\text { EF } \\
\text { EXP-UV }\end{array}$ & $\begin{array}{c}\text { GW-231 } \\
\text { CR } \\
\text { KHQ }\end{array}$ & $\begin{array}{c}\text { GW-236 } \\
\text { BC } \\
\text { S3 }\end{array}$ \\
\hline $\begin{array}{r}\text { Deneral Information } \\
\text { Date Installed } \\
\text { Total Depth Drilled } \\
\text { East Coordinate } \\
\text { North Coordinate } \\
\text { Measuring Point } \\
\text { Measuring Point Elevation } \\
\text { Ground Surface Elevation } \\
\text { Tag Depth-(TOC) }\end{array}$ & $\begin{array}{r}07 / 30 / 87 \\
11.3 \\
58,929 \\
29,163 \\
\text { TOWW } \\
935.83 \\
931.27 \\
15.59 \\
\end{array}$ & $\begin{array}{r}08 / 22 / 85 \\
45.2 \\
64,225 \\
28,949 \\
\text { TOWW } \\
915.64 \\
912.74 \\
49.00 \\
\end{array}$ & $\begin{array}{r}10 / 24 / 85 \\
158.0 \\
54,389 \\
28,359 \\
\text { TOWW } \\
1,106.16 \\
1,103.36 \\
159.34 \\
\end{array}$ & $\begin{array}{r}08 / 24 / 85 \\
25.0 \\
63,324 \\
28,954 \\
\text { TOWW } \\
911.82 \\
908.82 \\
28.55 \\
\end{array}$ & $\begin{array}{r}08 / 21 / 85 \\
90.5 \\
63,311 \\
28,938 \\
\text { TOWW } \\
911.62 \\
908.97 \\
93.57 \\
\end{array}$ & $\begin{array}{r}10 / 08 / 85 \\
200.0 \\
47,461 \\
29,155 \\
\text { TOWW } \\
943.11 \\
940.21 \\
203.30 \\
\end{array}$ & $\begin{array}{r}10 / 30 / 85 \\
55.0 \\
47,017 \\
29,256 \\
\text { TOWW } \\
949.00 \\
945.71 \\
51.45 \\
\end{array}$ & $\begin{array}{r}05 / 12 / 86 \\
406.4 \\
69,617 \\
28,388 \\
\text { TOWW } \\
923.11 \\
919.57 \\
409.48 \\
\end{array}$ & $\begin{array}{r}10 / 02 / 85 \\
35.0 \\
63,410 \\
24,725 \\
\text { TOWW } \\
849.67 \\
846.90 \\
37.70 \\
\end{array}$ & $\begin{array}{r}10 / 16 / 85 \\
18.5 \\
50,453 \\
29,712 \\
\text { TOWW } \\
983.21 \\
980.39 \\
21.14 \\
\end{array}$ \\
\hline $\begin{array}{r}\text { eologic Information } \\
\text { Hydrostratigraphic Unit } \\
\text { Geologic Formation } \\
\text { Aquifer Zone } \\
\text { Weathered Rock-Depth } \\
\text { Fresh Rock-Depth }\end{array}$ & $\begin{array}{r}\text { AQF } \\
\text { Cmn } \\
\text { WT }\end{array}$ & $\begin{array}{r}\mathrm{AQF} \\
\mathrm{Cmn} \\
\mathrm{BDR} \\
11.0 \\
\end{array}$ & $\begin{array}{c}\text { AQF } \\
\text { OCk } \\
\text { BDR } \\
36.0 \\
90.0 \\
\end{array}$ & $\begin{array}{r}\text { AQF } \\
\mathrm{Cmn} \\
\mathrm{BDR} \\
. \\
10.0 \\
\end{array}$ & $\begin{array}{l}\text { AQF } \\
\text { Cmn } \\
\text { BDR } \\
10.0 \\
\end{array}$ & $\begin{array}{r}\text { AQF } \\
\text { Cmn } \\
\text { BDR } \\
. \\
25.0 \\
\end{array}$ & $\begin{array}{l}\text { AQF } \\
\text { Cmn } \\
\text { BDR } \\
30.0 \\
\end{array}$ & $\begin{array}{l}\text { AQF } \\
\text { Cmn } \\
\text { BDR } \\
19.0 \\
38.0 \\
\end{array}$ & $\begin{array}{r}\text { AQF } \\
\text { OCk } \\
\text { BDR } \\
. \\
10.5 \\
\end{array}$ & $\begin{array}{r}\text { AQF } \\
\mathrm{Cmn} \\
\mathrm{WT} \\
9.0 \\
18.5 \\
\end{array}$ \\
\hline $\begin{array}{l}\text { onductor Casing } \\
\text { Casing Depth } \\
\text { Outside Diameter } \\
\text { Inside Diameter } \\
\text { Casing Material }\end{array}$ & NONE & $\begin{array}{r}13.0 \\
12.5 \\
11.75 \\
\text { PVC40 }\end{array}$ & $\begin{array}{r}92.0 \\
6.63 \\
\text { SF25 }\end{array}$ & $\begin{array}{r}11.0 \\
12.5 \\
11.75 \\
\text { PVC40 }\end{array}$ & $\begin{array}{r}11.0 \\
12.5 \\
11.75 \\
\text { PVC40 }\end{array}$ & $\begin{array}{r}32.0 \\
10.75 \\
10 \\
\text { STL }\end{array}$ & $\begin{array}{r}37.0 \\
10.75 \\
10 \\
\text { STL }\end{array}$ & $\begin{array}{r}31.0 \\
8.63 \\
\text { STL }\end{array}$ & $\begin{array}{r}11.0 \\
10.63 \\
10 \\
\text { PVC40 }\end{array}$ & NONE \\
\hline $\begin{array}{r}\text { Bll Casing } \\
\text { Borehole Depth } \\
\text { Borehole Diameter } \\
\text { Casing Depth } \\
\text { Outside Diameter } \\
\text { Inside Diameter } \\
\text { Casing Material }\end{array}$ & $\begin{array}{r}11.3 \\
10 \\
5.7 \\
4.5 \\
4 \\
\text { SS304 }\end{array}$ & $\begin{array}{r}45.2 \\
11 \\
34.7 \\
4.5 \\
4 \\
\text { PVC } 40\end{array}$ & $\begin{array}{r}158.0 \\
6 \\
148.0 \\
4.5 \\
4 \\
\text { PVC40 }\end{array}$ & $\begin{array}{r}25.0 \\
11 \\
19.5 \\
4.5 \\
4 \\
\text { PVC40 }\end{array}$ & $\begin{array}{r}90.5 \\
11 \\
80.0 \\
4.5 \\
4 \\
\text { PVC } 40\end{array}$ & $\begin{array}{r}150.0 \\
10 \\
150.0 \\
4.5 \\
4 \\
\text { STL }\end{array}$ & $\begin{array}{r}40.0 \\
10 \\
40.0 \\
4.5 \\
4 \\
\text { STL }\end{array}$ & $\begin{array}{r}341.0 \\
5.5 \\
341.0 \\
4.38 \\
4 \\
\text { STL }\end{array}$ & $\begin{array}{r}35.0 \\
11 \\
24.5 \\
4.5 \\
4 \\
\text { PVC } 40\end{array}$ & $\begin{array}{r}18.5 \\
8 \\
13.0 \\
4.5 \\
\text { PVC } 40\end{array}$ \\
\hline $\begin{array}{r}\text { nitored Interval } \\
\text { Top-Depth } \\
\text { Midpoint-Depth } \\
\text { Pump Intake-Depth } \\
\text { Bottom of Screen-Depth } \\
\text { Bottom-Depth } \\
\text { Top-Elevation } \\
\text { Midpoint-Elevation } \\
\text { Pump Intake-Elevation } \\
\text { Bottom-Elevation } \\
\text { Screen Length } \\
\text { Screen Material } \\
\text { Slot Size } \\
\text { Open-Hole Length } \\
\text { Open-Hole Diameter }\end{array}$ & $\begin{array}{r}4.3 \\
7.8 \\
922.33 \\
11.3 \\
11.3 \\
926.97 \\
923.47 \\
8.94 \\
919.97 \\
5.6 \\
\mathrm{SS} / \mathrm{sw} \\
0.01\end{array}$ & $\begin{array}{r}31.0 \\
38.1 \\
41.10 \\
44.7 \\
45.2 \\
881.74 \\
874.64 \\
871.64 \\
867.54 \\
10 \\
\mathrm{PVC} / \mathrm{sl} \\
0.01\end{array}$ & $\begin{array}{r}146.0 \\
152.0 \\
149.20 \\
158.0 \\
158.0 \\
957.36 \\
951.36 \\
954.16 \\
945.36 \\
10 \\
\text { PVC/sI } \\
0.01\end{array}$ & $\begin{array}{r}18.0 \\
21.5 \\
23.00 \\
24.5 \\
25.0 \\
890.82 \\
887.32 \\
885.82 \\
883.82 \\
5 \\
\mathrm{PVC} / \mathrm{sl} \\
0.01\end{array}$ & $\begin{array}{r}79.0 \\
84.8 \\
84.40 \\
90.0 \\
90.5 \\
829.97 \\
824.22 \\
824.62 \\
818.47 \\
10 \\
\mathrm{PVC} / \mathrm{sl} \\
0.01\end{array}$ & $\begin{array}{r}150.0 \\
175.0 \\
190.10 \\
. \\
200.0 \\
790.21 \\
765.21 \\
750.11 \\
740.21\end{array}$ & $\begin{array}{r}40.0 \\
47.5 \\
44.70 \\
. \\
55.0 \\
905.71 \\
898.21 \\
901.00 \\
890.71\end{array}$ & $\begin{array}{r}406.4 \\
578.57 \\
545.87 \\
536.11 \\
513.17\end{array}$ & $\begin{array}{r}22.8 \\
28.9 \\
28.70 \\
34.5 \\
35.0 \\
824.10 \\
818.00 \\
818.17 \\
811.90 \\
10 \\
\text { PVC/sI } \\
0.01\end{array}$ & $\begin{array}{r}10.0 \\
14.3 \\
964.71 \\
18.0 \\
18.5 \\
970.39 \\
966.14 \\
15.68 \\
961.89 \\
5 \\
\text { PVC/sl } \\
0.01\end{array}$ \\
\hline
\end{tabular}


APPENDIX C: MONITORING WELL CONSTRUCTION DETAILS, CY 2009

\begin{tabular}{|c|c|c|c|c|c|c|c|c|c|c|}
\hline $\begin{array}{r}\text { Well Number } \\
\text { Hydrogeologic Regime } \\
\text { Functional Area }\end{array}$ & $\begin{array}{c}\text { GW-240 } \\
\text { EF } \\
\text { NHP }\end{array}$ & $\begin{array}{c}\text { GW-242 } \\
\text { BC } \\
\text { BG }\end{array}$ & $\begin{array}{c}\text { GW-246 } \\
\text { BC } \\
\text { S3 }\end{array}$ & $\begin{array}{c}\text { GW-251 } \\
\text { EF } \\
\text { S2 }\end{array}$ & $\begin{array}{c}\text { GW-253 } \\
\text { EF } \\
\text { S2 }\end{array}$ & $\begin{array}{c}\text { GW-269 } \\
\text { EF } \\
\text { SY }\end{array}$ & $\begin{array}{c}\text { GW-270 } \\
\text { EF } \\
\text { SY }\end{array}$ & $\begin{array}{c}\text { GW-272 } \\
\text { EF } \\
\text { SY }\end{array}$ & $\begin{array}{c}\text { GW-274 } \\
\text { EF } \\
\text { SY }\end{array}$ & $\begin{array}{c}\text { GW-275 } \\
\text { EF } \\
\text { SY }\end{array}$ \\
\hline \multicolumn{11}{|l|}{ General Information } \\
\hline Date Installed & $10 / 31 / 85$ & $11 / 20 / 85$ & $03 / 11 / 86$ & 04/08/86 & $04 / 11 / 86$ & $06 / 16 / 86$ & 06/09/86 & $06 / 16 / 86$ & $06 / 09 / 86$ & $05 / 30 / 86$ \\
\hline Total Depth Drilled & 29.5 & 17.0 & 76.0 & 51.0 & 50.0 & 30.0 & 18.5 & 16.2 & 35.0 & 65.5 \\
\hline East Coordinate & 63,726 & 43,144 & 52,098 & 53,843 & 54,057 & 53,779 & 53,236 & 53,737 & 53,673 & 53,688 \\
\hline North Coordinate & 28,604 & 31,004 & 29,992 & 29,467 & 29,404 & 30,649 & 30,424 & 30,485 & 30,152 & 30,151 \\
\hline Measuring Point & TOWW & TOWW & Toww & TOWW & TOWW & TOWW & TOWW & TOWW & TOWW & TOWW \\
\hline Measuring Point Elevation & 922.90 & 978.69 & $1,009.19$ & $1,003.80$ & $1,004.24$ & $1,027.81$ & $1,008.96$ & $1,009.16$ & 995.60 & 995.53 \\
\hline Ground Surface Elevation & 919.50 & 974.78 & $1,006.07$ & $1,001.60$ & $1,001.60$ & $1,025.38$ & $1,006.35$ & $1,006.62$ & 992.94 & 993.08 \\
\hline Tag Depth-(TOC) & 32.55 & 20.18 & 76.50 & 50.04 & 50.51 & 33.50 & 21.50 & 19.16 & 36.12 & 68.47 \\
\hline \multicolumn{11}{|l|}{ Geologic Information } \\
\hline Hydrostratigraphic Unit & AQF & AQT & AQT & AQF & AQF & AQT & AQT & AQT & AQT & AQT \\
\hline Geologic Formation & $\mathrm{Cmn}$ & Cpv & $\mathrm{Cn}$ & $\mathrm{Cmn}$ & $\mathrm{Cmn}$ & $\mathrm{Cm}$ & $\mathrm{Cn}$ & $\mathrm{Cn}$ & $\mathrm{Cn}$ & $\mathrm{Cn}$ \\
\hline Aquifer Zone & BDR & WT & WT & $\mathrm{BDR}$ & WT & WT & $\mathrm{BDR}$ & WT & WT & BDR \\
\hline Weathered Rock-Depth & & 9.0 & 26.0 & 32.5 & & 10.0 & 5.0 & 5.0 & 3.0 & 5.0 \\
\hline Fresh Rock-Depth & 14.0 & & & & & & 11.0 & 15.0 & 35.0 & 35.0 \\
\hline \multicolumn{11}{|l|}{ Conductor Casing } \\
\hline Casing Depth & 14.0 & & 27.0 & & & & & & & 38.0 \\
\hline Outside Diameter & 12.5 & & 12.5 & & & & & & & 10.63 \\
\hline Inside Diameter & & & 12 & & & & & & & \\
\hline Casing Material & PVC40 & & PVC40 & & & & NONE & NONE & & PVC40 \\
\hline \multicolumn{11}{|l|}{ Well Casing } \\
\hline Borehole Depth & 29.5 & 17.0 & 76.0 & 51.0 & 50.0 & 30.0 & 18.5 & 16.2 & 35.0 & 65.5 \\
\hline Borehole Diameter & 11 & 8 & 11 & 8.25 & 8.25 & 10 & 10 & 10 & 8 & 10 \\
\hline Casing Depth & 24.0 & 10.6 & 46.5 & 37.5 & 37.0 & 23.7 & 13.0 & 10.9 & 28.5 & 54.8 \\
\hline Outside Diameter & 4.5 & 2.37 & 6.5 & 4.5 & 4.5 & 4.5 & 4.5 & 4.5 & 4.5 & 4.5 \\
\hline Inside Diameter & & & 6 & 4 & 4 & 4 & 4 & 4 & 4 & 4 \\
\hline Casing Material & PVC40 & SS304 & PVC40 & PVC40 & PVC40 & PVC40 & SS304 & SS304 & SS304 & SS304 \\
\hline \multicolumn{11}{|l|}{ Monitored Interval } \\
\hline Top-Depth & 21.0 & 9.0 & 34.2 & 35.0 & 36.2 & 21.9 & 11.0 & 8.8 & 25.8 & 53.3 \\
\hline Midpoint-Depth & 25.3 & 13.0 & 55.1 & 43.0 & 43.1 & 26.0 & 14.8 & 12.5 & 30.4 & 59.4 \\
\hline Pump Intake-Depth & 26.60 & 13.1 & 59.40 & 42.80 & 41.60 & 28.10 & 989.96 & 992.66 & 30.80 & 62.60 \\
\hline Bottom of Screen-Depth & 29.0 & 17.0 & 74.6 & 47.1 & 46.7 & 29.4 & 18.4 & 16.2 & 33.9 & 65.2 \\
\hline Bottom-Depth & 29.5 & 17.0 & 76.0 & 51.0 & 50.0 & 30.0 & 18.5 & 16.2 & 35.0 & 65.5 \\
\hline Top-Elevation & 898.50 & 965.78 & 971.87 & 966.60 & 965.40 & $1,003.48$ & 995.35 & 997.82 & 967.14 & 939.78 \\
\hline Midpoint-Elevation & 894.25 & 961.78 & 950.97 & 958.60 & 958.50 & 999.43 & 991.60 & 994.12 & 962.54 & 933.68 \\
\hline Pump Intake-Elevation & 892.90 & 961.69 & 946.69 & 958.80 & 960.04 & 997.31 & 16.39 & 13.96 & 962.10 & 930.53 \\
\hline Bottom-Elevation & 890.00 & 957.78 & 930.07 & 950.60 & 951.60 & 995.38 & 987.85 & 990.42 & 957.94 & 927.58 \\
\hline Screen Length & & 6.4 & 28.1 & 9.6 & 9.7 & 5.7 & 5.4 & 5.3 & 5.4 & 10.4 \\
\hline Screen Material & $\mathrm{PVC} / \mathrm{sl}$ & $\mathrm{SS} / \mathrm{sw}$ & PVC/sl & $\mathrm{PVC} / \mathrm{sl}$ & $\mathrm{PVC} / \mathrm{sl}$ & $\mathrm{PVC} / \mathrm{sl}$ & $\mathrm{SS} / \mathrm{sw}$ & $\mathrm{SS} / \mathrm{sw}$ & $\mathrm{SS} / \mathrm{sw}$ & SS/sw \\
\hline Slot Size & 0.01 & 0.01 & 0.03 & 0.01 & 0.01 & 0.02 & 0.01 & 0.01 & 0.01 & 0.01 \\
\hline Open-Hole Length & & & & & & & & & & \\
\hline Open-Hole Diameter & & & & & & & & & & \\
\hline
\end{tabular}


APPENDIX C: MONITORING WELL CONSTRUCTION DETAILS, CY 2009

\begin{tabular}{|c|c|c|c|c|c|c|c|c|c|c|}
\hline $\begin{array}{r}\text { Well Number } \\
\text { Hydrogeologic Regime } \\
\text { Functional Area }\end{array}$ & $\begin{array}{c}\text { GW-276 } \\
\text { BC } \\
\text { S3 }\end{array}$ & $\begin{array}{c}\text { GW-281 } \\
\text { EF } \\
\text { FF }\end{array}$ & $\begin{array}{c}\text { GW-289 } \\
\text { BC } \\
\text { BG }\end{array}$ & $\begin{array}{c}\text { GW-293 } \\
\text { CR } \\
\text { ECRWP }\end{array}$ & $\begin{array}{c}\text { GW-294 } \\
\text { CR } \\
\text { ECRWP }\end{array}$ & $\begin{array}{c}\text { GW-296 } \\
\text { CR } \\
\text { ECRWP }\end{array}$ & $\begin{array}{c}\text { GW-298 } \\
\text { CR } \\
\text { ECRWP }\end{array}$ & $\begin{array}{c}\text { GW-301 } \\
\text { CR } \\
\text { CRBAWP }\end{array}$ & $\begin{array}{c}\text { GW-305 } \\
\text { CR } \\
\text { LIV }\end{array}$ & $\begin{array}{c}\text { GW-307 } \\
\text { BC } \\
\text { RS }\end{array}$ \\
\hline \multicolumn{11}{|l|}{ General Information } \\
\hline Date Installed & $07 / 15 / 86$ & $08 / 20 / 86$ & $11 / 20 / 86$ & $06 / 11 / 87$ & 05/01/87 & $05 / 11 / 87$ & $07 / 27 / 87$ & $07 / 02 / 87$ & $08 / 25 / 87$ & 07/15/87 \\
\hline Total Depth Drilled & 18.5 & 17.5 & 40.8 & 214.0 & 128.0 & 147.0 & 190.0 & 182.0 & 179.6 & 41.6 \\
\hline East Coordinate & 52,557 & 61,907 & 42,875 & 62,321 & 62,483 & 62,023 & 62,445 & 61,964 & 52,962 & 49,655 \\
\hline North Coordinate & 29,926 & 29,771 & 29,982 & 28,112 & 27,958 & 27,994 & 27,495 & 27,662 & 28,548 & 29,346 \\
\hline Measuring Point & TOWW & TOC & Toww & TOC & TOC & TOC & TOC & TOWW & TOWW & TOWW \\
\hline Measuring Point Elevation & $1,001.57$ & 946.10 & 948.73 & $1,063.90$ & $1,083.60$ & $1,090.99$ & $1,049.01$ & $1,086.55$ & $1,183.72$ & 993.14 \\
\hline Ground Surface Elevation & 998.70 & 946.53 & 946.32 & $1,061.70$ & $1,083.67$ & $1,088.29$ & $1,046.40$ & $1,083.94$ & $1,181.07$ & 991.01 \\
\hline Tag Depth-(TOC) & 21.34 & 14.85 & 43.14 & 216.40 & 130.76 & 148.16 & 189.36 & 165.23 & 181.06 & 43.60 \\
\hline \multicolumn{11}{|l|}{ Geologic Information } \\
\hline Hydrostratigraphic Unit & AQT & AQT & AQT & AQF & AQF & AQF & AQF & AQF & AQF & AQF \\
\hline Geologic Formation & $\mathrm{Cn}$ & $\mathrm{Cn}$ & $\mathrm{Cm}$ & $\mathrm{OCk}$ & $\mathrm{OCk}$ & OCk & OCk & ock & ock & $\mathrm{Cmn}$ \\
\hline Aquifer Zone & WT & WT & WT & BDR & $\mathrm{BDR}$ & BDR & $\mathrm{BDR}$ & BDR & BDR & WT \\
\hline Weathered Rock-Depth & 18.5 & 17.5 & 24.0 & 57.0 & 62.0 & 67.0 & 65.0 & 94.0 & 53.0 & 41.6 \\
\hline Fresh Rock-Depth & & & 38.0 & 110.0 & 87.0 & 81.5 & 80.0 & 136.0 & 84.0 & \\
\hline \multicolumn{11}{|l|}{ Conductor Casing } \\
\hline Casing Depth & & & & 57.8 & 74.5 & 86.5 & 83.3 & 105.0 & 64.0 & \\
\hline Outside Diameter & & & & 10.75 & 10.75 & 10.75 & 10.75 & 10.75 & 10.75 & \\
\hline Inside Diameter & & & & & 10 & 10 & 10 & 10 & 10 & \\
\hline Casing Material & & & & SF25 & SF25 & SF25 & SF25 & SF25 & SF25 & NONE \\
\hline \multicolumn{11}{|l|}{ Well Casing } \\
\hline Borehole Depth & 18.5 & 17.5 & 40.8 & 197.0 & 128.0 & 147.0 & 190.0 & 163.5 & 179.6 & 41.6 \\
\hline Borehole Diameter & 8 & 6 & 9 & 10 & 10 & 10 & 10 & 10 & 10 & 10 \\
\hline Casing Depth & 13.0 & 5.0 & 30.6 & 197.0 & 117.6 & 136.3 & 176.0 & 151.0 & 168.9 & 30.9 \\
\hline Outside Diameter & 4.5 & 4.5 & 4.5 & 6.62 & 4.5 & 4.5 & 4.5 & 4.5 & 4.5 & 4.5 \\
\hline Inside Diameter & & 4 & & & & & 4 & 4 & 4 & 4 \\
\hline Casing Material & SS304 & SS304 & SS304 & SF25 & SS304 & SS304 & SS304 & SS304 & SS304 & SS304 \\
\hline \multicolumn{11}{|l|}{ Monitored Interval } \\
\hline Top-Depth & 11.3 & 4.0 & 28.9 & 197.0 & 113.0 & 134.4 & 171.1 & 148.5 & 165.3 & 28.7 \\
\hline Midpoint-Depth & 14.9 & 9.5 & 34.9 & 205.5 & 120.5 & 140.7 & 180.6 & 156.0 & 172.5 & 35.2 \\
\hline Pump Intake-Depth & 14.10 & & 35.60 & & & & & 157.40 & 173.40 & 954.64 \\
\hline Bottom of Screen-Depth & 18.3 & 15.0 & 40.6 & & 128.0 & 146.8 & 186.0 & 161.0 & 179.6 & 41.6 \\
\hline Bottom-Depth & 18.5 & 15.0 & 40.8 & 214.0 & 128.0 & 147.0 & 190.0 & 163.5 & 179.6 & 41.6 \\
\hline Top-Elevation & 987.40 & 942.53 & 917.42 & 864.70 & 970.67 & 953.89 & 875.30 & 935.44 & $1,015.77$ & 962.31 \\
\hline Midpoint-Elevation & 983.80 & 937.03 & 911.47 & 856.20 & 963.17 & 947.59 & 865.85 & 927.94 & $1,008.62$ & 955.86 \\
\hline Pump Intake-Elevation & 984.57 & & 910.73 & & & & & 926.55 & 1007.62 & 36.37 \\
\hline Bottom-Elevation & 980.20 & 931.53 & 905.52 & 847.70 & 955.67 & 941.29 & 856.40 & 920.44 & $1,001.47$ & 949.41 \\
\hline Screen Length & 5.3 & 10 & & & 10.4 & 10.5 & & 10 & 10.7 & 10.7 \\
\hline Screen Material| & $\mathrm{SS} / \mathrm{sw}$ & $\mathrm{SS} / \mathrm{sl}$ & $\mathrm{SS} / \mathrm{sw}$ & & $\mathrm{SS} / \mathrm{sw}$ & $\mathrm{SS} / \mathrm{sw}$ & $\mathrm{SS} / \mathrm{sw}$ & $\mathrm{SS} / \mathrm{sw}$ & $\mathrm{SS} / \mathrm{sw}$ & SS/sw \\
\hline Slot Size & 0.01 & 0.01 & 0.01 & & 0.01 & 0.01 & 0.01 & 0.01 & 0.01 & 0.01 \\
\hline Open-Hole Length & & & & 17 & & & & & & \\
\hline Open-Hole Diameter & & & & 6 & & & & & & \\
\hline
\end{tabular}


APPENDIX C: MONITORING WELL CONSTRUCTION DETAILS, CY 2009

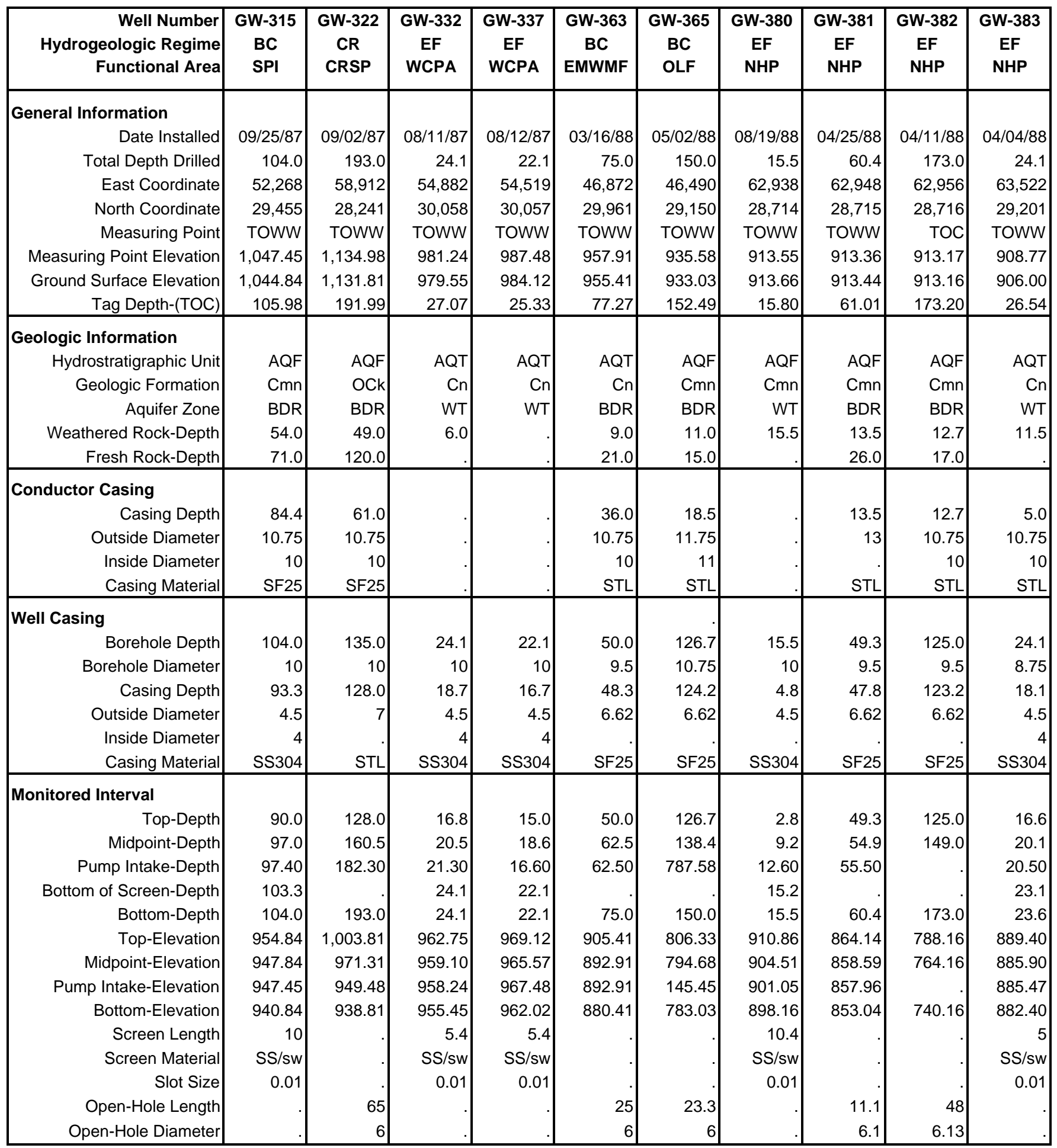


APPENDIX C: MONITORING WELL CONSTRUCTION DETAILS, CY 2009

\begin{tabular}{|c|c|c|c|c|c|c|c|c|c|c|}
\hline $\begin{array}{r}\text { Well Number } \\
\text { Hydrogeologic Regime } \\
\text { Functional Area }\end{array}$ & $\begin{array}{c}\text { GW-505 } \\
\text { EF } \\
\text { RG }\end{array}$ & $\begin{array}{c}\text { GW-508 } \\
\text { EF } \\
\text { RG }\end{array}$ & $\begin{array}{c}\text { GW-521 } \\
\text { CR } \\
\text { LIV }\end{array}$ & $\begin{array}{c}\text { GW-522 } \\
\text { CR } \\
\text { LIV }\end{array}$ & $\begin{array}{c}\text { GW-526 } \\
\text { BC } \\
\text { S3 }\end{array}$ & $\begin{array}{c}\text { GW-537 } \\
\text { BC } \\
\text { OLF }\end{array}$ & $\begin{array}{c}\text { GW-540 } \\
\text { CR } \\
\text { LII }\end{array}$ & $\begin{array}{c}\text { GW-557 } \\
\text { CR } \\
\text { LV }\end{array}$ & $\begin{array}{l}\text { GW-560 } \\
\text { CR } \\
\text { CDLVII }\end{array}$ & $\begin{array}{c}\text { GW-562 } \\
\text { CR } \\
\text { CDLVII }\end{array}$ \\
\hline \multicolumn{11}{|l|}{ General Information } \\
\hline Date Installed & 04/06/88 & $04 / 18 / 88$ & $09 / 14 / 88$ & 09/20/88 & $06 / 13 / 88$ & $09 / 14 / 88$ & 06/02/89 & $12 / 02 / 88$ & $12 / 30 / 88$ & 01/13/89 \\
\hline Total Depth Drilled & 13.5 & 15.0 & 136.0 & 195.5 & 123.0 & 24.5 & 171.5 & 139.0 & 117.0 & 133.0 \\
\hline East Coordinate & 53,037 & 53,148 & 52,040 & 52,612 & 50,708 & 49,539 & 52,371 & 59,520 & 60,743 & 61,640 \\
\hline North Coordinate & 30,400 & 30,281 & 28,541 & 28,377 & 30,033 & 30,057 & 27,489 & 26,450 & 25,692 & 26,276 \\
\hline Measuring Point & TOWW & TOC & TOWW & TOWW & TOWW & TOWW & TOWW & Toww & TOWW & TOWW \\
\hline Measuring Point Elevation & $1,015.19$ & $1,010.74$ & $1,182.88$ & $1,175.48$ & 998.25 & 976.65 & $1,072.31$ & $1,081.36$ & 949.05 & 934.69 \\
\hline Ground Surface Elevation & $1,011.60$ & $1,009.41$ & $1,179.46$ & $1,172.04$ & 995.34 & 974.49 & $1,069.38$ & $1,078.63$ & 945.76 & 931.86 \\
\hline Tag Depth-(TOC) & 16.80 & 15.11 & 136.70 & 197.10 & 123.80 & 27.35 & 173.83 & 136.07 & 82.90 & 61.24 \\
\hline \multicolumn{11}{|l|}{ Geologic Information } \\
\hline Hydrostratigraphic Unit & AQT & AQT & AQF & AQF & $\mathrm{AQT}$ & $\mathrm{AQT}$ & AQF & AQF & AQF & AQF \\
\hline Geologic Formation & $\mathrm{Cn}$ & $\mathrm{Cn}$ & ock & $\mathrm{OCk}$ & $\mathrm{Cn}$ & $\mathrm{Cn}$ & OCk & $\mathrm{OCk}$ & ock & ock \\
\hline Aquifer Zone & WT & WT & BDR & BDR & BDR & WT & $\mathrm{BDR}$ & WT & WT & WT \\
\hline Weathered Rock-Depth & & & & 85.0 & 3.5 & 14.9 & 110.0 & 113.8 & 92.0 & \\
\hline Fresh Rock-Depth & & & 54.0 & 130.0 & 23.6 & & 150.0 & 134.0 & & 52.0 \\
\hline \multicolumn{11}{|l|}{ Conductor Casing } \\
\hline Casing Depth & & & 60.5 & 90.0 & 23.6 & & 154.0 & 85.0 & & \\
\hline Outside Diameter & & & 10.75 & 10.75 & 10.75 & & 10.75 & 10.75 & & \\
\hline Inside Diameter & & & 10 & 10 & 10 & & 10 & 10 & & \\
\hline Casing Material & NONE & & STL & $\mathrm{STL}$ & STL & & STL & $\mathrm{STL}$ & & \\
\hline \multicolumn{11}{|l|}{ Well Casing } \\
\hline Borehole Depth & 13.5 & 15.0 & 136.0 & 195.5 & 101.0 & 24.5 & 171.5 & 138.0 & 117.0 & 60.0 \\
\hline Borehole Diameter & 7 & 7 & 9.5 & 9.5 & 9.5 & 8.75 & 9.25 & 9.5 & 9.5 & 9.5 \\
\hline Casing Depth & 1.9 & 2.2 & 124.9 & 184.6 & 99.7 & 8.0 & 161.2 & 115.8 & 49.0 & 38.0 \\
\hline Outside Diameter & 2.37 & 2.37 & 4.5 & 4.5 & 6.62 & 4.5 & 4.5 & 4.5 & 4.5 & 4.5 \\
\hline Inside Diameter & 2 & 2 & & 4 & & 4 & 4 & 4 & 4 & 4 \\
\hline Casing Material & SS304 & SS304 & SS304 & SS304 & SF25 & SS304 & SS304 & SS304 & SS304 & SS304 \\
\hline \multicolumn{11}{|l|}{ Monitored Interval } \\
\hline Top-Depth & 1.5 & 1.3 & 123.2 & 183.0 & 101.0 & 4.8 & 158.5 & 112.9 & 45.2 & 36.0 \\
\hline Midpoint-Depth & 7.5 & 8.2 & 129.6 & 189.2 & 112.0 & 14.1 & 165.0 & 125.5 & 57.1 & 48.0 \\
\hline Pump Intake-Depth & 997.69 & & 129.00 & 187.60 & 112.10 & 22.80 & 166.10 & 123.60 & 59.40 & 48.20 \\
\hline Bottom of Screen-Depth & 12.3 & 12.5 & 135.2 & 195.0 & & 23.0 & 171.5 & 135.8 & 69.0 & 58.0 \\
\hline Bottom-Depth & 13.5 & 15.0 & 136.0 & 195.3 & 123.0 & 23.3 & 171.5 & 138.0 & 69.0 & 60.0 \\
\hline Top-Elevation & $1,010.10$ & $1,008.11$ & $1,056.26$ & 989.04 & 894.34 & 969.69 & 910.88 & 965.73 & 900.56 & 895.86 \\
\hline Midpoint-Elevation & $1,004.10$ & $1,001.26$ & $1,049.86$ & 982.89 & 883.34 & 960.44 & 904.38 & 953.18 & 888.66 & 883.86 \\
\hline Pump Intake-Elevation & 13.91 & & 1050.48 & 984.48 & 883.25 & 951.65 & 903.31 & 955.06 & 886.35 & 883.69 \\
\hline Bottom-Elevation & 998.10 & 994.41 & $1,043.46$ & 976.74 & 872.34 & 951.19 & 897.88 & 940.63 & 876.76 & 871.86 \\
\hline Screen Length & 10.4 & 10.3 & 10.3 & 10.4 & & 15 & 10.3 & & & 20 \\
\hline Screen Material & $\mathrm{SS} / \mathrm{sw}$ & SS/sw & SS/sw & $\mathrm{SS} / \mathrm{sw}$ & & $\mathrm{SS} / \mathrm{sw}$ & $\mathrm{SS} / \mathrm{sl}$ & $\mathrm{SS} / \mathrm{sw}$ & $\mathrm{SS} / \mathrm{sw}$ & SS/sw \\
\hline Slot Size & 0.01 & 0.01 & 0.01 & 0.01 & & 0.01 & 0.01 & 0.01 & 0.01 & 0.01 \\
\hline Open-Hole Length & & & & & 22 & & & & & \\
\hline Open-Hole Diameter & & & & & 6.1 & & & & & \\
\hline
\end{tabular}


APPENDIX C: MONITORING WELL CONSTRUCTION DETAILS, CY 2009

\begin{tabular}{|c|c|c|c|c|c|c|c|c|c|c|}
\hline $\begin{array}{r}\text { Well Number } \\
\text { Hydrogeologic Regime } \\
\text { Functional Area }\end{array}$ & $\begin{array}{c}\text { GW-564 } \\
\text { CR } \\
\text { CDLVII }\end{array}$ & $\begin{array}{c}\text { GW-601 } \\
\text { BC } \\
\text { OLF }\end{array}$ & $\begin{array}{c}\text { GW-605 } \\
\text { EF } \\
\text { EXP-I }\end{array}$ & $\begin{array}{c}\text { GW-606 } \\
\text { EF } \\
\text { EXP-I }\end{array}$ & $\begin{array}{c}\text { GW-615 } \\
\text { BC } \\
\text { S3 }\end{array}$ & $\begin{array}{c}\text { GW-616 } \\
\text { BC } \\
\text { S3 }\end{array}$ & $\begin{array}{c}\text { GW-618 } \\
\text { EF } \\
\text { EXP-E }\end{array}$ & $\begin{array}{c}\text { GW-623 } \\
\text { BC } \\
\text { BG }\end{array}$ & $\begin{array}{c}\text { GW-627 } \\
\text { BC } \\
\text { BG }\end{array}$ & $\begin{array}{c}\text { GW-629 } \\
\text { BC } \\
\text { BG }\end{array}$ \\
\hline \multicolumn{11}{|l|}{ General Information } \\
\hline Date Installed & $01 / 27 / 89$ & 08/31/89 & 03/19/91 & 03/20/91 & $02 / 13 / 90$ & 03/10/90 & 03/15/90 & $08 / 02 / 90$ & $12 / 11 / 89$ & $02 / 02 / 90$ \\
\hline Total Depth Drilled & 88.0 & 356.0 & 40.5 & 175.0 & 245.0 & 269.0 & 37.0 & 349.0 & 270.0 & 312.0 \\
\hline East Coordinate & 59,865 & 47,629 & 62,002 & 61,951 & 52,224 & 51,907 & 54,738 & 44,138 & 42,774 & 43,047 \\
\hline North Coordinate & 25,873 & 28,903 & 28,707 & 28,708 & 30,009 & 29,724 & 29,798 & 29,388 & 29,505 & 29,522 \\
\hline Measuring Point & TOWW & TOWW & TOWW & TOWW & TOWW & TOWW & TOWW & TOC & TOWW & TOWW \\
\hline Measuring Point Elevation & 938.07 & $1,002.80$ & 919.06 & 919.59 & $1,017.55$ & $1,011.81$ & 985.14 & 925.21 & 943.51 & 928.03 \\
\hline Ground Surface Elevation & 935.12 & 999.09 & 916.97 & 916.98 & $1,014.17$ & $1,009.81$ & 982.64 & 922.01 & 940.39 & 924.42 \\
\hline Tag Depth-(TOC) & 78.74 & 358.61 & 42.00 & 174.36 & 246.84 & 270.59 & 38.30 & 277.93 & 270.96 & 314.59 \\
\hline \multicolumn{11}{|l|}{ Geologic Information } \\
\hline Hydrostratigraphic Unit & AQF & AQF & AQF & AQF & AQT & AQT & AQF & AQT & AQT & AQT \\
\hline Geologic Formation & OCk & $\mathrm{Cmn}$ & $\mathrm{Cmn}$ & $\mathrm{Cmn}$ & $\mathrm{Cn}$ & $\mathrm{Cn}$ & $\mathrm{Cmn}$ & $\mathrm{Cn}$ & $\mathrm{Cn}$ & $\mathrm{Cn}$ \\
\hline Aquifer Zone & WT & $\mathrm{BDR}$ & $\mathrm{BDR}$ & $\mathrm{BDR}$ & $\mathrm{BDR}$ & $\mathrm{BDR}$ & WT & BDR & $\mathrm{BDR}$ & BDR \\
\hline Weathered Rock-Depth & & 8.0 & & & 15.0 & 35.0 & 25.0 & 16.0 & 3.0 & 12.0 \\
\hline Fresh Rock-Depth & 72.0 & 54.0 & 9.5 & 10.8 & 40.0 & 42.0 & 27.0 & 38.0 & 43.0 & 42.0 \\
\hline \multicolumn{11}{|l|}{ Conductor Casing } \\
\hline Casing Depth & & 41.4 & 9.5 & 64.7 & 84.5 & 45.6 & 27.5 & 218.0 & 47.5 & 45.1 \\
\hline Outside Diameter & & 11.75 & 11.75 & 7 & 11.75 & 11.75 & 10.75 & 7 & 11.75 & 11.75 \\
\hline Inside Diameter & & 11 & 11 & 6.4 & 11 & 11 & 10 & 6.54 & 11 & 11 \\
\hline Casing Material & & STL & SJ55 & SJ55 & SJ55 & SJ55 & SJ55 & SJ55 & SJ55 & SJ55 \\
\hline \multicolumn{11}{|l|}{ Well Casing } \\
\hline Borehole Depth & 81.0 & 319.0 & 40.5 & 175.0 & 222.5 & 219.7 & 37.0 & 274.5 & 254.0 & 262.3 \\
\hline Borehole Diameter & 9.5 & 10.63 & 10.6 & 9.63 & 10.63 & 10.63 & 9.5 & 6 & 10.63 & 10.63 \\
\hline Casing Depth & 55.3 & 317.2 & 29.7 & 161.0 & 221.2 & 217.8 & 26.7 & 244.0 & 252.7 & 266.3 \\
\hline Outside Diameter & 4.5 & 7 & 4.25 & 4.25 & 7 & 7 & 4.5 & 2.37 & 7 & 7 \\
\hline Inside Diameter & 4 & & 4 & 4 & 6.54 & 6.54 & 4.25 & 2 & 6.54 & 6.54 \\
\hline Casing Material & SS304 & STL & SS304 & SS304 & SF25 & SF25 & SS304 & SS304 & SF25 & SF25 \\
\hline \multicolumn{11}{|l|}{ Monitored Interval } \\
\hline Top-Depth & 52.0 & 318.5 & 28.2 & 155.0 & 222.5 & 219.1 & 26.0 & 238.1 & 254.0 & 262.3 \\
\hline Midpoint-Depth & 66.5 & 337.3 & 34.1 & 163.0 & 233.8 & 244.1 & 31.5 & 256.2 & 262.0 & 287.2 \\
\hline Pump Intake-Depth & 65.50 & 657.80 & 33.90 & 166.40 & 68.60 & 263.00 & 32.50 & & 255.90 & 286.40 \\
\hline Bottom of Screen-Depth & 75.3 & & 39.7 & 171.0 & & & 37.0 & 274.2 & & \\
\hline Bottom-Depth & 81.0 & 356.0 & 39.9 & 171.0 & 245.0 & 269.0 & 37.0 & 274.2 & 270.0 & 312.0 \\
\hline Top-Elevation & 883.12 & 680.59 & 888.77 & 761.98 & 791.67 & 790.71 & 956.64 & 683.91 & 686.39 & 662.12 \\
\hline Midpoint-Elevation & 868.62 & 661.84 & 882.92 & 753.98 & 780.42 & 765.76 & 951.14 & 665.86 & 678.39 & 637.27 \\
\hline Pump Intake-Elevation & 869.57 & 341.29 & 883.06 & 750.59 & 945.55 & 746.81 & 950.14 & & 684.51 & 638.03 \\
\hline Bottom-Elevation & 854.12 & 643.09 & 877.07 & 745.98 & 769.17 & 740.81 & 945.64 & 647.81 & 670.39 & 612.42 \\
\hline Screen Length & & & & & & & 10.3 & 30.2 & & \\
\hline Screen Material & $\mathrm{SS} / \mathrm{sw}$ & & $\mathrm{SS} / \mathrm{sw}$ & SS/ppk & & & $\mathrm{SS} / \mathrm{sw}$ & SS/sw & & \\
\hline Slot Size & 0.01 & & 0.01 & 0.01 & & & 0.01 & 0.01 & & \\
\hline Open-Hole Length & & 37.5 & & & 22.5 & 49.9 & & & 16 & 49.7 \\
\hline Open-Hole Diameter & & 6.25 & & & 6.25 & 6.25 & & & 6.25 & 6.5 \\
\hline
\end{tabular}


APPENDIX C: MONITORING WELL CONSTRUCTION DETAILS, CY 2009

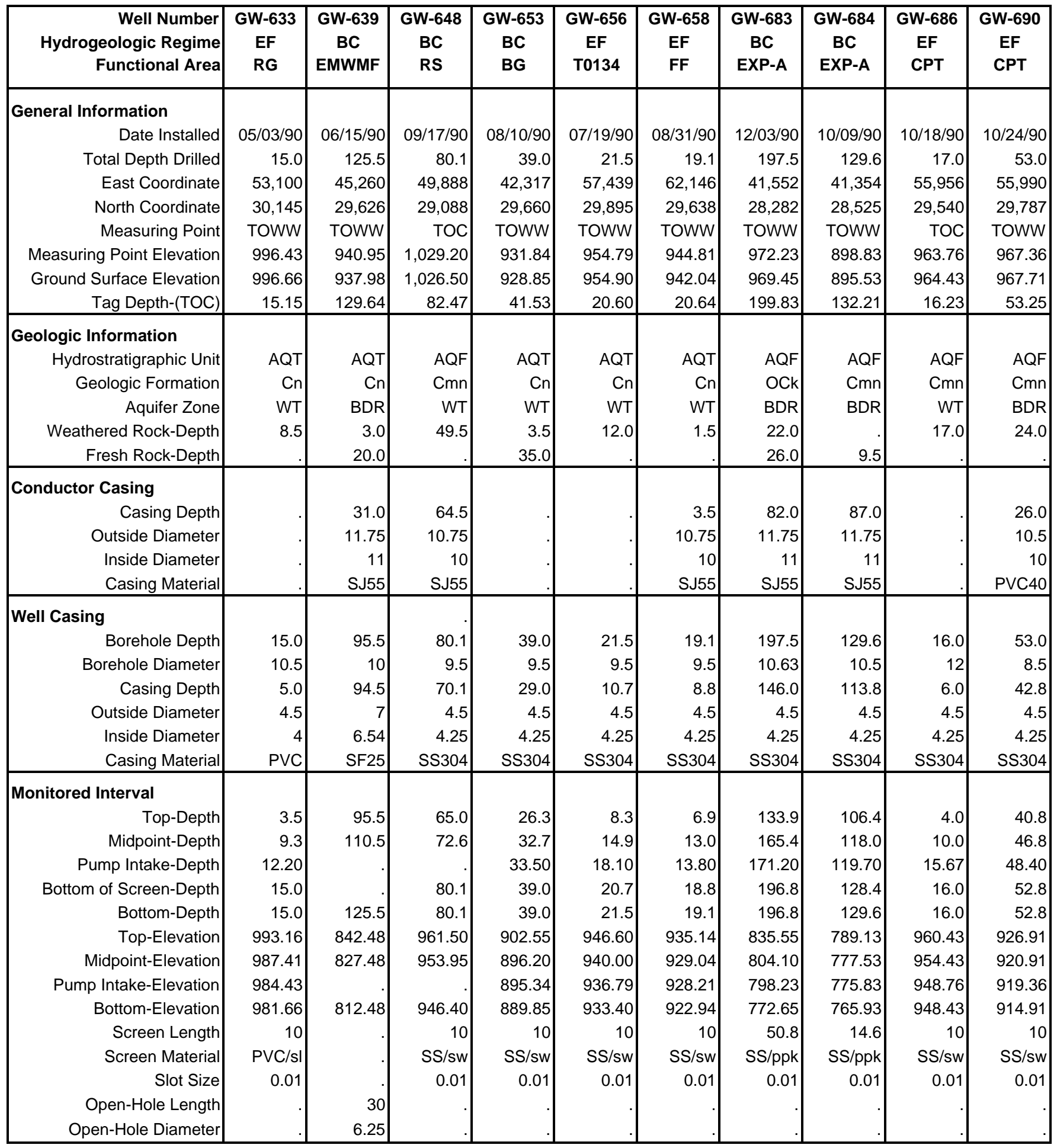


APPENDIX C: MONITORING WELL CONSTRUCTION DETAILS, CY 2009

\begin{tabular}{|c|c|c|c|c|c|c|c|c|c|c|}
\hline $\begin{array}{r}\text { Well Number } \\
\text { Hydrogeologic Regime } \\
\text { Functional Area }\end{array}$ & $\begin{array}{c}\text { GW-691 } \\
\text { EF } \\
\text { CPT }\end{array}$ & $\begin{array}{c}\text { GW-692 } \\
\text { EF } \\
\text { CPT }\end{array}$ & $\begin{array}{c}\text { GW-698 } \\
\text { EF } \\
\text { B8110 }\end{array}$ & $\begin{array}{c}\text { GW-700 } \\
\text { EF } \\
\text { B8110 }\end{array}$ & $\begin{array}{c}\text { GW-703 } \\
\text { BC } \\
\text { EXP-B }\end{array}$ & $\begin{array}{c}\text { GW-704 } \\
\text { BC } \\
\text { EXP-B }\end{array}$ & $\begin{array}{c}\text { GW-706 } \\
\text { BC } \\
\text { EXP-B }\end{array}$ & $\begin{array}{c}\text { GW-709 } \\
\text { CR } \\
\text { LII }\end{array}$ & $\begin{array}{c}\text { GW-712 } \\
\text { BC } \\
\text { EXP-W }\end{array}$ & $\begin{array}{c}\text { GW-713 } \\
\text { BC } \\
\text { EXP-W }\end{array}$ \\
\hline General Information & & & & & & & & & & \\
\hline Date Installed & $10 / 24 / 90$ & $10 / 25 / 90$ & $11 / 02 / 90$ & $10 / 03 / 90$ & $12 / 07 / 90$ & $12 / 20 / 90$ & 01/27/91 & 04/05/91 & 06/20/91 & 01/13/92 \\
\hline Total Depth Drilled & 20.0 & 53.0 & 75.0 & 31.0 & 182.0 & 256.0 & 182.5 & 80.6 & 457.5 & 315.2 \\
\hline East Coordinate & 55,983 & 56,001 & 56,804 & 56,828 & 44,931 & 44,935 & 44,944 & 52,372 & 36,507 & 36,434 \\
\hline North Coordinate & 29,794 & 29,653 & 29,277 & 29,453 & 28,806 & 28,845 & 28,946 & 25,344 & 28,233 & 28,236 \\
\hline Measuring Point & TOWW & TOWW & TOWW & TOWW & TOWW & TOWW & TOWW & TOWW & TOWW & TOWW \\
\hline Measuring Point Elevation & 968.59 & 964.38 & 970.09 & 960.18 & 955.29 & 945.33 & 929.47 & 906.81 & 877.89 & 881.43 \\
\hline Ground Surface Elevation & 968.09 & 964.55 & 970.09 & 957.78 & 951.80 & 941.99 & 925.78 & 903.84 & 873.61 & 877.83 \\
\hline Tag Depth-(TOC) & 20.39 & 53.05 & 74.88 & 33.19 & 185.29 & 258.65 & 185.79 & 83.52 & 460.53 & 318.39 \\
\hline Geologic Info & & & & & & & & & & \\
\hline Hydrostratigraphic Unit & AQF & AQF & AQF & AQF & AQF & AQF & AQF & AQF & AQF & AQF \\
\hline Geologic Formation & $\mathrm{Cmn}$ & $\mathrm{Cmn}$ & $\mathrm{Cmn}$ & $\mathrm{Cmn}$ & $\mathrm{Cmn}$ & $\mathrm{Cmn}$ & $\mathrm{Cmn}$ & OCk & OCk & $\mathrm{Cmn}$ \\
\hline Aquifer Zone & WT & BDR & BDR & WT & $\mathrm{BDR}$ & $\mathrm{BDR}$ & $\mathrm{BDR}$ & $\mathrm{BDR}$ & $\mathrm{BDR}$ & BDR \\
\hline Weathered Rock-Depth & 20.0 & 23.0 & 42.0 & 31.0 & 7.0 & 16.0 & 17.0 & 39.0 & 12.0 & 26.8 \\
\hline Fresh Rock-Depth & & & & & 10.0 & 23.0 & 27.0 & 43.0 & 66.0 & 63.8 \\
\hline or Casing & & & & & & & & & & \\
\hline Casing Depth & & 25.0 & 42.0 & & & 21.0 & 40.3 & 50.0 & 44.8 & 80.2 \\
\hline Outside Diameter & & 10.5 & 10.5 & & & 11.75 & 11.75 & 11.75 & 11.75 & \\
\hline Inside Diameter & & 10 & 10 & & & 11 & 11 & 11 & 11 & \\
\hline Casing Material & & PVC40 & PVC40 & & & SJ55 & SJ55 & SJ55 & SJ55 & SJ55 \\
\hline Well Casing & & & & & & & & & & \\
\hline Borehole Depth & 20.0 & 53.0 & 75.0 & 31.0 & 135.0 & 246.0 & 157.0 & 80.6 & 441.5 & 305.0 \\
\hline Borehole Diameter & 12 & 8.5 & 8.5 & 12 & 10.63 & 10.63 & 10.6 & 10.6 & 10.6 & 10.6 \\
\hline g Depth & 10.0 & 43.0 & 65.0 & 21.0 & 132.8 & 243.5 & 155.1 & 70.4 & 440.2 & 303.7 \\
\hline Outside Diameter & 4.5 & 4.5 & 4.5 & 4.5 & 7 & 7 & 7 & 4.25 & 7 & 7 \\
\hline Inside Diameter & 4.25 & 4.25 & 4.25 & 4.25 & 6.54 & 6.54 & 6.54 & 4 & 6.54 & 6.54 \\
\hline Casing Material & SS304 & SS304 & SS304 & SS304 & SF25 & SF25 & SF25 & SS304 & SF25 & SF25 \\
\hline Monitored Interval & & & & & & & & & & \\
\hline Top-Depth & 8.0 & 41.0 & 63.0 & 19.0 & 133.8 & 244.5 & 156.1 & 68.7 & 441.5 & 305.0 \\
\hline Midpoint-Depth & 14.0 & 47.0 & 69.0 & 25.0 & 157.9 & 250.3 & 169.3 & 74.7 & 449.5 & 310.1 \\
\hline Pump Intake-Depth & 14.50 & 48.20 & 71.00 & 26.10 & 158.50 & 250.20 & 174.80 & 75.50 & 446.20 & 307.40 \\
\hline Bottom of Screen-Depth & 20.0 & 53.0 & 75.0 & 31.0 & & & & 80.4 & & \\
\hline Bottom-Depth & 20.0 & 53.0 & 75.0 & 31.0 & 182.0 & 256.0 & 182.5 & 80.6 & 457.5 & 315.2 \\
\hline Top-Elevation & 960.09 & 923.55 & 907.09 & 938.78 & 818.00 & 697.49 & 769.68 & 835.14 & 432.11 & 572.83 \\
\hline Midpoint-Elevation & 954.09 & 917.55 & 901.09 & 932.78 & 793.90 & 691.74 & 756.48 & 829.19 & 424.11 & 567.73 \\
\hline Pump Intake-Elevation & 953.59 & 916.38 & 899.09 & 931.68 & 793.29 & 691.83 & 750.97 & 828.31 & 427.39 & 570.43 \\
\hline Bottom-Elevation & 948.09 & 911.55 & 895.09 & 926.78 & 769.80 & 685.99 & 743.28 & 823.24 & 416.11 & 562.63 \\
\hline Screen Length & & 10 & & 10 & & & & & & \\
\hline Screen Material & $\mathrm{SS} / \mathrm{sw}$ & SS/sw & SS/sw & SS/sw & & & & $\mathrm{SS} / \mathrm{sw}$ & & \\
\hline Slot Size & 0.01 & 0.01 & 0.01 & 0.01 & & & & 0.01 & & \\
\hline Open-Hole Length & & & & & 48.2 & 11.5 & 26.4 & & 16 & 10.2 \\
\hline Open-Hole Diameter & & & & & 6.25 & 6.5 & 6.25 & & 6.25 & 6.25 \\
\hline
\end{tabular}


APPENDIX C: MONITORING WELL CONSTRUCTION DETAILS, CY 2009

\begin{tabular}{|c|c|c|c|c|c|c|c|c|c|c|}
\hline $\begin{array}{r}\text { Well Number } \\
\text { Hydrogeologic Regime } \\
\text { Functional Area }\end{array}$ & $\begin{array}{l}\text { GW-714 } \\
\text { BC } \\
\text { EXP-W }\end{array}$ & $\begin{array}{c}\text { GW-722 } \\
\text { EF } \\
\text { EXP-J }\end{array}$ & $\begin{array}{c}\text { GW-724 } \\
\text { BC } \\
\text { EXP-C }\end{array}$ & $\begin{array}{c}\text { GW-725 } \\
\text { BC } \\
\text { EXP-C }\end{array}$ & $\begin{array}{c}\text { GW-726 } \\
\text { BC } \\
\text { BG }\end{array}$ & $\begin{array}{c}\text { GW-731 } \\
\text { CR } \\
\text { CRSDB }\end{array}$ & $\begin{array}{c}\text { GW-732 } \\
\text { CR } \\
\text { CRSDB }\end{array}$ & $\begin{array}{c}\text { GW-733 } \\
\text { EF } \\
\text { EXP-J }\end{array}$ & $\begin{array}{c}\text { GW-735 } \\
\text { EF } \\
\text { EXP-J }\end{array}$ & $\begin{array}{c}\text { GW-738 } \\
\text { BC } \\
\text { EXP-C }\end{array}$ \\
\hline \multicolumn{11}{|l|}{ General Information } \\
\hline Date Installed & $01 / 24 / 92$ & $08 / 09 / 91$ & $08 / 12 / 91$ & $08 / 27 / 91$ & $07 / 24 / 92$ & $09 / 12 / 91$ & 09/11/91 & $10 / 02 / 91$ & $10 / 30 / 91$ & $11 / 21 / 91$ \\
\hline Total Depth Drilled & 145.0 & 644.3 & 301.6 & 142.5 & 600.0 & 180.4 & 190.6 & 256.5 & 83.0 & 90.1 \\
\hline East Coordinate & 36,435 & 64,926 & 48,995 & 48,989 & 42,467 & 63,863 & 64,268 & 65,067 & 64,872 & 49,026 \\
\hline North Coordinate & 28,422 & 28,532 & 29,198 & 29,405 & 29,201 & 27,464 & 27,717 & 28,447 & 28,867 & 29,150 \\
\hline Measuring Point & TOWW & TOC & TOWW & Toww & TOC & TOWW & TOWW & TOWW & TOWW & TOWW \\
\hline Measuring Point Elevation & 875.88 & 953.71 & 979.75 & 961.63 & 925.39 & $1,049.38$ & $1,064.29$ & 959.84 & 924.46 & 983.31 \\
\hline Ground Surface Elevation & 872.30 & 951.04 & 976.62 & 958.26 & 922.77 & $1,045.75$ & $1,060.65$ & 955.69 & 921.34 & 980.36 \\
\hline Tag Depth-(TOC) & 146.90 & 642.68 & 293.60 & 145.42 & 602.62 & 178.53 & 192.84 & 259.93 & 81.81 & 91.78 \\
\hline \multicolumn{11}{|l|}{ Geologic Information } \\
\hline Hydrostratigraphic Unit & AQF & AQF & AQF & AQF & AQT & AQF & AQF & AQF & AQT & AQF \\
\hline Geologic Formation & $\mathrm{Cmn}$ & $\mathrm{Cmn}$ & $\mathrm{Cmn}$ & $\mathrm{Cmn}$ & $\mathrm{Cn}$ & OCk & OCk & $\mathrm{Cmn}$ & $\mathrm{Cn}$ & $\mathrm{Cmn}$ \\
\hline Aquifer Zone & $\mathrm{BDR}$ & $\mathrm{BDR}$ & $\mathrm{BDR}$ & BDR & $\mathrm{BDR}$ & $\mathrm{BDR}$ & $\mathrm{BDR}$ & $\mathrm{BDR}$ & $\mathrm{BDR}$ & BDR \\
\hline Weathered Rock-Depth & 27.0 & 54.0 & 33.5 & 14.0 & 3.0 & 95.4 & 85.0 & 42.5 & 19.0 & 12.0 \\
\hline Fresh Rock-Depth & 35.0 & 73.0 & 40.0 & 17.5 & 25.5 & 129.4 & 96.0 & 47.1 & 77.5 & 15.1 \\
\hline \multicolumn{11}{|l|}{ Conductor Casing } \\
\hline Casing Depth & 40.5 & 56.2 & 40.0 & 21.0 & & 122.0 & 100.7 & 51.8 & 25.5 & 16.5 \\
\hline Outside Diameter & 11.75 & 10.75 & 11.75 & 11.75 & & 11.75 & 11.75 & 11.75 & 11.75 & 11.75 \\
\hline Inside Diameter & 11 & 10 & 11 & 11 & & 11 & 11 & 11 & 11 & 11 \\
\hline Casing Material & SJ55 & SJ55 & SJ55 & SJ55 & NONE & SJ55 & SJ55 & SJ55 & SJ55 & SJ55 \\
\hline \multicolumn{11}{|l|}{ Well Casing } \\
\hline Borehole Depth & 115.1 & 75.0 & 289.6 & 132.5 & 600.0 & 175.4 & 189.5 & 240.1 & 83.0 & 90.1 \\
\hline Borehole Diameter & 10.6 & 6 & 10.6 & 10.6 & 3.64 & 10.6 & 10.6 & 10.6 & 10.6 & 10.6 \\
\hline Casing Depth & 113.8 & 74.5 & 288.3 & 131.2 & 39.9 & 165.2 & 179.3 & 238.8 & 67.9 & 67.3 \\
\hline Outside Diameter & 7 & 4.5 & 7 & 7 & 7 & 4.5 & 4.5 & 7 & 4.5 & 4.5 \\
\hline Inside Diameter & 6.54 & 4 & 6.54 & 6.54 & 6.54 & 4.25 & 4.25 & 6.54 & 4.25 & 4.25 \\
\hline Casing Material & SF25 & SJ55 & SF25 & SF25 & SF25 & SS304 & SS304 & SF25 & SS304 & SS304 \\
\hline \multicolumn{11}{|l|}{ Monitored Interval } \\
\hline Top-Depth & 115.1 & 74.5 & 289.6 & 132.5 & 39.9 & 164.0 & 178.3 & 240.1 & 67.5 & 63.5 \\
\hline Midpoint-Depth & 130.1 & 359.4 & 295.6 & 137.5 & 320.0 & 171.4 & 184.2 & 248.3 & 73.4 & 75.8 \\
\hline Pump Intake-Depth & 138.40 & & 294.40 & 137.10 & & 169.90 & 184.40 & 248.90 & 847.76 & 78.60 \\
\hline Bottom of Screen-Depth & & & & & & 175.2 & 189.3 & & 77.9 & 87.3 \\
\hline Bottom-Depth & 145.0 & 644.3 & 301.6 & 142.5 & 600.0 & 178.7 & 190.0 & 256.5 & 79.2 & 88.0 \\
\hline Top-Elevation & 757.20 & 876.54 & 687.02 & 825.76 & 882.87 & 881.75 & 882.35 & 715.59 & 853.84 & 916.86 \\
\hline Midpoint-Elevation & 742.25 & 591.64 & 681.02 & 820.76 & 602.82 & 874.40 & 876.50 & 707.39 & 847.99 & 904.61 \\
\hline Pump Intake-Elevation & 733.88 & & 682.25 & 821.13 & & 875.88 & 876.29 & 706.84 & 73.58 & 901.81 \\
\hline Bottom-Elevation & 727.30 & 306.74 & 675.02 & 815.76 & 322.77 & 867.05 & 870.65 & 699.19 & 842.14 & 892.36 \\
\hline Screen Length & & & & & & & & & & \\
\hline Screen Material & & & & & & $\mathrm{SS} / \mathrm{sw}$ & $\mathrm{SS} / \mathrm{sw}$ & & $\mathrm{SS} / \mathrm{sw}$ & SS/sw \\
\hline Slot Size & & & & & & 0.01 & 0.01 & & 0.01 & 0.01 \\
\hline Open-Hole Length & 29.9 & 569.8 & 12 & 10 & 560.1 & & & 16.4 & & \\
\hline Open-Hole Diameter & 6.25 & 3.5 & 6.25 & 6.25 & 3.64 & & & 6.25 & & \\
\hline
\end{tabular}


APPENDIX C: MONITORING WELL CONSTRUCTION DETAILS, CY 2009

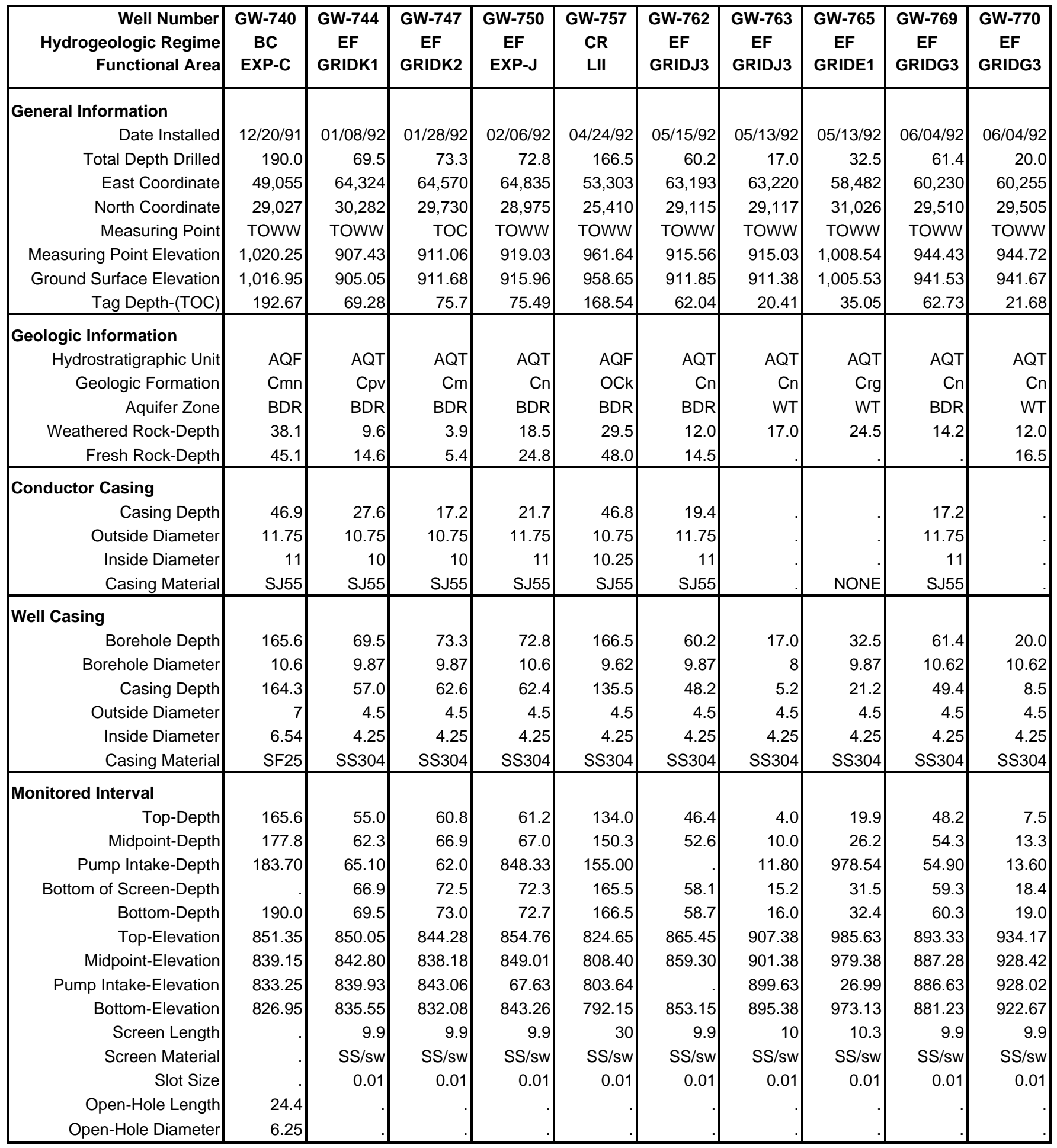


APPENDIX C: MONITORING WELL CONSTRUCTION DETAILS, CY 2009

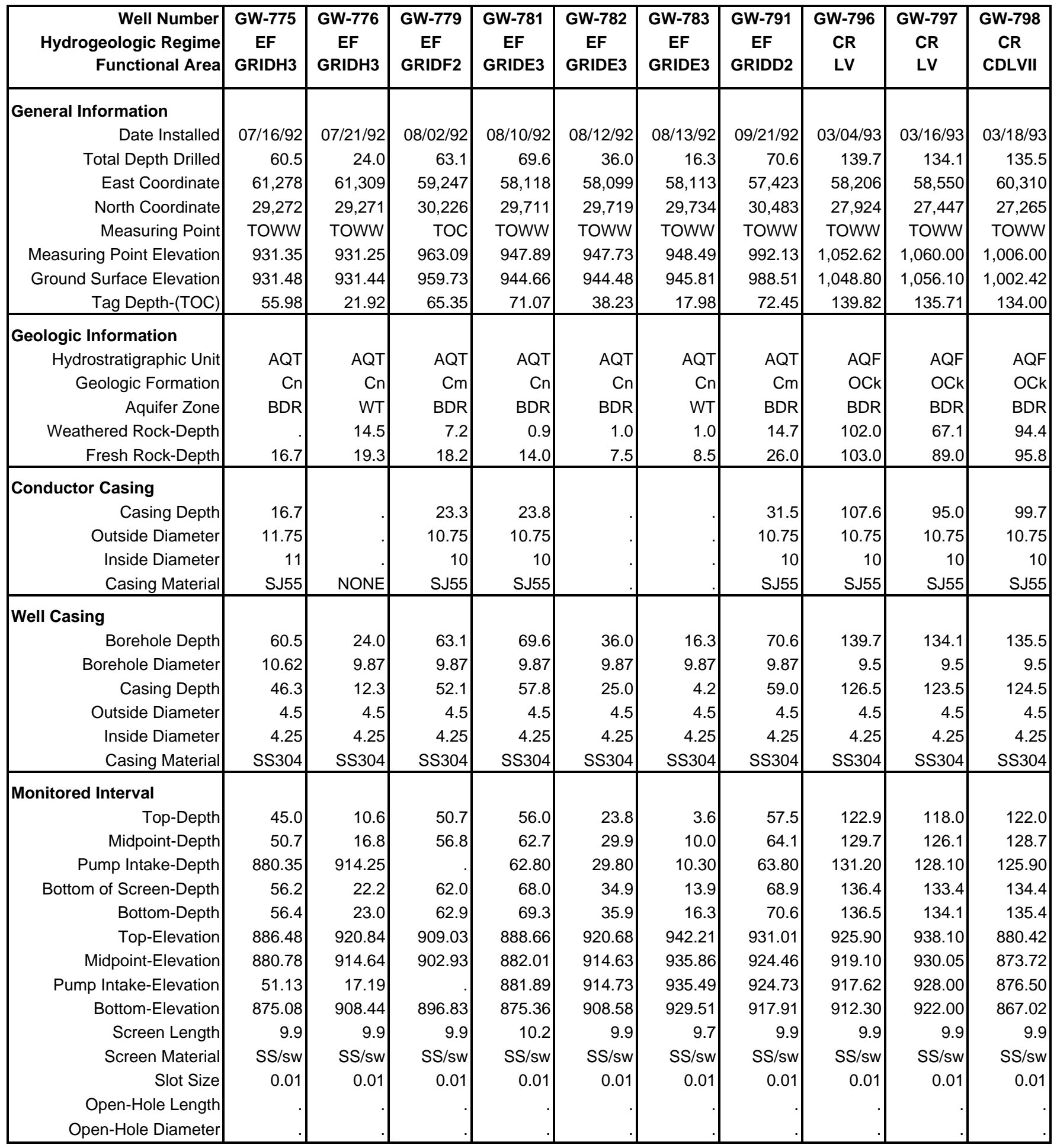


APPENDIX C: MONITORING WELL CONSTRUCTION DETAILS, CY 2009

\begin{tabular}{|c|c|c|c|c|c|c|c|c|c|c|}
\hline $\begin{array}{r}\text { Well Number } \\
\text { Hydrogeologic Regime } \\
\text { Functional Area }\end{array}$ & $\begin{array}{c}\text { GW-799 } \\
\text { CR } \\
\text { LV }\end{array}$ & $\begin{array}{c}\text { GW-801 } \\
\text { CR } \\
\text { LV }\end{array}$ & $\begin{array}{c}\text { GW-802 } \\
\text { EF } \\
\text { FF }\end{array}$ & $\begin{array}{c}\text { GW-816 } \\
\text { EF } \\
\text { EXP-SR }\end{array}$ & $\begin{array}{c}\text { GW-820 } \\
\text { EF } \\
\text { B9201-2 }\end{array}$ & $\begin{array}{c}\text { GW-831 } \\
\text { CR } \\
\text { FCAP }\end{array}$ & $\begin{array}{c}\text { GW-832 } \\
\text { EF } \\
\text { NHP }\end{array}$ & $\begin{array}{c}\text { GW-916 } \\
\text { BC } \\
\text { EMWMF }\end{array}$ & $\begin{array}{c}\text { GW-917 } \\
\text { BC } \\
\text { EMWMF }\end{array}$ & $\begin{array}{c}\text { GW-918 } \\
\text { BC } \\
\text { EMWMF }\end{array}$ \\
\hline \begin{tabular}{|} 
General Information \\
Date Installed \\
Total Depth Drilled \\
East Coordinate \\
North Coordinate \\
Measuring Point \\
Measuring Point Elevation \\
Ground Surface Elevation \\
Tag Depth-(TOC) \\
\end{tabular} & $\begin{array}{r}03 / 25 / 93 \\
92.0 \\
59,961 \\
26,746 \\
\text { TOWW } \\
981.29 \\
978.10 \\
97.58 \\
\end{array}$ & $\begin{array}{r}07 / 01 / 93 \\
188.9 \\
58,780 \\
26,808 \\
\text { TOWW } \\
1,097.16 \\
1,093.82 \\
190.92 \\
\end{array}$ & $\begin{array}{r}06 / 25 / 93 \\
26.5 \\
62,217 \\
29,655 \\
\mathrm{TOC} \\
941.83 \\
942.30 \\
25.42 \\
\end{array}$ & $\begin{array}{r}06 / 02 / 94 \\
16.1 \\
64,031 \\
31,582 \\
\text { TOWW } \\
898.42 \\
894.56 \\
17.99 \\
\end{array}$ & $\begin{array}{r}17.3 \\
59,773 \\
29,175 \\
\text { TOWW } \\
929.57 \\
929.67 \\
17.18 \\
\end{array}$ & $\begin{array}{r}07 / 30 / 96 \\
200.0 \\
56,593 \\
26,654 \\
\text { TOWW } \\
1,091.29 \\
1,088.04 \\
198.06 \\
\end{array}$ & $\begin{array}{r}05 / 09 / 96 \\
11.9 \\
64,134 \\
29,142 \\
\mathrm{TOC} \\
906.18 \\
906.83 \\
10.36 \\
\end{array}$ & $\begin{array}{r}01 / 29 / 01 \\
36.0 \\
48,276 \\
31,186 \\
\text { TOWW } \\
1,002.85 \\
1,000.00\end{array}$ & $\begin{array}{r}01 / 22 / 01 \\
51.0 \\
47,914 \\
30,463 \\
\text { TOWW } \\
997.10 \\
994.00\end{array}$ & $\begin{array}{r}02 / 02 / 01 \\
75.0 \\
47,549 \\
31,672 \\
\text { TOWW } \\
1,067.96 \\
1,065.00\end{array}$ \\
\hline $\begin{array}{r}\text { eologic Information } \\
\text { Hydrostratigraphic Unit } \\
\text { Geologic Formation } \\
\text { Aquifer Zone } \\
\text { Weathered Rock-Depth } \\
\text { Fresh Rock-Depth }\end{array}$ & $\begin{array}{l}\text { AQF } \\
\text { OCk } \\
\text { BDR } \\
60.8 \\
62.8\end{array}$ & $\begin{array}{r}\text { AQF } \\
\text { OCk } \\
\text { BDR } \\
112.5 \\
113.4\end{array}$ & $\begin{array}{r}\mathrm{AQT} \\
\mathrm{Cn} \\
\mathrm{WT} \\
10.0 \\
15.0\end{array}$ & $\begin{array}{r}\mathrm{AQT} \\
\mathrm{Cr} \\
\mathrm{WT}\end{array}$ & $\begin{array}{r}\mathrm{AQF} \\
\mathrm{Cmn} \\
\mathrm{WT}\end{array}$ & $\begin{array}{r}\text { AQF } \\
\text { OCk } \\
\text { BDR } \\
134.8 \\
140.8\end{array}$ & $\begin{array}{c}\mathrm{AQF} \\
\mathrm{Cmn} \\
\mathrm{WT}\end{array}$ & $\begin{array}{r}\mathrm{AQT} \\
\mathrm{CC} \\
\mathrm{WT} \\
10.0 \\
15.0\end{array}$ & $\begin{array}{r}\mathrm{AQT} \\
\mathrm{Cm} \\
\mathrm{WT} \\
21.0 \\
27.0\end{array}$ & $\begin{array}{r}\text { AQT } \\
\text { Cpv } \\
\text { WT } \\
. \\
30.0\end{array}$ \\
\hline \begin{tabular}{|r|} 
Conductor Casing \\
Casing Depth \\
Outside Diameter \\
Inside Diameter \\
Casing Material \\
\end{tabular} & $\begin{array}{r}65.0 \\
10.75 \\
10 \\
\text { SJ55 } \\
\end{array}$ & $\begin{array}{r}115.4 \\
10.75 \\
10 \\
\text { SJ55 } \\
\end{array}$ & & & & $\begin{array}{r}138.3 \\
10.75 \\
10 \\
\text { STL } \\
\end{array}$ & & & & \\
\hline $\begin{array}{l}\text { Nell Casing } \\
\text { Borehole Depth } \\
\text { Borehole Diameter } \\
\text { Casing Depth } \\
\text { Outside Diameter } \\
\text { Inside Diameter } \\
\text { Casing Material }\end{array}$ & $\begin{array}{r}92.0 \\
9.5 \\
81.0 \\
4.5 \\
4.25 \\
\text { SS304 } \\
\end{array}$ & $\begin{array}{r}188.9 \\
9.87 \\
178.1 \\
4.5 \\
4.25 \\
\text { SS304 } \\
\end{array}$ & $\begin{array}{r}26.5 \\
10.62 \\
15.5 \\
4.5 \\
4 \\
\text { PVC } 40\end{array}$ & $\begin{array}{r}15.8 \\
10 \\
4.2 \\
4.5 \\
4.25 \\
\text { SS304 } \\
\end{array}$ & $\begin{array}{r}4.5 \\
4 \\
\mathrm{PVC} \\
\end{array}$ & $\begin{array}{r}200.0 \\
9.87 \\
183.2 \\
4.5 \\
4.25 \\
\text { SS304 } \\
\end{array}$ & $\begin{array}{r}11.9 \\
12 \\
5.9 \\
6.63 \\
6 \\
\text { PVC } \\
\end{array}$ & & $\begin{array}{r}20.0 \\
2.37 \\
2.07 \\
\text { SS304 }\end{array}$ & $\begin{array}{r}20.0 \\
\text { SS304 } \\
\end{array}$ \\
\hline $\begin{array}{r}\text { onitored Interval } \\
\text { Top-Depth } \\
\text { Midpoint-Depth } \\
\text { Pump Intake-Depth } \\
\text { Bottom of Screen-Depth } \\
\text { Bottom-Depth } \\
\text { Top-Elevation } \\
\text { Midpoint-Elevation } \\
\text { Pump Intake-Elevation } \\
\text { Bottom-Elevation } \\
\text { Screen Length } \\
\text { Screen Material } \\
\text { Slot Size } \\
\text { Open-Hole Length } \\
\text { Open-Hole Diameter }\end{array}$ & $\begin{array}{r}78.7 \\
85.4 \\
84.80 \\
90.9 \\
92.0 \\
899.40 \\
892.75 \\
893.29 \\
886.10 \\
9.9 \\
\mathrm{SS} / \mathrm{sw} \\
0.01\end{array}$ & $\begin{array}{r}175.8 \\
182.4 \\
177.70 \\
188.0 \\
188.9 \\
918.02 \\
911.47 \\
916.16 \\
904.92 \\
9.9 \\
\mathrm{SS} / \mathrm{sw} \\
0.01\end{array}$ & $\begin{array}{r}13.3 \\
19.9 \\
. \\
25.5 \\
26.5 \\
929.00 \\
922.40\end{array}$ & $\begin{array}{r}2.9 \\
9.4 \\
11.10 \\
13.6 \\
15.8 \\
891.66 \\
885.21 \\
883.42 \\
878.76 \\
9.4 \\
\mathrm{SS} / \mathrm{sw} \\
0.01\end{array}$ & $\begin{array}{r}914.07 \\
912.37\end{array}$ & $\begin{array}{r}182.0 \\
190.8 \\
188.80 \\
193.6 \\
199.6 \\
906.04 \\
897.24 \\
899.29 \\
888.44 \\
10.4 \\
\mathrm{SS} / \mathrm{sw} \\
0.01\end{array}$ & $\begin{array}{r}4.0 \\
7.9 \\
. \\
10.9 \\
11.8 \\
902.83 \\
898.93 \\
. \\
895.03 \\
5 \\
\mathrm{PVC} / \mathrm{sl} \\
0.02\end{array}$ & $\begin{array}{r}975.35 \\
20 \\
\mathrm{SS} / \mathrm{sw} \\
0.01\end{array}$ & $\begin{array}{r}959.60 \\
30 \\
\mathrm{SS} / \mathrm{sw} \\
0.01\end{array}$ & $\begin{array}{r}1039.46 \\
. \\
10 \\
\mathrm{SS} / \mathrm{sW} \\
0.01\end{array}$ \\
\hline
\end{tabular}


APPENDIX C: MONITORING WELL CONSTRUCTION DETAILS, CY 2009

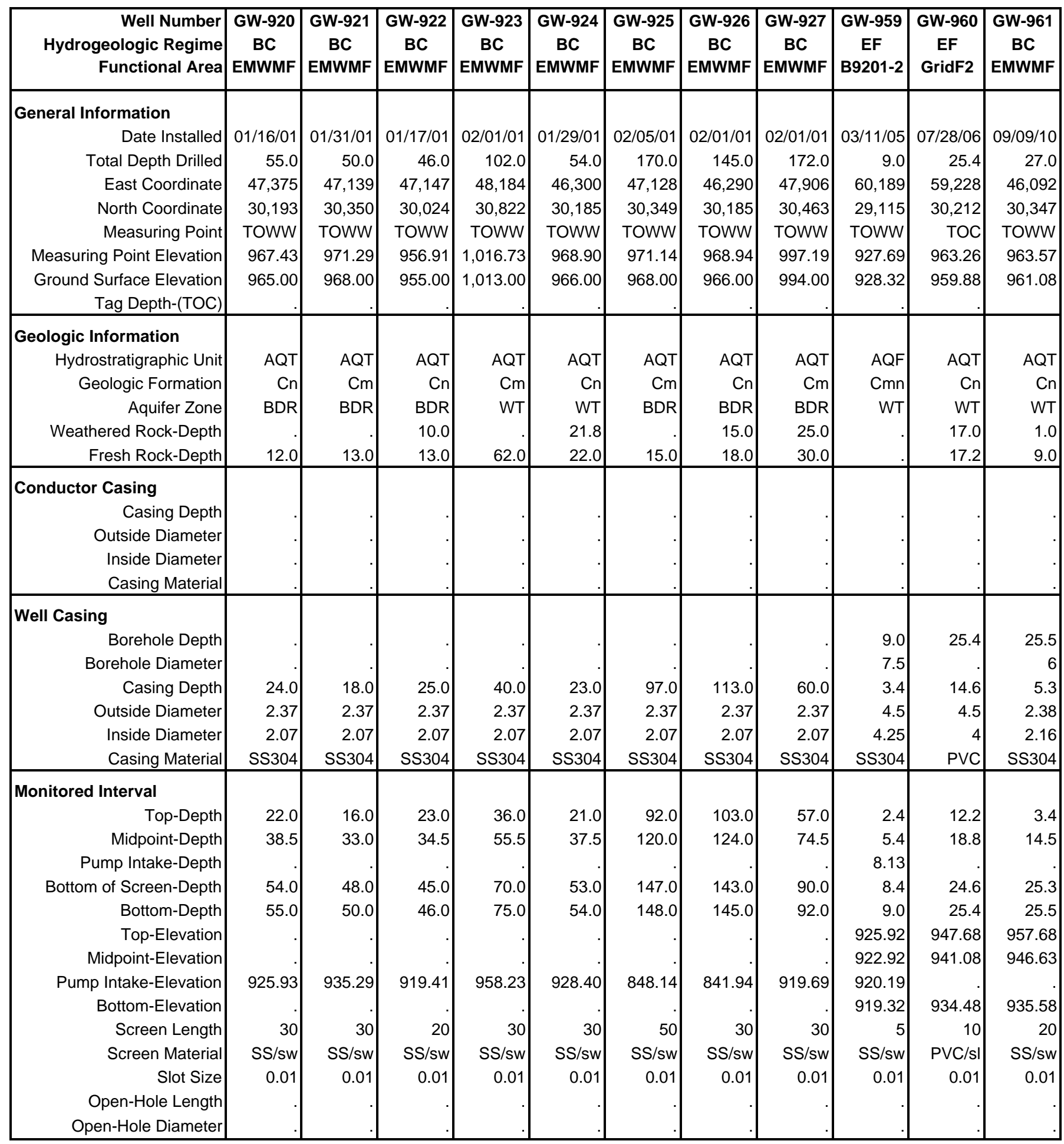



APPENDIX D

CY 2009 MONITORING DATA FOR THE BEAR CREEK HYDROGEOLOGIC REGIME 



\title{
EXPLANATION
}

\section{Sampling Point:}

\author{
BCK - Bear Creek Kilometer \\ EMW-VWUNDER - outfall for an underdrain installed to lower the water table and relieve hydrostatic \\ pressure beneath the EMWMF liner. \\ GW - Monitoring Well \\ NT - Northern Tributary (Bear Creek) \\ SS - South Side (of Bear Creek, spring sampling station)
}

\section{Location:}

\author{
BG - Bear Creek Burial Grounds \\ EMWMF - Environmental Management Waste Management Facility \\ EXP - Exit Pathway Monitoring Location: \\ Maynardville Limestone Picket (-A, -B, -C, -W) \\ Spring or Surface Water Location (-SW) \\ OLF - Oil Landfarm \\ RS - Rust Spoil Area \\ S3 - S-3 Site \\ SPI - Spoil Area I
}

\section{Monitoring Program:}

BJC - managed by Bechtel Jacobs Company LLC

GWPP - managed by Y-12 Groundwater Protection Program

\section{Sample Type:}

BAIL - Sample collected with a disposable bailer (free product investigation)

Dup - Field duplicate sample

PDB - Passive diffusion bag sample

\section{Units:}

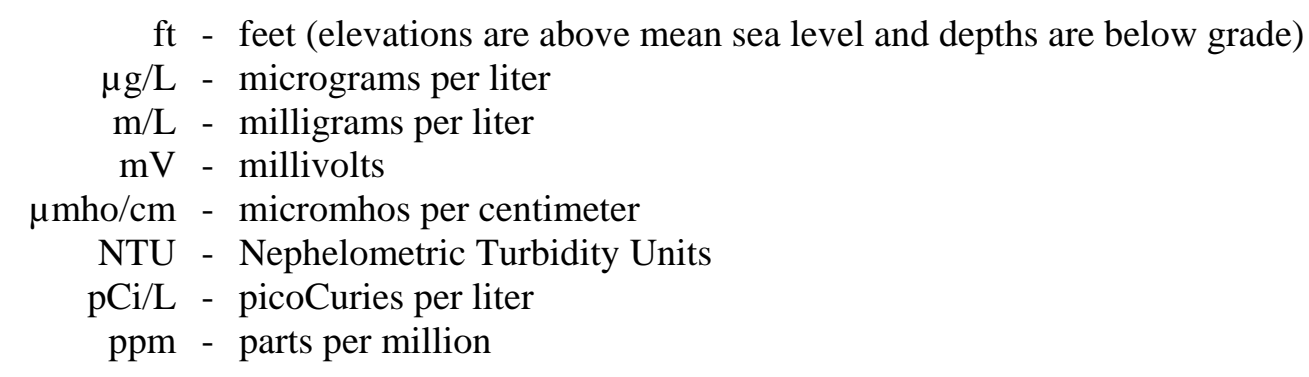




\section{EXPLANATION (continued)}

Only the analytes that were detected above the program reporting limits in at least one sample are included in this appendix. Additionally, results that are below the reporting limits are replaced with missing values (e.g., " < ") to emphasize the detected results. The first three sections of this appendix (D.1, D.2, and D.3) include results for all locations except those at the EMWMF, and results for that site are presented in the fourth section (D.4).

The following sections describe the reporting limits and data qualifiers for each sub-appendix. A comprehensive list of the GWPP analytes, analytical methods, and reporting limits is provided in Appendix B, Table B.5.

\section{D.1 Field Measurements, Miscellaneous Analytes, Major Ions, and Trace Metals:}

Results for all of the field measurements, miscellaneous analytes, and major ions are included in this appendix. The reporting limits for the major ions are shown in the following summary.

\begin{tabular}{|c|c|c|c|c|c|}
\hline \multirow{2}{*}{ Analyte } & \multicolumn{2}{|c|}{ Reporting Limit $(\mu \mathrm{g} / \mathrm{L})$} & \multirow{2}{*}{ Analyte } & \multicolumn{2}{|c|}{ Reporting Limit $(\mu \mathrm{g} / \mathrm{L})$} \\
\hline & GWPP & BJC & & GWPP & BJC \\
\hline $\begin{array}{r}\text { Cations } \\
\text { Calcium } \\
\text { Magnesium } \\
\text { Potassium } \\
\text { Sodium }\end{array}$ & $\begin{array}{l}0.2 \\
0.2 \\
2.0 \\
0.2\end{array}$ & $\begin{array}{c}0.01 \\
0.05 \\
0.025 \\
0.01\end{array}$ & $\begin{array}{r}\text { Anions } \\
\text { Bicarbonate } \\
\text { Carbonate } \\
\text { Chloride } \\
\text { Fluoride } \\
\text { Nitrate (as Nitrogen) } \\
\text { Sulfate }\end{array}$ & $\begin{array}{c}1.0 \\
1.0 \\
0.2 \\
0.1 \\
0.05 \\
0.25\end{array}$ & $\begin{array}{c}\text { NS } \\
\text { NS } \\
0.1 \\
0.05 \\
0.1 \\
0.1\end{array}$ \\
\hline
\end{tabular}

The Y-12 GWPP sampling and analysis plan (SAP) for CY 2009 (B\&W Y-12 2008) specifies trace metal reporting limits and analytical methods that are appropriate for DOE Order monitoring. The laboratories subcontracted by monitoring programs managed by BJC may use reporting limits (sometimes reporting estimated values) that are lower than the GWPP reporting limits for the metals. For this report, the analytical methods for metals used by BJC monitoring programs (EPA-7470, SW846-6010B, SW846-6020, and ASTM-D5174-M) are considered to be functionally equivalent to the methods used by the GWPP (Table B.5). To retain the highest quality data for DOE Order monitoring purposes and to standardize reporting limits for trace metal results obtained from all sources, the GWPP reporting limits were given precedence over the BJC reporting limits (BJC 2009a) shown on the following page. The trace metals shown in bold typeface below were detected in at least one groundwater or surface water sample collected during CY 2009 and are presented in Appendix D.1. 
EXPLANATION (continued)

\begin{tabular}{|r|c|c|r|c|c|}
\hline \multirow{2}{*}{ Analyte } & \multicolumn{2}{|c|}{ Reporting Limit $(\boldsymbol{\mu g} / \mathbf{L})$} & \multirow{2}{*}{ Analyte } & \multicolumn{2}{c|}{ Reporting Limit $(\boldsymbol{\mu g} / \mathbf{L})$} \\
\cline { 2 - 3 } & $\mathbf{G W P P}$ & $\mathbf{B J C}$ & & $\mathbf{G W P P}$ & BJC \\
\hline Aluminum & 0.2 & $0.05^{*}$ & Lithium & 0.01 & 0.01 \\
Antimony & $0.0025^{* *}$ & 0.003 & Manganese & 0.005 & 0.005 \\
Arsenic & $0.005^{* *}$ & 0.005 & Mercury & 0.00005 & 0.0002 \\
Barium & 0.004 & 0.005 & Molybdenum & 0.05 & NS \\
Beryllium & 0.0005 & 0.001 & Nickel & $0.005^{* *}$ & 0.01 \\
Boron & 0.1 & $0.01^{*}$ & Selenium & $0.01^{* *}$ & $0.0025^{*}$ \\
Cadmium & $0.0025^{* *}$ & $0.00013^{*}$ & Silver & 0.02 & $0.0015^{*}$ \\
Chromium & $0.01^{* *}$ & $0.005^{*}$ & Strontium & 0.005 & 0.005 \\
Cobalt & 0.02 & $0.005^{*}$ & Thallium & $0.0005^{* *}$ & 0.001 \\
Copper & 0.02 & $0.005^{*}$ & Thorium & 0.2 & NS \\
Iron & 0.05 & $0.01^{*}$ & Uranium & $0.0005^{* *}$ & 0.004 \\
Lead & $0.0005^{* *}$ & 0.002 & Vanadium & 0.02 & $0.01^{*}$ \\
& \multicolumn{3}{|c|}{ Zinc } & 0.05 & $0.01^{*}$ \\
\hline
\end{tabular}

To evaluate the lowest possible mercury concentrations in surface water and potential groundwater contributions, monitoring by BJC included the following results that are not presented in Appendix D.1.

\begin{tabular}{|c|c|c|c|}
\hline \multirow{2}{*}{ Sampling Location } & \multicolumn{3}{|c|}{ Mercury Concentration $(\mu \mathrm{g} / \mathrm{L})$ by Method EPA-1631 } \\
\hline & Feb. \& Mar. 2009 & July 2009 & Dec. 2009 \\
\hline GW-683 & 0.0000064 & 0.0000014 & . \\
\hline GW-684 & 0.0000050 & 0.0000005 & \\
\hline BCK-03.30 & & . & 0.0000019 \\
\hline BCK-04.55 & • & . & 0.0000020 \\
\hline BCK-07.87 & & & 0.0000028 \\
\hline BCK-09.20 & 0.0000037 & 0.0000039 & 0.0000033 \\
\hline BCK-11.54 & 0.0000083 & 0.0000042 & 0.0000058 \\
\hline BCK-11.84 & & & 0.0000076 \\
\hline BCK-12.34 & 0.0000114 & 0.0001272 & 0.0000090 \\
\hline NT-01 & & . & 0.0000067 \\
\hline NT-03 & & & 0.0000076 \\
\hline NT-08 & 0.0000048 & 0.0000038 & 0.0000038 \\
\hline S07 & & & 0.0000030 \\
\hline SS-4 & 0.0000166 & 0.0000090 & . \\
\hline SS-5 & 0.0000019 & 0.0000044 & 0.0000016 \\
\hline SS-6.6 & . & . & 0.0000029 \\
\hline SS-7 & • & . & 0.0000005 \\
\hline SS-8 & 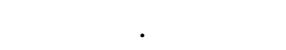 & 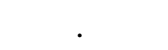 & 0.0000011 \\
\hline
\end{tabular}




\section{EXPLANATION (continued)}

The following symbols and data qualifiers are used in Appendix D.1:

. - Not analyzed or not applicable

$<\quad$ - Analyzed but not detected at the project reporting level

$\mathrm{J}$ - Positively identified; estimated concentration

Q - Result is inconsistent with historical measurements for the location

$\mathrm{R} \quad$ - The ion charge balance error (percent difference between summed cation charge and summed anion charge) exceeds $20 \%$ 


\section{EXPLANATION (continued)}

\section{D.2 Volatile Organic Compounds:}

The Y-12 GWPP reporting limits for volatile organic compounds (Table B.5) and those used for monitoring programs managed by BJC are contract-required quantitation limits. Results below the quantitation limit and above the instrument detection limit are reported as estimated quantities. Therefore, non-detected results are assumed to equal zero for all compounds.

As summarized below, 28 compounds were detected in the CY 2009 groundwater and surface water samples collected in the Bear Creek Regime. Results for these compounds are grouped by similar chemical composition (e.g., chloroethenes) in Appendix D.2.

\begin{tabular}{|r|c|c|r|c|c|}
\hline Compound & $\begin{array}{c}\text { No. } \\
\text { Detected }\end{array}$ & $\begin{array}{c}\text { Maximum } \\
(\mathbf{m} / \mathbf{L})\end{array}$ & Compound & $\begin{array}{r}\text { No. } \\
\text { Detected }\end{array}$ & $\begin{array}{c}\text { Maximum } \\
(\mathbf{m} / \mathbf{L})\end{array}$ \\
\hline Trichloroethene & 46 & 24,000 & 1,1,2-Trichloro-1,2,2-trifluoroethane & 5 & 190 \\
cis-1,2-Dichloroethene & 45 & 2,730 & Ethylbenzene & 5 & 11 \\
Tetrachloroethene & 35 & 180,000 & Methylene chloride & 4 & 29 \\
1,1-Dichloroethene & 29 & 2,700 & 1,2 -Dichloroethane & 3 & 24 \\
1,1-Dichloroethane & 28 & 11,000 & Dichlorodifluoromethane & 3 & 16 \\
Vinyl chloride & 19 & 320 & $2-B u t a n o n e$ & 3 & 10 \\
Benzene & 13 & 1,500 & 1,1,2-Trichloroethane & 2 & 43 \\
1,1,1-Trichloroethane & 12 & 1,200 & Carbon disulfide & 2 & $3 \mathrm{~J}$ \\
Chloroform & 10 & 30 & 1,2-Dichloropropane & 2 & $1.16 \mathrm{~J}$ \\
trans-1,2-Dichloroethene & 9 & 74 & Acetone & 1 & 81 \\
Chloroethane & 8 & 26 & Chlorobenzene & 1 & 13 \\
Total Xylene & 6 & 43 & Carbon tetrachloride & 1 & $4 \mathrm{~J}$ \\
Toluene & 6 & 32 & 1,4-Dichlorobenzene & 1 & $3 \mathrm{~J}$ \\
\hline
\end{tabular}

The following symbols and data qualifiers are used in Appendix D.2.

- $\quad$ - Not analyzed

$<\quad$ - Analyzed but not detected (also false-positive results)

$\mathrm{J}$ - Positively identified, estimated concentration below the contract-required quantitation limit

Q - Result is inconsistent with historical measurements for the location 


\section{EXPLANATION (continued)}

\section{D.3 Radiological Analytes:}

Reporting limits for radiological analytes are sample-specific and analyte-specific minimum detectable activities that are reported with each result. The following summary shows the primary radiological analytes relevant to DOE Order monitoring collected during CY 2009 in the Bear Creek Regime.

\begin{tabular}{|r|c|c|r|c|c|}
\hline Analyte & $\begin{array}{c}\text { No. of } \\
\text { Results }\end{array}$ & $\begin{array}{c}\text { No. } \\
\text { Detected }\end{array}$ & Analyte & $\begin{array}{c}\text { No. of } \\
\text { Results }\end{array}$ & $\begin{array}{c}\text { No. } \\
\text { Detected }\end{array}$ \\
\hline Gross Alpha & 64 & 33 & Strontium-89/90* & 2 & 0 \\
Gross Beta & 64 & 41 & Technetium-99 & 42 & 22 \\
Americium-241 & 2 & 0 & Uranium-234* & 34 & 26 \\
Neptunium-237 & 2 & 2 & Uranium-235* & 34 & 10 \\
Total Radium Alpha & 2 & 2 & Uranium-238 & 34 & 23 \\
\hline Note: * = Reported by BJC laboratories in Appendix D.3 as equivalent GWPP analytes: \\
Sr-90 = Sr-89/90; U-233/234 = U-234; U-235/236 = U-235. \\
\hline
\end{tabular}

Gross alpha and gross beta results are presented in the first three pages of Appendix D.3, followed by results for the primary isotopes shown above (pages D.3-4 through D.3-7).

The following notes and qualifiers apply to Appendix D.3:

Activity - Result in picoCuries per liter (pCi/L)

TPU - Total propagated uncertainty (two standard deviations); calculation includes the counting error (instrument uncertainty) as reported previously, plus other sources of uncertainty (e.g., volumetric, chemical yield)

MDA - Minimum detectable activity

- $\quad$ - Not analyzed or not applicable (TPU is not presented when the result is $<$ MDA)

$<\quad$ - Analyzed but less than the MDA (not detected)

Q - Result is inconsistent with historical measurements for the location

$\mathrm{R}$ - Result does not meet data quality objectives: exceeds the MDA but is less than the TPU. 


\section{EXPLANATION (continued)}

\section{D.4 Monitoring data for the EMWMF:}

As with previous tables in Appendix D, only the analytes that were detected above the program reporting limits in at least one sample are included. Results for all field measurements and major cations are presented, along with results for 18 metals and one volatile organic compound (cis-1,2-dichloroethene).

The following notes and qualifiers apply to Appendix D.4:

. - Not analyzed or not applicable (duplicate field measurements)

$<\quad$ - Analyzed but not detected at the program reporting level

$\mathrm{J}$ - Positively identified; estimated concentration

Q - Result is inconsistent with historical measurements for the location

Activity - Result in picoCuries per liter (pCi/L)

TPU - Total propagated uncertainty (two standard deviations); calculation includes the counting error (instrument uncertainty) as reported previously, plus other sources of uncertainty (e.g., volumetric, chemical yield)

MDA - Minimum detectable activity

* - Field measurements obtained on a previous date, as shown below:

\begin{tabular}{|c|c|c|c|c|c|}
\hline $\begin{array}{c}\text { Sampling } \\
\text { Location }\end{array}$ & $\begin{array}{c}\text { Date } \\
\text { Sampled }\end{array}$ & $\begin{array}{c}\text { Field } \\
\text { Measurements }\end{array}$ & $\begin{array}{c}\text { Sampling } \\
\text { Location }\end{array}$ & $\begin{array}{c}\text { Date } \\
\text { Sampled }\end{array}$ & $\begin{array}{c}\text { Field } \\
\text { Measurements }\end{array}$ \\
\hline GW-363 & $02 / 18 / 09$ & $02 / 17 / 09$ & GW-923 & $02 / 18 / 09$ & $02 / 17 / 09$ \\
GW-363 & $04 / 23 / 09$ & $04 / 22 / 09$ & GW-923 & $04 / 21 / 09$ & $04 / 20 / 09$ \\
GW-363 & $08 / 20 / 09$ & $08 / 19 / 09$ & GW-923 & $08 / 12 / 09$ & $08 / 11 / 09$ \\
GW-363 & $11 / 18 / 09$ & $08 / 20 / 09$ & GW-923 & $11 / 11 / 09$ & $11 / 10 / 09$ \\
GW-639 & $02 / 18 / 09$ & $02 / 17 / 09$ & GW-925 & $02 / 12 / 09$ & $02 / 11 / 09$ \\
GW-639 & $04 / 23 / 09$ & $04 / 22 / 09$ & GW-925 & $04 / 15 / 09$ & $04 / 14 / 09$ \\
GW-639 & $08 / 19 / 09$ & $08 / 18 / 09$ & GW-925 & $08 / 18 / 09$ & $08 / 17 / 09$ \\
GW-639 & $11 / 18 / 09$ & $11 / 17 / 09$ & GW-925 & $11 / 11 / 09$ & $11 / 10 / 09$ \\
& & & $G W-926$ & $11 / 17 / 09$ & $11 / 16 / 09$ \\
\hline
\end{tabular}




\section{EXPLANATION (continued)}

Quarterly monitoring at the EMWMF includes analyses for an extensive list of isotopes with low detection limits. The radiological data obtained for sampling locations at the EMWMF are summarized below.

\begin{tabular}{|r|c|c|r|c|c|}
\hline Analyte & $\begin{array}{c}\text { No. of } \\
\text { Results }\end{array}$ & $\begin{array}{c}\text { No. } \\
\text { Detected }\end{array}$ & Analyte & $\begin{array}{c}\text { No. of } \\
\text { Results }\end{array}$ & $\begin{array}{c}\text { No. } \\
\text { Detected }\end{array}$ \\
\hline Actinium-227* & 79 & 4 & Plutonium-239/240 & 79 & 1 \\
Americium-241 & 79 & 4 & Plutonium-241 & 79 & 0 \\
Americium-243 & 79 & 5 & Plutonium-242 & 79 & 4 \\
Carbon-14 & 79 & 0 & Plutonium-244 & 79 & 0 \\
Cesium-137 & 79 & 2 & Potassium-40 & 79 & 3 \\
Chlorine-36 & 79 & 6 & Radium-226 & 79 & 37 \\
Cobalt-60 & 79 & 0 & Radium-228 & 79 & 10 \\
Curium-242 & 79 & 0 & Strontium-90 & 79 & 29 \\
Curium-243/244 & 79 & 0 & Technetium-99 & 79 & 17 \\
Curium-245 & 79 & 8 & Thorium-227 & 79 & 4 \\
Curium-246* & 79 & 8 & Thorium-228 & 79 & 2 \\
Curium-247 & 79 & 1 & Thorium-229 & 79 & 2 \\
Curium-248 & 79 & 0 & Thorium-230 & 78 & 30 \\
Europium-152 & 79 & 0 & Thorium-231+234* & 79 & 30 \\
Europium-154 & 79 & 0 & Thorium-232 & 79 & 3 \\
Europium-155 & 79 & 0 & Tritium & 79 & 3 \\
Iodine-129 & 79 & 0 & Uranium-232 & 79 & 1 \\
Neptunium-237 & 79 & 1 & Uranium-233/234 & 79 & 48 \\
Nickel-63 & 79 & 1 & Uranium-235/236 & 79 & 9 \\
Plutonium-236 & 79 & 0 & Uranium-238 & 79 & 30 \\
Plutonium-238 & 79 & 0 & Yttrium-90* & 79 & 29 \\
\hline
\end{tabular}

Results for the isotopes that exceed the MDA (shown above as detected) are presented after the primary isotopic data (beginning on page D.4-10).

* The results for these isotopes are not presented because they are identical to the ones that are included (shown in bold typeface): Thorium-227 for Actinium-227*; Curium-245 for Curium-246*; Strontium-90 for Yttrium-90*; and Uranium-238 for Thorium231+234*. The pairs of results are identical because the isotopes are in secular equilibrium, with the parent isotope having the longer half-life. 


\section{EXPLANATION (continued)}

Additional Analytes Not Presented in Appendix D.4 tables:

As shown below, a semivolatile organic compound and pesticides were detected in at least one sample from several of the locations at the Environmental Management Waste Management Facility.

\begin{tabular}{|c|c|c|c|}
\hline Sampling Location & Date Sampled & Compound & Result $(\boldsymbol{\mu g} / \mathbf{L})$ \\
\hline Semivolatile Organics & & & \\
GW-639 & $11 / 18 / 09$ & Bis(2-ethylhexyl)phthalate & $8.49 \mathrm{Q}$ \\
GW-917 & $04 / 14 / 09$ & Bis(2-ethylhexyl)phthalate & $3.22 \mathrm{~J}$ \\
GW-918 & $02 / 10 / 09$ & Bis(2-ethylhexyl)phthalate & $4 \mathrm{~J}$ \\
GW-918 & $08 / 12 / 09$ & Bis(2-ethylhexyl)phthalate & 5.19 \\
GW-925 & $08 / 18 / 09$ & Bis(2-ethylhexyl)phthalate & $31 \mathrm{Q}$ \\
GW-926 & $02 / 10 / 09$ & Bis(2-ethylhexyl)phthalate & $4 \mathrm{~J}$ \\
GW-927 & $08 / 12 / 09$ & Bis(2-ethylhexyl)phthalate & $29.5 \mathrm{Q}$ \\
GW-961 & $11 / 23 / 09$ & Bis(2-ethylhexyl)phthalate & $3.25 \mathrm{~J}$ \\
EMWNT-05 & $11 / 09 / 09$ & Bis(2-ethylhexyl)phthalate & $3.37 \mathrm{Q}$ \\
& & & \\
Gesticides & $08 / 12 / 09$ & Heptachlor & $0.02 \mathrm{~J}$ \\
EMWNT-03A & $02 / 09 / 09$ & Endrin aldehyde & $0.01 \mathrm{~J}$ \\
EMWNT-05 & $08 / 10 / 09$ & Aldrin & $0.02 \mathrm{~J}$ \\
\hline
\end{tabular}

Because the concentrations are very low (most are estimated values), many are inconsistent with historical results (Q qualified), and the compounds are typically detected in only one sample from a location, these results are probably analytical artifacts. 

APPENDIX D.1

FIELD MEASUREMENTS, MISCELLANEOUS ANALYTES, MAJOR IONS, AND TRACE METALS 

APPENDIX D.1: CY 2009 MONITORING DATA FOR THE BEAR CREEK HYDROGEOLOGIC REGIME Field Measurements, Miscellaneous Analytes, Major lons, and Trace Metals

\begin{tabular}{|c|c|c|c|c|c|c|c|c|c|c|c|}
\hline Sampling Point & \multicolumn{2}{|c|}{ GW-008 } & GW-014 & \multicolumn{2}{|c|}{ GW-046 } & GW-058 & \multicolumn{2}{|c|}{ GW-065 } & GW-068 & \multicolumn{2}{|c|}{ GW-071 } \\
\hline Functional Area & \multicolumn{2}{|c|}{ OLF } & BG & \multicolumn{2}{|c|}{ BG } & BG & \multicolumn{2}{|c|}{ OLF } & BG & \multicolumn{2}{|c|}{ BG } \\
\hline Date Sampled & 01/06/09 & 07/06/09 & $03 / 04 / 09$ & 01/07/09 & 07/06/09 & 02/10/09 & $02 / 25 / 09$ & 08/06/09 & 03/03/09 & 03/04/09 & $08 / 10 / 09$ \\
\hline Program & BJC & BJC & GWPP & BJC & BJC & GWPP & GWPP & GWPP & GWPP & GWPP & GWPP \\
\hline Sample Type & & & & & & & NP & NP & & & \\
\hline Field Measurements & & & & & & & & & & & \\
\hline Time Sampled & $13: 40$ & $9: 45$ & $14: 30$ & $14: 00$ & $10: 55$ & $13: 35$ & $10: 00$ & $8: 15$ & $14: 45$ & $10: 10$ & $9: 45$ \\
\hline Measuring Point Elev. (ft) & 965.39 & 965.39 & 934.50 & 921.17 & 921.17 & 913.30 & 982.50 & 982.50 & 924.61 & 928.90 & 928.90 \\
\hline Depth to Water (ft) & 13.12 & 14.66 & 5.86 & 3.31 & 3.44 & 22.13 & 26.44 & 26.95 & 6.19 & 8.04 & 8.38 \\
\hline Groundwater Elevation (ft) & 952.27 & 950.73 & 928.64 & 917.86 & 917.73 & 891.17 & 956.06 & 955.55 & 918.42 & 920.86 & 920.52 \\
\hline Conductivity $(\mu \mathrm{mho} / \mathrm{cm})$ & 143 & 175 & 436 & 160 & 250 & 712 & 538 & 484 & 695 & 1,792 & 1,716 \\
\hline Dissolved Oxygen (ppm) & 0.84 & 12.63 & 0.83 & 13.05 & 0.38 & 4.21 & 5.4 & 6.7 & 1.14 & 0.39 & 0.29 \\
\hline Oxidation/Reduction (mV) & 75 & 54 & 60 & 140 & 197 & 197 & 180 & 227 & -60 & -350 & -370 \\
\hline Temperature (degrees C) & 16.3 & 16.2 & 12.4 & 14.5 & 16.9 & 15.1 & 12.6 & 16.2 & 11.2 & 7.7 & 22.6 \\
\hline Turbidity (NTU) & & 1 & & 11 & 3 & & & & & & \\
\hline $\mathrm{pH}$ & 4.89 & 4.49 & 6.84 & 5.12 & 5.25 & 7.11 & 6.87 & 6.7 & 7.38 & 10.56 & 10.2 \\
\hline $\begin{array}{r}\text { Miscellaneous Analytes } \\
\text { Dissolved Solids (mg/L) } \\
\text { Suspended Solids (mg/L) }\end{array}$ & & & & & & $\begin{array}{r}508 \\
6 \\
\end{array}$ & $\begin{array}{r}204 \\
< \\
\end{array}$ & $\begin{array}{r}239 \\
2 \\
\end{array}$ & $\begin{array}{r}303 \\
< \\
\end{array}$ & & \\
\hline Major lons (mg/L) & & & & & & & & & & & \\
\hline Calcium & 13.3 & 13 & & & & 90.7 & 75.6 & 76.4 & 67.2 & & \\
\hline Magnesium & 6.65 & 7 & & & & 21.9 & 12.6 & 11.9 & 18.1 & & \\
\hline Potassium & 1.38 & 1.2 & & & & 2.68 & $<$ & 3.01 & 7.17 & & \\
\hline Sodium & 3.04 & 2.6 & & & & 17.2 & 1.31 & 1.28 & 36.8 & & \\
\hline Bicarbonate & & & & & & 218 & 207 & 227 & 162 & & \\
\hline Carbonate & & & & & & $<$ & $<$ & $<$ & $<$ & & \\
\hline Chloride & & & & & & 35 & 0.611 & 0.889 & 105 & & \\
\hline Fluoride & & & & & & 0.231 & 0.107 & 0.128 & 0.118 & & \\
\hline Nitrate as $\mathrm{N}$ & & & & & & 11.4 & $<$ & $<$ & $<$ & & \\
\hline Sulfate & & & & & & 31.4 & 19.8 & 17.2 & 4.3 & & \\
\hline Charge balance error (\%) & & & & & & 2.3 & 3.1 & 0 & 2.6 & & \\
\hline Trace Metals (mg/L) & & & & & & & & & & & \\
\hline Aluminum & $<$ & $<$ & & & & 5.24 & $<$ & 0.286 & $<$ & & \\
\hline Arsenic & $<$ & $<$ & & & & & $<$ & $<$ & 0.00556 & 0.00932 & $<$ \\
\hline Barium & 0.0968 & 0.099 & & & & 0.0932 & 0.0174 & 0.0261 & 0.829 & & \\
\hline Beryllium & $<$ & $<$ & & & & & $<$ & & $<$ & & \\
\hline Boron & $<$ & $<$ & & & & $<$ & $<$ & $<$ & 0.107 & & \\
\hline Cadmium & $<$ & $<$ & & & & $<$ & $<$ & $<$ & $<$ & $<$ & $<$ \\
\hline Chromium & $<$ & $<$ & & & & 0.016 & $<$ & $<$ & $<$ & $<$ & $<$ \\
\hline Cobalt & 0.0274 & 0.03 & & & & $<$ & $<$ & $<$ & $<$ & & \\
\hline Iron & 3.65 & 5 & & & & 2.74 & $<$ & 0.277 & 0.295 & & \\
\hline Lead & $<$ & $<$ & & & & 0.00169 & 0.00349 & 0.00585 & 0.00109 & 0.00059 & 0.00101 \\
\hline Lithium & $<$ & $<$ & & & & 0.012 & $<$ & & 0.0581 & & \\
\hline Manganese & 2.93 & 2.6 & & & & 0.0777 & 0.019 & 0.161 & 0.0288 & & \\
\hline Mercury & $<$ & $<$ & & & & $<$ & $<$ & & $<$ & & \\
\hline Molybdenum & & & & & & $<$ & $<$ & $<$ & $<$ & & \\
\hline Nickel & 0.0236 & 0.029 & & & & $<$ & $<$ & $<$ & 0.0763 & $<$ & $<$ \\
\hline Selenium & $<$ & $<$ & & & & $<$ & $<$ & $<$ & $<$ & $<$ & $<$ \\
\hline Silver & & & & & & $<$ & $<$ & $<$ & $<$ & & \\
\hline Strontium & 0.0368 & 0.037 & & & & 0.17 & 0.131 & 0.14 & 2.06 & & \\
\hline Thallium & $<$ & $<$ & & & & $<$ & $<$ & $<$ & $<$ & $<$ & - \\
\hline Uranium & $<$ & $<$ & & $<$ & $<$ & 0.014 & 0.00814 & 0.0148 & $<$ & $<$ & $<$ \\
\hline Zinc & $<$ & $<$ & & & & & & & $<$ & & \\
\hline
\end{tabular}


APPENDIX D.1: CY 2009 MONITORING DATA FOR THE BEAR CREEK HYDROGEOLOGIC REGIME

Field Measurements, Miscellaneous Analytes, Major lons, and Trace Metals

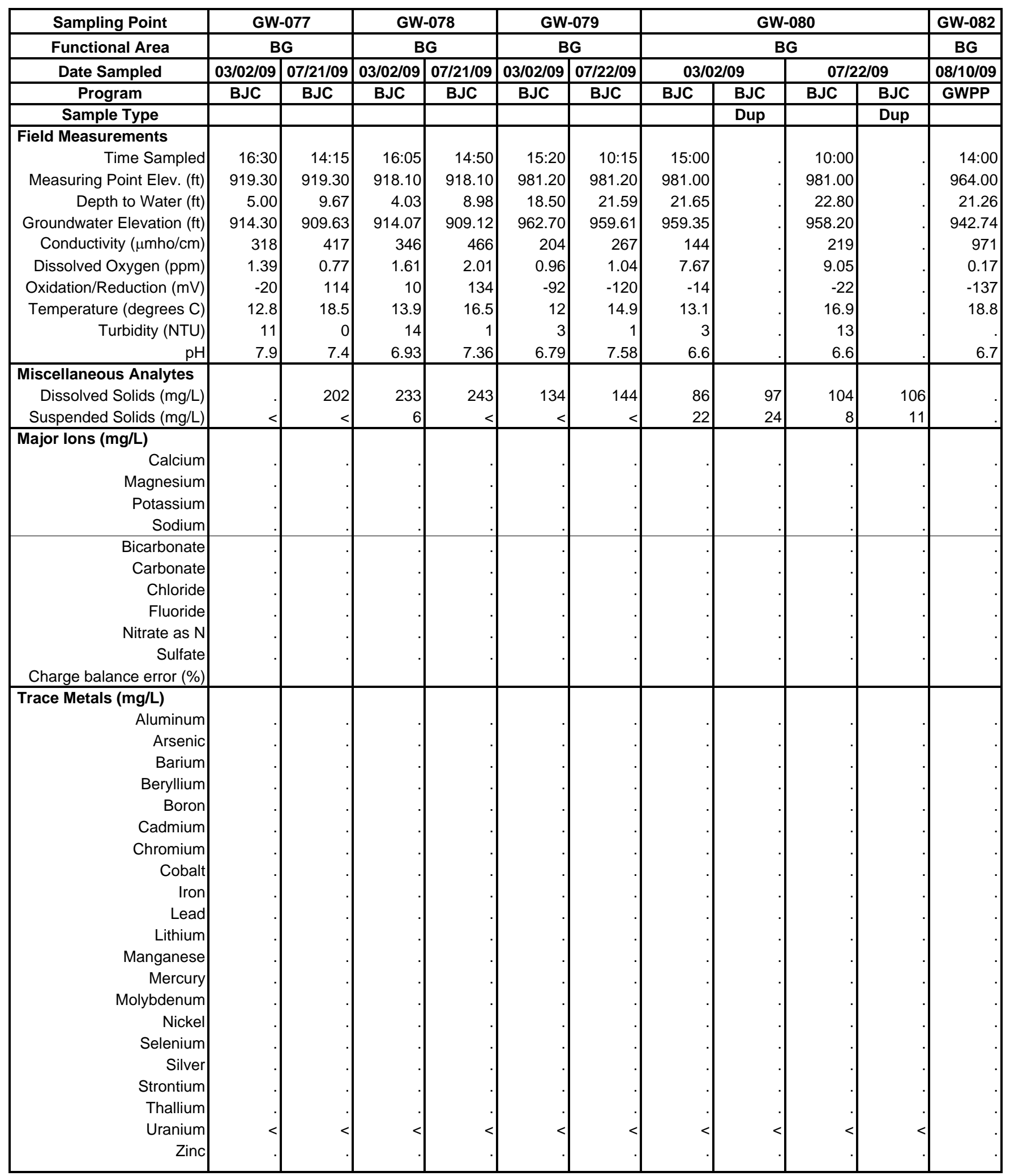


APPENDIX D.1: CY 2009 MONITORING DATA FOR THE BEAR CREEK HYDROGEOLOGIC REGIME Field Measurements, Miscellaneous Analytes, Major lons, and Trace Metals

\begin{tabular}{|c|c|c|c|c|c|c|c|c|c|c|c|}
\hline Sampling Point & \multicolumn{2}{|c|}{ GW-085 } & GW-100 & GW-101 & GW-122 & GW-127 & GW-225 & GW-229 & GW-236 & GW-242 & GW-246 \\
\hline Functional Area & \multicolumn{2}{|c|}{ OLF } & S3 & S3 & S3 & S3 & OLF & OLF & S3 & BG & S3 \\
\hline Date Sampled & \multicolumn{2}{|c|}{$02 / 23 / 09$} & $02 / 19 / 09$ & $02 / 19 / 09$ & $02 / 17 / 09$ & $02 / 17 / 09$ & $02 / 26 / 09$ & $02 / 26 / 09$ & $02 / 23 / 09$ & $03 / 05 / 09$ & $08 / 05 / 09$ \\
\hline Program & GWPP & GWPP & GWPP & GWPP & GWPP & GWPP & GWPP & GWPP & GWPP & GWPP & GWPP \\
\hline Sample Type & & Dup & & & & & & & & & \\
\hline Field Measurements & & & & & & & & & & & \\
\hline Time Sampled & $13: 30$ & $13: 30$ & $14: 30$ & $9: 35$ & $14: 25$ & $10: 25$ & $8: 30$ & $9: 35$ & $14: 55$ & 9:10 & 9:35 \\
\hline Measuring Point Elev. (ft) & 983.57 & 983.57 & 987.40 & $1,007.40$ & $1,007.20$ & $1,005.90$ & 943.11 & 949.00 & 983.21 & 978.69 & $1,009.19$ \\
\hline Depth to Water (ft) & 13.35 & 13.35 & 5.18 & 8.67 & 16.39 & 13.92 & 10.03 & 16.00 & 10.20 & 5.88 & 12.38 \\
\hline Groundwater Elevation (ft) & 970.22 & 970.22 & 982.22 & 998.73 & 990.81 & 991.98 & 933.08 & 933.00 & 973.01 & 972.81 & 996.81 \\
\hline Conductivity $(\mu \mathrm{mho} / \mathrm{cm})$ & 1,213 & 1,213 & 2,020 & 1,077 & 3,240 & 1,121 & 1,180 & 1,653 & 814 & 382 & 19,420 \\
\hline Dissolved Oxygen (ppm) & 0.94 & 0.94 & 1.1 & 0.27 & 0.29 & 4.32 & 0.14 & 0.08 & 0.55 & 0.64 & 0.35 \\
\hline Oxidation/Reduction (mV) & 144 & 144 & 154 & -64 & 136 & 167 & 159 & -61 & 252 & -13 & 305 \\
\hline Temperature (degrees C) & 15.2 & 15.2 & 11.6 & 10.8 & 15.7 & 8.6 & 11.2 & 14.8 & 12.2 & 13.1 & 19 \\
\hline Turbidity (NTU) & & & & & & & & & & & \\
\hline $\mathrm{pH}$ & 6.75 & 6.75 & 6.59 & 6.81 & 6.58 & 6.94 & 7.25 & 6.48 & 5.25 & 6.11 & 4.66 \\
\hline Miscellaneous Analytes & & & & & & & & & & & \\
\hline Dissolved Solids (mg/L) & & & 1,050 & 703 & 1,910 & 650 & & 776 & 486 & 66 & 15,800 \\
\hline Suspended Solids (mg/L) & & & 2 & 11 & 1 & 1 & & 28 & $<$ & 272 & 2 \\
\hline Major Ions (mg/L) & & & & & & & & & & & \\
\hline Calcium & & & 317 & 177 & 363 & 149 & & 197 & 98 & 39.7 & 2,630 \\
\hline Magnesium & & & 23.6 & 29 & 109 & 24 & & 36.5 & 12.6 & 14.4 & 576 \\
\hline Potassium & & & 2.72 & 2.33 & 22.3 & 2.14 & & 13.6 & 3.2 & 8 & 36 \\
\hline Sodium & & & 7.11 & 15.4 & 89.7 & 57.8 & & 75.3 & 17.5 & 11.3 & 454 \\
\hline Bicarbonate & & & 251 & 455 & 392 & 364 & & 615 & 67.5 & 137 & 58.7 \\
\hline Carbonate & & & $<$ & $<$ & $<$ & $<$ & & $<$ & $<$ & $<$ & $<$ \\
\hline Chloride & 7.19 & 7.28 & 360 & 10.2 & 88.4 & 112 & 85.4 & 127 & 25.4 & 12.2 & 276 \\
\hline Fluoride & & & $<$ & 0.261 & $<$ & 0.431 & & 0.12 & 0.154 & 0.192 & 1.08 \\
\hline Nitrate as $\mathrm{N}$ & 97.4 & 96.4 & 25.4 & 20.1 & 260 & 0.448 & $0.313 \mathrm{Q}$ & $<$ & 35.9 & $<$ & 2,829 \\
\hline Sulfate & 8.04 & 7.87 & 22.6 & 37.3 & 14.5 & 48.5 & 46 & 14.5 & 76.4 & 19.2 & 23.3 \\
\hline Charge balance error (\%) & & & 1.9 & 1.4 & 3.9 & 2 & & 0.8 & 4.2 & 5 & -3 \\
\hline Trace Metals (mg/L) & & & & & & & & & & & \\
\hline Aluminum & & & $<$ & $<$ & $<$ & $<$ & & $<$ & 0.306 & 16.4 & 44.2 \\
\hline Arsenic & & & $<$ & $<$ & $<$ & $<$ & & 0.0094 & $<$ & $<$ & $<$ \\
\hline Barium & & & 0.675 & 0.753 & 0.981 & 0.02 & & 1.36 & 0.0691 & 0.208 & 4.64 \\
\hline Beryllium & & & $<$ & $<$ & & $<$ & & $<$ & 0.00083 & 0.00054 & 0.0272 \\
\hline Boron & & & $<$ & $<$ & 0.432 & $<$ & & 3.44 & $<$ & $<$ & $<$ \\
\hline Cadmium & & & $<$ & $<$ & $<$ & $<$ & & $<$ & $<$ & $<$ & 0.279 \\
\hline Chromium & & & 0.0584 & $<$ & $<$ & $<$ & & $<$ & $<$ & 0.0158 & $<$ \\
\hline Cobalt & & & & $<$ & $<$ & $<$ & & $<$ & $<$ & $<$ & 0.442 \\
\hline Iron & & & 0.201 & 4.48 & 0.251 & $<$ & & 26.1 & $<$ & 21 & $<$ \\
\hline Lead & & & 0.00623 & 0.00296 & 0.00056 & $<$ & & 0.00243 & $<$ & 0.0045 & $<$ \\
\hline Lithium & & & 0.0174 & $<$ & 0.159 & $<$ & & 0.123 & $<$ & 0.139 & 0.58 \\
\hline Manganese & & & 0.0822 & 5.07 & 0.0814 & 0.207 & & 7.49 & 1.83 & 2.61 & 106 \\
\hline Mercury & & & & $<$ & & $<$ & & $<$ & $<$ & $<$ & 0.00025 \\
\hline Molybdenum & & & & & $<$ & $<$ & & $<$ & $<$ & $<$ & $<$ \\
\hline Nickel & & & 0.0292 & 0.00539 & $<$ & 0.0059 & & $<$ & 0.0166 & 0.0158 & 4.1 \\
\hline Selenium & & & & $<$ & $<$ & $<$ & & $<$ & $<$ & & $<$ \\
\hline Silver & & & & $<$ & $<$ & $<$ & & $<$ & $<$ & $<$ & $<$ \\
\hline Strontium & & & 0.569 & 0.745 & 11.7 & 0.305 & & 0.599 & 0.216 & 0.242 & 9.97 \\
\hline Thallium & & & & & & & & $<$ & $<$ & $<$ & $<$ \\
\hline Uranium & & & 0.00172 & 0.00342 & 0.00206 & 0.0534 & & 0.143 & 0.00793 & 0.00072 & 0.436 \\
\hline Zinc & & & 0.0551 & & & 0.114 & & & & & 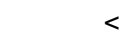 \\
\hline
\end{tabular}


APPENDIX D.1: CY 2009 MONITORING DATA FOR THE BEAR CREEK HYDROGEOLOGIC REGIME Field Measurements, Miscellaneous Analytes, Major lons, and Trace Metals

\begin{tabular}{|c|c|c|c|c|c|c|c|c|c|c|}
\hline Sampling Point & \multicolumn{2}{|c|}{ GW-276 } & \multicolumn{2}{|c|}{ GW-307 } & GW-526 & GW-537 & GW-601 & GW-615 & GW-616 & GW-623 \\
\hline Functional Area & \multicolumn{2}{|c|}{ S3 } & \multicolumn{2}{|c|}{ RS } & S3 & OLF & OLF & S3 & S3 & BG \\
\hline Date Sampled & $01 / 07 / 09$ & $07 / 06 / 09$ & \multicolumn{2}{|c|}{$02 / 10 / 09$} & $02 / 24 / 09$ & $08 / 05 / 09$ & $03 / 02 / 09$ & $02 / 18 / 09$ & $08 / 05 / 09$ & $03 / 03 / 09$ \\
\hline Program & BJC & BJC & GWPP & GWPP & GWPP & GWPP & GWPP & GWPP & GWPP & GWPP \\
\hline Sample Type & & & & Dup & & & & & & NP \\
\hline Field Measurements & & & & & & & & & & \\
\hline Time Sampled & $10: 30$ & $14: 45$ & 9:15 & 9:15 & $13: 25$ & $8: 20$ & $13: 40$ & $14: 00$ & $11: 05$ & $13: 00$ \\
\hline Measuring Point Elev. (ft) & $1,001.57$ & $1,001.57$ & 993.14 & 993.14 & 998.25 & 976.65 & $1,002.80$ & $1,017.55$ & $1,011.81$ & 925.21 \\
\hline Depth to Water (ft) & 3.62 & 5.84 & 30.14 & 30.14 & 13.20 & 5.97 & 64.22 & 12.69 & 9.45 & 5.29 \\
\hline Groundwater Elevation (ft) & 997.95 & 995.73 & 963.00 & 963.00 & 985.05 & 970.68 & 938.58 & $1,004.86$ & $1,002.36$ & 919.92 \\
\hline Conductivity $(\mu \mathrm{mho} / \mathrm{cm})$ & 446 & 755 & 951 & 951 & 10,350 & 3,710 & 979 & 60,700 & 2,400 & 1,491 \\
\hline Dissolved Oxygen (ppm) & 13.44 & 1.5 & 0.81 & 0.81 & 0.5 & 0.18 & 0.7 & 0.38 & 0.29 & 0.61 \\
\hline Oxidation/Reduction (mV) & 257 & 207 & 188 & 188 & 115 & 246 & 116 & 76 & 81 & -43 \\
\hline Temperature (degrees C) & 13.9 & 24.2 & 12.8 & 12.8 & 10.8 & 16.3 & 9.8 & 12.8 & 22.6 & 12.1 \\
\hline Turbidity (NTU) & 3 & 0 & & & & & & & & \\
\hline $\mathrm{pH}$ & 3.5 & 4.6 & 6.43 & 6.43 & 7.81 & 6.58 & 7.38 & 5.89 & 9.79 & 10.17 \\
\hline Miscellaneous Analytes & & & & & & & & & & \\
\hline Dissolved Solids (mg/L) & & & 541 & 482 & & & & 64,400 & & 924 \\
\hline Suspended Solids (mg/L) & & & $<$ & $<$ & & & & 1 & & $<$ \\
\hline Major Ions (mg/L) & & & & & & & & & & \\
\hline Calcium & 26 & 34 & 169 & 162 & & & & 9,430 & & 1.04 \\
\hline Magnesium & 4.66 & 5.4 & 16.2 & 15.7 & & & & 2,400 & & $<$ \\
\hline Potassium & 4.81 & 5 & 4.04 & 4.01 & & & & 124 & & 4.33 \\
\hline Sodium & 52.8 & 48 & 12.7 & 12.2 & & & & 2,550 & & 355 \\
\hline Bicarbonate & & & 370 & 370 & & & & 250 & & 269 \\
\hline Carbonate & & & $<$ & $<$ & & & & $<$ & & 236 \\
\hline Chloride & & & 35.6 & 31.4 & 30.9 & 23.4 & 87.7 & 110 & 17.2 & 95.2 \\
\hline Fluoride & & & & $<$ & & & & 0.156 & & 6.02 \\
\hline Nitrate as $\mathrm{N}$ & 12.2 & 11 & 0.301 & 0.284 & 1,560 & 397 & 16.6 & 10,400 & 255 & $<$ \\
\hline Sulfate & & & 91 & 90.4 & 2.72 & 5.5 & 75.7 & $<$ & 16.4 & 79.6 \\
\hline Charge balance error (\%) & & & 0.5 & -0.9 & & & & 2 & & 2.3 \\
\hline Trace Metals (mg/L) & & & & & & & & & & \\
\hline Aluminum & 1.96 & 1.6 & $<$ & $<$ & & & & $<$ & & 0.386 \\
\hline Arsenic & & $<$ & $<$ & $<$ & & & & $<$ & & 0.00789 \\
\hline Barium & 0.0652 & 0.06 & 0.0795 & 0.0761 & & & & 376 & & 0.0386 \\
\hline Beryllium & 0.00248 & 0.0021 & $<$ & $<$ & & & & $0.00529 \mathrm{Q}$ & & $<$ \\
\hline Boron & & 0.49 & $<$ & $<$ & & & & $<$ & & 0.807 \\
\hline Cadmium & 0.00788 & 0.0068 & $<$ & $<$ & & & & $<$ & & $<$ \\
\hline Chromium & & & $<$ & $<$ & & & & $<$ & & $<$ \\
\hline Cobalt & 0.0432 & 0.036 & $<$ & $<$ & & & & $<$ & & $<$ \\
\hline Iron & 0.0975 & $<$ & $<$ & $<$ & & & & 1.21 & & $<$ \\
\hline Lead & & & $<$ & $<$ & & & & $<$ & & 0.00122 \\
\hline Lithium & 0.0125 & 0.015 & $<$ & $<$ & & & & 1.16 & & 0.171 \\
\hline Manganese & 1.8 & 1.5 & 0.135 & 0.132 & & & & 22.4 & & $<$ \\
\hline Mercury & 0.000264 & $<$ & $<$ & $<$ & & & & $<$ & & $<$ \\
\hline Molybdenum & & & $<$ & $<$ & & & & $<$ & & $<$ \\
\hline Nickel & 0.0964 & 0.095 & $<$ & 0.00552 & & & & 0.15 & & $<$ \\
\hline Selenium & & $<$ & $<$ & $<$ & & & & $<$ & & $<$ \\
\hline Silver & & & $<$ & $<$ & & & & $<$ & & $<$ \\
\hline Strontium & 0.0638 & 0.078 & 0.267 & 0.257 & & & & 304 & & 0.111 \\
\hline Thallium & & & $<$ & $<$ & & & & $<$ & & $<$ \\
\hline Uranium & 0.39 & 0.35 & 0.0017 & 0.00175 & & & & 1.33 & & 0.00171 \\
\hline Zinc & & & & & & & & $<$ & & $<$ \\
\hline
\end{tabular}


APPENDIX D.1: CY 2009 MONITORING DATA FOR THE BEAR CREEK HYDROGEOLOGIC REGIME Field Measurements, Miscellaneous Analytes, Major lons, and Trace Metals

\begin{tabular}{|c|c|c|c|c|c|c|c|c|c|c|}
\hline Sampling Point & \multicolumn{3}{|c|}{ GW-648 } & \multicolumn{2}{|c|}{ GW-683 } & \multicolumn{2}{|c|}{ GW-684 } & GW-703 & \multicolumn{2}{|c|}{ GW-704 } \\
\hline Functional Area & \multicolumn{3}{|c|}{ RS } & \multicolumn{2}{|c|}{ EXP-A } & \multicolumn{2}{|c|}{ EXP-A } & EXP-B & \multicolumn{2}{|c|}{ EXP-B } \\
\hline Date Sampled & \multicolumn{2}{|c|}{$02 / 09 / 09$} & 08/05/09 & 03/04/09 & 07/21/09 & 03/03/09 & $07 / 20 / 09$ & $02 / 26 / 09$ & 03/03/09 & $07 / 21 / 09$ \\
\hline Program & GWPP & GWPP & GWPP & BJC & BJC & BJC & BJC & GWPP & BJC & BJC \\
\hline Sample Type & & Dup & & & & & & & & \\
\hline Field Measurements & & & & & & & & & & \\
\hline Time Sampled & $8: 45$ & $8: 45$ & $14: 50$ & $10: 00$ & $10: 40$ & $11: 15$ & $14: 00$ & $13: 50$ & $10: 10$ & $14: 45$ \\
\hline Measuring Point Elev. (ft) & $1,029.20$ & $1,029.20$ & $1,029.20$ & 972.23 & 972.23 & 898.83 & 898.83 & 955.29 & 945.33 & 945.33 \\
\hline Depth to Water (ft) & 67.46 & 67.46 & 68.26 & 88.64 & 89.15 & 15.37 & 15.69 & 39.91 & 30.26 & 36.08 \\
\hline Groundwater Elevation (ft) & 961.74 & 961.74 & 960.94 & 883.59 & 883.08 & 883.46 & 883.14 & 915.38 & 915.07 & 909.25 \\
\hline Conductivity $(\mu \mathrm{mho} / \mathrm{cm})$ & 470 & 470 & 401 & 322 & 343 & 438 & 360 & 718 & 510 & 374 \\
\hline Dissolved Oxygen (ppm) & 3.52 & 3.52 & 2.1 & 12.2 & 3.19 & 12.41 & 0.6 & 0.43 & 1.03 & 0.27 \\
\hline Oxidation/Reduction (mV) & 227 & 227 & 177 & 143 & 101 & 119 & 198 & 118 & 156 & 44 \\
\hline Temperature (degrees C) & 12.7 & 12.7 & 15.4 & 12.32 & 14.2 & 12.2 & 14.6 & 15.2 & 9.7 & 15.9 \\
\hline Turbidity (NTU) & & & & 2 & 2 & 7 & 2 & & 3 & 62 \\
\hline $\mathrm{pH}$ & 7.65 & 7.65 & 7.91 & 7.17 & 7.48 & 7.4 & 7.61 & 7.44 & 6.61 & 8.47 \\
\hline Miscellaneous Analytes & & & & & & & & & & \\
\hline Dissolved Solids (mg/L) & 118 & 235 & 182 & 247 & 278 & 271 & 482 & 328 & 374 & 343 \\
\hline Suspended Solids (mg/L) & $<$ & $<$ & 2 & $<$ & $<$ & $<$ & $<$ & 1 & $<$ & 16 \\
\hline Major lons (mg/L) & & & & & & & & & & \\
\hline Calcium & 51 & 50.6 & 38.2 & 50.6 & 52.9 & 67.8 & 63.3 & 82.6 & 72.8 & 37.6 \\
\hline Magnesium & 30.9 & 28.9 & 27.1 & 17.8 & 21.4 & 18.1 & 18.1 & 32.3 & 28.4 & 28.2 \\
\hline Potassium & $<$ & $<$ & $<$ & 1.09 & 1.08 & 5.25 & 4.77 & 5.43 & 2.99 & 15 \\
\hline Sodium & 1.63 & 1.53 & 0.814 & 4.92 & 3.74 & 7.19 & 7.2 & 13.7 & 15.9 & 14.6 \\
\hline Bicarbonate & 235 & 234 & 207 & 186 & 203 & 218 & 209 & 238 & 238 & 167 \\
\hline Carbonate & $<$ & $<$ & $<$ & $<$ & $<$ & $<$ & $<$ & $<$ & $<$ & $<$ \\
\hline Chloride & 4.19 & 4.25 & 1.6 & 10.8 & 7.42 & 15.3 & 18 & 25 & 35 & 30.4 \\
\hline Fluoride & 0.239 & 0.239 & 0.259 & 0.18 & 0.128 & 0.15 & 0.208 & 0.162 & 0.27 & 0.202 \\
\hline Nitrate as $\mathrm{N}$ & 0.154 & 0.617 & 0.152 & 2.3 & 0.7 & 2.1 & $<$ & 0.509 & 12.6 & 3.7 \\
\hline Sulfate & 4.12 & 4.07 & 2.24 & 18.7 & 21.9 & 15.6 & 16.4 & 25.7 & 26.1 & 24.4 \\
\hline Charge balance error (\%) & 2.3 & 0.3 & -1 & -4 & -2 & 0.5 & 0.4 & 10.9 & -3.3 & 2.3 \\
\hline Trace Metals (mg/L) & & & & & & & & & & \\
\hline Aluminum & $<$ & $<$ & $<$ & $<$ & $<$ & $<$ & $<$ & $<$ & $<$ & $<$ \\
\hline Arsenic & & $<$ & $<$ & $<$ & $<$ & $<$ & $<$ & $<$ & $<$ & $<$ \\
\hline Barium & 0.202 & 0.188 & 0.162 & 0.0975 & 0.116 & 0.1 & 0.0976 & 0.107 & 0.119 & 0.0644 \\
\hline Beryllium & $<$ & $<$ & $<$ & $<$ & $<$ & $<$ & $<$ & $<$ & $<$ & $<$ \\
\hline Boron & $<$ & $<$ & $<$ & $<$ & $<$ & $<$ & $<$ & $<$ & $<$ & $<$ \\
\hline Cadmium & $<$ & $<$ & $<$ & $<$ & $<$ & $<$ & $<$ & $<$ & $<$ & $<$ \\
\hline Chromium & $<$ & $<$ & $<$ & $<$ & 0.0179 & $<$ & $<$ & $<$ & $<$ & $<$ \\
\hline Cobalt & $<$ & $<$ & $<$ & $<$ & $<$ & $<$ & $<$ & $<$ & $<$ & $<$ \\
\hline Iron & $<$ & $<$ & $<$ & 0.0821 & 0.113 & $<$ & $<$ & 0.127 & 1.76 & 9.3 \\
\hline Lead & $<$ & $<$ & $<$ & $<$ & $<$ & $<$ & $<$ & $<$ & $<$ & $<$ \\
\hline Lithium & 0.0251 & 0.0251 & 0.0216 & $<$ & $<$ & 0.0269 & 0.0265 & 0.0193 & 0.0143 & 0.03 \\
\hline Manganese & $<$ & $<$ & $<$ & $<$ & $<$ & 0.042 & 0.0508 & $<$ & 0.0109 & 0.0681 \\
\hline Mercury & $<$ & $<$ & $<$ & $<$ & $<$ & $<$ & $<$ & $<$ & & \\
\hline Molybdenum & $<$ & $<$ & $<$ & & & & & $<$ & & \\
\hline Nickel & $<$ & $<$ & $<$ & $<$ & $<$ & $<$ & $<$ & $<$ & $<$ & $<$ \\
\hline Selenium & $<$ & $<$ & $<$ & $<$ & $<$ & $<$ & $<$ & $<$ & $<$ & $<$ \\
\hline Silver & $<$ & $<$ & $<$ & $<$ & $<$ & $<$ & $<$ & $<$ & $<$ & $<$ \\
\hline Strontium & 0.0735 & 0.0687 & 0.0613 & 0.112 & 0.14 & 0.185 & 0.171 & 0.274 & 0.374 & 0.152 \\
\hline Thallium & $<$ & $<$ & $<$ & $<$ & $<$ & $<$ & $<$ & $<$ & $<$ & $<$ \\
\hline Uranium & $<$ & $<$ & $<$ & & 0.016 & & 0.02 & 0.0138 & 0.013 & 0.0071 \\
\hline Zinc & $<$ & $<$ & $<$ & $<$ & $<$ & $<$ & $<$ & $<$ & $<$ & $<$ \\
\hline
\end{tabular}


APPENDIX D.1: CY 2009 MONITORING DATA FOR THE BEAR CREEK HYDROGEOLOGIC REGIME Field Measurements, Miscellaneous Analytes, Major lons, and Trace Metals

\begin{tabular}{|c|c|c|c|c|c|c|c|c|c|c|c|}
\hline Sampling Point & \multicolumn{2}{|c|}{ GW-706 } & \multicolumn{2}{|c|}{ GW-712 } & \multicolumn{4}{|c|}{ GW-713 } & \multicolumn{2}{|c|}{ GW-714 } & GW-724 \\
\hline Functional Area & \multicolumn{2}{|c|}{ EXP-B } & \multicolumn{2}{|c|}{ EXP-W } & \multicolumn{4}{|c|}{ EXP-W } & \multicolumn{2}{|c|}{ EXP-W } & EXP-C \\
\hline Date Sampled & 03/03/09 & 07/22/09 & $01 / 07 / 09$ & 07/06/09 & \multicolumn{2}{|c|}{$01 / 07 / 09$} & \multicolumn{2}{|c|}{$07 / 07 / 09$} & 01/06/09 & 07/06/09 & $02 / 25 / 09$ \\
\hline Program & BJC & BJC & BJC & BJC & BJC & BJC & $\mathrm{BJC}$ & BJC & BJC & BJC & GWPP \\
\hline Sample Type & & & & & & Dup & & Dup & & & \\
\hline Field Measurements & & & & & & & & & & & \\
\hline Time Sampled & $10: 55$ & $10: 15$ & $15: 30$ & $14: 00$ & $12: 00$ & & 9:15 & & $10: 40$ & $13: 40$ & $8: 20$ \\
\hline Measuring Point Elev. (ft) & 929.47 & 929.47 & 877.89 & 877.89 & 881.43 & & 881.43 & & 875.88 & 875.88 & 979.75 \\
\hline Depth to Water (ft) & 11.71 & 18.15 & 26.09 & 35.55 & 32.68 & & 38.46 & & 28.44 & 31.11 & 28.59 \\
\hline Groundwater Elevation (ft) & 917.76 & 911.32 & 851.80 & 842.34 & 848.75 & & 842.97 & & 847.44 & 844.77 & 951.16 \\
\hline Conductivity $(\mu \mathrm{mho} / \mathrm{cm})$ & 703 & 644 & 378 & 891 & 476 & & 567 & & 394 & 665 & 883 \\
\hline Dissolved Oxygen (ppm) & 0.17 & 0.33 & 0.55 & 0.42 & 0.65 & & 11.96 & & 1.59 & 8.5 & 1.55 \\
\hline Oxidation/Reduction (mV) & 113 & -26 & -60 & 37 & -112 & & -164 & & 129 & 42 & 165 \\
\hline Temperature (degrees C) & 11.5 & 16.1 & 10 & 19.6 & 10.6 & & 16.5 & & 12 & 21.4 & 13.4 \\
\hline Turbidity (NTU) & 2 & 17 & 15 & 27 & 8 & & 2 & & 6 & 13 & \\
\hline $\mathrm{pH}$ & 6.9 & 7.43 & 7.97 & 7.45 & 7.26 & & 7.78 & & 6.99 & 7.35 & 7.02 \\
\hline $\begin{array}{r}\text { Miscellaneous Analytes } \\
\text { Dissolved Solids (mg/L) } \\
\text { Suspended Solids (mg/L) } \\
\end{array}$ & $\begin{array}{r}522 \\
< \\
\end{array}$ & $\begin{array}{r}475 \\
11 \\
\end{array}$ & & & & & & & & & \\
\hline Major lons (mg/L) & & & & & & & & & & & \\
\hline Calcium & 115 & 94.9 & 52.2 & 21 & 58.7 & 57.8 & 16 & 26 & 59.7 & 63 & \\
\hline Magnesium & 22.8 & 20.2 & 30.9 & 30 & 30.8 & 30.4 & 28 & 28 & 24.2 & 25 & \\
\hline Potassium & 6.72 & 7.76 & 1.8 & 3 & 2.42 & 2.41 & 2.9 & 2.8 & 1.65 & 1.5 & \\
\hline Sodium & 22.5 & 21 & 6.88 & 11 & 12.2 & 12.2 & 10 & 11 & 6.32 & 5.8 & \\
\hline Bicarbonate & 285 & 207 & & & & & & & & & \\
\hline $\begin{array}{r}\text { Carbonate } \\
\text { Chloride }\end{array}$ & $\begin{array}{r}< \\
49.5\end{array}$ & $\begin{array}{r}< \\
52.7\end{array}$ & & & & & & & & & 64.2 \\
\hline Fluoride & 0.28 & 0.251 & & & & & & & & & \\
\hline Nitrate as $\mathrm{N}$ & 21.4 & 8.1 & 0.052 & $<$ & 0.028 & 0.029 & 0.01 & 0.015 & 0.24 & 0.34 & 12.9 \\
\hline Sulfate & 31.2 & 28.1 & & & & & & & & & 32.3 \\
\hline Charge balance error (\%) & -2.9 & 5 & & & & & & & & & \\
\hline Trace Metals (mg/L) & & & & & & & & & & & \\
\hline Aluminum & $<$ & $<$ & $<$ & $<$ & $<$ & $<$ & $<$ & $<$ & $<$ & $<$ & \\
\hline Arsenic & $<$ & $<$ & $<$ & $<$ & $<$ & $<$ & $<$ & $<$ & $<$ & $<$ & \\
\hline Barium & 0.158 & 0.145 & 0.0325 & 0.016 & 0.0451 & 0.0443 & 0.014 & 0.021 & 0.0858 & 0.086 & \\
\hline Beryllium & $<$ & $<$ & $<$ & $<$ & $<$ & $<$ & $<$ & $<$ & $<$ & $<$ & \\
\hline Boron & 0.114 & $<$ & $<$ & $<$ & $<$ & $<$ & $<$ & $<$ & $<$ & $<$ & \\
\hline Cadmium & $<$ & $<$ & $<$ & $<$ & $<$ & $<$ & $<$ & $<$ & $<$ & $<$ & \\
\hline Chromium & $<$ & $<$ & $<$ & $<$ & $<$ & $<$ & $<$ & $<$ & $<$ & $<$ & \\
\hline Cobalt & $<$ & $<$ & $<$ & $<$ & $<$ & $<$ & $<$ & $<$ & $<$ & $<$ & \\
\hline Iron & 0.945 & 3.32 & 1.61 & 1.8 & 0.783 & 0.871 & 0.21 & 1.4 & 0.274 & 2.4 & \\
\hline Lead & $<$ & & $<$ & $<$ & $<$ & $<$ & $<$ & $<$ & $<$ & $<$ & \\
\hline Lithium & 0.0193 & 0.0169 & $<$ & 0.016 & 0.0133 & 0.0137 & 0.016 & 0.016 & $<$ & 0.01 & \\
\hline Manganese & 0.0222 & 0.0496 & 0.0667 & 0.037 & 0.144 & 0.15 & 0.051 & 0.087 & 0.0703 & 0.022 & \\
\hline Mercury & & & & & & & & & & & \\
\hline Molybdenum & & & & & & & & & & & \\
\hline Nickel & $<$ & $<$ & $<$ & $<$ & $<$ & $<$ & $<$ & $<$ & $<$ & $<$ & \\
\hline Selenium & $<$ & $<$ & $<$ & $<$ & $<$ & $<$ & $<$ & $<$ & $<$ & $<$ & \\
\hline Silver & & $<$ & $<$ & $<$ & $<$ & $<$ & $<$ & $<$ & $<$ & $<$ & \\
\hline Strontium & 0.398 & 0.312 & 0.616 & 0.3 & 1.29 & 1.27 & 0.29 & 0.55 & 0.358 & 0.37 & \\
\hline Thallium & $<$ & & $<$ & $<$ & $<$ & $<$ & $<$ & $<$ & $<$ & $<$ & \\
\hline Uranium & 0.066 & 0.058 & $<$ & $<$ & $<$ & $<$ & $<$ & $<$ & $<$ & $<$ & \\
\hline Zinc & & $<$ & $<$ & $<$ & $<$ & $<$ & $<$ & $<$ & $<$ & $<$ & \\
\hline
\end{tabular}


APPENDIX D.1: CY 2009 MONITORING DATA FOR THE BEAR CREEK HYDROGEOLOGIC REGIME Field Measurements, Miscellaneous Analytes, Major lons, and Trace Metals

\begin{tabular}{|c|c|c|c|c|c|c|c|c|c|}
\hline Sampling Point & GW-725 & GW-726-04 & GW-726-06 & GW-726-09 & GW-726-12 & GW-726-16 & GW-726-20 & GW-726-23 & GW-738 \\
\hline Functional Area & EXP-C & BG & BG & BG & BG & BG & BG & BG & EXP-C \\
\hline Date Sampled & $02 / 25 / 09$ & $05 / 04 / 09$ & $05 / 04 / 09$ & $05 / 05 / 09$ & $05 / 05 / 09$ & $05 / 06 / 09$ & $05 / 06 / 09$ & $05 / 06 / 09$ & $02 / 25 / 09$ \\
\hline Program & GWPP & GWPP & GWPP & GWPP & GWPP & GWPP & GWPP & GWPP & GWPP \\
\hline \multicolumn{10}{|l|}{ Sample Type } \\
\hline Field Measurements & & & & & & & & & \\
\hline Time Sampled & $14: 10$ & $14: 25$ & $8: 36$ & $10: 06$ & $11: 25$ & $8: 20$ & $9: 25$ & $10: 22$ & 9:15 \\
\hline Measuring Point Elev. (ft) & 961.63 & & & & & & & & 983.31 \\
\hline Depth to Water (ft) & 9.51 & & & & & & & & 28.70 \\
\hline Groundwater Elevation (ft) & 952.12 & & & & & & & & \\
\hline Conductivity $(\mu \mathrm{mho} / \mathrm{cm})$ & 921 & 5,720 & 4,710 & 2,770 & 1,992 & 1,427 & 886 & 444 & 917 \\
\hline Dissolved Oxygen (ppm) & 0.08 & & & & & & & & 0.99 \\
\hline Oxidation/Reduction $(\mathrm{mV})$ & 113 & & & & & & & & 175 \\
\hline Temperature (degrees C) & 14.1 & 16.4 & 16.1 & 15.1 & 15.3 & 14.8 & 14.6 & 14.7 & 11.5 \\
\hline \multicolumn{10}{|l|}{ Turbidity (NTU) } \\
\hline $\mathrm{pH}$ & 6.69 & 8.06 & 7.97 & 8.06 & 8.18 & 8.84 & 9.13 & 8.89 & 6.74 \\
\hline \multicolumn{10}{|l|}{ Miscellaneous Analytes } \\
\hline Dissolved Solids (mg/L) & 560 & 3,020 & 2,490 & 1,550 & 1,160 & 832 & 496 & 258 & 458 \\
\hline Suspended Solids (mg/L) & 2 & 1 & 1 & $<$ & 1 & 1 & $<$ & 1 & $<$ \\
\hline \multicolumn{10}{|l|}{ Major lons (mg/L) } \\
\hline Calcium & 149 & 8.74 & 5.59 & 2.57 & 1.83 & 1.3 & 0.973 & 1.73 & 139 \\
\hline Magnesium & 23.6 & 2.55 & 1.65 & 0.737 & 0.495 & 0.383 & 0.215 & 0.568 & 23.9 \\
\hline Potassium & 3.05 & 6.55 & 4.94 & 3.26 & 2.8 & 2.95 & $<$ & 2.22 & 3.1 \\
\hline Sodium & 28.3 & 1,230 & 985 & 616 & 487 & 341 & 206 & 101 & 10.6 \\
\hline Bicarbonate & 337 & 508 & 541 & 741 & 682 & 547 & 344 & 200 & 336 \\
\hline Carbonate & $<$ & $<$ & $<$ & $<$ & 36.6 & 67.2 & 80.3 & 22.6 & $<$ \\
\hline Chloride & 66.7 & 1,520 & 1,110 & 399 & 165 & 37.6 & 4.97 & 1.03 & 22.9 \\
\hline Fluoride & 0.241 & 3.25 & 3.67 & 5.22 & 6.68 & 6.1 & 2.01 & 0.386 & $<$ \\
\hline Nitrate as $\mathrm{N}$ & $0.315 \mathrm{Q}$ & $<$ & $<$ & $<$ & $<$ & $<$ & $<$ & $<$ & 12.7 \\
\hline Sulfate & 38.2 & 4.02 & 19.2 & 36.3 & 46.3 & 45.2 & 17.6 & 7.11 & 34.2 \\
\hline Charge balance error (\%) & 6.2 & 1 & 0.8 & -0.1 & 2.5 & 1.4 & -0.4 & -0.8 & 2.5 \\
\hline \multicolumn{10}{|l|}{ Trace Metals (mg/L) } \\
\hline Aluminum & $<$ & 0.304 & $<$ & $<$ & $<$ & 1.04 & $<$ & 0.296 & $<$ \\
\hline Arsenic & $<$ & $<$ & $<$ & $<$ & $<$ & $<$ & $<$ & $<$ & $<$ \\
\hline Barium & 0.208 & 0.401 & 0.248 & 0.0993 & 0.0694 & 0.058 & 0.032 & 0.0583 & 0.065 \\
\hline Beryllium & $<$ & $<$ & $<$ & $<$ & $<$ & $<$ & $<$ & $<$ & $<$ \\
\hline Boron & $<$ & 0.365 & 0.39 & 0.467 & 0.683 & 0.891 & 1.07 & 0.534 & $<$ \\
\hline Cadmium & $<$ & $<$ & $<$ & $<$ & $<$ & $<$ & $<$ & $<$ & $<$ \\
\hline Chromium & $<$ & 0.0163 & $<$ & 0.012 & $<$ & 0.0106 & $<$ & $<$ & $<$ \\
\hline Cobalt & $<$ & $<$ & $<$ & $<$ & $<$ & $<$ & $<$ & $<$ & $<$ \\
\hline Iron & 0.492 & 0.458 & 0.0703 & 0.069 & 0.197 & 0.434 & 0.125 & 0.28 & $<$ \\
\hline Lead & $<$ & 0.00116 & & $<$ & 0.0182 & 0.00116 & 0.0006 & $<$ & 0.00409 \\
\hline Lithium & $<$ & 0.617 & 0.496 & 0.317 & 0.286 & 0.188 & 0.108 & 0.0601 & $<$ \\
\hline Manganese & 0.853 & 0.0108 & $<$ & $<$ & $<$ & $<$ & $<$ & $<$ & 0.0212 \\
\hline Mercury & $<$ & $<$ & $<$ & $<$ & $<$ & $<$ & $<$ & $<$ & $<$ \\
\hline Molybdenum & $<$ & $<$ & 0.0238 & 0.0226 & $<$ & $<$ & $<$ & $<$ & $<$ \\
\hline Nickel & $<$ & 0.00769 & $<$ & $<$ & $<$ & $<$ & $<$ & $<$ & $<$ \\
\hline Selenium & $<$ & 0.0231 & $<$ & $<$ & $<$ & $<$ & $<$ & $<$ & $<$ \\
\hline Silver & & $<$ & & $<$ & $<$ & $<$ & $<$ & $<$ & $<$ \\
\hline Strontium & 0.353 & 1.06 & 0.719 & 0.317 & 0.21 & 0.12 & 0.0735 & 0.112 & 0.156 \\
\hline Thallium & $<$ & $<$ & $<$ & $<$ & $<$ & $<$ & $<$ & $<$ & $<$ \\
\hline Uranium & 0.0114 & $<$ & $<$ & $<$ & 0.000605 & 0.00064 & $<$ & $<$ & 0.00324 \\
\hline Zinc & $<$ & 0.321 & 0.107 & 0.182 & 0.0797 & 0.178 & 0.152 & 0.0957 & $<$ \\
\hline
\end{tabular}


APPENDIX D.1: CY 2009 MONITORING DATA FOR THE BEAR CREEK HYDROGEOLOGIC REGIME Field Measurements, Miscellaneous Analytes, Major lons, and Trace Metals

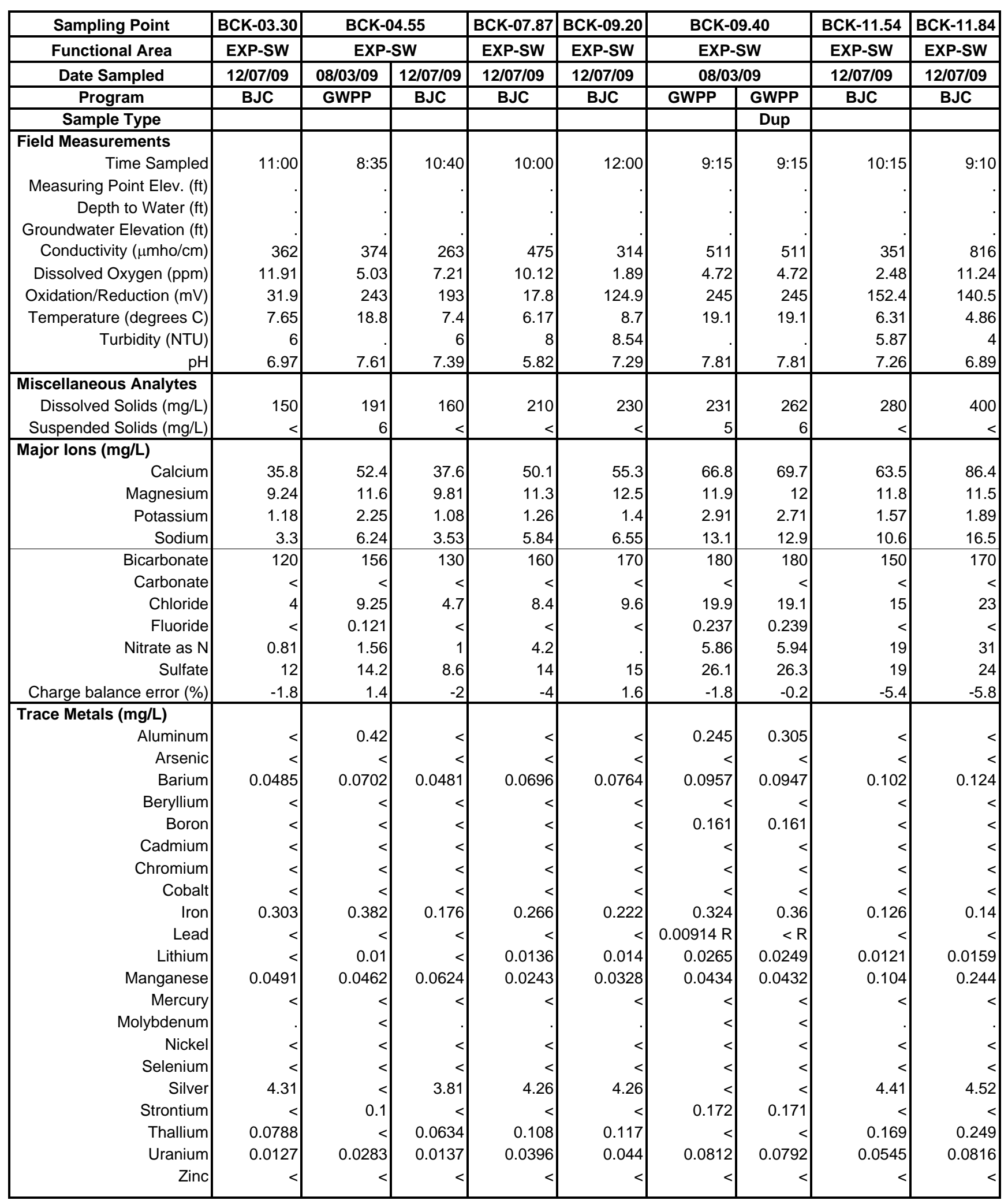


APPENDIX D.1: CY 2009 MONITORING DATA FOR THE BEAR CREEK HYDROGEOLOGIC REGIME

Field Measurements, Miscellaneous Analytes, Major lons, and Trace Metals

\begin{tabular}{|c|c|c|c|c|c|c|c|c|c|c|}
\hline Sampling Point & BCK-11.97 & BCK-12.34 & \multicolumn{8}{|c|}{ NT-01 } \\
\hline Functional Area & EXP-SW & EXP-SW & \multicolumn{8}{|c|}{ EXP-SW } \\
\hline Date Sampled & $08 / 03 / 09$ & $12 / 07 / 09$ & \multicolumn{2}{|c|}{$06 / 25 / 09$} & \multicolumn{2}{|c|}{$07 / 20 / 09$} & $08 / 03 / 09$ & \multicolumn{2}{|c|}{$11 / 17 / 09$} & $12 / 07 / 09$ \\
\hline Program & GWPP & BJC & BJC & BJC & BJC & $\mathrm{BJC}$ & GWPP & BJC & BJC & BJC \\
\hline Sample Type & & & & Dup & & Dup & & & Dup & \\
\hline Field Measurements & & & & & & & & & & \\
\hline Time Sampled & $13: 25$ & $8: 30$ & $8: 55$ & & 9:10 & & $14: 05$ & $8: 15$ & & $8: 45$ \\
\hline Measuring Point Elev. (ft) & & & & & & & & & & \\
\hline Depth to Water (ft) & & & & & & & & & & \\
\hline Groundwater Elevation (ft) & & & & & & & & & & \\
\hline Conductivity $(\mu \mathrm{mho} / \mathrm{cm})$ & 1,061 & 658 & & & & & 1,490 & & & 1,122 \\
\hline Dissolved Oxygen (ppm) & 5.26 & 1.35 & & & & & 5.06 & & & 11.06 \\
\hline Oxidation/Reduction (mV) & 235 & 183.3 & & & & & 235 & & & 105.4 \\
\hline Temperature (degrees C) & 21.8 & 7.69 & & & & & 24 & & & 7.2 \\
\hline Turbidity (NTU) & & 4.31 & & & & & & & & 5 \\
\hline $\mathrm{pH}$ & 7.89 & 6.93 & & & & & 7.26 & & & 6.57 \\
\hline Miscellaneous Analytes & & & & & & & & & & \\
\hline Dissolved Solids (mg/L) & 621 & 550 & & & & & 1,150 & & & 510 \\
\hline Suspended Solids (mg/L) & 2 & $<$ & & & & & 3 & & & $<$ \\
\hline Major lons (mg/L) & & & & & & & & & & \\
\hline Calcium & 133 & 110 & 116 & 113 & 36.4 & 36.3 & 205 & 140 & 150 & 101 \\
\hline Magnesium & 19.1 & 15.2 & 17.6 & 17.1 & 5.36 & 5.31 & 30.1 & 19 & 20 & 15.7 \\
\hline Potassium & 3.61 & 2.41 & 4.18 & 4 & 3.09 & 3.01 & 4.16 & 2.4 & 2.5 & 2.24 \\
\hline Sodium & 52 & 27.7 & 15.6 & 15.2 & 4.9 & 4.9 & 27.6 & $16 \mathrm{~J}$ & 16 & 13.6 \\
\hline Bicarbonate & $568 \mathrm{Q}$ & 220 & & & & & 217 & & & 130 \\
\hline Carbonate & & $<$ & & & & & $<$ & & & $<$ \\
\hline Chloride & 70.1 & 40 & & & & & 24.5 & & & 11 \\
\hline Fluoride & 0.552 & $<$ & & & & & 0.67 & & & $<$ \\
\hline Nitrate as $\mathrm{N}$ & 28.5 & & & & & & 122 & & & 61 \\
\hline Sulfate & 34.6 & 26 & & & & & 20.4 & & & 14 \\
\hline Charge balance error (\%) & $-20.8 \mathrm{R}$ & 13.8 & & & & & -0.7 & & & -4 \\
\hline Trace Metals (mg/L) & & & & & & & & & & \\
\hline Aluminum & $<$ & $<$ & 1.76 & 1.39 & 2.07 & 1.94 & 0.287 & 0.35 & 0.42 & 0.314 \\
\hline Arsenic & $<$ & $<$ & $<$ & & $<$ & $<$ & $<$ & $<$ & $<$ & $<$ \\
\hline Barium & 0.169 & 0.153 & 0.203 & 0.196 & 0.0843 & 0.0844 & 0.376 & 0.25 & 0.26 & 0.202 \\
\hline Beryllium & $<$ & $<$ & $<$ & $<$ & $<$ & $<$ & $<$ & $<$ & $<$ & $<$ \\
\hline Boron & 0.174 & $<$ & 0.47 & 0.466 & 0.448 & 0.452 & 0.542 & 0.15 & 0.16 & 0.152 \\
\hline Cadmium & $<$ & 0.0034 & 0.00949 & 0.00922 & $<$ & $<$ & 0.0101 & 0.011 & 0.011 & 0.0076 \\
\hline Chromium & $<$ & $<$ & $<$ & & $<$ & $<$ & $<$ & $<$ & $<$ & $<$ \\
\hline Cobalt & $<$ & $<$ & $<$ & $<$ & $<$ & $<$ & $<$ & $<$ & $<$ & $<$ \\
\hline Iron & 0.122 & 0.162 & 1.41 & 1.11 & 1.78 & 1.76 & 0.196 & 0.13 & 0.18 & 0.361 \\
\hline Lead & $<$ & $<$ & $<$ & $<$ & $<$ & $<$ & $<$ & $<$ & $<$ & $<$ \\
\hline Lithium & 0.0237 & 0.018 & 0.0836 & 0.081 & 0.0702 & 0.0703 & 0.0826 & 0.026 & 0.027 & 0.0286 \\
\hline Manganese & 0.157 & 0.959 & 1.87 & 1.79 & 0.638 & 0.632 & 2.68 & 2.2 & 2.3 & 2.07 \\
\hline Mercury & $<$ & $<$ & & & & & $<$ & & & $<$ \\
\hline Molybdenum & $<$ & & & & & & $<$ & & & \\
\hline Nickel & $<$ & 0.0148 & 0.0382 & 0.0368 & 0.0123 & 0.012 & 0.049 & 0.044 & 0.047 & 0.0318 \\
\hline Selenium & $<$ & $<$ & $<$ & $<$ & $<$ & $<$ & $<$ & $<$ & $<$ & $<$ \\
\hline Silver & $<$ & 4.27 & $<$ & $<$ & $<$ & $<$ & $<$ & 4.4 & 4.6 & 4.58 \\
\hline Strontium & 0.393 & $<$ & 0.347 & 0.338 & 0.0999 & 0.0997 & 0.595 & $<$ & $<$ & $<$ \\
\hline Thallium & $<$ & 0.311 & $<$ & $<$ & $<$ & $<$ & $<$ & 0.37 & 0.38 & 0.302 \\
\hline Uranium & 0.158 & 0.11 & 1 & & t & . & 0.0213 & 0.011 & 0.01 & 0.0082 \\
\hline Zinc & & $<$ & $<$ & $<$ & $<$ & $<$ & & $<$ & $<$ & $<$ \\
\hline
\end{tabular}


APPENDIX D.1: CY 2009 MONITORING DATA FOR THE BEAR CREEK HYDROGEOLOGIC REGIME

Field Measurements, Miscellaneous Analytes, Major lons, and Trace Metals

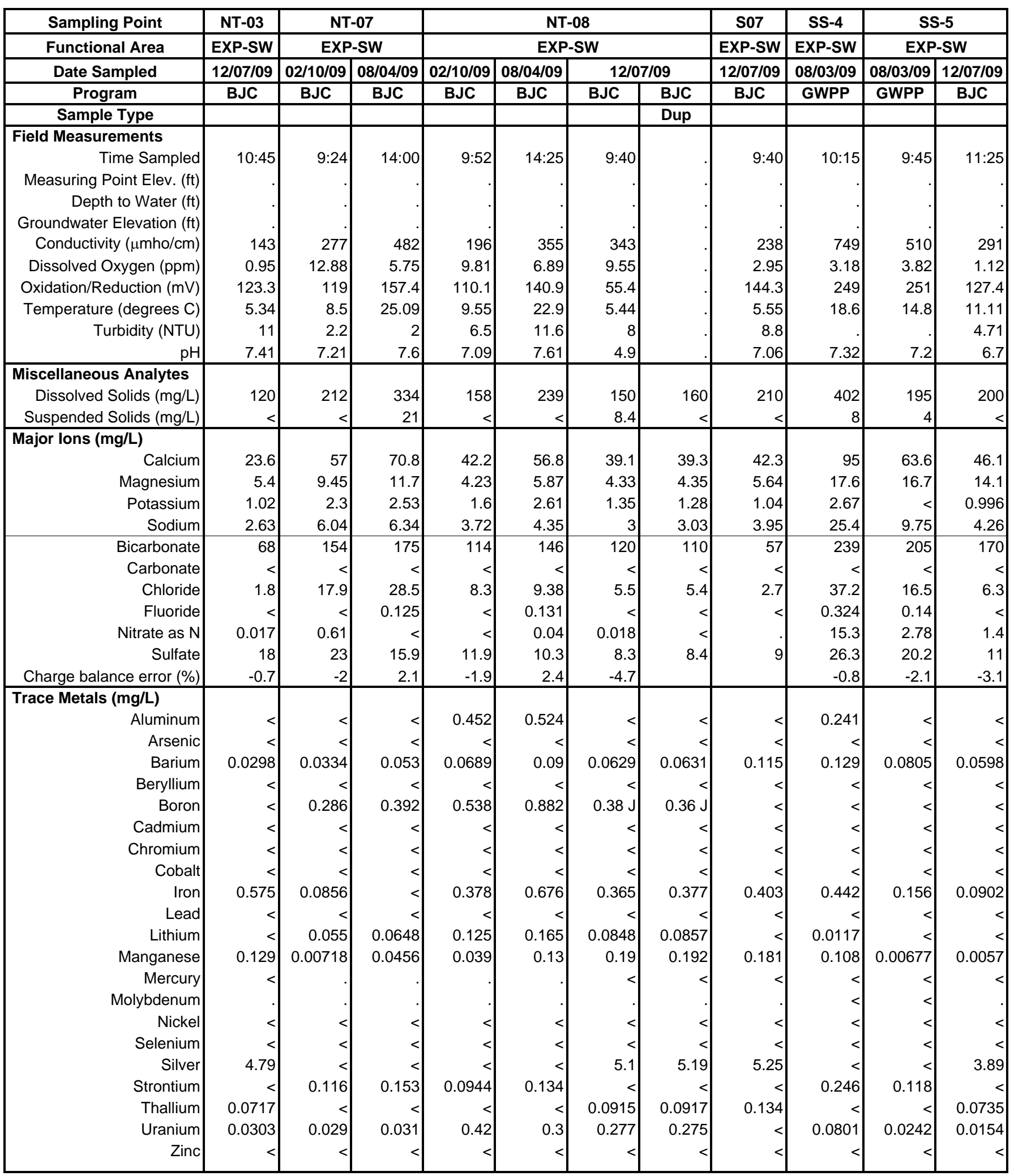


APPENDIX D.1: CY 2009 MONITORING DATA FOR THE BEAR CREEK HYDROGEOLOGIC REGIME Field Measurements, Miscellaneous Analytes, Major lons, and Trace Metals

\begin{tabular}{|c|c|c|c|c|c|c|}
\hline Sampling Point & \multicolumn{2}{|c|}{ SS-6 } & SS-6.6 & SS-7 & \multicolumn{2}{|c|}{ SS-8 } \\
\hline Functional Area & \multicolumn{2}{|c|}{ EXP-SW } & EXP-SW & EXP-SW & \multicolumn{2}{|c|}{ EXP-SW } \\
\hline Date Sampled & $01 / 05 / 09$ & $07 / 06 / 09$ & $12 / 07 / 09$ & $12 / 07 / 09$ & \multicolumn{2}{|c|}{$12 / 07 / 09$} \\
\hline Program & BJC & BJC & BJC & BJC & BJC & BJC \\
\hline Sample Type & & & & & & Dup \\
\hline Field Measurements & & & & & & \\
\hline Time Sampled & $14: 40$ & $13: 10$ & $10: 30$ & $10: 00$ & 9:00 & \\
\hline Measuring Point Elev. (ft) & & & & & & \\
\hline Depth to Water (ft) & & & & & & \\
\hline Groundwater Elevation (ft) & & & & & & \\
\hline Conductivity $(\mu \mathrm{mho} / \mathrm{cm})$ & 319 & 410 & 394 & 292 & 247 & \\
\hline Dissolved Oxygen (ppm) & 7.28 & 9.21 & & 5.94 & 5.33 & \\
\hline Oxidation/Reduction (mV) & 68.3 & 72 & & 201 & 190 & \\
\hline Temperature (degrees C) & 12.81 & 16.06 & 9.9 & 13.1 & 10.3 & \\
\hline Turbidity (NTU) & 1.75 & 11.4 & 4 & 4 & 5 & \\
\hline $\mathrm{pH}$ & 6.92 & 7.86 & & 6.87 & 6.64 & \\
\hline Miscellaneous Analytes & & & & & & \\
\hline Dissolved Solids (mg/L) & & & 140 & 140 & 130 & 130 \\
\hline Suspended Solids (mg/L) & & & 22 & $<$ & $<$ & $<$ \\
\hline Major Ions (mg/L) & & & & & & \\
\hline Calcium & 47.4 & 53 & 31.1 & 29.3 & 33.5 & 31.4 \\
\hline Magnesium & 16 & 19 & 14.2 & 14.3 & 9.46 & 9.09 \\
\hline Potassium & 0.873 & 0.9 & 0.521 & 0.676 & 0.748 & 0.651 \\
\hline Sodium & 3.88 & 3.2 & 1.33 & 2.67 & 2.84 & 2.69 \\
\hline Bicarbonate & & & 140 & 140 & 120 & 130 \\
\hline Carbonate & & & $<$ & $<$ & $<$ & $<$ \\
\hline Chloride & & & 2.1 & 4.2 & 4.5 & 4.5 \\
\hline Fluoride & & & $<$ & $<$ & $<$ & $<$ \\
\hline Nitrate as $\mathrm{N}$ & 0.68 & 0.6 & 0.1 & 0.064 & 0.19 & 0.19 \\
\hline Sulfate & & & 5.3 & 4.1 & 2.9 & 2.9 \\
\hline Charge balance error (\%) & & & -3.1 & -4.1 & -0.1 & \\
\hline Trace Metals (mg/L) & & & & & & \\
\hline Aluminum & $<$ & $<$ & $<$ & $<$ & $<$ & $<$ \\
\hline Arsenic & $<$ & $<$ & $<$ & $<$ & $<$ & $<$ \\
\hline Barium & 0.0648 & 0.078 & 0.0572 & 0.0431 & 0.038 & 0.0366 \\
\hline Beryllium & $<$ & $<$ & $<$ & $<$ & $<$ & $<$ \\
\hline Boron & $<$ & $<$ & $<$ & $<$ & $<$ & $<$ \\
\hline Cadmium & $<$ & $<$ & $<$ & $<$ & $<$ & $<$ \\
\hline Chromium & $<$ & $<$ & $<$ & $<$ & $<$ & $<$ \\
\hline Cobalt & $<$ & $<$ & $<$ & $<$ & $<$ & $<$ \\
\hline Iron & 0.118 & 0.15 & 0.208 & $<$ & 0.0897 & 0.16 \\
\hline Lead & $<$ & $<$ & $<$ & $<$ & $<$ & $<$ \\
\hline Lithium & $<$ & $<$ & $<$ & $<$ & $<$ & $<$ \\
\hline Manganese & 0.00978 & 0.024 & 0.0231 & $<$ & 0.0238 & 0.0251 \\
\hline Mercury & & & $<$ & $<$ & $<$ & $<$ \\
\hline Molybdenum & & & & & & \\
\hline Nickel & $<$ & $<$ & $<$ & $<$ & $<$ & $<$ \\
\hline Selenium & $<$ & $<$ & $<$ & $<$ & $<$ & $<$ \\
\hline Silver & $<$ & $<$ & 3.76 & 3.57 & 3.83 & 3.73 \\
\hline Strontium & 0.0696 & 0.077 & $<$ & $<$ & $<$ & $<$ \\
\hline Thallium & $<$ & $<$ & 0.0362 & 0.0274 & 0.0376 & 0.0361 \\
\hline Uranium & 0.0065 & 0.0057 & $<$ & $<$ & $<$ & $<$ \\
\hline Zinc & $<$ & & $<$ & $<$ & $<$ & $<$ \\
\hline
\end{tabular}



APPENDIX D.2

VOLATILE ORGANIC COMPOUNDS 

APPENDIX D.2: CY 2009 MONITORING DATA FOR THE BEAR CREEK HYDROGEOLOGIC REGIME Volatile Organic Compounds

\begin{tabular}{|c|c|c|c|c|c|c|c|c|c|c|}
\hline Sampling Point & \multicolumn{2}{|c|}{ GW-008 } & GW-014 & \multicolumn{2}{|c|}{ GW-046 } & \multicolumn{2}{|c|}{ GW-053 } & GW-058 & \multicolumn{2}{|c|}{ GW-065 } \\
\hline Functional Area & \multicolumn{2}{|c|}{ OLF } & BG & \multicolumn{2}{|c|}{ BG } & \multirow{2}{*}{\multicolumn{2}{|c|}{$\frac{\text { BG }}{03 / 03 / 09}$}} & BG & \multicolumn{2}{|c|}{ OLF } \\
\hline Date Sampled & $01 / 06 / 09$ & 07/06/09 & 03/04/09 & $01 / 07 / 09$ & 07/06/09 & & & $02 / 10 / 09$ & $02 / 25 / 09$ & 08/06/09 \\
\hline Program & BJC & BJC & GWPP & BJC & BJC & GWPP & GWPP & GWPP & GWPP & GWPP \\
\hline Sample Type & & & & & & Dup & PDB & & NP & NP \\
\hline Chloroethenes $(\mu \mathrm{g} / \mathrm{L})$ & & & & & & & & & & \\
\hline Tetrachloroethene & 30.3 & 51 & 28 & 306 & 1300 & $<$ & $<$ & $<$ & $<$ & $<$ \\
\hline Trichloroethene & 11.3 & 7.7 & 160 & 783 & 620 & $2 \mathrm{~J}$ & $3 \mathrm{~J}$ & $<$ & $<$ & $<$ \\
\hline cis-1,2-Dichloroethene & 23.1 & 24 & 710 & 2,730 & 2,400 & 11 & 11 & $<$ & $<$ & $<$ \\
\hline trans-1,2-Dichloroethene & $<$ & $<$ & $1 \mathrm{~J}$ & 15.6 & $<$ & $<$ & $<$ & $<$ & $<$ & $<$ \\
\hline 1,1-Dichloroethene & 5.48 & 5.8 & 34 & 31 & 98 & $<$ & $<$ & $<$ & $<$ & $<$ \\
\hline Vinyl chloride & $<$ & $<$ & 120 & 223 & 320 & $<$ & $<$ & $<$ & $<$ & $<$ \\
\hline Chloroethanes ( $\mu \mathrm{g} / \mathrm{L})$ & & & & & & & & & & \\
\hline 1,1,1-Trichloroethane & $<$ & $<$ & $<$ & 19 & 85 & $<$ & $<$ & $<$ & $<$ & $<$ \\
\hline 1,1,2-Trichloroethane & $<$ & $<$ & $<$ & $<$ & $<$ & $<$ & $<$ & $<$ & $<$ & $<$ \\
\hline 1,2-Dichloroethane & $<$ & $<$ & $<$ & $<$ & $<$ & $<$ & $<$ & $<$ & $<$ & $<$ \\
\hline 1,1-Dichloroethane & 12.1 & 13 & 180 & $<$ & 360 & $3 \mathrm{~J}$ & $3 \mathrm{~J}$ & $<$ & $<$ & $<$ \\
\hline Chloroethane & $<$ & $<$ & $<$ & $<$ & $<$ & $<$ & $<$ & $<$ & $<$ & $<$ \\
\hline Chloromethanes ( $\mu \mathrm{g} / \mathrm{L})$ & & & & & & & & & & \\
\hline Carbon tetrachloride & $<$ & $<$ & $<$ & $<$ & $<$ & $<$ & $<$ & $<$ & $<$ & $<$ \\
\hline Chloroform & $<$ & $<$ & $<$ & $<$ & $<$ & $<$ & $<$ & $<$ & $<$ & $<$ \\
\hline Methylene chloride & $<$ & $<$ & $<$ & $<$ & $<$ & $<$ & $<$ & $<$ & $<$ & $<$ \\
\hline Petrol. Hydrocarb. ( $\mu \mathrm{g} / \mathrm{L})$ & & & & & & & & & & \\
\hline Benzene & $1.09 \mathrm{~J}$ & 1 & $1 \mathrm{~J}$ & 9.06 & $180 \mathrm{Q}$ & $<$ & $<$ & $<$ & $<$ & $<$ \\
\hline Ethylbenzene & $<$ & $<$ & $<$ & $<$ & $<$ & $<$ & $<$ & $<$ & $<$ & $<$ \\
\hline Toluene & $<$ & $<$ & $<$ & $<$ & $<$ & $<$ & $<$ & $<$ & $<$ & $<$ \\
\hline Total Xylene & $<$ & & $<$ & $<$ & & $<$ & $<$ & $<$ & $<$ & $<$ \\
\hline Chlorofluorocarbons ( $\mu \mathrm{g} / \mathrm{L})$ & & & & & & & & & & \\
\hline 1,1,2-Trichloro-1,2,2-trifluoroethane & & & $<$ & & & $<$ & $<$ & $<$ & $<$ & $<$ \\
\hline Dichlorodifluoromethane & & & $<$ & & & $<$ & $<$ & $<$ & $<$ & $<$ \\
\hline Miscellaneous ( $\mu \mathrm{g} / \mathrm{L})$ & & & & & & & & & & \\
\hline 1,2-Dichloropropane & $1.16 \mathrm{~J}$ & 1.1 & $<$ & $<$ & $<$ & $<$ & $<$ & $<$ & $<$ & $<$ \\
\hline 1,4-Dichlorobenzene & & & $<$ & & & $<$ & $<$ & $<$ & $<$ & $<$ \\
\hline 2-Butanone & $<$ & $<$ & $<$ & $<$ & $<$ & $<$ & $<$ & $<$ & $<$ & $<$ \\
\hline Acetone & $<$ & $<$ & $<$ & $<$ & $<$ & & & $<$ & $<$ & $<$ \\
\hline Carbon disulfide & $<$ & $<$ & $<$ & $<$ & $<$ & & & $<$ & $<$ & $<$ \\
\hline Chlorobenzene & $<$ & $<$ & $<$ & $<$ & $<$ & $<$ & $<$ & $<$ & $<$ & $<$ \\
\hline
\end{tabular}


APPENDIX D.2: CY 2009 MONITORING DATA FOR THE BEAR CREEK HYDROGEOLOGIC REGIME Volatile Organic Compounds

\begin{tabular}{|c|c|c|c|c|c|c|c|c|c|}
\hline Sampling Point & GW-068 & \multicolumn{2}{|c|}{ GW-071 } & \multicolumn{2}{|c|}{ GW-077 } & \multicolumn{2}{|c|}{ GW-078 } & \multicolumn{2}{|c|}{ GW-079 } \\
\hline Functional Area & BG & \multicolumn{2}{|c|}{ BG } & \multicolumn{2}{|c|}{ BG } & \multicolumn{2}{|c|}{ BG } & \multicolumn{2}{|c|}{ BG } \\
\hline Date Sampled & 03/03/09 & 03/04/09 & $08 / 10 / 09$ & 03/02/09 & $07 / 21 / 09$ & 03/02/09 & $07 / 21 / 09$ & $03 / 02 / 09$ & $07 / 22 / 09$ \\
\hline Program & GWPP & GWPP & GWPP & BJC & BJC & BJC & BJC & $\mathrm{BJC}$ & BJC \\
\hline \multicolumn{10}{|l|}{ Sample Type } \\
\hline Chloroethenes $(\mu \mathrm{g} / \mathrm{L})$ & & & & & & & & & \\
\hline Tetrachloroethene & $2 \mathrm{~J}$ & 610 & 240 & $<$ & $<$ & $<$ & $<$ & $<$ & $<$ \\
\hline Trichloroethene & 93 & 63 & 47 & $<$ & $<$ & $<$ & $<$ & $<$ & $<$ \\
\hline cis-1,2-Dichloroethene & 1,900 & 38 & 25 & $<$ & $<$ & $<$ & $<$ & $<$ & $<$ \\
\hline trans-1,2-Dichloroethene & $3 \mathrm{~J}$ & $<$ & $1 \mathrm{~J}$ & $<$ & $<$ & $<$ & $<$ & $<$ & $<$ \\
\hline 1,1-Dichloroethene & 180 & 78 & 75 & $<$ & $<$ & $<$ & $<$ & $<$ & $<$ \\
\hline Vinyl chloride & 320 & 2 & 3 & $<$ & $<$ & $<$ & $<$ & $<$ & $<$ \\
\hline Chloroethanes $(\mu \mathrm{g} / \mathrm{L})$ & & & & & & & & & \\
\hline 1,1,1-Trichloroethane & $<$ & 190 & 200 & $<$ & $<$ & $<$ & $<$ & $<$ & $<$ \\
\hline 1,1,2-Trichloroethane & $<$ & $<$ & $<$ & $<$ & $<$ & $<$ & $<$ & $<$ & $<$ \\
\hline 1,2-Dichloroethane & $<$ & & $<$ & $<$ & $<$ & $<$ & $<$ & $<$ & $<$ \\
\hline 1,1-Dichloroethane & 850 & 2,900 & 2,200 & $<$ & $<$ & $<$ & $<$ & $<$ & $<$ \\
\hline Chloroethane & 6 & 20 & 20 & $<$ & $<$ & $<$ & $<$ & $<$ & $<$ \\
\hline Chloromethanes ( $\mu \mathrm{g} / \mathrm{L})$ & & & & & & & & & \\
\hline Carbon tetrachloride & $<$ & $<$ & $<$ & $<$ & $<$ & $<$ & $<$ & $<$ & $<$ \\
\hline Chloroform & $<$ & $<$ & $<$ & $<$ & $<$ & $<$ & $<$ & $<$ & $<$ \\
\hline Methylene chloride & $<$ & $<$ & $<$ & $<$ & $<$ & $<$ & $<$ & $<$ & $<$ \\
\hline Petrol. Hydrocarb. ( $\mu \mathrm{g} / \mathrm{L})$ & & & & & & & & & \\
\hline Benzene & 110 & 1,500 & 740 & $<$ & $<$ & $<$ & $<$ & $<$ & $<$ \\
\hline Ethylbenzene & $<$ & $3 \mathrm{~J}$ & $1 \mathrm{~J}$ & $<$ & $<$ & $<$ & $<$ & $<$ & $<$ \\
\hline Toluene & 8 & 30 & 16 & $<$ & $<$ & $<$ & $<$ & $<$ & $<$ \\
\hline Total Xylene & $5 \mathrm{~J}$ & 9 & $4 \mathrm{~J}$ & $<$ & $<$ & $<$ & $<$ & $<$ & $<$ \\
\hline Chlorofluorocarbons ( $\mu \mathrm{g} / \mathrm{L})$ & & & & & & & & & \\
\hline 1,1,2-Trichloro-1,2,2-trifluoroethane & $<$ & 190 & 120 & & & & & & \\
\hline Dichlorodifluoromethane & $<$ & $<$ & $<$ & & & & & & \\
\hline Miscellaneous ( $\mu \mathrm{g} / \mathrm{L})$ & & & & & & & & & \\
\hline 1,2-Dichloropropane & $<$ & $<$ & $<$ & $<$ & $<$ & $<$ & $<$ & $<$ & $<$ \\
\hline 1,4-Dichlorobenzene & $<$ & $<$ & $<$ & & & & & & \\
\hline 2-Butanone & $<$ & $<$ & $<$ & $<$ & $<$ & $<$ & $<$ & $<$ & $<$ \\
\hline Acetone & $<$ & $<$ & $<$ & $<$ & $<$ & $<$ & $<$ & $<$ & $<$ \\
\hline Carbon disulfide & $<$ & $<$ & $<$ & $<$ & $<$ & $<$ & $<$ & $<$ & $<$ \\
\hline Chlorobenzene & $<$ & $<$ & $<$ & $<$ & $<$ & $<$ & $<$ & $<$ & $<$ \\
\hline
\end{tabular}


APPENDIX D.2: CY 2009 MONITORING DATA FOR THE BEAR CREEK HYDROGEOLOGIC REGIME Volatile Organic Compounds

\begin{tabular}{|c|c|c|c|c|c|c|c|c|c|c|}
\hline Sampling Point & \multicolumn{4}{|c|}{ GW-080 } & GW-082 & GW-098 & GW-100 & GW-101 & GW-122 & GW-127 \\
\hline Functional Area & \multicolumn{4}{|c|}{ BG } & BG & OLF & S3 & S3 & S3 & S3 \\
\hline Date Sampled & \multicolumn{2}{|c|}{$03 / 02 / 09$} & \multicolumn{2}{|c|}{$07 / 22 / 09$} & $08 / 10 / 09$ & $02 / 25 / 09$ & $02 / 19 / 09$ & 02/19/09 & $02 / 17 / 09$ & $02 / 17 / 09$ \\
\hline Program & BJC & $\mathrm{BJC}$ & BJC & BJC & GWPP & GWPP & GWPP & GWPP & GWPP & GWPP \\
\hline Sample Type & & Dup & & Dup & & PDB & & & & \\
\hline Chloroethenes ( $\mu \mathrm{g} / \mathrm{L})$ & & & & & & & & & & \\
\hline Tetrachloroethene & $<$ & $<$ & $<$ & $<$ & $<$ & $<$ & $<$ & $<$ & $<$ & $<$ \\
\hline Trichloroethene & $<$ & $<$ & $<$ & $<$ & $2 \mathrm{~J}$ & 7 & $<$ & $<$ & $<$ & $<$ \\
\hline cis-1,2-Dichloroethene & $<$ & $<$ & $<$ & $<$ & 150 & $2 \mathrm{~J}$ & $<$ & $<$ & $<$ & $<$ \\
\hline trans-1,2-Dichloroethene & $<$ & $<$ & $<$ & $<$ & $<$ & $<$ & $<$ & $<$ & $<$ & $<$ \\
\hline 1,1-Dichloroethene & $<$ & $<$ & $<$ & $<$ & $2 \mathrm{~J}$ & $2 \mathrm{~J}$ & $<$ & $<$ & $<$ & $<$ \\
\hline Vinyl chloride & $<$ & $<$ & $<$ & $<$ & 92 & $<$ & $<$ & $<$ & $<$ & $<$ \\
\hline Chloroethanes ( $\mu \mathrm{g} / \mathrm{L})$ & & & & & & & & & & \\
\hline 1,1,1-Trichloroethane & $<$ & $<$ & $<$ & $<$ & $<$ & $<$ & $<$ & $<$ & $<$ & $<$ \\
\hline 1,1,2-Trichloroethane & $<$ & $<$ & $<$ & $<$ & $<$ & $<$ & $<$ & $<$ & $<$ & $<$ \\
\hline 1,2-Dichloroethane & $<$ & $<$ & $<$ & $<$ & $<$ & $<$ & $<$ & $<$ & $<$ & $<$ \\
\hline 1,1-Dichloroethane & $<$ & $<$ & $<$ & $<$ & 77 & $<$ & $<$ & $<$ & $<$ & $<$ \\
\hline Chloroethane & $<$ & $<$ & $<$ & $<$ & 7 & $<$ & $<$ & $<$ & $<$ & $<$ \\
\hline Chloromethanes $(\mu \mathrm{g} / \mathrm{L})$ & & & & & & & & & & \\
\hline Carbon tetrachloride & $<$ & $<$ & $<$ & $<$ & $<$ & $<$ & $<$ & $<$ & $<$ & $<$ \\
\hline Chloroform & $<$ & $<$ & $<$ & $<$ & $<$ & $<$ & $<$ & $<$ & $<$ & $<$ \\
\hline Methylene chloride & $<$ & $<$ & $<$ & $<$ & $<$ & $<$ & $<$ & $<$ & $<$ & $<$ \\
\hline Petrol. Hydrocarb. ( $\mu \mathrm{g} / \mathrm{L})$ & & & & & & & & & & \\
\hline Benzene & $<$ & $<$ & $<$ & $<$ & $3 \mathrm{~J}$ & $<$ & $<$ & $<$ & $<$ & $<$ \\
\hline Ethylbenzene & $<$ & $<$ & $<$ & $<$ & $<$ & $<$ & $<$ & $<$ & $<$ & $<$ \\
\hline Toluene & $<1$ & $<$ & $<$ & $<$ & $<$ & $<$ & $<$ & $<$ & $<$ & $<$ \\
\hline Total Xylene & $<$ & $<$ & $<$ & $<$ & $<$ & $<$ & $<$ & $<$ & $<$ & $<$ \\
\hline Chlorofluorocarbons $(\mu \mathrm{g} / \mathrm{L})$ & & & & & & & & & & \\
\hline 1,1,2-Trichloro-1,2,2-trifluoroethane & & & & & $<$ & $<$ & $<$ & $<$ & $<$ & $<$ \\
\hline Dichlorodifluoromethane & & & & & $<$ & $<$ & $<$ & $<$ & $<$ & $<$ \\
\hline Miscellaneous ( $\mu \mathrm{g} / \mathrm{L})$ & & & & & & & & & & \\
\hline 1,2-Dichloropropane & $<$ & $<$ & $<$ & $<$ & $<$ & $<$ & $<$ & $<$ & $<$ & $<$ \\
\hline 1,4-Dichlorobenzene & & & & & $<$ & $<$ & $<$ & $<$ & $<$ & $<$ \\
\hline 2-Butanone & $<$ & $<$ & $<$ & $<$ & $<$ & $<$ & $<$ & $<$ & $<$ & $<$ \\
\hline Acetone & $<$ & $<$ & $<$ & $<$ & $<$ & & $<$ & $<$ & $<$ & $<$ \\
\hline Carbon disulfide & $<$ & $<$ & $<$ & $<$ & $<$ & & $<$ & $<$ & $<$ & $<$ \\
\hline Chlorobenzene & $<1$ & $<$ & $<$ & $<$ & $<$ & $<$ & $<$ & $<$ & $<$ & $<$ \\
\hline
\end{tabular}


APPENDIX D.2: CY 2009 MONITORING DATA FOR THE BEAR CREEK HYDROGEOLOGIC REGIME Volatile Organic Compounds

\begin{tabular}{|c|c|c|c|c|c|c|c|c|c|}
\hline Sampling Point & GW-225 & GW-229 & GW-236 & GW-242 & GW-246 & \multicolumn{2}{|c|}{ GW-276 } & \multicolumn{2}{|c|}{ GW-289 } \\
\hline Functional Area & OLF & OLF & S3 & BG & S3 & \multicolumn{2}{|c|}{ S3 } & \multirow{2}{*}{\multicolumn{2}{|c|}{$\frac{\text { BG }}{08 / 06 / 09}$}} \\
\hline Date Sampled & $02 / 26 / 09$ & 02/26/09 & $02 / 23 / 09$ & $03 / 05 / 09$ & $08 / 05 / 09$ & 01/07/09 & \multirow{2}{*}{$\begin{array}{c}07 / 06 / 09 \\
B J C\end{array}$} & & \\
\hline Program & GWPP & GWPP & GWPP & GWPP & GWPP & BJC & & GWPP & GWPP \\
\hline Sample Type & & & & & & & & Dup & PDB \\
\hline Chloroethenes ( $\mu \mathrm{g} / \mathrm{L})$ & & & & & & & & & \\
\hline Tetrachloroethene & $1 \mathrm{~J}$ & $<$ & $<$ & $5 \mathrm{~J}$ & 97 & 6.43 & 6.1 & 270 & 260 \\
\hline Trichloroethene & 280 & 6 & $<$ & $2 \mathrm{~J}$ & $1 \mathrm{~J}$ & $<$ & $<$ & 11 & 12 \\
\hline cis-1,2-Dichloroethene & $2 \mathrm{~J}$ & 340 & $<$ & 47 & $<$ & $<$ & $<$ & $2 \mathrm{~J}$ & $2 \mathrm{~J}$ \\
\hline trans-1,2-Dichloroethene & $<$ & $<$ & $<$ & $<$ & $<$ & $<$ & $<$ & $<$ & $<$ \\
\hline 1,1-Dichloroethene & $2 \mathrm{~J}$ & 42 & $<$ & $<$ & $3 \mathrm{~J}$ & $<$ & $<$ & $<$ & $<$ \\
\hline Vinyl chloride & $<$ & 43 & $<$ & 18 & $<$ & $<$ & $<$ & $<$ & $<$ \\
\hline Chloroethanes ( $\mu \mathrm{g} / \mathrm{L})$ & & & & & & & & & \\
\hline 1,1,1-Trichloroethane & $<$ & 5 & $<$ & $<$ & $<$ & $<$ & $<$ & $<$ & $<$ \\
\hline 1,1,2-Trichloroethane & $<$ & $<$ & $<$ & $<$ & $<$ & $<$ & $<$ & $<$ & $<$ \\
\hline 1,2-Dichloroethane & $<$ & $<$ & $<$ & $<$ & $<$ & $<$ & $<$ & $<$ & $<$ \\
\hline 1,1-Dichloroethane & $<$ & 9 & $<$ & $4 \mathrm{~J}$ & $<$ & $<$ & $<$ & $<$ & $<$ \\
\hline Chloroethane & $<$ & $<$ & $<$ & $<$ & $<$ & $<$ & $<$ & $<$ & $<$ \\
\hline Chloromethanes $(\mu \mathrm{g} / \mathrm{L})$ & & & & & & & & & \\
\hline Carbon tetrachloride & $4 \mathrm{~J}$ & $<$ & $<$ & $<$ & $<$ & $<$ & $<$ & $<$ & $<$ \\
\hline Chloroform & $2 \mathrm{~J}$ & $<$ & $<$ & $<$ & 30 & $<$ & $<$ & $<$ & $<$ \\
\hline Methylene chloride & $<$ & $<$ & $<$ & $<$ & 15 & $<$ & $<$ & $<$ & $<$ \\
\hline Petrol. Hydrocarb. ( $\mu \mathrm{g} / \mathrm{L})$ & & & & & & & & & \\
\hline Benzene & $<$ & 13 & $<$ & $<$ & $<$ & $<$ & $<$ & $<$ & $<$ \\
\hline Ethylbenzene & $<$ & $<$ & $<$ & $<$ & $<$ & $<$ & $<$ & $<$ & $<$ \\
\hline Toluene & $<$ & $<$ & $<$ & $<$ & $<$ & $<$ & $<$ & $<$ & $<$ \\
\hline Total Xylene & $<$ & $<$ & $<$ & $<$ & $<$ & $<$ & & $<$ & $<$ \\
\hline Chlorofluorocarbons $(\mu \mathrm{g} / \mathrm{L})$ & & & & & & & & & \\
\hline 1,1,2-Trichloro-1,2,2-trifluoroethane & $<$ & 42 & $<$ & 30 & 46 & & & $<$ & $<$ \\
\hline Dichlorodifluoromethane & $<$ & $<$ & $<$ & 16 & $<$ & & & $<$ & $<$ \\
\hline Miscellaneous ( $\mu \mathrm{g} / \mathrm{L})$ & & & & & & & & & \\
\hline 1,2-Dichloropropane & $<$ & $<$ & $<$ & $<$ & $<$ & $<$ & $<$ & $<$ & $<$ \\
\hline 1,4-Dichlorobenzene & $<$ & $3 \mathrm{~J}$ & $<$ & $<$ & $<$ & $\cdot 1$ & & $<$ & $<$ \\
\hline 2-Butanone & $<$ & $<$ & $<$ & $<$ & $<$ & $<$ & $<$ & 9 & 9 \\
\hline Acetone & $<$ & $<$ & $<$ & $<$ & $<$ & $<$ & $<$ & & \\
\hline Carbon disulfide & $<$ & $<$ & $<$ & $<$ & $<$ & $<$ & $<$ & & \\
\hline Chlorobenzene & $<$ & 13 & $<$ & $<$ & $<$ & $<$ & $<$ & $<$ & $<$ \\
\hline
\end{tabular}


APPENDIX D.2: CY 2009 MONITORING DATA FOR THE BEAR CREEK HYDROGEOLOGIC REGIME Volatile Organic Compounds

\begin{tabular}{|c|c|c|c|c|c|c|c|c|c|}
\hline Sampling Point & \multicolumn{2}{|c|}{ GW-307 } & GW-315 & GW-365 & GW-601 & GW-615 & GW-623 & \multicolumn{2}{|c|}{ GW-627 } \\
\hline Functional Area & \multicolumn{2}{|c|}{ RS } & SPI & OLF & OLF & S3 & BG & \multicolumn{2}{|c|}{ BG } \\
\hline Date Sampled & \multicolumn{2}{|c|}{$02 / 10 / 09$} & $02 / 17 / 09$ & $03 / 02 / 09$ & $03 / 02 / 09$ & 02/18/09 & $03 / 03 / 09$ & $03 / 05 / 09$ & 08/06/09 \\
\hline Program & GWPP & GWPP & GWPP & GWPP & GWPP & GWPP & GWPP & GWPP & GWPP \\
\hline Sample Type & & Dup & PDB & PDB & & & NP & PDB & PDB \\
\hline Chloroethenes $(\mu \mathrm{g} / \mathrm{L})$ & & & & & & & & & \\
\hline Tetrachloroethene & $<$ & $<$ & $<$ & $<$ & $<$ & $<$ & 25,000 & 710 & 870 \\
\hline Trichloroethene & 12 & 13 & $<$ & 14 & 83 & $<$ & 19,000 & 230 & 330 \\
\hline cis-1,2-Dichloroethene & $2 \mathrm{~J}$ & $2 \mathrm{~J}$ & $<$ & 40 & $<$ & $<$ & 640 & 45 & 39 \\
\hline trans-1,2-Dichloroethene & $<$ & $<$ & $<$ & $<$ & $<$ & $<$ & 22 & $4 \mathrm{~J}$ & $5 \mathrm{~J}$ \\
\hline 1,1-Dichloroethene & $<$ & $<$ & $<$ & 14 & $<$ & $<$ & 290 & 48 & 49 \\
\hline Vinyl chloride & $<$ & $<$ & $<$ & $<$ & $<$ & $<$ & 150 & 53 & 78 \\
\hline Chloroethanes ( $\mu \mathrm{g} / \mathrm{L})$ & & & & & & & & & \\
\hline 1,1,1-Trichloroethane & $<$ & $<$ & $<$ & $<$ & $<$ & $<$ & $<$ & $<$ & $<$ \\
\hline 1,1,2-Trichloroethane & $<$ & $<$ & $<$ & $<$ & $<$ & $<$ & $<$ & $<$ & $<$ \\
\hline 1,2-Dichloroethane & $<$ & $<$ & $<$ & $<$ & $<$ & $<$ & $<$ & $<$ & $<$ \\
\hline 1,1-Dichloroethane & $1 \mathrm{~J}$ & $1 \mathrm{~J}$ & $<$ & $3 \mathrm{~J}$ & $<$ & $<$ & 3,300 & 130 & 130 \\
\hline Chloroethane & $<$ & $<$ & $<$ & $<$ & $<$ & $<$ & $<$ & $1 \mathrm{~J}$ & $3 \mathrm{~J}$ \\
\hline Chloromethanes $(\mu \mathrm{g} / \mathrm{L})$ & & & & & & & & & \\
\hline Carbon tetrachloride & $<$ & $<$ & $<$ & $<$ & $<$ & $<$ & $<$ & $<$ & $<$ \\
\hline Chloroform & $<$ & $<$ & $<$ & $<$ & $<$ & $<$ & $<$ & $<$ & $<$ \\
\hline Methylene chloride & $<$ & $<$ & $<$ & $<$ & $<$ & 5 & 29 & $<$ & $<$ \\
\hline Petrol. Hydrocarb. ( $\mu \mathrm{g} / \mathrm{L})$ & & & & & & & & & \\
\hline Benzene & $<$ & $<$ & $<$ & $<$ & $<$ & $<$ & 10 & $<$ & $<$ \\
\hline Ethylbenzene & $<$ & $<$ & $<$ & $<$ & $<$ & $<$ & 11 & $<$ & $<$ \\
\hline Toluene & $<$ & $<$ & $<$ & $<$ & $<$ & $<$ & $3 \mathrm{~J}$ & $<$ & $<$ \\
\hline Total Xylene & $<$ & $<$ & $<$ & $<$ & $<$ & $<$ & 43 & $<$ & $<$ \\
\hline Chlorofluorocarbons ( $\mu \mathrm{g} / \mathrm{L})$ & & & & & & & & & \\
\hline 1,1,2-Trichloro-1,2,2-trifluoroethane & $<$ & $<$ & $<$ & $<$ & $<$ & $<$ & $<$ & $<$ & $<$ \\
\hline Dichlorodifluoromethane & $<$ & $<$ & $<$ & $<$ & $<$ & $<$ & $<$ & $<$ & $<$ \\
\hline Miscellaneous $(\mu \mathrm{g} / \mathrm{L})$ & & & & & & & & & \\
\hline 1,2-Dichloropropane & $<$ & $<$ & $<$ & $<$ & $<$ & $<$ & $<$ & $<$ & $<$ \\
\hline 1,4-Dichlorobenzene & $<$ & $<$ & $<$ & $<$ & $<$ & $<$ & $<$ & $<$ & $<$ \\
\hline 2-Butanone & $<$ & $<$ & $<$ & $<$ & $<$ & $<$ & $<$ & $<$ & 10 \\
\hline Acetone & $<$ & $<$ & & & $<$ & $<$ & 81 & . & \\
\hline Carbon disulfide & $<$ & $<$ & & & $<$ & $<$ & $<$ & ${ }^{\prime}$ & \\
\hline Chlorobenzene & $<$ & $<$ & $<$ & $<$ & $<$ & $<$ & $<$ & $<$ & $<$ \\
\hline
\end{tabular}


APPENDIX D.2: CY 2009 MONITORING DATA FOR THE BEAR CREEK HYDROGEOLOGIC REGIME Volatile Organic Compounds

\begin{tabular}{|c|c|c|c|c|c|c|c|c|c|}
\hline Sampling Point & \multicolumn{3}{|c|}{ GW-629 } & \multicolumn{3}{|c|}{ GW-648 } & GW-653 & \multicolumn{2}{|c|}{ GW-683 } \\
\hline Functional Area & \multicolumn{3}{|c|}{ BG } & \multicolumn{3}{|c|}{ RS } & BG & \multicolumn{2}{|c|}{ EXP-A } \\
\hline Date Sampled & $03 / 05 / 09$ & 08/06/09 & 09/09/09 & \multicolumn{2}{|c|}{$02 / 09 / 09$} & \multirow{2}{*}{$\begin{array}{c}08 / 05 / 09 \\
\text { GWPP }\end{array}$} & 03/05/09 & \multirow{2}{*}{$\frac{03 / 04 / 09}{B J C}$} & \multirow{2}{*}{$\begin{array}{c}07 / 21 / 09 \\
\text { BJC }\end{array}$} \\
\hline Program & GWPP & GWPP & GWPP & GWPP & GWPP & & GWPP & & \\
\hline Sample Type & PDB & PDB & BAIL & & Dup & & PDB & & \\
\hline Chloroethenes ( $\mu \mathrm{g} / \mathrm{L})$ & & & & & & & & & \\
\hline Tetrachloroethene & $100,000 \mathrm{Q}$ & 130,000 & 180,000 & $<$ & $<$ & $<$ & 13 & $<$ & $<$ \\
\hline Trichloroethene & $21,000 \mathrm{Q}$ & 17,000 & 24,000 & $<$ & $<$ & $<$ & 24 & $<$ & $<$ \\
\hline cis-1,2-Dichloroethene & $220 \mathrm{Q}$ & $250 \mathrm{~J}$ & $<$ & $<$ & $<$ & $<$ & 190 & $<$ & $<$ \\
\hline trans-1,2-Dichloroethene & 74 & 72 & $<$ & $<$ & $<$ & $<$ & $<$ & $<$ & $<$ \\
\hline 1,1-Dichloroethene & $1,200 \mathrm{Q}$ & 2,100 & $2,700 \mathrm{~J}$ & $<$ & $<$ & $<$ & $5 \mathrm{~J}$ & $<$ & $<$ \\
\hline Vinyl chloride & $120 \mathrm{Q}$ & 200 & $<$ & $<$ & $<$ & $<$ & $<$ & $<$ & $<$ \\
\hline Chloroethanes ( $\mu \mathrm{g} / \mathrm{L})$ & & & & & & & & & \\
\hline 1,1,1-Trichloroethane & $560 \mathrm{Q}$ & 940 & $1,200 \mathrm{~J}$ & $<$ & $<$ & $<$ & $<$ & $<$ & 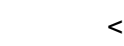 \\
\hline 1,1,2-Trichloroethane & $43 \mathrm{Q}$ & 43 & $<$ & $<$ & $<$ & $<$ & $<$ & $<$ & $<$ \\
\hline 1,2-Dichloroethane & $<$ & 24 & $<$ & $<$ & $<$ & $<$ & $<$ & $<$ & 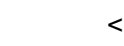 \\
\hline 1,1-Dichloroethane & $6,500 \mathrm{Q}$ & 8,100 & 11,000 & $<$ & $<$ & $<$ & 11 & $<$ & $<$ \\
\hline Chloroethane & $11 \mathrm{Q}$ & 26 & $<$ & $<$ & $<$ & $<$ & $<$ & $<$ & $<$ \\
\hline Chloromethanes ( $\mu \mathrm{g} / \mathrm{L})$ & & & & & & & & & \\
\hline Carbon tetrachloride & $<$ & $<$ & $<$ & $<$ & $<$ & $<$ & $<$ & $<$ & $<$ \\
\hline Chloroform & $2 \mathrm{~J}$ & $2 \mathrm{~J}$ & $<$ & $<$ & $<$ & $<$ & $1 \mathrm{~J}$ & $<$ & $<$ \\
\hline Methylene chloride & $<$ & $3 \mathrm{~J}$ & $<$ & $<$ & $<$ & $<$ & $<$ & $<$ & $<$ \\
\hline Petrol. Hydrocarb. ( $\mu \mathrm{g} / \mathrm{L})$ & & & & & & & & & \\
\hline Benzene & $26 \mathrm{Q}$ & 28 & $<$ & $<$ & $<$ & $<$ & $<$ & $<$ & 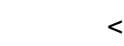 \\
\hline Ethylbenzene & $3 \mathrm{~J}$ & $4 \mathrm{~J}$ & $<$ & $<$ & $<$ & $<$ & $<$ & $<$ & 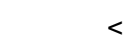 \\
\hline Toluene & $29 \mathrm{Q}$ & 32 & $<$ & $<$ & $<$ & $<$ & $<$ & $<$ & $<$ \\
\hline Total Xylene & $15 \mathrm{Q}$ & 23 & $<$ & $<$ & $<$ & $<$ & $<$ & $<$ & $<$ \\
\hline Chlorofluorocarbons $(\mu \mathrm{g} / \mathrm{L})$ & & & & & & & & & \\
\hline 1,1,2-Trichloro-1,2,2-trifluoroethane & $<$ & $<$ & $<$ & $<$ & $<$ & $<$ & $<$ & & \\
\hline Dichlorodifluoromethane & $3 \mathrm{~J}$ & $3 \mathrm{~J}$ & $<$ & $<$ & $<$ & $<$ & $<$ & & \\
\hline Miscellaneous ( $\mu \mathrm{g} / \mathrm{L})$ & & & & & & & & & \\
\hline 1,2-Dichloropropane & $<$ & $<$ & $<$ & $<$ & $<$ & $<$ & $<$ & $<$ & $<$ \\
\hline 1,4-Dichlorobenzene & $<$ & $<$ & $<$ & $<$ & $<$ & $<$ & $<$ & . & \\
\hline 2-Butanone & $<$ & $<$ & $<$ & $<$ & $<$ & $<$ & $<$ & $<$ & $<$ \\
\hline Acetone & & & $<$ & $<$ & $<$ & $<$ & & $<$ & $<$ \\
\hline Carbon disulfide & & & $<$ & $<$ & $<$ & $<$ & & $<$ & 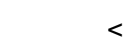 \\
\hline Chlorobenzene & $<$ & $<$ & $<$ & $<$ & $<$ & $<$ & $<$ & $<$ & $<$ \\
\hline
\end{tabular}


APPENDIX D.2: CY 2009 MONITORING DATA FOR THE BEAR CREEK HYDROGEOLOGIC REGIME Volatile Organic Compounds

\begin{tabular}{|c|c|c|c|c|c|c|c|c|c|}
\hline Sampling Point & \multicolumn{2}{|c|}{ GW-684 } & GW-703 & \multicolumn{2}{|c|}{ GW-704 } & \multicolumn{2}{|c|}{ GW-706 } & \multicolumn{2}{|c|}{ GW-712 } \\
\hline Functional Area & \multicolumn{2}{|c|}{ EXP-A } & EXP-B & \multicolumn{2}{|c|}{ EXP-B } & \multicolumn{2}{|c|}{ EXP-B } & \multicolumn{2}{|c|}{ EXP-W } \\
\hline Date Sampled & $03 / 03 / 09$ & 07/20/09 & $02 / 26 / 09$ & $03 / 03 / 09$ & 07/21/09 & 03/03/09 & $07 / 22 / 09$ & $01 / 07 / 09$ & $07 / 06 / 09$ \\
\hline Program & BJC & BJC & GWPP & BJC & BJC & BJC & BJC & BJC & BJC \\
\hline \multicolumn{10}{|l|}{ Sample Type } \\
\hline \multicolumn{10}{|l|}{ Chloroethenes ( $\mu \mathrm{g} / \mathrm{L})$} \\
\hline Tetrachloroethene & $<$ & $<$ & $<$ & $<$ & $<$ & $<$ & $<$ & $<$ & $<$ \\
\hline Trichloroethene & $<$ & $<$ & 10 & 40 & 21.1 & 15.5 & 8.04 & $<$ & $<$ \\
\hline cis-1,2-Dichloroethene & $<$ & $<$ & 9 & 5.53 & $3.62 \mathrm{~J}$ & 28.6 & 12.8 & $<$ & $<$ \\
\hline trans-1,2-Dichloroethene & $<$ & $<$ & $<$ & $<$ & $<$ & $<$ & $<$ & $<$ & $<$ \\
\hline 1,1-Dichloroethene & $<$ & $<$ & $<$ & $3.22 \mathrm{~J}$ & $1.22 \mathrm{~J}$ & 3.51 & $<$ & $<$ & $<$ \\
\hline Vinyl chloride & $<$ & $<$ & $<$ & $<$ & $<$ & $<$ & $<$ & $<$ & $<$ \\
\hline \multicolumn{10}{|l|}{ Chloroethanes ( $\mu \mathrm{g} / \mathrm{L})$} \\
\hline 1,1,1-Trichloroethane & $<$ & $<$ & $<$ & $<$ & $<$ & $<$ & $<$ & $<$ & $<$ \\
\hline 1,1,2-Trichloroethane & $<$ & $<$ & $<$ & $<$ & $<$ & $<$ & $<$ & $<$ & $<$ \\
\hline 1,2-Dichloroethane & $<$ & $<$ & $<$ & $<$ & $<$ & $<$ & $<$ & $<$ & $<$ \\
\hline 1,1-Dichloroethane & $<$ & $<$ & $<$ & $<$ & $<$ & $<$ & $<$ & $<$ & $<$ \\
\hline Chloroethane & $<$ & $<$ & $<$ & $<$ & $<$ & $<$ & $<$ & $<$ & $<$ \\
\hline \multicolumn{10}{|l|}{ Chloromethanes $(\mu \mathrm{g} / \mathrm{L})$} \\
\hline Carbon tetrachloride & $<$ & $<$ & $<$ & $<$ & $<$ & $<$ & $<$ & $<$ & $<$ \\
\hline Chloroform & $<$ & $<$ & $<$ & $<$ & $<$ & $<$ & $<$ & $<$ & $<$ \\
\hline Methylene chloride & $<$ & $<$ & $<$ & $<$ & $<$ & $<$ & $<$ & $<$ & $<$ \\
\hline \multicolumn{10}{|l|}{ Petrol. Hydrocarb. ( $\mu \mathrm{g} / \mathrm{L})$} \\
\hline Benzene & $<$ & $<$ & $<$ & $<$ & $<$ & $<$ & $<$ & $<$ & $<$ \\
\hline Ethylbenzene & $<$ & $<$ & $<$ & $<$ & $<$ & $<$ & $<$ & $<$ & $<$ \\
\hline Toluene & $<$ & $<$ & $<$ & $<$ & $<$ & $<$ & $<$ & $<$ & $<$ \\
\hline Total Xylene & $<$ & $<$ & $<$ & $<$ & $<$ & $<$ & $<$ & $<$ & \\
\hline \multicolumn{10}{|l|}{ Chlorofluorocarbons $(\mu \mathrm{g} / \mathrm{L})$} \\
\hline \multirow{2}{*}{\multicolumn{10}{|c|}{$\begin{array}{r}\text { 1,1,2-Trichloro-1,2,2-trifluoroethane } \\
\text { Dichlorodifluoromethane }\end{array}$}} \\
\hline & & & & & & & & & \\
\hline \multicolumn{10}{|l|}{ Miscellaneous $(\mu \mathrm{g} / \mathrm{L})$} \\
\hline 1,2-Dichloropropane & $<$ & $<$ & $<$ & $<$ & $<$ & $<$ & $<$ & $<$ & $<$ \\
\hline 1,4-Dichlorobenzene & & & $<$ & & & & & & 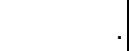 \\
\hline 2-Butanone & $<$ & $<$ & $<$ & $<$ & $<$ & $<$ & $<$ & $<$ & $<$ \\
\hline Acetone & $<$ & $<$ & $<$ & $<$ & $<$ & $<$ & $<$ & $<$ & $<$ \\
\hline Carbon disulfide & $<$ & $<$ & $<$ & $<$ & $<$ & $<$ & $<$ & $<$ & $<$ \\
\hline Chlorobenzene & $<$ & $<$ & $<$ & $<$ & $<$ & $<$ & $<$ & $<$ & $<$ \\
\hline
\end{tabular}


APPENDIX D.2: CY 2009 MONITORING DATA FOR THE BEAR CREEK HYDROGEOLOGIC REGIME Volatile Organic Compounds

\begin{tabular}{|c|c|c|c|c|c|c|c|c|c|}
\hline Sampling Point & \multicolumn{4}{|c|}{ GW-713 } & \multicolumn{2}{|c|}{ GW-714 } & \multirow{2}{*}{$\frac{\text { GW-724 }}{\text { EXP-C }}$} & \multirow{2}{*}{$\frac{\text { GW-725 }}{\text { EXP-C }}$} & \multirow{2}{*}{$\frac{\text { GW-726-04 }}{\text { BG }}$} \\
\hline Functional Area & \multicolumn{4}{|c|}{ EXP-W } & \multicolumn{2}{|c|}{ EXP-W } & & & \\
\hline Date Sampled & \multicolumn{2}{|c|}{$01 / 07 / 09$} & \multicolumn{2}{|c|}{$07 / 07 / 09$} & 01/06/09 & $07 / 06 / 09$ & $02 / 25 / 09$ & $02 / 25 / 09$ & 05/04/09 \\
\hline Program & $\mathrm{BJC}$ & BJC & BJC & BJC & BJC & BJC & GWPP & GWPP & GWPP \\
\hline Sample Type & & Dup & & Dup & & & & & \\
\hline Chloroethenes ( $\mu \mathrm{g} / \mathrm{L})$ & & & & & & & & & \\
\hline Tetrachloroethene & $<$ & $<$ & $<$ & $<$ & $<$ & $<$ & $3 \mathrm{~J}$ & $2 \mathrm{~J}$ & $<$ \\
\hline Trichloroethene & $<$ & $<$ & $<$ & $<$ & $<$ & $<$ & 90 & 10 & $<$ \\
\hline cis-1,2-Dichloroethene & $<$ & $<$ & $<$ & $<$ & $<$ & $<$ & $2 \mathrm{~J}$ & $<$ & $<$ \\
\hline trans-1,2-Dichloroethene & $<$ & $<$ & $<$ & $<$ & $<$ & $<$ & $<$ & $<$ & $<$ \\
\hline 1,1-Dichloroethene & $<$ & $<$ & $<$ & $<$ & $<$ & $<$ & $<$ & $<$ & $<$ \\
\hline Vinyl chloride & $<$ & $<$ & $<$ & $<$ & $<$ & $<$ & $<$ & $<$ & $<$ \\
\hline Chloroethanes ( $\mu \mathrm{g} / \mathrm{L})$ & & & & & & & & & \\
\hline 1,1,1-Trichloroethane & $<$ & $<$ & $<$ & $<$ & $<$ & $<$ & $<$ & $<$ & $<$ \\
\hline 1,1,2-Trichloroethane & $<$ & $<$ & $<$ & $<$ & $<$ & $<$ & $<$ & $<$ & $<$ \\
\hline 1,2-Dichloroethane & $<$ & $<$ & $<$ & $<$ & $<$ & $<$ & $<$ & $<$ & $<$ \\
\hline 1,1-Dichloroethane & $<$ & $<$ & $<$ & $<$ & $<$ & $<$ & $<$ & $<$ & $<$ \\
\hline Chloroethane & $<$ & $<$ & $<$ & $<$ & $<$ & $<$ & $<$ & $<$ & $<$ \\
\hline Chloromethanes $(\mu \mathrm{g} / \mathrm{L})$ & & & & & & & & & \\
\hline Carbon tetrachloride & $<$ & $<$ & $<$ & $<$ & $<$ & $<$ & $<$ & $<$ & $<$ \\
\hline Chloroform & $<$ & $<$ & $<$ & $<$ & $<$ & $<$ & $<$ & $<$ & $<$ \\
\hline Methylene chloride & $<$ & $<$ & $<$ & $<$ & $<$ & $<$ & $<$ & $<$ & $<$ \\
\hline Petrol. Hydrocarb. ( $\mu \mathrm{g} / \mathrm{L})$ & & & & & & & & & \\
\hline Benzene & $<$ & $<$ & $<$ & $<$ & $<$ & $<$ & $<$ & $<$ & $<$ \\
\hline Ethylbenzene & $<$ & $<$ & $<$ & $<$ & $<$ & $<$ & $<$ & $<$ & $<$ \\
\hline Toluene & $<$ & $<$ & $<$ & $<$ & $<$ & $<$ & $<$ & $<$ & $<$ \\
\hline Total Xylene & $<$ & $<$ & .1 & & $<$ & & $<$ & $<$ & $<$ \\
\hline Chlorofluorocarbons $(\mu \mathrm{g} / \mathrm{L})$ & & & & & & & & & \\
\hline 1,1,2-Trichloro-1,2,2-trifluoroethane & & & & & & & $<$ & $<$ & $<$ \\
\hline Dichlorodifluoromethane & & & & & & & $<$ & $<$ & $<$ \\
\hline Miscellaneous ( $\mu \mathrm{g} / \mathrm{L})$ & & & & & & & & & \\
\hline 1,2-Dichloropropane & $<$ & $<$ & $<$ & $<$ & $<$ & $<$ & $<$ & $<$ & $<$ \\
\hline 1,4-Dichlorobenzene & & & & & & & $<$ & $<$ & $<$ \\
\hline 2-Butanone & $<$ & $<$ & $<$ & $<$ & $<$ & $<$ & $<$ & $<$ & $<$ \\
\hline Acetone & $<$ & $<$ & $<$ & $<$ & $<$ & $<$ & $<$ & $<$ & $<$ \\
\hline Carbon disulfide & $<$ & $<$ & $<$ & $<$ & $<$ & $<$ & $<$ & $<$ & $<$ \\
\hline Chlorobenzene & $<$ & $<$ & $<$ & $<$ & $<$ & $<$ & $<$ & $<$ & $<$ \\
\hline
\end{tabular}


APPENDIX D.2: CY 2009 MONITORING DATA FOR THE BEAR CREEK HYDROGEOLOGIC REGIME Volatile Organic Compounds

\begin{tabular}{|c|c|c|c|c|c|c|c|c|}
\hline Sampling Point & GW-726-06 & GW-726-09 & GW-726-12 & GW-726-16 & GW-726-20 & GW-726-23 & GW-738 & GW-740 \\
\hline Functional Area & BG & BG & BG & BG & BG & BG & EXP-C & EXP-C \\
\hline Date Sampled & 05/04/09 & 05/05/09 & 05/05/09 & 05/06/09 & 05/06/09 & 05/06/09 & $02 / 25 / 09$ & $02 / 24 / 09$ \\
\hline Program & GWPP & GWPP & GWPP & GWPP & GWPP & GWPP & GWPP & GWPP \\
\hline Sample Type & & & & & & & & PDB \\
\hline $\begin{array}{r}\text { Chloroethenes }(\mu \mathbf{g} / \mathbf{L}) \\
\text { Tetrachloroethene } \\
\text { Trichloroethene } \\
\text { cis-1,2-Dichloroethene } \\
\text { trans-1,2-Dichloroethene } \\
\text { 1,1-Dichloroethene } \\
\text { Vinyl chloride } \\
\end{array}$ & $\begin{array}{l}< \\
< \\
< \\
< \\
< \\
<\end{array}$ & $\begin{array}{l}< \\
< \\
< \\
< \\
< \\
<\end{array}$ & $\begin{array}{l}< \\
< \\
< \\
< \\
< \\
< \\
<\end{array}$ & $\begin{array}{l}< \\
< \\
< \\
< \\
< \\
< \\
<\end{array}$ & $\begin{array}{l}< \\
< \\
< \\
< \\
< \\
<\end{array}$ & $\begin{array}{l}< \\
< \\
< \\
< \\
< \\
<\end{array}$ & $\begin{array}{r}< \\
20 \\
< \\
< \\
< \\
<\end{array}$ & \begin{tabular}{r|}
$<$ \\
27 \\
$3 \mathrm{~J}$ \\
$<$ \\
$<$ \\
$<$ \\
$<$
\end{tabular} \\
\hline $\begin{array}{r}\text { Chloroethanes }(\mu \mathrm{g} / \mathrm{L}) \\
\text { 1,1,1-Trichloroethane } \\
\text { 1,1,2-Trichloroethane } \\
\text { 1,2-Dichloroethane } \\
\text { 1,1-Dichloroethane } \\
\text { Chloroethane }\end{array}$ & $\begin{array}{l}< \\
< \\
< \\
< \\
<\end{array}$ & $\begin{array}{l}< \\
< \\
< \\
< \\
<\end{array}$ & $\begin{array}{l}< \\
< \\
< \\
< \\
<\end{array}$ & $\begin{array}{l}< \\
< \\
< \\
< \\
<\end{array}$ & $\begin{array}{l}< \\
< \\
< \\
< \\
<\end{array}$ & $\begin{array}{l}< \\
< \\
< \\
< \\
<\end{array}$ & $\begin{array}{l}< \\
< \\
< \\
< \\
<\end{array}$ & $\begin{array}{l}< \\
< \\
< \\
<\end{array}$ \\
\hline $\begin{array}{r}\text { Chloromethanes }(\mu \mathbf{g} / \mathbf{L}) \\
\text { Carbon tetrachloride } \\
\text { Chloroform } \\
\text { Methylene chloride }\end{array}$ & $\begin{array}{l}< \\
< \\
<\end{array}$ & $\begin{array}{l}< \\
< \\
<\end{array}$ & $\begin{array}{l}< \\
< \\
<\end{array}$ & $\begin{array}{l}< \\
< \\
<\end{array}$ & $\begin{array}{l}< \\
< \\
<\end{array}$ & $\begin{array}{l}< \\
< \\
<\end{array}$ & $\begin{array}{l}< \\
< \\
<\end{array}$ & $\begin{array}{l}< \\
< \\
<\end{array}$ \\
\hline $\begin{array}{r}\text { Petrol. Hydrocarb. }(\mu \mathrm{g} / \mathrm{L}) \\
\text { Benzene } \\
\text { Ethylbenzene } \\
\text { Toluene } \\
\text { Total Xylene } \\
\end{array}$ & $\begin{array}{l}< \\
< \\
< \\
<\end{array}$ & $\begin{array}{l}< \\
< \\
< \\
<\end{array}$ & $\begin{array}{l}< \\
< \\
< \\
<\end{array}$ & $\begin{array}{l}< \\
< \\
< \\
<\end{array}$ & $\begin{array}{l}< \\
< \\
< \\
<\end{array}$ & $\begin{array}{l}< \\
< \\
< \\
<\end{array}$ & $\begin{array}{l}< \\
< \\
< \\
<\end{array}$ & $\begin{array}{l}< \\
< \\
< \\
<\end{array}$ \\
\hline $\begin{array}{r}\text { Chlorofluorocarbons ( } \mu \mathbf{g} / \mathbf{L}) \\
\text { 1,1,2-Trichloro-1,2,2-trifluoroethane } \\
\text { Dichlorodifluoromethane } \\
\end{array}$ & $\begin{array}{l}< \\
<\end{array}$ & $\begin{array}{l}< \\
<\end{array}$ & $\begin{array}{l}< \\
<\end{array}$ & $\begin{array}{l}< \\
<\end{array}$ & $\begin{array}{l}< \\
<\end{array}$ & $\begin{array}{l}< \\
<\end{array}$ & $\begin{array}{l}< \\
<\end{array}$ & $\begin{array}{l}< \\
<\end{array}$ \\
\hline $\begin{array}{r}\text { Miscellaneous }(\mu \mathbf{g} / \mathbf{L}) \\
\text { 1,2-Dichloropropane } \\
\text { 1,4-Dichlorobenzene } \\
2 \text {-Butanone } \\
\text { Acetone } \\
\text { Carbon disulfide } \\
\text { Chlorobenzene }\end{array}$ & $\begin{array}{l}< \\
< \\
< \\
< \\
< \\
<\end{array}$ & $\begin{array}{r}< \\
3 \mathrm{~J} \\
<\end{array}$ & $\begin{array}{l}< \\
< \\
< \\
< \\
<\end{array}$ & $\begin{array}{l}< \\
< \\
< \\
< \\
< \\
<\end{array}$ & $\begin{array}{r}< \\
< \\
< \\
< \\
3 \mathrm{~J} \\
<\end{array}$ & $\begin{array}{l}< \\
< \\
< \\
< \\
< \\
<\end{array}$ & $\begin{array}{l}< \\
< \\
< \\
< \\
< \\
<\end{array}$ & $\begin{array}{l}< \\
< \\
<\end{array}$ \\
\hline
\end{tabular}


APPENDIX D.2: CY 2009 MONITORING DATA FOR THE BEAR CREEK HYDROGEOLOGIC REGIME Volatile Organic Compounds

\begin{tabular}{|c|c|c|c|c|c|c|c|c|c|}
\hline Sampling Point & BCK-03.30 & \multicolumn{2}{|c|}{ BCK-04.55 } & \multirow{2}{*}{\begin{tabular}{|c|} 
BCK-07.87 \\
EXP-SW
\end{tabular}} & BCK-09.20 & \multicolumn{2}{|c|}{ BCK-09.40 } & BCK-11.54 & BCK-11.84 \\
\hline Functional Area & EXP-SW & EXP. & -sw & & EXP-SW & \multicolumn{2}{|c|}{ EXP-SW } & \multirow{2}{*}{ EXP-SW } & EXP-SW \\
\hline Date Sampled & $12 / 07 / 09$ & 08/03/09 & $12 / 07 / 09$ & $12 / 07 / 09$ & $12 / 07 / 09$ & $08 / 0$ & $3 / 09$ & & $12 / 07 / 09$ \\
\hline Program & BJC & GWPP & BJC & BJC & BJC & GWPP & GWPP & BJC & BJC \\
\hline Sample Type & & & & & & & Dup & & \\
\hline Chloroethenes ( $\mu \mathrm{g} / \mathrm{L})$ & & & & & & & & & \\
\hline Tetrachloroethene & $<$ & $2 \mathrm{~J}$ & $<$ & $<$ & 1.3 & $<$ & $<$ & $<$ & $<$ \\
\hline Trichloroethene & $<$ & $<$ & $<$ & $<$ & 1.5 & $<$ & $<$ & $<$ & $<$ \\
\hline cis-1,2-Dichloroethene & $<$ & $<$ & $<$ & 1.2 & 7 & $3 \mathrm{~J}$ & $3 \mathrm{~J}$ & $<$ & $<$ \\
\hline trans-1,2-Dichloroethene & $<$ & $<$ & $<$ & $<$ & $<$ & $<$ & $<$ & $<$ & $<$ \\
\hline 1,1-Dichloroethene & $<$ & $<$ & $<$ & $<$ & $<$ & $<$ & $<$ & $<$ & $<$ \\
\hline Vinyl chloride & $<$ & $<$ & $<$ & $<$ & $<$ & $<$ & $<$ & $<$ & $<$ \\
\hline Chloroethanes $(\mu \mathrm{g} / \mathrm{L})$ & & & & & & & & & \\
\hline 1,1,1-Trichloroethane & $<$ & $<$ & $<$ & $<$ & $<$ & $<$ & $<$ & $<$ & $<$ \\
\hline 1,1,2-Trichloroethane & $<$ & $<$ & $<$ & $<$ & $<$ & $<$ & $<$ & $<$ & $<$ \\
\hline 1,2-Dichloroethane & $<$ & $<$ & $<$ & $<$ & $<$ & $<$ & $<$ & $<$ & $<$ \\
\hline 1,1-Dichloroethane & $<$ & $<$ & $<$ & $<$ & $<$ & $<$ & $<$ & $<$ & $<$ \\
\hline Chloroethane & $<$ & $<$ & $<$ & $<$ & $<$ & $<$ & $<$ & $<$ & $<$ \\
\hline Chloromethanes ( $\mu \mathrm{g} / \mathrm{L})$ & & & & & & & & & \\
\hline Carbon tetrachloride & $<$ & $<$ & $<$ & $<$ & $<$ & $<$ & $<$ & $<$ & $<$ \\
\hline Chloroform & $<$ & $<$ & $<$ & $<$ & $<$ & $<$ & $<$ & $<$ & $<$ \\
\hline Methylene chloride & $<$ & $<$ & $<$ & $<$ & $<$ & $<$ & $<$ & $<$ & $<$ \\
\hline Petrol. Hydrocarb. ( $\mu \mathrm{g} / \mathrm{L})$ & & & & & & & & & \\
\hline Benzene & $<$ & $<$ & $<$ & $<$ & $<$ & $<$ & $<$ & $<$ & $<$ \\
\hline Ethylbenzene & $<$ & $<$ & $<$ & $<$ & $<$ & $<$ & $<$ & $<$ & $<$ \\
\hline Toluene & $<1$ & $<$ & $<$ & $<$ & $<$ & $<$ & $<$ & $<$ & $<$ \\
\hline Total Xylene & $<$ & $<$ & $<$ & $<$ & $<$ & $<$ & $<$ & $<$ & $<$ \\
\hline Chlorofluorocarbons ( $\mu \mathrm{g} / \mathrm{L})$ & & & & & & & & & \\
\hline 1,1,2-Trichloro-1,2,2-trifluoroethane & & $<$ & & & & $<$ & $<$ & & \\
\hline Dichlorodifluoromethane & & $<$ & & & & $<$ & $<$ & & \\
\hline Miscellaneous ( $\mu \mathrm{g} / \mathrm{L})$ & & & & & & & & & \\
\hline 1,2-Dichloropropane & $<$ & $<$ & $<$ & $<$ & $<$ & $<$ & $<$ & $<$ & $<$ \\
\hline 1,4-Dichlorobenzene & $<$ & $<$ & $<$ & $<$ & $<$ & $<$ & $<$ & $<$ & $<$ \\
\hline 2-Butanone & $<$ & $<$ & $<$ & $<$ & $<$ & $<$ & $<$ & $<$ & $<$ \\
\hline Acetone & $<$ & $<$ & $<$ & $<$ & $<$ & $<$ & $<$ & $<$ & $<$ \\
\hline Carbon disulfide & $<$ & $<$ & $<$ & $<$ & $<$ & $<$ & $<$ & $<$ & $<$ \\
\hline Chlorobenzene & $<1$ & $<$ & $<$ & $<$ & $<$ & $<$ & $<$ & $<$ & $<$ \\
\hline
\end{tabular}


APPENDIX D.2: CY 2009 MONITORING DATA FOR THE BEAR CREEK HYDROGEOLOGIC REGIME Volatile Organic Compounds

\begin{tabular}{|c|c|c|c|c|c|c|c|c|c|}
\hline Sampling Point & BCK-11.97 & BCK-12.34 & \multicolumn{2}{|c|}{ NT-01 } & NT-03 & \multicolumn{2}{|c|}{ NT-07 } & \multicolumn{2}{|c|}{ NT-08 } \\
\hline Functional Area & EXP-SW & EXP-SW & \multicolumn{2}{|c|}{ EXP-SW } & EXP-SW & \multicolumn{2}{|c|}{ EXP-SW } & \multicolumn{2}{|c|}{ EXP-SW } \\
\hline Date Sampled & $08 / 03 / 09$ & $12 / 07 / 09$ & 08/03/09 & $12 / 07 / 09$ & $12 / 07 / 09$ & 02/10/09 & $08 / 04 / 09$ & 02/10/09 & $08 / 04 / 09$ \\
\hline Program & GWPP & BJC & GWPP & BJC & BJC & BJC & BJC & BJC & BJC \\
\hline \multicolumn{10}{|l|}{ Sample Type } \\
\hline Chloroethenes ( $\mu \mathrm{g} / \mathrm{L})$ & & & & & & & & & \\
\hline Tetrachloroethene & $<$ & 7.5 & 20 & 26 & $<$ & 35.3 & 36.5 & 17.8 & 5.59 \\
\hline Trichloroethene & $<$ & $<$ & $<$ & $<$ & $<$ & 31 & 34.1 & 19.2 & 6.15 \\
\hline cis-1,2-Dichloroethene & $<$ & $<$ & $<$ & 1.1 & $<$ & 50.2 & 186 & 95.4 & 47.2 \\
\hline trans-1,2-Dichloroethene & $<$ & $<$ & $<$ & $<$ & $<$ & $<$ & $<$ & & $<$ \\
\hline 1,1-Dichloroethene & $<$ & $<$ & $<$ & $<$ & $<$ & 4.78 & 7.33 & $2.88 \mathrm{~J}$ & $<$ \\
\hline Vinyl chloride & $<$ & $<$ & $<$ & $<$ & $<$ & 1.03 & 3.41 & 1.71 & $<$ \\
\hline \multicolumn{10}{|l|}{ Chloroethanes ( $\mu \mathrm{g} / \mathrm{L})$} \\
\hline 1,1,1-Trichloroethane & $<$ & $<$ & $<$ & $<$ & $<$ & $1.36 \mathrm{~J}$ & $3.47 \mathrm{~J}$ & $<$ & $<$ \\
\hline 1,1,2-Trichloroethane & $<$ & $<$ & $<$ & $<$ & $<$ & $<$ & $<$ & $<$ & $<$ \\
\hline 1,2-Dichloroethane & $<$ & $<$ & $<$ & $<$ & $<$ & $<$ & $<$ & $<$ & $<$ \\
\hline 1,1-Dichloroethane & $<$ & $<$ & $<$ & $<$ & $<$ & 16 & 23.5 & 7.13 & $3.19 \mathrm{~J}$ \\
\hline Chloroethane & $<$ & $<$ & $<$ & $<$ & $<$ & $<$ & $<$ & $<$ & $<$ \\
\hline \multicolumn{10}{|l|}{ Chloromethanes ( $\mu \mathrm{g} / \mathrm{L})$} \\
\hline Carbon tetrachloride & $<$ & $<$ & $<$ & $<$ & $<$ & $<$ & $<$ & $<$ & $<$ \\
\hline Chloroform & $<$ & $<$ & $<$ & $<$ & $<$ & $1.7 \mathrm{~J}$ & $2.62 \mathrm{~J}$ & $1.26 \mathrm{~J}$ & $<$ \\
\hline Methylene chloride & $<$ & $<$ & $<$ & $<$ & $<$ & $<$ & $<$ & $<$ & $<$ \\
\hline \multicolumn{10}{|l|}{ Petrol. Hydrocarb. ( $\mu \mathrm{g} / \mathrm{L})$} \\
\hline Benzene & $<$ & $<$ & $<$ & $<$ & $<$ & $<$ & $<$ & $<$ & $<$ \\
\hline Ethylbenzene & $<$ & $<$ & $<$ & $<$ & $<$ & $<$ & $<$ & $<$ & $<$ \\
\hline Toluene & $<$ & $<$ & $<$ & $<$ & $<$ & $<$ & $<$ & $<$ & $<$ \\
\hline Total Xylene & $<$ & $<$ & $<$ & $<$ & $<$ & $<$ & $<$ & $<$ & $<$ \\
\hline \multicolumn{10}{|l|}{ Chlorofluorocarbons $(\mu \mathrm{g} / \mathrm{L})$} \\
\hline 1,1,2-Trichloro-1,2,2-trifluoroethane & $<$ & & $<$ & & & & & & \\
\hline Dichlorodifluoromethane & $<$ & & $<$ & & & & & & \\
\hline \multicolumn{10}{|l|}{ Miscellaneous ( $\mu \mathrm{g} / \mathrm{L})$} \\
\hline 1,2-Dichloropropane & $<$ & $<$ & $<$ & $<$ & $<$ & $<$ & $<$ & $<$ & $<$ \\
\hline 1,4-Dichlorobenzene & $<$ & $<$ & $<$ & $<$ & $<$ & & & & \\
\hline 2-Butanone & $<$ & $<$ & $<$ & $<$ & $<$ & $<$ & $<$ & $<$ & $<$ \\
\hline Acetone & $<$ & $<$ & $<$ & $<$ & $<$ & $<$ & $<$ & $<$ & $<$ \\
\hline Carbon disulfide & $<$ & $<$ & $<$ & $<$ & $<$ & $<$ & $<$ & $<$ & $<$ \\
\hline Chlorobenzene & $<$ & $<$ & $<$ & $<$ & $<$ & $<$ & $<$ & $<$ & $<$ \\
\hline
\end{tabular}


APPENDIX D.2: CY 2009 MONITORING DATA FOR THE BEAR CREEK HYDROGEOLOGIC REGIME Volatile Organic Compounds

\begin{tabular}{|c|c|c|c|c|c|c|c|c|}
\hline Sampling Point & \multicolumn{2}{|c|}{ NT-08 } & S07 & SS-4 & \multicolumn{2}{|c|}{ SS-5 } & \multicolumn{2}{|c|}{ SS-6 } \\
\hline Functional Area & \multicolumn{2}{|c|}{ EXP-SW } & EXP-SW & EXP-SW & \multicolumn{2}{|c|}{ EXP-SW } & \multicolumn{2}{|c|}{ EXP-SW } \\
\hline Date Sampled & \multicolumn{2}{|c|}{$12 / 07 / 09$} & $12 / 07 / 09$ & $08 / 03 / 09$ & \multirow{2}{*}{\begin{tabular}{c|}
$08 / 03 / 09$ \\
GWPP
\end{tabular}} & $12 / 07 / 09$ & \multirow{2}{*}{$\frac{01 / 05 / 09}{B J C}$} & \multirow{2}{*}{$\begin{array}{c}07 / 06 / 09 \\
\text { BJC }\end{array}$} \\
\hline Program & BJC & $\mathrm{BJC}$ & BJC & GWPP & & BJC & & \\
\hline Sample Type & & Dup & & & & & & \\
\hline \multicolumn{9}{|l|}{ Chloroethenes $(\mu \mathrm{g} / \mathrm{L})$} \\
\hline Tetrachloroethene & 24 & 23 & $<$ & $<$ & $<$ & $<$ & $<$ & $<$ \\
\hline Trichloroethene & 28 & 27 & $<$ & $3 \mathrm{~J}$ & $<$ & $<$ & $<$ & $<$ \\
\hline cis-1,2-Dichloroethene & 150 & 170 & $<$ & $3 \mathrm{~J}$ & $<$ & $<$ & $<$ & $<$ \\
\hline trans-1,2-Dichloroethene & $<$ & $<$ & $<$ & $<$ & $<$ & $<$ & $<$ & $<$ \\
\hline 1,1-Dichloroethene & 4.7 & 4.6 & $<$ & $<$ & $<$ & $<$ & $<$ & $<$ \\
\hline Vinyl chloride & 4.8 & 4.3 & $<$ & $<$ & $<$ & $<$ & $<$ & $<$ \\
\hline \multicolumn{9}{|l|}{ Chloroethanes ( $\mu \mathrm{g} / \mathrm{L})$} \\
\hline 1,1,1-Trichloroethane & 1.6 & 1.6 & $<$ & $<$ & $<$ & $<$ & $<$ & $<$ \\
\hline 1,1,2-Trichloroethane & $<$ & $<$ & $<$ & $<$ & $<$ & $<$ & $<$ & $<$ \\
\hline 1,2-Dichloroethane & 1 & 1.1 & $<$ & $<$ & $<$ & $<$ & $<$ & $<$ \\
\hline 1,1-Dichloroethane & 9.8 & 9.5 & $<$ & $<$ & $<$ & $<$ & $<$ & $<$ \\
\hline Chloroethane & $<$ & $<$ & $<$ & $<$ & $<$ & $<$ & $<$ & $<$ \\
\hline \multicolumn{9}{|l|}{ Chloromethanes ( $\mu \mathrm{g} / \mathrm{L})$} \\
\hline Carbon tetrachloride & $<$ & $<$ & $<$ & $<$ & $<$ & $<$ & $<$ & $<$ \\
\hline Chloroform & 1.9 & 1.8 & $<$ & $<$ & $<$ & $<$ & $<$ & $<$ \\
\hline Methylene chloride & $<$ & $<$ & $<$ & $<$ & $<$ & $<$ & $<$ & $<$ \\
\hline \multicolumn{9}{|l|}{ Petrol. Hydrocarb. ( $\mu \mathrm{g} / \mathrm{L})$} \\
\hline Benzene & $<$ & $<$ & $<$ & $<$ & $<$ & $<$ & $<$ & $<$ \\
\hline Ethylbenzene & $<$ & $<$ & $<$ & $<$ & $<$ & $<$ & $<$ & $<$ \\
\hline Toluene & $<$ & $<$ & $<$ & $<$ & $<$ & $<$ & $<$ & $<$ \\
\hline Total Xylene & $<$ & $<$ & $<$ & $<$ & $<$ & $<$ & $<$ & \\
\hline \multicolumn{9}{|l|}{ Chlorofluorocarbons $(\mu \mathrm{g} / \mathrm{L})$} \\
\hline 1,1,2-Trichloro-1,2,2-trifluoroethane & & & & $<$ & $<$ & & & \\
\hline Dichlorodifluoromethane & & & & $<$ & $<$ & & & \\
\hline \multicolumn{9}{|l|}{ Miscellaneous ( $\mu \mathrm{g} / \mathrm{L})$} \\
\hline 1,2-Dichloropropane & $<$ & $<$ & $<$ & $<$ & $<$ & $<$ & $<$ & $<$ \\
\hline 1,4-Dichlorobenzene & $<$ & $<$ & $<$ & $<$ & $<$ & $<$ & & \\
\hline 2-Butanone & $<$ & $<$ & $<$ & $<$ & $<$ & $<$ & $<$ & $<$ \\
\hline Acetone & $<$ & $<$ & $<$ & $<$ & $<$ & $<$ & $<$ & $<$ \\
\hline Carbon disulfide & $<$ & $<$ & $<$ & $<$ & $<$ & $<$ & $<$ & $<$ \\
\hline Chlorobenzene & $<$ & $<$ & $<$ & $<$ & $<$ & $<$ & $<$ & $<$ \\
\hline
\end{tabular}


APPENDIX D.2: CY 2009 MONITORING DATA FOR THE BEAR CREEK HYDROGEOLOGIC REGIME Volatile Organic Compounds

\begin{tabular}{|c|c|c|c|c|}
\hline Sampling Point & SS-6.6 & SS-7 & \multicolumn{2}{|c|}{ SS-8 } \\
\hline Functional Area & EXP-SW & EXP-SW & \multicolumn{2}{|c|}{ EXP-SW } \\
\hline Date Sampled & $12 / 07 / 09$ & $12 / 07 / 09$ & \multicolumn{2}{|c|}{$12 / 07 / 09$} \\
\hline Program & BJC & BJC & BJC & BJC \\
\hline Sample Type & & & & Dup \\
\hline \multicolumn{5}{|l|}{ Chloroethenes ( $\mu \mathrm{g} / \mathrm{L})$} \\
\hline Tetrachloroethene & $<$ & $<$ & $<$ & $<$ \\
\hline Trichloroethene & $<$ & $<$ & $<$ & $<$ \\
\hline cis-1,2-Dichloroethene & $<$ & $<$ & $<$ & $<$ \\
\hline trans-1,2-Dichloroethene & $<$ & $<$ & $<$ & $<$ \\
\hline 1,1-Dichloroethene & $<$ & $<$ & $<$ & $<$ \\
\hline Vinyl chloride & $<$ & $<$ & $<$ & $<$ \\
\hline \multicolumn{5}{|l|}{ Chloroethanes ( $\mu \mathrm{g} / \mathrm{L})$} \\
\hline 1,1,1-Trichloroethane & $<$ & $<$ & $<$ & $<$ \\
\hline 1,1,2-Trichloroethane & $<$ & $<$ & $<$ & $<$ \\
\hline 1,2-Dichloroethane & $<$ & $<$ & $<$ & $<$ \\
\hline 1,1-Dichloroethane & $<$ & $<$ & $<$ & $<$ \\
\hline Chloroethane & $<$ & $<$ & $<$ & $<$ \\
\hline \multicolumn{5}{|l|}{ Chloromethanes ( $\mu \mathrm{g} / \mathrm{L})$} \\
\hline Carbon tetrachloride & $<$ & $<$ & $<$ & $<$ \\
\hline Chloroform & $<$ & $<$ & $<$ & $<$ \\
\hline Methylene chloride & $<$ & $<$ & $<$ & $<$ \\
\hline \multicolumn{5}{|l|}{ Petrol. Hydrocarb. ( $\mu \mathrm{g} / \mathrm{L})$} \\
\hline Benzene & $<$ & $<$ & $<$ & $<$ \\
\hline Ethylbenzene & $<$ & $<$ & $<$ & $<$ \\
\hline Toluene & $<$ & $<$ & $<$ & $<$ \\
\hline Total Xylene & $<$ & $<$ & $<$ & $<$ \\
\hline \multicolumn{5}{|l|}{ Chlorofluorocarbons ( $\mu \mathrm{g} / \mathrm{L})$} \\
\hline \multicolumn{5}{|l|}{$\begin{array}{r}\text { 1,1,2-Trichloro-1,2,2-trifluoroethane } \\
\text { Dichlorodifluoromethane }\end{array}$} \\
\hline \multicolumn{5}{|l|}{ Miscellaneous ( $\mu \mathrm{g} / \mathrm{L})$} \\
\hline 1,2-Dichloropropane & $<$ & $<$ & $<$ & $<$ \\
\hline 1,4-Dichlorobenzene & $<$ & $<$ & $<$ & $<$ \\
\hline 2-Butanone & $<$ & $<$ & $<$ & $<$ \\
\hline Acetone & $<$ & $<$ & $<$ & $<$ \\
\hline Carbon disulfide & $<$ & $<$ & $<$ & $<$ \\
\hline Chlorobenzene & $<$ & $<$ & $<$ & $<$ \\
\hline
\end{tabular}



APPENDIX D.3

RADIOLOGICAL ANALYTES 

APPENDIX D.3: CY 2009 MONITORING DATA FOR THE BEAR CREEK HYDROGEOLOGIC REGIME Radiological Analytes: Gross Alpha and Gross Beta Activity

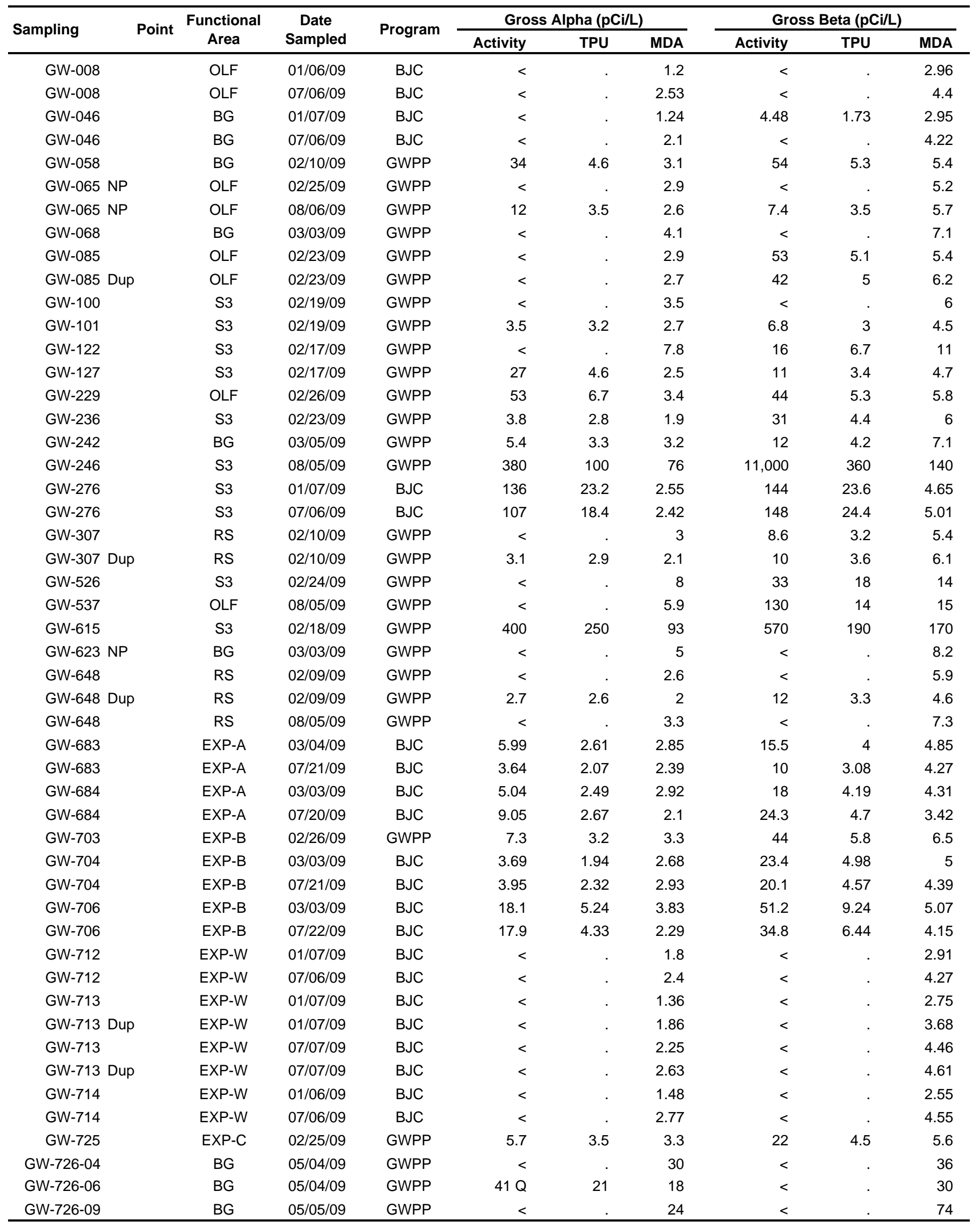


APPENDIX D.3: CY 2009 MONITORING DATA FOR THE BEAR CREEK HYDROGEOLOGIC REGIME Radiological Analytes: Gross Alpha and Gross Beta Activity

\begin{tabular}{|c|c|c|c|c|c|c|c|c|c|c|}
\hline \multirow{2}{*}{ Sampling } & \multirow{2}{*}{ Point } & \multirow{2}{*}{$\begin{array}{c}\text { Functional } \\
\text { Area }\end{array}$} & \multirow{2}{*}{$\begin{array}{c}\text { Date } \\
\text { Sampled }\end{array}$} & \multirow{2}{*}{ Program } & \multicolumn{3}{|c|}{ Gross Alpha (pCi/L) } & \multicolumn{3}{|c|}{ Gross Beta (pCi/L) } \\
\hline & & & & & Activity & TPU & MDA & Activity & TPU & MDA \\
\hline GW-726-16 & & BG & 05/06/09 & GWPP & $<$ & . & 9.5 & $<$ & . & 17 \\
\hline GW-726-20 & & BG & 05/06/09 & GWPP & $<$ & . & 7.8 & 30 & 8.4 & 13 \\
\hline GW-726-23 & & BG & 05/06/09 & GWPP & $<$ & . & 3.2 & $<$ & . & 7.5 \\
\hline BCK-04.55 & & EXP-SW & 08/03/09 & GWPP & 12 & 3.5 & 3.4 & 14 & 4.1 & 6.5 \\
\hline BCK-09.40 Dup & & EXP-SW & 08/03/09 & GWPP & 31 & 5 & 2.9 & 36 & 5.4 & 5.5 \\
\hline BCK-09.40 & & EXP-SW & 08/03/09 & GWPP & 36 & 5.1 & 2.9 & 22 & 5 & 6.9 \\
\hline BCK-11.97 & & EXP-SW & 08/03/09 & GWPP & 64 & 7.6 & 5.1 & 84 & 7.9 & 7.1 \\
\hline NT-01 & & EXP-SW & 08/03/09 & GWPP & 5.8 & 4.2 & 5.1 & 310 & 14 & 6.9 \\
\hline
\end{tabular}


APPENDIX D.3: CY 2009 MONITORING DATA FOR THE BEAR CREEK HYDROGEOLOGIC REGIME Radiological Analytes: Isotopic Analyses

\begin{tabular}{|c|c|c|c|c|c|c|c|c|c|c|c|c|}
\hline Sampling Point & \multicolumn{6}{|c|}{ GW-276 } & \multicolumn{3}{|c|}{ GW-526 } & \multicolumn{3}{|c|}{ GW-537 } \\
\hline Functional Area & \multicolumn{6}{|c|}{ S3 } & \multicolumn{3}{|c|}{ S3 } & \multicolumn{3}{|c|}{ OLF } \\
\hline Date Sampled & \multicolumn{3}{|c|}{$01 / 07 / 09$} & \multicolumn{3}{|c|}{$07 / 06 / 09$} & \multicolumn{3}{|c|}{$02 / 24 / 09$} & \multicolumn{3}{|c|}{$08 / 05 / 09$} \\
\hline Program & \multicolumn{3}{|c|}{ BJC } & \multicolumn{3}{|c|}{ BJC } & \multicolumn{3}{|c|}{ GWPP } & \multicolumn{3}{|c|}{ GWPP } \\
\hline \multicolumn{13}{|l|}{ Sample Type } \\
\hline Result (pCi/L) & Activity & TPU & MDA & Activity & TPU & MDA & Activity & TPU & MDA & Activity & TPU & MDA \\
\hline Gross Alpha & 136 & 23.2 & 2.55 & 107 & 18.4 & 2.42 & $<$ & & 8 & $<$ & 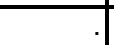 & 5.9 \\
\hline Gross Beta & 144 & 23.6 & 4.65 & 148 & 24.4 & 5.01 & 33 & 18 & 14 & 130 & 14 & 15 \\
\hline Americium-241 & $<$ & & 0.108 & $<$ & & 0.17 & & & & & & \\
\hline Neptunium-237 & 4.86 & 2.02 & 0.228 & 5.78 & 2.4 & 0.15 & & & & & & \\
\hline Total Radium Alpha & 0.216 & 0.141 & 0.186 & 0.303 & 0.164 & 0.181 & & & & & & \\
\hline Strontium-89/90 & $<$ & & 2.26 & $<$ & & 2.03 & 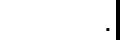 & & 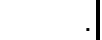 & & 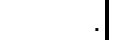 & \\
\hline Technetium-99 & 152 & 26.2 & 10.4 & 150 & 25.2 & 6.33 & $<$ & & 14 & 470 & 15 & 14 \\
\hline Uranium-234 & 58.7 & 9.84 & 0.186 & 54.6 & 9.7 & 0.561 & & & & & & \\
\hline Uranium-235 & 6.55 & 1.41 & 0.158 & 6.94 & 1.79 & 0.561 & & & & & & \\
\hline Uranium-238 & 126 & 20.6 & 0.158 & 122 & 20.7 & 0.584 & & & & & & \\
\hline
\end{tabular}

\begin{tabular}{|c|c|c|c|c|c|c|c|c|c|c|c|c|}
\hline Sampling Point & \multicolumn{6}{|c|}{ GW-683 } & \multicolumn{6}{|c|}{ GW-684 } \\
\hline Functional Area & \multicolumn{6}{|c|}{ EXP-A } & \multicolumn{6}{|c|}{ EXP-A } \\
\hline Date Sampled & \multicolumn{3}{|c|}{$03 / 04 / 09$} & \multicolumn{3}{|c|}{$07 / 21 / 09$} & \multicolumn{3}{|c|}{$03 / 03 / 09$} & \multicolumn{3}{|c|}{$07 / 20 / 09$} \\
\hline Program & \multicolumn{3}{|c|}{ BJC } & \multicolumn{3}{|c|}{ BJC } & \multicolumn{3}{|c|}{$\mathrm{BJC}$} & \multicolumn{3}{|c|}{ BJC } \\
\hline \multicolumn{13}{|l|}{ Sample Type } \\
\hline Result (pCi/L) & Activity & TPU & MDA & Activity & TPU & MDA & Activity & TPU & MDA & Activity & TPU & MDA \\
\hline Gross Alpha & 5.99 & 2.61 & 2.85 & 3.64 & 2.07 & 2.39 & 5.04 & 2.49 & 2.92 & 9.05 & 2.67 & 2.1 \\
\hline Gross Beta & 15.5 & 4 & 4.85 & 10.1 & 3.08 & 4.27 & 17.6 & 4.19 & 4.31 & 24.3 & 4.7 & 3.42 \\
\hline Americium-241 & & & & & & & & & & & & \\
\hline Neptunium-237 & & & & & & & & & & & & \\
\hline Total Radium Alpha & & & & & & & & & & & & \\
\hline Strontium-89/90 & & & & & & & & & & & & \\
\hline Technetium-99 & 21.1 & 7.94 & 11.1 & 7.82 & 4.34 & 6.52 & 21.1 & 7.53 & 10.3 & 11.9 & 4.45 & 6 \\
\hline Uranium-234 & 4.7 & 1.35 & 0.438 & 2.93 & 0.992 & 0.497 & 5.87 & 1.6 & 0.458 & 4.06 & 1.21 & 0.444 \\
\hline Uranium-235 & $<$ & & 0.438 & $0.188 \mathrm{R}$ & 0.223 & 0.17 & $<$ & & 0.422 & 0.528 & 0.386 & 0.382 \\
\hline Uranium-238 & 7.28 & 1.82 & 0.404 & 6.15 & 1.6 & 0.447 & 7.47 & 1.89 & 0.422 & 7.08 & 1.76 & 0.382 \\
\hline
\end{tabular}

\begin{tabular}{|c|c|c|c|c|c|c|c|c|c|c|c|c|}
\hline Sampling Point & \multicolumn{6}{|c|}{ GW-704 } & \multicolumn{6}{|c|}{ GW-706 } \\
\hline Functional Area & \multicolumn{6}{|c|}{ EXP-B } & \multicolumn{6}{|c|}{ EXP-B } \\
\hline Date Sampled & \multicolumn{3}{|c|}{$03 / 03 / 09$} & \multicolumn{3}{|c|}{$07 / 21 / 09$} & \multicolumn{3}{|c|}{$03 / 03 / 09$} & \multicolumn{3}{|c|}{$07 / 22 / 09$} \\
\hline Program & \multicolumn{3}{|c|}{ BJC } & \multicolumn{3}{|c|}{ BJC } & \multicolumn{3}{|c|}{ BJC } & \multicolumn{3}{|c|}{ BJC } \\
\hline \multicolumn{13}{|l|}{ Sample Type } \\
\hline Result (pCi/L) & Activity & TPU & MDA & Activity & TPU & MDA & Activity & TPU & MDA & Activity & TPU & MDA \\
\hline Gross Alpha & 3.69 & 1.94 & 2.68 & 3.95 & 2.32 & 2.93 & 18.1 & 5.24 & 3.83 & $\begin{array}{l}17.9 \\
\end{array}$ & 4.33 & 2.29 \\
\hline Gross Beta & 23.4 & 4.98 & 5 & 20.1 & 4.57 & 4.39 & 51.2 & 9.24 & 5.07 & 34.8 & 6.44 & 4.15 \\
\hline Americium-241 & & & & & & & & & & & & \\
\hline Neptunium-237 & & & & & & & & & & & & \\
\hline Total Radium Alpha & & & & & & & & & & & & \\
\hline Strontium-89/90 & & & & & & & & & & & & \\
\hline Technetium-99 & 38 & 9.31 & 10.1 & 7.91 & 4.33 & 6.47 & 76 & 15.2 & 12 & 37.4 & 7.88 & 6.29 \\
\hline Uranium-234 & 3.31 & 1.06 & 0.471 & 1.77 & 0.717 & 0.367 & 11.9 & 2.6 & 0.453 & 12 & 2.58 & 0.43 \\
\hline Uranium-235 & $<$ & & 0.344 & $<$ & & 0.367 & 0.994 & 0.534 & 0.35 & 0.659 & 0.435 & 0.455 \\
\hline Uranium-238 & 4.1 & 1.21 & 0.344 & 2.81 & 0.939 & 0.281 & 24.2 & 4.64 & 0.35 & 19.4 & 3.8 & 0.37 \\
\hline
\end{tabular}


APPENDIX D.3: CY 2009 MONITORING DATA FOR THE BEAR CREEK HYDROGEOLOGIC REGIME

Radiological Analytes: Isotopic Analyses

\begin{tabular}{|c|c|c|c|c|c|c|c|c|c|c|c|c|}
\hline Sampling Point & \multicolumn{6}{|c|}{ GW-712 } & \multicolumn{6}{|c|}{ GW-713 } \\
\hline Functional Area & \multicolumn{6}{|c|}{ EXP-W } & \multicolumn{6}{|c|}{ EXP-W } \\
\hline Date Sampled & \multicolumn{3}{|c|}{$01 / 07 / 09$} & \multicolumn{3}{|c|}{$07 / 06 / 09$} & \multicolumn{6}{|c|}{$01 / 07 / 09$} \\
\hline Program & \multicolumn{3}{|c|}{ BJC } & \multicolumn{3}{|c|}{ BJC } & \multicolumn{6}{|c|}{ BJC } \\
\hline Sample Type & & & & & & & & & & & Dup & \\
\hline Result (pCi/L) & Activity & TPU & MDA & Activity & TPU & MDA & Activity & TPU & MDA & Activity & TPU & MDA \\
\hline Gross Alpha & $<$ & & 1.8 & $<$ & & 2.4 & $<$ & & 1.36 & $<$ & & 1.86 \\
\hline Gross Beta & $<$ & & 2.91 & $<$ & & 4.27 & $<$ & & 2.75 & $<$ & & 3.68 \\
\hline Americium-241 & & & & & & & & & & & & \\
\hline Neptunium-237 & & & & & & & . & & & & & \\
\hline Total Radium Alpha & & & & . & & & 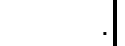 & & & o & & \\
\hline Strontium-89/90 & & & & & & & & & & & & \\
\hline Technetium-99 & $<$ & & 10.9 & $<$ & & 8.21 & $<$ & & 10.6 & $<$ & & 10.9 \\
\hline Uranium-234 & 0.373 & 0.331 & 0.364 & $<$ & & 0.372 & $<$ & & 0.325 & $<$ & & 0.214 \\
\hline Uranium-235 & $<$ & & 0.364 & $<$ & & 0.334 & $<$ & & 0.276 & $<$ & & 0.369 \\
\hline Uranium-238 & $<$ & & 0.31 & $<$ & & 0.284 & $<$ & & 0.276 & $<$ & & 0.369 \\
\hline
\end{tabular}

\begin{tabular}{|c|c|c|c|c|c|c|c|c|c|c|c|c|}
\hline Sampling Point & \multicolumn{6}{|c|}{ GW-713 } & \multicolumn{6}{|c|}{ GW-714 } \\
\hline Functional Area & \multicolumn{6}{|c|}{ EXP-W } & \multicolumn{6}{|c|}{ EXP-W } \\
\hline Date Sampled & \multicolumn{6}{|c|}{$07 / 07 / 09$} & \multicolumn{3}{|c|}{$01 / 06 / 09$} & \multicolumn{3}{|c|}{$07 / 06 / 09$} \\
\hline Program & \multicolumn{6}{|c|}{ BJC } & \multicolumn{3}{|c|}{$\mathrm{BJC}$} & \multicolumn{3}{|c|}{$\mathrm{BJC}$} \\
\hline Sample Type & \multicolumn{6}{|c|}{ Dup } & & & & & & \\
\hline Result (pCi/L) & Activity & TPU & MDA & Activity & TPU & MDA & Activity & TPU & MDA & Activity & TPU & MDA \\
\hline Gross Alpha & $<$ & & 2.25 & $<$ & & 2.63 & $<$ & & 1.48 & $<$ & & 2.77 \\
\hline Gross Beta & $<$ & & 4.46 & $<$ & & 4.61 & $<$ & & 2.55 & $<$ & & 4.55 \\
\hline Americium-241 & & & & $\cdot$ & & & & & & & & \\
\hline Neptunium-237 & & & & & & & & & & & & \\
\hline Total Radium Alpha & & & & . & & & & & & & & \\
\hline Strontium-89/90 & & & & . & & & 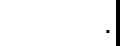 & & & . & & \\
\hline Technetium-99 & $<$ & & 6.55 & $<$ & & 7.02 & $<$ & & 10.9 & $<$ & & 6.26 \\
\hline Uranium-234 & $<$ & & 0.565 & $<$ & & 0.335 & 0.841 & 0.325 & 0.159 & 1.1 & 0.593 & 0.549 \\
\hline Uranium-235 & $<$ & & 0.36 & $<$ & & 0.335 & $<$ & & 0.159 & $<$ & & 0.499 \\
\hline Uranium-238 & $<$ & & 0.401 & $<$ & & 0.483 & 0.355 & 0.205 & 0.179 & 0.747 & 0.477 & 0.441 \\
\hline
\end{tabular}

\begin{tabular}{|c|c|c|c|c|c|c|c|c|c|c|c|c|}
\hline Sampling Point & \multicolumn{3}{|c|}{ BCK-03.30 } & \multicolumn{3}{|c|}{ BCK-04.55 } & \multicolumn{3}{|c|}{ BCK-07.87 } & \multicolumn{3}{|c|}{ BCK-09.20 } \\
\hline Functional Area & \multicolumn{3}{|c|}{ EXP-SW } & \multicolumn{3}{|c|}{ EXP-SW } & \multicolumn{3}{|c|}{ EXP-SW } & \multicolumn{3}{|c|}{ EXP-SW } \\
\hline Date Sampled & \multicolumn{3}{|c|}{$12 / 07 / 09$} & \multicolumn{3}{|c|}{$12 / 07 / 09$} & \multicolumn{3}{|c|}{$12 / 07 / 09$} & \multicolumn{3}{|c|}{$12 / 07 / 09$} \\
\hline Program & \multicolumn{3}{|c|}{$\mathrm{BJC}$} & \multicolumn{3}{|c|}{ BJC } & \multicolumn{3}{|c|}{$\mathrm{BJC}$} & \multicolumn{3}{|c|}{$\mathrm{BJC}$} \\
\hline \multicolumn{13}{|l|}{ Sample Type } \\
\hline Result (pCi/L) & Activity & TPU & MDA & Activity & TPU & MDA & Activity & TPU & MDA & Activity & TPU & MDA \\
\hline $\begin{array}{r}\text { Gross Alpha } \\
\text { Gross Beta } \\
\text { Americium-241 } \\
\text { Neptunium-237 } \\
\text { Total Radium Alpha } \\
\text { Strontium-89/90 }\end{array}$ & & & & & & & & & & & & \\
\hline Technetium-99 & 12.6 & 6.52 & 9.8 & 9.44 & 6.06 & 9.41 & 27.5 & 8.24 & 10.4 & 19.5 & 7.2 & 9.95 \\
\hline Uranium-234 & 1.82 & 0.778 & 0.511 & 2.21 & 0.874 & 0.333 & 5.72 & 1.58 & 0.599 & & & \\
\hline Uranium-235 & $<$ & & 0.5 & $<$ & & 0.333 & $<$ & & 0.523 & & & \\
\hline Uranium-238 & 3.85 & 1.2 & 0.317 & 4.42 & 1.34 & 0.401 & 12.1 & 2.69 & 0.325 & & & \\
\hline
\end{tabular}


APPENDIX D.3: CY 2009 MONITORING DATA FOR THE BEAR CREEK HYDROGEOLOGIC REGIME

Radiological Analytes: Isotopic Analyses

\begin{tabular}{|c|c|c|c|c|c|c|c|c|c|c|c|c|}
\hline Sampling Point & \multicolumn{3}{|c|}{ BCK-11.54 } & \multicolumn{3}{|c|}{ BCK-11.84 } & \multicolumn{3}{|c|}{ BCK-12.34 } & \multicolumn{3}{|c|}{ NT-01 } \\
\hline Functional Area & \multicolumn{3}{|c|}{ EXP-SW } & \multicolumn{3}{|c|}{ EXP-SW } & \multicolumn{3}{|c|}{ EXP-SW } & \multicolumn{3}{|c|}{ EXP-SW } \\
\hline Date Sampled & \multicolumn{3}{|c|}{$12 / 07 / 09$} & \multicolumn{3}{|c|}{$12 / 07 / 09$} & \multicolumn{3}{|c|}{$12 / 07 / 09$} & \multicolumn{3}{|c|}{$12 / 07 / 09$} \\
\hline Program & \multicolumn{3}{|c|}{ BJC } & \multicolumn{3}{|c|}{ BJC } & \multicolumn{3}{|c|}{$\mathrm{BJC}$} & \multicolumn{3}{|c|}{$\mathrm{BJC}$} \\
\hline \multicolumn{13}{|l|}{ Sample Type } \\
\hline Result (pCi/L) & Activity & TPU & MDA & Activity & TPU & MDA & Activity & TPU & MDA & Activity & TPU & MDA \\
\hline \multirow{2}{*}{\multicolumn{13}{|c|}{$\begin{array}{r}\text { Gross Alpha } \\
\text { Gross Beta }\end{array}$}} \\
\hline & & & & & & & & & & & & \\
\hline & \multicolumn{12}{|c|}{ Americium-241 } \\
\hline \multicolumn{13}{|l|}{ Neptunium-237 } \\
\hline \multirow{2}{*}{\multicolumn{13}{|c|}{ Total Radium Alpha }} \\
\hline & & & & & & & & & & & & \\
\hline Technetium-99 & 58.7 & 12.1 & 10.1 & 99.7 & 18.2 & 10.4 & 159 & 27 & 9.68 & 313 & 51.4 & 10.4 \\
\hline Uranium-234 & & & & 13.3 & 2.86 & 0.41 & & & & 3.71 & 1.19 & 0.624 \\
\hline Uranium-235 & & & & 1.54 & 0.685 & 0.341 & & & & $<$ & & 0.481 \\
\hline Uranium-238 & & & & 23.8 & 4.6 & 0.41 & & & & 2.79 & 0.987 & 0.449 \\
\hline
\end{tabular}

\begin{tabular}{|c|c|c|c|c|c|c|c|c|c|c|c|c|}
\hline Sampling Point & \multicolumn{3}{|c|}{ NT-03 } & \multicolumn{6}{|c|}{ NT-07 } & \multicolumn{3}{|c|}{ NT-08 } \\
\hline Functional Area & \multicolumn{3}{|c|}{ EXP-SW } & \multicolumn{6}{|c|}{ EXP-SW } & \multicolumn{3}{|c|}{ EXP-SW } \\
\hline Date Sampled & \multicolumn{3}{|c|}{$12 / 07 / 09$} & \multicolumn{3}{|c|}{$02 / 10 / 09$} & \multicolumn{3}{|c|}{$08 / 04 / 09$} & \multicolumn{3}{|c|}{$12 / 07 / 09$} \\
\hline Program & \multicolumn{3}{|c|}{ BJC } & \multicolumn{3}{|c|}{$\mathrm{BJC}$} & \multicolumn{3}{|c|}{$\mathrm{BJC}$} & \multicolumn{3}{|c|}{ BJC } \\
\hline \multicolumn{13}{|l|}{ Sample Type } \\
\hline Result (pCi/L) & Activity & TPU & MDA & Activity & TPU & MDA & Activity & TPU & MDA & Activity & TPU & MDA \\
\hline $\begin{array}{r}\text { Gross Alpha } \\
\text { Gross Beta } \\
\text { Americium-241 } \\
\text { Neptunium-237 } \\
\text { Total Radium Alpha } \\
\text { Strontium-89/90 } \\
\text { Technetium-99 } \\
\text { Uranium-234 } \\
\text { Uranium-235 } \\
\text { Uranium-238 }\end{array}$ & $<$ & & 10.1 & $\begin{array}{r}6.77 \\
0.886 \\
9.42\end{array}$ & $\begin{array}{r}1.74 \\
0.522 \\
2.21\end{array}$ & $\begin{array}{l}0.409 \\
0.444 \\
0.475\end{array}$ & $\begin{array}{l}7.64 \\
1.17 \\
12.5\end{array}$ & $\begin{array}{r}1.97 \\
0.625 \\
2.82 \\
\end{array}$ & $\begin{array}{r}0.56 \\
0.348 \\
0.494\end{array}$ & $<$ & & 9.88 \\
\hline
\end{tabular}

\begin{tabular}{|c|c|c|c|c|c|c|c|c|c|c|c|c|}
\hline Sampling Point & \multicolumn{3}{|c|}{ NT-08 } & \multicolumn{3}{|c|}{ S07 } & \multicolumn{3}{|c|}{ SS-5 } & \multicolumn{3}{|c|}{ SS-6 } \\
\hline Functional Area & \multicolumn{3}{|c|}{ EXP-SW } & \multicolumn{3}{|c|}{ EXP-SW } & \multicolumn{3}{|c|}{ EXP-SW } & \multicolumn{3}{|c|}{ EXP-SW } \\
\hline Date Sampled & \multicolumn{3}{|c|}{$12 / 07 / 09$} & \multicolumn{3}{|c|}{$12 / 07 / 09$} & \multicolumn{3}{|c|}{$12 / 07 / 09$} & \multicolumn{3}{|c|}{$01 / 05 / 09$} \\
\hline Program & \multicolumn{3}{|c|}{ BJC } & \multicolumn{3}{|c|}{ BJC } & \multicolumn{3}{|c|}{ BJC } & \multicolumn{3}{|c|}{ BJC } \\
\hline Sample Type & \multicolumn{3}{|c|}{ Dup } & & & & & & & & & \\
\hline Result (pCi/L) & Activity & TPU & MDA & Activity & TPU & MDA & Activity & TPU & MDA & Activity & TPU & MDA \\
\hline Gross Alpha & & & & & & & & & & 2.67 & 1.2 & 1.49 \\
\hline Gross Beta & & & & & & & & & & 4.2 & 1.66 & 2.85 \\
\hline Americium-241 & & & & & & & & & & & & \\
\hline Neptunium-237 & & & & & & & & & & & & \\
\hline Total Radium Alpha & & & & & & & & & & & & \\
\hline Strontium-89/90 & & & & & & & & & & & & \\
\hline Technetium-99 & $<$ & & 10.1 & & & & $<$ & & 11.1 & $<$ & & 11.1 \\
\hline Uranium-234 & & & & $<$ & & 0.479 & & & & 2.23 & 0.917 & 0.216 \\
\hline Uranium-235 & & & & $<$ & & 0.412 & & & & $<$ & & 0.566 \\
\hline Uranium-238 & & & & $<$ & & 0.315 & & & & 2.42 & 0.972 & 0.502 \\
\hline
\end{tabular}


APPENDIX D.3: CY 2009 MONITORING DATA FOR THE BEAR CREEK HYDROGEOLOGIC REGIME

Radiological Analytes: Isotopic Analyses

\begin{tabular}{|c|c|c|c|c|c|c|c|c|c|c|c|c|}
\hline Sampling Point & \multicolumn{3}{|c|}{ SS-6 } & \multicolumn{3}{|c|}{ SS-6.6 } & \multicolumn{3}{|c|}{ SS-7 } & \multicolumn{3}{|c|}{ SS-8 } \\
\hline Functional Area & \multicolumn{3}{|c|}{ EXP-SW } & \multicolumn{3}{|c|}{ EXP-SW } & \multicolumn{3}{|c|}{ EXP-SW } & \multicolumn{3}{|c|}{ EXP-SW } \\
\hline Date Sampled & \multicolumn{3}{|c|}{$07 / 06 / 09$} & \multicolumn{3}{|c|}{$12 / 07 / 09$} & \multicolumn{3}{|c|}{$12 / 07 / 09$} & \multicolumn{3}{|c|}{$12 / 07 / 09$} \\
\hline Program & \multicolumn{3}{|c|}{ BJC } & \multicolumn{3}{|c|}{ BJC } & \multicolumn{3}{|c|}{ BJC } & \multicolumn{3}{|c|}{$\mathrm{BJC}$} \\
\hline \multicolumn{13}{|l|}{ Sample Type } \\
\hline Result (pCi/L) & Activity & TPU & MDA & Activity & TPU & MDA & Activity & TPU & MDA & Activity & TPU & MDA \\
\hline Gross Alpha & 3.19 & 1.19 & 1.33 & & & & & & & & & \\
\hline Gross Beta & 3.64 & 1.49 & 2.62 & & & & & & & & & \\
\hline Americium-241 & & & & & & & & & & & & \\
\hline Neptunium-237 & & & & & & & & & & & & \\
\hline Total Radium Alpha & & & & & & & & & & & & \\
\hline Strontium-89/90 & & & & & & & & & & & & \\
\hline Technetium-99 & $<$ & & 6.25 & $<$ & & 9.72 & $<$ & & 10.6 & $<$ & & 9.9 \\
\hline Uranium-234 & 1.53 & 0.683 & 0.356 & 0.54 & 0.404 & 0.434 & 0.724 & 0.476 & 0.424 & 0.55 & 0.377 & 0.166 \\
\hline Uranium-235 & $<$ & & 0.303 & $<$ & & 0.358 & $<$ & & 0.381 & $<$ & & 0.166 \\
\hline Uranium-238 & 2 & 0.792 & 0.304 & 0.475 & 0.38 & 0.434 & $<$ & & 0.424 & $<$ & & 0.166 \\
\hline
\end{tabular}

\begin{tabular}{|r|r|r|r|}
\hline Sampling Point & \multicolumn{3}{|c|}{ SS-8 } \\
\hline Functional Area & \multicolumn{2}{|c|}{ EXP-SW } \\
\hline Date Sampled & \multicolumn{2}{|c|}{ 12/07/09 } \\
\hline Program & \multicolumn{3}{|c|}{ BJC } \\
\hline Sample Type & \multicolumn{3}{|c|}{ Dup } \\
\hline Result (pCi/L) & Activity & \multicolumn{1}{|c|}{ TPU } & MDA \\
\hline Gross Alpha &. &. &. \\
Gross Beta &. & &. \\
Americium-241 &. & &. \\
Neptunium-237 &. &. &. \\
Total Radium Alpha &. &. &. \\
Strontium-89/90 &. &. &. \\
Technetium-99 & 10.9 & 6.52 & 10 \\
Uranium-234 & $<$ &. & 0.375 \\
Uranium-235 & $<$ &. & 0.319 \\
Uranium-238 & $<$ &. & 0.375 \\
\hline
\end{tabular}


APPENDIX D.4

MONITORING DATA FOR THE EMWMF 

APPENDIX D.4: CY 2009 MONITORING DATA FOR THE BEAR CREEK HYDROGEOLOGIC REGIME Monitoring Data for the EMWMF: Field Measurements, Major Cations, Trace Metals, and Organics

\begin{tabular}{|c|c|c|c|c|c|c|c|c|c|c|}
\hline Sampling Point & \multicolumn{4}{|c|}{ GW-363 } & \multicolumn{4}{|c|}{ GW-639 } & \multicolumn{2}{|c|}{ GW-916 } \\
\hline Date Sampled & $2 / 18 / 09^{*}$ & $4 / 23 / 09^{*}$ & $8 / 20 / 09^{*}$ & 11/19/09* & $2 / 18 / 09^{*}$ & $4 / 23 / 09^{*}$ & $8 / 19 / 09 *$ & $11 / 18 / 09^{*}$ & 02/12/09 & 04/15/09 \\
\hline Program & BJC & BJC & BJC & BJC & BJC & BJC & BJC & $\mathrm{BJC}$ & BJC & BJC \\
\hline \multicolumn{11}{|l|}{ Sample Type } \\
\hline Field Measurements & & & & & & & & & & \\
\hline Time Sampled & $15: 00$ & $10: 25$ & $9: 30$ & $10: 00$ & $11: 10$ & 9:15 & $8: 30$ & $14: 00$ & $10: 30$ & $14: 30$ \\
\hline Measuring Point Elev. (ft) & 957.91 & 957.91 & 957.91 & 957.91 & 940.95 & 940.95 & 940.95 & 940.95 & $1,002.85$ & $1,002.85$ \\
\hline Depth to Water (ft) & 4.82 & 4.25 & 4.46 & 4.35 & 10.56 & 9.50 & 10.59 & 10.05 & 4.45 & 4.54 \\
\hline Groundwater Elevation (ft) & 953.09 & 953.66 & 953.45 & 953.56 & 930.39 & 931.45 & 930.36 & 930.90 & 998.40 & 998.31 \\
\hline Conductivity $(\mu \mathrm{mho} / \mathrm{cm})$ & 764 & 507 & 520 & 520 & 1,456 & 980 & 1,043 & 1,074 & 319 & 352 \\
\hline Dissolved Oxygen (ppm) & 3.82 & 2.18 & 0.92 & 3.16 & 1.98 & 0.59 & 2.3 & 2.27 & 11.66 & 2.89 \\
\hline Oxidation/Reduction (mV) & 133 & 111 & 136 & 79 & 153 & 143 & 120 & 140 & 11 & 67 \\
\hline Temperature (degrees C) & 16.2 & 17 & 19.4 & 16 & 14.5 & 15.2 & 18.9 & 15.7 & 13.89 & 13.3 \\
\hline Turbidity (NTU) & 5 & 4 & 1 & 5 & 5 & 8 & 1 & 2 & 9 & 3 \\
\hline $\mathrm{pH}$ & 8.67 & 8.69 & 9.06 & 9.2 & 8.9 & 8.91 & 9.19 & 9.22 & 7.26 & 6.75 \\
\hline \multicolumn{11}{|l|}{ Major Cations (mg/L) } \\
\hline Calcium & 1.18 & 1.15 & 1.15 & 1.21 & 0.862 & 0.892 & 0.958 & 0.876 & 40 & 39.5 \\
\hline Magnesium & 0.473 & 0.469 & 0.451 & 0.486 & 0.262 & 0.272 & 0.259 & 0.27 & 6.24 & 6.23 \\
\hline Potassium & 1.24 & 1.31 & 1.04 & 1.22 & 1.66 & 1.79 & 1.55 & 1.56 & 3.25 & 3.28 \\
\hline Sodium & 116 & 111 & 110 & 101 & 219 & 223 & 206 & 197 & 26.8 & 25.7 \\
\hline \multicolumn{11}{|l|}{ Trace Metals (mg/L) } \\
\hline Aluminum & $<$ & $<$ & $<$ & $<$ & $<$ & $<$ & $<$ & $<$ & 0.204 & 0.497 \\
\hline Arsenic & $<$ & $<$ & $<$ & $<$ & $<$ & $<$ & $<$ & $<$ & $<$ & $<$ \\
\hline Barium & 0.0459 & 0.0453 & 0.0452 & 0.0465 & 0.062 & 0.0628 & 0.06 & 0.062 & 0.129 & 0.133 \\
\hline Beryllium & & $<$ & $<$ & $<$ & $<$ & $<$ & $<$ & $<$ & $<$ & $<$ \\
\hline Boron & 0.314 & 0.314 & 0.315 & 0.285 & 0.592 & 0.59 & 0.588 & 0.578 & $<$ & $<$ \\
\hline Chromium & $<$ & $<$ & $<$ & $<$ & $<$ & $<$ & $<$ & $<$ & $<$ & $<$ \\
\hline Copper & $<$ & $<$ & $<$ & $<$ & $<$ & $<$ & $<$ & $<$ & $<$ & $<$ \\
\hline Iron & 0.0574 & $<$ & 0.175 & 0.236 & $<$ & 0.0792 & 0.0565 & 0.0561 & 0.49 & 0.594 \\
\hline Lead & & $<$ & & $<$ & $<$ & $<$ & $<$ & $<$ & $<$ & $<$ \\
\hline Lithium & 0.04 & 0.0484 & 0.0358 & 0.0387 & 0.0872 & 0.092 & 0.0812 & 0.0857 & 0.0561 & 0.058 \\
\hline Manganese & $<$ & $<$ & $<$ & $<$ & $<$ & $<$ & $<$ & $<$ & 0.154 & 0.139 \\
\hline Mercury & $<$ & $<$ & $<$ & $<$ & $<$ & $<$ & $<$ & $<$ & $<$ & $<$ \\
\hline Nickel & $<$ & $<$ & $<$ & $<$ & $<$ & $<$ & $<$ & $<$ & $<$ & $<$ \\
\hline Strontium & 0.0683 & 0.0664 & 0.0652 & 0.068 & 0.0916 & 0.0924 & 0.0898 & 0.0932 & 1.09 & 1.08 \\
\hline Thallium & $<$ & $<$ & $<$ & $<$ & $<$ & $<$ & $0.00108 \mathrm{~J}$ & $<$ & $<$ & $<$ \\
\hline Uranium & $<$ & $<$ & $<$ & $<$ & $<$ & $<$ & $<$ & $<$ & $<$ & $<$ \\
\hline Vanadium & $<$ & $<$ & $<$ & $<$ & $<$ & $<$ & $<$ & $<$ & $<$ & $<$ \\
\hline Zinc & $<$ & $<$ & $<$ & $<$ & $<$ & $<$ & $<$ & $<$ & $<$ & $<$ \\
\hline \begin{tabular}{|} 
Chloroethenes $(\mu \mathbf{g} / \mathbf{L})$ \\
cis-1,2-Dichloroethene
\end{tabular} & $<$ & $<$ & $<$ & $<$ & $<$ & $<$ & $<$ & $<$ & $<$ & $<$ \\
\hline
\end{tabular}


APPENDIX D.4: CY 2009 MONITORING DATA FOR THE BEAR CREEK HYDROGEOLOGIC REGIME Monitoring Data for the EMWMF: Field Measurements, Major Cations, Trace Metals, and Organics

\begin{tabular}{|c|c|c|c|c|c|c|c|c|c|c|}
\hline Sampling Point & \multicolumn{2}{|c|}{ GW-916 } & \multicolumn{4}{|c|}{ GW-917 } & \multicolumn{4}{|c|}{ GW-918 } \\
\hline Date Sampled & $08 / 11 / 09$ & $11 / 11 / 09$ & $02 / 09 / 09$ & $04 / 14 / 09$ & 08/12/09 & $11 / 09 / 09$ & $02 / 10 / 09$ & $04 / 15 / 09$ & $08 / 12 / 09$ & $11 / 12 / 09$ \\
\hline Program & BJC & BJC & BJC & BJC & BJC & BJC & BJC & BJC & BJC & BJC \\
\hline \multicolumn{11}{|l|}{ Sample Type } \\
\hline \multicolumn{11}{|l|}{ Field Measurements } \\
\hline Time Sampled & $10: 55$ & $14: 55$ & $15: 00$ & $10: 30$ & $14: 00$ & $10: 50$ & $10: 30$ & $13: 50$ & $9: 30$ & $10: 00$ \\
\hline Measuring Point Elev. (ft) & $1,002.85$ & $1,002.85$ & 997.10 & 997.10 & 997.10 & 997.10 & $1,067.96$ & $1,067.96$ & $1,067.96$ & $1,067.96$ \\
\hline Depth to Water (ft) & 5.65 & 3.89 & 22.00 & 19.31 & 20.16 & 19.10 & 9.00 & 5.60 & 5.74 & 5.55 \\
\hline Groundwater Elevation (ft) & 997.20 & 998.96 & 975.10 & 977.79 & 976.94 & 978.00 & $1,058.96$ & $1,062.36$ & $1,062.22$ & $1,062.41$ \\
\hline Conductivity $(\mu \mathrm{mho} / \mathrm{cm})$ & 315 & 469 & 740 & 387 & 395 & 533 & 96 & 105 & 106 & 128 \\
\hline Dissolved Oxygen (ppm) & 1.88 & 2.25 & 1.38 & 0.89 & 0.36 & 1.21 & 12.23 & 5.38 & 9.83 & 5.4 \\
\hline Oxidation/Reduction (mV) & -105 & 92 & 7 & 118 & -24 & -62 & 152 & 97 & 114 & 35 \\
\hline Temperature (degrees C) & 15.9 & 15.8 & 18.1 & 15.9 & 16.8 & 16.2 & 15.3 & 14.6 & 16.1 & 15.49 \\
\hline Turbidity (NTU) & 3 & 1 & 2 & 5 & 1 & 2 & 17 & 5 & 29 & 31 \\
\hline $\mathrm{pH}$ & 7.47 & 7.43 & 6.91 & 6.54 & 7.09 & 7.32 & 5.56 & 6.44 & 6 & 5.18 \\
\hline \multicolumn{11}{|l|}{ Major Cations (mg/L) } \\
\hline Calcium & 41.6 & 40.3 & 62.6 & 57.6 & 63.4 & 67 & 10.4 & 10.4 & 10.2 & 11 \\
\hline Magnesium & 6.56 & 5.87 & 8.35 & 7.94 & 7.96 & 8.8 & 4.29 & 4.21 & 4.15 & 4.61 \\
\hline Potassium & 3.76 & 3.19 & 1.26 & 1.26 & 1.22 & 1.27 & 1.99 & 1.92 & 2.13 & 2.11 \\
\hline Sodium & 27.8 & 28 & 9.29 & 8.75 & 9.15 & 9.9 & 4.56 & 4.44 & 4.35 & 4.68 \\
\hline \multicolumn{11}{|l|}{ Trace Metals (mg/L) } \\
\hline Aluminum & 1.49 & 0.238 & $<$ & $<$ & 0.229 & 0.223 & 0.373 & 0.28 & 1.84 & 1.32 \\
\hline Arsenic & & & $<$ & $<$ & $<$ & $<$ & $<$ & $<$ & $<$ & $<$ \\
\hline Barium & 0.157 & 0.165 & 0.17 & 0.162 & 0.188 & 0.181 & 0.114 & 0.113 & 0.129 & 0.127 \\
\hline Beryllium & $<$ & $<$ & $<$ & $<$ & $<$ & $<$ & $<$ & $<$ & $<$ & $<$ \\
\hline Boron & $<$ & $<$ & $<$ & $<$ & $<$ & $<$ & $<$ & $<$ & $<$ & $<$ \\
\hline Chromium & $<$ & $<$ & $<$ & $<$ & $<$ & $<$ & $<$ & $<$ & $<$ & $<$ \\
\hline Copper & $<$ & $<$ & $<$ & $<$ & $<$ & $<$ & $<$ & $<$ & $<$ & $<$ \\
\hline Iron & 1.34 & 0.248 & 0.142 & 0.173 & 2.13 & 0.497 & 0.282 & 0.208 & 1.19 & 0.862 \\
\hline Lead & & & & $<$ & $<$ & $<$ & $<$ & $<$ & $<$ & 0.00282 \\
\hline Lithium & 0.0612 & 0.062 & 0.0165 & 0.0157 & 0.0162 & 0.018 & 0.0124 & 0.0121 & 0.0138 & 0.0139 \\
\hline Manganese & 0.203 & 0.0776 & 0.0285 & 0.0184 & 0.0506 & 0.0368 & 0.00532 & $<$ & 0.0222 & 0.0146 \\
\hline Mercury & $<$ & $<$ & $<$ & $<$ & $<$ & $<$ & $<$ & $<$ & $<$ & $<$ \\
\hline Nickel & $<$ & $<$ & $<$ & $<$ & $<$ & $<$ & $<$ & $<$ & $<$ & $<$ \\
\hline Strontium & 1.14 & 1.03 & 0.128 & 0.122 & 0.135 & 0.139 & 0.048 & 0.0471 & 0.0487 & 0.0493 \\
\hline Thallium & $<$ & $<$ & $<$ & $<$ & $<$ & $<$ & $<$ & $<$ & $<$ & $<$ \\
\hline Uranium & $<$ & $<$ & $<$ & $<$ & $<$ & $<$ & $<$ & $<$ & $<$ & $<$ \\
\hline Vanadium & $<$ & $<$ & $<$ & $<$ & $<$ & $<$ & $<$ & $<$ & $<$ & $<$ \\
\hline Zinc & $<$ & $<$ & $<$ & $<$ & $<$ & $<$ & 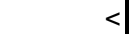 & $<$ & $<$ & $<$ \\
\hline \multirow{2}{*}{$\begin{array}{l}\text { Chloroethenes }(\mu \mathbf{g} / \mathbf{L}) \\
\text { cis-1,2-Dichloroethene }\end{array}$} & & & & & & & & & & \\
\hline & $<$ & $<$ & $<$ & $<$ & $<$ & $<$ & $<$ & $<$ & $<$ & $<$ \\
\hline
\end{tabular}


APPENDIX D.4: CY 2009 MONITORING DATA FOR THE BEAR CREEK HYDROGEOLOGIC REGIME Monitoring Data for the EMWMF: Field Measurements, Major Cations, Trace Metals, and Organics

\begin{tabular}{|c|c|c|c|c|c|c|c|c|c|c|}
\hline Sampling Point & \multicolumn{4}{|c|}{ GW-920 } & \multicolumn{4}{|c|}{ GW-921 } & \multicolumn{2}{|c|}{ GW-922 } \\
\hline Date Sampled & 02/10/09 & $04 / 16 / 09$ & 08/11/09 & $11 / 12 / 09$ & $02 / 11 / 09$ & $04 / 14 / 09$ & 08/13/09 & $11 / 10 / 09$ & 02/10/09 & $04 / 16 / 09$ \\
\hline Program & BJC & BJC & $\mathrm{BJC}$ & BJC & BJC & BJC & BJC & BJC & BJC & BJC \\
\hline \multicolumn{11}{|l|}{ Sample Type } \\
\hline Field Measurements & & & & & & & & & & \\
\hline Time Sampled & $14: 40$ & $10: 20$ & $10: 30$ & $15: 10$ & $14: 50$ & $14: 30$ & $14: 15$ & $14: 00$ & $10: 20$ & 10:00 \\
\hline Measuring Point Elev. (ft) & 967.43 & 967.43 & 967.43 & 967.43 & 971.29 & 971.29 & 971.29 & 971.29 & 956.91 & 956.91 \\
\hline Depth to Water (ft) & 6.65 & 6.08 & 7.47 & 6.42 & 6.21 & 5.28 & 6.12 & 6.23 & 5.40 & 4.97 \\
\hline Groundwater Elevation (ft) & 960.78 & 961.35 & 959.96 & 961.01 & 965.08 & 966.01 & 965.17 & 965.06 & 951.51 & 951.94 \\
\hline Conductivity $(\mu \mathrm{mho} / \mathrm{cm})$ & 609 & 346 & 375 & 426 & 755 & 728 & 417 & 572 & 605 & 298 \\
\hline Dissolved Oxygen (ppm) & 1.96 & 0.79 & 3.44 & 0.75 & 1.01 & 3.2 & 1.65 & 0.67 & 1.6 & 2.4 \\
\hline Oxidation/Reduction (mV) & 17 & 12 & 25 & 80 & 105 & 66 & 113 & 119 & 34 & -7 \\
\hline Temperature (degrees C) & 16 & 14.6 & 17 & 16 & 17 & 16.4 & 17.3 & 16.1 & 15.5 & 14.8 \\
\hline Turbidity (NTU) & 1 & 2 & 1 & 2 & 1 & 1 & 1 & 2 & 2 & 6 \\
\hline $\mathrm{pH}$ & 6.9 & 6.3 & 6.96 & 7.27 & 7.1 & 7.03 & 7.56 & 7.35 & 7.07 & 7.99 \\
\hline \multicolumn{11}{|l|}{ Major Cations (mg/L) } \\
\hline Calcium & 53.3 & 54.8 & 47.5 & 50 & 41.5 & 64.1 & 50.2 & 59.2 & 44.5 & 42.2 \\
\hline Magnesium & 8.28 & 8.28 & 7.45 & 7.92 & 11.6 & 15.1 & 12.1 & 13.6 & 9.73 & 9.12 \\
\hline Potassium & 1.62 & 1.47 & 1.52 & 1.51 & 2.66 & 2.9 & 2.68 & 2.73 & 2.81 & 2.72 \\
\hline Sodium & 5.68 & 5.2 & 5.33 & 5.75 & 24.7 & 20.8 & 22.3 & 20.4 & 8.86 & 8.39 \\
\hline \multicolumn{11}{|l|}{ Trace Metals (mg/L) } \\
\hline Aluminum & $<$ & $<$ & $<$ & $<$ & $<$ & $<$ & $<$ & $<$ & $<$ & 0.211 \\
\hline Arsenic & $<$ & $<$ & $<$ & $<$ & $<$ & $<$ & $<$ & $<$ & $<$ & 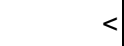 \\
\hline Barium & 0.244 & 0.225 & 0.234 & 0.251 & 0.252 & 0.232 & 0.223 & 0.253 & 0.684 & 0.686 \\
\hline Beryllium & $<$ & $<$ & $<$ & $<$ & $<$ & $<$ & $<$ & $<$ & $<$ & 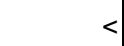 \\
\hline Boron & $<$ & $<$ & $<$ & $<$ & $<$ & $<$ & $<$ & $<$ & $<$ & $<$ \\
\hline Chromium & $<$ & $<$ & $<$ & $<$ & $<$ & $<$ & $<$ & $<$ & $<$ & $<$ \\
\hline Copper & $<$ & $<$ & $<$ & $<$ & $<$ & $<$ & $<$ & $<$ & $<$ & $<$ \\
\hline Iron & 0.233 & 0.165 & 0.138 & 0.229 & 0.0577 & $<$ & $<$ & $<$ & 0.119 & 0.455 \\
\hline Lead & $<$ & & $<$ & $<$ & $<$ & $<$ & $<$ & $<$ & $<$ & 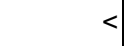 \\
\hline Lithium & 0.0112 & 0.0116 & $<$ & 0.011 & 0.0234 & 0.0204 & 0.0207 & 0.021 & 0.0133 & 0.0128 \\
\hline Manganese & 0.0348 & 0.0781 & 0.0266 & 0.0457 & 0.00808 & 0.00542 & 0.011 & 0.00866 & 0.0203 & 0.0338 \\
\hline Mercury & $<$ & $<$ & $<$ & $<$ & $<$ & $<$ & $<$ & $<$ & $<$ & 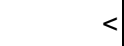 \\
\hline Nickel & $<$ & $<$ & $<$ & $<$ & $<$ & $<$ & $<$ & $<$ & $<$ & $<$ \\
\hline Strontium & 0.426 & 0.391 & 0.411 & 0.436 & 1.13 & 1.08 & 1.1 & 1.13 & 0.767 & 0.76 \\
\hline Thallium & $<$ & $<$ & $<$ & $<$ & $<$ & $<$ & $0.001 \mathrm{~J}$ & $<$ & $<$ & 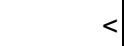 \\
\hline Uranium & $<$ & $<$ & $<$ & . & 0.00492 & $<$ & $<$ & $<$ & $<$ & 4 \\
\hline Vanadium & $<$ & $<$ & $<$ & $<$ & $<$ & $<$ & $<$ & $<$ & $<$ & $<$ \\
\hline Zinc & $<$ & $<$ & $<$ & $<$ & $<$ & $<$ & $<$ & $<$ & $<$ & $<$ \\
\hline $\begin{array}{l}\text { Chloroethenes }(\mu \mathbf{g} / \mathbf{L}) \\
\quad \text { cis-1,2-Dichloroethene }\end{array}$ & $<$ & $<$ & $<$ & $<$ & $<$ & $<$ & $<$ & $<$ & $<$ & $<$ \\
\hline
\end{tabular}


APPENDIX D.4: CY 2009 MONITORING DATA FOR THE BEAR CREEK HYDROGEOLOGIC REGIME Monitoring Data for the EMWMF: Field Measurements, Major Cations, Trace Metals, and Organics

\begin{tabular}{|c|c|c|c|c|c|c|c|c|}
\hline Sampling Point & \multicolumn{2}{|c|}{ GW-922 } & \multicolumn{4}{|c|}{ GW-923 } & \multirow{2}{*}{\multicolumn{2}{|c|}{$\begin{array}{c}\text { GW-924 } \\
02 / 11 / 09\end{array}$}} \\
\hline Date Sampled & 08/10/09 & $11 / 11 / 09$ & $2 / 18 / 09 *$ & $4 / 21 / 09 *$ & $8 / 12 / 09 *$ & $11 / 11 / 09^{*}$ & & \\
\hline Program & BJC & BJC & BJC & BJC & BJC & BJC & BJC & BJC \\
\hline Sample Type & & & & & & & & Dup \\
\hline Field Measurements & & & & & & & & \\
\hline Time Sampled & $11: 10$ & $14: 20$ & $9: 30$ & $13: 20$ & $9: 20$ & $9: 40$ & $9: 40$ & \\
\hline Measuring Point Elev. (ft) & 956.91 & 956.91 & $1,016.73$ & $1,016.73$ & $1,016.73$ & $1,016.73$ & 968.90 & \\
\hline Depth to Water (ft) & 5.08 & 4.77 & 29.85 & 22.13 & 31.16 & 30.05 & 8.56 & \\
\hline Groundwater Elevation (ft) & 951.83 & 952.14 & 986.88 & 994.60 & 985.57 & 986.68 & 960.34 & \\
\hline Conductivity $(\mu \mathrm{mho} / \mathrm{cm})$ & 336 & 407 & 292 & 318 & 433 & 391 & 273 & \\
\hline Dissolved Oxygen (ppm) & 0.56 & 1.51 & 8.27 & 6.77 & 6.1 & 3.01 & 11.46 & \\
\hline Oxidation/Reduction (mV) & 29 & -135 & 152 & 167 & 96 & -55 & 70 & \\
\hline Temperature (degrees C) & 15.7 & 16.2 & 13.91 & 15.8 & 17.1 & 14.6 & 15.9 & \\
\hline Turbidity (NTU) & 1 & 1 & 681 & 316 & 1000 & 747 & 3 & \\
\hline $\mathrm{pH}$ & 7.51 & 7.57 & 6.99 & 6.6 & 6.56 & 6.84 & 7.16 & \\
\hline Major Cations (mg/L) & & & & & & & & \\
\hline Calcium & 39.9 & 40.3 & 25.2 & 37.7 & 31.2 & 29.2 & 57.3 & 56 \\
\hline Magnesium & 9.24 & 9.92 & 10.7 & 12.2 & 12.1 & 14.5 & 4.81 & 4.75 \\
\hline Potassium & 2.82 & 2.98 & 2.53 & 2.43 & 5.62 & 6.96 & 0.862 & 0.882 \\
\hline Sodium & 9.31 & 10.1 & $2.05 \mathrm{Q}$ & 5.42 & 3.1 & 1.96 & 5.68 & 5.61 \\
\hline Trace Metals (mg/L) & & & & & & & & \\
\hline Aluminum & $<$ & $<$ & 4.23 & 3.89 & 4.63 & 26.2 & $<$ & $<$ \\
\hline Arsenic & $<$ & $<$ & $<$ & $<$ & $<$ & 0.00539 & $<$ & $<$ \\
\hline Barium & 0.695 & 0.709 & 0.149 & 0.202 & 0.231 & 0.555 & 0.3 & 0.296 \\
\hline Beryllium & $<$ & $<$ & $<$ & $<$ & $<$ & 0.0011 & $<$ & $<$ \\
\hline Boron & $<$ & $<$ & $<$ & $<$ & $<$ & $<$ & $<$ & $<$ \\
\hline Chromium & $<$ & $<$ & 0.0205 & 0.0178 & 0.0164 & $0.124 \mathrm{Q}$ & $<$ & $<$ \\
\hline Copper & $<$ & $<$ & $<$ & $<$ & $<$ & 0.045 & $<$ & 8 \\
\hline Iron & 0.301 & 0.159 & 2.72 & 2.56 & 3.63 & 19.3 & 0.138 & 0.148 \\
\hline Lead & $<$ & $<$ & 0.00238 & 0.00209 & 0.00534 & 0.0218 & $<$ & $<$ \\
\hline Lithium & 0.0134 & 0.0138 & $<$ & $<$ & 0.0103 & 0.0306 & 0.0119 & 0.0112 \\
\hline Manganese & 0.0191 & 0.0103 & 0.0478 & 0.0525 & 0.0827 & 0.387 & 0.0348 & 0.0348 \\
\hline Mercury & $<$ & $<$ & $<$ & $<$ & $<$ & $<$ & $<$ & $<$ \\
\hline Nickel & $<$ & $<$ & 0.0159 & 0.0146 & 0.0171 & $0.0919 \mathrm{Q}$ & $<$ & $<$ \\
\hline Strontium & 0.829 & 0.885 & 0.0694 & 0.0852 & 0.0847 & 0.0913 & 0.104 & 0.103 \\
\hline Thallium & $<$ & $<$ & $<$ & $<$ & $<$ & $<$ & $<$ & $<$ \\
\hline Uranium & $<$ & $<$ & $<$ & $<$ & $<$ & $<$ & $<$ & $<$ \\
\hline Vanadium & $<$ & $<$ & $<$ & $<$ & $<$ & 0.0356 & $<$ & $<$ \\
\hline Zinc & $<$ & $<$ & $<$ & $<$ & $<$ & 0.0653 & $<$ & $<$ \\
\hline $\begin{array}{l}\text { Chloroethenes }(\mu \mathrm{g} / \mathbf{L}) \\
\quad \text { cis-1,2-Dichloroethene }\end{array}$ & $<$ & $<$ & $<$ & $<$ & $<$ & $<$ & $<$ & $<$ \\
\hline
\end{tabular}


APPENDIX D.4: CY 2009 MONITORING DATA FOR THE BEAR CREEK HYDROGEOLOGIC REGIME Monitoring Data for the EMWMF: Field Measurements, Major Cations, Trace Metals, and Organics

\begin{tabular}{|c|c|c|c|c|c|c|c|c|c|}
\hline \multirow{3}{*}{$\begin{array}{c}\text { Sampling Point } \\
\text { Date Sampled } \\
\text { Program }\end{array}$} & \multicolumn{5}{|c|}{ GW-924 } & \multicolumn{4}{|c|}{ GW-925 } \\
\hline & \multicolumn{2}{|c|}{$04 / 20 / 09$} & \multicolumn{2}{|c|}{$08 / 17 / 09$} & \multirow{2}{*}{\begin{tabular}{c|}
$11 / 16 / 09$ \\
$B J C$
\end{tabular}} & \multirow{2}{*}{\begin{tabular}{|c|}
$2 / 12 / 09^{*}$ \\
$B J C$
\end{tabular}} & \multirow{2}{*}{\begin{tabular}{c|}
$4 / 15 / 09^{*}$ \\
$B J C$
\end{tabular}} & \multirow{2}{*}{\begin{tabular}{|c|}
$8 / 18 / 09^{*}$ \\
$B J C$
\end{tabular}} & \multirow{2}{*}{$\begin{array}{c}11 / 11 / 09^{*} \\
B J C\end{array}$} \\
\hline & BJC & BJC & BJC & BJC & & & & & \\
\hline Sample Type & & Dup & & Dup & & & & & \\
\hline Field Measurements & & & & & & & & & \\
\hline Time Sampled & $10: 40$ & & $10: 30$ & & 10:00 & $10: 00$ & 9:00 & $9: 30$ & $10: 00$ \\
\hline Measuring Point Elev. (ft) & 968.90 & & 968.90 & & 968.90 & 971.14 & 971.14 & 971.14 & 971.14 \\
\hline Depth to Water (ft) & 6.71 & & 9.64 & & 9.15 & 4.40 & 3.46 & 4.12 & 4.02 \\
\hline Groundwater Elevation (ft) & 962.19 & & 959.26 & & 959.75 & 966.74 & 967.68 & 967.02 & 967.12 \\
\hline Conductivity $(\mu \mathrm{mho} / \mathrm{cm})$ & 355 & & 366 & & 547 & 1,162 & 694 & 631 & 735 \\
\hline Dissolved Oxygen (ppm) & 1.11 & & 7.2 & & 1.06 & 2.92 & 12.17 & 1.84 & 1.7 \\
\hline Oxidation/Reduction (mV) & 141 & & 40 & & -69 & 116 & 38 & 98 & 114 \\
\hline Temperature (degrees C) & 15.5 & & 17.3 & & 16.4 & 15.5 & 15.3 & 18.1 & 15.3 \\
\hline Turbidity (NTU) & 1 & & 1 & & 1 & 9 & 26 & 7 & 8 \\
\hline $\mathrm{pH}$ & 7.02 & & 7.21 & & 7.9 & 9.3 & 9.55 & 9.25 & 9.74 \\
\hline Major Cations (mg/L) & & & & & & & & & \\
\hline Calcium & 55.1 & 53.7 & 56 & 55.6 & 55.8 & 3.48 & 2.12 & 2.07 & 2.18 \\
\hline Magnesium & 4.65 & 4.55 & 4.78 & 4.74 & 4.56 & 1.33 & 0.957 & 0.984 & 1 \\
\hline Potassium & 0.83 & 0.842 & 0.77 & 0.706 & 0.784 & 2.07 & 1.76 & 1.56 & 1.52 \\
\hline Sodium & 5.31 & 5.19 & 5.43 & 5.45 & 5.3 & 163 & 152 & 143 & 131 \\
\hline Trace Metals (mg/L) & & & & & & & & & \\
\hline Aluminum & $<$ & $<$ & $<$ & $<$ & $<$ & 1.92 & 0.538 & 0.634 & 0.624 \\
\hline Arsenic & $<$ & $<$ & $<$ & $<$ & $<$ & $<$ & $<$ & $<$ & $<$ \\
\hline Barium & 0.288 & 0.281 & 0.277 & 0.275 & 0.296 & 0.177 & 0.137 & 0.135 & 0.141 \\
\hline Beryllium & $<$ & $<$ & $<$ & $<$ & $<$ & $<$ & $<$ & $<$ & $<$ \\
\hline Boron & $<$ & $<$ & $<$ & $<$ & $<$ & 0.273 & 0.228 & 0.229 & 0.193 \\
\hline Chromium & $<$ & $<$ & $<$ & $<$ & $<$ & $<$ & $<$ & $<$ & $<$ \\
\hline Copper & $<$ & $<$ & $<$ & $<$ & $<$ & $<$ & $<$ & $<$ & $<$ \\
\hline Iron & 0.0525 & 0.0515 & 0.059 & 0.0561 & 0.242 & 0.961 & 0.238 & 0.248 & 0.33 \\
\hline Lead & $<$ & $<$ & $<$ & $<$ & $<$ & 0.00378 & $<$ & $<$ & $<$ \\
\hline Lithium & 0.0134 & 0.0109 & $<$ & $<$ & 0.0122 & 0.0535 & 0.0566 & 0.0468 & 0.0489 \\
\hline Manganese & 0.0269 & 0.0252 & 0.029 & 0.0286 & 0.0438 & 0.0222 & $<$ & 0.00518 & 0.00746 \\
\hline Mercury & $<$ & $<$ & $<$ & $<$ & $<$ & $<$ & $<$ & $<$ & $<$ \\
\hline Nickel & $<$ & $<$ & $<$ & $<$ & $<$ & 0.0104 & $<$ & $<$ & $<$ \\
\hline Strontium & 0.102 & 0.1 & 0.1 & 0.0992 & 0.0997 & 0.224 & 0.198 & 0.187 & 0.196 \\
\hline Thallium & $<$ & $<$ & $0.00101 \mathrm{~J}$ & $<$ & $<$ & $<$ & $<$ & $<$ & $<$ \\
\hline Uranium & $<$ & $<$ & $<$ & $<$ & $<$ & $<$ & $<$ & $<$ & $<$ \\
\hline Vanadium & $<$ & $<$ & $<$ & $<$ & $<$ & $<$ & $<$ & $<$ & $<$ \\
\hline Zinc & $<$ & $<$ & $<$ & $<$ & $<$ & $<$ & $<$ & $<$ & $<$ \\
\hline $\begin{array}{l}\text { Chloroethenes }(\mu \mathrm{g} / \mathrm{L}) \\
\text { cis-1,2-Dichloroethene }\end{array}$ & $<$ & $<1$ & $<$ & $<$ & $<$ & $<$ & $<$ & $<$ & $<$ \\
\hline
\end{tabular}


APPENDIX D.4: CY 2009 MONITORING DATA FOR THE BEAR CREEK HYDROGEOLOGIC REGIME Monitoring Data for the EMWMF: Field Measurements, Major Cations, Trace Metals, and Organics

\begin{tabular}{|c|c|c|c|c|c|c|c|c|c|}
\hline Sampling Point & \multicolumn{4}{|c|}{ GW-926 } & \multicolumn{4}{|c|}{ GW-927 } & \multirow{2}{*}{\begin{tabular}{|c|} 
GW-961 \\
$11 / 23 / 09$ \\
\end{tabular}} \\
\hline Date Sampled & 02/10/09 & $04 / 20 / 09$ & $08 / 17 / 09$ & $11 / 17 / 09^{*}$ & $02 / 09 / 09$ & $04 / 14 / 09$ & $08 / 12 / 09$ & $11 / 10 / 09$ & \\
\hline Program & BJC & BJC & BJC & BJC & BJC & BJC & BJC & BJC & BJC \\
\hline \multicolumn{10}{|l|}{ Sample Type } \\
\hline Field Measurements & & & & & & & & & \\
\hline Time Sampled & $15: 30$ & 13:50 & $14: 00$ & $9: 45$ & $11: 45$ & $15: 10$ & $15: 00$ & $13: 40$ & $10: 40$ \\
\hline Measuring Point Elev. (ft) & 968.94 & 968.94 & 968.94 & 968.94 & 997.19 & 997.19 & 997.19 & 997.19 & 963.57 \\
\hline Depth to Water (ft) & 7.73 & 6.72 & 7.89 & 7.51 & 17.41 & 14.54 & 16.25 & 14.61 & 12.53 \\
\hline Groundwater Elevation (ft) & 961.21 & 962.22 & 961.05 & 961.05 & 979.78 & 982.65 & 980.94 & 982.58 & 951.04 \\
\hline Conductivity $(\mu \mathrm{mho} / \mathrm{cm})$ & 286 & 305 & 350 & 424 & 720 & 399 & 413 & 597 & 590 \\
\hline Dissolved Oxygen (ppm) & 11.27 & 0.76 & 0.15 & 1.27 & 1.3 & 1.09 & 6.81 & 1.5 & 1.85 \\
\hline Oxidation/Reduction (mV) & -54 & -15 & -106 & 61 & -74 & -53 & -134 & -146 & 12 \\
\hline Temperature (degrees C) & 16.8 & 15.1 & 15.4 & 15.6 & 15.6 & 15.5 & 18.5 & 14.6 & 15.58 \\
\hline Turbidity (NTU) & 1 & 2 & 1 & 1 & 0 & 1 & 2 & 2 & 182 \\
\hline $\mathrm{pH}$ & 7.41 & 7.86 & 7.7 & 7.49 & 6.89 & 6.8 & 7.39 & 7.9 & 6.2 \\
\hline \multicolumn{10}{|l|}{ Major Cations (mg/L) } \\
\hline Calcium & 42.6 & 41.2 & 43.6 & 41.1 & 67.7 & 65 & 66.8 & 68.8 & 45.9 \\
\hline Magnesium & 10.1 & 10.4 & 10.9 & 9.96 & 6.79 & 6.61 & 6.57 & 6.99 & 7.31 \\
\hline Potassium & 2.01 & 2.07 & 2.06 & 1.89 & 0.887 & 0.901 & 0.835 & 0.883 & 3.03 \\
\hline Sodium & 9.61 & 9.34 & 10.8 & 9.7 & 7.77 & 7.74 & 7.46 & 7.78 & 7.59 \\
\hline \multicolumn{10}{|l|}{ Trace Metals (mg/L) } \\
\hline Aluminum & $<$ & $<$ & $<$ & $<$ & $<$ & $<$ & $<$ & $<$ & 7.52 \\
\hline Arsenic & $<$ & $<$ & $<$ & $<$ & $<$ & $<$ & $<$ & $<$ & 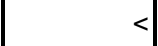 \\
\hline Barium & 0.208 & 0.209 & 0.224 & 0.208 & 0.201 & 0.198 & 0.204 & 0.209 & 0.181 \\
\hline Beryllium & $<$ & $<$ & $<$ & $<$ & $<$ & $<$ & $<$ & $<$ & $<$ \\
\hline Boron & $<$ & $<$ & $<$ & $<$ & $<$ & $<$ & $<$ & $<$ & \\
\hline Chromium & $<$ & $<$ & $<$ & $<$ & $<$ & $<$ & $<$ & $<$ & 0.0132 \\
\hline Copper & $<$ & $<$ & $<$ & $<$ & $<$ & $<$ & $<$ & $<$ & - \\
\hline Iron & 0.132 & 0.115 & 0.125 & 0.127 & 0.124 & 0.115 & 0.127 & 0.275 & 5.72 \\
\hline Lead & $<$ & $<$ & $<$ & $<$ & $<$ & $<$ & $<$ & $<$ & 0.00874 \\
\hline Lithium & 0.0126 & 0.0117 & 0.0109 & 0.0124 & 0.0164 & 0.0162 & 0.0151 & 0.0177 & 0.0184 \\
\hline Manganese & 0.0123 & 0.0126 & 0.0221 & 0.0203 & 0.0211 & 0.0222 & 0.021 & 0.0269 & 0.517 \\
\hline Mercury & $<$ & $<$ & $<$ & $<$ & $<$ & $<$ & $<$ & $<$ & 4 \\
\hline Nickel & $<$ & $<$ & $<$ & $<$ & $<$ & $<$ & $<$ & $<$ & 0.0122 \\
\hline Strontium & 0.658 & 0.72 & 0.714 & 0.67 & 0.116 & 0.115 & 0.121 & 0.12 & 0.0887 \\
\hline Thallium & $<$ & $<$ & $<$ & $<$ & $<$ & $<$ & $<$ & $<$ & 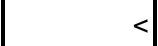 \\
\hline Uranium & $<$ & $<$ & $<$ & $<$ & $<$ & $<$ & $<$ & $<$ & \\
\hline Vanadium & $<$ & $<$ & $<$ & $<$ & $<$ & $<$ & $<$ & $<$ & $<$ \\
\hline Zinc & $<$ & $<$ & $<$ & $<$ & $<$ & $<$ & $<$ & $<$ & $<$ \\
\hline $\begin{array}{l}\text { Chloroethenes }(\mu \mathrm{g} / \mathrm{L}) \\
\quad \text { cis-1,2-Dichloroethene }\end{array}$ & $<$ & $<$ & $<1$ & $<$ & $<$ & $<$ & $<$ & $<$ & $<$ \\
\hline
\end{tabular}


APPENDIX D.4: CY 2009 MONITORING DATA FOR THE BEAR CREEK HYDROGEOLOGIC REGIME Monitoring Data for the EMWMF: Field Measurements, Major Cations, Trace Metals, and Organics

\begin{tabular}{|c|c|c|c|c|c|c|c|c|c|c|}
\hline Sampling Point & \multicolumn{4}{|c|}{ EMWNT-03A } & \multicolumn{4}{|c|}{ EMWNT-05 } & \multirow{2}{*}{\multicolumn{2}{|c|}{$\begin{array}{c}\text { EMW-VWEIR } \\
02 / 09 / 09\end{array}$}} \\
\hline Date Sampled & 02/09/09 & $04 / 13 / 09$ & $08 / 10 / 09$ & $11 / 09 / 09$ & $02 / 09 / 09$ & $04 / 13 / 09$ & $08 / 10 / 09$ & $11 / 09 / 09$ & & \\
\hline Program & BJC & BJC & BJC & BJC & BJC & BJC & BJC & BJC & $\mathrm{BJC}$ & BJC \\
\hline Sample Type & & & & & & & & & & Dup \\
\hline Field Measurements & & & & & & & & & & \\
\hline Time Sampled & $9: 40$ & $10: 45$ & $14: 05$ & $11: 55$ & $10: 15$ & $10: 15$ & $13: 15$ & $11: 20$ & 9:20 & \\
\hline Measuring Point Elev. (ft) & & & & & & & & & & \\
\hline Depth to Water (ft) & & & & & & & & & & \\
\hline Groundwater Elevation (ft) & & & & & & & & & & \\
\hline Conductivity $(\mu \mathrm{mho} / \mathrm{cm})$ & 78 & 91 & 428 & 176 & 185 & 133 & 327 & 240 & 334 & \\
\hline Dissolved Oxygen (ppm) & 9.71 & 7.72 & 4.09 & 9.86 & 12.7 & 8.44 & 8.11 & 10.11 & 14.29 & \\
\hline Oxidation/Reduction (mV) & 68 & 81.7 & 68 & -5.8 & -9.7 & 13.6 & 89 & -52.6 & 100.9 & \\
\hline Temperature (degrees C) & 8.49 & 13.5 & 25.9 & 12.65 & 7.82 & 13.6 & 24.3 & 13.18 & 10.57 & \\
\hline Turbidity (NTU) & 11.7 & 16.3 & 35.9 & 17 & 5.46 & 9.97 & 35.2 & 18 & 2.4 & \\
\hline $\mathrm{pH}$ & 7.18 & 6.91 & 7.46 & 7.35 & 7.57 & 7.24 & 8.05 & 7.7 & 8.54 & \\
\hline Major Cations (mg/L) & & & & & & & & & & \\
\hline Calcium & 17.3 & 10.8 & 61 & 25.5 & 21.3 & 15.5 & 41 & 31.6 & 42.6 & 40.9 \\
\hline Magnesium & 3.6 & 3 & 11.7 & 5.78 & 6.64 & 5.03 & 11.2 & 9.57 & 8.9 & 8.54 \\
\hline Potassium & 1.27 & 1.45 & 1.64 & 1.6 & 1.52 & 1.66 & 2.45 & 1.99 & 2.7 & 2.6 \\
\hline Sodium & 2.82 & 2.17 & 4.72 & 3.46 & 3.87 & 2.56 & 6.02 & 5 & 9.78 & 9.43 \\
\hline Trace Metals (mg/L) & & & & & & & & & & \\
\hline Aluminum & 1.54 & 1.05 & $<$ & 0.525 & 0.233 & 0.568 & 0.792 & 0.594 & 1.43 & 1.21 \\
\hline Arsenic & $<$ & $<$ & $<$ & $<$ & $<$ & $<$ & $<$ & $<$ & $<$ & $<$ \\
\hline Barium & 0.0356 & 0.0386 & 0.205 & 0.0539 & 0.0425 & 0.0422 & 0.0878 & 0.081 & 0.0464 & 0.0444 \\
\hline Beryllium & $<$ & $<$ & $<$ & $<$ & $<$ & $<$ & $<$ & $<$ & $<$ & $<$ \\
\hline Boron & $<$ & $<$ & $<$ & $<$ & $<$ & $<$ & $<$ & $<$ & 0.105 & 0.102 \\
\hline Chromium & $<$ & $<$ & $<$ & $<$ & $<$ & $<$ & $<$ & $<$ & $<$ & $<$ \\
\hline Copper & $<$ & $<$ & $<$ & $<$ & $<$ & $<$ & $<$ & $<$ & $<$ & $<$ \\
\hline Iron & 1.13 & 1.04 & 2.75 & 3.72 & 0.682 & 0.772 & 3.22 & 2.75 & 1.11 & 1.08 \\
\hline Lead & 0.00316 & $<$ & $<$ & $<$ & $0.00245 \mathrm{~J}$ & $<$ & $0.00251 \mathrm{~J}$ & $<$ & $<$ & $<$ \\
\hline Lithium & $<$ & $<$ & $<$ & $<$ & $<$ & $<$ & $<$ & $<$ & $<$ & $<$ \\
\hline Manganese & 0.0574 & 0.122 & 5.59 & 1 & 0.123 & 0.127 & 1.47 & 1.61 & 0.082 & 0.0784 \\
\hline Mercury & $<$ & $<$ & $<$ & $0.000103 \mathrm{~J}$ & $<$ & $<$ & $<$ & $0.000097 \mathrm{~J}$ & $<$ & $<$ \\
\hline Nickel & $<$ & $<$ & $<$ & $<$ & $<$ & $<$ & $<$ & $<$ & $<$ & $<$ \\
\hline Strontium & 0.0347 & 0.029 & 0.128 & 0.0625 & 0.0538 & 0.039 & 0.103 & 0.0819 & 0.115 & 0.111 \\
\hline Thallium & $<$ & $<$ & $0.00547 \mathrm{Q}$ & $0.00147 \mathrm{~J}$ & $<$ & $<$ & $0.0013 \mathrm{~J}$ & $0.00196 \mathrm{~J}$ & $<$ & $<$ \\
\hline Uranium & $<$ & $<$ & $<$ & $<$ & $<$ & $<$ & $<$ & $<$ & 0.0084 & 0.00868 \\
\hline Vanadium & $<$ & $<$ & $<$ & $<$ & $<$ & $<$ & $<$ & $<$ & $<$ & $<$ \\
\hline Zinc & $<$ & $<$ & $<$ & $<$ & $<$ & $<$ & $<$ & $<$ & $<$ & $<$ \\
\hline $\begin{array}{l}\text { hloroethenes }(\mu \mathbf{g} / \mathbf{L}) \\
\quad \text { cis-1,2-Dichloroethene }\end{array}$ & $<$ & $<$ & $<$ & $<$ & $<$ & $<$ & $<$ & $<$ & $<$ & $<$ \\
\hline
\end{tabular}


APPENDIX D.4: CY 2009 MONITORING DATA FOR THE BEAR CREEK HYDROGEOLOGIC REGIME Monitoring Data for the EMWMF: Field Measurements, Major Cations, Trace Metals, and Organics

\begin{tabular}{|c|c|c|c|c|c|c|c|c|c|}
\hline \multirow{2}{*}{$\begin{array}{c}\text { Sampling Point } \\
\text { Date Sampled }\end{array}$} & \multicolumn{4}{|c|}{ EMW-VWEIR } & \multicolumn{5}{|c|}{ EMW-VWUNDER } \\
\hline & $04 / 13 / 09$ & $08 / 10 / 09$ & \multicolumn{2}{|c|}{$11 / 09 / 09$} & \multirow{2}{*}{$\frac{02 / 12 / 09}{\mathrm{BJC}}$} & \multirow{2}{*}{\begin{tabular}{c|}
$04 / 16 / 09$ \\
$B J C$
\end{tabular}} & \multirow{2}{*}{$\frac{08 / 11 / 09}{\text { BJC }}$} & \multicolumn{2}{|c|}{$11 / 12 / 09$} \\
\hline Program & BJC & BJC & BJC & BJC & & & & BJC & $\mathrm{BJC}$ \\
\hline Sample Type & & & & Dup & & & & & Dup \\
\hline Field Measurements & & & & & & & & & \\
\hline Time Sampled & $9: 20$ & 9:10 & $10: 00$ & & $14: 00$ & $10: 10$ & $15: 00$ & $9: 40$ & \\
\hline Measuring Point Elev. (ft) & & & & & & & & & \\
\hline Depth to Water (ft) & & & & & & & & & \\
\hline Groundwater Elevation (ft) & & & & & & & & & \\
\hline Conductivity $(\mu \mathrm{mho} / \mathrm{cm})$ & 343 & 327 & 459 & & 723 & 372 & 647 & 594 & \\
\hline Dissolved Oxygen (ppm) & 8.69 & 6.2 & 10.65 & & 4.7 & 5.82 & 2.59 & 5.9 & \\
\hline Oxidation/Reduction (mV) & 150.5 & 144 & 205.8 & & 183 & 43 & 100 & 165 & \\
\hline Temperature (degrees C) & 14.96 & 26.5 & 13.94 & & 17.3 & 14.4 & 21.1 & 15.7 & \\
\hline Turbidity (NTU) & 90.3 & 15.4 & 13 & & 2 & 1 & 21 & 11 & \\
\hline $\mathrm{pH}$ & 7.86 & 7.91 & 7.57 & & 6.21 & 6.83 & 6.09 & 6.12 & \\
\hline Major Cations (mg/L) & & & & & & & & & \\
\hline Calcium & 52.2 & 43.5 & 74.2 & 75.5 & 59.2 & 61.9 & $83.4 \mathrm{Q}$ & 70.2 & 68.9 \\
\hline Magnesium & 9.94 & 9.06 & 11.3 & 11.4 & 9.22 & 10.5 & 11.6 & 11.3 & 11 \\
\hline Potassium & 3.08 & 4.59 & 3.91 & 4.06 & 2.1 & 2.07 & 2.49 & 2.08 & 2.06 \\
\hline Sodium & 6.48 & 6.79 & 11 & 11.4 & 8.4 & 8.86 & 8.06 & 9.56 & 9.69 \\
\hline Trace Metals (mg/L) & & & & & & & & & \\
\hline Aluminum & 3.07 & 0.271 & 0.386 & 0.424 & $<$ & $<$ & $<$ & $<$ & $<$ \\
\hline Arsenic & & & & $<$ & $<$ & $<$ & $<$ & $<$ & $<$ \\
\hline Barium & 0.048 & 0.0921 & 0.0846 & 0.0872 & 0.0824 & 0.0858 & 0.113 & 0.0912 & 0.0916 \\
\hline Beryllium & $<$ & $<$ & $<$ & $<$ & $<$ & $<$ & $<$ & $<$ & $<$ \\
\hline Boron & $<$ & $<$ & $<$ & $<$ & $<$ & $<$ & $<$ & $<$ & $<$ \\
\hline Chromium & $<$ & $<$ & $<$ & $<$ & $<$ & $<$ & $<$ & $<$ & $<$ \\
\hline Copper & $<$ & $<$ & $<$ & $<$ & $<$ & $<$ & $<$ & $<$ & $<$ \\
\hline Iron & 2.36 & 0.334 & 0.288 & 0.295 & $<$ & 0.0988 & 0.136 & $<$ & $<$ \\
\hline Lead & $<$ & $0.00287 \mathrm{~J}$ & $<$ & $<$ & $<$ & $<$ & $<$ & $<$ & $<$ \\
\hline Lithium & $<$ & $<$ & $<$ & $<$ & $<$ & $<$ & $<$ & $<$ & $<$ \\
\hline Manganese & 0.235 & 0.165 & 0.222 & 0.229 & $<$ & 0.015 & 0.404 & 0.00538 & 0.00548 \\
\hline Mercury & $<$ & $<$ & $0.00008 \mathrm{~J}$ & $0.000082 \mathrm{~J}$ & $<$ & $<$ & $<$ & $<$ & $<$ \\
\hline Nickel & $<$ & $<$ & $<$ & $<$ & $<$ & $<$ & $<$ & $<$ & $<$ \\
\hline Strontium & 0.129 & 0.139 & 0.218 & 0.224 & 0.173 & 0.18 & 0.221 & 0.201 & 0.205 \\
\hline Thallium & $<$ & $<$ & $<$ & $<$ & $<$ & $<$ & $<$ & $<$ & $<$ \\
\hline Uranium & $<$ & $<$ & 0.00593 & 0.0077 & $<$ & $<$ & $<$ & $<$ & $<$ \\
\hline Vanadium & $<$ & $<$ & & $<$ & $<$ & $<$ & $<$ & $<$ & $<$ \\
\hline Zinc & $<$ & $<1<-1$ & 0.0616 & 0.0644 & $<$ & $<1<-1$ & $<$ & $<$ & $<$ \\
\hline Chloroethenes $(\mu \mathrm{g} / \mathrm{L})$ & & & & & & & & & \\
\hline cis-1,2-Dichloroethene & $<$ & $<$ & $<$ & $<$ & $<$ & $<$ & $<$ & $<$ & $<$ \\
\hline
\end{tabular}


APPENDIX D.4: CY 2009 MONITORING DATA FOR THE BEAR CREEK HYDROGEOLOGIC REGIME Monitoring Data for the EMWMF: Field Measurements, Major Cations, Trace Metals, and Organics

\begin{tabular}{|c|c|c|c|c|}
\hline Sampling Point & \multicolumn{4}{|c|}{ NT-04 } \\
\hline Date Sampled & 02/09/09 & $04 / 13 / 09$ & $08 / 10 / 09$ & $11 / 09 / 09$ \\
\hline Program & BJC & BJC & BJC & BJC \\
\hline \multicolumn{5}{|l|}{ Sample Type } \\
\hline Field Measurements & \multirow{5}{*}{$8: 50$} & \multirow{5}{*}{$9: 45$} & \multirow{5}{*}{$9: 40$} & \multirow{5}{*}{$10: 40$} \\
\hline Time Sampled & & & & \\
\hline Measuring Point Elev. (ft) & & & & \\
\hline Depth to Water (ft) & & & & \\
\hline Groundwater Elevation (ft) & & & & \\
\hline Conductivity $(\mu \mathrm{mho} / \mathrm{cm})$ & 338 & 548 & 633 & 575 \\
\hline Dissolved Oxygen (ppm) & 9.6 & 6.4 & 7.05 & 8.57 \\
\hline Oxidation/Reduction (mV) & 16.5 & 12.3 & 146 & 21 \\
\hline Temperature (degrees C) & 10.33 & 13.05 & 23.6 & 13.68 \\
\hline Turbidity (NTU) & 2.2 & 10.1 & 6.2 & 7 \\
\hline $\mathrm{pH}$ & 6.82 & 7.05 & 7.45 & 7.65 \\
\hline \multicolumn{5}{|l|}{ Major Cations (mg/L) } \\
\hline Calcium & 92.5 & 93.1 & 106 & 105 \\
\hline Magnesium & 16.2 & 16.8 & 19.5 & 18.8 \\
\hline Potassium & 1.94 & 1.91 & 2.47 & 2.4 \\
\hline Sodium & 7.45 & 8.3 & 8.65 & 9.31 \\
\hline \multicolumn{5}{|l|}{ Trace Metals (mg/L) } \\
\hline Aluminum & $<$ & 1.02 & 0.206 & $<$ \\
\hline Arsenic & $<$ & $<$ & $<$ & $<$ \\
\hline Barium & 0.52 & 0.399 & 0.502 & 0.489 \\
\hline Beryllium & $<$ & $<$ & $<$ & $<$ \\
\hline Boron & $<$ & $<$ & $<$ & $<$ \\
\hline Chromium & $<$ & $<$ & $<$ & $<$ \\
\hline Copper & $<$ & $<$ & $<$ & $<$ \\
\hline Iron & 1.09 & 2.07 & 0.692 & 0.502 \\
\hline Lead & $<$ & $<$ & $<$ & $<$ \\
\hline Lithium & $<$ & $<$ & $<$ & $<$ \\
\hline Manganese & 0.6 & 0.785 & 0.696 & 0.594 \\
\hline Mercury & $<$ & $<$ & $<$ & $.000108 \mathrm{~J}$ \\
\hline Nickel & $<$ & $<$ & $<$ & $<$ \\
\hline Strontium & 0.241 & 0.237 & 0.279 & 0.272 \\
\hline Thallium & $<$ & $<$ & $<$ & $0.001 \mathrm{~J}$ \\
\hline Uranium & $<$ & $<$ & $<$ & $<$ \\
\hline Vanadium & $<$ & $<$ & 0.0213 & $<$ \\
\hline Zinc & $<$ & $<$ & $<$ & $<$ \\
\hline \multicolumn{5}{|l|}{ Chloroethenes ( $\mu \mathrm{g} / \mathrm{L})$} \\
\hline cis-1,2-Dichloroethene & $3.14 \mathrm{~J}$ & 5.83 & $1.15 \mathrm{~J}$ & $<$ \\
\hline
\end{tabular}


APPENDIX D.4: CY 2009 MONITORING DATA FOR THE BEAR CREEK HYDROGEOLOGIC REGIME Monitoring Data for the EMWMF: Radiological Analytes

\begin{tabular}{|c|c|c|c|c|c|}
\hline \multirow{2}{*}{$\begin{array}{r}\text { Sampling } \\
\text { Point }\end{array}$} & \multirow{2}{*}{$\begin{array}{c}\text { Date } \\
\text { Sampled }\end{array}$} & \multirow{2}{*}{ Isotope } & \multicolumn{3}{|c|}{ Result (pCi/L) } \\
\hline & & & Activity & TPU & MDA \\
\hline GW-363 & $04 / 23 / 09$ & Americium-243 & 0.24 & 0.17 & 0.14 \\
\hline GW-363 & 08/20/09 & Chlorine-36 & $4.19 \mathrm{Q}$ & 2.18 & 2.88 \\
\hline GW-363 & 04/23/09 & Curium-245 & 0.24 & 0.18 & 0.14 \\
\hline GW-363 & $11 / 19 / 09$ & Curium-245 & 0.12 & 0.11 & 0.07 \\
\hline GW-363 & $11 / 19 / 09$ & Potassium-40 & 23.7 & 21.5 & 21.2 \\
\hline GW-363 & 02/18/09 & Radium-226 & 0.17 & 0.13 & 0.17 \\
\hline GW-363 & 08/20/09 & Radium-226 & 0.31 & 0.18 & 0.18 \\
\hline GW-363 & 08/20/09 & Radium-228 & 0.68 & 0.26 & 0.62 \\
\hline GW-363 & 08/20/09 & Strontium-90 & 1.58 & 0.65 & 1.21 \\
\hline GW-363 & 04/23/09 & Technetium-99 & 3.08 & 1.82 & 3 \\
\hline GW-639 & $04 / 23 / 09$ & Americium-241 & 0.21 & 0.15 & 0.15 \\
\hline GW-639 & 08/19/09 & Americium-241 & 0.16 & 0.14 & 0.16 \\
\hline GW-639 & $11 / 18 / 09$ & Chlorine-36 & 3.33 & 2.35 & 3.28 \\
\hline GW-639 & 08/19/09 & Curium-245 & 0.28 & 0.23 & 0.26 \\
\hline GW-639 & $11 / 18 / 09$ & Plutonium-242 & 0.2 & 0.17 & 0.09 \\
\hline GW-639 & 02/18/09 & Radium-226 & 0.48 & 0.21 & 0.2 \\
\hline GW-639 & 08/19/09 & Radium-226 & 0.25 & 0.15 & 0.16 \\
\hline GW-639 & 04/23/09 & Technetium-99 & 3.08 & 1.82 & 3.01 \\
\hline GW-639 & 08/19/09 & Technetium-99 & 8.21 & 1.99 & 3.13 \\
\hline GW-639 & $11 / 18 / 09$ & Thorium-227 & 0.18 & 0.15 & 0.15 \\
\hline GW-639 & 04/23/09 & Thorium-230 & 0.22 & 0.2 & 0.21 \\
\hline GW-639 & $11 / 18 / 09$ & Thorium-230 & 0.27 & 0.18 & 0.07 \\
\hline GW-639 & 02/18/09 & Uranium-233/234 & 0.46 & 0.22 & 0.17 \\
\hline GW-639 & 04/23/09 & Uranium-233/234 & 0.61 & 0.26 & 0.07 \\
\hline GW-639 & 08/19/09 & Uranium-233/234 & 0.33 & 0.19 & 0.14 \\
\hline GW-639 & $11 / 18 / 09$ & Uranium-233/234 & 0.42 & 0.22 & 0.12 \\
\hline GW-639 & 04/23/09 & Uranium-238 & 0.17 & 0.13 & 0.07 \\
\hline GW-639 & $11 / 18 / 09$ & Uranium-238 & 0.13 & 0.12 & 0.12 \\
\hline GW-916 & $02 / 12 / 09$ & Americium-243 & 0.33 & 0.22 & 0.18 \\
\hline GW-916 & 02/12/09 & Curium-245 & 0.38 & 0.25 & 0.25 \\
\hline GW-916 & 02/12/09 & Radium-226 & 0.22 & 0.16 & 0.2 \\
\hline GW-916 & 02/12/09 & Strontium-90 & 2.88 & 0.77 & 1.28 \\
\hline GW-916 & 08/11/09 & Strontium-90 & 1.69 & 0.64 & 1.19 \\
\hline GW-916 & 02/12/09 & Thorium-230 & 0.27 & 0.2 & 0.19 \\
\hline GW-916 & $11 / 11 / 09$ & Thorium-230 & 0.12 & 0.11 & 0.11 \\
\hline GW-916 & 04/15/09 & Uranium-233/234 & 0.28 & 0.17 & 0.15 \\
\hline GW-916 & 08/11/09 & Uranium-233/234 & 0.18 & 0.15 & 0.18 \\
\hline GW-916 & 04/15/09 & Uranium-235/236 & 0.17 & 0.14 & 0.07 \\
\hline $\mathrm{GW}-917$ & $02 / 09 / 09$ & Americium-243 & 0.34 & 0.31 & 0.19 \\
\hline GW-917 & 02/09/09 & Curium-245 & 1.01 & 0.57 & 0.37 \\
\hline GW-917 & 02/09/09 & Plutonium-239/240 & 0.19 & 0.18 & 0.18 \\
\hline GW-917 & 04/14/09 & Radium-226 & 0.19 & 0.13 & 0.12 \\
\hline GW-917 & 08/12/09 & Radium-226 & 0.13 & 0.12 & 0.12 \\
\hline GW-917 & 11/09/09 & Radium-226 & 0.23 & 0.16 & 0.2 \\
\hline GW-917 & 08/12/09 & Strontium-90 & 1.82 & 0.62 & 1.12 \\
\hline GW-917 & 04/14/09 & Thorium-229 & 0.85 & 0.74 & 0.18 \\
\hline GW-917 & $04 / 14 / 09$ & Uranium-233/234 & 0.12 & 0.11 & 0.07 \\
\hline GW-918 & $02 / 10 / 09$ & Americium-243 & 0.26 & 0.24 & 0.14 \\
\hline GW-918 & 02/10/09 & Curium-245 & 0.3 & 0.26 & 0.28 \\
\hline GW-918 & 02/10/09 & Radium-226 & 0.19 & 0.14 & 0.18 \\
\hline GW-918 & 04/15/09 & Radium-226 & 0.2 & 0.13 & 0.12 \\
\hline GW-918 & 02/10/09 & Strontium-90 & 3.1 & 1.15 & 2.12 \\
\hline GW-918 & 02/10/09 & Thorium-230 & 0.19 & 0.16 & 0.13 \\
\hline GW-918 & 04/15/09 & Thorium-230 & 0.37 & 0.28 & 0.22 \\
\hline GW-918 & 08/12/09 & Uranium-233/234 & 0.24 & 0.17 & 0.19 \\
\hline GW-918 & $11 / 12 / 09$ & Uranium-238 & 0.22 & 0.17 & 0.16 \\
\hline
\end{tabular}


APPENDIX D.4: CY 2009 MONITORING DATA FOR THE BEAR CREEK HYDROGEOLOGIC REGIME Monitoring Data for the EMWMF: Radiological Analytes

\begin{tabular}{|c|c|c|c|c|c|}
\hline \multirow{2}{*}{$\begin{array}{r}\text { Sampling } \\
\text { Point }\end{array}$} & \multirow{2}{*}{$\begin{array}{c}\text { Date } \\
\text { Sampled }\end{array}$} & \multirow{2}{*}{ Isotope } & \multicolumn{3}{|c|}{ Result (pCi/L) } \\
\hline & & & Activity & TPU & MDA \\
\hline GW-920 & $02 / 10 / 09$ & Radium-226 & 0.19 & 0.14 & 0.13 \\
\hline GW-920 & 04/16/09 & Radium-226 & 0.16 & 0.12 & 0.14 \\
\hline GW-920 & 08/11/09 & Radium-226 & 0.19 & 0.15 & 0.13 \\
\hline GW-920 & 02/10/09 & Strontium-90 & 1.8 & 0.83 & 1.56 \\
\hline GW-920 & 08/11/09 & Strontium-90 & 1.83 & 0.66 & 1.2 \\
\hline GW-920 & 04/16/09 & Technetium-99 & 3.07 & 1.82 & 3 \\
\hline GW-920 & $11 / 12 / 09$ & Technetium-99 & 3.01 & 1.74 & 2.87 \\
\hline GW-920 & 08/11/09 & Uranium-232 & 1.69 & 1.15 & 0.07 \\
\hline GW-920 & 02/10/09 & Uranium-233/234 & 0.46 & 0.23 & 0.14 \\
\hline GW-920 & 04/16/09 & Uranium-233/234 & 0.47 & 0.22 & 0.14 \\
\hline GW-920 & 08/11/09 & Uranium-233/234 & 0.2 & 0.14 & 0.12 \\
\hline GW-920 & 02/10/09 & Uranium-238 & 0.21 & 0.15 & 0.07 \\
\hline GW-920 & 04/16/09 & Uranium-238 & 0.45 & 0.21 & 0.12 \\
\hline GW-920 & $08 / 11 / 09$ & Uranium-238 & 0.12 & 0.11 & 0.12 \\
\hline GW-921 & $02 / 11 / 09$ & Radium-226 & 0.3 & 0.17 & 0.14 \\
\hline GW-921 & 04/14/09 & Radium-226 & 0.31 & 0.18 & 0.16 \\
\hline GW-921 & 08/13/09 & Radium-226 & 0.24 & 0.15 & 0.18 \\
\hline GW-921 & $11 / 10 / 09$ & Radium-226 & 0.29 & 0.19 & 0.2 \\
\hline GW-921 & 02/11/09 & Radium-228 & 0.68 & 0.23 & 0.56 \\
\hline GW-921 & 08/13/09 & Radium-228 & 0.7 & 0.26 & 0.62 \\
\hline GW-921 & 04/14/09 & Technetium-99 & 3.08 & 1.82 & 3 \\
\hline GW-921 & $11 / 10 / 09$ & Technetium-99 & 3.02 & 1.75 & 2.89 \\
\hline GW-921 & 08/13/09 & Thorium-230 & 0.18 & 0.15 & 0.18 \\
\hline GW-921 & $11 / 10 / 09$ & Thorium-230 & 0.15 & 0.14 & 0.15 \\
\hline GW-921 & 04/14/09 & Uranium-233/234 & 0.53 & 0.24 & 0.13 \\
\hline GW-921 & 08/13/09 & Uranium-233/234 & 0.23 & 0.18 & 0.19 \\
\hline GW-921 & $11 / 10 / 09$ & Uranium-233/234 & 0.24 & 0.18 & 0.19 \\
\hline GW-921 & 11/10/09 & Uranium-235/236 & 0.17 & 0.16 & 0.17 \\
\hline GW-921 & 04/14/09 & Uranium-238 & 0.37 & 0.19 & 0.13 \\
\hline GW-921 & $11 / 10 / 09$ & Uranium-238 & 0.15 & 0.13 & 0.08 \\
\hline $\mathrm{GW}-922$ & $02 / 10 / 09$ & Americium-243 & $1.36 \mathrm{Q}$ & 0.68 & 0.32 \\
\hline GW-922 & 02/10/09 & Curium-245 & $1.52 \mathrm{Q}$ & 0.73 & 0.32 \\
\hline GW-922 & 02/10/09 & Radium-226 & 0.24 & 0.17 & 0.17 \\
\hline GW-922 & 08/10/09 & Radium-226 & 0.29 & 0.18 & 0.07 \\
\hline GW-922 & 02/10/09 & Strontium-90 & 2.21 & 0.93 & 1.76 \\
\hline GW-922 & 08/10/09 & Strontium-90 & 1.83 & 0.55 & 0.94 \\
\hline GW-922 & 04/16/09 & Technetium-99 & 3.08 & 1.82 & 3 \\
\hline GW-922 & 02/10/09 & Uranium-233/234 & 0.17 & 0.14 & 0.16 \\
\hline GW-922 & 08/10/09 & Uranium-233/234 & 0.17 & 0.13 & 0.07 \\
\hline GW-923 & $02 / 18 / 09$ & Radium-226 & 0.14 & 0.11 & 0.13 \\
\hline GW-923 & 04/22/09 & Radium-226 & 0.51 & 0.27 & 0.19 \\
\hline GW-923 & $11 / 11 / 09$ & Radium-226 & 0.22 & 0.16 & 0.17 \\
\hline GW-923 & 08/12/09 & Strontium-90 & 1.74 & 0.61 & 1.11 \\
\hline GW-923 & 04/22/09 & Technetium-99 & 3.09 & 1.83 & 3.02 \\
\hline GW-923 & $11 / 11 / 09$ & Technetium-99 & 3.08 & 1.78 & 2.95 \\
\hline GW-923 & 04/22/09 & Thorium-228 & 0.44 & 0.29 & 0.27 \\
\hline GW-923 & 02/18/09 & Thorium-230 & 0.18 & 0.15 & 0.18 \\
\hline GW-923 & 04/22/09 & Thorium-230 & 0.46 & 0.29 & 0.18 \\
\hline GW-923 & 08/12/09 & Thorium-230 & 0.34 & 0.21 & 0.2 \\
\hline GW-923 & $11 / 11 / 09$ & Thorium-230 & 0.24 & 0.18 & 0.08 \\
\hline GW-923 & 04/22/09 & Thorium-232 & 0.49 & 0.3 & 0.21 \\
\hline GW-923 & 08/13/09 & Tritium & 403 & 189.07 & 301 \\
\hline GW-923 & 04/22/09 & Uranium-233/234 & 0.6 & 0.27 & 0.14 \\
\hline GW-923 & 08/12/09 & Uranium-233/234 & 0.55 & 0.33 & 0.24 \\
\hline GW-923 & $11 / 11 / 09$ & Uranium-233/234 & 0.22 & 0.21 & 0.21 \\
\hline GW-923 & 02/18/09 & Uranium-238 & 0.15 & 0.14 & 0.14 \\
\hline GW-923 & 04/22/09 & Uranium-238 & 0.45 & 0.23 & 0.12 \\
\hline GW-923 & 08/12/09 & Uranium-238 & 0.28 & 0.24 & 0.28 \\
\hline
\end{tabular}


APPENDIX D.4: CY 2009 MONITORING DATA FOR THE BEAR CREEK HYDROGEOLOGIC REGIME Monitoring Data for the EMWMF: Radiological Analytes

\begin{tabular}{|c|c|c|c|c|c|}
\hline \multirow{2}{*}{$\begin{array}{r}\text { Sampling } \\
\text { Point } \\
\end{array}$} & \multirow{2}{*}{$\begin{array}{c}\text { Date } \\
\text { Sampled }\end{array}$} & \multirow{2}{*}{ Isotope } & \multicolumn{3}{|c|}{ Result (pCi/L) } \\
\hline & & & Activity & TPU & MDA \\
\hline GW-924 & $11 / 16 / 09$ & Americium-241 & 0.15 & 0.13 & 0.12 \\
\hline GW-924 Dup & 02/11/09 & Cesium-137 & 8.24 Q & 4.86 & 3.95 \\
\hline GW-924 & 02/11/09 & Chlorine-36 & 2.86 & 1.82 & 2.47 \\
\hline GW-924 & 04/20/09 & Radium-226 & 0.18 & 0.12 & 0.16 \\
\hline GW-924 Dup & 04/20/09 & Radium-226 & 0.4 & 0.2 & 0.13 \\
\hline GW-924 Dup & 08/17/09 & Radium-226 & 0.19 & 0.14 & 0.15 \\
\hline GW-924 & $02 / 11 / 09$ & Radium-228 & 0.88 & 0.32 & 0.78 \\
\hline GW-924 Dup & $02 / 11 / 09$ & Radium-228 & 1.12 & 0.28 & 0.65 \\
\hline GW-924 & 08/17/09 & Strontium-90 & 1.41 & 0.63 & 1.19 \\
\hline GW-924 & $11 / 16 / 09$ & Technetium-99 & 3.02 & 1.75 & 2.89 \\
\hline GW-924 & 02/11/09 & Thorium-230 & 0.28 & 0.22 & 0.26 \\
\hline GW-924 Dup & 02/11/09 & Thorium-230 & 0.26 & 0.2 & 0.24 \\
\hline GW-924 & $11 / 16 / 09$ & Thorium-230 & 0.28 & 0.19 & 0.2 \\
\hline GW-924 & 04/20/09 & Uranium-233/234 & 0.12 & 0.11 & 0.12 \\
\hline GW-924 Dup & 04/20/09 & Uranium-233/234 & 0.24 & 0.16 & 0.11 \\
\hline GW-924 Dup & 08/17/09 & Uranium-233/234 & 0.21 & 0.16 & 0.17 \\
\hline GW-924 & 11/16/09 & Uranium-233/234 & 0.13 & 0.12 & 0.07 \\
\hline GW-924 Dup & 08/17/09 & Uranium-238 & 0.21 & 0.16 & 0.17 \\
\hline GW-925 & $04 / 15 / 09$ & Curium-245 & 0.23 & 0.17 & 0.19 \\
\hline GW-925 & 08/18/09 & Potassium-40 & 113 & 108.6 & 86.6 \\
\hline GW-925 & 02/12/09 & Radium-226 & 0.17 & 0.14 & 0.15 \\
\hline GW-925 & 04/15/09 & Technetium-99 & 3.1 & 1.83 & 3.02 \\
\hline GW-925 & 08/18/09 & Thorium-227 & 0.23 & 0.16 & 0.12 \\
\hline GW-925 & $11 / 11 / 09$ & Thorium-230 & 0.14 & 0.13 & 0.14 \\
\hline GW-925 & 02/12/09 & Uranium-233/234 & 0.22 & 0.16 & 0.19 \\
\hline GW-925 & 08/18/09 & Uranium-233/234 & 0.4 & 0.21 & 0.12 \\
\hline GW-925 & $11 / 11 / 09$ & Uranium-233/234 & 0.31 & 0.19 & 0.18 \\
\hline GW-925 & $11 / 11 / 09$ & Uranium-238 & 0.18 & 0.15 & 0.15 \\
\hline $\mathrm{GW}-926$ & $02 / 10 / 09$ & Cesium-137 & 4.78 & 4.31 & 3.86 \\
\hline GW-926 & 02/10/09 & Radium-226 & 0.3 & 0.19 & 0.21 \\
\hline GW-926 & 08/17/09 & Radium-226 & 0.16 & 0.12 & 0.14 \\
\hline GW-926 & 02/10/09 & Radium-228 & 0.87 & 0.25 & 0.58 \\
\hline GW-926 & 08/17/09 & Radium-228 & 0.71 & 0.24 & 0.57 \\
\hline GW-926 & 02/10/09 & Strontium-90 & 2.06 & 0.88 & 1.65 \\
\hline GW-926 & 08/17/09 & Strontium-90 & 1.69 & 0.61 & 1.1 \\
\hline GW-926 & 02/10/09 & Thorium-230 & 0.31 & 0.24 & 0.27 \\
\hline GW-926 & $11 / 17 / 09$ & Thorium-230 & 0.25 & 0.17 & 0.14 \\
\hline GW-926 & 02/10/09 & Thorium-232 & 0.18 & 0.17 & 0.18 \\
\hline GW-926 & 04/20/09 & Uranium-233/234 & 0.19 & 0.14 & 0.14 \\
\hline GW-926 & 11/17/09 & Uranium-233/234 & 0.23 & 0.16 & 0.07 \\
\hline $\mathrm{GW}-927$ & $04 / 14 / 09$ & Curium-247 & 0.3 & 0.25 & 0.24 \\
\hline GW-927 & 02/09/09 & Radium-226 & 0.38 & 0.17 & 0.1 \\
\hline GW-927 & 08/12/09 & Radium-226 & 0.28 & 0.16 & 0.06 \\
\hline GW-927 & 04/14/09 & Radium-228 & 1.34 & 0.3 & 0.6 \\
\hline GW-927 & 08/12/09 & Radium-228 & 0.9 & 0.24 & 0.55 \\
\hline GW-927 & 02/09/09 & Strontium-90 & 2.93 & 0.96 & 1.72 \\
\hline GW-927 & 08/12/09 & Strontium-90 & 1.72 & 0.79 & 1.53 \\
\hline GW-927 & $11 / 10 / 09$ & Strontium-90 & 1.34 & 0.67 & 1.28 \\
\hline GW-927 & 04/14/09 & Thorium-230 & 0.19 & 0.18 & 0.1 \\
\hline GW-927 & 04/14/09 & Uranium-233/234 & 0.16 & 0.13 & 0.11 \\
\hline $\mathrm{GW}-961$ & $11 / 23 / 09$ & Chlorine-36 & 6.51 & 2.43 & 2.98 \\
\hline GW-961 & $11 / 23 / 09$ & Radium-226 & 0.26 & 0.16 & 0.19 \\
\hline GW-961 & $11 / 23 / 09$ & Strontium-90 & 1.74 & 0.63 & 1.13 \\
\hline GW-961 & 11/23/09 & Thorium-230 & 0.15 & 0.13 & 0.14 \\
\hline GW-961 & 11/23/09 & Uranium-233/234 & 0.23 & 0.16 & 0.19 \\
\hline GW-961 & $11 / 23 / 09$ & Uranium-238 & 0.2 & 0.14 & 0.07 \\
\hline
\end{tabular}


APPENDIX D.4: CY 2009 MONITORING DATA FOR THE BEAR CREEK HYDROGEOLOGIC REGIME Monitoring Data for the EMWMF: Radiological Analytes

\begin{tabular}{|c|c|c|c|c|c|}
\hline \multirow{2}{*}{$\begin{array}{r}\text { Sampling } \\
\text { Point }\end{array}$} & \multirow{2}{*}{$\begin{array}{c}\text { Date } \\
\text { Sampled }\end{array}$} & \multirow{2}{*}{ Isotope } & \multicolumn{3}{|c|}{ Result (pCi/L) } \\
\hline & & & Activity & TPU & MDA \\
\hline EMWNT-03A & 08/10/09 & Chlorine-36 & $2.81 \mathrm{Q}$ & 1.97 & 2.73 \\
\hline EMWNT-03A & 08/10/09 & Plutonium-242 & 0.13 & 0.12 & 0.12 \\
\hline EMWNT-03A & 08/10/09 & Radium-226 & 0.48 & 0.4 & 0.38 \\
\hline EMWNT-03A & 04/13/09 & Strontium-90 & $3.5 \mathrm{Q}$ & 0.93 & 1.62 \\
\hline EMWNT-03A & $11 / 09 / 09$ & Strontium-90 & 2.01 & 0.67 & 1.18 \\
\hline EMWNT-03A & $11 / 09 / 09$ & Thorium-227 & 0.41 & 0.27 & 0.29 \\
\hline EMWNT-03A & 08/10/09 & Thorium-230 & 0.6 & 0.4 & 0.3 \\
\hline EMWNT-03A & $11 / 09 / 09$ & Thorium-230 & 0.4 & 0.26 & 0.3 \\
\hline EMWNT-03A & 04/13/09 & Uranium-233/234 & 0.33 & 0.28 & 0.31 \\
\hline EMWNT-03A & 08/10/09 & Uranium-233/234 & 0.77 & 0.48 & 0.56 \\
\hline EMWNT-03A & 08/10/09 & Uranium-238 & 0.68 & 0.42 & 0.36 \\
\hline EMWNT-03A & $11 / 09 / 09$ & Uranium-238 & 0.21 & 0.17 & 0.14 \\
\hline EMWNT-05 & $11 / 09 / 09$ & Neptunium-237 & 0.2 & 0.15 & 0.08 \\
\hline EMWNT-05 & 08/10/09 & Radium-226 & 0.91 & 0.5 & 0.36 \\
\hline EMWNT-05 & 08/10/09 & Thorium-227 & 0.18 & 0.14 & 0.07 \\
\hline EMWNT-05 & 08/10/09 & Thorium-228 & 0.91 & 0.35 & 0.12 \\
\hline EMWNT-05 & 04/13/09 & Thorium-229 & 1.34 & 1.33 & 0.2 \\
\hline EMWNT-05 & 08/10/09 & Thorium-230 & 0.87 & 0.34 & 0.12 \\
\hline EMWNT-05 & $11 / 09 / 09$ & Thorium-230 & 0.29 & 0.2 & 0.16 \\
\hline EMWNT-05 & 08/10/09 & Thorium-232 & 0.64 & 0.28 & 0.12 \\
\hline EMWNT-05 & 02/09/09 & Uranium-233/234 & 0.28 & 0.23 & 0.26 \\
\hline EMWNT-05 & 04/13/09 & Uranium-233/234 & 0.67 & 0.41 & 0.31 \\
\hline EMWNT-05 & 08/10/09 & Uranium-233/234 & 0.96 & 0.53 & 0.54 \\
\hline EMWNT-05 & 08/10/09 & Uranium-235/236 & 0.5 & 0.4 & 0.34 \\
\hline EMWNT-05 & 04/13/09 & Uranium-238 & 0.37 & 0.31 & 0.34 \\
\hline EMWNT-05 & 08/10/09 & Uranium-238 & 0.92 & 0.49 & 0.36 \\
\hline EMW-VWEIR Dup & $11 / 09 / 09$ & Americium-241 & 0.4 & 0.28 & 0.12 \\
\hline EMW-VWEIR & $11 / 09 / 09$ & Nickel-63 & 27.5 & 13.3 & 21.3 \\
\hline EMW-VWEIR & $11 / 09 / 09$ & Plutonium-242 & 0.16 & 0.13 & 0.12 \\
\hline EMW-VWEIR & 08/10/09 & Potassium-40 & 62.2 & 47.92 & 48.6 \\
\hline EMW-VWEIR & $11 / 09 / 09$ & Radium-226 & 0.74 & 0.5 & 0.63 \\
\hline EMW-VWEIR & 02/09/09 & Strontium-90 & 18.4 & 1.73 & 1.99 \\
\hline EMW-VWEIR Dup & 02/09/09 & Strontium-90 & 15.8 & 1.52 & 1.87 \\
\hline EMW-VWEIR & 04/13/09 & Strontium-90 & 25 & 2.02 & 2.28 \\
\hline EMW-VWEIR & 08/10/09 & Strontium-90 & 35.8 & 1.89 & 1.44 \\
\hline EMW-VWEIR & $11 / 09 / 09$ & Strontium-90 & 17.1 & 1.26 & 1.23 \\
\hline EMW-VWEIR Dup & $11 / 09 / 09$ & Strontium-90 & 14.5 & 1.17 & 1.39 \\
\hline EMW-VWEIR & 04/13/09 & Technetium-99 & 5.19 & 3.13 & 5.18 \\
\hline EMW-VWEIR & 08/10/09 & Technetium-99 & 6.92 & 3.22 & 5.28 \\
\hline EMW-VWEIR Dup & $11 / 09 / 09$ & Technetium-99 & 6.85 & 3.13 & 5.12 \\
\hline EMW-VWEIR & 02/09/09 & Thorium-230 & 0.17 & 0.15 & 0.14 \\
\hline EMW-VWEIR & 08/10/09 & Thorium-230 & 0.2 & 0.16 & 0.16 \\
\hline EMW-VWEIR & 11/09/09 & Thorium-230 & 0.43 & 0.26 & 0.25 \\
\hline EMW-VWEIR Dup & $11 / 09 / 09$ & Thorium-230 & 0.56 & 0.3 & 0.23 \\
\hline EMW-VWEIR & 08/10/09 & Tritium & 837 & 199.94 & 279 \\
\hline EMW-VWEIR & 02/09/09 & Uranium-233/234 & 4.59 & 1.14 & 0.31 \\
\hline EMW-VWEIR Dup & 02/09/09 & Uranium-233/234 & 5.31 & 1.27 & 0.27 \\
\hline EMW-VWEIR & 04/13/09 & Uranium-233/234 & 8.4 & 1.68 & 0.31 \\
\hline EMW-VWEIR & 08/10/09 & Uranium-233/234 & 6.24 & 1.54 & 0.17 \\
\hline EMW-VWEIR & $11 / 09 / 09$ & Uranium-233/234 & 44.7 & 6.65 & 0.16 \\
\hline EMW-VWEIR Dup & $11 / 09 / 09$ & Uranium-233/234 & 51.3 & 7.67 & 0.18 \\
\hline EMW-VWEIR Dup & 02/09/09 & Uranium-235/236 & 0.42 & 0.33 & 0.28 \\
\hline EMW-VWEIR & 04/13/09 & Uranium-235/236 & 0.41 & 0.31 & 0.29 \\
\hline EMW-VWEIR & 08/10/09 & Uranium-235/236 & 0.44 & 0.38 & 0.35 \\
\hline EMW-VWEIR & $11 / 09 / 09$ & Uranium-235/236 & 2.18 & 0.59 & 0.08 \\
\hline EMW-VWEIR Dup & $11 / 09 / 09$ & Uranium-235/236 & 2.48 & 0.67 & 0.15 \\
\hline
\end{tabular}


APPENDIX D.4: CY 2009 MONITORING DATA FOR THE BEAR CREEK HYDROGEOLOGIC REGIME Monitoring Data for the EMWMF: Radiological Analytes

\begin{tabular}{|c|c|c|c|c|c|}
\hline \multirow{2}{*}{$\begin{array}{r}\text { Sampling } \\
\text { Point }\end{array}$} & \multirow{2}{*}{$\begin{array}{c}\text { Date } \\
\text { Sampled }\end{array}$} & \multirow{2}{*}{ Isotope } & \multicolumn{3}{|c|}{ Result (pCi/L) } \\
\hline & & & Activity & TPU & MDA \\
\hline EMW-VWEIR & $02 / 09 / 09$ & Uranium-238 & 2.66 & 0.8 & 0.25 \\
\hline EMW-VWEIR Dup & 02/09/09 & Uranium-238 & 3.83 & 1.02 & 0.13 \\
\hline EMW-VWEIR & 04/13/09 & Uranium-238 & 1.74 & 0.6 & 0.12 \\
\hline EMW-VWEIR & 08/10/09 & Uranium-238 & 1.02 & 0.52 & 0.28 \\
\hline EMW-VWEIR & 11/09/09 & Uranium-238 & 2.84 & 0.66 & 0.13 \\
\hline EMW-VWEIR Dup & $11 / 09 / 09$ & Uranium-238 & 2.62 & 0.64 & 0.16 \\
\hline EMW-VWUNDER & $08 / 11 / 09$ & Chlorine-36 & $3.28 \mathrm{Q}$ & 2.11 & $\overline{2.9}$ \\
\hline EMW-VWUNDER & 02/12/09 & Plutonium-242 & 0.36 & 0.22 & 0.14 \\
\hline EMW-VWUNDER & 02/12/09 & Radium-226 & 0.17 & 0.12 & 0.14 \\
\hline EMW-VWUNDER & 08/11/09 & Radium-226 & 0.23 & 0.16 & 0.14 \\
\hline EMW-VWUNDER Dup & $11 / 12 / 09$ & Radium-226 & 0.17 & 0.13 & 0.11 \\
\hline EMW-VWUNDER & 08/11/09 & Radium-228 & 0.63 & 0.23 & 0.56 \\
\hline EMW-VWUNDER & 02/12/09 & Strontium-90 & 1.48 & 0.75 & 1.43 \\
\hline EMW-VWUNDER & 08/11/09 & Strontium-90 & $4.7 \mathrm{Q}$ & 0.76 & 1.14 \\
\hline EMW-VWUNDER Dup & $11 / 12 / 09$ & Technetium-99 & 3.04 & 1.76 & 2.91 \\
\hline EMW-VWUNDER & 04/16/09 & Thorium-230 & 0.18 & 0.17 & 0.17 \\
\hline EMW-VWUNDER & 08/11/09 & Thorium-230 & 0.2 & 0.16 & 0.16 \\
\hline EMW-VWUNDER & 02/12/09 & Uranium-233/234 & 0.33 & 0.2 & 0.16 \\
\hline EMW-VWUNDER & 04/16/09 & Uranium-233/234 & 0.17 & 0.13 & 0.11 \\
\hline EMW-VWUNDER & 08/11/09 & Uranium-233/234 & 0.51 & 0.25 & 0.13 \\
\hline EMW-VWUNDER & 04/16/09 & Uranium-235/236 & 0.18 & 0.15 & 0.08 \\
\hline EMW-VWUNDER & 04/16/09 & Uranium-238 & 0.2 & 0.14 & 0.07 \\
\hline EMW-VWUNDER & 08/11/09 & Uranium-238 & 0.17 & 0.14 & 0.13 \\
\hline NT-04 & $04 / 13 / 09$ & Strontium-90 & 2.31 & 0.93 & 1.76 \\
\hline NT-04 & $11 / 09 / 09$ & Strontium-90 & 1.74 & 0.77 & 1.44 \\
\hline NT-04 & 11/09/09 & Technetium-99 & 5.03 & 3.03 & 5.01 \\
\hline NT-04 & 02/09/09 & Tritium & 351 & 158.67 & 251 \\
\hline NT-04 & 02/09/09 & Uranium-233/234 & 1.69 & 0.59 & 0.26 \\
\hline NT-04 & 04/13/09 & Uranium-233/234 & 1.52 & 0.62 & 0.38 \\
\hline NT-04 & 08/10/09 & Uranium-233/234 & 0.64 & 0.4 & 0.37 \\
\hline NT-04 & $11 / 09 / 09$ & Uranium-233/234 & 1.07 & 0.4 & 0.2 \\
\hline NT-04 & 02/09/09 & Uranium-238 & 1.39 & 0.53 & 0.23 \\
\hline NT-04 & 04/13/09 & Uranium-238 & 1.88 & 0.69 & 0.15 \\
\hline NT-04 & 08/10/09 & Uranium-238 & 0.83 & 0.45 & 0.26 \\
\hline NT-04 & $11 / 09 / 09$ & Uranium-238 & 1.6 & 0.5 & 0.21 \\
\hline
\end{tabular}


APPENDIX E

CY 2009 MONITORING DATA FOR THE UPPER EAST FORK POPLAR CREEK HYDROGEOLOGIC REGIME 



\section{EXPLANATION}

Sampling Point:

200A6 - Surface water location in storm drain near the outfall to Upper East Fork Poplar Creek

GHK - Gum Hollow Branch Kilometer (surface water sampling location)

GW - Groundwater monitoring well (also hyphenated numbers [e.g., 55-3A])

NPR - North of Pine Ridge near the Scarboro Community (surface water sampling location)

SCR - Spring sampling location in Union Valley

SP - Spring sampling location in the Y-12 Complex

STATION - Surface water sampling location in Upper East Fork Poplar Creek

\section{Location:}

B8110 - Building 81-10

B9201-2 - Building 9201-2

B9201-5 - Building 9201-5

CPT - Coal Pile Trench

EXP-E - Exit Pathway Picket E

EXP-I - Exit Pathway Picket I

EXP-J - Exit Pathway Picket J

EXP-SR - Along Scarboro Road in the gap through Pine Ridge

EXP-SW - Surface water or spring sampling station

EXP-UV - East of the Oak Ridge Reservation boundary in Union Valley

FF - Fuel Facility (Building 9754-2)

GRID - Comprehensive Groundwater Monitoring Plan Grid Location (MMES 1990b)

NHP - New Hope Pond

RG - Rust Garage Area

S2 - S-2 Site

S3 - S-3 Site

SY - Y-12 Salvage Yard

T0134 - Tank 0134-U

T2331 - Tank 2331-U

UOV - Uranium Oxide Vault

WCPA - Waste Coolant Processing Area

Y-12 - Y-12 Complex

\section{Monitoring Program:}

BJC - managed by Bechtel Jacobs Company LLC

GWPP - managed by the Y-12 Groundwater Protection Program

\section{Sample Type:}

Dup - field duplicate sample

PDB - passive diffusion bag sample

$\mathrm{NP} \quad$ - sample collected without purging the well (no purge method) 


\section{EXPLANATION (continued)}

Units:

$\begin{array}{rll}\mathrm{ft} & - & \text { feet (elevations are above mean sea level and depths are below grade) } \\ \mu \mathrm{g} / \mathrm{L} & - & \text { micrograms per liter } \\ \mathrm{mg} / \mathrm{L} & - & \text { milligrams per liter } \\ \mathrm{mV} & - & \text { millivolts } \\ \mu \mathrm{mho} / \mathrm{cm} & - & \text { micromhos per centimeter } \\ \mathrm{NTU} & - & \text { nephelometric turbidity units } \\ \mathrm{pCi} / \mathrm{L} & - & \text { picoCuries per liter } \\ \mathrm{ppm} & - & \text { parts per million }\end{array}$

Only analytes detected above reporting limits in at least one sample are included in this appendix. Additionally, results that are below the reporting limits are replaced with missing values (e.g., " < ") to emphasize the detected results. The following sections describe the analytes, reporting limits, and data qualifiers for each subappendix. A comprehensive list of the GWPP analytes, analytical methods, and reporting limits is provided in Appendix B, Table B.5.

\section{E.1 Field Measurements, Miscellaneous Analytes, Major Ions, and Trace Metals:}

Results for all of the field measurements, miscellaneous analytes, and major ions are included in this appendix. The reporting limits for the major ions are shown in the following summary.

\begin{tabular}{|c|c|c|c|c|c|}
\hline \multirow{2}{*}{ Analyte } & \multicolumn{2}{|c|}{ Reporting Limit (mg/L) } & \multirow{2}{*}{ Analyte } & \multicolumn{2}{|c|}{ Reporting Limit (mg/L) } \\
\hline & GWPP & BJC & & GWPP & BJC \\
\hline $\begin{array}{r}\text { Calcium } \\
\text { Magnesium } \\
\text { Potassium } \\
\text { Sodium }\end{array}$ & $\begin{array}{l}0.2 \\
0.2 \\
2.0 \\
0.2\end{array}$ & $\begin{array}{c}0.01 \\
0.05 \\
0.025 \\
0.01\end{array}$ & $\begin{array}{r}\text { Anions } \\
\text { Bicarbonate } \\
\text { Carbonate } \\
\text { Chloride } \\
\text { Fluoride } \\
\text { Nitrate (as Nitrogen) } \\
\text { Sulfate }\end{array}$ & $\begin{array}{c}1.0 \\
1.0 \\
0.2 \\
0.1 \\
0.05 \\
0.25\end{array}$ & $\begin{array}{c}\text { NS } \\
\text { NS } \\
0.1 \\
0.05 \\
0.1 \\
0.1\end{array}$ \\
\hline
\end{tabular}

The major ion results for one of the samples collected from well GW-170 are qualitative because the ion charge balance error (percent) exceeds 20\%. The geochemistry of samples from well GW-170 has reflected potential grout contamination since CY 2000, as shown by the elevated pH (typically > 10).

The Y-12 GWPP SAP (B\&W Y-12 2008) specifies analytical methods and reporting limits for trace metals that are appropriate for DOE Order monitoring. The laboratories subcontracted for the monitoring programs managed by BJC may use reporting limits (sometimes reporting estimated values) that are lower than the GWPP reporting limits for the metals. For this report, the analytical methods for metals used by BJC monitoring programs (EPA-7470, SW846-6010B, SW846-6020, and ASTM-D5174-M) are considered to be functionally equivalent to the methods used by the GWPP (Table B.5). To retain the highest quality data for DOE Order monitoring purposes and to standardize reporting limits for trace metal results obtained from all sources, the GWPP reporting limits were given precedence over the BJC reporting limits (BJC 2009a) shown below. The trace metals shown in bold typeface below were detected in at least one sample collected during CY 2009 and are presented in Appendix E.1. 


\section{EXPLANATION (continued)}

\begin{tabular}{|r|c|c|r|c|c|}
\hline \multirow{2}{*}{ Analyte } & \multicolumn{2}{|c|}{ Reporting Limit $(\mathbf{m g} / \mathbf{L})$} & \multirow{2}{*}{ Analyte } & \multicolumn{2}{c|}{ Reporting Limit (mg/L) } \\
\cline { 2 - 3 } \cline { 4 - 5 } & GWPP & BJC & & GWPP & BJC \\
\hline Aluminum & 0.2 & $0.05^{*}$ & Lithium & 0.01 & 0.01 \\
Antimony & $0.0025^{* *}$ & 0.003 & Manganese & 0.005 & 0.005 \\
Arsenic & $0.005^{* *}$ & 0.005 & Mercury & 0.00005 & 0.0002 \\
Barium & 0.004 & 0.005 & Molybdenum & 0.05 & NS \\
Beryllium & 0.0005 & 0.001 & Nickel & $0.005^{* *}$ & 0.01 \\
Boron & 0.1 & $0.01^{*}$ & Selenium & $0.01^{* *}$ & $0.0025^{*}$ \\
Cadmium & $0.0025^{* *}$ & $0.00013^{*}$ & Silver & 0.02 & $0.0015^{*}$ \\
Chromium & $0.01^{* *}$ & $0.005^{*}$ & Strontium & 0.005 & 0.005 \\
Cobalt & 0.02 & $0.005^{*}$ & Thallium & $0.0005^{* *}$ & 0.001 \\
Copper & 0.02 & $0.005^{*}$ & Thorium & 0.2 & NS \\
Iron & 0.05 & $0.01^{*}$ & Uranium & $0.0005^{* *}$ & 0.004 \\
Lead & $0.0005^{* *}$ & 0.002 & Vanadium & 0.02 & $0.01^{*}$ \\
& & & Zinc & 0.05 & $0.01^{*}$ \\
\hline
\end{tabular}

Note: * - the GWPP reporting limit is used instead of the BJC reporting limit; ** - samples collected after June 2009 were diluted (additional 2X) before analysis which doubled the reporting limit; “NS” - not specified.

To evaluate mercury concentrations in surface water as it exits the Y-12 complex, monitoring by BJC included the following results that are not presented in Appendix E.1.

\begin{tabular}{|c|c|c|}
\hline \multirow{2}{*}{$\begin{array}{c}\text { Station 17 } \\
\text { Sampling Date }\end{array}$} & \multicolumn{2}{|c|}{ Mercury Concentration (mg/L) by Method EPA-1631 } \\
\cline { 2 - 3 } & Total & Dissolved (filtered) \\
\hline $06 / 09 / 09$ & 0.0002895 & 0.0000757 \\
$12 / 17 / 09$ & 0.0002849 & 0.0001211 \\
\hline
\end{tabular}

The following symbols and qualifiers are used in Appendix E.1:

- $\quad$ - Not analyzed or not applicable

$<\quad$ - Analyzed but not detected at the project reporting level

$\mathrm{Q} \quad$ - $\quad$ Result is inconsistent with historical measurements for the location

$\mathrm{R}$ - Result does not meet data quality objectives 


\section{EXPLANATION (continued)}

\section{E.2 Volatile Organic Compounds:}

The Y-12 GWPP reporting limits for volatile organic compounds (Table B.5) and those used for monitoring programs managed by BJC are contract-required quantitation limits. Results below the quantitation limit and above the instrument detection limit are reported as estimated quantities. Therefore, non-detected results are assumed to equal zero for all compounds.

As summarized below, 30 compounds were detected in the CY 2009 groundwater samples collected in the East Fork Regime. Results for these compounds are grouped by similar chemical composition (e.g., chloroethenes) in Appendix E.2.

\begin{tabular}{|c|c|c|c|c|c|}
\hline Compound & $\begin{array}{c}\text { No. } \\
\text { Detected }\end{array}$ & $\begin{array}{c}\text { Maximum } \\
(\mu \mathrm{g} / \mathrm{L})\end{array}$ & Compound & \begin{tabular}{|c|c} 
No. \\
Detected
\end{tabular} & $\begin{array}{c}\text { Maximum } \\
(\mu \mathrm{g} / \mathrm{L})\end{array}$ \\
\hline Tetrachloroethene & 79 & 51,000 & Bromoform & 5 & 10.1 \\
\hline Trichloroethene & 65 & 6,400 & Toluene & 4 & 2,110 \\
\hline cis-1,2-Dichloroethene & 59 & 1,500 & Total Xylene & 3 & 6,670 \\
\hline Chloroform & 44 & 120 & 2-Butanone & 3 & 6 \\
\hline Carbon tetrachloride & 39 & 1,340 & Ethylbenzene & 2 & 837 \\
\hline 1,1-Dichloroethene & 34 & 210 & 1,1,1,2-Tetrachloroethane & 2 & $2 \mathrm{~J}$ \\
\hline Vinyl chloride & 26 & 530 & Ethylene & 2 & $1.56 \mathrm{~J}$ \\
\hline trans-1,2-Dichloroethene & 24 & 76 & 1,2-Dichloroethane & 1 & 373 \\
\hline 1,1-Dichloroethane & 20 & 46 & Styrene & 1 & $4 \mathrm{~J}$ \\
\hline 1,1,2-Trichloro-1,2,2-trifluoroethane & 18 & 2,300 & Trichlorofluoromethane & 1 & $2 \mathrm{~J}$ \\
\hline Methane & 15 & 729 & Ethane & 1 & $1.76 \mathrm{~J}$ \\
\hline Benzene & 9 & 8,110 & 1,2-Dichloropropane & 1 & $1 \mathrm{~J}$ \\
\hline 1,1,1-Trichloroethane & 8 & 52 & 1,4-Dichlorobenzene & 1 & $1 \mathrm{~J}$ \\
\hline Acetone & 6 & 45 & Bromodichloromethane & 1 & $1 \mathrm{~J}$ \\
\hline Methylene chloride & 5 & 48.8 & Chloroethane & 1 & $1 \mathrm{~J}$ \\
\hline
\end{tabular}

Also presented in Appendix E.2 are results for volatile organic gases (ethane, ethylene, and methane) as natural attenuation indicators for groundwater samples collected from nine wells in the East Fork Regime.

The following symbols and data qualifiers are used in Appendix E.2.

- $\quad$ - Not analyzed

$<\quad$ - Analyzed but not detected

$\mathrm{J}$ - Positively identified, estimated concentration below the contract-required quantitation limit

Q - Result is inconsistent with historical measurements for the location 


\section{EXPLANATION (continued)}

\section{E.3 Radiological Analytes:}

Reporting limits for radiological analytes are sample-specific and analyte-specific minimum detectable activities that are reported with each result. The following summary shows the radiological analytes reported for at least one groundwater sample collected during CY 2009 in the East Fork Regime.

\begin{tabular}{|r|c|c|c|c|c|}
\hline Analyte & $\begin{array}{c}\text { No. of } \\
\text { Results }\end{array}$ & $\begin{array}{c}\text { No. } \\
\text { Detected }\end{array}$ & Analyte & $\begin{array}{c}\text { No. of } \\
\text { Results }\end{array}$ & $\begin{array}{c}\text { No. } \\
\text { Detected }\end{array}$ \\
\hline Gross Alpha & 89 & 34 & Uranium-234* & 14 & 13 \\
Gross Beta & 89 & 51 & Uranium-235* & 14 & 8 \\
Technetium-99 & 12 & 2 & Uranium-238 & 14 & 12 \\
\hline Note: * Reported by BJC laboratories in Appendix E.3 as equivalent GWPP analytes: \\
U-233/234 = U-234; U-235/236 = U-235.
\end{tabular}

Results for gross alpha and gross beta are presented in the first four pages of Appendix E.3, followed by the results for the isotopes. The following notes and qualifiers apply to Appendix E.3:

Result - Activity in picoCuries per liter (pCi/L)

TPU - Total propagated uncertainty (two standard deviations); calculation includes the counting error (instrument uncertainty) as reported previously, plus other sources of uncertainty (e.g., volumetric, chemical yield)

MDA - Minimum detectable activity

. - Not analyzed or not applicable (TPU is not presented when the result is $<$ MDA)

$<\quad$ - Analyzed but less than the MDA (not detected)

$\mathrm{R}$ - Result does not meet data quality objectives: exceeds the MDA but is less than the TPU 

APPENDIX E.1

FIELD MEASUREMENTS, MISCELLANEOUS ANALYTES, MAJOR IONS, AND TRACE METALS 

APPENDIX E.1: CY 2009 MONITORING DATA FOR THE UPPER EAST FORK POPLAR CREEK HYDROGEOLOGIC REGIME Field Measurements, Miscellaneous Analytes, Major Ions, and Trace Metals

\begin{tabular}{|c|c|c|c|c|c|c|c|c|c|c|}
\hline Sampling Point & $55-2 A$ & 55-2B & $55-2 \mathrm{C}$ & \multicolumn{2}{|c|}{$55-3 A$} & \multicolumn{2}{|c|}{$55-3 B$} & \multicolumn{2}{|c|}{$55-3 C$} & $56-1 A$ \\
\hline Functional Area & GRIDB3 & GRIDB3 & GRIDB3 & \multicolumn{2}{|c|}{ B9201-5 } & \multicolumn{2}{|c|}{ B9201-5 } & \multicolumn{2}{|c|}{ B9201-5 } & Y12 \\
\hline Date Sampled & $10 / 27 / 09$ & $10 / 26 / 09$ & $10 / 26 / 09$ & 05/14/09 & $10 / 20 / 09$ & $05 / 14 / 09$ & $10 / 21 / 09$ & 05/13/09 & $10 / 21 / 09$ & $07 / 28 / 09$ \\
\hline Program & GWPP & GWPP & GWPP & GWPP & GWPP & GWPP & GWPP & GWPP & GWPP & GWPP \\
\hline \multicolumn{11}{|l|}{ Sample Type } \\
\hline Field Measurements & \multirow{13}{*}{$9: 35$} & & & & & & & & & \\
\hline Time Sampled & & $9: 50$ & $11: 00$ & $10: 30$ & $14: 50$ & $8: 50$ & $9: 50$ & $14: 15$ & $11: 10$ & $10: 30$ \\
\hline Measuring Point Elev. (ft) & & 977.42 & 977.02 & 972.46 & 972.46 & 973.32 & 973.32 & 974.34 & 974.34 & 969.25 \\
\hline Depth to Water (ft) & & 7.69 & 8.18 & 11.68 & 11.71 & 12.25 & 12.66 & 12.65 & 13.92 & 7.88 \\
\hline \multicolumn{10}{|l|}{ Groundwater Elevation (ft) } & \\
\hline Conductivity ( $\mu \mathrm{mho} / \mathrm{cm})$ & & 2,570 & 2,430 & 754 & 693 & 443 & 439 & 451 & 454 & 494 \\
\hline Dissolved Oxygen (ppm) & & 0.35 & 1.72 & 2.43 & 0.9 & 1.69 & 0.46 & 0.76 & 1.73 & 0.95 \\
\hline Iron $(++)$ & & & & & & & & & & \\
\hline Manganese $(++)$ & & & & & & & & & & \\
\hline Oxidation/Reduction (mV) & & 194 & 144 & 160 & 137 & 141 & -31 & 131 & 76 & 295 \\
\hline Temperature (degrees C) & & 17.8 & 16.8 & 17.8 & 19.7 & 18.4 & 15.8 & 21.6 & 15 & 24.1 \\
\hline \multicolumn{10}{|l|}{ Turbidity (NTU) } & \\
\hline $\mathrm{pH}$ & & 6.21 & 6.83 & 7.02 & 6.82 & 7.36 & 7.23 & 7.33 & 7.39 & 7.53 \\
\hline \multicolumn{11}{|l|}{ Miscellaneous Analytes } \\
\hline Dissolved Solids (mg/L) & & 2,030 & & 404 & 360 & 233 & 195 & 208 & 251 & 313 \\
\hline Suspended Solids (mg/L) & & $<$ & & $<$ & $<$ & $<$ & $<$ & $<$ & $<$ & 1 \\
\hline \multicolumn{11}{|l|}{ Major lons (mg/L) } \\
\hline Calcium & & 384 & & 103 & 102 & 58.8 & 58.1 & 52.3 & 55.2 & 66.4 \\
\hline Magnesium & & 33.5 & & 14.6 & 13.1 & 11.5 & 11 & 12.3 & 12.3 & 11.9 \\
\hline Potassium & & 3.36 & & 3.13 & 3.41 & 4.39 & 4.26 & 6.75 & 6.8 & 3.02 \\
\hline Sodium & & 11.7 & & 8.98 & 9.37 & 3.49 & 3.83 & 12.6 & 13 & 13.6 \\
\hline Bicarbonate & & 139 & & 151 & 166 & 137 & 146 & 167 & 172 & 130 \\
\hline Carbonate & & $<$ & & $<$ & $<$ & $<$ & $<$ & $<$ & $<$ & $<$ \\
\hline Chloride & 14.1 & 15 & 13.2 & 16.7 & 15.1 & 30.7 & 32.1 & 17.9 & 20.5 & 23.3 \\
\hline Fluoride & & $<$ & & $<$ & $<$ & $<$ & $<$ & $<$ & $<$ & 0.471 \\
\hline Nitrate as $\mathrm{N}$ & 212 & 292 & 261 & 1.44 & 1.26 & $<$ & $<$ & $<$ & $<$ & 0.633 \\
\hline Sulfate & 20.6 & 20.1 & 16.4 & 155 & 138 & 24.6 & 28.4 & 27.8 & 39.7 & 72 \\
\hline Charge balance error (\%) & & -4.2 & & -0.1 & -0.3 & 0.3 & -3.9 & -0.9 & -3.6 & 1.4 \\
\hline \multicolumn{11}{|l|}{ Trace Metals (mg/L) } \\
\hline Aluminum & & $<$ & & $<$ & $<$ & $<$ & $<$ & $<$ & $<$ & $<$ \\
\hline Antimony & & & & $<$ & & $<$ & $<$ & $<$ & $<$ & $<$ \\
\hline Arsenic & & & & $<$ & & $<$ & $<$ & $<$ & $<$ & $<$ \\
\hline Barium & & 0.964 & & 0.0381 & 0.045 & 0.257 & & 0.149 & & 0.0639 \\
\hline Beryllium & & $<$ & & & & $<$ & $<$ & $<$ & $<$ & $<$ \\
\hline Boron & & $<$ & & 0.131 & 0.131 & $<$ & $<$ & 0.108 & 0.103 & $<$ \\
\hline Cadmium & & & & & & $<$ & $<$ & $<$ & $<$ & $<$ \\
\hline Chromium & & & & 0.00392 & & $<$ & $<$ & $<$ & $<$ & 0.145 \\
\hline Cobalt & & $<$ & & & $<$ & $<$ & $<$ & $<$ & $<$ & $<$ \\
\hline Copper & & $<$ & & $<$ & $<$ & $<$ & $<$ & $<$ & $<$ & $<$ \\
\hline Iron & & $<$ & & $<$ & $<$ & $<$ & 0.101 & $<$ & $<$ & 0.904 \\
\hline Lead & & & & $<$ & & $<$ & 0.00107 & $<$ & $<$ & $<$ \\
\hline Lithium & & 0.0232 & & $<$ & 0.0108 & 0.0156 & 0.0158 & 0.0193 & 0.0207 & 0.0169 \\
\hline Manganese & & 0.712 & & 0.0084 & 0.0056 & 0.00571 & 0.0356 & 0.0178 & 0.0251 & 0.0067 \\
\hline Mercury & & $<$ & & & $<$ & $<$ & $<$ & $<$ & $<$ & 0.0000835 \\
\hline Nickel & & & & 0.025 & & $<$ & $<$ & $<$ & & 0.102 \\
\hline Strontium & & 1.23 & & 0.273 & 0.269 & 0.725 & 0.686 & 1.37 & 1.37 & 0.414 \\
\hline Thallium & & $<$ & & & & $<$ & $<$ & $<$ & $<$ & $<$ \\
\hline Uranium & & $<$ & & 0.000635 & $<$ & $<$ & $<$ & $<$ & $<$ & 0.00194 \\
\hline Zinc & & $<$ & & $<$ & $<$ & $<$ & $<$ & $<$ & $<$ & 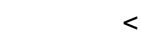 \\
\hline
\end{tabular}


APPENDIX E.1: CY 2009 MONITORING DATA FOR THE UPPER EAST FORK POPLAR CREEK HYDROGEOLOGIC REGIME Field Measurements, Miscellaneous Analytes, Major Ions, and Trace Metals

\begin{tabular}{|c|c|c|c|c|c|c|c|c|c|c|}
\hline Sampling Point & \multicolumn{2}{|c|}{$56-1 C$} & $56-2 A$ & $56-2 B$ & $56-3 A$ & $56-3 B$ & $56-3 C$ & $56-4 A$ & GW- & 108 \\
\hline Functional Area & \multicolumn{2}{|c|}{ Y12 } & GRIDC3 & GRIDC3 & Y12 & Y12 & Y12 & Y12 & \multicolumn{2}{|c|}{ S3 } \\
\hline Date Sampled & \multicolumn{2}{|c|}{$07 / 28 / 09$} & $07 / 29 / 09$ & $07 / 29 / 09$ & $07 / 30 / 09$ & $07 / 29 / 09$ & $07 / 30 / 09$ & $05 / 12 / 09$ & $01 / 12 / 09$ & $07 / 08 / 09$ \\
\hline Program & GWPP & GWPP & GWPP & GWPP & GWPP & GWPP & GWPP & GWPP & BJC & BJC \\
\hline Sample Type & & Dup & & & & & & NP & & \\
\hline \multicolumn{11}{|l|}{ Field Measurements } \\
\hline Time Sampled & $8: 40$ & $8: 40$ & $13: 45$ & $9: 30$ & $9: 40$ & $14: 50$ & 11:05 & $14: 25$ & $14: 30$ & $9: 45$ \\
\hline Measuring Point Elev. (ft) & 969.49 & 969.49 & 963.53 & 962.45 & 963.03 & 964.33 & 962.86 & 962.07 & 999.00 & 999.00 \\
\hline Depth to Water (ft) & 7.10 & 7.10 & 8.25 & 7.50 & 10.10 & 10.56 & 10.16 & 10.27 & 7.02 & 6.67 \\
\hline \multicolumn{11}{|l|}{ Groundwater Elevation (ft) } \\
\hline Conductivity $(\mu \mathrm{mho} / \mathrm{cm})$ & 401 & 401 & 647 & 605 & 542 & 560 & 583 & 218 & 37,615 & 54,002 \\
\hline Dissolved Oxygen (ppm) & 1.06 & 1.06 & 0.13 & 0.85 & 2.83 & 0.34 & 0.32 & 2.5 & 14.42 & 8.09 \\
\hline \multicolumn{11}{|l|}{$\begin{array}{r}\text { Iron }(++) \\
\text { Manganese }(++)\end{array}$} \\
\hline Oxidation/Reduction (mV) & 310 & 310 & 45 & 227 & 248 & 189 & 217 & 128 & 202 & 253 \\
\hline Temperature (degrees C) & 23.2 & 23.2 & 20.8 & 21 & 20.2 & 20.4 & 20.3 & 19 & 17.1 & 21.8 \\
\hline \multicolumn{11}{|l|}{ Turbidity (NTU) } \\
\hline $\mathrm{pH}$ & 7.52 & 7.52 & 7.01 & 7.15 & 6.87 & 7.03 & 7.11 & 7.26 & 5.28 & 5.4 \\
\hline \multicolumn{11}{|l|}{ Miscellaneous Analytes } \\
\hline Dissolved Solids (mg/L) & 275 & 231 & 376 & 366 & 246 & 300 & 340 & 115 & & \\
\hline Suspended Solids (mg/L) & $<$ & $<$ & 3 & 2 & 3 & 1 & 3 & 3 & & \\
\hline \multicolumn{11}{|l|}{ Major lons (mg/L) } \\
\hline Calcium & 28.3 & 28.2 & 101 & 90.2 & 76 & 94.3 & 97.6 & 22.6 & 9,840 & 12,000 \\
\hline Magnesium & 8.5 & 8.61 & 7.92 & 12.3 & 7.07 & 4.43 & 6.44 & 3.25 & 996 & 980 \\
\hline Potassium & 3.66 & 3.9 & 2.71 & 2.76 & 2.13 & $<$ & 2.19 & $<$ & 24.2 & 38 \\
\hline Sodium & 46.5 & 48.6 & 8.71 & 11.8 & 4.95 & 5.21 & 8.13 & 6.07 & 48.7 & 520 \\
\hline Bicarbonate & 189 & 189 & 196 & 185 & 203 & 193 & 174 & 69.1 & 894 & 780 \\
\hline Carbonate & $<$ & $<$ & $<$ & $<$ & $<$ & $<$ & $<$ & $<$ & $<$ & $<$ \\
\hline Chloride & 5.37 & 5.63 & 31 & 14.6 & 8.36 & 15 & 15.5 & 2.77 & 183 & 180 \\
\hline Fluoride & 0.337 & 0.334 & $<$ & & 0.165 & $<$ & $<$ & $<$ & $<$ & $<$ \\
\hline Nitrate as $\mathrm{N}$ & $<$ & $<$ & 0.295 & 0.985 & 0.427 & 0.484 & 0.82 & 1.45 & 8,030 & $38,000 \mathrm{Q}$ \\
\hline Sulfate & 11.6 & 11.6 & 73.3 & 95.1 & 29.7 & 62 & 101 & 9.85 & 9.3 & $<$ \\
\hline Charge balance error (\%) & 0.5 & 1.6 & -1.6 & -0.5 & -3.2 & -2.8 & -2.2 & -3.2 & -1.8 & \\
\hline \multicolumn{11}{|l|}{ Trace Metals (mg/L) } \\
\hline Aluminum & $<$ & $<$ & $<$ & $<$ & $<$ & $<$ & 0.315 & 1.26 & $<$ & $<$ \\
\hline Antimony & $<$ & $<$ & $<$ & $<$ & $<$ & $<$ & $<$ & $<$ & $<$ & $<$ \\
\hline Arsenic & & $<$ & $<$ & $<$ & $<$ & $<$ & $<$ & $<$ & $<$ & 0.0058 \\
\hline Barium & 0.256 & 0.267 & 0.108 & 0.0561 & 0.0914 & 0.0949 & 0.0683 & 0.0402 & 75.4 & 67 \\
\hline Beryllium & & $<$ & $<$ & $<$ & $<$ & $<$ & $<$ & $<$ & $<$ & $0.0023 \mathrm{Q}$ \\
\hline Boron & 0.141 & 0.144 & 0.122 & 0.141 & 0.164 & $<$ & $<$ & $<$ & $<$ & $<$ \\
\hline Cadmium & $<$ & $<$ & $<$ & $<$ & $<$ & $<$ & $<$ & $<$ & $0.00486 \mathrm{Q}$ & $<$ \\
\hline Chromium & $<$ & $<$ & $<$ & $<$ & $<$ & $<$ & $<$ & 0.0204 & $<$ & 0.017 \\
\hline Cobalt & $<$ & $<$ & $<$ & $<$ & $<$ & $<$ & $<$ & $<$ & 0.16 & 0.16 \\
\hline Copper & $<$ & $<$ & $<$ & $<$ & $<$ & $<$ & $<$ & $<$ & $<$ & $<$ \\
\hline Iron & $<$ & $<$ & 0.206 & $<$ & 0.0602 & 0.0568 & 0.213 & 0.663 & $<$ & $<$ \\
\hline Lead & $<$ & $<$ & $<$ & $<$ & $<$ & $<$ & $<$ & $<$ & $<$ & 0.0068 \\
\hline Lithium & 0.0224 & 0.0234 & 0.013 & 0.0158 & $<$ & $<$ & $<$ & $<$ & 0.467 & 0.34 \\
\hline Manganese & 0.0471 & 0.0465 & $<$ & $<$ & $<$ & $<$ & $<$ & 0.0102 & 158 & 170 \\
\hline Mercury & $<$ & $<$ & $<$ & $<$ & $<$ & 5.2E-05 & $<$ & $<$ & $<$ & $<$ \\
\hline Nickel & $<$ & $<$ & 0.0156 & $<$ & 0.0102 & $<$ & $<$ & 0.0214 & 0.203 & 0.12 \\
\hline Strontium & 0.855 & 0.885 & 0.244 & 0.299 & 0.139 & 0.136 & 0.184 & 0.0414 & 29.8 & 28 \\
\hline Thallium & $<$ & $<$ & $<$ & $<$ & $<$ & $<$ & $<$ & $<$ & $<$ & $<$ \\
\hline Uranium & $<$ & $<$ & $<$ & $<$ & $<$ & $<$ & $<$ & $<$ & 0.014 & 0.013 \\
\hline Zinc & $<$ & $<$ & $<$ & $<$ & $<$ & $<$ & $<$ & $<$ & $<$ & $<$ \\
\hline
\end{tabular}


APPENDIX E.1: CY 2009 MONITORING DATA FOR THE UPPER EAST FORK POPLAR CREEK HYDROGEOLOGIC REGIME Field Measurements, Miscellaneous Analytes, Major lons, and Trace Metals

\begin{tabular}{|c|c|c|c|c|c|c|c|c|c|c|c|}
\hline Sampling Point & \multicolumn{2}{|c|}{ GW-151 } & \multicolumn{2}{|c|}{ GW-154 } & \multicolumn{2}{|c|}{ GW-169 } & \multicolumn{4}{|c|}{ GW-170 } & \multirow{3}{*}{$\begin{array}{l}\text { GW-171 } \\
\text { EXP-UV } \\
03 / 05 / 09\end{array}$} \\
\hline Functional Area & \multicolumn{2}{|c|}{ NHP } & \multicolumn{2}{|c|}{ NHP } & \multicolumn{2}{|c|}{ EXP-UV } & \multicolumn{4}{|c|}{ EXP-UV } & \\
\hline Date Sampled & 03/03/09 & 07/23/09 & $03 / 03 / 09$ & 07/23/09 & $03 / 04 / 09$ & $07 / 23 / 09$ & \multicolumn{2}{|c|}{$03 / 04 / 09$} & \multicolumn{2}{|c|}{$07 / 23 / 09$} & \\
\hline Program & BJC & BJC & $\mathrm{BJC}$ & $\mathrm{BJC}$ & BJC & $\mathrm{BJC}$ & BJC & $\mathrm{BJC}$ & BJC & $\mathrm{BJC}$ & BJC \\
\hline Sample Type & & & & & & & & Dup & & Dup & \\
\hline \multicolumn{12}{|l|}{ Field Measurements } \\
\hline Measuring Point Elev. (ft) & 916.17 & 916.17 & 911.70 & 911.70 & 932.12 & 932.12 & 932.64 & 932.64 & 932.64 & 932.64 & 920.72 \\
\hline Depth to Water (ft) & 15.62 & 15.91 & 9.11 & & 31.51 & 31.40 & 35.21 & & 36.05 & & 3.81 \\
\hline \multicolumn{12}{|l|}{ Groundwater Elevation (ft) } \\
\hline Conductivity $(\mu \mathrm{mho} / \mathrm{cm})$ & 474 & 455 & 669 & & 223 & 457 & 1,365 & & 1,231 & & 328 \\
\hline Dissolved Oxygen (ppm) & 0.3 & 1.05 & 4.2 & & 5.58 & 6.9 & 0.23 & & 0.2 & & 1.03 \\
\hline \multirow{2}{*}{\multicolumn{12}{|c|}{$\begin{array}{r}\text { Iron }(++) \\
\text { Manganese }(++)\end{array}$}} \\
\hline & & & & & & & & & & & \\
\hline Oxidation/Reduction (mV) & 84 & 84 & 109 & & 152 & 170 & -178 & & -91 & & -9 \\
\hline Temperature (degrees C) & 14.6 & 17.1 & 12.4 & & 14.4 & 16.1 & 13.7 & & 16.1 & & 14.8 \\
\hline Turbidity (NTU) & 1 & 2 & 4 & & 14 & 5 & 1 & & 3 & & 61 \\
\hline $\mathrm{pH}$ & 7.12 & 7.19 & 7.4 & & 6.43 & 6.95 & 11.7 & & 10.31 & & 5.73 \\
\hline \multicolumn{12}{|l|}{ Miscellaneous Analytes } \\
\hline Dissolved Solids (mg/L) & 284 & 334 & 482 & 759 & 162 & 229 & 380 & 395 & 336 & 325 & 249 \\
\hline Suspended Solids (mg/L) & $<$ & $<$ & 24 & 11 & 12 & 10 & 8 & 8 & 15 & 13 & 23 \\
\hline \multicolumn{12}{|l|}{ Major lons (mg/L) } \\
\hline Calcium & 56.5 & 58.3 & 124 & 277 & 51.1 & 68.2 & 124 & 120 & 106 & 105 & \\
\hline Magnesium & 25.3 & 26.2 & 18.9 & 22 & 2.74 & 3.7 & 1.02 & 1.77 & 1.9 & 1.65 & \\
\hline Potassium & 2.24 & 2.23 & 5.47 & 6.96 & 2.45 & 2.58 & 12.5 & 12.2 & 12.7 & 12.4 & \\
\hline Sodium & 7.37 & 7.26 & 7.2 & 8.51 & 1.1 & 1.22 & 6.05 & 5.88 & 5.73 & 5.62 & \\
\hline Bicarbonate & 238 & 226 & & & 135 & 193 & $<$ & $<$ & $<$ & $<$ & \\
\hline Carbonate & $<$ & $<$ & & & $<$ & $<$ & 87.1 & 55.4 & 20.3 & 16.2 & \\
\hline Chloride & 19.9 & 20 & & & 1.4 & 1.83 & 5.5 & 5.4 & 5.75 & 5.86 & \\
\hline Fluoride & 0.16 & 0.134 & & & $<$ & $<$ & 0.17 & 0.18 & 0.123 & 0.124 & \\
\hline Nitrate as N & 0.74 & 0.38 & & & 0.62 & 0.35 & 0.27 & 0.27 & 0.22 & 0.23 & \\
\hline Sulfate & 22.4 & 24.4 & & & 4.5 & 7.06 & 7.1 & 7.1 & 8.03 & 8.04 & \\
\hline Charge balance error (\%) & -5.1 & -1.7 & & & 0.2 & -3.2 & -1.6 & & $72.5 \mathrm{R}$ & & \\
\hline \multicolumn{12}{|l|}{ Trace Metals (mg/L) } \\
\hline Aluminum & $<$ & $<$ & $<$ & 2.83 & 0.769 & 0.2 & 0.225 & 0.312 & 0.359 & 0.308 & \\
\hline Antimony & $<$ & $<$ & $<$ & $<$ & $<$ & $<$ & $<$ & $<$ & $<$ & $<$ & \\
\hline Arsenic & $<$ & $<$ & $<$ & $<$ & $<$ & $<$ & $<$ & $<$ & $<$ & $<$ & \\
\hline Barium & 0.179 & 0.177 & 0.0878 & 0.394 & 0.0268 & 0.0308 & 0.16 & 0.156 & 0.159 & 0.156 & \\
\hline Beryllium & $<$ & $<$ & $<$ & & & $<$ & $<$ & $<$ & $<$ & $<$ & \\
\hline Boron & $<$ & $<$ & $<$ & 0.101 & $<$ & $<$ & $<$ & $<$ & $<$ & $<$ & \\
\hline Cadmium & $<$ & $<$ & $<$ & 0.00466 & $<$ & $<$ & $<$ & $<$ & $<$ & $<$ & \\
\hline Chromium & $<$ & $<$ & $<$ & & $<$ & $<$ & $<$ & $<$ & $<$ & $<$ & \\
\hline Cobalt & $<$ & $<$ & $<$ & $<$ & $<$ & $<$ & $<$ & $<$ & $<$ & $<$ & \\
\hline Copper & $<$ & $<$ & $<$ & 0.0298 & $<$ & $<$ & $<$ & $<$ & $<$ & $<$ & \\
\hline Iron & $<$ & $<$ & 0.144 & 3.06 & 0.554 & 0.164 & 0.438 & 0.859 & 0.851 & 0.671 & \\
\hline Lead & $<$ & $<$ & $<$ & 0.019 & 0.00244 & $<$ & $<$ & $<$ & $<$ & $<$ & \\
\hline Lithium & $<$ & $<$ & $<$ & 0.0142 & $<$ & $<$ & 0.0342 & 0.0332 & 0.0334 & 0.0327 & \\
\hline Manganese & $<$ & $<$ & 0.91 & 6.58 & 0.016 & 0.00582 & $<$ & 0.0072 & 0.0073 & 0.0058 & \\
\hline Mercury & & & & & & & & & & & \\
\hline Nickel & $<$ & $<$ & $<$ & 0.0229 & $<$ & $<$ & $<$ & $<$ & $<$ & $<$ & \\
\hline Strontium & 0.54 & 0.538 & 0.45 & 0.564 & 0.0638 & 0.0877 & 0.618 & 0.601 & 0.632 & 0.622 & \\
\hline Thallium & $<$ & $<$ & & 0.00567 & $<$ & $<$ & $<$ & $<$ & $<$ & $<$ & \\
\hline Uranium & $<$ & $<$ & 0.6 & 0.56 & & & & &. & & \\
\hline Zinc & $<$ & $<$ & $<$ & 0.132 & $<$ & $<$ & $<$ & $<$ & $<$ & $<$ & \\
\hline
\end{tabular}


APPENDIX E.1: CY 2009 MONITORING DATA FOR THE UPPER EAST FORK POPLAR CREEK HYDROGEOLOGIC REGIME Field Measurements, Miscellaneous Analytes, Major lons, and Trace Metals

\begin{tabular}{|c|c|c|c|c|c|c|c|c|c|c|c|}
\hline Sampling Point & GW-172 & \multicolumn{2}{|c|}{ GW-193 } & GW-204 & GW-219 & \multicolumn{2}{|c|}{ GW-222 } & \multicolumn{2}{|c|}{ GW-223 } & GW-230 & GW-251 \\
\hline Functional Area & EXP-UV & \multicolumn{2}{|c|}{ T2331 } & T0134 & UOV & \multirow{2}{*}{\multicolumn{2}{|c|}{$\begin{array}{c}\text { NHP } \\
04 / 30 / 09\end{array}$}} & \multicolumn{2}{|c|}{ NHP } & EXP-UV & S2 \\
\hline Date Sampled & $03 / 05 / 09$ & $01 / 13 / 09$ & $07 / 07 / 09$ & $05 / 12 / 09$ & 05/11/09 & & & 03/03/09 & $07 / 22 / 09$ & $03 / 05 / 09$ & $04 / 30 / 09$ \\
\hline Program & $\mathrm{BJC}$ & BJC & BJC & GWPP & GWPP & GWPP & GWPP & BJC & BJC & BJC & GWPP \\
\hline Sample Type & & & & & & & Dup & & & & \\
\hline Field Measurements & & & & & & & & & & & \\
\hline Time Sampled & $14: 00$ & & $13: 35$ & $13: 50$ & $15: 25$ & $8: 35$ & $8: 35$ & $16: 40$ & $14: 20$ & $14: 20$ & $13: 40$ \\
\hline Measuring Point Elev. (ft) & 926.69 & 934.17 & 934.17 & 958.74 & 935.83 & 911.82 & 911.82 & 911.62 & 911.62 & 923.11 & $1,003.80$ \\
\hline Depth to Water (ft) & 13.76 & 8.62 & 9.23 & 8.68 & 9.79 & 9.91 & 9.91 & 9.45 & 9.81 & 11.03 & 15.10 \\
\hline Groundwater Elevation (ft) & & & & & & & & & & & \\
\hline Conductivity $(\mu \mathrm{mho} / \mathrm{cm})$ & 571 & 517 & 910 & 254 & 668 & 746 & 746 & 560 & 613 & 939 & 694 \\
\hline Dissolved Oxygen (ppm) & 0.46 & 3.3 & 1.7 & 3.03 & 0.9 & 2.9 & 2.9 & 1.13 & 0.77 & 0.29 & 0.35 \\
\hline Iron $(++)$ & 1.34 & & & & & & & & & 1.23 & \\
\hline Manganese $(++)$ & 0.9 & & & & & & & & & 0.8 & \\
\hline Oxidation/Reduction (mV) & -94 & 167 & -157 & 134 & 139 & 146 & 146 & -12 & -25 & -50 & 236 \\
\hline Temperature (degrees C) & 15.3 & 11.3 & 29.3 & 22.5 & 19 & 15.8 & 15.8 & 14.1 & 19.1 & 14.7 & 16.8 \\
\hline Turbidity (NTU) & 1 & 2 & 1 & & & & & 2 & 0 & 7 & \\
\hline $\mathrm{pH}$ & 6.29 & 7.27 & 7.35 & 7.6 & 6.66 & 7.26 & 7.26 & 6.79 & 7.07 & 7 & 6.1 \\
\hline Miscellaneous Analytes & & & & & & & & & & & \\
\hline Dissolved Solids (mg/L) & 365 & & & & & 435 & 396 & 360 & 440 & 587 & 383 \\
\hline Suspended Solids (mg/L) & $<$ & & & & & $<$ & $<$ & $<$ & $<$ & 5 & $<$ \\
\hline Major Ions (mg/L) & & & & & & & & & & & \\
\hline Calcium & & & & & & 86.9 & 90.3 & 86.8 & 91.5 & & 87.7 \\
\hline Magnesium & & & & & & 15.2 & 16 & 12.7 & 13 & & 9.42 \\
\hline Potassium & & & & & & 3.86 & 3.91 & 1.92 & 1.91 & & 2.2 \\
\hline Sodium & & & & & & 45 & 47.3 & 14.7 & 20.2 & & 8.37 \\
\hline Bicarbonate & & & & & & 211 & 211 & 226 & 211 & & 142 \\
\hline Carbonate & & & & & & $<$ & $<$ & $<$ & $<$ & & $<$ \\
\hline Chloride & & & & & & 79 & 79.2 & 35.9 & 60.6 & & 5.11 \\
\hline Fluoride & & & & & & 0.288 & 0.298 & 0.16 & 0.172 & & 0.91 \\
\hline Nitrate as $\mathrm{N}$ & & & & & & 0.221 & 0.219 & $<$ & $<$ & & 38.7 \\
\hline Sulfate & & & & & & 49.9 & 49.9 & 53.2 & 53.8 & & 8.68 \\
\hline Charge balance error (\%) & & & & & & 0.8 & 3.0 & -4.6 & -3.6 & & -3.5 \\
\hline Trace Metals (mg/L) & & & & & & & & & & & \\
\hline Aluminum & & & & & & $<$ & $<$ & $<$ & $<$ & & $<$ \\
\hline Antimony & & & & $<$ & $<$ & $<$ & $<$ & $<$ & $<$ & & $<$ \\
\hline Arsenic & & & & $<$ & $<$ & & $<$ & $<$ & $<$ & & $<$ \\
\hline Barium & & & & & & 0.165 & 0.174 & 0.284 & 0.296 & & 0.072 \\
\hline Beryllium & & & & & & $<$ & & $<$ & $<$ & & $<$ \\
\hline Boron & & & & & & & & $<$ & $<$ & & $<$ \\
\hline Cadmium & & & & $<$ & $<$ & $<$ & $<$ & $<$ & $<$ & & 0.0788 \\
\hline Chromium & & & & 0.00464 & 0.00354 & $<$ & $<$ & $<$ & $<$ & & $<$ \\
\hline Cobalt & & & & & & $<$ & $<$ & $<$ & $<$ & & $<$ \\
\hline Copper & & & & & & $<$ & $<$ & $<$ & $<$ & & 0.16 \\
\hline Iron & & & & & & $<$ & $<$ & 0.234 & 0.254 & & $<$ \\
\hline Lead & & & & $<$ & & $<$ & $<$ & $<$ & $<$ & & $<$ \\
\hline Lithium & & & & & & & & & $<$ & & $<$ \\
\hline Manganese & & & & & & 0.0071 & 0.0064 & 0.511 & 0.53 & & 2.22 \\
\hline Mercury & & & & & & $<$ & $<$ & & & & $<$ \\
\hline Nickel & & & & $<$ & 0.0216 & $<$ & $<$ & $<$ & $<$ & & 0.0241 \\
\hline Strontium & & & & & & 0.299 & 0.314 & 0.24 & 0.246 & & 0.171 \\
\hline Thallium & & & & & & $<$ & $<$ & $<$ & 0.00103 & & 0.00085 \\
\hline Uranium & & & & 0.0421 & 0.555 & 0.228 & 0.219 & 0.04 & 0.046 & & 0.0022 \\
\hline Zinc & & & & & & $<$ & $<$ & $<$ & $<$ & & 0.128 \\
\hline
\end{tabular}


APPENDIX E.1: CY 2009 MONITORING DATA FOR THE UPPER EAST FORK POPLAR CREEK HYDROGEOLOGIC REGIME Field Measurements, Miscellaneous Analytes, Major lons, and Trace Metals

\begin{tabular}{|c|c|c|c|c|c|c|c|c|c|c|}
\hline Sampling Point & GW-253 & GW-270 & GW-272 & \multicolumn{2}{|c|}{ GW-274 } & GW-275 & GW-281 & \multicolumn{2}{|c|}{ GW-380 } & GW-381 \\
\hline Functional Area & S2 & SY & SY & \multicolumn{2}{|c|}{ SY } & SY & FF & \multicolumn{2}{|c|}{ NHP } & NHP \\
\hline Date Sampled & $03 / 04 / 09$ & $04 / 28 / 09$ & $04 / 21 / 09$ & \multicolumn{2}{|c|}{$04 / 21 / 09$} & $04 / 27 / 09$ & 08/13/09 & $03 / 04 / 09$ & $07 / 23 / 09$ & $10 / 19 / 09$ \\
\hline Program & BJC & GWPP & GWPP & GWPP & GWPP & GWPP & BJC & $\mathrm{BJC}$ & $\mathrm{BJC}$ & GWPP \\
\hline Sample Type & & & & & Dup & & & & & \\
\hline Field Measurements & & & & & & & & & & \\
\hline Time Sampled & $17: 05$ & 9:00 & $10: 40$ & $14: 25$ & $14: 25$ & $13: 20$ & $14: 20$ & $10: 40$ & $10: 10$ & $11: 05$ \\
\hline Measuring Point Elev. (ft) & $1,004.24$ & $1,008.96$ & $1,009.16$ & 995.60 & 995.60 & 995.53 & 946.10 & 913.55 & 913.55 & 913.36 \\
\hline Depth to Water (ft) & 5.87 & 2.31 & 5.25 & 3.52 & 3.52 & 4.08 & 3.15 & 10.71 & & 10.98 \\
\hline Groundwater Elevation (ft) & & & & & & & & & & \\
\hline Conductivity $(\mu \mathrm{mho} / \mathrm{cm})$ & 5,734 & 1,506 & 5,790 & 12,360 & 12,360 & 45,400 & 747 & 395 & & 708 \\
\hline Dissolved Oxygen (ppm) & 1.51 & 2.79 & 0.88 & 0.23 & 0.23 & 0.3 & 1.83 & 5.44 & & 0.36 \\
\hline Iron $(++)$ & 0.09 & & & & & & & & & \\
\hline Manganese $(++)$ & 57 & & & & & & & & & \\
\hline Oxidation/Reduction (mV) & 235 & 130 & 137 & 215 & 215 & 100 & 154 & 147 & & -122 \\
\hline Temperature (degrees C) & 14 & 19.4 & 15.4 & 16.1 & 16.1 & 21.8 & 19.1 & 12.9 & & 16 \\
\hline Turbidity (NTU) & 4 & & & & & & 13 & 35 & & \\
\hline $\mathrm{pH}$ & 5.3 & 7.06 & 6.68 & 5.57 & 5.57 & 6.71 & 6.8 & 6.9 & & 7.1 \\
\hline Miscellaneous Analytes & & & & & & & & & & \\
\hline Dissolved Solids (mg/L) & 4,010 & 1,060 & 4,280 & 10,400 & 10,500 & 45,900 & & 263 & 274 & \\
\hline Suspended Solids (mg/L) & 5 & 3 & $<$ & $<$ & $<$ & $<$ & & 37 & 9 & \\
\hline Major Ions (mg/L) & & & & & & & & & & \\
\hline Calcium & 547 & 202 & 824 & 1,970 & 1,980 & 10,100 & & 49.4 & 43.5 & \\
\hline Magnesium & 122 & 36.2 & 136 & 306 & 309 & 1,430 & & 19.4 & 16.2 & \\
\hline Potassium & 8.61 & 5.67 & 4.18 & $<$ & $<$ & 36 & & 1.85 & 1.71 & \\
\hline Sodium & 128 & 14.3 & 15.5 & 219 & 221 & 127 & & 17.5 & 14.6 & \\
\hline Bicarbonate & 63.4 & 192 & 104 & 600 & 629 & 59.8 & & 182 & 166 & \\
\hline Carbonate & $<$ & $<$ & $<$ & $<$ & $<$ & $<$ & & $<$ & $<$ & \\
\hline Chloride & 121 & 12.3 & 5.32 & 46.8 & 46.4 & 49.3 & & 23.2 & 17.4 & \\
\hline Fluoride & 8.9 & $<$ & $<$ & $<$ & $<$ & $<$ & & 0.31 & 0.22 & \\
\hline Nitrate as $\mathrm{N}$ & 744 & 107 & 682 & 1,739 & 1,729 & 8,960 & & 1.9 & 0.92 & \\
\hline Sulfate & 28.3 & 51.4 & 9.81 & 3.11 & 3.07 & 2.62 & & 23.8 & 28.4 & \\
\hline Charge balance error (\%) & -15.4 & 3.5 & 1.9 & -1.7 & -1.3 & -1.1 & & -0.7 & -3.4 & \\
\hline Trace Metals (mg/L) & & & & & & & & & & \\
\hline Aluminum & 3.52 & $<$ & $<$ & $<$ & $<$ & $<$ & & 1.26 & $<$ & \\
\hline Antimony & $<$ & $<$ & $<$ & $<$ & $<$ & $<$ & & 0.00338 & $<$ & \\
\hline Arsenic & $<$ & $<$ & $<$ & $<$ & $<$ & $<$ & & 0.00534 & 0.0104 & \\
\hline Barium & 0.273 & 0.169 & 2.46 & 11.7 & 11.8 & 153 & & 0.0396 & 0.0371 & \\
\hline Beryllium & 0.0123 & $<$ & $<$ & $<$ & $<$ & $<$ & & $<$ & $<$ & \\
\hline Boron & 0.3 & $<$ & $<$ & $<$ & $<$ & $<$ & & $<$ & $<$ & \\
\hline Cadmium & 4.2 & $<$ & $<$ & $<$ & $<$ & $<$ & & $<$ & $<$ & \\
\hline Chromium & $<$ & $<$ & $<$ & $<$ & $<$ & $<$ & & 0.702 & 1.02 & \\
\hline Cobalt & 0.259 & $<$ & $<$ & $<$ & $<$ & $<$ & & $<$ & $<$ & \\
\hline Copper & 65.6 & $<$ & $<$ & $<$ & $<$ & $<$ & & $<$ & $<$ & \\
\hline Iron & 0.147 & $<$ & $<$ & $<$ & $<$ & $<$ & & 4.17 & 2.9 & \\
\hline Lead & 0.0638 & 0.00101 & 0.00231 & $<$ & $<$ & $<$ & & 0.00251 & $<$ & \\
\hline Lithium & 0.0554 & 0.0267 & 0.0428 & $<$ & $<$ & 0.418 & & $<$ & $<$ & \\
\hline Manganese & 46.8 & 0.0071 & 0.0068 & 55.8 & 56.2 & 1.88 & & 0.0735 & 0.0242 & \\
\hline Mercury & & $<$ & $<$ & 0.0001 & 0.0001 & $<$ & & & & \\
\hline Nickel & 2.25 & $<$ & 0.00817 & 0.135 & 0.134 & 0.0738 & & 0.119 & 0.15 & \\
\hline Strontium & 0.985 & 2.75 & 1.6 & 5.97 & 6.01 & 77.3 & & 0.0706 & 0.0618 & \\
\hline Thallium & 0.00801 & $<$ & $<$ & $<$ & $<$ & $<$ & & $<$ & $<$ & \\
\hline Uranium & 0.0044 & 0.0011 & 0.0044 & 0.0099 & 0.0099 & $<$ & & 0.0051 & $<$ & \\
\hline Zinc & 6.34 & $<$ & $<$ & $<$ & $<$ & $<$ & & $<$ & $<$ & \\
\hline
\end{tabular}


APPENDIX E.1: CY 2009 MONITORING DATA FOR THE UPPER EAST FORK POPLAR CREEK HYDROGEOLOGIC REGIME

Field Measurements, Miscellaneous Analytes, Major Ions, and Trace Metals

\begin{tabular}{|c|c|c|c|c|c|c|c|c|c|c|c|}
\hline Sampling Point & \multicolumn{2}{|c|}{ GW-382 } & \multicolumn{2}{|c|}{ GW-505 } & \multicolumn{4}{|c|}{ GW-605 } & \multicolumn{2}{|c|}{ GW-606 } & \multirow{3}{*}{$\begin{array}{c}\text { GV-618 } \\
\text { EXP-E } \\
03 / 30 / 09\end{array}$} \\
\hline \multirow{2}{*}{$\begin{array}{c}\text { Functional Area } \\
\text { Date Sampled }\end{array}$} & \multicolumn{2}{|c|}{ NHP } & \multirow{2}{*}{\multicolumn{2}{|c|}{$\begin{array}{c}\text { RG } \\
04 / 20 / 09\end{array}$}} & \multicolumn{4}{|c|}{ EXP-I } & \multicolumn{2}{|c|}{ EXP-I } & \\
\hline & \multirow{2}{*}{$\begin{array}{c}03 / 04 / 09 \\
B J C \\
\end{array}$} & \multirow{2}{*}{$\begin{array}{c}07 / 23 / 09 \\
\text { BJC }\end{array}$} & & & \multicolumn{2}{|c|}{$01 / 08 / 09$} & \multicolumn{2}{|c|}{$07 / 07 / 09$} & \multirow{2}{*}{$\frac{01 / 08 / 09}{\text { BJC }}$} & \multirow{2}{*}{$\begin{array}{c}07 / 07 / 09 \\
\text { BJC }\end{array}$} & \\
\hline Program & & & GWPP & GWPP & $\mathrm{BJC}$ & BJC & BJC & BJC & & & BJC \\
\hline Sample Type & & & & Dup & & Dup & & Dup & & & \\
\hline Field Measurements & & & & & & & & & & & \\
\hline Time Sampled & $14: 20$ & $10: 30$ & 9:05 & 9:05 & 10:00 & & $9: 40$ & & $14: 20$ & $10: 00$ & $9: 55$ \\
\hline Measuring Point Elev. (ft) & 913.17 & 913.17 & $1,015.19$ & $1,015.19$ & 919.06 & & 919.06 & & 919.59 & 919.59 & 985.14 \\
\hline Depth to Water (ft) & 11.75 & 11.22 & 4.51 & 4.51 & 11.27 & & 11.45 & & 12.28 & 13.63 & 12.55 \\
\hline Groundwater Elevation ( $\mathrm{ft}$ ) & & & & & & & & & & & \\
\hline Conductivity $(\mu \mathrm{mho} / \mathrm{cm})$ & 644 & 638 & 352 & 352 & 1,160 & & 818 & & 1,158 & 1,344 & 594 \\
\hline Dissolved Oxygen (ppm) & 1.36 & 1.42 & 5.26 & 5.26 & 0.49 & & 0.92 & & 2.42 & 1.46 & 0.28 \\
\hline Iron $(++)$ & & & & & & & & & & & 0.15 \\
\hline Manganese $(++)$ & & & & & & & & & & & 0.4 \\
\hline Oxidation/Reduction (mV) & 124 & 121 & 187 & 187 & 168 & & 193 & & 170 & 102 & 7 \\
\hline Temperature (degrees C) & 15.5 & 21.2 & 15.2 & 15.2 & 15.2 & & 17.4 & & 11.5 & 19.5 & 16.8 \\
\hline Turbidity (NTU) & 31 & 14 & & & 10 & & 0 & & 5 & 2 & 0 \\
\hline $\mathrm{pH}$ & 7.3 & 6.65 & 6.84 & 6.84 & 6.58 & & 7 & & 6.84 & 6.48 & 6.59 \\
\hline Miscellaneous Analytes & & & & & & & & & & & \\
\hline Dissolved Solids (mg/L) & 382 & 440 & & & & & & & & & 378 \\
\hline Suspended Solids (mg/L) & 7 & 6 & & & & & & & & & 8 \\
\hline Major Ions (mg/L) & & & & & & & & & & & \\
\hline Calcium & 86.7 & 77 & & & 102 & 98.3 & 100 & 100 & 89.1 & 97 & 98 \\
\hline Magnesium & 23.9 & 21.4 & & & 22.8 & 22 & 22 & 22 & 41.2 & 43 & 8.8 \\
\hline Potassium & 3.56 & 3.82 & & & 2.74 & 2.63 & 2.6 & 2.6 & 4.05 & 4.9 & 3.92 \\
\hline Sodium & 17.2 & 17.2 & & & 20.6 & 20.1 & 17 & 17 & 7.38 & 7.4 & 13.2 \\
\hline Bicarbonate & 285 & 268 & & & 354 & 358 & 300 & 310 & 366 & 340 & 308 \\
\hline Carbonate & $<$ & $<$ & & & $<$ & $<$ & $<$ & $<$ & $<$ & $<$ & $<$ \\
\hline Chloride & 59.3 & 65.9 & & & 31.2 & 32.9 & 40 & 39 & 29.2 & 24 & 7.7 \\
\hline Fluoride & 0.28 & 0.168 & & & 0.1 & 0.1 & $<$ & $<$ & 0.2 & $<$ & 0.29 \\
\hline Nitrate as $\mathrm{N}$ & 0.2 & 0.07 & & & 0.2 & 0.22 & 0.17 & 0.17 & 12.8 & 16 & 0.029 \\
\hline Sulfate & 4 & 4.39 & & & 32.8 & 32.2 & 33 & 32 & 31.6 & 61 & 17.2 \\
\hline Charge balance error (\%) & -2.4 & -6.3 & & & -4.4 & & -1.4 & & -8.1 & -5.7 & -3.5 \\
\hline Trace Metals (mg/L) & & & & & & & & & & & \\
\hline Aluminum & $<$ & $<$ & & & $<$ & $<$ & $<$ & $<$ & $<$ & $<$ & $<$ \\
\hline Antimony & $<$ & $<$ & $<$ & $<$ & $<$ & $<$ & $<$ & $<$ & $<$ & $<$ & $<$ \\
\hline Arsenic & & $<$ & $<$ & $<$ & $<$ & $<$ & $<$ & $<$ & & $<$ & $<$ \\
\hline Barium & 0.588 & 0.528 & $\cdot$ & & 0.0538 & 0.0522 & 0.05 & 0.051 & 0.194 & 0.19 & 0.0382 \\
\hline Beryllium & $<$ & $<$ & & & $<$ & $<$ & $<$ & $<$ & $<$ & $<$ & $<$ \\
\hline Boron & $<$ & $<$ & & & $<$ & $<$ & $<$ & $<$ & $<$ & $<$ & $<$ \\
\hline Cadmium & $<$ & $<$ & $<$ & $<$ & $<$ & $<$ & $<$ & $<$ & $<$ & $<$ & $<$ \\
\hline Chromium & $<$ & $<$ & 0.113 & 0.0942 & $<$ & $<$ & $<$ & $<$ & $<$ & $<$ & $<$ \\
\hline Cobalt & $<$ & $<$ & & & $<$ & $<$ & $<$ & $<$ & $<$ & $<$ & $<$ \\
\hline Copper & $<$ & $<$ & & & $<$ & $<$ & $<$ & $<$ & $<$ & $<$ & $<$ \\
\hline Iron & 2.33 & 3.19 & & & 0.0659 & 0.0541 & $<$ & $<$ & $<$ & $<$ & 0.126 \\
\hline Lead & $<$ & $<$ & 0.0147 & 0.0121 & $<$ & $<$ & $<$ & $<$ & $<$ & $<$ & $<$ \\
\hline Lithium & & $<$ & & & $<$ & & $<$ & $<$ & 0.0108 & 0.015 & $<$ \\
\hline Manganese & 0.0343 & 0.032 & & & 0.201 & 0.188 & 0.18 & 0.19 & 0.0105 & 0.0099 & 0.276 \\
\hline Mercury & & & & & & & & & & & \\
\hline Nickel & $<$ & $<$ & 0.0195 & 0.0159 & $<$ & $<$ & $<$ & $<$ & $<$ & $<$ & $<$ \\
\hline Strontium & 0.31 & 0.29 & & & 0.201 & 0.196 & 0.2 & 0.2 & 0.612 & 0.71 & 0.201 \\
\hline Thallium & $<$ & $<$ & $<$ & $<$ & $<$ & $<$ & $<$ & $<$ & $<$ & $<$ & $<$ \\
\hline Uranium & $<$ & $<$ & $0.0629 \mathrm{Q}$ & 0.0562 & 0.13 & 0.13 & 0.1 & 0.1 & 0.005 & 0.0051 & $<$ \\
\hline Zinc & $<$ & $<$ & & & $<$ & 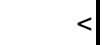 & $<$ & $<$ & $<$ & $<$ & $<$ \\
\hline
\end{tabular}


APPENDIX E.1: CY 2009 MONITORING DATA FOR THE UPPER EAST FORK POPLAR CREEK HYDROGEOLOGIC REGIME Field Measurements, Miscellaneous Analytes, Major lons, and Trace Metals

\begin{tabular}{|c|c|c|c|c|c|c|c|c|c|c|}
\hline Sampling Point & GW-633 & GW-658 & GW-686 & GW-690 & \multicolumn{3}{|c|}{ GW-691 } & GW-692 & \multicolumn{2}{|r|}{ GW-698 } \\
\hline Functional Area & RG & FF & CPT & CPT & \multicolumn{3}{|c|}{ CPT } & CPT & \multirow{2}{*}{\multicolumn{2}{|c|}{$\begin{array}{c}\text { B8110 } \\
04 / 29 / 09\end{array}$}} \\
\hline Date Sampled & $04 / 28 / 09$ & 08/13/09 & 05/13/09 & 05/13/09 & 05/12/09 & \multicolumn{2}{|c|}{$10 / 20 / 09$} & $05 / 12 / 09$ & & \\
\hline Program & GWPP & BJC & GWPP & GWPP & GWPP & GWPP & GWPP & GWPP & GWPP & GWPP \\
\hline Sample Type & & & & & & & Dup & & & Dup \\
\hline Field Measurements & & & & & & & & & & \\
\hline Time Sampled & $15: 55$ & $15: 40$ & 9:05 & $10: 20$ & 9:10 & $10: 40$ & $10: 40$ & 10:10 & $13: 35$ & $13: 35$ \\
\hline Measuring Point Elev. (ft) & 996.43 & 944.81 & 963.76 & 967.36 & 968.59 & 968.59 & 968.59 & 964.38 & 970.09 & 970.09 \\
\hline Depth to Water (ft) & 3.02 & 10.97 & 12.39 & 10.02 & 11.58 & 11.89 & 11.89 & 9.06 & 30.74 & 30.74 \\
\hline Groundwater Elevation (ft) & & & & & & & & & & \\
\hline Conductivity $(\mu \mathrm{mho} / \mathrm{cm})$ & 6,380 & 651 & 1,049 & 1,237 & 888 & 961 & 961 & 836 & 1,734 & 1,734 \\
\hline Dissolved Oxygen (ppm) & 0.48 & 0.93 & 1.49 & 0.77 & 0.77 & 0.41 & 0.41 & 0.25 & 0.17 & 0.17 \\
\hline Iron $(++)$ & & & & & & & & & & \\
\hline Manganese $(++)$ & & & & & & & & & & \\
\hline Oxidation/Reduction (mV) & 244 & -57 & 138 & 145 & 164 & 153 & 153 & 145 & 134 & 134 \\
\hline Temperature (degrees C) & 23 & 27.9 & 17.5 & 17.7 & 14.8 & 15.9 & 15.9 & 17.7 & 18.8 & 18.8 \\
\hline Turbidity (NTU) & & 5 & & & & & & & & \\
\hline $\mathrm{pH}$ & 5.12 & 6.06 & 6.62 & 6.76 & 6.24 & 6.42 & 6.42 & 7.12 & 6.67 & 6.67 \\
\hline $\begin{array}{l}\text { Miscellaneous Analytes } \\
\text { Dissolved Solids (mg/L) } \\
\text { Suspended Solids (mg/L) }\end{array}$ & $\begin{array}{r}5,430 \\
1\end{array}$ & & & & & & & & & \\
\hline Major lons (mg/L) & & & & & & & & & & \\
\hline Calcium & 1,130 & & & & & & & & & \\
\hline Magnesium & 112 & & & & & & & & & \\
\hline Potassium & 7.12 & & & & & & & & & \\
\hline Sodium & 98.9 & & & & & & & & & \\
\hline Bicarbonate & 306 & & & & & & & & & \\
\hline Carbonate & $<$ & & & & & & & & & \\
\hline Chloride & 40 & & 15.5 & 70.8 & 8.69 & 7.12 & 7.18 & 19.4 & 17.2 & 17.2 \\
\hline Fluoride & $<$ & & & & & & & & & \\
\hline Nitrate as $\mathrm{N}$ & 823 & & 1.07 & 4.06 & 0.282 & 0.437 & 0.43 & $<$ & 90.1 & 90.2 \\
\hline Sulfate & 2.4 & & 232 & 300 & $324 \mathrm{Q}$ & 338 & 342 & 277 & 60 & 59.9 \\
\hline Charge balance error (\%) & 3.0 & & & & & & & & & \\
\hline Trace Metals (mg/L) & & & & & & & & & & \\
\hline Aluminum & $<$ & & & & & & & & & \\
\hline Antimony & $<$ & & & & & & & & & \\
\hline Arsenic & $<$ & & & & & & & & & \\
\hline Barium & 4.93 & & & & & & & & & \\
\hline Beryllium & $<$ & & & & & & & & & \\
\hline Boron & $<$ & & & & & & & & & \\
\hline Cadmium & $<$ & & & & & & & & & \\
\hline Chromium & $<$ & & & & & & & & & \\
\hline Cobalt & $<$ & & & & & & & & & \\
\hline Copper & $<$ & & & & & & & & & \\
\hline Iron & $<$ & & & & & & & & & \\
\hline Lead & $<$ & & & & & & & & & \\
\hline Lithium & 0.167 & & & & & & & & & \\
\hline Manganese & 3.81 & & & & & & & & & \\
\hline Mercury & $<$ & & $<$ & $<$ & $<$ & $<$ & $<$ & 0.00051 & 0.00036 & 0.00038 \\
\hline Nickel & 0.208 & & & & & & & & & \\
\hline Strontium & 2.69 & & & & & & & & & \\
\hline Thallium & $<$ & & & & & & & & & \\
\hline Uranium & $<$ & & & & & & & & & \\
\hline Zinc & $<$ & & & & & & & & & \\
\hline
\end{tabular}


APPENDIX E.1: CY 2009 MONITORING DATA FOR THE UPPER EAST FORK POPLAR CREEK HYDROGEOLOGIC REGIME

Field Measurements, Miscellaneous Analytes, Major Ions, and Trace Metals

\begin{tabular}{|c|c|c|c|c|c|c|c|c|c|c|}
\hline \multicolumn{2}{|l|}{ Sampling Point } & \multicolumn{2}{|c|}{ GW-722-14 } & \multicolumn{2}{|c|}{ GW-722-17 } & \multicolumn{2}{|c|}{ GW-722-20 } & \multicolumn{2}{|c|}{ GW-722-22 } & GW-7 \\
\hline \multicolumn{2}{|l|}{ Functional Area } & \multicolumn{2}{|c|}{ EXP-J } & \multicolumn{2}{|c|}{ EXP-J } & \multicolumn{2}{|c|}{ EXP-J } & \multicolumn{2}{|c|}{ EXP-J } & EX \\
\hline Date Sampled & $10 / 21 / 09$ & $03 / 02 / 09$ & 09/02/09 & $03 / 02 / 09$ & $09 / 02 / 09$ & $03 / 02 / 09$ & $09 / 02 / 09$ & $03 / 02 / 09$ & $09 / 02 / 09$ & $03 / 02 / 09$ \\
\hline Program & GWPP & BJC & GWPP & BJC & GWPP & BJC & GWPP & BJC & GWPP & BJC \\
\hline \multicolumn{11}{|l|}{ Sample Type } \\
\hline \multicolumn{11}{|l|}{ Field Measurements } \\
\hline Time Sampled & 15:00 & 12:55 & $9: 32$ & $13: 20$ & 11:04 & $12: 40$ & $14: 15$ & $12: 25$ & $15: 13$ & $12: 05$ \\
\hline Measuring Point Elev. (ft) & 970.09 & 953.71 & 953.71 & 953.71 & 953.71 & 953.71 & 953.71 & 953.71 & 953.71 & 953.71 \\
\hline Depth to Water (ft) & 20.52 & & & & & & & & & \\
\hline \multicolumn{11}{|l|}{ Groundwater Elevation (ft) } \\
\hline Conductivity $(\mu \mathrm{mho} / \mathrm{cm})$ & 744 & 515 & 534 & 538 & 565 & 489 & 512 & 481 & 511 & 389 \\
\hline Dissolved Oxygen (ppm) & 1.44 & 10.58 & & 10.63 & & 10.81 & & 11.37 & & 11.53 \\
\hline \multirow{2}{*}{\multicolumn{11}{|c|}{$\begin{array}{r}\text { Iron }(++) \\
\text { Manganese }(++)\end{array}$}} \\
\hline & & & & & & & & & & \\
\hline Oxidation/Reduction (mV) & 157 & 129 & & 113 & & 128 & & 140 & & 174 \\
\hline Temperature (degrees C) & 19.2 & 14.28 & 17 & 14.61 & 17.5 & 14.01 & 18.4 & 14.1 & 18.3 & 14.78 \\
\hline Turbidity (NTU) & & & & & & & & 2 & & \\
\hline $\mathrm{pH}$ & 6.64 & 7.21 & 7.1 & 7.48 & 7.44 & 7.35 & 7.02 & 7.31 & 7.17 & 7.22 \\
\hline \multicolumn{11}{|l|}{ Miscellaneous Analytes } \\
\hline Dissolved Solids (mg/L) & & & 268 & & 319 & & 252 & & 260 & \\
\hline Suspended Solids (mg/L) & & & 4 & & $<$ & & $<$ & & $<$ & \\
\hline \multicolumn{11}{|l|}{ Major lons (mg/L) } \\
\hline Calcium & & & 58.8 & & 42.7 & & 52.9 & & 56.9 & \\
\hline Magnesium & & & 27.9 & & 26 & & 29.8 & & 28.1 & \\
\hline Potassium & & & $<$ & & 2.17 & & $<$ & & $<$ & \\
\hline Sodium & & & 15.6 & & 32.9 & & 15.5 & & 12.7 & \\
\hline Bicarbonate & & & 256 & & 217 & & 245 & & 254 & \\
\hline Carbonate & & & & & $<$ & & $<$ & & $<$ & \\
\hline Chloride & 9.54 & & 8.85 & & 31 & & 9.19 & & 5.47 & \\
\hline Fluoride & & & 0.174 & & 0.638 & & 0.316 & & 0.223 & \\
\hline Nitrate as $\mathrm{N}$ & 12.1 & & 0.346 & & 0.06 & & 0.182 & & 0.259 & \\
\hline Sulfate & 18.2 & & 16.6 & & 31.7 & & 21.1 & & 16.6 & \\
\hline Charge balance error (\%) & & & 1.4 & & -1.3 & & 1.2 & & 0.9 & \\
\hline \multicolumn{11}{|l|}{ Trace Metals (mg/L) } \\
\hline Aluminum & & & $<$ & & $<$ & & $<$ & & $<$ & \\
\hline Antimony & & & $<$ & & $<$ & & $<$ & & $<$ & \\
\hline Arsenic & & & $<$ & & $<$ & & $<$ & & $<$ & \\
\hline Barium & & & 0.136 & & 0.111 & & 0.0964 & & 0.1 & \\
\hline Beryllium & & & & & & & $<$ & & $<$ & \\
\hline Boron & & & 0.112 & & 0.128 & & $<$ & & $<$ & \\
\hline Cadmium & & & $<$ & & $<$ & & $<$ & & $<$ & \\
\hline Chromium & & & $<$ & & $<$ & & $<$ & & $<$ & \\
\hline Cobalt & & & $<$ & & $<$ & & $<$ & & $<$ & \\
\hline Copper & & & $<$ & & $<$ & & $<$ & & $<$ & \\
\hline Iron & & & $<$ & & & & $<$ & & $<$ & \\
\hline Lead & & & & & 0.00109 & & $<$ & & $<$ & \\
\hline Lithium & & & 0.0179 & & 0.0283 & & 0.0175 & & 0.0163 & \\
\hline Manganese & & & $<$ & & $<$ & & $<$ & & $<$ & \\
\hline Mercury & 0.00079 & & $<$ & & $<$ & & $<$ & & $<$ & \\
\hline Nickel & & & & & $<$ & & $<$ & & $<$ & \\
\hline Strontium & & & 0.716 & & 1.2 & & 0.69 & & 0.667 & \\
\hline Thallium & & & & & $<$ & & & & $<$ & \\
\hline Uranium & & & & & & & & & $<$ & \\
\hline Zinc & & & 0.294 & & 0.052 & & 0.0523 & & $<$ & \\
\hline
\end{tabular}


APPENDIX E.1: CY 2009 MONITORING DATA FOR THE UPPER EAST FORK POPLAR CREEK HYDROGEOLOGIC REGIME Field Measurements, Miscellaneous Analytes, Major Ions, and Trace Metals

\begin{tabular}{|c|c|c|c|c|c|c|c|c|c|c|}
\hline Sampling Point & $22-33$ & \multicolumn{2}{|c|}{ GW-733 } & \multirow{3}{*}{$\begin{array}{c}\text { GW-735 } \\
\text { EXP-J } \\
08 / 26 / 09\end{array}$} & \multirow{3}{*}{$\begin{array}{l}\text { GW-744 } \\
\text { GRIDK1 } \\
\end{array}$} & \multirow{2}{*}{$\begin{array}{l}\text { GW-747 } \\
\text { GRIDK2 } \\
\end{array}$} & GW-750 & \multicolumn{3}{|c|}{ GW-762 } \\
\hline Functional Area & P-J & \multicolumn{2}{|c|}{ EXP-J } & & & & EXP-J & \multicolumn{3}{|c|}{ GRIDJ3 } \\
\hline Date Sampled & $09 / 03 / 09$ & $01 / 12 / 09$ & $07 / 07 / 09$ & & & $08 / 31 / 09$ & $04 / 29 / 09$ & \multicolumn{2}{|c|}{$03 / 04 / 09$} & $07 / 2$ \\
\hline Program & GWPP & BJC & BJC & GWPP & GWPP & GWPP & GWPP & BJC & BJC & BJC \\
\hline Sample Type & & & & & & & & & Dup & \\
\hline Field Measurements & & & & & & & & & & \\
\hline Time Sampled & $8: 30$ & 10:05 & $15: 15$ & $14: 25$ & $10: 05$ & $14: 00$ & 15:05 & $10: 30$ & $10: 30$ & 15:15 \\
\hline Measuring Point Elev. (ft) & 953.71 & 959.84 & 959.84 & 924.46 & 907.43 & 911.06 & 919.03 & 915.56 & 915.56 & 915.56 \\
\hline Depth to Water (ft) & & 56.43 & 59.34 & 23.02 & 7.15 & 5.10 & 12.52 & 13.61 & & 13.87 \\
\hline Groundwater Elevation (ft) & & & & & & & & & & \\
\hline Conductivity $(\mu \mathrm{mho} / \mathrm{cm})$ & 424 & 469 & 505 & 691 & 489 & 298 & 546 & 579 & & 606 \\
\hline Dissolved Oxygen (ppm) & & 1.24 & 1 & 0.35 & 0.23 & 0.33 & 0.52 & 0.54 & & 1.27 \\
\hline Iron $(++)$ & & & & & & & & & & \\
\hline Manganese $(++)$ & & & & & & & & & & \\
\hline Oxidation/Reduction (mV) & & 94 & 72 & 81 & -199 & -78 & -8 & 120 & & 102 \\
\hline Temperature (degrees C) & 16.7 & 9.1 & 24.9 & 18.6 & 22.2 & 20.8 & 17.2 & 16.6 & & 21.2 \\
\hline Turbidity (NTU) & & 2 & 0 & & & & & 2 & & 12 \\
\hline $\mathrm{pH}$ & 6.92 & 7.02 & 7.63 & 6.81 & 7.48 & 7.23 & 6.95 & 6.7 & & 7.07 \\
\hline Miscellaneous Analytes & & & & & & & & & & \\
\hline Dissolved Solids (mg/L) & 232 & & & 251 & 176 & 270 & 288 & 381 & 365 & 404 \\
\hline Suspended Solids (mg/L) & $<$ & & & $<$ & $<$ & 4 & $<$ & 6 & $<$ & 9 \\
\hline Major lons (mg/L) & & & & & & & & & & \\
\hline Calcium & 69.7 & & & 130 & 47.7 & 39.9 & 88.6 & 75.2 & 80 & 78 \\
\hline Magnesium & 9.37 & & & 9.1 & 10.9 & 9.69 & 11.8 & 21.7 & 23.2 & 22.6 \\
\hline Potassium & $<$ & & & 2.35 & 3.48 & 2.3 & 4.35 & 3.89 & 4.08 & 5.57 \\
\hline Sodium & 2.57 & & & 4.2 & 36.1 & 33.4 & 7.22 & 12.1 & 12.7 & 13 \\
\hline Bicarbonate & 207 & & & 317 & 230 & 199 & 245 & 277 & 285 & 260 \\
\hline Carbonate & $<$ & & & $<$ & $<$ & $<$ & $<$ & $<$ & $<$ & $<$ \\
\hline Chloride & 3.01 & & & 17.4 & 7.22 & 2.13 & 4.58 & 38.2 & 37.2 & 40.4 \\
\hline Fluoride & & & & $<$ & $<$ & 0.199 & $<$ & 0.16 & 0.11 & $<$ \\
\hline Nitrate as $\mathrm{N}$ & 0.585 & & & 0.102 & $<$ & $<$ & $<$ & 0.02 & $<$ & $<$ \\
\hline Sulfate & 10.6 & & & 22.3 & 18 & 13.3 & 19.9 & 14.9 & 14.9 & 16.6 \\
\hline Charge balance error (\%) & -1.4 & & & 1.2 & -2.4 & -0.3 & 3.4 & -5.9 & & -1.7 \\
\hline Trace Metals (mg/L) & & & & & & & & & & \\
\hline Aluminum & $<$ & & & $<$ & $<$ & $<$ & $<$ & $<$ & $<$ & 0.725 \\
\hline Antimony & $<$ & & & $<$ & $<$ & $<$ & $<$ & $<$ & $<$ & $<$ \\
\hline Arsenic & $<$ & & & $<$ & $<$ & $<$ & $<$ & $<$ & $<$ & $<$ \\
\hline Barium & 0.0288 & & & 0.334 & 0.302 & 0.174 & 0.735 & 0.484 & 0.518 & 0.538 \\
\hline Beryllium & $<$ & & & $<$ & $<$ & & $<$ & $<$ & $<$ & $<$ \\
\hline Boron & $<$ & & & $<$ & $<$ & $<$ & $<$ & $<$ & $<$ & $<$ \\
\hline Cadmium & $<$ & & & $<$ & $<$ & $<$ & $<$ & $<$ & $<$ & $<$ \\
\hline Chromium & $<$ & & & $<$ & $<$ & $<$ & $<$ & $<$ & $<$ & $<$ \\
\hline Cobalt & $<$ & & & $<$ & $<$ & $<$ & $<$ & $<$ & $<$ & $<$ \\
\hline Copper & $<$ & & & $<$ & $<$ & $<$ & $<$ & $<$ & $<$ & $<$ \\
\hline Iron & $<$ & & & $<$ & $<$ & 0.222 & 0.0928 & $<$ & $<$ & 0.444 \\
\hline Lead & $<$ & & & $<$ & $<$ & $<$ & $<$ & $<$ & 0.00209 & $<$ \\
\hline Lithium & $<$ & & & $<$ & 0.0276 & 0.0177 & 0.0116 & 0.0134 & 0.0149 & 0.0207 \\
\hline Manganese & $<$ & & & 0.191 & 0.0172 & 0.0156 & 0.0606 & 0.0453 & 0.0482 & 0.085 \\
\hline Mercury & $<$ & & & $<$ & $<$ & $<$ & $<$ & & & \\
\hline Nickel & & & & $<$ & $<$ & & $<$ & $<$ & $<$ & $<$ \\
\hline Strontium & 0.0584 & & & 0.273 & 1.4 & 0.757 & 0.678 & 0.678 & 0.725 & 0.73 \\
\hline Thallium & & & & $<$ & $<$ & & $<$ & $<$ & $<$ & $<$ \\
\hline Uranium & $<$ & & & $<$ & $<$ & $<$ & $<$ & $<$ & $<$ & $<$ \\
\hline Zinc & $<$ & & & $<$ & $<$ & $<$ & $<$ & $<$ & $<$ & $<$ \\
\hline
\end{tabular}


APPENDIX E.1: CY 2009 MONITORING DATA FOR THE UPPER EAST FORK POPLAR CREEK HYDROGEOLOGIC REGIME

Field Measurements, Miscellaneous Analytes, Major Ions, and Trace Metals

\begin{tabular}{|c|c|c|c|c|c|c|c|c|c|c|}
\hline Sampling Point & & GW-763 & GW-765 & GW-776 & GW-779 & GW-781 & \begin{tabular}{|l|} 
GW-782 \\
\end{tabular} & GW-802 & GW-816 & GW \\
\hline Functional Area & & GRIDJ3 & GRIDE1 & GRIDH3 & GRIDF2 & GRIDE3 & GRIDE3 & FF & EXP-SR & $\mathbf{N}$ \\
\hline Date Sampled & $3 / 09$ & $10 / 14 / 09$ & $05 / 07 / 09$ & 09/01/09 & \begin{tabular}{|l|}
$08 / 31 / 09$ \\
\end{tabular} & $08 / 27 / 09$ & 08/27/09 & 08/13/09 & $08 / 26 / 09$ & $03 / 03 / 09$ \\
\hline Program & $\mathrm{BJC}$ & GWPP & GWPP & GWPP & GWPP & GWPP & GWPP & $\mathrm{BJC}$ & GWPP & $\mathrm{BJC}$ \\
\hline Sample Type & Dup & & & & & & & & & \\
\hline \multicolumn{11}{|l|}{ Field Measurements } \\
\hline Time Sampled & $15: 15$ & $11: 15$ & $8: 50$ & $10: 30$ & $10: 10$ & 9:15 & $10: 40$ & $14: 40$ & $8: 35$ & $14: 25$ \\
\hline Measuring Point Elev. (ft) & 915.56 & 915.03 & $1,008.54$ & 931.25 & 963.09 & 947.89 & 947.73 & 941.83 & 898.42 & 906.18 \\
\hline Depth to Water (ft) & & 9.07 & 18.14 & 14.58 & 9.43 & 7.99 & 9.84 & 5.51 & 12.10 & 7.50 \\
\hline \multicolumn{11}{|l|}{ Groundwater Elevation (ft) } \\
\hline Conductivity $(\mu \mathrm{mho} / \mathrm{cm})$ & & 792 & 759 & 613 & 446 & 444 & 565 & 864 & 437 & 385 \\
\hline Dissolved Oxygen (ppm) & & 0.22 & 0.74 & 3.69 & 0.54 & 1.38 & 2.3 & 2.81 & 0.21 & 6.41 \\
\hline \multicolumn{11}{|l|}{ Iron (++) } \\
\hline \multicolumn{11}{|l|}{ Manganese $(++)$} \\
\hline Oxidation/Reduction (mV) & & -84 & 149 & 125 & 87 & 93 & 128 & 158 & -65 & 112 \\
\hline Temperature (degrees C) & & 21.7 & 17.8 & 21.1 & 21.2 & 22.2 & 19.6 & 23.4 & 19.6 & 11.6 \\
\hline \multicolumn{11}{|l|}{ Turbidity (NTU) } \\
\hline $\mathrm{pH}$ & & 6.48 & 6.78 & 7.02 & 9.1 & 8.17 & 7.01 & 7.07 & 6.3 & 7.4 \\
\hline \multicolumn{11}{|l|}{ Miscellaneous Analytes } \\
\hline Dissolved Solids (mg/L) & 392 & & 425 & 333 & 248 & 181 & 331 & & 178 & 253 \\
\hline Suspended Solids (mg/L) & $<$ & & $<$ & 2 & 2 & $<$ & 3 & & 20 & 26 \\
\hline \multicolumn{11}{|l|}{ Major lons (mg/L) } \\
\hline Calcium & 76.6 & & 129 & 95.1 & 3.14 & 9.02 & 78 & & 49.4 & 68.8 \\
\hline Magnesium & 22.2 & & 13.7 & 6.05 & 2.28 & 3.04 & 9.74 & & 13.4 & 13.5 \\
\hline Potassium & 5.37 & & $<$ & 2.83 & 2.48 & 5.15 & 3.39 & & 4.76 & 2.31 \\
\hline Sodium & 12.8 & & 10.9 & 15.6 & 96.2 & 83.6 & 11 & & 5.96 & 10.1 \\
\hline Bicarbonate & 264 & & 324 & 191 & 154 & 195 & 206 & & 178 & 202 \\
\hline Carbonate & $<$ & & $<$ & $<$ & 57.1 & $<$ & $<$ & & $<$ & $<$ \\
\hline Chloride & 40.3 & & 30.9 & 35.1 & 10.9 & 6.38 & 22.9 & & 9.34 & 14.2 \\
\hline Fluoride & $<$ & & $<$ & $<$ & 0.477 & $<$ & $<$ & & 0.116 & 0.22 \\
\hline Nitrate as $\mathrm{N}$ & $<$ & & $<$ & 1.46 & $<$ & 0.114 & 0.755 & & $<$ & 1.4 \\
\hline Sulfate & 16.3 & & 11.1 & 51.8 & 8.48 & 9.41 & 22 & & 6.86 & 22.9 \\
\hline Charge balance error (\%) & & & 3.0 & 0.0 & -1.6 & 2.1 & -0.2 & & -0.3 & 0.2 \\
\hline \multicolumn{11}{|l|}{ Trace Metals (mg/L) } \\
\hline Aluminum & 0.388 & & $<$ & $<$ & $<$ & $<$ & $<$ & & $<$ & 0.726 \\
\hline Antimony & $<$ & & $<$ & $<$ & $<$ & $<$ & $<$ & & $<$ & \\
\hline Arsenic & $<$ & & $<$ & $<$ & $<$ & $<$ & $<$ & & $<$ & $<$ \\
\hline Barium & 0.527 & & 0.167 & 0.0874 & 0.222 & 0.267 & 0.367 & & 0.0753 & 0.0579 \\
\hline Beryllium & $<$ & & $<$ & & & & $<$ & & $<$ & \\
\hline Boron & $<$ & & $<$ & $<$ & 0.19 & 0.556 & $<$ & & $<$ & $<$ \\
\hline Cadmium & $<$ & & $<$ & $<$ & $<$ & $<$ & $<$ & & $<$ & $<$ \\
\hline Chromium & $<$ & & $<$ & 0.036 & $<$ & $<$ & $<$ & & $<$ & $<$ \\
\hline Cobalt & $<$ & & $<$ & & $<$ & $<$ & $<$ & & $<$ & $<$ \\
\hline Copper & $<$ & & $<$ & & $<$ & $<$ & $<$ & & $<$ & $<$ \\
\hline Iron & 0.264 & & 0.115 & 0.173 & $<$ & $<$ & 0.263 & & 14 & 0.69 \\
\hline Lead & & & 0.00088 & $0.072 \mathrm{Q}$ & $<$ & $<$ & $<$ & & $<$ & $<$ \\
\hline Lithium & 0.0192 & & 0.0161 & & 0.0364 & 0.0628 & 0.0136 & & $<$ & 0.0111 \\
\hline Manganese & 0.0655 & & 0.0313 & 0.00742 & $<$ & $<$ & 0.00731 & & 0.88 & 0.0281 \\
\hline Mercury & & & & & $<$ & $<$ & $<$ & & $<$ & \\
\hline Nickel & $<$ & & 0.0151 & 0.178 & $<$ & $<$ & 0.0323 & & $<$ & $<$ \\
\hline Strontium & 0.72 & & 0.189 & 0.161 & 0.402 & 0.508 & 0.666 & & 0.0649 & 0.142 \\
\hline Thallium & $<$ & & & $<$ & $<$ & $<$ & $<$ & & $<$ & - \\
\hline Uranium & $<$ & & & $<$ & $<$ & $<$ & $<$ & & $<$ & 0.0085 \\
\hline Zinc & $<$ & & 0.0789 & $<$ & $<$ & $<$ & $<$ & & $<$ & 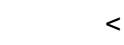 \\
\hline
\end{tabular}


APPENDIX E.1: CY 2009 MONITORING DATA FOR THE UPPER EAST FORK POPLAR CREEK HYDROGEOLOGIC REGIME Field Measurements, Miscellaneous Analytes, Major lons, and Trace Metals

\begin{tabular}{|c|c|c|c|c|c|c|c|c|c|}
\hline Sampling Point & .832 & GW-959 & GW-960 & GHK2.51WSW & NPR12.0SW & NPR23.0SW & SCR7.1SP & SCR7.8SP & SP \\
\hline Functional Area & IP & B9201-2 & GRIDF2 & EXP & EXP & EXP & EXP-SW & EXP-SW & EXP \\
\hline Date Sampled & $07 / 23 / 09$ & $05 / 06 / 09$ & $05 / 07 / 09$ & $01 / 29 / 09$ & $01 / 29 / 09$ & $01 / 29 / 09$ & $02 / 05 / 09$ & $02 / 05 / 09$ & $08 / 0$ \\
\hline Program & $\mathrm{BJC}$ & GWPP & GWPP & GWPP & GWPP & GWPP & $\mathrm{BJC}$ & $\mathrm{BJC}$ & GWPP \\
\hline \multicolumn{10}{|l|}{ Sample Type } \\
\hline \multicolumn{10}{|l|}{ Field Measurements } \\
\hline Time Sampled & 9:05 & $14: 10$ & $10: 25$ & $13: 35$ & 14:15 & 13:55 & $10: 50$ & $10: 30$ & $14: 50$ \\
\hline Measuring Point Elev. (ft) & 906.18 & 927.69 & & & & & & & \\
\hline Depth to Water (ft) & 7.07 & 2.51 & 12.68 & & & & & & \\
\hline \multicolumn{10}{|l|}{ Groundwater Elevation (ft) } \\
\hline Conductivity $(\mu \mathrm{mho} / \mathrm{cm})$ & 506 & 581 & 820 & 118 & 86 & 91 & 381 & 340 & 570 \\
\hline Dissolved Oxygen (ppm) & 4.39 & 0.28 & 0.51 & 6.5 & 6.5 & 6.49 & 10.42 & 12.94 & 3.69 \\
\hline Iron (++) & & & & & & & 0 & 0.01 & \\
\hline Manganese $(++)$ & & & & & & & 0 & 0.1 & \\
\hline Oxidation/Reduction ( $\mathrm{mV}$ ) & 159 & 140 & -55 & 293 & 279 & 278 & 119.6 & 149 & 216 \\
\hline Temperature (degrees C) & 20.2 & 18.1 & 18 & 8.4 & 7.4 & 7.9 & 5.69 & 7.89 & 16.1 \\
\hline Turbidity (NTU) & 7 & & & & & & 3.46 & 2.99 & \\
\hline $\mathrm{pH}$ & 7.25 & 6.98 & 6.97 & 6.82 & 6.78 & 6.81 & 7.63 & 7.77 & 7.21 \\
\hline \multicolumn{10}{|l|}{ Miscellaneous Analytes } \\
\hline Dissolved Solids (mg/L) & 266 & 313 & 456 & 213 & 112 & 124 & 242 & 213 & 250 \\
\hline Suspended Solids (mg/L) & $<$ & 1 & 3 & 5 & 4 & 2 & $<$ & 20 & 2 \\
\hline \multicolumn{10}{|l|}{ Major Ions (mg/L) } \\
\hline Calcium & 49.1 & 81.9 & 105 & 11.8 & 5.64 & 7.41 & & & 55.1 \\
\hline Magnesium & 11.5 & 8.73 & 19.4 & 3.5 & 3.01 & 3.18 & & & 32.9 \\
\hline Potassium & 2.01 & 3.37 & 3.63 & $<$ & 2.28 & 2.42 & & & $<$ \\
\hline Sodium & 8.8 & 26.7 & 26 & 1.28 & 2.16 & 1.69 & & & 2.17 \\
\hline Bicarbonate & 141 & 164 & 222 & 43.3 & 30.4 & 33.1 & & & 245 \\
\hline Carbonate & $<$ & $<$ & $<$ & $<$ & $<$ & $<$ & & & $<$ \\
\hline Chloride & 11.2 & 3.22 & 83.1 & 0.971 & 1.08 & 0.929 & & & 3.97 \\
\hline Fluoride & 0.309 & 0.381 & $<$ & $<$ & $<$ & $<$ & & & $<$ \\
\hline Nitrate as $\mathrm{N}$ & 0.78 & 0.138 & $<$ & 0.21 & 0.172 & 0.177 & & & 9.08 \\
\hline Sulfate & 31.7 & 103 & 44.2 & 14.2 & 12.7 & 11.3 & & & 6.26 \\
\hline Charge balance error (\%) & -0.5 & 4.4 & 2.3 & -12.7 & -14.6 & -9.9 & & & -2.1 \\
\hline \multicolumn{10}{|l|}{ Trace Metals (mg/L) } \\
\hline Aluminum & $<$ & $<$ & $<$ & 0.4 & $<$ & 1.02 & & & $<$ \\
\hline Antimony & $<$ & $<$ & $<$ & $<$ & $<$ & $<$ & & & $<$ \\
\hline Arsenic & $<$ & $<$ & $<$ & $<$ & $<$ & $<$ & & & $<$ \\
\hline Barium & 0.0464 & 0.0973 & 0.153 & 0.0363 & 0.0341 & 0.0394 & & & 0.158 \\
\hline Beryllium & $<$ & $<$ & $<$ & $<$ & & & & & $<$ \\
\hline Boron & $<$ & $<$ & $<$ & $<$ & $<$ & $<$ & & & $<$ \\
\hline Cadmium & $<$ & $<$ & $<$ & $<$ & $<$ & $<$ & & & $<$ \\
\hline Chromium & $<$ & $<$ & $<$ & $<$ & $<$ & $<$ & & & $<$ \\
\hline Cobalt & $<$ & $<$ & $<$ & $<$ & $<$ & $<$ & & & $<$ \\
\hline Copper & $<$ & $<$ & $<$ & & $<$ & $<$ & & & $<$ \\
\hline Iron & 0.06 & $<$ & 2.95 & 0.268 & 0.0825 & 0.643 & & & $<$ \\
\hline Lead & & $<$ & $<$ & 0.00187 & 0.000745 & 0.00064 & & & $<$ \\
\hline Lithium & 0.0148 & $<$ & 0.0114 & & & & & & $<$ \\
\hline Manganese & 0.00619 & 0.031 & 0.289 & 0.0203 & 0.00773 & 0.0212 & & & 0.0108 \\
\hline Mercury & & $<$ & $<$ & $<$ & $<$ & $<$ & & & $<$ \\
\hline Nickel & & $<$ & $<$ & & $<$ & $<$ & & & $<$ \\
\hline Strontium & 0.118 & 0.21 & 1.94 & 0.0351 & 0.0282 & 0.0235 & & & 0.0442 \\
\hline Thallium & $<$ & & $<$ & & & & & & $<$ \\
\hline Uranium & 0.0068 & 0.00102 & $<$ & & $<$ & & & & 0.0013 \\
\hline Zinc & $<$ & 0.08 & $<$ & 0.0783 & 0.0766 & 0.0833 & & & $<$ \\
\hline
\end{tabular}


APPENDIX E.1: CY 2009 MONITORING DATA FOR THE UPPER EAST FORK POPLAR CREEK HYDROGEOLOGIC REGIME Field Measurements, Miscellaneous Analytes, Major Ions, and Trace Metals

\begin{tabular}{|c|c|c|c|c|c|c|c|c|c|}
\hline Sampling Point & \multirow{3}{*}{$\begin{array}{l}-17 \\
-S W \\
3 / 09\end{array}$} & \multicolumn{2}{|c|}{$200 A 6$} & \multicolumn{2}{|c|}{$200 A 6$} & \multicolumn{4}{|c|}{ STATION 8} \\
\hline Functional Area & & \multicolumn{2}{|c|}{ EXP-SW } & \multicolumn{2}{|c|}{ EXP-SW } & \multicolumn{4}{|c|}{ EXP-SW } \\
\hline Date Sampled & & 01/06/09 & $01 / 22 / 09$ & $08 / 19 / 09$ & $09 / 10 / 09$ & $01 / 06 / 09$ & $01 / 22 / 09$ & $08 / 19 / 09$ & $09 / 10 / 09$ \\
\hline Program & GWPP & $\mathrm{BJC}$ & BJC & BJC & BJC & $\mathrm{BJC}$ & BJC & BJC & $\mathrm{BJC}$ \\
\hline Sample Type & Dup & & & & & & & & \\
\hline Field Measurements & & & & & & & & & \\
\hline $\begin{array}{r}\text { Time Sampled } \\
\text { Measuring Point Elev. (ft) } \\
\text { Depth to Water (ft) }\end{array}$ & $14: 50$ & $9: 15$ & $9: 40$ & $10: 15$ & 9:00 & $9: 00$ & $9: 25$ & $9: 45$ & 9:15 \\
\hline $\begin{array}{r}\text { Groundwater Elevation (ft) } \\
\text { Conductivity }(\mu \mathrm{mho} / \mathrm{cm})\end{array}$ & 570 & 309 & 341 & 434 & 397 & 301 & 262 & 430 & 317 \\
\hline $\begin{array}{r}\text { Dissolved Oxygen }(\mathrm{ppm}) \\
\text { Iron }(++) \\
\text { Manganese }(++)\end{array}$ & 3.69 & 9.19 & 7.12 & 5.72 & 10.92 & 9.53 & 8.26 & 5.93 & 9.88 \\
\hline Oxidation/Reduction (mV) & 216 & 114.2 & 149.6 & 13.6 & 164.3 & 130 & 153.2 & 4.4 & 143.2 \\
\hline Temperature (degrees C) & 16.1 & 15.06 & 16.38 & 25.6 & 22.6 & 13.69 & 12 & 25.8 & 18.13 \\
\hline Turbidity (NTU) & & 9.37 & 2.07 & 25 & 1.19 & 6.61 & 4.65 & 7 & 4.66 \\
\hline $\mathrm{pH}$ & 7.21 & 7.55 & 7.8 & 7.44 & 8.5 & 7.8 & 8.17 & 7.82 & 8.04 \\
\hline $\begin{array}{l}\text { Miscellaneous Analytes } \\
\text { Dissolved Solids (mg/L) }\end{array}$ & 293 & 214 & 219 & 288 & 241 & 175 & 208 & 284 & 250 \\
\hline Suspended Solids (mg/L) & 2 & $<$ & $<$ & 16 & 22 & 25 & $<$ & 5 & $<$ \\
\hline Major Ions (mg/L) & & & & & & & & & \\
\hline Calcium & 56.5 & 45.8 & 47.3 & 57.6 & 49.8 & 39.7 & 39 & 55.9 & 40.5 \\
\hline Magnesium & 32.2 & 9.09 & 11.9 & 13.4 & 12.3 & 10.2 & 11.8 & 12.6 & 11.1 \\
\hline Potassium & $<$ & 2.18 & 2.09 & 2.83 & 2.3 & 2.08 & 1.94 & 2.9 & 1.82 \\
\hline Sodium & 2.05 & 6.86 & 10.9 & 10.1 & 10.5 & 8.5 & 10.3 & 11.2 & 8.62 \\
\hline $\begin{array}{r}\text { Bicarbonate } \\
\text { Carbonate } \\
\text { Chloride } \\
\text { Fluoride } \\
\text { Nitrate as } \mathrm{N} \\
\text { Sulfate } \\
\text { Charge balance error (\%) }\end{array}$ & $\begin{array}{r}245 \\
< \\
4.06 \\
< \\
9.12 \\
6.31 \\
-2.1 \\
\end{array}$ & & & & & & & & \\
\hline Trace Metals (mg/L) & & & & & & & & & \\
\hline Aluminum & $<$ & 0.539 & $<$ & 0.378 & $<$ & 0.384 & $<$ & $<$ & $<$ \\
\hline Antimony & $<$ & $<$ & $<$ & $<$ & $<$ & $<$ & $<$ & $<$ & $<$ \\
\hline Arsenic & $<$ & $<$ & $<$ & $<$ & $<$ & $<$ & $<$ & $<$ & $<$ \\
\hline Barium & 0.154 & 0.0472 & 0.0464 & 0.063 & 0.0489 & 0.0409 & 0.0384 & 0.0579 & 0.0373 \\
\hline Beryllium & $<$ & & $<$ & & $<$ & $<$ & $<$ & $<$ & $<$ \\
\hline Boron & $<$ & 0.145 & $<$ & 0.356 & $<$ & $<$ & $<$ & 0.116 & $<$ \\
\hline Cadmium & $<$ & $<$ & $<$ & $<$ & $<$ & $<$ & $<$ & $<$ & $<$ \\
\hline Chromium & $<$ & $<$ & $<$ & $<$ & $<$ & $<$ & $<$ & $<$ & $<$ \\
\hline Cobalt & $<$ & $<$ & $<$ & $<$ & $<$ & $<$ & $<$ & $<$ & $<$ \\
\hline Copper & $<$ & $<$ & $<$ & $<$ & $<$ & $<$ & $<$ & $<$ & $<$ \\
\hline Iron & $<$ & 0.41 & 0.0802 & 0.465 & 0.0524 & 0.303 & 0.153 & 0.207 & 0.136 \\
\hline Lead & $<$ & $<$ & $<$ & $<$ & $<$ & $<$ & $<$ & $<$ & $<$ \\
\hline Lithium & $<$ & 0.0695 & 0.0461 & 0.126 & 0.0271 & 0.0309 & 0.0118 & 0.0458 & 0.0121 \\
\hline Manganese & 0.0122 & 0.0418 & 0.0492 & 0.0446 & 0.021 & 0.0502 & 0.0436 & 0.0364 & 0.0622 \\
\hline Mercury & $<$ & & & & & & & & \\
\hline Nickel & & & & $<$ & $<$ & $<$ & $<$ & $<$ & $<$ \\
\hline Strontium & 0.0432 & 0.127 & 0.151 & 0.165 & 0.162 & 0.129 & 0.14 & 0.162 & 0.136 \\
\hline Thallium & & & & $<$ & $<$ & $<$ & $<$ & $<$ & $<$ \\
\hline Uranium & 0.00133 & 0.088 & 0.042 & 0.043 & 0.014 & 0.036 & 0.013 & 0.031 & $<$ \\
\hline Zinc & $<$ & $<$ & $<$ & $<$ & $<$ & $<$ & $<$ & $<$ & $<$ \\
\hline
\end{tabular}


APPENDIX E.2

VOLATILE ORGANIC COMPOUNDS 

APPENDIX E.2: CY 2009 MONITORING DATA FOR THE UPPER EAST FORK POPLAR CREEK HYDROGEOLOGIC REGIME Volatile Organic Compounds

\begin{tabular}{|c|c|c|c|c|c|c|c|c|c|c|}
\hline Sampling Point & $55-2 A$ & $55-2 B$ & $55-2 \mathrm{C}$ & \multicolumn{2}{|c|}{$55-3 A$} & \multicolumn{2}{|c|}{$55-3 B$} & \multicolumn{2}{|c|}{$55-3 C$} & $56-1 A$ \\
\hline Functional Area & GRIDB3 & GRIDB3 & GRIDB3 & \multicolumn{2}{|c|}{ B9201-5 } & \multicolumn{2}{|c|}{ B9201-5 } & \multicolumn{2}{|c|}{ B9201-5 } & Y12 \\
\hline Date Sampled & $10 / 27 / 09$ & $10 / 26 / 09$ & $10 / 26 / 09$ & 05/14/09 & $10 / 20 / 09$ & 05/14/09 & $10 / 21 / 09$ & 05/13/09 & $10 / 21 / 09$ & $07 / 28 / 09$ \\
\hline Program & GWPP & GWPP & GWPP & GWPP & GWPP & GWPP & GWPP & GWPP & GWPP & GWPP \\
\hline \multicolumn{11}{|l|}{ Sample Type } \\
\hline \multicolumn{11}{|l|}{ Chloroethenes ( $\mu \mathrm{g} / \mathrm{L})$} \\
\hline Tetrachloroethene & 200 & 390 & 260 & 17,000 & 17,000 & 46,000 & 51,000 & 8,300 & 4,500 & $<$ \\
\hline Trichloroethene & 100 & 170 & 140 & 1,600 & 1,700 & 5,000 & 6,400 & 1,500 & 1,200 & $<$ \\
\hline cis-1,2-Dichloroethene & 280 & 430 & 450 & 1,200 & 1,300 & 1,100 & 1,500 & 1,400 & 1,200 & $<$ \\
\hline trans-1,2-Dichloroethene & $4 \mathrm{~J}$ & 7 & 7 & 24 & 38 & 52 & 76 & 23 & 24 & $<$ \\
\hline 1,1-Dichloroethene & 7 & 13 & 15 & 31 & 50 & 140 & 210 & 37 & 37 & $<$ \\
\hline Vinyl chloride & 7 & 14 & 13 & 44 & 110 & $27 \mathrm{Q}$ & 530 & 150 & 160 & $<$ \\
\hline \multicolumn{11}{|l|}{ Chloroethanes ( $\mu \mathrm{g} / \mathrm{L})$} \\
\hline 1,1,1,2-Tetrachloroethane & $<$ & $<$ & $<$ & $<$ & $<$ & $<$ & $<$ & $<$ & $<$ & $<$ \\
\hline 1,1,1-Trichloroethane & $<$ & $<$ & $<$ & $<$ & $<$ & $<$ & $<$ & $<$ & $<$ & $<$ \\
\hline 1,2-Dichloroethane & $<$ & $<$ & $<$ & $<$ & $<$ & $<$ & $<$ & $<$ & $<$ & $<$ \\
\hline 1,1-Dichloroethane & 8 & 11 & 17 & 7 & 10 & 33 & 46 & 6 & 7 & $<$ \\
\hline Chloroethane & $<$ & $<$ & $<$ & $<$ & $1 \mathrm{~J}$ & $<$ & $<$ & $<$ & $<$ & $<$ \\
\hline \multicolumn{11}{|l|}{ Chloromethanes $(\mu \mathrm{g} / \mathrm{L})$} \\
\hline Carbon tetrachloride & $<$ & $<$ & $<$ & $<$ & $<$ & $<$ & $<$ & $<$ & $<$ & $<$ \\
\hline Chloroform & $<$ & $<$ & $<$ & $<$ & $<$ & $<$ & $<$ & $<$ & $<$ & $3 \mathrm{~J}$ \\
\hline Methylene chloride & $<$ & $<$ & $<$ & $<$ & $<$ & $<$ & $<$ & $<$ & $<$ & $<$ \\
\hline \multicolumn{11}{|l|}{ Petrol. Hydrocarb. ( $\mu \mathrm{g} / \mathrm{L})$} \\
\hline Benzene & $<$ & $<$ & $<$ & $<$ & $<$ & $2 \mathrm{~J}$ & $1 \mathrm{~J}$ & $<$ & $<$ & $<$ \\
\hline Ethylbenzene & $<$ & $<$ & $<$ & $<$ & $<$ & $<$ & $<$ & $<$ & $<$ & $<$ \\
\hline Toluene & $<$ & $<$ & $<$ & $<$ & $<$ & $2 \mathrm{~J}$ & $4 \mathrm{~J}$ & $<$ & $<$ & $<$ \\
\hline Total Xylene & $<$ & $<$ & $<$ & $<$ & $<$ & $<$ & $<$ & $<$ & $<$ & $<$ \\
\hline Styrene & $<$ & $<$ & $<$ & $<$ & $<$ & $<$ & $<$ & $<$ & $<$ & $<$ \\
\hline \multicolumn{11}{|l|}{ Miscellaneous ( $\mu \mathrm{g} / \mathrm{L})$} \\
\hline 1,1,2-Trichloro-1,2,2-trifluoroethane & 130 & 330 & 190 & 14 & 30 & $<$ & $<$ & $3 \mathrm{~J}$ & 7 & $<$ \\
\hline Trichlorofluoromethane & $<$ & $<$ & $<$ & $<$ & $<$ & $<$ & $<$ & $<$ & $<$ & $<$ \\
\hline 1,2-Dichloropropane & $<$ & $<$ & $<$ & $<$ & $<$ & $<$ & $<$ & $<$ & $<$ & $<$ \\
\hline 1,4-Dichlorobenzene & $<$ & $<$ & $<$ & $<$ & $<$ & $1 \mathrm{~J}$ & $<$ & $<$ & $<$ & $<$ \\
\hline 2-Butanone & $<$ & $<$ & $<$ & $<$ & $<$ & $<$ & $<$ & $<$ & $<$ & $<$ \\
\hline Acetone & $<$ & $<$ & $<$ & $<$ & $<$ & $<$ & $<$ & $<$ & $<$ & $<$ \\
\hline Bromodichloromethane & $<$ & $<$ & $<$ & $<$ & $<$ & $<$ & $<$ & $<$ & $<$ & $<$ \\
\hline Bromoform & $<$ & $<$ & $<$ & $<$ & $<$ & $<$ & $<$ & $<$ & $<$ & $<$ \\
\hline \multicolumn{11}{|l|}{ Natural Attenuation $(\mu \mathrm{g} / \mathrm{L})$} \\
\hline Ethane & & & & & & & & & & \\
\hline Ethylene & & & & & & & & & & \\
\hline Methane & & & & & & & & & & \\
\hline
\end{tabular}


APPENDIX E.2: CY 2009 MONITORING DATA FOR THE UPPER EAST FORK POPLAR CREEK HYDROGEOLOGIC REGIME Volatile Organic Compounds

\begin{tabular}{|c|c|c|c|c|c|c|c|c|c|}
\hline Sampling Point & \multicolumn{2}{|c|}{$56-1 C$} & $56-2 A$ & $56-2 B$ & $56-2 \mathrm{C}$ & $56-3 A$ & $56-3 B$ & $56-3 C$ & $56-4 \mathrm{~A}$ \\
\hline Functional Area & \multicolumn{2}{|c|}{ Y12 } & GRIDC3 & GRIDC3 & GRIDC3 & Y12 & Y12 & Y12 & Y12 \\
\hline Date Sampled & \multicolumn{2}{|c|}{$07 / 28 / 09$} & 07/29/09 & 07/29/09 & $07 / 28 / 09$ & $07 / 30 / 09$ & 07/29/09 & $07 / 30 / 09$ & $05 / 12 / 09$ \\
\hline Program & GWPP & GWPP & GWPP & GWPP & GWPP & GWPP & GWPP & GWPP & GWPP \\
\hline Sample Type & & Dup & & & PDB & & & & NP \\
\hline \multicolumn{10}{|l|}{ Chloroethenes ( $\mu \mathrm{g} / \mathrm{L})$} \\
\hline Tetrachloroethene & $<$ & $<$ & 12 & 1,000 & 40 & 14 & 150 & 520 & $2 \mathrm{~J}$ \\
\hline Trichloroethene & $<$ & $<$ & $3 \mathrm{~J}$ & 75 & 170 & $5 \mathrm{~J}$ & 15 & 38 & $<$ \\
\hline cis-1,2-Dichloroethene & $<$ & $<$ & $3 \mathrm{~J}$ & 98 & 920 & $2 \mathrm{~J}$ & 20 & 68 & $<$ \\
\hline trans-1,2-Dichloroethene & $<$ & $<$ & $<$ & $2 \mathrm{~J}$ & 7 & $<$ & $<$ & $1 \mathrm{~J}$ & $<$ \\
\hline 1,1-Dichloroethene & $<$ & $<$ & $<$ & $2 \mathrm{~J}$ & 13 & $<$ & $<$ & $2 \mathrm{~J}$ & $<$ \\
\hline Vinyl chloride & $<$ & $<$ & $<$ & $<$ & 59 & $<$ & $<$ & $<$ & $<$ \\
\hline \multicolumn{10}{|l|}{ Chloroethanes ( $\mu \mathrm{g} / \mathrm{L})$} \\
\hline 1,1,1,2-Tetrachloroethane & $<$ & $<$ & $<$ & $<$ & & $<$ & $<$ & $<$ & $<$ \\
\hline 1,1,1-Trichloroethane & $<$ & $<$ & $<$ & $<$ & $<$ & $<$ & $<$ & $<$ & $<$ \\
\hline 1,2-Dichloroethane & $<$ & $<$ & $<$ & $<$ & $<$ & $<$ & $<$ & $<$ & $<$ \\
\hline 1,1-Dichloroethane & $<$ & $<$ & $<$ & $<$ & $<$ & $<$ & $<$ & $<$ & $3 \mathrm{~J}$ \\
\hline Chloroethane & $<$ & $<$ & $<$ & $<$ & $<$ & $<$ & $<$ & $<$ & $<$ \\
\hline \multicolumn{10}{|l|}{ Chloromethanes ( $\mu \mathrm{g} / \mathrm{L})$} \\
\hline Carbon tetrachloride & $<$ & $<$ & $<$ & $<$ & $<$ & $<$ & $<$ & $<$ & $<$ \\
\hline Chloroform & $<$ & $<$ & $<$ & $<$ & $<$ & $<$ & $1 \mathrm{~J}$ & $<$ & $<$ \\
\hline Methylene chloride & $<$ & $<$ & $<$ & $<$ & $<$ & $<$ & $<$ & $<$ & $<$ \\
\hline \multicolumn{10}{|l|}{ Petrol. Hydrocarb. ( $\mu \mathrm{g} / \mathrm{L})$} \\
\hline Benzene & $<$ & $<$ & $<$ & $<$ & $<$ & $<$ & $<$ & $<$ & $<$ \\
\hline Ethylbenzene & $<$ & $<$ & $<$ & $<$ & $<$ & $<$ & $<$ & $<$ & $<$ \\
\hline Toluene & $<$ & $<$ & $<$ & $<$ & $<$ & $<$ & $<$ & $<$ & $<$ \\
\hline Total Xylene & $<$ & $<$ & $<$ & $<$ & $<$ & $<$ & $<$ & $<$ & $<$ \\
\hline Styrene & $<$ & $<$ & $<$ & $<$ & & $<$ & $<$ & $<$ & $<$ \\
\hline \multicolumn{10}{|l|}{ Miscellaneous ( $\mu \mathrm{g} / \mathrm{L})$} \\
\hline 1,1,2-Trichloro-1,2,2-trifluoroethane & $<$ & $<$ & $<$ & $2 \mathrm{~J}$ & $<$ & $<$ & $<$ & $1 \mathrm{~J}$ & $<$ \\
\hline Trichlorofluoromethane & $<$ & $<$ & $<$ & $<$ & $<$ & $<$ & $<$ & $<$ & $<$ \\
\hline 1,2-Dichloropropane & $<$ & $<$ & $<$ & $<$ & $<$ & $<$ & $<$ & $<$ & $<$ \\
\hline 1,4-Dichlorobenzene & $<$ & $<$ & $<$ & $<$ & $<$ & $<$ & $<$ & $<$ & $<$ \\
\hline 2-Butanone & $<$ & $<$ & $<$ & $<$ & 6 & $<$ & $<$ & $<$ & $<$ \\
\hline Acetone & $<$ & $<$ & $<$ & $<$ & & $<$ & $<$ & $<$ & $<$ \\
\hline Bromodichloromethane & $<$ & $<$ & $<$ & $<$ & $<$ & $<$ & $<$ & $<$ & $<$ \\
\hline Bromoform & $<$ & $<$ & $<$ & $<$ & $<$ & $<$ & $<$ & $<$ & $<$ \\
\hline \multicolumn{10}{|l|}{ Natural Attenuation $(\mu \mathrm{g} / \mathrm{L})$} \\
\hline Ethane & & & & & & & & & \\
\hline Ethylene & & & & & & & & & \\
\hline Methane & & & & & & & & & \\
\hline
\end{tabular}


APPENDIX E.2: CY 2009 MONITORING DATA FOR THE UPPER EAST FORK POPLAR CREEK HYDROGEOLOGIC REGIME Volatile Organic Compounds

\begin{tabular}{|c|c|c|c|c|c|c|c|c|c|c|}
\hline Sampling Point & \multicolumn{2}{|c|}{ GW-108 } & \multicolumn{2}{|c|}{ GW-151 } & \multicolumn{2}{|c|}{ GW-153 } & \multicolumn{2}{|c|}{ GW-154 } & \multicolumn{2}{|c|}{ GW-169 } \\
\hline Functional Area & \multicolumn{2}{|c|}{ S3 } & \multicolumn{2}{|c|}{ NHP } & \multicolumn{2}{|c|}{ NHP } & \multicolumn{2}{|c|}{ NHP } & \multicolumn{2}{|c|}{ EXP-UV } \\
\hline Date Sampled & 01/12/09 & $07 / 08 / 09$ & 03/03/09 & $07 / 23 / 09$ & \multicolumn{2}{|c|}{$10 / 14 / 09$} & 03/03/09 & $07 / 23 / 09$ & $03 / 04 / 09$ & $07 / 23 / 09$ \\
\hline Program & BJC & BJC & BJC & BJC & GWPP & GWPP & BJC & BJC & BJC & BJC \\
\hline Sample Type & & & & & PDB & Dup & & & & \\
\hline Chloroethenes ( $\mu \mathrm{g} / \mathrm{L})$ & & & & & & & & & & \\
\hline Tetrachloroethene & 11 & 6 & 691 & 731 & $<$ & $<$ & $<$ & $<$ & $1.03 \mathrm{~J}$ & $1.25 \mathrm{~J}$ \\
\hline Trichloroethene & 5.7 & 3.4 & $110 \mathrm{~J}$ & $115 \mathrm{~J}$ & $<$ & $<$ & $<$ & $<$ & $<$ & $<$ \\
\hline cis-1,2-Dichloroethene & $<$ & $<$ & $61.4 \mathrm{~J}$ & $59.6 \mathrm{~J}$ & $<$ & $<$ & $<$ & $<$ & $<$ & $<$ \\
\hline trans-1,2-Dichloroethene & $<$ & $<$ & & $<$ & $<$ & $<$ & $<$ & $<$ & $<$ & $<$ \\
\hline 1,1-Dichloroethene & $1.37 \mathrm{~J}$ & 1 & $1.54 \mathrm{~J}$ & $1.63 \mathrm{~J}$ & $<$ & $<$ & $<$ & $<$ & $<$ & $<$ \\
\hline Vinyl chloride & $<$ & $<$ & $<$ & $<$ & $<$ & $<$ & $<$ & $<$ & $<$ & $<$ \\
\hline Chloroethanes ( $\mu \mathrm{g} / \mathrm{L})$ & & & & & & & & & & \\
\hline 1,1,1,2-Tetrachloroethane & & & & & & & & & & \\
\hline 1,1,1-Trichloroethane & $<$ & $<$ & $<$ & $<$ & $<$ & $<$ & $<$ & $<$ & $<$ & $<$ \\
\hline 1,2-Dichloroethane & $<$ & $<$ & $<$ & $<$ & $<$ & $<$ & $<$ & $<$ & $<$ & $<$ \\
\hline 1,1-Dichloroethane & $<$ & $<$ & $<$ & $<$ & $<$ & $<$ & $<$ & $<$ & $<$ & $<$ \\
\hline Chloroethane & $<$ & $<$ & $<$ & $<$ & $<$ & $<$ & $<$ & $<$ & $<$ & $<$ \\
\hline Chloromethanes ( $\mu \mathrm{g} / \mathrm{L})$ & & & & & & & & & & \\
\hline Carbon tetrachloride & $<$ & $<$ & 1,140 & 1,340 & 68 & 64 & $<$ & $<$ & $<$ & $<$ \\
\hline Chloroform & 31.6 & 30 & $62.1 \mathrm{~J}$ & $74.5 \mathrm{~J}$ & $4 \mathrm{~J}$ & $4 \mathrm{~J}$ & $<$ & $<$ & $<$ & $<$ \\
\hline Methylene chloride & 48.8 & 47 & $<$ & $<$ & $<$ & $<$ & $<$ & $<$ & $<$ & $<$ \\
\hline Petrol. Hydrocarb. ( $\mu \mathrm{g} / \mathrm{L})$ & & & & & & & & & & \\
\hline Benzene & $1.52 \mathrm{~J}$ & $<$ & $<$ & $<$ & $<$ & $<$ & $<$ & $<$ & $<$ & $<$ \\
\hline Ethylbenzene & $<$ & $<$ & $<$ & $<$ & $<$ & $<$ & $<$ & $<$ & $<$ & $<$ \\
\hline Toluene & $<$ & $<$ & $<$ & $<$ & $<$ & $<$ & $<$ & $<$ & $<$ & $<$ \\
\hline Total Xylene & $<$ & & $<$ & $<$ & $<$ & $<$ & $<$ & $<$ & $<$ & $<$ \\
\hline Styrene & $<$ & $<$ & $<$ & $<$ & & & $<$ & $<$ & $<$ & $<$ \\
\hline Miscellaneous ( $\mu \mathrm{g} / \mathrm{L})$ & & & & & & & & & & \\
\hline 1,1,2-Trichloro-1,2,2-trifluoroethane & & & & & $<$ & $<$ & & & & \\
\hline Trichlorofluoromethane & & & & & $<$ & $<$ & & & & \\
\hline 1,2-Dichloropropane & $<$ & $<$ & $<$ & $<$ & $<$ & $<$ & $<$ & $<$ & $<$ & $<$ \\
\hline 1,4-Dichlorobenzene & & & & & $<$ & $<$ & & & & \\
\hline 2-Butanone & $<$ & $<$ & $<$ & $<$ & $<$ & $<$ & $<$ & $<$ & $<$ & $<$ \\
\hline Acetone & $<$ & $<$ & $<$ & $<$ & . & . & $<$ & $<$ & $<$ & $<$ \\
\hline Bromodichloromethane & $<$ & $<$ & $<$ & $<$ & $<$ & $<$ & $<$ & $<$ & $<$ & $<$ \\
\hline Bromoform & 10.1 & 3.9 & $<$ & $<$ & $<$ & $<$ & $<$ & $<$ & $<$ & $<$ \\
\hline Natural Attenuation $(\mu \mathrm{g} / \mathrm{L})$ & & & & & & & & & & \\
\hline Ethane & & & $<$ & $<$ & & & $<$ & $<$ & & \\
\hline Ethylene & & & $<$ & $<$ & & & $<$ & $<$ & & \\
\hline Methane & & & 110 & 129 & & & 30.3 & 13.3 & & \\
\hline
\end{tabular}


APPENDIX E.2: CY 2009 MONITORING DATA FOR THE UPPER EAST FORK POPLAR CREEK HYDROGEOLOGIC REGIME Volatile Organic Compounds

\begin{tabular}{|c|c|c|c|c|c|c|c|c|c|c|}
\hline Sampling Point & \multicolumn{4}{|c|}{ GW-170 } & GW-171 & GW-172 & \multicolumn{2}{|c|}{ GW-220 } & \multicolumn{2}{|c|}{ GW-222 } \\
\hline Functional Area & \multicolumn{4}{|c|}{ EXP-UV } & EXP-UV & EXP-UV & \multicolumn{2}{|c|}{ NHP } & \multirow{2}{*}{\multicolumn{2}{|c|}{$\begin{array}{c}\text { NHP } \\
04 / 30 / 09\end{array}$}} \\
\hline Date Sampled & \multicolumn{2}{|c|}{ 03/04/09 } & \multicolumn{2}{|c|}{$07 / 23 / 09$} & 03/05/09 & 03/05/09 & $04 / 29 / 09$ & $10 / 14 / 09$ & & \\
\hline Program & $\mathrm{BJC}$ & BJC & BJC & BJC & BJC & BJC & GWPP & GWPP & GWPP & GWPP \\
\hline Sample Type & & Dup & & Dup & & & PDB & PDB & & Dup \\
\hline Chloroethenes ( $\mu \mathrm{g} / \mathrm{L})$ & & & & & & & & & & \\
\hline Tetrachloroethene & $<$ & $1.09 \mathrm{~J}$ & $<$ & $<$ & $<$ & $<$ & 210 & 180 & 13 & 12 \\
\hline Trichloroethene & $1.08 \mathrm{~J}$ & $1.08 \mathrm{~J}$ & $<$ & $<$ & $<$ & $<$ & 100 & 100 & $2 \mathrm{~J}$ & $2 \mathrm{~J}$ \\
\hline cis-1,2-Dichloroethene & $<$ & $<$ & $<$ & $<$ & $<$ & $<$ & 65 & 56 & 5 & $5 \mathrm{~J}$ \\
\hline trans-1,2-Dichloroethene & $<$ & $<$ & $<$ & $<$ & $<$ & $<$ & $<$ & $<$ & $<$ & $<$ \\
\hline 1,1-Dichloroethene & $<$ & $<$ & $<$ & $<$ & $<$ & $<$ & $<$ & $3 \mathrm{~J}$ & $<$ & $<$ \\
\hline Vinyl chloride & $<$ & $<$ & $<$ & $<$ & $<$ & $<$ & $<$ & $<$ & $<$ & $<$ \\
\hline Chloroethanes ( $\mu \mathrm{g} / \mathrm{L})$ & & & & & & & & & & \\
\hline 1,1,1,2-Tetrachloroethane & & & & & & & & & $<$ & $<$ \\
\hline 1,1,1-Trichloroethane & $<$ & $<$ & $<$ & $<$ & $<$ & $<$ & $<$ & $<$ & $<$ & $<$ \\
\hline 1,2-Dichloroethane & $<$ & $<$ & $<$ & $<$ & $<$ & $<$ & $<$ & $<$ & $<$ & $<$ \\
\hline 1,1-Dichloroethane & $<$ & $<$ & $<$ & $<$ & $<$ & $<$ & $<$ & $<$ & $<$ & $<$ \\
\hline Chloroethane & $<$ & $<$ & $<$ & $<$ & $<$ & $<$ & $<$ & $<$ & $<$ & $<$ \\
\hline Chloromethanes ( $\mu \mathrm{g} / \mathrm{L})$ & & & & & & & & & & \\
\hline Carbon tetrachloride & $1.79 \mathrm{~J}$ & $1.8 \mathrm{~J}$ & $2.1 \mathrm{~J}$ & $1.8 \mathrm{~J}$ & $<$ & $<$ & 670 & 690 & $<$ & $<$ \\
\hline Chloroform & $<$ & $<$ & $<$ & $1.03 \mathrm{~J}$ & $<$ & $<$ & 71 & 70 & $<$ & $<$ \\
\hline Methylene chloride & $<$ & $<$ & $<$ & $<$ & $<$ & $<$ & $<$ & $<$ & $<$ & $<$ \\
\hline Petrol. Hydrocarb. ( $\mu \mathrm{g} / \mathrm{L})$ & & & & & & & & & & \\
\hline Benzene & $<$ & $<$ & $<$ & $<$ & $<$ & $<$ & $<$ & $<$ & $<$ & $<$ \\
\hline Ethylbenzene & $<$ & $<$ & $<$ & $<$ & $<$ & $<$ & $<$ & $<$ & $<$ & $<$ \\
\hline Toluene & $<$ & $<$ & $<$ & $<$ & $<$ & $<$ & $<$ & $<$ & $<$ & $<$ \\
\hline Total Xylene & $<$ & $<$ & $<$ & $<$ & $<$ & $<$ & $<$ & $<$ & $<$ & $<$ \\
\hline Styrene & $<$ & $<$ & $<$ & $<$ & $<$ & $<$ & & & $<$ & $<$ \\
\hline Miscellaneous ( $\mu \mathrm{g} / \mathrm{L})$ & & & & & & & & & & \\
\hline 1,1,2-Trichloro-1,2,2-trifluoroethane & & & & & & & $<$ & $2 \mathrm{~J}$ & $<$ & $<$ \\
\hline Trichlorofluoromethane & & & & & & & $<$ & $2 \mathrm{~J}$ & $<$ & $<$ \\
\hline 1,2-Dichloropropane & $<$ & $<$ & $<$ & $<$ & $<$ & $<$ & $<$ & $<$ & $<$ & $<$ \\
\hline 1,4-Dichlorobenzene & & & & & & & $<$ & $<$ & $<$ & $<$ \\
\hline 2-Butanone & $<$ & $<$ & $<$ & $<$ & $<$ & $<$ & $<$ & $<$ & $<$ & $<$ \\
\hline Acetone & $<$ & $<$ & $<$ & $<$ & $<$ & $<$ & . & & $<$ & $<$ \\
\hline Bromodichloromethane & $<$ & $<$ & $<$ & $<$ & $<$ & $<$ & $<$ & $<$ & $<$ & $<$ \\
\hline Bromoform & $<$ & $<$ & $<$ & $<$ & $<$ & $<$ & $<$ & $<$ & $<$ & $<$ \\
\hline Natural Attenuation ( $\mu \mathrm{g} / \mathrm{L})$ & & & & & & & & & & \\
\hline Ethane & & & & & & & & & & \\
\hline Ethylene & & & & & & & & & & \\
\hline Methane & & & & & & & & & & \\
\hline
\end{tabular}


APPENDIX E.2: CY 2009 MONITORING DATA FOR THE UPPER EAST FORK POPLAR CREEK HYDROGEOLOGIC REGIME Volatile Organic Compounds

\begin{tabular}{|c|c|c|c|c|c|c|c|c|c|}
\hline Sampling Point & \multicolumn{2}{|c|}{ GW-223 } & GW-230 & GW-240 & GW-251 & GW-253 & GW-269 & GW-270 & GW-272 \\
\hline Functional Area & \multicolumn{2}{|c|}{ NHP } & EXP-UV & NHP & S2 & S2 & SY & SY & SY \\
\hline Date Sampled & 03/03/09 & $07 / 22 / 09$ & 03/05/09 & $10 / 14 / 09$ & $04 / 30 / 09$ & 03/04/09 & $04 / 21 / 09$ & $04 / 28 / 09$ & 04/21/09 \\
\hline Program & BJC & BJC & BJC & GWPP & GWPP & BJC & GWPP & GWPP & GWPP \\
\hline Sample Type & & & & PDB & & & PDB & & \\
\hline Chloroethenes ( $\mu \mathrm{g} / \mathrm{L})$ & & & & & & & & & \\
\hline Tetrachloroethene & 21.8 & 21 & $<$ & $<$ & 230 & 766 & 13 & $<$ & $<$ \\
\hline Trichloroethene & 13.4 & 10.3 & $<$ & $<$ & 110 & 812 & $5 \mathrm{~J}$ & $<$ & $<$ \\
\hline cis-1,2-Dichloroethene & 80.2 & 52.8 & 9.05 & $<$ & 14 & 257 & 63 & $<$ & $<$ \\
\hline trans-1,2-Dichloroethene & $<$ & $<$ & $<$ & $<$ & $<$ & $<$ & $<$ & $<$ & $<$ \\
\hline 1,1-Dichloroethene & $<$ & $<$ & $<$ & $<$ & $<$ & 4.28 & 160 & $<$ & $<$ \\
\hline Vinyl chloride & 5.04 & 4.71 & 1.72 & $<$ & $<$ & 75.6 & $<$ & $<$ & $<$ \\
\hline Chloroethanes $(\mu \mathrm{g} / \mathrm{L})$ & & & & & & & & & \\
\hline 1,1,1,2-Tetrachloroethane & & & & & $<$ & & & $<$ & $<$ \\
\hline 1,1,1-Trichloroethane & $<$ & $<$ & $<$ & $<$ & $<$ & $<$ & 12 & $<$ & $<$ \\
\hline 1,2-Dichloroethane & $<$ & $<$ & $<$ & $<$ & $<$ & $<$ & $<$ & $<$ & $<$ \\
\hline 1,1-Dichloroethane & $<$ & $<$ & $<$ & $<$ & $<$ & $<$ & $5 \mathrm{~J}$ & $<$ & $<$ \\
\hline Chloroethane & $<$ & $<$ & $<$ & $<$ & $<$ & $<$ & $<$ & $<$ & $<$ \\
\hline Chloromethanes ( $\mu \mathrm{g} / \mathrm{L})$ & & & & & & & & & \\
\hline Carbon tetrachloride & $<$ & $<$ & $<$ & $3 \mathrm{~J}$ & $2 \mathrm{~J}$ & $42.4 \mathrm{~J}$ & $<$ & $<$ & $<$ \\
\hline Chloroform & $<$ & $<$ & $<$ & $<$ & 7 & $42.9 \mathrm{~J}$ & $4 \mathrm{~J}$ & $<$ & $<$ \\
\hline Methylene chloride & $<$ & $<$ & $<$ & $<$ & $<$ & $<$ & $<$ & $<$ & $<$ \\
\hline Petrol. Hydrocarb. ( $\mu \mathrm{g} / \mathrm{L})$ & & & & & & & & & \\
\hline Benzene & $<$ & $<$ & $<$ & $<$ & $<$ & $<$ & $<$ & $<$ & $<$ \\
\hline Ethylbenzene & $<$ & $<$ & $<$ & $<$ & $<$ & $<$ & $<$ & $<$ & $<$ \\
\hline Toluene & $<$ & $<$ & $<$ & $<$ & $<$ & $<$ & $<$ & $<$ & $<$ \\
\hline Total Xylene & $<$ & $<$ & $<$ & $<$ & $<$ & $<$ & $<$ & $<$ & $<$ \\
\hline Styrene & $<$ & $<$ & $<$ & & $<$ & $<$ & & $<$ & $<$ \\
\hline Miscellaneous ( $\mu \mathrm{g} / \mathrm{L})$ & & & & & & & & & \\
\hline 1,1,2-Trichloro-1,2,2-trifluoroethane & & & & $<$ & $<$ & & 19 & $<$ & $<$ \\
\hline Trichlorofluoromethane & & & & $<$ & $<$ & & $<$ & $<$ & $<$ \\
\hline 1,2-Dichloropropane & $<$ & $<$ & $<$ & $<$ & $<$ & $<$ & $<$ & $<$ & $<$ \\
\hline 1,4-Dichlorobenzene & & & & $<$ & $<$ & & $<$ & $<$ & $<$ \\
\hline 2-Butanone & $<$ & $<$ & $<$ & $<$ & $<$ & $<$ & $<$ & $<$ & $<$ \\
\hline Acetone & $<$ & $<$ & $<$ & . & $<$ & $4.31 \mathrm{~J}$ & . & $<$ & $<$ \\
\hline Bromodichloromethane & $<$ & $<$ & $<$ & $<$ & $<$ & $<$ & $<$ & $<$ & $<$ \\
\hline Bromoform & $<$ & $<$ & $<$ & $<$ & $<$ & $<$ & $<$ & $<$ & $<$ \\
\hline Natural Attenuation $(\mu \mathrm{g} / \mathrm{L})$ & & & & & & & & & \\
\hline Ethane & $<$ & $<$ & & & & $1.76 \mathrm{~J}$ & & & \\
\hline Ethylene & $<$ & $<$ & & & & & & & \\
\hline Methane & 43.9 & 57.2 & & & & 8.95 & & & \\
\hline
\end{tabular}


APPENDIX E.2: CY 2009 MONITORING DATA FOR THE UPPER EAST FORK POPLAR CREEK HYDROGEOLOGIC REGIME Volatile Organic Compounds

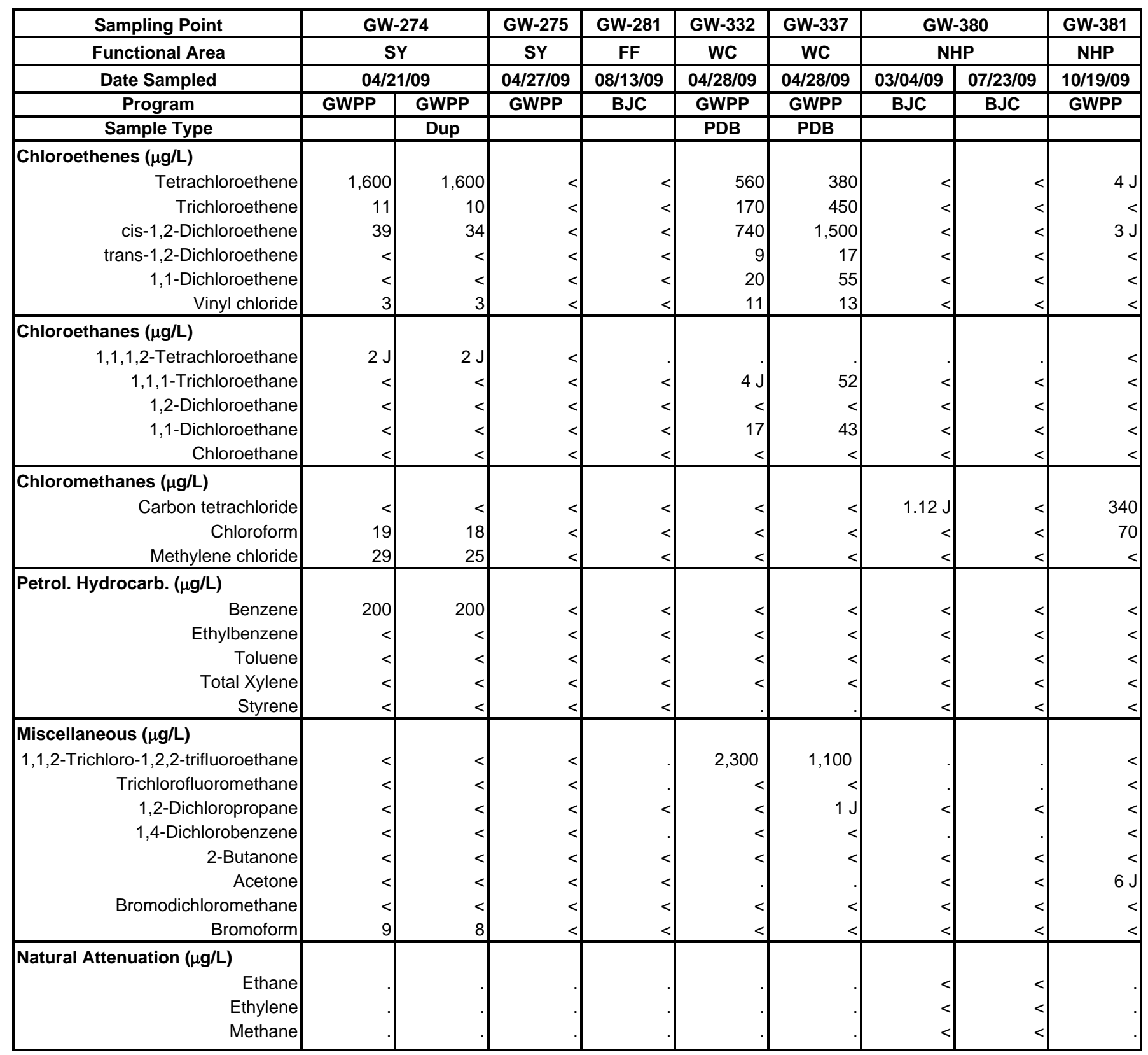


APPENDIX E.2: CY 2009 MONITORING DATA FOR THE UPPER EAST FORK POPLAR CREEK HYDROGEOLOGIC REGIME Volatile Organic Compounds

\begin{tabular}{|c|c|c|c|c|c|c|c|c|c|c|}
\hline Sampling Point & \multicolumn{2}{|c|}{ GW-382 } & GW-383 & GW-508 & \multicolumn{4}{|c|}{ GW-605 } & \multicolumn{2}{|c|}{ GW-606 } \\
\hline Functional Area & \multicolumn{2}{|c|}{ NHP } & NHP & RG & \multicolumn{4}{|c|}{ EXP-I } & \multicolumn{2}{|c|}{ EXP-I } \\
\hline Date Sampled & 03/04/09 & $07 / 23 / 09$ & $10 / 14 / 09$ & $04 / 20 / 09$ & \multicolumn{2}{|c|}{$01 / 08 / 09$} & \multicolumn{2}{|c|}{ 07/07/09 } & $01 / 08 / 09$ & \multirow{2}{*}{\begin{tabular}{|c|}
$07 / 07 / 09$ \\
BJC \\
\end{tabular}} \\
\hline Program & BJC & BJC & GWPP & GWPP & BJC & BJC & BJC & BJC & $\mathrm{BJC}$ & \\
\hline Sample Type & & & PDB & PDB & & Dup & & Dup & & \\
\hline \multicolumn{11}{|l|}{ Chloroethenes ( $\mu \mathrm{g} / \mathrm{L})$} \\
\hline Tetrachloroethene & 25.5 & $16.9 \mathrm{~J}$ & 120 & $<$ & 62 & 71 & 110 & 110 & 6 & 5 \\
\hline Trichloroethene & $<$ & $<$ & 150 & $<$ & 56 & 61 & 110 & 100 & $0.3 \mathrm{~J}$ & $<$ \\
\hline cis-1,2-Dichloroethene & $6.65 \mathrm{~J}$ & $<$ & 210 & $<$ & 81 & 81 & 160 & 160 & $<$ & $<$ \\
\hline trans-1,2-Dichloroethene & $<$ & $<$ & $3 \mathrm{~J}$ & $<$ & $0.6 \mathrm{~J}$ & $0.7 \mathrm{~J}$ & $<$ & $<$ & $<$ & $<$ \\
\hline 1,1-Dichloroethene & $<$ & $<$ & $4 \mathrm{~J}$ & $<$ & $0.6 \mathrm{~J}$ & $0.6 \mathrm{~J}$ & $<$ & $<$ & $<$ & $<$ \\
\hline Vinyl chloride & $<$ & $<$ & 5 & $<$ & $0.9 \mathrm{~J}$ & $0.8 \mathrm{~J}$ & $<$ & $<$ & $<$ & $<$ \\
\hline \multicolumn{11}{|l|}{ Chloroethanes ( $\mu \mathrm{g} / \mathrm{L})$} \\
\hline 1,1,1,2-Tetrachloroethane & & & & $<$ & & & & & & \\
\hline 1,1,1-Trichloroethane & $<$ & $<$ & $<$ & $<$ & $<$ & $<$ & $<$ & $<$ & $<$ & $<$ \\
\hline 1,2-Dichloroethane & $<$ & $<$ & $<$ & $<$ & $<$ & $<$ & $<$ & $<$ & $<$ & $<$ \\
\hline 1,1-Dichloroethane & $<$ & $<$ & $<$ & $<$ & $<$ & $<$ & $<$ & $<$ & $<$ & $<$ \\
\hline Chloroethane & $<$ & $<$ & $<$ & $<$ & $<$ & $<$ & $<$ & $<$ & $<$ & $<$ \\
\hline \multicolumn{11}{|l|}{ Chloromethanes $(\mu \mathrm{g} / \mathrm{L})$} \\
\hline Carbon tetrachloride & 439 & 378 & $<$ & $<$ & 48 & 54 & 81 & 81 & 61 & 50 \\
\hline Chloroform & 120 & 107 & $<$ & $<$ & 12 & 11 & 15 & 14 & 46 & 42 \\
\hline Methylene chloride & $<$ & $<$ & $<$ & $<$ & $<$ & $<$ & $<$ & $<$ & $<$ & $<$ \\
\hline \multicolumn{11}{|l|}{ Petrol. Hydrocarb. ( $\mu \mathrm{g} / \mathrm{L})$} \\
\hline Benzene & $<$ & $<$ & $<$ & 280 & $<$ & $<$ & $<$ & $<$ & $0.4 \mathrm{~J}$ & $<$ \\
\hline Ethylbenzene & $<$ & $<$ & $<$ & 310 & $<$ & $<$ & $<$ & $<$ & $<$ & $<$ \\
\hline Toluene & $<$ & $<$ & $<$ & 890 & $<$ & $<$ & $<$ & $<$ & $<$ & $<$ \\
\hline Total Xylene & $<$ & $<$ & $<$ & 1,500 & $<$ & $<$ & & . & $<$ & \\
\hline Styrene & $<$ & $<$ & . & $4 \mathrm{~J}$ & $<$ & $<$ & $<$ & $<$ & $<$ & $<$ \\
\hline \multicolumn{11}{|l|}{ Miscellaneous ( $\mu \mathrm{g} / \mathrm{L})$} \\
\hline 1,1,2-Trichloro-1,2,2-trifluoroethane & & & $<$ & $<$ & & & & & & \\
\hline Trichlorofluoromethane & & & $<$ & $<$ & & & & & & \\
\hline 1,2-Dichloropropane & $<$ & $<$ & $<$ & $<$ & $<$ & $<$ & $<$ & $<$ & $<$ & $<$ \\
\hline 1,4-Dichlorobenzene & & & $<$ & $<$ & & & & & & \\
\hline 2-Butanone & $<$ & $<$ & $<$ & $<$ & $<$ & $<$ & $<$ & $<$ & $<$ & $<$ \\
\hline Acetone & $<$ & $<$ & . & 45 & $<$ & $<$ & $<$ & $<$ & $<$ & $<$ \\
\hline Bromodichloromethane & $<$ & $<$ & $<$ & $<$ & $<$ & $<$ & $<$ & $<$ & $<$ & $<$ \\
\hline Bromoform & $<$ & $<$ & $<$ & $<$ & $<$ & $<$ & $<$ & $<$ & $<$ & $<$ \\
\hline Natural Attenuation ( $\mu \mathrm{g} / \mathrm{L})$ & & & & & & & & & & \\
\hline Ethane & $<$ & $<$ & & & & & & & & \\
\hline Ethylene & $<$ & $<$ & & & & & & & & \\
\hline Methane & 666 & 729 & & & & & & & & \\
\hline
\end{tabular}


APPENDIX E.2: CY 2009 MONITORING DATA FOR THE UPPER EAST FORK POPLAR CREEK HYDROGEOLOGIC REGIME Volatile Organic Compounds

\begin{tabular}{|c|c|c|c|c|c|c|c|c|c|c|}
\hline Sampling Point & GW-618 & GW-633 & GW-656 & GW-658 & GW-686 & GW-690 & \multicolumn{3}{|c|}{ GW-691 } & GW-692 \\
\hline Functional Area & EXP-E & RG & T0134 & FF & CPT & CPT & \multicolumn{3}{|c|}{ СРT } & СРT \\
\hline Date Sampled & 03/30/09 & $04 / 28 / 09$ & 05/12/09 & 08/13/09 & 05/13/09 & 05/13/09 & 05/12/09 & \multicolumn{2}{|c|}{$10 / 20 / 09$} & 05/12/09 \\
\hline Program & BJC & GWPP & GWPP & BJC & GWPP & GWPP & GWPP & \begin{tabular}{|l|} 
GWPP \\
\end{tabular} & GWPP & GWPP \\
\hline Sample Type & & & PDB & & & & & & Dup & \\
\hline \multicolumn{11}{|l|}{ Chloroethenes ( $\mu \mathrm{g} / \mathrm{L})$} \\
\hline Tetrachloroethene & $2.34 \mathrm{~J}$ & 190 & 32 & $<$ & 6 & 65 & $14 \mathrm{Q}$ & 5 & $4 \mathrm{~J}$ & 7 \\
\hline Trichloroethene & 7.81 & 7 & 2,700 & $<$ & $4 \mathrm{~J}$ & $2 \mathrm{~J}$ & $<\mathrm{Q}$ & $<$ & $<$ & $1 \mathrm{~J}$ \\
\hline cis-1,2-Dichloroethene & 12 & 12 & 150 & $<$ & $3 \mathrm{~J}$ & $3 \mathrm{~J}$ & $<Q$ & $<$ & $<$ & 17 \\
\hline trans-1,2-Dichloroethene & $<$ & $<$ & 19 & $<$ & $<$ & $<$ & $<$ & $<$ & $<$ & $<$ \\
\hline 1,1-Dichloroethene & $<$ & $2 \mathrm{~J}$ & 150 & $<$ & $<$ & $<$ & $<$ & $<$ & $<$ & $<$ \\
\hline Vinyl chloride & $<$ & $<$ & $<$ & $<$ & $<$ & $<$ & $<$ & $<$ & $<$ & $<$ \\
\hline \multicolumn{11}{|l|}{ Chloroethanes ( $\mu \mathrm{g} / \mathrm{L})$} \\
\hline 1,1,1,2-Tetrachloroethane & & $<$ & & & $<$ & $<$ & $<$ & $<$ & $<$ & $<$ \\
\hline 1,1,1-Trichloroethane & $<$ & $<$ & $<$ & $<$ & $<$ & $<$ & $<$ & $<$ & $<$ & $<$ \\
\hline 1,2-Dichloroethane & $<$ & $<$ & $<$ & 373 & $<$ & $<$ & $<$ & $<$ & $<$ & $<$ \\
\hline 1,1-Dichloroethane & $<$ & $<$ & 12 & $<$ & $<$ & $<$ & $<$ & $<$ & $<$ & $<$ \\
\hline Chloroethane & $<$ & $<$ & $<$ & $<$ & $<$ & $<$ & $<$ & $<$ & $<$ & $<$ \\
\hline \multicolumn{11}{|l|}{ Chloromethanes $(\mu \mathrm{g} / \mathrm{L})$} \\
\hline Carbon tetrachloride & $<$ & $<$ & $<$ & $<$ & $<$ & $<$ & $<$ & $<$ & $<$ & $<$ \\
\hline Chloroform & $<$ & 13 & $<$ & $<$ & $<$ & $<$ & $21 \mathrm{Q}$ & $<$ & $<$ & $4 \mathrm{~J}$ \\
\hline Methylene chloride & $<$ & 18 & $<$ & $<$ & $<$ & $<$ & $<$ & $<$ & $<$ & $<$ \\
\hline \multicolumn{11}{|l|}{ Petrol. Hydrocarb. ( $\mu \mathrm{g} / \mathrm{L}$ ) } \\
\hline Benzene & $<$ & 2,100 & $<$ & 8,110 & $<$ & $<$ & $<$ & $<$ & $<$ & $<$ \\
\hline Ethylbenzene & $<$ & $<$ & $<$ & 837 & $<$ & $<$ & $<$ & $<$ & $<$ & $<$ \\
\hline Toluene & $<$ & $<$ & $<$ & 2,110 & $<$ & $<$ & $<$ & $<$ & $<$ & $<$ \\
\hline Total Xylene & $<$ & 33 & $<$ & 6,670 & $<$ & $<$ & $<$ & $<$ & $<$ & $<$ \\
\hline Styrene & $<$ & $<$ & & $<$ & $<$ & $<$ & $<$ & $<$ & $<$ & $<$ \\
\hline \multicolumn{11}{|l|}{ Miscellaneous ( $\mu \mathrm{g} / \mathrm{L})$} \\
\hline 1,1,2-Trichloro-1,2,2-trifluoroethane & & $<$ & $<$ & & $<$ & $<$ & $<$ & $<$ & $<$ & $<$ \\
\hline Trichlorofluoromethane & & $<$ & $<$ & & $<$ & $<$ & $<$ & $<$ & $<$ & $<$ \\
\hline 1,2-Dichloropropane & $<$ & $<$ & $<$ & $<$ & $<$ & $<$ & $<$ & $<$ & $<$ & $<$ \\
\hline 1,4-Dichlorobenzene & & $<$ & $<$ & & $<$ & $<$ & $<$ & $<$ & $<$ & $<$ \\
\hline 2-Butanone & $<$ & $<$ & $<$ & $<$ & $<$ & $<$ & $<$ & $<$ & $<$ & $<$ \\
\hline Acetone & $<$ & $7 \mathrm{~J}$ & & $<$ & $<$ & $<$ & $<$ & $<$ & $<$ & $<$ \\
\hline Bromodichloromethane & $<$ & $<$ & $<$ & $<$ & $<$ & $<$ & $1 \mathrm{~J}$ & $<$ & $<$ & $<$ \\
\hline Bromoform & $<$ & $2 \mathrm{~J}$ & $<$ & $<$ & $<$ & $<$ & $<$ & $<$ & $<$ & $<$ \\
\hline \multicolumn{11}{|l|}{ Natural Attenuation $(\mu \mathrm{g} / \mathrm{L})$} \\
\hline Ethane & $<$ & & & & & & & & & \\
\hline Ethylene & $<$ & & & & & & & & & \\
\hline Methane & 12.7 & & & & & & & & & \\
\hline
\end{tabular}


APPENDIX E.2: CY 2009 MONITORING DATA FOR THE UPPER EAST FORK POPLAR CREEK HYDROGEOLOGIC REGIME Volatile Organic Compounds

\begin{tabular}{|c|c|c|c|c|c|c|c|c|c|c|}
\hline Sampling Point & \multicolumn{3}{|c|}{ GW-698 } & GW-700 & \multicolumn{2}{|c|}{ GW-722-14 } & \multicolumn{2}{|c|}{ GW-722-17 } & \multicolumn{2}{|c|}{ GW-722-20 } \\
\hline Functional Area & \multicolumn{3}{|c|}{ B8110 } & B8110 & \multicolumn{2}{|c|}{ EXP-J } & \multicolumn{2}{|c|}{ EXP-J } & \multicolumn{2}{|c|}{ EXP-J } \\
\hline Date Sampled & \multicolumn{2}{|c|}{$04 / 29 / 09$} & $10 / 21 / 09$ & $07 / 28 / 09$ & $03 / 02 / 09$ & $09 / 02 / 09$ & 03/02/09 & $09 / 02 / 09$ & $03 / 02 / 09$ & $09 / 02 / 09$ \\
\hline Program & GWPP & GWPP & GWPP & GWPP & BJC & GWPP & BJC & GWPP & BJC & GWPP \\
\hline Sample Type & & Dup & & PDB & & & & & & \\
\hline Chloroethenes ( $\mu \mathrm{g} / \mathrm{L}$ ) & & & & & & & & & & \\
\hline Tetrachloroethene & 100 & 100 & 14 & 17 & 3 & $4 \mathrm{~J}$ & 4 & $1 \mathrm{~J}$ & 8 & $3 \mathrm{~J}$ \\
\hline Trichloroethene & 280 & 270 & 35 & 10 & $1.04 \mathrm{~J}$ & $1 \mathrm{~J}$ & $<$ & $<$ & $1.72 \mathrm{~J}$ & $<$ \\
\hline cis-1,2-Dichloroethene & 24 & 23 & $3 \mathrm{~J}$ & 35 & $<$ & $<$ & $<$ & $<$ & $<$ & $<$ \\
\hline trans-1,2-Dichloroethene & $<$ & $<$ & $<$ & $<$ & $<$ & $<$ & $<$ & $<$ & $<$ & $<$ \\
\hline 1,1-Dichloroethene & $<$ & $<$ & $<$ & $<$ & $<$ & $<$ & $<$ & $<$ & $<$ & $<$ \\
\hline Vinyl chloride & $<$ & $<$ & $<$ & $<$ & $<$ & $<$ & $<$ & $<$ & $<$ & $<$ \\
\hline Chloroethanes ( $\mu \mathrm{g} / \mathrm{L})$ & & & & & & & & & & \\
\hline 1,1,1,2-Tetrachloroethane & $<$ & $<$ & $<$ & , & & $<$ & & $<$ & & $<$ \\
\hline 1,1,1-Trichloroethane & $<$ & $<$ & $<$ & $<$ & $<$ & $<$ & $<$ & $<$ & $<$ & $<$ \\
\hline 1,2-Dichloroethane & $<$ & $<$ & $<$ & $<$ & $<$ & $<$ & $<$ & $<$ & $<$ & $<$ \\
\hline 1,1-Dichloroethane & $<$ & $<$ & $<$ & $<$ & $<$ & $<$ & $<$ & $<$ & $<$ & $<$ \\
\hline Chloroethane & $<$ & $<$ & $<$ & $<$ & $<$ & $<$ & $<$ & $<$ & $<$ & $<$ \\
\hline Chloromethanes ( $\mu \mathrm{g} / \mathrm{L})$ & & & & & & & & & & \\
\hline Carbon tetrachloride & $2 \mathrm{~J}$ & $<$ & $<$ & $<$ & 20.3 & 26 & 23 & 16 & 51.2 & 27 \\
\hline Chloroform & 10 & 10 & $1 \mathrm{~J}$ & $<$ & $2.16 \mathrm{~J}$ & $2 \mathrm{~J}$ & $4.96 \mathrm{~J}$ & $4 \mathrm{~J}$ & 7.19 & 6 \\
\hline Methylene chloride & $<$ & $<$ & $<$ & $<$ & $<$ & $<$ & $<$ & $<$ & $<$ & $<$ \\
\hline Petrol. Hydrocarb. ( $\mu \mathrm{g} / \mathrm{L})$ & & & & & & & & & & \\
\hline Benzene & $<$ & $<$ & $<$ & $<$ & $<$ & $<$ & $<$ & $<$ & $<$ & $<$ \\
\hline Ethylbenzene & $<$ & $<$ & $<$ & $<$ & $<$ & $<$ & $<$ & $<$ & $<$ & $<$ \\
\hline Toluene & $<$ & $<$ & $<$ & $<$ & $<$ & $<$ & $<$ & $<$ & $<$ & $<$ \\
\hline Total Xylene & $<$ & $<$ & $<$ & $<$ & $<$ & $<$ & $<$ & $<$ & $<$ & $<$ \\
\hline Styrene & $<$ & $<$ & $<$ & & $<$ & $<$ & $<$ & $<$ & $<$ & $<$ \\
\hline Miscellaneous ( $\mu \mathrm{g} / \mathrm{L})$ & & & & & & & & & & \\
\hline 1,1,2-Trichloro-1,2,2-trifluoroethane & 12 & 13 & $2 \mathrm{~J}$ & $<$ & & $<$ & & $<$ & & $<$ \\
\hline Trichlorofluoromethane & $<$ & $<$ & $<$ & $<$ & & $<$ & & $<$ & & $<$ \\
\hline 1,2-Dichloropropane & $<$ & $<$ & $<$ & $<$ & $<$ & $<$ & $<$ & $<$ & $<$ & $<$ \\
\hline 1,4-Dichlorobenzene & $<$ & $<$ & $<$ & $<$ & & $<$ & & $<$ & . & $<$ \\
\hline 2-Butanone & $<$ & $<$ & $<$ & 6 & $<$ & $<$ & $<$ & $<$ & $<$ & $<$ \\
\hline Acetone & $<$ & $<$ & $<$ & to & $<$ & $<$ & $<$ & $<$ & $<$ & $3 \mathrm{~J}$ \\
\hline Bromodichloromethane & $<$ & $<$ & $<$ & $<$ & $<$ & $<$ & $<$ & $<$ & $<$ & $<$ \\
\hline Bromoform & $<$ & $<$ & $<$ & $<$ & $<$ & $<$ & $<$ & $<$ & $<$ & $<$ \\
\hline Natural Attenuation ( $\mu \mathrm{g} / \mathrm{L})$ & & & & & & & & & & \\
\hline Ethane & & & & & & & & & & \\
\hline Ethylene & & & & & & & & & & \\
\hline Methane & & & & & & & & & & \\
\hline
\end{tabular}


APPENDIX E.2: CY 2009 MONITORING DATA FOR THE UPPER EAST FORK POPLAR CREEK HYDROGEOLOGIC REGIME Volatile Organic Compounds

\begin{tabular}{|c|c|c|c|c|c|c|c|c|c|c|}
\hline Sampling Point & \multicolumn{2}{|c|}{ GW-722-22 } & \multicolumn{2}{|c|}{ GW-722-33 } & \multicolumn{2}{|c|}{ GW-733 } & GW-735 & GW-744 & GW-747 & GW-750 \\
\hline Functional Area & \multicolumn{2}{|c|}{ EXP-J } & \multicolumn{2}{|c|}{ EXP-J } & \multicolumn{2}{|c|}{ EXP-J } & EXP-J & GRIDK1 & GRIDK2 & EXP-J \\
\hline Date Sampled & $03 / 02 / 09$ & $09 / 02 / 09$ & $03 / 02 / 09$ & $09 / 03 / 09$ & $01 / 12 / 09$ & 07/07/09 & $08 / 26 / 09$ & $08 / 26 / 09$ & $08 / 31 / 09$ & $04 / 29 / 09$ \\
\hline Program & BJC & GWPP & BJC & GWPP & BJC & BJC & GWPP & GWPP & GWPP & GWPP \\
\hline \multicolumn{11}{|l|}{ Sample Type } \\
\hline \multicolumn{11}{|l|}{ Chloroethenes ( $\mu \mathrm{g} / \mathrm{L})$} \\
\hline Tetrachloroethene & 3 & $2 \mathrm{~J}$ & $<$ & $<$ & $<$ & $<$ & $<$ & $<$ & $1 \mathrm{~J}$ & $<$ \\
\hline Trichloroethene & $1.26 \mathrm{~J}$ & $<$ & $<$ & $<$ & $<$ & $<$ & $<$ & $<$ & $<$ & $<$ \\
\hline cis-1,2-Dichloroethene & $<$ & $<$ & $<$ & $<$ & $<$ & $<$ & $<$ & $<$ & $<$ & $<$ \\
\hline trans-1,2-Dichloroethene & $<$ & $<$ & $<$ & $<$ & $<$ & $<$ & $<$ & $<$ & $<$ & $<$ \\
\hline 1,1-Dichloroethene & $<$ & $<$ & $<$ & $<$ & $<$ & $<$ & $<$ & $<$ & $<$ & $<$ \\
\hline Vinyl chloride & $<$ & $<$ & $<$ & $<$ & $<$ & $<$ & $<$ & $<$ & $<$ & $<$ \\
\hline \multicolumn{11}{|l|}{ Chloroethanes ( $\mu \mathrm{g} / \mathrm{L})$} \\
\hline 1,1,1,2-Tetrachloroethane & & $<$ & & $<$ & & & $<$ & $<$ & $<$ & $<$ \\
\hline 1,1,1-Trichloroethane & $<$ & $<$ & $<$ & $<$ & $<$ & $<$ & $<$ & $<$ & $<$ & $<$ \\
\hline 1,2-Dichloroethane & $<$ & $<$ & $<$ & $<$ & $<$ & $<$ & $<$ & $<$ & $<$ & $<$ \\
\hline 1,1-Dichloroethane & $<$ & $<$ & $<$ & $<$ & $<$ & $<$ & $<$ & $<$ & $<$ & $<$ \\
\hline Chloroethane & $<$ & $<$ & $<$ & $<$ & $<$ & $<$ & $<$ & $<$ & $<$ & $<$ \\
\hline \multicolumn{11}{|l|}{ Chloromethanes $(\mu \mathrm{g} / \mathrm{L})$} \\
\hline Carbon tetrachloride & 21.8 & 13 & $<$ & $<$ & 6.06 & 7.3 & $<$ & $<$ & $<$ & $<$ \\
\hline Chloroform & $2.06 \mathrm{~J}$ & $2 \mathrm{~J}$ & $<$ & $<$ & $<$ & 1 & $<$ & $<$ & $<$ & $<$ \\
\hline Methylene chloride & $<$ & $<$ & $<$ & $<$ & $<$ & $<$ & $<$ & $<$ & $<$ & $<$ \\
\hline \multicolumn{11}{|l|}{ Petrol. Hydrocarb. $(\mu \mathrm{g} / \mathrm{L})$} \\
\hline Benzene & $<$ & $<$ & $<$ & $<$ & $<$ & $<$ & $<$ & $<$ & $<$ & $<$ \\
\hline Ethylbenzene & $<$ & $<$ & $<$ & $<$ & $<$ & $<$ & $<$ & $<$ & $<$ & $<$ \\
\hline Toluene & $<$ & $<$ & $<$ & $<$ & $<$ & $<$ & $<$ & $<$ & $<$ & $<$ \\
\hline Total Xylene & $<$ & $<$ & $<$ & $<$ & $<$ & 1 & $<$ & $<$ & $<$ & $<$ \\
\hline Styrene & $<$ & $<$ & $<$ & $<$ & $<$ & $<$ & $<$ & $<$ & $<$ & $<$ \\
\hline \multicolumn{11}{|l|}{ Miscellaneous ( $\mu \mathrm{g} / \mathrm{L})$} \\
\hline 1,1,2-Trichloro-1,2,2-trifluoroethane & & $<$ & & $<$ & & & $<$ & $<$ & $<$ & $<$ \\
\hline Trichlorofluoromethane & & $<$ & & $<$ & & & $<$ & $<$ & $<$ & $<$ \\
\hline 1,2-Dichloropropane & $<$ & $<$ & $<$ & $<$ & $<$ & $<$ & $<$ & $<$ & $<$ & $<$ \\
\hline 1,4-Dichlorobenzene & & $<$ & & $<$ & & & $<$ & $<$ & $<$ & $<$ \\
\hline 2-Butanone & $<$ & $<$ & $<$ & $<$ & $<$ & $<$ & $<$ & $<$ & $<$ & $<$ \\
\hline Acetone & $<$ & $8 \mathrm{~J}$ & $<$ & $<$ & $<$ & $<$ & $<$ & $<$ & $<$ & $<$ \\
\hline Bromodichloromethane & $<$ & $<$ & $<$ & $<$ & $<$ & $<$ & $<$ & $<$ & $<$ & $<$ \\
\hline Bromoform & $<$ & $<$ & $<$ & $<$ & $<$ & $<$ & $<$ & $<$ & $<$ & $<$ \\
\hline \multicolumn{11}{|l|}{ Natural Attenuation $(\mu \mathrm{g} / \mathrm{L})$} \\
\hline Ethane & & & & & & & & & & \\
\hline Ethylene & & & & & & & & & & \\
\hline Methane & & & & & & & & & & \\
\hline
\end{tabular}


APPENDIX E.2: CY 2009 MONITORING DATA FOR THE UPPER EAST FORK POPLAR CREEK HYDROGEOLOGIC REGIME Volatile Organic Compounds

\begin{tabular}{|c|c|c|c|c|c|c|c|c|c|c|}
\hline Sampling Point & \multicolumn{4}{|c|}{ GW-762 } & GW-763 & GW-765 & GW-769 & GW-769 & GW-770 & GW-775 \\
\hline Functional Area & \multicolumn{4}{|c|}{ GRIDJ3 } & GRIDJ3 & GRIDE1 & GRIDG3 & GRIDG3 & GRIDG3 & GRIDH3 \\
\hline Date Sampled & \multicolumn{2}{|c|}{ 03/04/09 } & \multicolumn{2}{|c|}{ 07/23/09 } & $10 / 14 / 09$ & $05 / 07 / 09$ & $04 / 29 / 09$ & $10 / 13 / 09$ & $10 / 13 / 09$ & $08 / 27 / 09$ \\
\hline Program & BJC & BJC & BJC & BJC & GWPP & GWPP & GWPP & GWPP & GWPP & GWPP \\
\hline Sample Type & & Dup & & Dup & & & PDB & PDB & PDB & PDB \\
\hline Chloroethenes ( $\mu \mathrm{g} / \mathrm{L})$ & & & & & & & & & & \\
\hline Tetrachloroethene & 2,460 & 2,430 & 2,090 & 2,140 & $<$ & $<$ & 22 & 9 & $<$ & $<$ \\
\hline Trichloroethene & $172 \mathrm{~J}$ & $180 \mathrm{~J}$ & $101 \mathrm{~J}$ & $145 \mathrm{~J}$ & $<$ & $<$ & 7 & $4 \mathrm{~J}$ & $<$ & $4 \mathrm{~J}$ \\
\hline cis-1,2-Dichloroethene & $67.3 \mathrm{~J}$ & $70.9 \mathrm{~J}$ & $67.8 \mathrm{~J}$ & $67.9 \mathrm{~J}$ & 17 & $<$ & 6 & $4 \mathrm{~J}$ & $<$ & $<$ \\
\hline trans-1,2-Dichloroethene & $3.1 \mathrm{~J}$ & $3.08 \mathrm{~J}$ & $3.04 \mathrm{~J}$ & $2.64 \mathrm{~J}$ & $<$ & $<$ & $<$ & $<$ & $<$ & $<$ \\
\hline 1,1-Dichloroethene & $54.2 \mathrm{~J}$ & $56.9 \mathrm{~J}$ & $52.8 \mathrm{~J}$ & $52.4 \mathrm{~J}$ & $<$ & $<$ & $2 \mathrm{~J}$ & $2 \mathrm{~J}$ & $<$ & $<$ \\
\hline Vinyl chloride & 4.63 & 5.06 & 4.72 & 4.33 & 4 & $<$ & $<$ & $<$ & $<$ & $<$ \\
\hline Chloroethanes $(\mu \mathrm{g} / \mathrm{L})$ & & & & & & & & & & \\
\hline 1,1,1,2-Tetrachloroethane & & & & & $<$ & $<$ & . & & & \\
\hline 1,1,1-Trichloroethane & $1.37 \mathrm{~J}$ & $1.59 \mathrm{~J}$ & $1.5 \mathrm{~J}$ & $1.6 \mathrm{~J}$ & $<$ & $<$ & $<$ & $<$ & $<$ & $<$ \\
\hline 1,2-Dichloroethane & & $<$ & $<$ & $<$ & $<$ & $<$ & $<$ & $<$ & $<$ & $<$ \\
\hline 1,1-Dichloroethane & 11.5 & 11.6 & 13.1 & 12.9 & $<$ & $<$ & $<$ & $<$ & $<$ & $<$ \\
\hline Chloroethane & $<$ & $<$ & $<$ & $<$ & $<$ & $<$ & $<$ & $<$ & $<$ & $<$ \\
\hline Chloromethanes $(\mu \mathrm{g} / \mathrm{L})$ & & & & & & & & & & \\
\hline Carbon tetrachloride & $<$ & $<$ & $<$ & $<$ & $<$ & $<$ & 160 & 120 & 12 & $<$ \\
\hline Chloroform & $<$ & $<$ & $<$ & $<$ & $<$ & $<$ & 6 & $5 \mathrm{~J}$ & $2 \mathrm{~J}$ & $<$ \\
\hline Methylene chloride & $<$ & $<$ & $<$ & $<$ & $<$ & $<$ & $<$ & $<$ & $<$ & $<$ \\
\hline Petrol. Hydrocarb. ( $\mu \mathrm{g} / \mathrm{L})$ & & & & & & & & & & \\
\hline Benzene & $<$ & $<$ & $<$ & $<$ & $<$ & $<$ & $<$ & $<$ & $<$ & $<$ \\
\hline Ethylbenzene & $<$ & $<$ & $<$ & $<$ & $<$ & $<$ & $<$ & $<$ & $<$ & $<$ \\
\hline Toluene & $<$ & $<$ & $<$ & $<$ & $<$ & $<$ & $<$ & $<$ & $<$ & $<$ \\
\hline Total Xylene & $<$ & $<$ & $<$ & $<$ & $<$ & $<$ & $<$ & $<$ & $<$ & $<$ \\
\hline Styrene & $<$ & $<$ & $<$ & $<$ & $<$ & $<$ & & & & \\
\hline Miscellaneous ( $\mu \mathrm{g} / \mathrm{L})$ & & & & & & & & & & \\
\hline 1,1,2-Trichloro-1,2,2-trifluoroethane & & & & & $<$ & $<$ & $2 \mathrm{~J}$ & $<$ & $<$ & $<$ \\
\hline Trichlorofluoromethane & & & & & $<$ & $<$ & $<$ & $<$ & $<$ & $<$ \\
\hline 1,2-Dichloropropane & $<$ & $<$ & $<$ & $<$ & $<$ & $<$ & $<$ & $<$ & $<$ & $<$ \\
\hline 1,4-Dichlorobenzene & & & & & $<$ & $<$ & $<$ & $<$ & $<$ & $<$ \\
\hline 2-Butanone & $<$ & $<$ & $<$ & $<$ & $<$ & $<$ & $<$ & $<$ & $<$ & 6 \\
\hline Acetone & $<$ & $<$ & $<$ & $<$ & $<$ & $<$ & . & & . & \\
\hline Bromodichloromethane & $<$ & $<$ & $<$ & $<$ & $<$ & $<$ & $<$ & $<$ & $<$ & $<$ \\
\hline Bromoform & $<$ & $<$ & $<$ & $<$ & $<$ & $<$ & $<$ & $<$ & $<$ & $<$ \\
\hline Natural Attenuation $(\mu \mathrm{g} / \mathrm{L})$ & & & & & & & & & & \\
\hline Ethane & & $<$ & $<$ & $<$ & & & & & & \\
\hline Ethylene & $1.56 \mathrm{~J}$ & $1.44 \mathrm{~J}$ & $<$ & $<$ & & & & & & \\
\hline Methane & 26.9 & 20.7 & 15.4 & 16.1 & & & & & & \\
\hline
\end{tabular}


APPENDIX E.2: CY 2009 MONITORING DATA FOR THE UPPER EAST FORK POPLAR CREEK HYDROGEOLOGIC REGIME Volatile Organic Compounds

\begin{tabular}{|c|c|c|c|c|c|c|c|c|c|}
\hline Sampling Point & GW-776 & GW-779 & GW-781 & GW-782 & GW-783 & GW-791 & GW-802 & GW-816 & GW-820 \\
\hline Functional Area & GRIDH3 & GRIDF2 & GRIDE3 & GRIDE3 & GRIDE3 & GRIDD2 & FF & EXP-SR & B9201-2 \\
\hline Date Sampled & 09/01/09 & $08 / 31 / 09$ & $08 / 27 / 09$ & $08 / 27 / 09$ & $08 / 27 / 09$ & $08 / 27 / 09$ & 08/13/09 & $08 / 26 / 09$ & 04/29/09 \\
\hline Program & GWPP & GWPP & GWPP & GWPP & GWPP & GWPP & BJC & GWPP & GWPP \\
\hline Sample Type & & & & & PDB & PDB & & & PDB \\
\hline \multicolumn{10}{|l|}{ Chloroethenes ( $\mu \mathrm{g} / \mathrm{L})$} \\
\hline Tetrachloroethene & $<$ & $<$ & $<$ & 36 & $4 \mathrm{~J}$ & 22 & $<$ & $<$ & 870 \\
\hline Trichloroethene & $1 \mathrm{~J}$ & $<$ & $<$ & 16 & $2 \mathrm{~J}$ & $<$ & $<$ & $<$ & 350 \\
\hline cis-1,2-Dichloroethene & $<$ & $<$ & $<$ & 8 & $1 \mathrm{~J}$ & $<$ & $<$ & $<$ & 490 \\
\hline trans-1,2-Dichloroethene & $<$ & $<$ & $<$ & $2 \mathrm{~J}$ & $<$ & $<$ & $<$ & $<$ & $4 \mathrm{~J}$ \\
\hline 1,1-Dichloroethene & $<$ & $<$ & $<$ & 9 & $<$ & $<$ & $<$ & $<$ & $1 \mathrm{~J}$ \\
\hline Vinyl chloride & $<$ & $<$ & $<$ & $<$ & $<$ & $<$ & $<$ & $<$ & $<$ \\
\hline \multicolumn{10}{|l|}{ Chloroethanes ( $\mu \mathrm{g} / \mathrm{L})$} \\
\hline 1,1,1,2-Tetrachloroethane & $<$ & $<$ & $<$ & $<$ & & & . & $<$ & \\
\hline 1,1,1-Trichloroethane & $<$ & $<$ & $<$ & $1 \mathrm{~J}$ & $<$ & $<$ & $<$ & $<$ & $<$ \\
\hline 1,2-Dichloroethane & $<$ & $<$ & $<$ & $<$ & $<$ & $<$ & $<$ & $<$ & $<$ \\
\hline 1,1-Dichloroethane & $<$ & $<$ & $<$ & 20 & $2 \mathrm{~J}$ & $<$ & $<$ & $<$ & $<$ \\
\hline Chloroethane & $<$ & $<$ & $<$ & $<$ & $<$ & $<$ & $<$ & $<$ & $<$ \\
\hline \multicolumn{10}{|l|}{ Chloromethanes $(\mu \mathrm{g} / \mathrm{L})$} \\
\hline Carbon tetrachloride & $<$ & $<$ & $<$ & $4 \mathrm{~J}$ & $<$ & $<$ & $<$ & $<$ & $<$ \\
\hline Chloroform & $<$ & $<$ & $<$ & $<$ & $<$ & $<$ & $<$ & $<$ & $<$ \\
\hline Methylene chloride & $<$ & $<$ & $<$ & $<$ & $<$ & $<$ & $<$ & $<$ & $<$ \\
\hline \multicolumn{10}{|l|}{ Petrol. Hydrocarb. ( $\mu \mathrm{g} / \mathrm{L})$} \\
\hline Benzene & $<$ & $<$ & $<$ & $<$ & $<$ & $<$ & $<$ & $<$ & $<$ \\
\hline Ethylbenzene & $<$ & $<$ & $<$ & $<$ & $<$ & $<$ & $<$ & $<$ & $<$ \\
\hline Toluene & $<$ & $<$ & $<$ & $<$ & $<$ & $<$ & $<$ & $<$ & $<$ \\
\hline Total Xylene & $<$ & $<$ & $<$ & $<$ & $<$ & $<$ & $<$ & $<$ & $<$ \\
\hline Styrene & $<$ & $<$ & $<$ & $<$ & & & $<$ & $<$ & \\
\hline \multicolumn{10}{|l|}{ Miscellaneous ( $\mu \mathrm{g} / \mathrm{L})$} \\
\hline 1,1,2-Trichloro-1,2,2-trifluoroethane & $<$ & $<$ & $<$ & $<$ & $<$ & $<$ & & $<$ & 20 \\
\hline Trichlorofluoromethane & $<$ & $<$ & $<$ & $<$ & $<$ & $<$ & & $<$ & $<$ \\
\hline 1,2-Dichloropropane & $<$ & $<$ & $<$ & $<$ & $<$ & $<$ & $<$ & $<$ & $<$ \\
\hline 1,4-Dichlorobenzene & $<$ & $<$ & $<$ & $<$ & $<$ & $<$ &. & $<$ & $<$ \\
\hline 2-Butanone & $<$ & $<$ & $<$ & $<$ & $<$ & $<$ & $<$ & $<$ & $<$ \\
\hline Acetone & $<$ & $<$ & $<$ & $<$ & . & & $<$ & $<$ & \\
\hline Bromodichloromethane & $<$ & $<$ & $<$ & $<$ & $<$ & $<$ & $<$ & $<$ & $<$ \\
\hline Bromoform & $<$ & $<$ & $<$ & $<$ & $<$ & $<$ & $<$ & $<$ & $<$ \\
\hline \multicolumn{10}{|l|}{ Natural Attenuation $(\mu \mathrm{g} / \mathrm{L})$} \\
\hline Ethane & & & & & & & & & \\
\hline Ethylene & & & & & & & & & \\
\hline Methane & & & & & & & & & \\
\hline
\end{tabular}


APPENDIX E.2: CY 2009 MONITORING DATA FOR THE UPPER EAST FORK POPLAR CREEK HYDROGEOLOGIC REGIME Volatile Organic Compounds

\begin{tabular}{|c|c|c|c|c|c|c|c|}
\hline Sampling Point & \multicolumn{2}{|c|}{ GW-832 } & GW-959 & GW-960 & GHK2.51WSW & NPR12.0SW & NPR23.0SW \\
\hline Functional Area & \multicolumn{2}{|c|}{ NHP } & B9201-2 & GRIDF2 & EXP & EXP & EXP \\
\hline Date Sampled & 03/03/09 & 07/23/09 & 05/06/09 & 05/07/09 & 01/29/09 & $01 / 29 / 09$ & $01 / 29 / 09$ \\
\hline Program & BJC & BJC & GWPP & GWPP & GWPP & GWPP & GWPP \\
\hline \multicolumn{8}{|l|}{ Sample Type } \\
\hline Chloroethenes ( $\mu \mathrm{g} / \mathrm{L})$ & & & & & & & \\
\hline Tetrachloroethene & $<$ & 4 & $<$ & $<$ & $<$ & $<$ & $<$ \\
\hline Trichloroethene & $<$ & $<$ & $<$ & $<$ & $<$ & $<$ & $<$ \\
\hline cis-1,2-Dichloroethene & $<$ & $<$ & 9 & $<$ & $<$ & $<$ & $<$ \\
\hline trans-1,2-Dichloroethene & $<$ & $<$ & $<$ & $<$ & $<$ & $<$ & $<$ \\
\hline 1,1-Dichloroethene & $<$ & $<$ & $<$ & $<$ & $<$ & $<$ & $<$ \\
\hline Vinyl chloride & $<$ & $<$ & $<$ & $<$ & $<$ & $<$ & $<$ \\
\hline \multicolumn{8}{|l|}{ Chloroethanes ( $\mu \mathrm{g} / \mathrm{L})$} \\
\hline 1,1,1,2-Tetrachloroethane & & & $<$ & $<$ & $<$ & $<$ & $<$ \\
\hline 1,1,1-Trichloroethane & $<$ & $<$ & $<$ & $<$ & $<$ & $<$ & $<$ \\
\hline 1,2-Dichloroethane & $<$ & $<$ & $<$ & $<$ & $<$ & $<$ & $<$ \\
\hline 1,1-Dichloroethane & $<$ & $<$ & $<$ & $<$ & $<$ & $<$ & $<$ \\
\hline Chloroethane & $<$ & $<$ & $<$ & $<$ & $<$ & $<$ & $<$ \\
\hline \multicolumn{8}{|l|}{ Chloromethanes ( $\mu \mathrm{g} / \mathrm{L})$} \\
\hline Carbon tetrachloride & $<$ & 6.77 & $<$ & $<$ & $<$ & $<$ & $<$ \\
\hline Chloroform & $<$ & $1.49 \mathrm{~J}$ & $<$ & $<$ & $<$ & $<$ & $<$ \\
\hline Methylene chloride & $<$ & $<$ & $<$ & $<$ & $<$ & $<$ & $<$ \\
\hline \multicolumn{8}{|l|}{ Petrol. Hydrocarb. ( $\mu \mathrm{g} / \mathrm{L})$} \\
\hline Benzene & $<$ & $<$ & $<$ & $<$ & $<$ & $<$ & $<$ \\
\hline Ethylbenzene & $<$ & $<$ & $<$ & $<$ & $<$ & $<$ & $<$ \\
\hline Toluene & $<$ & $<$ & $<$ & $<$ & $<$ & $<$ & $<$ \\
\hline Total Xylene & $<$ & $<$ & $<$ & $<$ & $<$ & $<$ & $<$ \\
\hline Styrene & $<$ & $<$ & $<$ & $<$ & $<$ & $<$ & $<$ \\
\hline \multicolumn{8}{|l|}{ Miscellaneous ( $\mu \mathrm{g} / \mathrm{L})$} \\
\hline 1,1,2-Trichloro-1,2,2-trifluoroethane & & & $<$ & $<$ & $<$ & $<$ & $<$ \\
\hline Trichlorofluoromethane & & & $<$ & $<$ & $<$ & $<$ & $<$ \\
\hline 1,2-Dichloropropane & $<$ & $<$ & $<$ & $<$ & $<$ & $<$ & $<$ \\
\hline 1,4-Dichlorobenzene & & & $<$ & $<$ & $<$ & $<$ & $<$ \\
\hline 2-Butanone & $<$ & $<$ & $<$ & $<$ & $<$ & $<$ & $<$ \\
\hline Acetone & $<$ & $<$ & $<$ & $<$ & $<$ & $<$ & $<$ \\
\hline Bromodichloromethane & $<$ & $<$ & $<$ & $<$ & $<$ & $<$ & $<$ \\
\hline Bromoform & $<$ & $<$ & $<$ & $<$ & $<$ & $<$ & $<$ \\
\hline \multicolumn{8}{|l|}{ Natural Attenuation $(\mu \mathrm{g} / \mathrm{L})$} \\
\hline Ethane & $<$ & $<$ & & & & & \\
\hline Ethylene & $<$ & $<$ & & & & & \\
\hline Methane & $<$ & 5.18 & & & & & \\
\hline
\end{tabular}


APPENDIX E.2: CY 2009 MONITORING DATA FOR THE UPPER EAST FORK POPLAR CREEK HYDROGEOLOGIC REGIME Volatile Organic Compounds

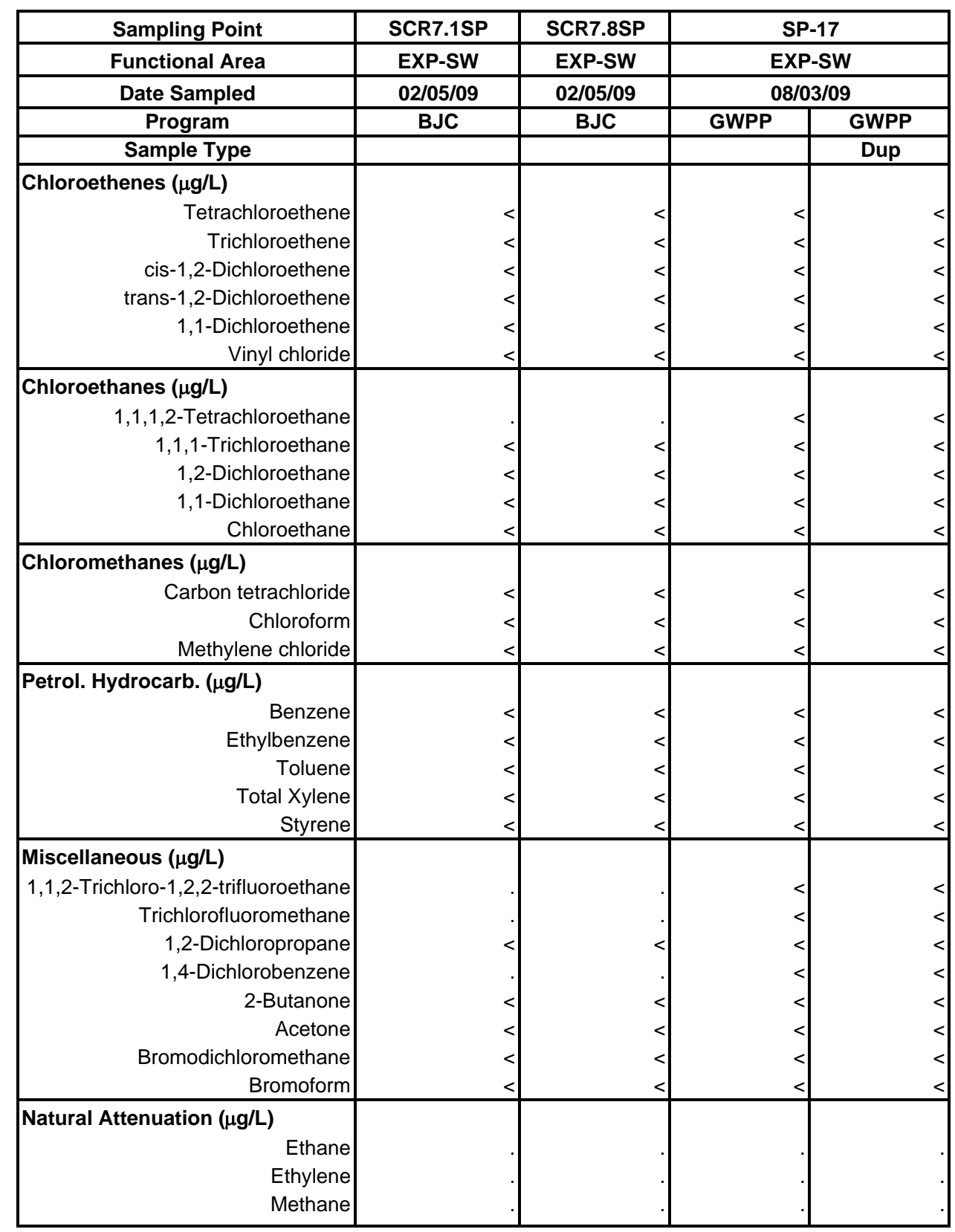


APPENDIX E.3

RADIOLOGICAL ANALYTES 

APPENDIX E.3: CY 2009 MONITORING DATA FOR THE UPPER EAST FORK POPLAR CREEK HYDROGEOLOGIC REGIME Radiological Analytes: Gross Alpha and Gross Beta Activity

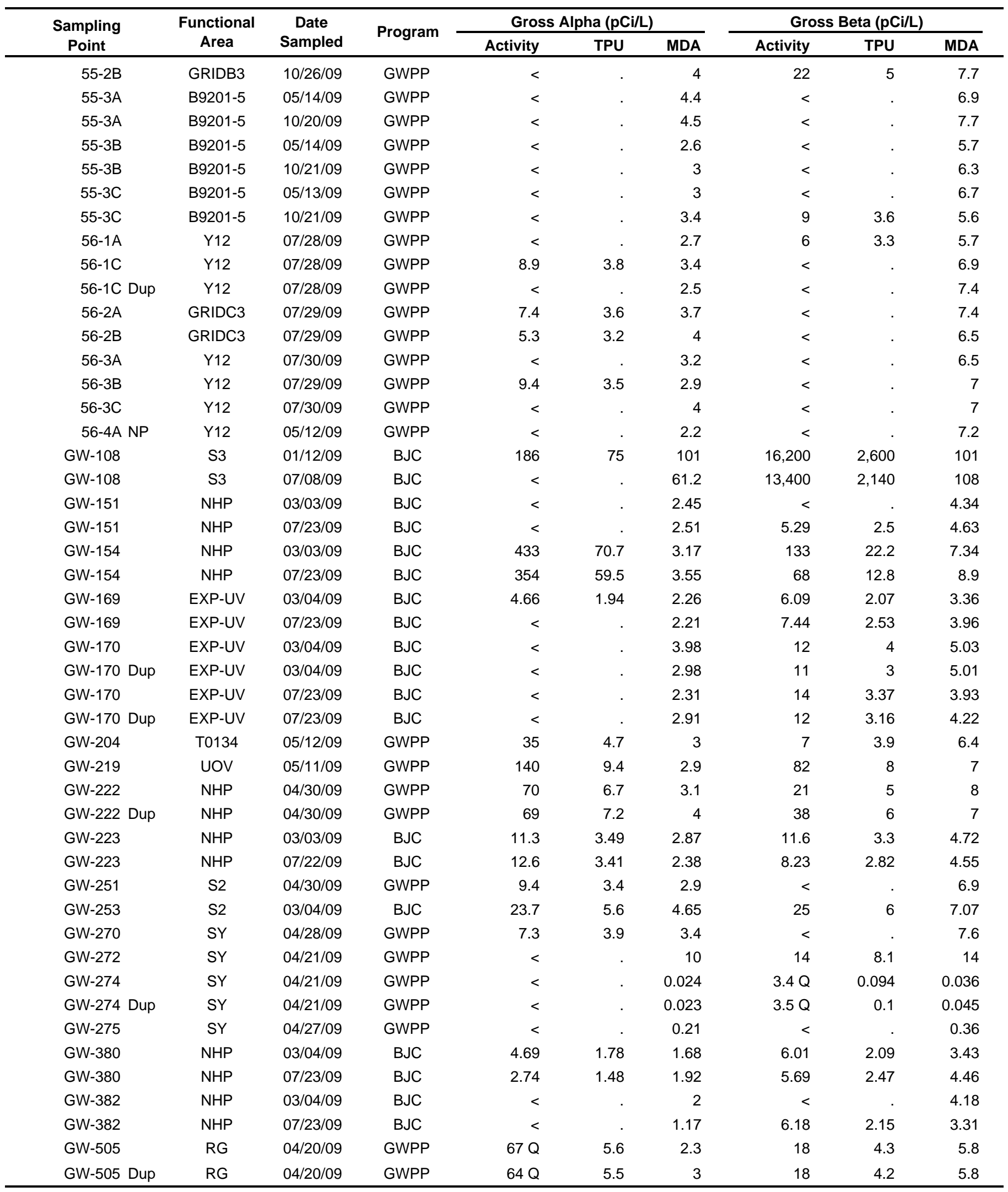


APPENDIX E.3: CY 2009 MONITORING DATA FOR THE UPPER EAST FORK POPLAR CREEK HYDROGEOLOGIC REGIME Radiological Analytes: Gross Alpha and Gross Beta Activity

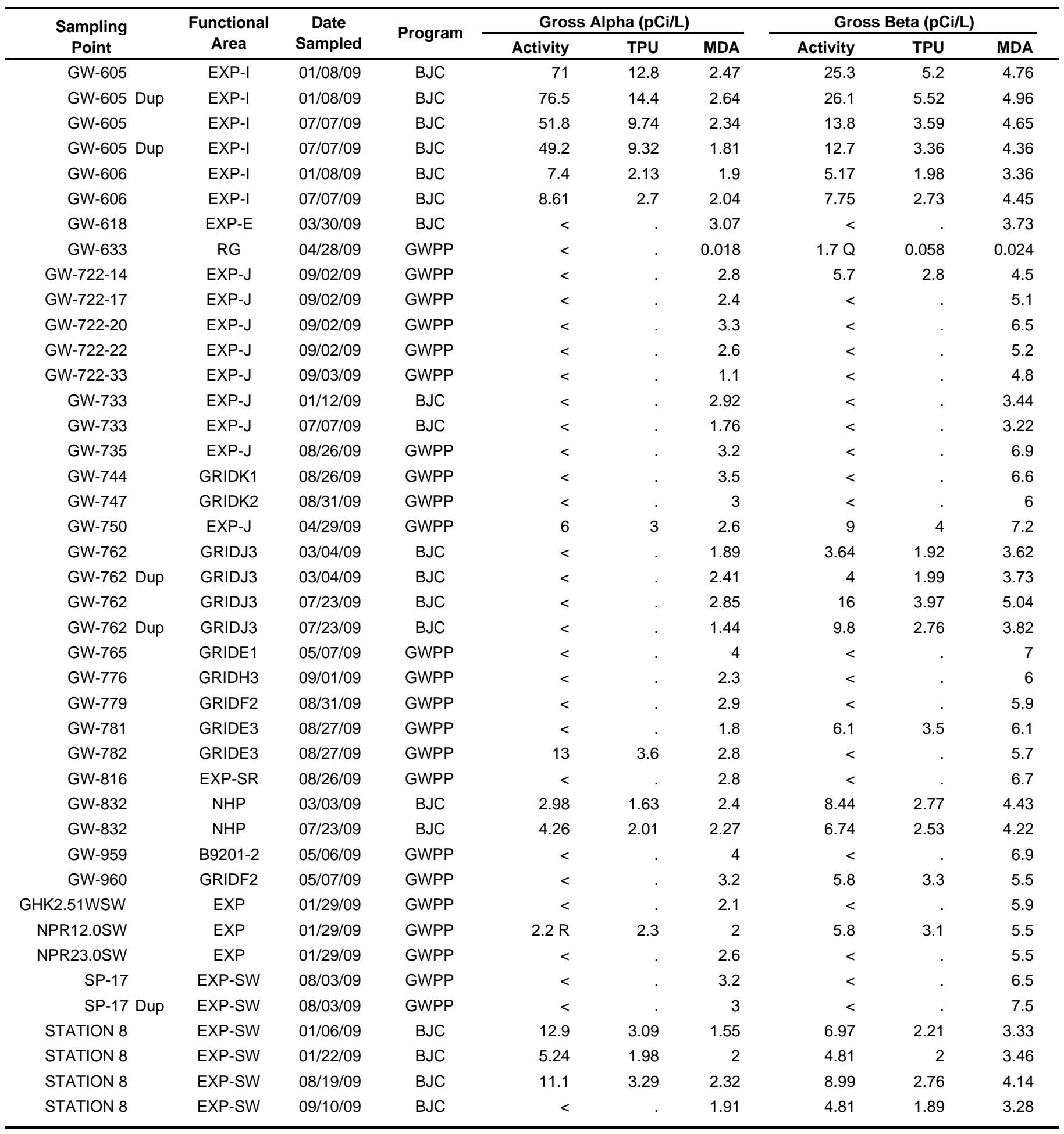


APPENDIX E.3: CY 2008 MONITORING DATA FOR THE UPPER EAST FORK POPLAR CREEK HYDROGEOLOGIC REGIME Radiological Analytes: Isotopic Analyses

\begin{tabular}{|c|c|c|c|c|c|c|c|c|c|c|c|c|}
\hline Sampling Point & \multicolumn{6}{|c|}{ GW-108 } & \multicolumn{6}{|c|}{ GW-151 } \\
\hline Functional Area & \multicolumn{6}{|c|}{ S3 } & \multicolumn{6}{|c|}{ NHP } \\
\hline Date Sampled & \multicolumn{3}{|c|}{$01 / 12 / 09$} & \multicolumn{3}{|c|}{$07 / 08 / 09$} & \multicolumn{3}{|c|}{$03 / 03 / 09$} & \multicolumn{3}{|c|}{$07 / 23 / 09$} \\
\hline Program & \multicolumn{3}{|c|}{ BJC } & \multicolumn{3}{|c|}{ BJC } & \multicolumn{3}{|c|}{ BJC } & \multicolumn{3}{|c|}{ BJC } \\
\hline \multicolumn{13}{|l|}{ Sample Type } \\
\hline Result (pCi/L) & Activity & TPU & MDA & Activity & TPU & MDA & Activity & TPU & MDA & Activity & TPU & MDA \\
\hline Gross Alpha & 186 & 75 & 101 & $<$ & & 61.2 & $<$ & & 2.45 & $<$ & & 2.51 \\
\hline Gross Beta & 16,200 & 2,600 & 101 & 13,400 & 2,140 & 108 & $<$ & & 4.34 & 5.29 & 2.5 & 4.63 \\
\hline Technetium-99 & 80,000 & 12,800 & 515 & 29,000 & 4,620 & 25.6 & & & & & & \\
\hline Uranium-234 & & & & & & & 0.73 & 0.507 & 0.555 & $<$ & & 0.494 \\
\hline Uranium-235 & & & & & & & $<$ & & 0.405 & $<$ & & 0.188 \\
\hline Uranium-238 & & & & & & & $<$ & & 0.405 & $<$ & & 0.188 \\
\hline
\end{tabular}

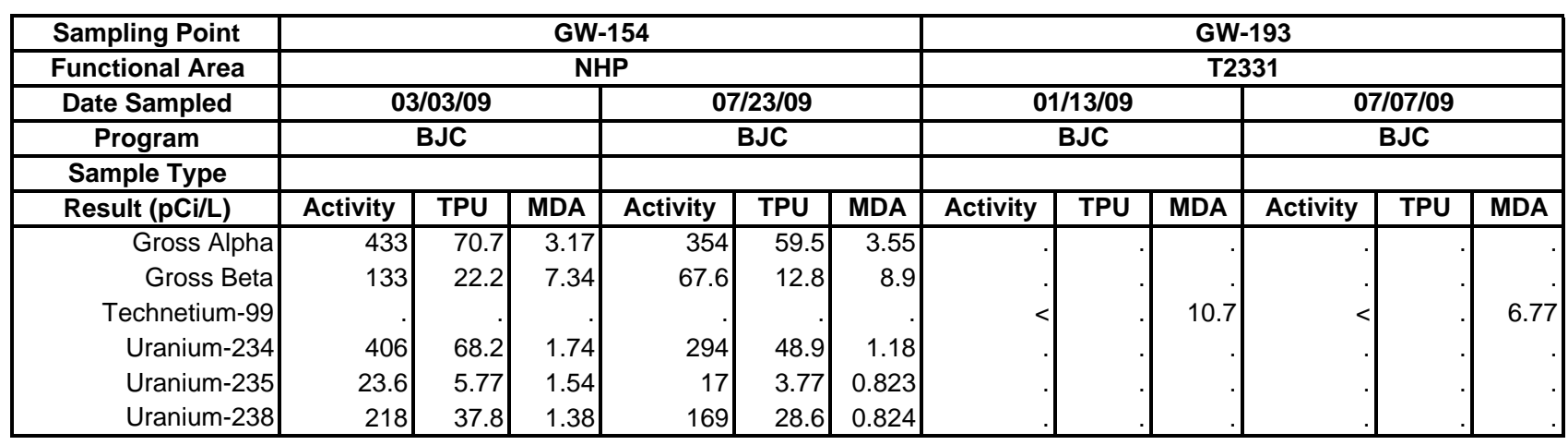

\begin{tabular}{|c|c|c|c|c|c|c|c|c|c|c|c|c|}
\hline Sampling Point & \multicolumn{3}{|c|}{ GW-204 } & \multicolumn{3}{|c|}{ GW-219 } & \multicolumn{6}{|c|}{ GW-223 } \\
\hline Functional Area & \multicolumn{3}{|c|}{ T0134 } & \multicolumn{3}{|c|}{ UOV } & \multicolumn{6}{|c|}{ NHP } \\
\hline Date Sampled & \multicolumn{3}{|c|}{$05 / 12 / 09$} & \multicolumn{3}{|c|}{$05 / 11 / 09$} & \multicolumn{3}{|c|}{$03 / 03 / 09$} & \multicolumn{3}{|c|}{$07 / 22 / 09$} \\
\hline Program & \multicolumn{3}{|c|}{ GWPP } & \multicolumn{3}{|c|}{ GWPP } & \multicolumn{3}{|c|}{$\mathrm{BJC}$} & \multicolumn{3}{|c|}{$\mathrm{BJC}$} \\
\hline \multicolumn{13}{|l|}{ Sample Type } \\
\hline Result (pCi/L) & Activity & TPU & MDA & Activity & TPU & MDA & Activity & TPU & MDA & Activity & TPU & MDA \\
\hline Gross Alpha & 35 & 4.7 & 3 & 140 & 9.4 & 2.9 & 11.3 & 3.49 & 2.87 & 12.6 & 3.41 & 2.38 \\
\hline Gross Beta & 7.3 & 3.9 & 6.4 & 82 & 8.1 & 7 & 11.6 & 3.3 & 4.72 & 8.23 & 2.82 & 4.55 \\
\hline \multicolumn{13}{|l|}{ Technetium-99 } \\
\hline Uranium-234 & 25 & 3.6 & 4.3 & 26 & 3.5 & 4.3 & 4.86 & 1.41 & 0.378 & 6.49 & 1.65 & 0.415 \\
\hline Uranium-235 & 0.85 & 0.4 & 0.43 & 2 & 0.55 & 0.4 & 0.538 & 0.4 & 0.322 & 0.725 & 0.448 & 0.343 \\
\hline Uranium-238 & 16 & 2.2 & 0.31 & 190 & 19 & 0.29 & 13.2 & 2.87 & 0.458 & 15.3 & 3.15 & 0.415 \\
\hline
\end{tabular}

\begin{tabular}{|c|c|c|c|c|c|c|c|c|c|c|c|c|}
\hline Sampling Point & \multicolumn{12}{|c|}{ GW-605 } \\
\hline Functional Area & \multicolumn{12}{|c|}{ EXP-I } \\
\hline Date Sampled & \multicolumn{6}{|c|}{$01 / 08 / 09$} & \multicolumn{6}{|c|}{$07 / 07 / 09$} \\
\hline Program & \multicolumn{6}{|c|}{ BJC } & \multicolumn{6}{|c|}{ BJC } \\
\hline Sample Type & \multicolumn{6}{|c|}{ Dup } & & & & \multicolumn{3}{|c|}{ Dup } \\
\hline Result (pCi/L) & Activity & TPU & MDA & Activity & TPU & MDA & Activity & TPU & MDA & Activity & TPU & MDA \\
\hline Gross Alpha & 71 & 12.8 & 2.47 & 76.5 & 14.4 & 2.64 & 51.8 & 9.74 & 2.34 & 49.2 & 9.32 & 1.81 \\
\hline Gross Beta & 25.3 & 5.2 & 4.76 & 26.1 & 5.52 & 4.96 & 13.8 & 3.59 & 4.65 & 12.7 & 3.36 & 4.36 \\
\hline Technetium-99 & $<$ & & 10.3 & $<$ & & 10.7 & $<$ & & 6.45 & $<$ & & 6.85 \\
\hline Uranium-234 & & & & & & & & & & & & \\
\hline Uranium-235 & & & & & & & & & & & & \\
\hline Uranium-238 & & & & & & & & & & & & \\
\hline
\end{tabular}


APPENDIX E.3: CY 2008 MONITORING DATA FOR THE UPPER EAST FORK POPLAR CREEK HYDROGEOLOGIC REGIME Radiological Analytes: Isotopic Analyses

\begin{tabular}{|c|c|c|c|c|c|c|c|c|c|c|c|c|}
\hline Sampling Point & \multicolumn{6}{|c|}{ GW-606 } & \multicolumn{6}{|c|}{ GW-733 } \\
\hline Functional Area & \multicolumn{6}{|c|}{ EXP-I } & \multicolumn{6}{|c|}{ EXP-J } \\
\hline Date Sampled & \multicolumn{3}{|c|}{$01 / 08 / 09$} & \multicolumn{3}{|c|}{$07 / 07 / 09$} & \multicolumn{3}{|c|}{$01 / 12 / 09$} & \multicolumn{3}{|c|}{$07 / 07 / 09$} \\
\hline Program & \multicolumn{3}{|c|}{ BJC } & \multicolumn{3}{|c|}{ BJC } & \multicolumn{3}{|c|}{ BJC } & \multicolumn{3}{|c|}{ BJC } \\
\hline \multicolumn{13}{|l|}{ Sample Type } \\
\hline Result (pCi/L) & Activity & TPU & MDA & Activity & TPU & MDA & Activity & TPU & MDA & Activity & TPU & MDA \\
\hline Gross Alpha & 7.4 & 2.13 & 1.9 & 8.61 & 2.7 & 2.04 & $<$ & & 2.92 & $<$ & & 1.76 \\
\hline Gross Betal & 5.17 & 1.98 & 3.36 & 7.75 & 2.73 & 4.45 & $<$ & & 3.44 & $<$ & & 3.22 \\
\hline Technetium-99 & $<$ & & 10.9 & $<$ & & 6.54 & $<$ & & 10.2 & $<$ & & 6.31 \\
\hline Uranium-234 & & & & & & & & & & & & \\
\hline Uranium-235 & & & & & & & & & & & & \\
\hline Uranium-238 & & & & & & & & & & & & \\
\hline
\end{tabular}

\begin{tabular}{|c|c|c|c|c|c|c|c|c|c|c|c|c|}
\hline Sampling Point & \multicolumn{6}{|c|}{ GW-832 } & \multicolumn{6}{|c|}{ STATION 8} \\
\hline Functional Area & \multicolumn{6}{|c|}{ NHP } & \multicolumn{6}{|c|}{ EXP-SW } \\
\hline Date Sampled & \multicolumn{3}{|c|}{$03 / 03 / 09$} & \multicolumn{3}{|c|}{$07 / 23 / 09$} & \multicolumn{3}{|c|}{$01 / 06 / 09$} & \multicolumn{3}{|c|}{$01 / 22 / 09$} \\
\hline Program & \multicolumn{3}{|c|}{ BJC } & \multicolumn{3}{|c|}{ BJC } & \multicolumn{3}{|c|}{ BJC } & \multicolumn{3}{|c|}{ BJC } \\
\hline \multicolumn{13}{|l|}{ Sample Type } \\
\hline Result (pCi/L) & Activity & TPU & MDA & Activity & TPU & MDA & Activity & TPU & MDA & Activity & TPU & MDA \\
\hline Gross Alpha & 2.98 & 1.63 & 2.4 & 4.26 & 2.01 & 2.27 & 12.9 & 3.09 & 1.55 & 5.24 & 1.98 & 2 \\
\hline Gross Beta & 8.44 & 2.77 & 4.43 & 6.74 & 2.53 & 4.22 & 6.97 & 2.21 & 3.33 & 4.81 & 2 & 3.46 \\
\hline \multicolumn{13}{|l|}{ Technetium-99 } \\
\hline Uranium-234 & 1.56 & 0.705 & 0.445 & 1.04 & 0.543 & 0.432 & 3.35 & 1.07 & 0.667 & 1.91 & 0.787 & 0.319 \\
\hline Uranium-235 & $<$ & & 0.313 & $<$ & & 0.457 & 0.592 & 0.434 & 0.574 & $0.193 \mathrm{R}$ & 0.242 & 0.185 \\
\hline Uranium-238 & 2.24 & 0.863 & 0.41 & 2.27 & 0.834 & 0.372 & 13.2 & 2.76 & 0.401 & 4.09 & 1.24 & 0.185 \\
\hline
\end{tabular}

\begin{tabular}{|c|c|c|c|c|c|c|}
\hline Sampling Point & \multicolumn{6}{|c|}{ STATION 8} \\
\hline Functional Area & \multicolumn{6}{|c|}{ EXP-SW } \\
\hline Date Sampled & \multicolumn{3}{|c|}{$08 / 19 / 09$} & \multicolumn{3}{|c|}{ 09/10/09 } \\
\hline Program & \multicolumn{3}{|c|}{ BJC } & \multicolumn{3}{|c|}{$\mathrm{BJC}$} \\
\hline \multicolumn{7}{|l|}{ Sample Type } \\
\hline Result (pCi/L) & Activity & TPU & MDA & Activity & TPU & MDA \\
\hline Gross Alpha & 11.1 & 3.29 & 2.32 & $<$ & & 1.91 \\
\hline Gross Beta & 8.99 & 2.76 & 4.14 & 4.81 & 1.89 & 3.28 \\
\hline \multicolumn{7}{|l|}{ Technetium-99 } \\
\hline Uranium-234 & 4.24 & 1.25 & 0.543 & 1.11 & 0.595 & 0.526 \\
\hline Uranium-235 & $<$ & & 0.346 & $<$ & & 0.501 \\
\hline Uranium-238 & 11.1 & 2.46 & 0.386 & 1.32 & 0.648 & 0.501 \\
\hline
\end{tabular}


APPENDIX F

CY 2009 MONITORING DATA FOR THE CHESTNUT RIDGE HYDROGEOLOGIC REGIME 



\section{EXPLANATION}

\section{Sampling Point:}

GW - Groundwater monitoring well (e.g., GW-141; one exception is 1090)

MCK - McCoy Branch Kilometer

S17 - Surface water station in SCR5

SCR - South Chestnut Ridge (tributary prefix for spring and surface water sampling locations)

\section{Location:}

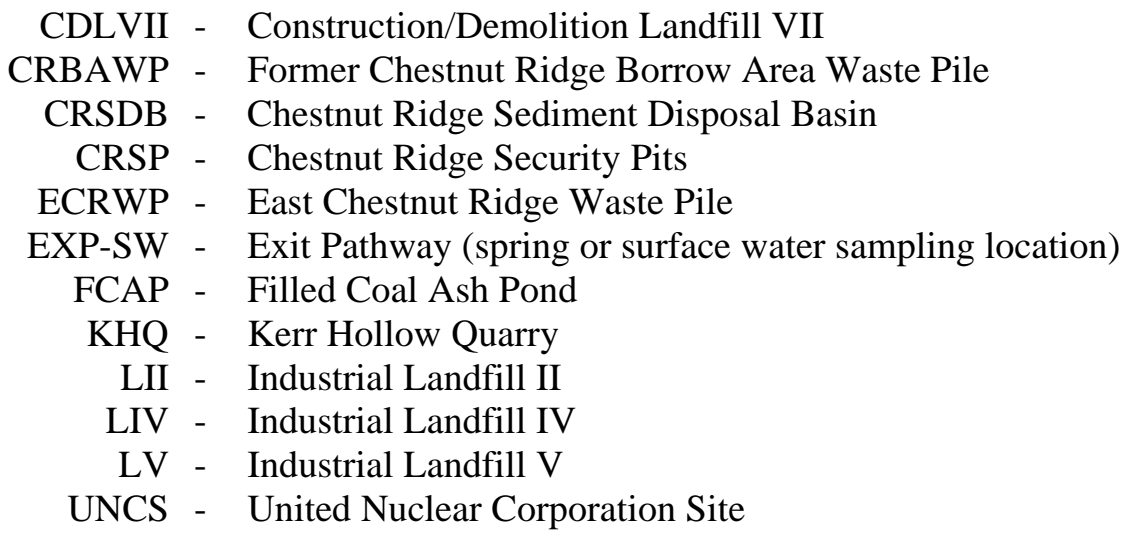

\section{Monitoring Program:}

BJC - monitoring program managed by Bechtel Jacobs Company LLC

GWPP - managed by the Y-12 Groundwater Protection Program

\section{Sample Type:}

Dup - field duplicate sample

PDB - passive diffusion bag sample

\section{Units:}

$\mathrm{ft}$ - feet (elevations are above mean sea level and depths are below grade)

$\mu \mathrm{g} / \mathrm{L}$ - micrograms per liter

mg/L - milligrams per liter

$\mathrm{mV}$ - millivolts

$\mu \mathrm{mho} / \mathrm{cm}$ - micromhos per centimeter

NTU - Nephelometric Turbidity Units

$\mathrm{pCi} / \mathrm{L}$ - picoCuries per liter

ppm - parts per million 


\section{EXPLANATION (continued)}

Only analytes detected above the program reporting limits in at least one sample are presented in this appendix. Additionally, results that are below the reporting limits are replaced with values (e.g., "<") to emphasize the detected results. The following sections describe the reporting limits and data qualifiers for each subsection of the appendix. A comprehensive list of the Y-12 GWPP analytes, analytical methods, and reporting limits is provided in Appendix B, Table B.5.

\section{F.1 Field Measurements, Miscellaneous Analytes, Major Ions, and Trace Metals:}

Results for all of the field measurements, miscellaneous analytes, and major ions are included in this appendix. The reporting limits for the major ions are shown in the following summary.

\begin{tabular}{|c|c|c|c|c|c|}
\hline \multirow{2}{*}{ Analyte } & \multicolumn{2}{|c|}{ Reporting Limit (mg/L) } & \multirow{2}{*}{ Analyte } & \multicolumn{2}{|c|}{ Reporting Limit (mg/L) } \\
\hline & GWPP & BJC & & GWPP & BJC \\
\hline $\begin{array}{l}\text { Cations } \\
\qquad \begin{array}{c}\text { Calcium } \\
\text { Magnesium } \\
\text { Potassium } \\
\text { Sodium }\end{array}\end{array}$ & $\begin{array}{l}0.2 \\
0.2 \\
2.0 \\
0.2\end{array}$ & $\begin{array}{c}0.01 \\
0.05 \\
0.025 \\
0.01\end{array}$ & $\begin{array}{r}\text { Anions } \\
\text { Bicarbonate } \\
\text { Carbonate } \\
\text { Chloride } \\
\text { Fluoride } \\
\text { Nitrate (as Nitrogen) } \\
\text { Sulfate }\end{array}$ & $\begin{array}{c}1.0 \\
1.0 \\
0.2 \\
0.1 \\
0.05 \\
0.25\end{array}$ & $\begin{array}{c}\text { NS } \\
\text { NS } \\
0.1 \\
0.05 \\
0.1 \\
0.1\end{array}$ \\
\hline
\end{tabular}

The Y-12 GWPP SAP (B\&W Y-12 2008) specifies analytical methods and reporting limits for trace metals that are appropriate for DOE Order monitoring. Some of the laboratories used for the monitoring programs managed by BJC report metals results (often as estimated values) that are lower than the GWPP reporting limits for the metals. For this report, the analytical methods for metals used by BJC monitoring programs (EPA-7470, SW846-6010B, SW846-6020, and ASTM-D5174-M) are considered to be functionally equivalent to the methods used by the GWPP (Table B.5) To retain the highest quality data for DOE Order monitoring purposes and to standardize reporting limits for trace metal results obtained from all sources, the GWPP reporting limits were given precedence over the BJC reporting limits (BJC 2009a) shown below. Results for the trace metals shown in bold typeface below are presented in Appendix F.1 because the metal was detected at a level above the associated reporting limit in at least one groundwater or surface water sample. 
EXPLANATION (continued)

\begin{tabular}{|c|c|c|c|c|c|}
\hline \multirow{2}{*}{ Analyte } & \multicolumn{2}{|c|}{ Reporting Limit (mg/L) } & \multirow{2}{*}{ Analyte } & \multicolumn{2}{|c|}{ Reporting Limit (mg/L) } \\
\hline & GWPP & BJC & & GWPP & BJC \\
\hline $\begin{array}{r}\text { Aluminum } \\
\text { Antimony } \\
\text { Arsenic } \\
\text { Barium } \\
\text { Beryllium } \\
\text { Boron } \\
\text { Cadmium } \\
\text { Chromium } \\
\text { Cobalt } \\
\text { Copper } \\
\text { Iron } \\
\text { Lead }\end{array}$ & $\begin{array}{c}0.2 \\
0.0025^{* *} \\
0.005^{* *} \\
0.004 \\
0.0005 \\
0.1 \\
0.0025^{* *} \\
0.01^{* *} \\
0.02 \\
0.02 \\
0.05 \\
0.0005^{* *}\end{array}$ & $\begin{array}{c}0.05^{*} \\
0.003 \\
0.005 \\
0.005 \\
0.001 \\
0.01^{*} \\
0.00013^{*} \\
0.005^{*} \\
0.005^{*} \\
0.005^{*} \\
0.01^{*} \\
0.002\end{array}$ & $\begin{array}{r}\text { Lithium } \\
\text { Manganese } \\
\text { Mercury } \\
\text { Molybdenum } \\
\text { Nickel } \\
\text { Selenium } \\
\text { Silver } \\
\text { Strontium } \\
\text { Thallium } \\
\text { Thorium } \\
\text { Uranium } \\
\text { Vanadium } \\
\text { Zinc }\end{array}$ & $\begin{array}{c}0.01 \\
0.005 \\
0.00005 \\
0.05 \\
0.005^{* *} \\
0.01^{* *} \\
0.02 \\
0.005 \\
0.0005^{* *} \\
0.2 \\
0.0005^{* *} \\
0.02 \\
0.05\end{array}$ & $\begin{array}{c}0.01 \\
0.005 \\
0.0002 \\
\mathrm{NS} \\
0.01 \\
0.0025^{*} \\
0.0015^{*} \\
0.005 \\
0.001 \\
\mathrm{NS} \\
0.004 \\
0.01^{*} \\
0.01^{*}\end{array}$ \\
\hline
\end{tabular}

Note: * - the GWPP reporting limit is used instead of the BJC reporting limit; ** - samples collected after June 2009 were diluted (additional 2X) before analysis which doubled the reporting limit; "NS” - not specified.

To evaluate the lowest possible mercury concentrations in surface water in McCoy Branch downstream of the FCAP, monitoring by BJC included the following results that are not presented in Appendix F.1.

\begin{tabular}{|c|c|c|}
\hline \multirow{2}{*}{ Surface Water Station } & \multicolumn{2}{|c|}{ Mercury Concentration (mg/L) by Method EPA-1631 } \\
\cline { 2 - 3 } & $\mathbf{0 3 / 1 8 / 0 9}$ & $\mathbf{0 9 / 0 3 / 0 9}$ \\
\hline MCK 2.0 & 0.0000027 & 0.0000016 \\
MCK 1.4 & 0.0000006 & 0.0000008 \\
\hline
\end{tabular}

The following symbols and data qualifiers are used in Appendix F.1:

- - Not analyzed or not applicable

$<\quad$ - Analyzed but not detected at the project reporting level

J - Positively identified; estimated concentration (BJC results) 


\section{EXPLANATION (continued)}

\section{F.2 Volatile Organic Compounds:}

The reporting limits for volatile organic compounds shown in Table B.5 and those used for monitoring programs managed by BJC are contract-required quantitation limits. Results below the quantitation limit and above the instrument detection limit are reported as estimated quantities. Therefore, non-detected results are assumed to equal zero for all compounds.

As summarized below, 20 compounds were detected in groundwater samples collected in the Chestnut Ridge Regime during CY 2009. Results for these compounds are grouped by similar chemical composition (e.g., chloroethenes) in Appendix F.2.

\begin{tabular}{|r|c|c|r|c|c|}
\hline Compound & $\begin{array}{c}\text { No. } \\
\text { Detected }\end{array}$ & $\begin{array}{c}\text { Maximum } \\
(\boldsymbol{\mu g} / \mathbf{L})\end{array}$ & Compound & $\begin{array}{c}\text { No. } \\
\text { Detected }\end{array}$ & $\begin{array}{c}\text { Maximum } \\
(\boldsymbol{\mu g} / \mathbf{L})\end{array}$ \\
\hline 1,1-Dichloroethane & 14 & 75 & 1,1,2-Trichloro-1,2,2-trifluoroethane & 3 & 3 \\
1,1-Dichloroethene & 14 & 53 & Benzene & 3 & $0.061 \mathrm{~J}$ \\
1,1,1-Trichloroethane & 14 & 21 & 1,2-Dichloroethane & 2 & $0.12 \mathrm{~J}$ \\
Trichlorofluoromethane & 9 & 32 & Carbon disulfide & 2 & $0.038 \mathrm{~J}$ \\
Chloromethane & 8 & $1 \mathrm{~J}$ & Chloroethane & 1 & $0.25 \mathrm{~J}$ \\
Tetrachloroethene & 7 & 15 & trans-1,2-Dichloroethene & 1 & $0.16 \mathrm{~J}$ \\
Chloroform & 7 & $0.13 \mathrm{~J}$ & 1,4-Dichlorobenzene & 1 & $0.12 \mathrm{~J}$ \\
cis-1,2-Dichloroethene & 4 & 13 & Toluene & 1 & $0.11 \mathrm{~J}$ \\
Trichloroethene & 4 & $6.8 \mathrm{Q}$ & Carbon tetrachloride & 1 & $0.059 \mathrm{~J}$ \\
Acetone & 4 & $2 \mathrm{~J}$ & Total Xylene & 1 & $0.056 \mathrm{~J}$ \\
\hline
\end{tabular}

The following symbols and data qualifiers are used in Appendix F.2:

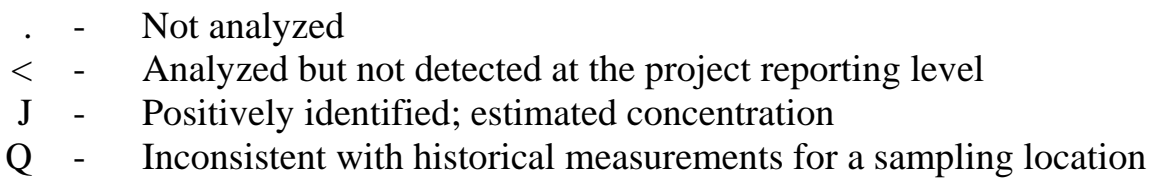




\section{EXPLANATION (continued)}

\section{F.3 Radiological Analytes}

Reporting limits for radiological analytes are sample-specific and analyte-specific minimum detectable activities that are reported with each result. The following summary shows the radiological analytes reported for at least one groundwater sample collected during CY 2009 in the Chestnut Ridge Regime.

\begin{tabular}{|r|c|c|r|c|c|}
\hline \multicolumn{1}{|c|}{ Analyte } & $\begin{array}{c}\text { No. of } \\
\text { Results }\end{array}$ & $\begin{array}{c}\text { No. } \\
\text { Detected }\end{array}$ & Analyte & $\begin{array}{c}\text { No. of } \\
\text { Results }\end{array}$ & $\begin{array}{c}\text { No. } \\
\text { Detected }\end{array}$ \\
\hline Gross Alpha & 82 & 17 & Strontium-89/90 & 8 & 0 \\
Gross Beta & 72 & 19 & Technetium-99 & 2 & 0 \\
Cesium-137 & 4 & 0 & Uranium-234 & 8 & 3 \\
Cobalt-60 & 4 & 0 & Uranium-235 & 8 & 0 \\
Potassium-40 & 4 & 0 & Uranium-238 & 8 & 2 \\
\hline Note: * Reported by BJC laboratories in Appendix F.3 as equivalent GWPP analytes: \\
U-233/234 = U-234; U-235/236 = U-235.
\end{tabular}

Results for gross alpha and gross beta are presented in the first two pages of Appendix F.3, followed by results for the isotopes. The following notes and qualifiers apply to this appendix:

Result - Activity in picoCuries per liter (pCi/L)

TPU - Total propagated uncertainty (two standard deviations); calculation includes the counting error (instrument uncertainty) plus other sources of uncertainty (e.g., volumetric, chemical yield)

MDA - Minimum detectable activity

. - Not analyzed or not applicable (TPU is not presented when the result is $<$ MDA)

$<\quad$ - Analyzed but less than the MDA 

APPENDIX F.1

FIELD MEASUREMENTS, MISCELLANEOUS ANALYTES, MAJOR IONS, AND TRACE METALS 

APPENDIX F.1: CY 2009 MONITORING DATA FOR THE CHESTNUT RIDGE HYDROGEOLOGIC REGIME

Field Measurements, Miscellaneous Analytes, Major lons, and Trace Metals

\begin{tabular}{|c|c|c|c|c|c|c|c|c|c|c|}
\hline Sampling Point & \multicolumn{2}{|c|}{1090} & \multicolumn{2}{|c|}{ GW-141 } & GW-143 & GW-144 & GW-145 & \multicolumn{2}{|c|}{ GW-156 } & GW-159 \\
\hline Functional Area & \multicolumn{2}{|c|}{ UNCS } & \multicolumn{2}{|c|}{ LIV } & KHQ & KHQ & KHQ & \multirow{2}{*}{\multicolumn{2}{|c|}{$\begin{array}{c}\text { CRSDB } \\
01 / 13 / 09\end{array}$}} & CRSDB \\
\hline Date Sampled & $03 / 05 / 09$ & $07 / 27 / 09$ & $01 / 29 / 09$ & $07 / 16 / 09$ & $01 / 08 / 09$ & $01 / 06 / 09$ & $01 / 08 / 09$ & & & $01 / 13 / 09$ \\
\hline Program & BJC & BJC & BJC & BJC & BJC & BJC & BJC & BJC & BJC & $\mathrm{BJC}$ \\
\hline Sample Type & & & & & & & & & Dup & \\
\hline Field Measurements & & & & & & & & & & \\
\hline Time Sampled & $11: 20$ & $10: 40$ & $10: 20$ & $9: 50$ & $10: 10$ & $14: 00$ & $14: 00$ & $10: 35$ & & $9: 55$ \\
\hline Measuring Point Elev. (ft) & $1,104.48$ & $1,104.48$ & $1,186.23$ & $1,186.23$ & 913.98 & 913.54 & 840.24 & $1,049.28$ & & $1,051.38$ \\
\hline Depth to Water (ft) & 49.06 & 54.97 & 94.04 & 96.27 & 78.07 & 79.77 & 14.42 & 142.31 & & 116.96 \\
\hline Groundwater Elevation (ft) & $1,055.42$ & $1,049.51$ & $1,092.19$ & $1,089.96$ & 835.91 & 833.77 & 825.82 & 906.97 & & 934.42 \\
\hline Conductivity $(\mu \mathrm{mho} / \mathrm{cm})$ & 479 & 652 & 309 & 565 & 355 & 280 & 394 & 536 & & 533 \\
\hline Dissolved Oxygen (ppm) & 1.92 & 2.15 & 8.1 & 7.38 & 18.05 & 6.55 & 2.59 & 15.04 & & 3.62 \\
\hline Oxidation/Reduction (mV) & 132 & 182 & 117 & 180 & -103 & 132 & 167 & 171 & & 135 \\
\hline Temperature (degrees C) & 15.7 & 18.1 & 11.9 & 18.3 & 9.9 & 14.4 & 12.4 & 11.7 & & 9.9 \\
\hline Turbidity (NTU) & 1 & 1 & 1 & 1 & 2 & 1 & 1 & 0 & & 1 \\
\hline $\mathrm{pH}$ & 7.3 & 7.11 & 7.42 & 6.96 & 7.44 & 7.4 & 7.26 & 6.69 & & 6.98 \\
\hline Miscellaneous Analytes & & & & & & & & & & \\
\hline Dissolved Solids (mg/L) & 412 & 283 & 191 & 207 & 261 & 221 & 284 & 380 & 382 & 180 \\
\hline Suspended Solids (mg/L) & $<$ & $<$ & $<$ & $<$ & $<$ & $<$ & $<$ & 11 & $<$ & $<$ \\
\hline Major lons (mg/L) & & & & & & & & & & \\
\hline Calcium & 55.8 & 52.8 & 42.2 & 39 & 28.2 & 46.5 & 42 & 68.2 & 67.9 & 41.2 \\
\hline Magnesium & 32.4 & 29.7 & 26.7 & 23.7 & 23.5 & 16 & 33.8 & 41.4 & 41.2 & 25.2 \\
\hline Potassium & 0.896 & 0.942 & $<$ & $<$ & 17.1 & 1.4 & 11.7 & 19.8 & 19.6 & 0.947 \\
\hline Sodium & 6.43 & 6.82 & $<$ & $<$ & 21.4 & 1.33 & 3.83 & 4.7 & 4.68 & 0.512 \\
\hline Bicarbonate & 277 & 265 & 200 & 187 & & & & & & \\
\hline Carbonate & $<$ & $<$ & $<$ & $<$ & & & & & & \\
\hline Chloride & 13.1 & 17.8 & $<$ & $<$ & & & & & & \\
\hline Fluoride & $<$ & $<$ & $<$ & $<$ & & & & & & \\
\hline Nitrate as $\mathrm{N}$ & 0.7 & 0.32 & $<$ & $<$ & & & & & & \\
\hline Sulfate & 3.1 & 3.72 & $<$ & $<$ & & & & & & \\
\hline Charge balance error (\%) & -2.3 & -4.4 & 3.7 & 2.1 & & & & & & \\
\hline Trace Metals (mg/L) & & & & & & & & & & \\
\hline Aluminum & $<$ & $<$ & $<$ & $<$ & $<$ & $<$ & $<$ & $<$ & $<$ & $<$ \\
\hline Arsenic & $<$ & $<$ & $<$ & $<$ & $<$ & $<$ & $<$ & $<$ & $<$ & $<$ \\
\hline Barium & 0.0273 & 0.0266 & 0.014 & 0.017 & 0.0456 & 0.0408 & 0.09 & 0.0316 & 0.0312 & 0.0122 \\
\hline Boron & $<$ & $<$ & $<$ & $<$ & 0.83 & $<$ & 0.235 & $<$ & $<$ & $<$ \\
\hline Chromium & $<$ & $<$ & $<$ & 0.067 & $<$ & $<$ & $<$ & $<$ & $<$ & $<$ \\
\hline Iron & $<$ & $<$ & $<$ & $<$ & 0.894 & 0.0573 & $<$ & $<$ & $<$ & $<$ \\
\hline Lead & $<$ & $<$ & $<$ & $<$ & $<$ & $<$ & $<$ & $<$ & $<$ & $<$ \\
\hline Lithium & $<$ & $<$ &. & 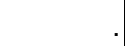 & 0.276 & 0.0215 & 0.102 & $<$ & $<$ & $<$ \\
\hline Manganese & $<$ & $<$ & $<$ & $<$ & 0.0117 & 0.00556 & 0.00852 & $<$ & $<$ & $<$ \\
\hline Nickel & $<$ & $<$ & $<$ & 0.023 & $<$ & $<$ & $<$ & $<$ & $<$ & $<$ \\
\hline Strontium & 0.025 & 0.025 & 0.014 & 0.013 & 2.82 & 0.13 & 6.65 & 0.026 & 0.026 & 0.0195 \\
\hline Thallium & $<$ & $<$ & $<$ & $<$ & $<$ & $<$ & $<$ & $<$ & $<$ & $<$ \\
\hline Uranium & $<$ & $<$ & $<$ & $<$ & $<$ & $<$ & 0.01 & $<$ & $<$ & $<$ \\
\hline
\end{tabular}


APPENDIX F.1: CY 2009 MONITORING DATA FOR THE CHESTNUT RIDGE HYDROGEOLOGIC REGIME

Field Measurements, Miscellaneous Analytes, Major lons, and Trace Metals

\begin{tabular}{|c|c|c|c|c|c|c|c|c|c|c|}
\hline Sampling Point & \multicolumn{2}{|c|}{ GW-161 } & GW-175 & \multicolumn{2}{|c|}{ GW-177 } & \multicolumn{2}{|c|}{ GW-203 } & \multicolumn{3}{|c|}{ GW-205 } \\
\hline Functional Area & \multicolumn{2}{|c|}{ ECRWP } & CRSP & \multicolumn{2}{|c|}{ CRSP } & \multicolumn{2}{|c|}{ UNCS } & \multicolumn{3}{|c|}{ UNCS } \\
\hline Date Sampled & 01/14/09 & $07 / 08 / 09$ & $12 / 15 / 09$ & $01 / 14 / 09$ & 07/09/09 & $03 / 05 / 09$ & $07 / 27 / 09$ & $03 / 05 / 09$ & $07 / 27 / 09$ & $10 / 15 / 09$ \\
\hline Program & BJC & BJC & GWPP & BJC & BJC & BJC & BJC & BJC & BJC & BJC \\
\hline \multicolumn{11}{|l|}{ Sample Type } \\
\hline Field Measurements & & & & & & & & & & \\
\hline Time Sampled & $10: 20$ & $14: 40$ & $10: 10$ & $10: 00$ & 10:05 & $11: 00$ & $14: 10$ & $11: 15$ & $15: 10$ & $13: 50$ \\
\hline Measuring Point Elev. (ft) & $1,093.54$ & $1,093.54$ & $1,084.19$ & $1,158.20$ & $1,158.20$ & $1,105.45$ & $1,105.45$ & $1,104.14$ & $1,104.14$ & $1,104.14$ \\
\hline Depth to Water (ft) & 156.38 & 159.98 & 109.81 & 117.47 & 117.95 & 82.96 & 78.99 & 78.95 & 76.41 & 75.88 \\
\hline Groundwater Elevation (ft) & 937.16 & 933.56 & 974.38 & $1,040.73$ & $1,040.25$ & $1,022.49$ & $1,026.46$ & $1,025.19$ & $1,027.73$ & $1,028.26$ \\
\hline Conductivity $(\mu \mathrm{mho} / \mathrm{cm})$ & 280 & 565 & 460 & 615 & 569 & 271 & 374 & 320 & 430 & 430 \\
\hline Dissolved Oxygen (ppm) & 1.13 & 0.62 & 3.74 & 3.73 & 3.06 & 10.19 & 4.62 & 3.02 & 8.16 & 1.82 \\
\hline Oxidation/Reduction $(\mathrm{mV})$ & 3 & -76 & 209 & 161 & 184 & 86 & 168 & 54 & -92 & 14 \\
\hline Temperature (degrees C) & 11.4 & 17.8 & 12.9 & 8.9 & 19.4 & 14.6 & 20.5 & 14 & 21 & 16.8 \\
\hline Turbidity (NTU) & 28 & 16 & & 2 & 2 & 7 & 1 & 4 & 2 & \\
\hline $\mathrm{pH}$ & 7.42 & 6.65 & 7.09 & 6.96 & 7.44 & 7.46 & 7.73 & 9.41 & 10.05 & 9.87 \\
\hline Miscellaneous Analytes & & & & & & & & & & \\
\hline Dissolved Solids (mg/L) & & & & 241 & 250 & 180 & 164 & 194 & 243 & \\
\hline Suspended Solids (mg/L) & & & & $<$ & $<$ & 7 & $<$ & $<$ & $<$ & \\
\hline Major lons (mg/L) & & & & & & & & & & \\
\hline Calcium & 38.8 & 39 & & 49.9 & 49 & 35.6 & 28.6 & 1.27 & 1.66 & \\
\hline Magnesium & 24.3 & 24 & & 29.8 & 29 & 19.9 & 15.7 & 12.5 & 12.7 & \\
\hline Potassium & 4.1 & 3.9 & & 4.18 & 2.8 & 0.912 & 0.75 & 78.2 & 72 & \\
\hline Sodium & 2.92 & 3 & & 1.35 & 1.1 & 0.719 & 0.5 & 10.9 & 9.94 & \\
\hline Bicarbonate & 241 & 200 & & & & 186 & 147 & 55.4 & 92.9 & \\
\hline Carbonate & $<$ & $<$ & & & & $<$ & $<$ & 119 & 76.8 & \\
\hline Chloride & 3 & 2.9 & & & & 3.2 & 1.81 & 2.6 & 2.88 & \\
\hline Fluoride & $<$ & $<$ & & & & $<$ & 3.81 & $<$ & $<$ & \\
\hline Nitrate as $\mathrm{N}$ & 0.03 & $<$ & & & & 0.44 & 0.48 & 0.072 & 0.07 & \\
\hline Sulfate & 0.45 & $<$ & & & & 1.9 & 0.9 & 4 & 4.44 & \\
\hline Charge balance error (\%) & -8.2 & 0.9 & & & & -5.6 & -8.1 & -1.5 & -4 & \\
\hline Trace Metals (mg/L) & & & & & & & & & & \\
\hline Aluminum & $<$ & $<$ & & $<$ & $<$ & 0.28 & $<$ & $<$ & $<$ & \\
\hline Arsenic & $<$ & $<$ & & $<$ & $<$ & $<$ & $<$ & $<$ & $<$ & \\
\hline Barium & 0.00799 & 0.0077 & & 0.0183 & 0.019 & 0.013 & 0.00924 & $<$ & $<$ & \\
\hline Boron & $<$ & $<$ & & & $<$ & $<$ & $<$ & $<$ & $<$ & \\
\hline Chromium & $<$ & $<$ & & 0.0144 & $<$ & $<$ & $<$ & $<$ & $<$ & \\
\hline Iron & 2.31 & 2.3 & & $<$ & $<$ & 0.246 & $<$ & $<$ & $<$ & \\
\hline Lead & $<$ & $<$ & & $<$ & $<$ & $<$ & $<$ & $<$ & $<$ & \\
\hline Lithium & & $<$ & & $<$ & $<$ & $<$ & $<$ & 0.128 & 0.119 & \\
\hline Manganese & 0.0257 & 0.04 & & $<$ & 0.043 & $<$ & $<$ & $<$ & $<$ & \\
\hline Nickel & $<$ & $<$ & & 0.0119 & 0.01 & $<$ & $<$ & $<$ & $<$ & \\
\hline Strontium & 0.016 & 0.017 & & 0.0208 & 0.02 & 0.0124 & 0.0111 & $<$ & $<$ & \\
\hline Thallium & $<$ & $<$ & & $<$ & $<$ & $<$ & $<$ & $<$ & $<$ & \\
\hline Uranium & $<$ & $<$ & & $<$ & $<$ & $<$ & $<$ & $<$ & $<$ & \\
\hline
\end{tabular}


APPENDIX F.1: CY 2009 MONITORING DATA FOR THE CHESTNUT RIDGE HYDROGEOLOGIC REGIME

Field Measurements, Miscellaneous Analytes, Major lons, and Trace Metals

\begin{tabular}{|c|c|c|c|c|c|c|c|c|c|c|}
\hline Sampling Point & \multicolumn{2}{|c|}{ GW-217 } & \multicolumn{2}{|c|}{ GW-221 } & \multicolumn{2}{|c|}{ GW-231 } & \multicolumn{4}{|c|}{ GW-294 } \\
\hline Functional Area & \multicolumn{2}{|c|}{ LIV } & \multicolumn{2}{|c|}{ UNCS } & \multirow{2}{*}{\multicolumn{2}{|c|}{$\begin{array}{c}\text { KHQ } \\
01 / 12 / 09\end{array}$}} & \multicolumn{4}{|c|}{ ECRWP } \\
\hline Date Sampled & \multirow{2}{*}{$\begin{array}{c}01 / 28 / 09 \\
\text { BJC }\end{array}$} & \multirow{2}{*}{\begin{tabular}{|c|}
$07 / 13 / 09$ \\
BJC \\
\end{tabular}} & \multirow{2}{*}{$\begin{array}{c}03 / 05 / 09 \\
\text { BJC }\end{array}$} & \multirow{2}{*}{\begin{tabular}{|c|}
$07 / 27 / 09$ \\
BJC
\end{tabular}} & & & \multicolumn{2}{|c|}{$01 / 14 / 09$} & \multicolumn{2}{|c|}{$07 / 08 / 09$} \\
\hline Program & & & & & $\mathrm{BJC}$ & $\mathrm{BJC}$ & BJC & BJC & BJC & $\mathrm{BJC}$ \\
\hline Sample Type & & & & & & Dup & & Dup & & Dup \\
\hline Field Measurements & & & & & & & & & & \\
\hline Time Sampled & $10: 30$ & $14: 00$ & $10: 00$ & $15: 45$ & $14: 20$ & & $15: 15$ & & $10: 30$ & \\
\hline Measuring Point Elev. (ft) & $1,177.03$ & $1,177.03$ & $1,106.16$ & $1,106.16$ & 849.67 & & $1,083.60$ & & $1,083.60$ & \\
\hline Depth to Water (ft) & 107.10 & 111.61 & 85.46 & 80.40 & 11.48 & & 93.91 & & 97.33 & \\
\hline Groundwater Elevation (ft) & $1,069.93$ & $1,065.42$ & $1,020.70$ & $1,025.76$ & 838.19 & & 989.69 & & 986.27 & \\
\hline Conductivity $(\mu \mathrm{mho} / \mathrm{cm})$ & 556 & 472 & 262 & 362 & 506 & & 374 & & 725 & \\
\hline Dissolved Oxygen (ppm) & 7.27 & 7.29 & 5.63 & 4.56 & 4.8 & & 13.91 & & 6.94 & \\
\hline Oxidation/Reduction (mV) & 139 & 184 & 126 & 176 & 169 & & 197 & & 159 & \\
\hline Temperature (degrees C) & 12.8 & 21.5 & 15.3 & 18.3 & 13.2 & & 11.4 & & 17.6 & \\
\hline Turbidity (NTU) & 1 & 1 & 1 & 2 & 1 & & 0 & & 1 & \\
\hline $\mathrm{pH}$ & 7.17 & 8.05 & 7.7 & 7.59 & 6.68 & & 7.01 & & 6.51 & \\
\hline Miscellaneous Analytes & & & & & & & & & & \\
\hline Dissolved Solids (mg/L) & 182 & 196 & 181 & 156 & 179 & 201 & & & & \\
\hline Suspended Solids (mg/L) & $<$ & $<$ & $<$ & $<$ & $<$ & $<$ & & & & \\
\hline Major lons (mg/L) & & & & & & & & & & \\
\hline Calcium & 36.4 & 36.2 & 31 & 29 & 40.4 & 40.5 & 50.7 & 51.2 & 54 & 54 \\
\hline Magnesium & 23.5 & 21.9 & 18.3 & 16.6 & 19.8 & 19.9 & 30.4 & 30.8 & 32 & 32 \\
\hline Potassium & $<$ & $<$ & 0.901 & 0.984 & 1.1 & 1.1 & 1.31 & 1.33 & 1.1 & 1.1 \\
\hline Sodium & 4.9 & 4.1 & 0.432 & 0.435 & 0.674 & 0.657 & 4.1 & 4.04 & 3.7 & 3.9 \\
\hline Bicarbonate & 180 & 184 & 210 & 158 & & & 283 & 312 & 250 & 250 \\
\hline Carbonate & $<$ & $<$ & $<$ & $<$ & & & $<$ & $<$ & $<$ & $<$ \\
\hline Chloride & $<$ & $<$ & 1.5 & 1.75 & & & 7.7 & 7.4 & 7 & 7.1 \\
\hline Fluoride & $<$ & $<$ & $<$ & $<$ & & & $<$ & $<$ & $<$ & $<$ \\
\hline Nitrate as $\mathrm{N}$ & $<$ & $<$ & 0.47 & 0.21 & & & 2.5 & 1.9 & 1.6 & 1.6 \\
\hline Sulfate & 5.3 & $<$ & 1.5 & 1.58 & & & 2.3 & 2.2 & 2.5 & 2.3 \\
\hline Charge balance error (\%) & 3.3 & 1.4 & -16.4 & -6.5 & & & -7.6 & & 1.4 & \\
\hline Trace Metals (mg/L) & & & & & & & & & & \\
\hline Aluminum & $<$ & $<$ & $<$ & $<$ & $<$ & $<$ & $<$ & $<$ & $<$ & $<$ \\
\hline Arsenic & $<$ & $<$ & $<$ & $<$ & $<$ & $<$ & $<$ & $<$ & $<$ & $<$ \\
\hline Barium & 0.03 & $0.033 \mathrm{~J}$ & 0.0075 & 0.00729 & 0.0718 & 0.0708 & 0.011 & 0.011 & 0.011 & 0.011 \\
\hline Boron & $<$ & $<$ & $<$ & $<$ & $<$ & $<$ & $<$ & $<$ & $<$ & $<$ \\
\hline Chromium & $<$ & $<$ & $<$ & $<$ & $<$ & $<$ & $<$ & $<$ & $<$ & $<$ \\
\hline Iron & $<$ & $<$ & $<$ & $<$ & $<$ & $<$ & $<$ & $<$ & $<$ & $<$ \\
\hline Lead & $<$ & $<$ & $<$ & $<$ & $<$ & $<$ & $<$ & $<$ & $<$ & $<$ \\
\hline Lithium & 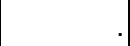 & 1 & $<$ & $<$ & $<$ & $<$ & $<$ & $<$ & $<$ & $<$ \\
\hline Manganese & $<$ & $<$ & $<$ & $<$ & $<$ & $<$ & $<$ & $<$ & $<$ & $<$ \\
\hline Nickel & $<$ & $<$ & $<$ & $<$ & $<$ & $<$ & $<$ & $<$ & $<$ & $<$ \\
\hline Strontium & 0.017 & 0.017 & 0.00988 & 0.00996 & 0.0452 & 0.0446 & 0.0238 & 0.0238 & 0.025 & 0.025 \\
\hline Thallium & $<$ & $<$ & $<$ & $<$ & $<$ & $<$ & $<$ & $<$ & $<$ & $<$ \\
\hline Uranium & $<$ & $<$ & $<$ & $<$ & $<$ & $<$ & $<$ & $<$ & $<$ & $<$ \\
\hline
\end{tabular}


APPENDIX F.1: CY 2009 MONITORING DATA FOR THE CHESTNUT RIDGE HYDROGEOLOGIC REGIME

Field Measurements, Miscellaneous Analytes, Major lons, and Trace Metals

\begin{tabular}{|c|c|c|c|c|c|c|c|c|c|c|}
\hline Sampling Point & \multicolumn{2}{|c|}{ GW-296 } & \multicolumn{2}{|c|}{ GW-298 } & \multicolumn{4}{|c|}{ GW-301 } & \multicolumn{2}{|c|}{ GW-305 } \\
\hline Functional Area & \multicolumn{2}{|c|}{ ECRWP } & \multicolumn{2}{|c|}{ ECRWP } & \multicolumn{4}{|c|}{ CRBAWP } & \multicolumn{2}{|c|}{ LIV } \\
\hline Date Sampled & 01/14/09 & $07 / 08 / 09$ & $01 / 13 / 09$ & 07/08/09 & $01 / 1$ & & $07 / 0$ & & $01 / 28 / 09$ & 07/09/09 \\
\hline Program & BJC & BJC & BJC & BJC & BJC & $\mathrm{BJC}$ & $\mathrm{BJC}$ & $\mathrm{BJC}$ & BJC & BJC \\
\hline Sample Type & & & & & & Dup & & Dup & & \\
\hline Field Measurements & & & & & & & & & & \\
\hline Time Sampled & $10: 25$ & 9:10 & $15: 15$ & $13: 30$ & $13: 30$ & & $13: 40$ & & 10:05 & $12: 30$ \\
\hline Measuring Point Elev. (ft) & $1,090.99$ & $1,090.99$ & $1,049.01$ & $1,049.01$ & $1,086.55$ & & $1,086.55$ & & $1,183.72$ & $1,183.72$ \\
\hline Depth to Water (ft) & 117.54 & 118.34 & 104.75 & 109.96 & 131.94 & & 134.61 & & 118.68 & 122.49 \\
\hline Groundwater Elevation (ft) & 973.45 & 972.65 & 944.26 & 939.05 & 954.61 & & 951.94 & & $1,065.04$ & $1,061.23$ \\
\hline Conductivity $(\mu \mathrm{mho} / \mathrm{cm})$ & 395 & 540 & 235 & 428 & 294 & & 520 & & 313 & 514 \\
\hline Dissolved Oxygen (ppm) & 13.09 & 11.97 & 2.84 & 8.56 & 4.7 & & 6.72 & & 6.49 & 6.93 \\
\hline Oxidation/Reduction $(\mathrm{mV})$ & 204 & 102 & 165 & 20 & 151 & & 201 & & 140 & 44 \\
\hline Temperature (degrees C) & 12.2 & 15.3 & 10.3 & 19.4 & 11.2 & & 18 & & 12.7 & 22 \\
\hline Turbidity (NTU) & 5 & 3 & 1 & 1 & 1 & & 0 & & 10 & 1 \\
\hline $\mathrm{pH}$ & 7.02 & 6.95 & 8.07 & 7.8 & 7.98 & & 7.63 & & 7.81 & 7.92 \\
\hline $\begin{array}{r}\text { Miscellaneous Analytes } \\
\text { Dissolved Solids }(\mathrm{mg} / \mathrm{L}) \\
\text { Suspended Solids }(\mathrm{mg} / \mathrm{L})\end{array}$ & & & & & & & & & $\begin{array}{r}198 \\
21.2\end{array}$ & $\begin{array}{r}198 \\
6.8\end{array}$ \\
\hline Major lons (mg/L) & & & & & & & & & & \\
\hline Calcium & 54.3 & 53 & 36.5 & 38 & & & & & 34.9 & 30.5 \\
\hline Magnesium & 33 & 31 & 21.6 & 22 & & & & & 22.6 & 19.1 \\
\hline Potassium & 0.925 & 0.87 & 0.992 & 1 & & & & & $<$ & $<$ \\
\hline Sodium & 1.61 & 2.8 & 1.58 & 2.4 & & & & & 10.2 & 6.2 \\
\hline Bicarbonate & 279 & 260 & 200 & 180 & & & & & 181 & 182 \\
\hline Carbonate & $<$ & $<$ & $<$ & $<$ & & & & & $<$ & $<$ \\
\hline Chloride & 2.9 & 4.5 & 0.91 & 0.72 & & & & & 3.1 & $<$ \\
\hline Fluoride & $<$ & $<$ & $<$ & $<$ & & & & & $<$ & $<$ \\
\hline Nitrate as $\mathrm{N}$ & 0.37 & 0.21 & 0.069 & 0.09 & & & & & $<$ & $<$ \\
\hline Sulfate & 1.3 & 1.3 & 5 & 5.5 & & & & & 8.4 & $<$ \\
\hline Charge balance error (\%) & -1.7 & -0.2 & -5.6 & 1.3 & & & & & 2.1 & -3.9 \\
\hline Trace Metals (mg/L) & & & & & & & & & & \\
\hline Aluminum & $<$ & $<$ & $<$ & $<$ & & & & & $<$ & $<$ \\
\hline Arsenic & $<$ & $<$ & $<$ & $<$ & & & & & $<$ & $<$ \\
\hline Barium & 0.0122 & 0.012 & 0.0172 & 0.017 & & & & & $<$ & $<$ \\
\hline Boron & $<$ & $<$ & $<$ & $<$ & & & & & $<$ & $<$ \\
\hline Chromium & $<$ & $<$ & $<$ & $<$ & & & & & 0.13 & 0.013 \\
\hline Iron & $<$ & $<$ & $<$ & $<$ & & & & & 0.53 & $<$ \\
\hline Lead & $<$ & $<$ & $<$ & $<$ & & & & & $<$ & $<$ \\
\hline Lithium & $<$ & $<$ & $<$ & $<$ & & & & & & \\
\hline Manganese & $<$ & $<$ & $<$ & $<$ & & & & & 0.022 & $<$ \\
\hline Nickel & $<$ & $<$ & $<$ & $<$ & & & & & 0.07 & 0.028 \\
\hline Strontium & 0.0185 & 0.02 & 0.0249 & 0.026 & & & & & 0.033 & 0.019 \\
\hline Thallium & $<$ & $<$ & $<$ & $<$ & & & & & $<$ & $<$ \\
\hline Uranium & $<$ & $<$ & $<$ & $<$ & & & & & $<$ & $<$ \\
\hline
\end{tabular}


APPENDIX F.1: CY 2009 MONITORING DATA FOR THE CHESTNUT RIDGE HYDROGEOLOGIC REGIME

Field Measurements, Miscellaneous Analytes, Major lons, and Trace Metals

\begin{tabular}{|c|c|c|c|c|c|c|c|c|c|}
\hline Sampling Point & \multicolumn{2}{|c|}{ GW-305 } & GW-322 & \multicolumn{2}{|c|}{ GW-521 } & \multicolumn{4}{|c|}{ GW-522 } \\
\hline Functional Area & \multicolumn{2}{|c|}{ LIV } & CRSP & \multicolumn{2}{|c|}{ LIV } & \multicolumn{4}{|c|}{ LIV } \\
\hline Date Sampled & $08 / 27 / 09$ & $12 / 14 / 09$ & $12 / 16 / 09$ & $01 / 28 / 09$ & 07/09/09 & \multicolumn{2}{|c|}{$01 / 28 / 09$} & \multicolumn{2}{|c|}{ 07/09/09 } \\
\hline Program & $\mathrm{BJC}$ & BJC & GWPP & $\mathrm{BJC}$ & $\mathrm{BJC}$ & $\mathrm{BJC}$ & $\mathrm{BJC}$ & $\mathrm{BJC}$ & $\mathrm{BJC}$ \\
\hline Sample Type & & & & & & & Dup & & Dup \\
\hline Field Measurements & & & & & & & & & \\
\hline Time Sampled & $10: 30$ & $14: 40$ & $11: 20$ & $14: 20$ & $13: 45$ & $14: 00$ & & $10: 20$ & \\
\hline Measuring Point Elev. (ft) & $1,183.72$ & $1,183.72$ & $1,134.98$ & $1,182.88$ & $1,182.88$ & $1,175.48$ & . & $1,175.48$ & \\
\hline Depth to Water (ft) & 125.41 & 116.85 & 145.24 & 84.60 & 83.29 & 96.61 & & 101.24 & \\
\hline Groundwater Elevation (ft) & $1,058.31$ & $1,066.87$ & 989.74 & $1,098.28$ & $1,099.59$ & $1,078.87$ & 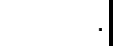 & $1,074.24$ & \\
\hline Conductivity $(\mu \mathrm{mho} / \mathrm{cm})$ & 466 & 423 & 594 & 460 & 362 & 344 & & 481 & \\
\hline Dissolved Oxygen (ppm) & 5.43 & 4.06 & 4.13 & 4.71 & 10.38 & 8.35 & 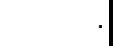 & 10.78 & \\
\hline Oxidation/Reduction $(\mathrm{mV})$ & 96 & 88 & 187 & 103 & 13 & 132 & & 68 & \\
\hline Temperature (degrees C) & 20.2 & 14.1 & 10 & 13.4 & 17.3 & 13.6 & & 16.8 & \\
\hline Turbidity (NTU) & 3 & 2 & & 2 & 2 & 1 & & 2 & \\
\hline $\mathrm{pH}$ & 7.93 & 8.26 & 7 & 7.57 & 8.04 & 7.38 & & 7.14 & \\
\hline Miscellaneous Analytes & & & & & & & & & \\
\hline Dissolved Solids (mg/L) & & & & 137 & 148 & 216 & 229 & 208 & 203 \\
\hline Suspended Solids (mg/L) & & & & $<$ & $<$ & $<$ & $<$ & $<$ & $<$ \\
\hline Major Ions (mg/L) & & & & & & & & & \\
\hline Calcium & & & & 23.3 & 26.1 & 45.6 & 45.7 & 40.8 & 41.4 \\
\hline Magnesium & & & & 23.9 & 20.4 & 29.1 & 29.3 & 24.5 & 24.7 \\
\hline Potassium & & & & $<$ & $<$ & $<$ & $<$ & $<$ & $<$ \\
\hline Sodium & & & & 2.7 & 3.1 & $<$ & $<$ & $<$ & $<$ \\
\hline Bicarbonate & & & & 148 & 155 & 214 & 217 & 213 & 212 \\
\hline Carbonate & & & & $<$ & 7 & $<$ & $<$ & $<$ & $<$ \\
\hline Chloride & & & & $<$ & $<$ & $<$ & $<$ & $<$ & $<$ \\
\hline Fluoride & & & & $<$ & $<$ & $<$ & $<$ & $<$ & $<$ \\
\hline Nitrate as $\mathrm{N}$ & & & & $<$ & $<$ & $<$ & $<$ & $<$ & $<$ \\
\hline Sulfate & & & & $<$ & $<$ & 6.9 & 7 & $<$ & $<$ \\
\hline Charge balance error (\%) & & & & 4.6 & -1.9 & 2.7 & & -2.5 & \\
\hline Trace Metals (mg/L) & & & & & & & & & \\
\hline Aluminum & & & & $<$ & $<$ & $<$ & $<$ & $<$ & $<$ \\
\hline Arsenic & & & & $<$ & $<$ & $<$ & $<$ & $<$ & $<$ \\
\hline Barium & & & & $<$ & $<$ & 0.011 & 0.012 & 0.012 & 0.012 \\
\hline Boron & & & & $<$ & $<$ & $<$ & $<$ & $<$ & $<$ \\
\hline Chromium & & & & $<$ & $<$ & $<$ & $<$ & $<$ & $<$ \\
\hline Iron & & & & $<$ & $<$ & $<$ & $<$ & $<$ & $<$ \\
\hline Lead & & & & $<$ & $<$ & $<$ & $<$ & $<$ & $<$ \\
\hline Lithium & & & & & & & 1 & $\sigma^{\circ}$ & \\
\hline Manganese & & & & $<$ & $<$ & $<$ & $<$ & $<$ & $<$ \\
\hline Nickel & & & & $<$ & $<$ & $<$ & $<$ & $<$ & $<$ \\
\hline Strontium & & & & $<$ & $<$ & 0.018 & 0.018 & 0.018 & 0.018 \\
\hline Thallium & & & & $<$ & $<$ & $<$ & $<$ & $<$ & $<$ \\
\hline Uranium & & & & $<$ & $<$ & $<$ & $<$ & $<$ & $<$ \\
\hline
\end{tabular}


APPENDIX F.1: CY 2009 MONITORING DATA FOR THE CHESTNUT RIDGE HYDROGEOLOGIC REGIME

Field Measurements, Miscellaneous Analytes, Major Ions, and Trace Metals

\begin{tabular}{|c|c|c|c|c|c|c|c|c|c|c|}
\hline Sampling Point & \multicolumn{2}{|c|}{ GW-540 } & \multicolumn{2}{|c|}{ GW-557 } & \multicolumn{2}{|c|}{ GW-560 } & \multicolumn{2}{|c|}{ GW-562 } & \multicolumn{2}{|c|}{ GW-564 } \\
\hline Functional Area & \multicolumn{2}{|c|}{ LII } & \multicolumn{2}{|c|}{ LV } & \multicolumn{2}{|c|}{ CDLVII } & \multicolumn{2}{|c|}{ CDLVII } & \multirow{2}{*}{\multicolumn{2}{|c|}{$\begin{array}{c}\text { CDLVII } \\
02 / 02 / 09\end{array}$}} \\
\hline Date Sampled & $02 / 02 / 09$ & $07 / 13 / 09$ & $02 / 02 / 09$ & $07 / 14 / 09$ & $02 / 02 / 09$ & $07 / 15 / 09$ & $02 / 02 / 09$ & $07 / 15 / 09$ & & \\
\hline Program & BJC & BJC & BJC & BJC & BJC & BJC & BJC & BJC & $\mathrm{BJC}$ & $\mathrm{BJC}$ \\
\hline Sample Type & & & & & & & & & & Dup \\
\hline Field Measurements & & & & & & & & & & \\
\hline Time Sampled & $10: 15$ & $14: 00$ & $14: 15$ & $13: 30$ & $14: 15$ & $13: 35$ & $10: 15$ & $10: 20$ & $13: 45$ & \\
\hline Measuring Point Elev. (ft) & $1,072.31$ & $1,072.31$ & $1,081.36$ & $1,081.36$ & 949.05 & 949.05 & 934.69 & 934.69 & 938.07 & \\
\hline Depth to Water (ft) & 85.07 & 84.07 & 125.59 & 124.43 & 53.45 & 51.45 & 18.80 & 15.64 & 12.21 & \\
\hline Groundwater Elevation (ft) & 987.24 & 988.24 & 955.77 & 956.93 & 895.60 & 897.60 & 915.89 & 919.05 & 925.86 & \\
\hline Conductivity $(\mu \mathrm{mho} / \mathrm{cm})$ & 361 & 614 & 256 & 387 & 540 & 600 & 552 & 435 & 206 & \\
\hline Dissolved Oxygen (ppm) & 13.57 & 11.28 & 13.56 & 11.9 & 6.91 & 5.08 & 5.71 & 12.71 & 6.64 & \\
\hline Oxidation/Reduction $(\mathrm{mV})$ & 27 & -1 & 29 & 27 & 175 & 89 & 179 & 73 & 113 & \\
\hline Temperature (degrees C) & 11.9 & 18.4 & 11.1 & 16.8 & 12.7 & 19.6 & 11.7 & 16.6 & 13.4 & \\
\hline Turbidity (NTU) & 6 & 6 & 7 & 5 & 2 & 4 & 28 & 21 & 1 & \\
\hline $\mathrm{pH}$ & 7.1 & 7.6 & 7.67 & 7.52 & 6.71 & 7.45 & 6.53 & 7.35 & 6.63 & \\
\hline $\begin{array}{l}\text { Miscellaneous Analytes } \\
\text { Dissolved Solids (mg/L) }\end{array}$ & 254 & 275 & 171 & 179 & 187 & 181 & 216 & 197 & 139 & 145 \\
\hline Suspended Solids $(\mathrm{mg} / \mathrm{L})$ & $<$ & $<$ & $<$ & $<$ & $<$ & $<$ & $<$ & 4 & $<$ & $<$ \\
\hline Major lons (mg/L) & & & & & & & & & & \\
\hline Calcium & 46.2 & 44.4 & 36.7 & 32.4 & 43.1 & 38.2 & 39.7 & 37.7 & 32.6 & 31.9 \\
\hline Magnesium & 30.1 & 29.1 & 21 & 19.3 & 18.8 & 17 & 22.6 & 22.1 & 12.2 & 12 \\
\hline Potassium & 2.8 & $<$ & $<$ & $<$ & $<$ & $<$ & $<$ & $<$ & $<$ & $<$ \\
\hline Sodium & 16.5 & 14.8 & $<$ & $<$ & $<$ & $<$ & 2.3 & 2 & $<$ & $<$ \\
\hline Bicarbonate & 249 & 260 & 162 & 166 & 165 & 169 & 181 & 194 & 106 & 105 \\
\hline Carbonate & $<$ & $<$ & $<$ & $<$ & $<$ & $<$ & $<$ & $<$ & $<$ & $<$ \\
\hline Chloride & $<$ & $<$ & $<$ & $<$ & $<$ & $<$ & $<$ & $<$ & $<$ & $<$ \\
\hline Fluoride & $<$ & $<$ & $<$ & $<$ & $<$ & $<$ & $<$ & $<$ & $<$ & $<$ \\
\hline Nitrate as $\mathrm{N}$ & $<$ & $<$ & $<$ & $<$ & $<$ & $<$ & $<$ & $<$ & 0.54 & 0.54 \\
\hline Sulfate & 6.8 & $<$ & $<$ & $<$ & $<$ & $<$ & $<$ & $<$ & 11.1 & 11.2 \\
\hline Charge balance error (\%) & 4.2 & 0.5 & 4.7 & -1.7 & 5.7 & -1.1 & 4.3 & -1.2 & 4.8 & \\
\hline Trace Metals (mg/L) & & & & & & & & & & \\
\hline Aluminum & $<$ & $<$ & $<$ & $<$ & $<$ & $<$ & 0.52 & 1 & $<$ & 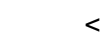 \\
\hline Arsenic & $<$ & $<$ & $<$ & $<$ & $<$ & $<$ & $<$ & $<$ & $<$ & $<$ \\
\hline Barium & 0.015 & $0.013 \mathrm{~J}$ & 0.011 & $<$ & 0.25 & 0.23 & 0.013 & 0.013 & 0.022 & 0.021 \\
\hline Boron & $<$ & $<$ & $<$ & $<$ & $<$ & $<$ & & $<$ & $<$ & $<$ \\
\hline Chromium & $<$ & $<$ & $<$ & $<$ & $<$ & $<$ & $<$ & $<$ & $<$ & $<$ \\
\hline Iron & $<$ & $<$ & $<$ & $<$ & $<$ & $<$ & 0.36 & 0.55 & $<$ & $<$ \\
\hline Lead & $<$ & $<$ & $<$ & $<$ & $<$ & $<$ & $<$ & $<$ & $<$ & $<$ \\
\hline Lithium & & & & & & & & & & \\
\hline Manganese & $<$ & $<$ & $<$ & $<$ & $<$ & $<$ & $<$ & 0.01 & $<$ & $<$ \\
\hline Nickel & $<$ & & $<$ & $<$ & $<$ & $<$ & $<$ & $<$ & $<$ & $<$ \\
\hline Strontium & 0.033 & 0.032 & 0.016 & 0.015 & 0.027 & 0.024 & 0.021 & 0.02 & 0.053 & 0.052 \\
\hline Thallium & $<$ & $<$ & $<$ & $<$ & $<$ & $<$ & $<$ & $<$ & $<$ & $<$ \\
\hline Uranium & $<$ & $<$ & $<$ & $<$ & $<$ & $<$ & $<$ & $<$ & $<$ & $<$ \\
\hline
\end{tabular}


APPENDIX F.1: CY 2009 MONITORING DATA FOR THE CHESTNUT RIDGE HYDROGEOLOGIC REGIME

Field Measurements, Miscellaneous Analytes, Major lons, and Trace Metals

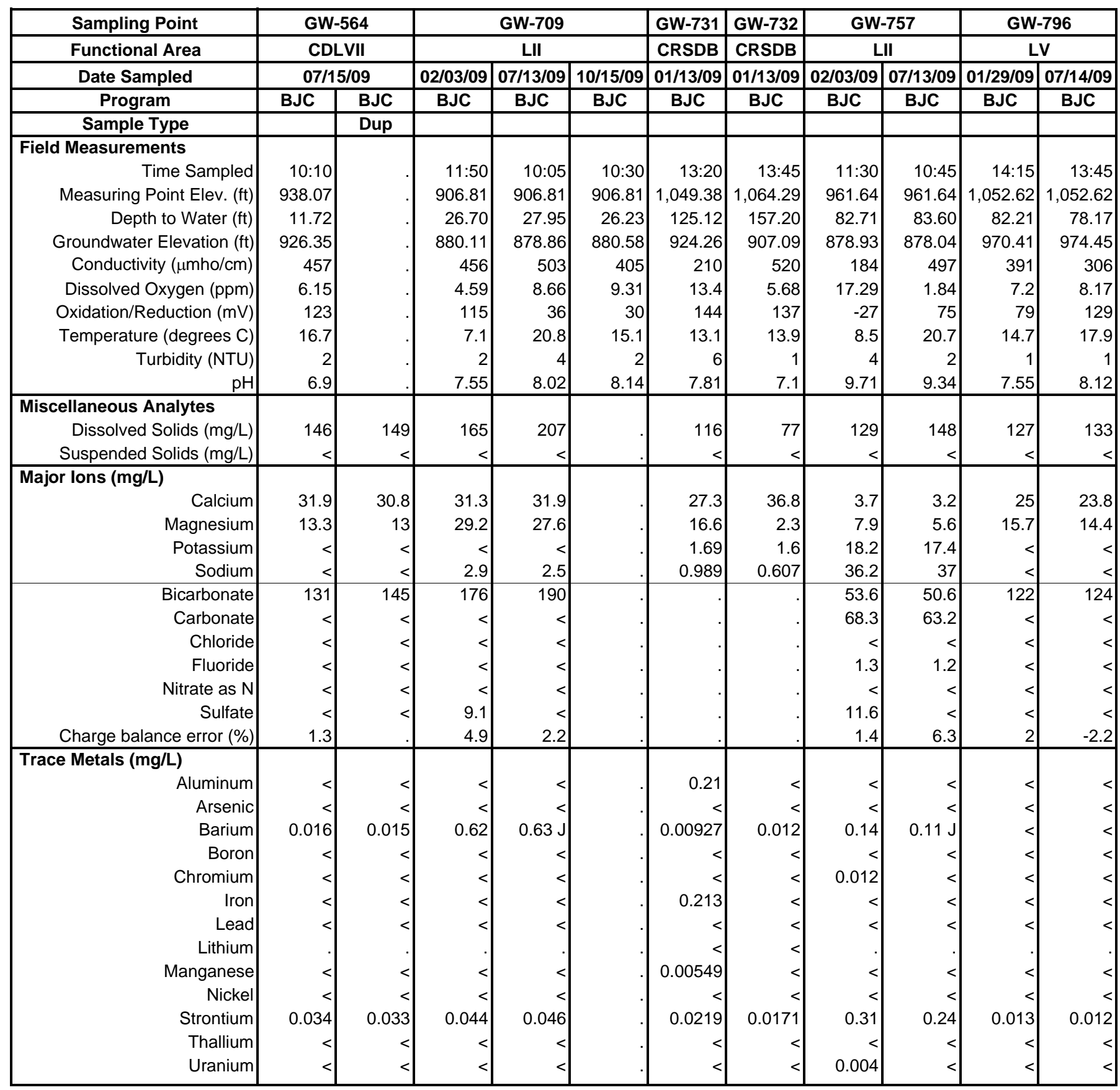


APPENDIX F.1: CY 2009 MONITORING DATA FOR THE CHESTNUT RIDGE HYDROGEOLOGIC REGIME

Field Measurements, Miscellaneous Analytes, Major lons, and Trace Metals

\begin{tabular}{|c|c|c|c|c|c|c|c|c|c|c|}
\hline Sampling Point & \multicolumn{2}{|c|}{ GW-797 } & \multicolumn{2}{|c|}{ GW-798 } & \multicolumn{2}{|c|}{ GW-799 } & \multicolumn{2}{|c|}{ GW-801 } & \multicolumn{2}{|c|}{ GW-831 } \\
\hline Functional Area & \multicolumn{2}{|c|}{ LV } & \multicolumn{2}{|c|}{ CDLVII } & \multicolumn{2}{|c|}{ LV } & \multicolumn{2}{|c|}{ LV } & \multicolumn{2}{|c|}{ FCAP } \\
\hline Date Sampled & 01/29/09 & 07/14/09 & 02/02/09 & 07/14/09 & $01 / 29 / 09$ & 07/14/09 & $01 / 29 / 09$ & 07/13/09 & $01 / 14 / 09$ & 07/08/09 \\
\hline Program & BJC & BJC & BJC & BJC & BJC & BJC & BJC & BJC & BJC & BJC \\
\hline \multicolumn{11}{|l|}{ Sample Type } \\
\hline \multicolumn{11}{|l|}{ Field Measurements } \\
\hline Time Sampled & $10: 00$ & $10: 30$ & $9: 40$ & 13:45 & $14: 15$ & 9:50 & $13: 45$ & $14: 15$ & $13: 55$ & $14: 55$ \\
\hline Measuring Point Elev. (ft) & $1,060.00$ & $1,060.00$ & $1,006.00$ & $1,006.00$ & 981.29 & 981.29 & $1,097.16$ & $1,097.16$ & $1,091.29$ & $1,091.29$ \\
\hline Depth to Water (ft) & 75.20 & 74.71 & 86.95 & 82.73 & 25.45 & 24.31 & 116.43 & 114.94 & 132.12 & 129.66 \\
\hline Groundwater Elevation (ft) & 984.80 & 985.29 & 919.05 & 923.27 & 955.84 & 956.98 & 980.73 & 982.22 & 959.17 & 961.63 \\
\hline Conductivity $(\mu \mathrm{mho} / \mathrm{cm})$ & 785 & 670 & 227 & 452 & 238 & 350 & 225 & 476 & 462 & 405 \\
\hline Dissolved Oxygen (ppm) & 5.2 & 8.98 & 5.8 & 4.98 & 5.45 & 5.76 & 13.05 & 6.76 & 2.14 & 3.18 \\
\hline Oxidation/Reduction (mV) & 154 & 70 & 84 & 137 & 128 & 189 & 119 & 110 & 120 & 168 \\
\hline Temperature (degrees C) & 10.5 & 19.3 & 14.2 & 18.9 & 14.6 & 17.2 & 12.2 & 17 & 9.9 & 19.6 \\
\hline Turbidity (NTU) & 1 & 3 & 1 & 4 & 1 & 1 & 4 & 4 & 1 & \\
\hline $\mathrm{pH}$ & 6.76 & 7.41 & 7.53 & 5.81 & 8.61 & 8.31 & 7.47 & 6.59 & 7.99 & 8.21 \\
\hline \multicolumn{11}{|l|}{ Miscellaneous Analytes } \\
\hline Dissolved Solids (mg/L) & 299 & 303 & 149 & 153 & 148 & 152 & 152 & 157 & & \\
\hline Suspended Solids (mg/L) & $<$ & $<$ & $<$ & $<$ & $<$ & $<$ & $<$ & $<$ & & \\
\hline \multicolumn{11}{|l|}{ Major lons (mg/L) } \\
\hline Calcium & 55.1 & 50.4 & 30.2 & 27.9 & 31.8 & 29 & 32.6 & 31.4 & & \\
\hline Magnesium & 33.8 & 29.8 & 16.9 & 16.1 & 18.3 & 16.1 & 19.9 & 18.2 & & \\
\hline Potassium & $<$ & $<$ & $<$ & $<$ & $<$ & $<$ & $<$ & $<$ & & \\
\hline Sodium & 5.2 & 4.6 & $<$ & $<$ & $<$ & $<$ & $<$ & $<$ & & \\
\hline Bicarbonate & 200 & 203 & 135 & 136 & 137 & 142 & 149 & 152 & & \\
\hline Carbonate & $<$ & $<$ & $<$ & $<$ & $<$ & $<$ & $<$ & $<$ & & \\
\hline Chloride & 7.2 & 6.3 & $<$ & $<$ & $<$ & $<$ & $<$ & $<$ & & \\
\hline Fluoride & $<$ & $<$ & $<$ & $<$ & $<$ & $<$ & $<$ & $<$ & & \\
\hline Nitrate as $\mathrm{N}$ & 2.8 & 2.5 & 0.59 & 0.6 & 0.95 & 0.89 & $<$ & $<$ & & \\
\hline Sulfate & 53.4 & $<$ & $<$ & $<$ & $<$ & $<$ & $<$ & $<$ & & \\
\hline Charge balance error (\%) & 2.2 & 7.9 & 2.8 & -0.8 & 4.8 & -2.3 & 4.6 & 0.4 & & \\
\hline \multicolumn{11}{|l|}{ Trace Metals (mg/L) } \\
\hline Aluminum & $<$ & $<$ & $<$ & $<$ & $<$ & $<$ & $<$ & $<$ & & \\
\hline Arsenic & $<$ & $<$ & $<$ & $<$ & $<$ & $<$ & $<$ & $<$ & & \\
\hline Barium & $<$ & 0.011 & 0.01 & 0.01 & $<$ & $<$ & $<$ & $<$ & & \\
\hline Boron & $<$ & $<$ & $<$ & $<$ & $<$ & $<$ & $<$ & $<$ & & \\
\hline Chromium & $<$ & $<$ & $<$ & $<$ & 0.026 & 0.033 & $<$ & $<$ & & \\
\hline Iron & $<$ & $<$ & $<$ & $<$ & 0.11 & $<$ & $<$ & $<$ & & \\
\hline Lead & $<$ & $<$ & $<$ & $<$ & $<$ & $<$ & $<$ & $<$ & & \\
\hline Lithium & & & 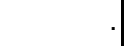 & . & & & & & & \\
\hline Manganese & $<$ & $<$ & $<$ & $<$ & $<$ & $<$ & $<$ & $<$ & & \\
\hline Nickel & $<$ & $<$ & $<$ & $<$ & $<$ & $<$ & $<$ & $<$ & & \\
\hline Strontium & 0.032 & 0.03 & 0.017 & 0.016 & 0.019 & 0.018 & 0.016 & 0.016 & & \\
\hline Thallium & $<$ & $<$ & $<$ & $<$ & $<$ & $<$ & $<$ & $<$ & & \\
\hline Uranium & $<$ & $<$ & $<$ & $<$ & 0.004 & $<$ & $<$ & $<$ & & \\
\hline
\end{tabular}


APPENDIX F.1: CY 2009 MONITORING DATA FOR THE CHESTNUT RIDGE HYDROGEOLOGIC REGIME

Field Measurements, Miscellaneous Analytes, Major lons, and Trace Metals

\begin{tabular}{|c|c|c|c|c|c|c|c|c|c|}
\hline Sampling Point & \multicolumn{2}{|c|}{ MCK 1.4} & \multicolumn{2}{|c|}{ MCK 2.0} & \multicolumn{4}{|c|}{ MCK 2.05} & \multirow{2}{*}{$\frac{\text { S17 }}{\text { EXP-SW }}$} \\
\hline Functional Area & \multicolumn{2}{|c|}{ EXP-SW } & \multicolumn{2}{|c|}{ EXP-SW } & \multicolumn{4}{|c|}{ EXP-SW } & \\
\hline Date Sampled & 03/18/09 & $09 / 03 / 09$ & 03/18/09 & 09/03/09 & \multicolumn{2}{|c|}{$03 / 18 / 09$} & \multicolumn{2}{|c|}{$09 / 03 / 09$} & $10 / 12 / 09$ \\
\hline Program & BJC & BJC & BJC & BJC & BJC & BJC & BJC & BJC & GWPP \\
\hline Sample Type & & & & & & Dup & & Dup & \\
\hline Field Measurements & & & & & & & & & \\
\hline Time Sampled & $10: 30$ & $9: 30$ & $9: 35$ & $8: 45$ & $9: 50$ & $9: 50$ & 9:05 & 9:05 & $10: 20$ \\
\hline Measuring Point Elev. (ft) & & & & & & & & & \\
\hline Depth to Water (ft) & & & & & & & & & \\
\hline Groundwater Elevation (ft) & & & & & & & & & \\
\hline Conductivity $(\mu \mathrm{mho} / \mathrm{cm})$ & 260 & & 187 & 648 & 296 & & 690 & & 499 \\
\hline Dissolved Oxygen (ppm) & 10.25 & & 9.32 & 10.4 & 6.22 & & 8.84 & & 3.5 \\
\hline Oxidation/Reduction (mV) & 69 & & 147 & 178 & 35.6 & & 170 & & 206 \\
\hline Temperature (degrees C) & 10.39 & & 10.39 & 16.5 & 13.1 & & 15.3 & & 14.5 \\
\hline Turbidity (NTU) & 2.06 & & 1.45 & 1.48 & 6.16 & & 3.22 & & \\
\hline $\mathrm{pH}$ & 7.77 & & 7.63 & 7.25 & 6.64 & & 6.84 & & 7.08 \\
\hline Miscellaneous Analytes & & & & & & & & & \\
\hline Dissolved Solids (mg/L) & & & 114 & 233 & 195 & 252 & 268 & 271 & 228 \\
\hline Suspended Solids (mg/L) & & & $<$ & 67 & 17 & 43 & $<$ & $<$ & 2 \\
\hline Major lons (mg/L) & & & & & & & & & \\
\hline Calcium & 38.4 & 37.7 & 20.2 & 48.4 & 39 & 39.5 & 57.8 & 59.4 & 51 \\
\hline Magnesium & 11.6 & 11.2 & 4.98 & 15.6 & 14.3 & 14.5 & 14.9 & 14.4 & 29.9 \\
\hline Potassium & 1.88 & 2.05 & 4.04 & 4.92 & 4.2 & 4.25 & 5.5 & 5.54 & $<$ \\
\hline Sodium & 2.01 & 1.95 & 1.15 & 2.12 & 1.61 & 1.63 & 2.59 & 2.65 & 1.58 \\
\hline Bicarbonate & & & 38.6 & 166 & 148 & 143 & 172 & 178 & 230 \\
\hline Carbonate & & & $<$ & $<$ & $<$ & $<$ & $<$ & $<$ & $<$ \\
\hline Chloride & & & 1.8 & 1.86 & 1.8 & 1.8 & 1.86 & 1.82 & 2.66 \\
\hline Fluoride & & & 0.12 & 0.13 & 0.1 & $<$ & 0.171 & 0.18 & $<$ \\
\hline Nitrate as $\mathrm{N}$ & & & & & & & & & 6.94 \\
\hline Sulfate & & & 31.2 & 29.7 & 27.7 & 28.6 & 41.5 & 41 & 4.39 \\
\hline Charge balance error (\%) & & & 3 & -1 & -4.2 & & 0 & & -1.8 \\
\hline Trace Metals (mg/L) & & & & & & & & & \\
\hline Aluminum & $<$ & $<$ & $<$ & $<$ & $<$ & $<$ & $<$ & $<$ & $<$ \\
\hline Arsenic & 0.005 & 0.00604 & $<$ & 0.0159 & 0.101 & 0.0918 & 0.0212 & 0.0229 & \\
\hline Barium & 0.0525 & 0.0544 & 0.0401 & 0.0798 & 0.0865 & 0.0846 & 0.0708 & 0.0666 & 0.135 \\
\hline Boron & $<$ & $<$ & $<$ & 0.21 & 0.165 & 0.167 & 0.25 & 0.256 & $<$ \\
\hline Chromium & $<$ & $<$ & $<$ & $<$ & $<$ & $<$ & $<$ & $<$ & 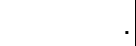 \\
\hline Iron & $<$ & $<$ & 0.114 & 0.374 & 4.56 & 3.56 & 0.402 & 0.428 & $<$ \\
\hline Lead & $<$ & $<$ & $<$ & $<$ & $<$ & $<$ & $<$ & $<$ & \\
\hline Lithium & 0.0137 & 0.0215 & 0.0378 & 0.0734 & 0.05 & 0.0502 & 0.0892 & 0.0959 & $<$ \\
\hline Manganese & 0.0519 & 0.0247 & 0.0176 & 0.425 & 0.655 & 0.622 & 0.387 & 0.339 & 0.00717 \\
\hline Nickel & & & $<$ & $<$ & $<$ & $<$ & $<$ & $<$ & \\
\hline Strontium & 0.235 & 0.24 & 0.366 & 0.859 & 0.643 & 0.65 & 1.13 & 1.19 & 0.0284 \\
\hline Thallium & $<$ & 0.0011 & $<$ & $<$ & $<$ & $<$ & $<$ & $<$ & \\
\hline Uranium & & & $<$ & $<$ & $<$ & $<$ & $<$ & $<$ & \\
\hline
\end{tabular}


APPENDIX F.1: CY 2009 MONITORING DATA FOR THE CHESTNUT RIDGE HYDROGEOLOGIC REGIME

Field Measurements, Miscellaneous Analytes, Major lons, and Trace Metals

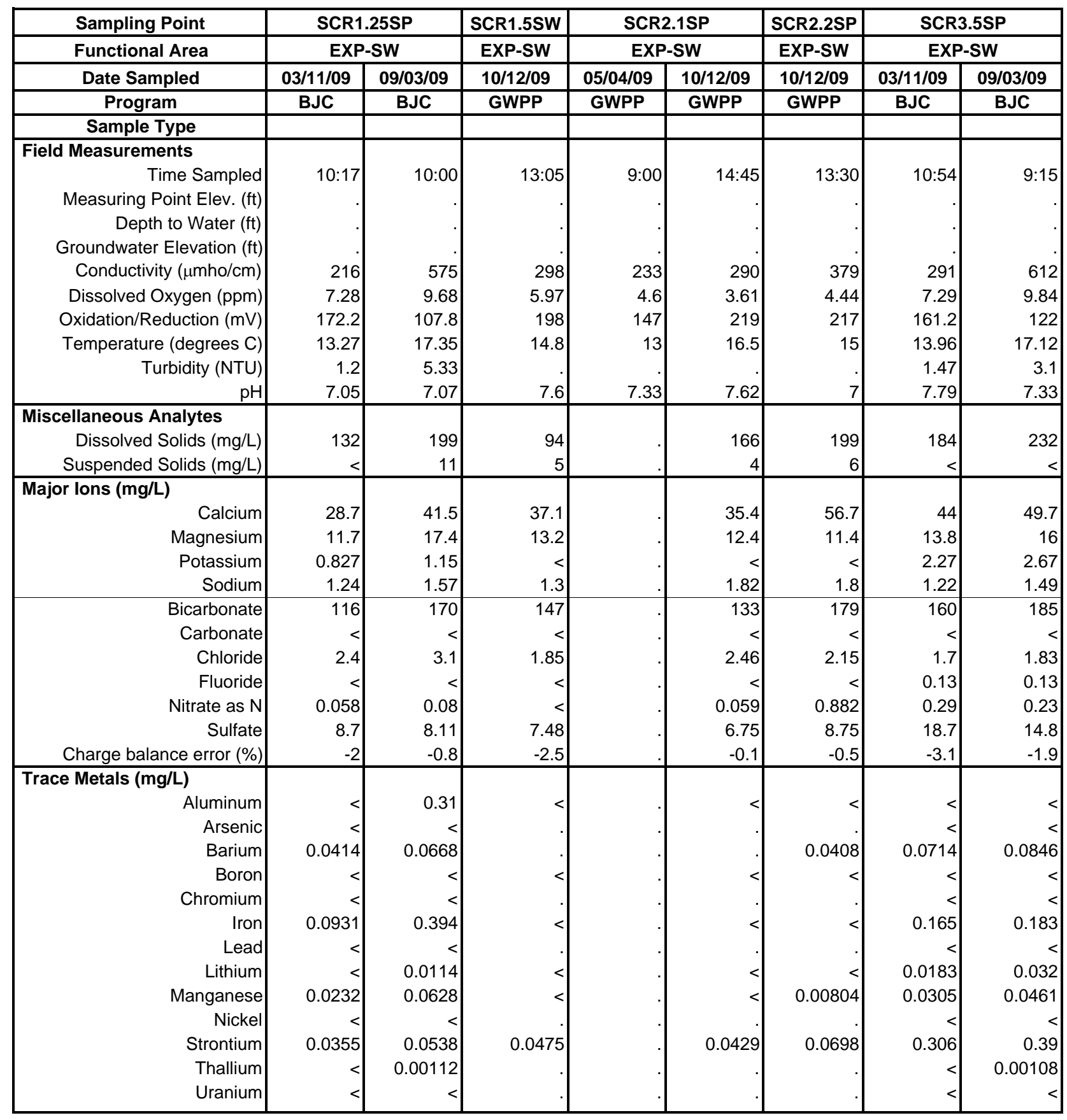


APPENDIX F.1: CY 2009 MONITORING DATA FOR THE CHESTNUT RIDGE HYDROGEOLOGIC REGIME Field Measurements, Miscellaneous Analytes, Major lons, and Trace Metals

\begin{tabular}{|c|c|c|c|c|c|}
\hline Sampling Point & SCR3.5SW & \multicolumn{2}{|c|}{ SCR4.3SP } & \multicolumn{2}{|c|}{ UNC SW-1 } \\
\hline Functional Area & EXP-SW & \multicolumn{2}{|c|}{ EXP-SW } & \multicolumn{2}{|c|}{ EXP-SW } \\
\hline Date Sampled & $10 / 12 / 09$ & $01 / 29 / 09$ & $07 / 14 / 09$ & $03 / 11 / 09$ & $08 / 19 / 09$ \\
\hline Program & GWPP & BJC & BJC & BJC & BJC \\
\hline \multicolumn{6}{|l|}{ Sample Type } \\
\hline \multicolumn{6}{|l|}{ Field Measurements } \\
\hline Time Sampled & $14: 00$ & 9:00 & $10: 15$ & $10: 00$ & $9: 00$ \\
\hline Measuring Point Elev. (ft) & & & & & \\
\hline Depth to Water (ft) & & & & & \\
\hline Groundwater Elevation (ft) & & & & & \\
\hline Conductivity $(\mu \mathrm{mho} / \mathrm{cm})$ & 380 & 221 & 435 & 90 & 183 \\
\hline Dissolved Oxygen (ppm) & 5.85 & 13.24 & 5.56 & 5.51 & 6.29 \\
\hline Oxidation/Reduction $(\mathrm{mV})$ & 222 & 196 & 202 & 205.7 & 67.3 \\
\hline Temperature (degrees C) & 15.3 & 12.1 & 18.2 & 14.88 & 20.6 \\
\hline Turbidity (NTU) & & 34 & 11 & 5.63 & 14 \\
\hline $\mathrm{pH}$ & 7.6 & 6.58 & 6.73 & 6.04 & 6.03 \\
\hline \multicolumn{6}{|l|}{ Miscellaneous Analytes } \\
\hline Dissolved Solids (mg/L) & 217 & 191 & 219 & & \\
\hline Suspended Solids (mg/L) & 4 & $<$ & 12 & & \\
\hline \multicolumn{6}{|l|}{ Major lons (mg/L) } \\
\hline Calcium & 51.4 & 33.3 & 41.1 & 7.14 & 18 \\
\hline Magnesium & 14.3 & 10.5 & 12 & 2.33 & 4.83 \\
\hline Potassium & 2.67 & 2.1 & 2.1 & 0.562 & 0.717 \\
\hline Sodium & 1.39 & 2.6 & 2.7 & 2.52 & 3.48 \\
\hline Bicarbonate & 183 & 85.1 & 131 & 30 & 51.8 \\
\hline Carbonate & $<$ & $<$ & $<$ & $<$ & $<$ \\
\hline Chloride & 1.44 & 4.3 & $<$ & 3.8 & 4.73 \\
\hline Fluoride & 0.115 & $<$ & $<$ & $<$ & $<$ \\
\hline Nitrate as $\mathrm{N}$ & 0.302 & 0.94 & 0.5 & 0.063 & 0.14 \\
\hline Sulfate & 14.9 & 32.7 & $<$ & 7.5 & 9.58 \\
\hline Charge balance error (\%) & -2.1 & 2.3 & 9.5 & -12.6 & 3.1 \\
\hline \multicolumn{6}{|l|}{ Trace Metals (mg/L) } \\
\hline Aluminum & $<$ & 1.3 & 1.4 & 0.818 & $<$ \\
\hline Arsenic & & $<$ & $<$ & $<$ & $<$ \\
\hline Barium & 0.0843 & 0.07 & 0.097 & 0.0217 & 0.0348 \\
\hline Boron & & $<$ & $<$ & $<$ & 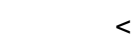 \\
\hline Chromium & & $<$ & $<$ & $<$ & $<$ \\
\hline Iron & 0.136 & 1.6 & 0.63 & 0.481 & 0.104 \\
\hline Lead & & $<$ & $<$ & 0.00312 & $<$ \\
\hline Lithium & 0.0209 & & & $<$ & 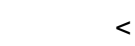 \\
\hline Manganese & 0.0607 & 0.025 & 0.011 & 0.0147 & 0.0108 \\
\hline Nickel & & $<$ & $<$ & $<$ & $<$ \\
\hline Strontium & 0.332 & 0.11 & 0.13 & 0.0214 & 0.0448 \\
\hline Thallium & & $<$ & $<$ & $<$ & $<$ \\
\hline Uranium & & $<$ & $<$ & & \\
\hline
\end{tabular}



APPENDIX F.2

VOLATILE ORGANIC COMPOUNDS 

APPENDIX F.2: CY 2009 MONITORING DATA FOR THE CHESTNUT RIDGE HYDROGEOLOGIC REGIME Volatile Organic Compounds

\begin{tabular}{|c|c|c|c|c|c|c|c|c|}
\hline Sampling Point & \multicolumn{2}{|c|}{ GW-141 } & GW-143 & GW-144 & GW-145 & GW-161 & GW-161 & GW-174 \\
\hline Functional Area & \multicolumn{2}{|c|}{ LIV } & KHQ & KHQ & KHQ & ECRWP & ECRWP & CRSP \\
\hline Date Sampled & 01/29/09 & 07/16/09 & $01 / 08 / 09$ & 01/06/09 & $01 / 08 / 09$ & $01 / 14 / 09$ & 07/08/09 & $10 / 13 / 09$ \\
\hline Program & BJC & BJC & BJC & BJC & BJC & BJC & BJC & GWPP \\
\hline Sample Type & & & & & & & & PDB \\
\hline Chloroethenes ( $\mu \mathrm{g} / \mathrm{L})$ & & & & & & & & \\
\hline Tetrachloroethene & $<$ & $<$ & $<$ & $<$ & $<$ & $<$ & $<$ & $<$ \\
\hline Trichloroethene & $<$ & $<$ & $<$ & $<$ & $<$ & $<$ & $<$ & $<$ \\
\hline cis-1,2-Dichloroethene & $<$ & $<$ & $<$ & $<$ & $<$ & $<$ & $<$ & $<$ \\
\hline trans-1,2-Dichloroethene & $<$ & $<$ & $<$ & $<$ & $<$ & $<$ & $<$ & $<$ \\
\hline 1,1-Dichloroethene & $<$ & $<$ & $<$ & $<$ & $<$ & $<$ & $<$ & $<$ \\
\hline Chloroethanes ( $\mu \mathrm{g} / \mathrm{L})$ & & & & & & & & \\
\hline 1,1,1-Trichloroethane & $<$ & $<$ & $<$ & $<$ & $<$ & $<$ & $<$ & $<$ \\
\hline 1,2-Dichloroethane & $<$ & $<$ & $<$ & $<$ & $<$ & $<$ & $<$ & $<$ \\
\hline 1,1-Dichloroethane & $<$ & $<$ & $<$ & $<$ & $<$ & $<$ & $<$ & $<$ \\
\hline Chloroethane & $<$ & $<$ & $<$ & $<$ & $<$ & $<$ & $<$ & $<$ \\
\hline Chloromethanes $(\mu \mathrm{g} / \mathrm{L})$ & & & & & & & & \\
\hline Carbon tetrachloride & $<$ & $<$ & $<$ & $<$ & $<$ & $<$ & $<$ & $<$ \\
\hline Choroform & $<$ & $<$ & $<$ & $<$ & $<$ & $<$ & $<$ & $<$ \\
\hline Chloromethane & $<$ & $<$ & $<$ & $<$ & $<$ & $<$ & $<$ & $<$ \\
\hline Miscellaneous ( $\mu \mathrm{g} / \mathrm{L})$ & & & & & & & & \\
\hline 1,1,2-Trichloro-1,2,2-trifluoroethane & & & & & & & & $3 \mathrm{~J}$ \\
\hline Trichlorofluoromethane & $<$ & $<$ & & & & & & 10 \\
\hline 1,4-Dichlorobenzene & $<$ & $<$ & & & & & & $<$ \\
\hline Benzene & $<$ & $<$ & $<$ & $<$ & $<$ & $<$ & $<$ & $<$ \\
\hline Toluene & $<$ & $<$ & $<$ & $<$ & $<$ & $<$ & $<$ & $<$ \\
\hline Total Xylene & $<$ & $<$ & $<$ & $<$ & $<$ & $<$ & $<$ & $<$ \\
\hline Acetone & $<$ & $<$ & $<$ & $<$ & $<$ & $<$ & $<$ & . \\
\hline Carbon disulfide & $<$ & $<$ & $<$ & $<$ & $<$ & $<$ & $<$ & \\
\hline
\end{tabular}


APPENDIX F.2: CY 2009 MONITORING DATA FOR THE CHESTNUT RIDGE HYDROGEOLOGIC REGIME Volatile Organic Compounds

\begin{tabular}{|c|c|c|c|c|c|c|c|c|}
\hline Sampling Point & \multicolumn{2}{|c|}{ GW-175 } & \multicolumn{2}{|c|}{ GW-176 } & \multicolumn{2}{|c|}{ GW-177 } & GW-180 & GW-205 \\
\hline Functional Area & \multicolumn{2}{|c|}{ CRSP } & \multirow{2}{*}{\multicolumn{2}{|c|}{$\begin{array}{c}\text { CRSP } \\
10 / 13 / 09\end{array}$}} & \multicolumn{2}{|c|}{ CRSP } & CRSP & UNCS \\
\hline Date Sampled & \multirow{2}{*}{$\begin{array}{c}10 / 13 / 09 \\
\text { GWPP }\end{array}$} & \multirow{2}{*}{$\begin{array}{c}12 / 15 / 09 \\
\text { GWPP }\end{array}$} & & & \multirow{2}{*}{$\begin{array}{c}01 / 14 / 09 \\
B J C\end{array}$} & \multirow{2}{*}{$\frac{07 / 09 / 09}{\text { BJC }}$} & $10 / 13 / 09$ & \multirow{2}{*}{$\frac{10 / 15 / 09}{\text { BJC }}$} \\
\hline Program & & & GWPP & GWPP & & & GWPP & \\
\hline Sample Type & PDB & & PDB & Dup & & & PDB & \\
\hline \multicolumn{9}{|l|}{ Chloroethenes ( $\mu \mathrm{g} / \mathrm{L})$} \\
\hline Tetrachloroethene & $<$ & $4 \mathrm{~J}$ & $<$ & $1 \mathrm{~J}$ & $<$ & $<$ & $4 \mathrm{~J}$ & $<$ \\
\hline Trichloroethene & $<$ & $<$ & $<$ & $<$ & $<$ & $<$ & $<$ & $<$ \\
\hline cis-1,2-Dichloroethene & $<$ & $<$ & $<$ & $<$ & $<$ & $<$ & $1 \mathrm{~J}$ & $<$ \\
\hline trans-1,2-Dichloroethene & $<$ & $<$ & $<$ & $<$ & $<$ & $<$ & $<$ & $<$ \\
\hline 1,1-Dichloroethene & $<$ & $<$ & 23 & 25 & 8.09 & 3.5 & $<$ & $<$ \\
\hline \multicolumn{9}{|l|}{ Chloroethanes $(\mu \mathrm{g} / \mathrm{L})$} \\
\hline 1,1,1-Trichloroethane & $<$ & $<$ & 20 & 21 & 7.75 & 2.7 & $<$ & $<$ \\
\hline 1,2-Dichloroethane & $<$ & $<$ & $<$ & $<$ & $<$ & $<$ & $<$ & $<$ \\
\hline 1,1-Dichloroethane & $<$ & $<$ & 46 & 49 & 39 & 19 & $<$ & $<$ \\
\hline Chloroethane & $<$ & $<$ & $<$ & $<$ & $<$ & $<$ & $<$ & $<$ \\
\hline \multicolumn{9}{|l|}{ Chloromethanes $(\mu \mathrm{g} / \mathrm{L})$} \\
\hline Carbon tetrachloride & $<$ & $<$ & $<$ & $<$ & $<$ & $<$ & $<$ & $<$ \\
\hline Choroform & $<$ & $<$ & $<$ & $<$ & $<$ & $<$ & $<$ & $<$ \\
\hline Chloromethane & $<$ & $<$ & $<$ & $<$ & $<$ & $<$ & $<$ & $<$ \\
\hline \multicolumn{9}{|l|}{ Miscellaneous ( $\mu \mathrm{g} / \mathrm{L})$} \\
\hline 1,1,2-Trichloro-1,2,2-trifluoroethane & $<$ & $<$ & $<$ & $<$ & & & $2 \mathrm{~J}$ & \\
\hline Trichlorofluoromethane & $<$ & $3 \mathrm{~J}$ & $2 \mathrm{~J}$ & $1 \mathrm{~J}$ & & & $5 \mathrm{~J}$ & $<$ \\
\hline 1,4-Dichlorobenzene & $<$ & $<$ & $<$ & $<$ & & & $<$ & $<$ \\
\hline Benzene & $<$ & $<$ & $<$ & $<$ & $<$ & $<$ & $<$ & $<$ \\
\hline Toluene & $<$ & $<$ & $<$ & $<$ & $<$ & $<$ & $<$ & $<$ \\
\hline Total Xylene & $<$ & $<$ & $<$ & $<$ & $<$ & $<$ & $<$ & $<$ \\
\hline Acetone & & $<$ & & & $<$ & $<$ & & $<$ \\
\hline Carbon disulfide & & $<$ & & & $<$ & $<$ & & $<$ \\
\hline
\end{tabular}


APPENDIX F.2: CY 2009 MONITORING DATA FOR THE CHESTNUT RIDGE HYDROGEOLOGIC REGIME Volatile Organic Compounds

\begin{tabular}{|c|c|c|c|c|c|c|c|c|}
\hline Sampling Point & \multicolumn{2}{|c|}{ GW-217 } & \multicolumn{2}{|c|}{ GW-231 } & \multicolumn{2}{|c|}{ GW-294 } & \multicolumn{2}{|c|}{ GW-294 } \\
\hline Functional Area & \multicolumn{2}{|c|}{ LIV } & \multicolumn{2}{|c|}{ KHQ } & \multicolumn{2}{|c|}{ ECRWP } & \multicolumn{2}{|c|}{ ECRWP } \\
\hline Date Sampled & $01 / 28 / 09$ & 07/13/09 & \multicolumn{2}{|c|}{$01 / 12 / 09$} & \multicolumn{2}{|c|}{$01 / 14 / 09$} & \multicolumn{2}{|c|}{$07 / 08 / 09$} \\
\hline Program & BJC & BJC & BJC & BJC & BJC & BJC & BJC & BJC \\
\hline Sample Type & & & & Dup & & Dup & & Dup \\
\hline Chloroethenes ( $\mu \mathrm{g} / \mathrm{L}$ ) & & & & & & & & \\
\hline Tetrachloroethene & $<$ & $<$ & $<$ & $<$ & $<$ & $<$ & $<$ & $<$ \\
\hline Trichloroethene & $6.8 \mathrm{Q}$ & $<$ & $<$ & $<$ & $<$ & $<$ & $<$ & $<$ \\
\hline cis-1,2-Dichloroethene & $2.6 \mathrm{Q}$ & $<$ & $<$ & $<$ & $<$ & $<$ & $<$ & $<$ \\
\hline trans-1,2-Dichloroethene & $<$ & $<$ & $<$ & $<$ & $<$ & $<$ & $<$ & $<$ \\
\hline 1,1-Dichloroethene & $<$ & $<$ & $<$ & $<$ & $<$ & $<$ & $<$ & $<$ \\
\hline Chloroethanes ( $\mu \mathrm{g} / \mathrm{L})$ & & & & & & & & \\
\hline 1,1,1-Trichloroethane & $<$ & $<$ & $<$ & $<$ & $<$ & $<$ & $<$ & $<$ \\
\hline 1,2-Dichloroethane & $<$ & $<$ & $<$ & $<$ & $<$ & $<$ & $<$ & $<$ \\
\hline 1,1-Dichloroethane & $<$ & $<$ & $<$ & $<$ & $<$ & $<$ & $<$ & $<$ \\
\hline Chloroethane & $<$ & $<$ & $<$ & $<$ & $<$ & $<$ & $<$ & $<$ \\
\hline Chloromethanes ( $\mu \mathrm{g} / \mathrm{L})$ & & & & & & & & \\
\hline Carbon tetrachloride & $<$ & $<$ & $<$ & $<$ & $<$ & $<$ & $<$ & $<$ \\
\hline Choroform & $<$ & $<$ & $<$ & $<$ & $<$ & $<$ & $<$ & $<$ \\
\hline Chloromethane & $<$ & $<$ & $<$ & $<$ & $<$ & $<$ & $0.64 \mathrm{~J}$ & $0.4 \mathrm{~J}$ \\
\hline Miscellaneous ( $\mu \mathrm{g} / \mathrm{L})$ & & & & & & & & \\
\hline 1,1,2-Trichloro-1,2,2-trifluoroethane & & & & & & & & \\
\hline Trichlorofluoromethane & $<$ & $<$ & & & & & & \\
\hline 1,4-Dichlorobenzene & $<$ & $<$ & & & & & & \\
\hline Benzene & $<$ & $<$ & $<$ & $<$ & $<$ & $<$ & $<$ & $<$ \\
\hline Toluene & $<$ & $<$ & $<$ & $<$ & $<$ & $<$ & $<$ & $<$ \\
\hline Total Xylene & $<$ & $<$ & $<$ & $<$ & $<$ & $<$ & $<$ & $<$ \\
\hline Acetone & $<$ & $<$ & $<$ & $<$ & $<$ & $<$ & $<$ & $<$ \\
\hline Carbon disulfide & $<$ & $<$ & $<$ & $<$ & $<$ & $<$ & $<$ & $<$ \\
\hline
\end{tabular}


APPENDIX F.2: CY 2009 MONITORING DATA FOR THE CHESTNUT RIDGE HYDROGEOLOGIC REGIME Volatile Organic Compounds

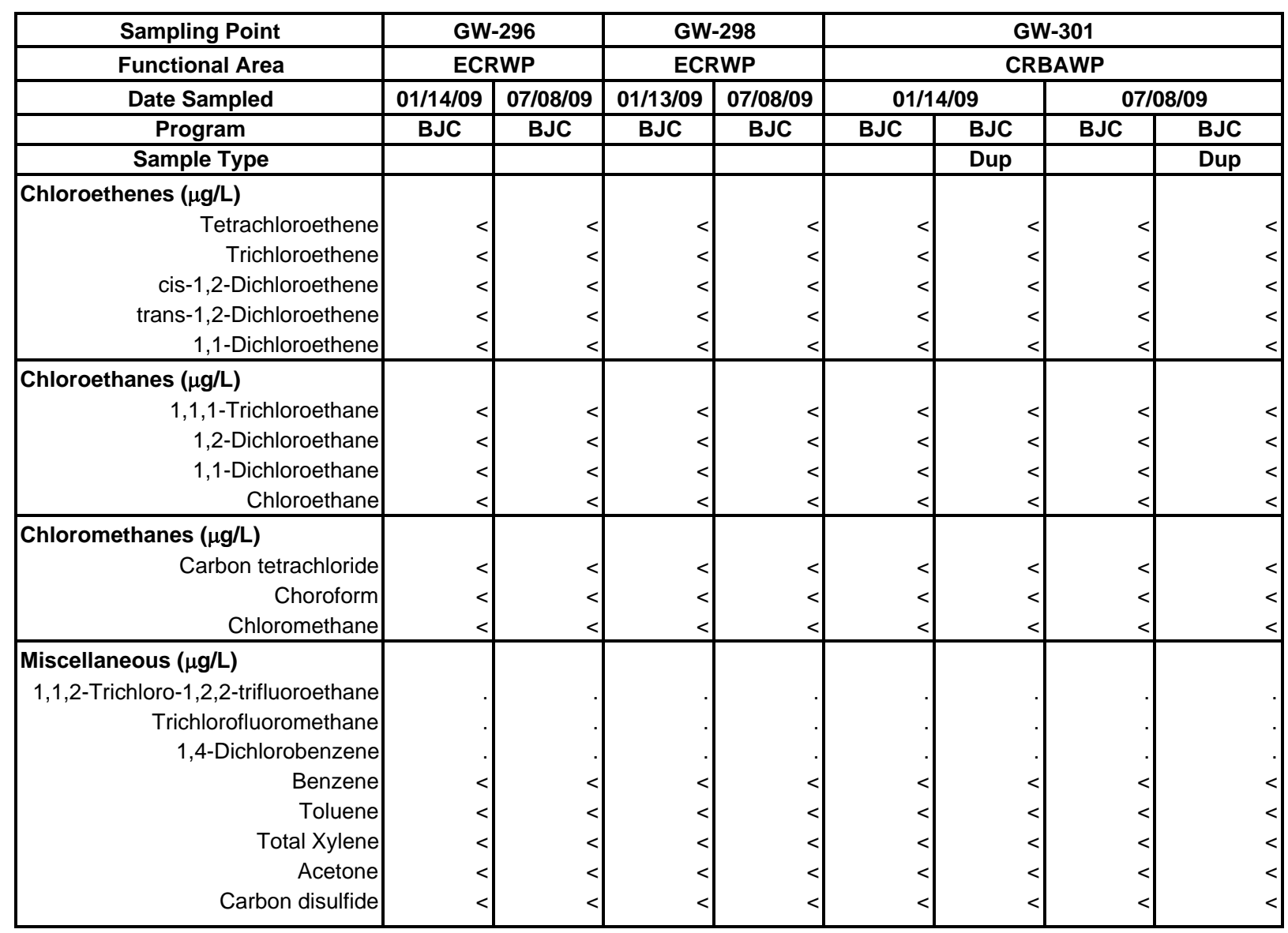


APPENDIX F.2: CY 2009 MONITORING DATA FOR THE CHESTNUT RIDGE HYDROGEOLOGIC REGIME Volatile Organic Compounds

\begin{tabular}{|c|c|c|c|c|c|c|c|c|}
\hline Sampling Point & \multicolumn{4}{|c|}{ GW-305 } & \multicolumn{2}{|c|}{ GW-322 } & \multicolumn{2}{|c|}{ GW-521 } \\
\hline Functional Area & \multicolumn{4}{|c|}{ LIV } & \multicolumn{2}{|c|}{ CRSP } & \multicolumn{2}{|c|}{ LIV } \\
\hline Date Sampled & $01 / 28 / 09$ & 07/09/09 & $08 / 27 / 09$ & $12 / 14 / 09$ & $10 / 13 / 09$ & $12 / 16 / 09$ & $01 / 28 / 09$ & $07 / 09 / 09$ \\
\hline Program & BJC & BJC & BJC & BJC & GWPP & GWPP & BJC & BJC \\
\hline Sample Type & & & & & PDB & & & \\
\hline Chloroethenes ( $\mu \mathrm{g} / \mathrm{L})$ & & & & & & & & \\
\hline Tetrachloroethene & $<$ & $<$ & $<$ & $<$ & $1 \mathrm{~J}$ & $4 \mathrm{~J}$ & $<$ & $<$ \\
\hline Trichloroethene & $<$ & $<$ & $<$ & $<$ & $<$ & $<$ & $<$ & $<$ \\
\hline cis-1,2-Dichloroethene & & $<$ & $<$ & $<$ & $<$ & $<$ & $<$ & $<$ \\
\hline trans-1,2-Dichloroethene & $<$ & $<$ & $<$ & $<$ & $<$ & $<$ & $<$ & $<$ \\
\hline 1,1-Dichloroethene & 9.1 & 8.6 & 8.7 & 7.9 & 53 & 43 & $<$ & $<$ \\
\hline Chloroethanes ( $\mu \mathrm{g} / \mathrm{L})$ & & & & & & & & \\
\hline 1,1,1-Trichloroethane & 18 & 16 & 16 & 14 & 15 & 16 & $<$ & $<$ \\
\hline 1,2-Dichloroethane & $<$ & $<$ & $<$ & $<$ & $<$ & $<$ & $<$ & $<$ \\
\hline 1,1-Dichloroethane & 38 & 39 & 40 & 36 & 75 & 61 & $<$ & $<$ \\
\hline Chloroethane & $<$ & $<$ & $<$ & $<$ & $<$ & $<$ & $<$ & $<$ \\
\hline Chloromethanes $(\mu \mathrm{g} / \mathrm{L})$ & & & & & & & & \\
\hline Carbon tetrachloride & $<$ & $0.059 \mathrm{~J}$ & $<$ & $<$ & $<$ & $<$ & $<$ & $<$ \\
\hline Choroform & $0.13 \mathrm{~J}$ & $0.067 \mathrm{~J}$ & $0.076 \mathrm{~J}$ & $<$ & $<$ & $<$ & $<$ & $<$ \\
\hline Chloromethane & $<$ & $<$ & $<$ & $<$ & $<$ & $<$ & $<$ & $<$ \\
\hline Miscellaneous ( $\mu \mathrm{g} / \mathrm{L})$ & & & & & & & & \\
\hline 1,1,2-Trichloro-1,2,2-trifluoroethane & & & & & $<$ & $3 \mathrm{~J}$ & & \\
\hline Trichlorofluoromethane & $<$ & $<$ & $<$ & $<$ & 32 & 25 & $<$ & $<$ \\
\hline 1,4-Dichlorobenzene & $<$ & $<$ & $<$ & $<$ & $<$ & $<$ & $<$ & $<$ \\
\hline Benzene & $0.027 \mathrm{~J}$ & $0.031 \mathrm{~J}$ & $0.061 \mathrm{~J}$ & $<$ & $<$ & $<$ & $<$ & $<$ \\
\hline Toluene & $<$ & $<$ & $<$ & $<$ & $<$ & $<$ & $<$ & $<$ \\
\hline Total Xylene & $<$ & $<$ & $<$ & $<$ & $<$ & $<$ & $<$ & $<$ \\
\hline Acetone & $<$ & $<$ & $1.5 \mathrm{~J}$ & $<$ & & $<$ & $<$ & $<$ \\
\hline Carbon disulfide & $0.038 \mathrm{~J}$ & $<$ & $<$ & $<$ & & $<$ & $<$ & $<$ \\
\hline
\end{tabular}


APPENDIX F.2: CY 2009 MONITORING DATA FOR THE CHESTNUT RIDGE HYDROGEOLOGIC REGIME Volatile Organic Compounds

\begin{tabular}{|c|c|c|c|c|c|c|c|c|}
\hline Sampling Point & \multicolumn{4}{|c|}{ GW-522 } & \multicolumn{2}{|c|}{ GW-540 } & \multicolumn{2}{|c|}{ GW-557 } \\
\hline Functional Area & \multicolumn{4}{|c|}{ LIV } & \multicolumn{2}{|c|}{ LII } & \multicolumn{2}{|c|}{ LV } \\
\hline Date Sampled & \multicolumn{2}{|c|}{$01 / 28 / 09$} & \multicolumn{2}{|c|}{$07 / 09 / 09$} & $02 / 02 / 09$ & \multirow{2}{*}{\begin{tabular}{c|}
$07 / 13 / 09$ \\
$B J C$
\end{tabular}} & $02 / 02 / 09$ & \multirow{2}{*}{$\begin{array}{c}07 / 14 / 09 \\
\text { BJC }\end{array}$} \\
\hline Program & BJC & BJC & BJC & BJC & BJC & & BJC & \\
\hline Sample Type & & Dup & & Dup & & & & \\
\hline Chloroethenes ( $\mu \mathrm{g} / \mathrm{L}$ ) & & & & & & & & \\
\hline Tetrachloroethene & $<$ & $<$ & $<$ & $<$ & $<$ & $<$ & $<$ & $<$ \\
\hline Trichloroethene & $<$ & $<$ & $<$ & $<$ & $<$ & $<$ & $<$ & $<$ \\
\hline cis-1,2-Dichloroethene & $<$ & $<$ & $<$ & $<$ & $<$ & $<$ & $<$ & $<$ \\
\hline trans-1,2-Dichloroethene & $<$ & $<$ & $<$ & $<$ & $<$ & $<$ & $<$ & $<$ \\
\hline 1,1-Dichloroethene & $<$ & $<$ & $<$ & $<$ & $<$ & $<$ & $<$ & $<$ \\
\hline Chloroethanes ( $\mu \mathrm{g} / \mathrm{L})$ & & & & & & & & \\
\hline 1,1,1-Trichloroethane & $<$ & $<$ & $<$ & $<$ & $<$ & $<$ & $<$ & $<$ \\
\hline 1,2-Dichloroethane & $<$ & $<$ & $<$ & $<$ & $<$ & $<$ & $<$ & $<$ \\
\hline 1,1-Dichloroethane & $<$ & $<$ & $<$ & $<$ & $<$ & $<$ & $<$ & $<$ \\
\hline Chloroethane & $<$ & $<$ & $<$ & $0.25 \mathrm{~J}$ & $<$ & $<$ & $<$ & $<$ \\
\hline Chloromethanes $(\mu \mathrm{g} / \mathrm{L})$ & & & & & & & & \\
\hline Carbon tetrachloride & $<$ & $<$ & $<$ & $<$ & $<$ & $<$ & $<$ & $<$ \\
\hline Choroform & $<$ & $<$ & $<$ & $<$ & $<$ & $<$ & $<$ & $<$ \\
\hline Chloromethane & $<$ & $<$ & $<$ & $<$ & $<$ & $<$ & $0.37 \mathrm{~J}$ & $<$ \\
\hline Miscellaneous ( $\mu \mathrm{g} / \mathrm{L})$ & & & & & & & & \\
\hline 1,1,2-Trichloro-1,2,2-trifluoroethane & & & & & & & & \\
\hline Trichlorofluoromethane & $<$ & $<$ & $<$ & $<$ & $<$ & $<$ & $<$ & $<$ \\
\hline 1,4-Dichlorobenzene & $<$ & $<$ & $<$ & $<$ & $<$ & $<$ & $<$ & $<$ \\
\hline Benzene & $<$ & $<$ & $<$ & $<$ & $<$ & $<$ & $<$ & $<$ \\
\hline Toluene & $<$ & $<$ & $<$ & $<$ & $<$ & $<$ & $<$ & $<$ \\
\hline Total Xylene & $<$ & $<$ & $<$ & $<$ & $<$ & $<$ & $<$ & $<$ \\
\hline Acetone & $<$ & $<$ & $<$ & $<$ & $<$ & $<$ & $<$ & $<$ \\
\hline Carbon disulfide & $<$ & $<$ & $<$ & $<$ & $0.029 \mathrm{~J}$ & $<$ & $<$ & $<$ \\
\hline
\end{tabular}


APPENDIX F.2: CY 2009 MONITORING DATA FOR THE CHESTNUT RIDGE HYDROGEOLOGIC REGIME Volatile Organic Compounds

\begin{tabular}{|c|c|c|c|c|c|c|c|c|}
\hline Sampling Point & \multicolumn{2}{|c|}{ GW-560 } & \multicolumn{2}{|c|}{ GW-562 } & \multicolumn{4}{|c|}{ GW-564 } \\
\hline Functional Area & \multicolumn{2}{|c|}{ CDLVII } & \multicolumn{2}{|c|}{ CDLVII } & \multicolumn{4}{|c|}{ CDLVII } \\
\hline Date Sampled & $02 / 02 / 09$ & 07/15/09 & $02 / 02 / 09$ & $07 / 15 / 09$ & $02 / 0$ & & $07 / 1$ & \\
\hline Program & BJC & BJC & BJC & BJC & BJC & BJC & BJC & BJC \\
\hline Sample Type & & & & & & Dup & & Dup \\
\hline $\begin{array}{r}\text { Chloroethenes }(\mu \mathbf{g} / \mathbf{L}) \\
\text { Tetrachloroethene } \\
\text { Trichloroethene } \\
\text { cis-1,2-Dichloroethene } \\
\text { trans-1,2-Dichloroethene } \\
\text { 1,1-Dichloroethene }\end{array}$ & $\begin{array}{l}< \\
< \\
< \\
< \\
<\end{array}$ & $\begin{array}{l}< \\
< \\
< \\
< \\
<\end{array}$ & $\begin{array}{l}< \\
< \\
< \\
< \\
<\end{array}$ & $\begin{array}{l}< \\
< \\
< \\
< \\
<\end{array}$ & $\begin{array}{l}< \\
< \\
< \\
< \\
<\end{array}$ & $\begin{array}{l}< \\
< \\
< \\
< \\
<\end{array}$ & $\begin{array}{l}< \\
< \\
< \\
< \\
<\end{array}$ & $\begin{array}{l}< \\
< \\
< \\
< \\
<\end{array}$ \\
\hline $\begin{array}{r}\text { Chloroethanes }(\boldsymbol{\mu} \mathbf{g} / \mathbf{L}) \\
\text { 1,1,1-Trichloroethane } \\
1,2-\text { Dichloroethane } \\
\text { 1,1-Dichloroethane } \\
\text { Chloroethane }\end{array}$ & $\begin{array}{l}< \\
< \\
< \\
<\end{array}$ & $\begin{array}{l}< \\
< \\
< \\
<\end{array}$ & $\begin{array}{l}< \\
< \\
< \\
<\end{array}$ & $\begin{array}{l}< \\
< \\
< \\
<\end{array}$ & $\begin{array}{l}< \\
< \\
< \\
<\end{array}$ & $\begin{array}{l}< \\
< \\
< \\
<\end{array}$ & $\begin{array}{l}< \\
< \\
< \\
<\end{array}$ & $\begin{array}{l}< \\
< \\
< \\
<\end{array}$ \\
\hline $\begin{array}{r}\text { Chloromethanes }(\mu \mathbf{g} / \mathbf{L}) \\
\text { Carbon tetrachloride } \\
\text { Choroform } \\
\text { Chloromethane }\end{array}$ & $\begin{array}{r}< \\
< \\
0.25 \mathrm{~J}\end{array}$ & $\begin{array}{l}< \\
< \\
<\end{array}$ & $\begin{array}{l}< \\
< \\
<\end{array}$ & $\begin{array}{l}< \\
< \\
<\end{array}$ & $\begin{array}{l}< \\
< \\
<\end{array}$ & \begin{tabular}{rr|} 
& $<$ \\
& $<$ \\
0.6 & $\mathrm{~J}$ \\
\end{tabular} & $\begin{array}{r}< \\
0.045 \mathrm{~J} \\
<\end{array}$ & $\begin{array}{r}< \\
0.051 \mathrm{~J} \\
<\end{array}$ \\
\hline $\begin{array}{r}\text { Miscellaneous }(\mu \mathbf{g} / \mathbf{L}) \\
\text { 1,1,2-Trichloro-1,2,2-trifluoroethane } \\
\text { Trichlorofluoromethane } \\
\text { 1,4-Dichlorobenzene } \\
\text { Benzene } \\
\text { Toluene } \\
\text { Total Xylene } \\
\text { Acetone } \\
\text { Carbon disulfide }\end{array}$ & $\begin{array}{l}< \\
< \\
< \\
< \\
< \\
< \\
<\end{array}$ & $\begin{array}{l}< \\
< \\
< \\
< \\
< \\
< \\
<\end{array}$ & $\begin{array}{l}< \\
< \\
< \\
< \\
< \\
< \\
<\end{array}$ & $\begin{array}{l}< \\
< \\
< \\
< \\
< \\
< \\
<\end{array}$ & $\begin{array}{l}< \\
< \\
< \\
< \\
< \\
< \\
<\end{array}$ & $\begin{array}{l}< \\
< \\
< \\
< \\
< \\
< \\
<\end{array}$ & $\begin{array}{l}\cdot \\
< \\
< \\
< \\
< \\
< \\
<\end{array}$ & $\begin{array}{l}< \\
< \\
< \\
< \\
< \\
< \\
<\end{array}$ \\
\hline
\end{tabular}


APPENDIX F.2: CY 2009 MONITORING DATA FOR THE CHESTNUT RIDGE HYDROGEOLOGIC REGIME Volatile Organic Compounds

\begin{tabular}{|c|c|c|c|c|c|c|c|}
\hline Sampling Point & \multicolumn{3}{|c|}{ GW-709 } & \multicolumn{2}{|c|}{ GW-757 } & \multicolumn{2}{|c|}{ GW-796 } \\
\hline Functional Area & \multicolumn{3}{|c|}{ LII } & \multicolumn{2}{|c|}{ LII } & \multicolumn{2}{|c|}{ LV } \\
\hline Date Sampled & $02 / 03 / 09$ & 07/13/09 & $10 / 15 / 09$ & $02 / 03 / 09$ & 07/13/09 & 01/29/09 & 07/14/09 \\
\hline Program & BJC & BJC & BJC & BJC & BJC & BJC & BJC \\
\hline \multicolumn{8}{|l|}{ Sample Type } \\
\hline Chloroethenes ( $\mu \mathrm{g} / \mathrm{L})$ & & & & & & & \\
\hline Tetrachloroethene & $<$ & $<$ & $<$ & $<$ & $<$ & $<$ & $<$ \\
\hline Trichloroethene & $<$ & $<$ & $<$ & $<$ & $<$ & $<$ & $<$ \\
\hline cis-1,2-Dichloroethene & $<$ & $<$ & $<$ & $<$ & $<$ & $<$ & $<$ \\
\hline trans-1,2-Dichloroethene & $<$ & $<$ & $<$ & $<$ & $<$ & $<$ & $<$ \\
\hline 1,1-Dichloroethene & $<$ & $<$ & $<$ & $<$ & $<$ & $0.081 \mathrm{~J}$ & $0.2 \mathrm{~J}$ \\
\hline Chloroethanes ( $\mu \mathrm{g} / \mathrm{L})$ & & & & & & & \\
\hline 1,1,1-Trichloroethane & $<$ & $<$ & $<$ & $<$ & $<$ & $0.46 \mathrm{~J}$ & $0.41 \mathrm{~J}$ \\
\hline 1,2-Dichloroethane & $<$ & $<$ & $<$ & $<$ & $<$ & $<$ & $<$ \\
\hline 1,1-Dichloroethane & $<$ & $<$ & $<$ & $<$ & $<$ & $0.39 \mathrm{~J}$ & $0.41 \mathrm{~J}$ \\
\hline Chloroethane & $<$ & $<$ & $<$ & $<$ & $<$ & $<$ & $<$ \\
\hline Chloromethanes $(\mu \mathrm{g} / \mathrm{L})$ & & & & & & & \\
\hline Carbon tetrachloride & $<$ & $<$ & $<$ & $<$ & $<$ & $<$ & $<$ \\
\hline Choroform & $0.076 \mathrm{~J}$ & $0.059 \mathrm{~J}$ & $<$ & $<$ & $<$ & $<$ & $<$ \\
\hline Chloromethane & $<$ & $0.53 \mathrm{~J}$ & $<$ & $<$ & $<$ & $<$ & $<$ \\
\hline Miscellaneous ( $\mu \mathrm{g} / \mathrm{L})$ & & & & & & & \\
\hline 1,1,2-Trichloro-1,2,2-trifluoroethane & & & & & & & \\
\hline Trichlorofluoromethane & $<$ & $<$ & $<$ & $<$ & $<$ & $<$ & $<$ \\
\hline 1,4-Dichlorobenzene & $<$ & $<$ & $<$ & $<$ & $<$ & $<$ & $<$ \\
\hline Benzene & $<$ & $<$ & $<$ & $<$ & $<$ & $<$ & $<$ \\
\hline Toluene & $<$ & $<$ & $<$ & $<$ & $<$ & $<$ & $<$ \\
\hline Total Xylene & $<$ & $<$ & $<$ & $<$ & $<$ & $<$ & $<$ \\
\hline Acetone & $<$ & $<$ & $<$ & $<$ & $<$ & $<$ & $<$ \\
\hline Carbon disulfide & $<$ & $<$ & $<$ & $<$ & $<$ & $<$ & $<$ \\
\hline
\end{tabular}


APPENDIX F.2: CY 2009 MONITORING DATA FOR THE CHESTNUT RIDGE HYDROGEOLOGIC REGIME Volatile Organic Compounds

\begin{tabular}{|c|c|c|c|c|c|c|c|c|}
\hline Sampling Point & \multicolumn{2}{|c|}{ GW-797 } & \multicolumn{2}{|c|}{ GW-798 } & \multicolumn{2}{|c|}{ GW-799 } & \multicolumn{2}{|c|}{ GW-801 } \\
\hline Functional Area & \multicolumn{2}{|c|}{ LV } & \multicolumn{2}{|c|}{ CDLVII } & \multicolumn{2}{|c|}{ LV } & \multicolumn{2}{|c|}{ LV } \\
\hline Date Sampled & $01 / 29 / 09$ & 07/14/09 & $02 / 02 / 09$ & $07 / 14 / 09$ & 01/29/09 & $07 / 14 / 09$ & $01 / 29 / 09$ & 07/13/09 \\
\hline Program & $\mathrm{BJC}$ & BJC & BJC & BJC & BJC & BJC & BJC & BJC \\
\hline \multicolumn{9}{|l|}{ Sample Type } \\
\hline \multicolumn{9}{|l|}{ Chloroethenes ( $\mu \mathrm{g} / \mathrm{L})$} \\
\hline Tetrachloroethene & $<$ & $<$ & 15 & 11 & $<$ & $<$ & $<$ & $<$ \\
\hline Trichloroethene & $<$ & $<$ & $1.2 \mathrm{~J}$ & $1.3 \mathrm{~J}$ & $0.045 \mathrm{~J}$ & $<$ & $<$ & $<$ \\
\hline cis-1,2-Dichloroethene & $<$ & $<$ & 13 & 13 & $<$ & $<$ & $<$ & $<$ \\
\hline trans-1,2-Dichloroethene & $<$ & $<$ & $<$ & $0.16 \mathrm{~J}$ & $<$ & $<$ & $<$ & $<$ \\
\hline 1,1-Dichloroethene & $<$ & $<$ & 8.7 & 6.7 & $<$ & $<$ & $<$ & $<$ \\
\hline \multicolumn{9}{|l|}{ Chloroethanes $(\mu \mathrm{g} / \mathrm{L})$} \\
\hline 1,1,1-Trichloroethane & $<$ & $<$ & $2.9 \mathrm{~J}$ & $2.4 \mathrm{~J}$ & $<$ & $<$ & $<$ & $<$ \\
\hline 1,2-Dichloroethane & $<$ & $<$ & $0.12 \mathrm{~J}$ & $0.12 \mathrm{~J}$ & $<$ & $<$ & $<$ & $<$ \\
\hline 1,1-Dichloroethane & $<$ & $<$ & $4.5 \mathrm{~J}$ & $4.7 \mathrm{~J}$ & $<$ & $<$ & $<$ & $<$ \\
\hline Chloroethane & $<$ & $<$ & $<$ & $<$ & $<$ & $<$ & $<$ & $<$ \\
\hline \multicolumn{9}{|l|}{ Chloromethanes ( $\mu \mathrm{g} / \mathrm{L})$} \\
\hline Carbon tetrachloride & $<$ & $<$ & $<$ & $<$ & $<$ & $<$ & $<$ & $<$ \\
\hline Choroform & $<$ & $<$ & $<$ & $<$ & $<$ & $<$ & $<$ & $<$ \\
\hline Chloromethane & $<$ & $<$ & $<$ & $0.35 \mathrm{~J}$ & $<$ & $<$ & $<$ & $<$ \\
\hline \multicolumn{9}{|l|}{ Miscellaneous ( $\mu \mathrm{g} / \mathrm{L}$ ) } \\
\hline 1,1,2-Trichloro-1,2,2-trifluoroethane & & & & & & & & \\
\hline Trichlorofluoromethane & $<$ & $<$ & 22 & 18 & $<$ & $<$ & $<$ & $<$ \\
\hline 1,4-Dichlorobenzene & $<$ & $<$ & $<$ & $<$ & $<$ & $0.12 \mathrm{~J}$ & $<$ & $<$ \\
\hline Benzene & $<$ & $<$ & $<$ & $<$ & $<$ & $<$ & $<$ & $<$ \\
\hline Toluene & $<$ & $<$ & $<$ & $<$ & $<$ & $0.11 \mathrm{~J}$ & $<$ & $<$ \\
\hline Total Xylene & $<$ & $<$ & $<$ & $<$ & $<$ & $0.056 \mathrm{~J}$ & $<$ & $<$ \\
\hline Acetone & $<$ & $1.8 \mathrm{~J}$ & $<$ & $2 \mathrm{~J}$ & $<$ & $1.6 \mathrm{~J}$ & $<$ & $<$ \\
\hline Carbon disulfide & $<$ & $<$ & $<$ & $<$ & $<$ & $<$ & $<$ & $<$ \\
\hline
\end{tabular}


APPENDIX F.2: CY 2009 MONITORING DATA FOR THE CHESTNUT RIDGE HYDROGEOLOGIC REGIME Volatile Organic Compounds

\begin{tabular}{|c|c|c|c|c|c|c|c|c|}
\hline Sampling Point & \multicolumn{2}{|c|}{ GW-831 } & S17 & \multicolumn{2}{|c|}{ SCR1.25SP } & SCR1.5SW & \multicolumn{2}{|c|}{ SCR2.1SP } \\
\hline Functional Area & \multicolumn{2}{|c|}{ FCAP } & EXP-SW & \multicolumn{2}{|c|}{ EXP-SW } & EXP-SW & \multicolumn{2}{|c|}{ EXP-SW } \\
\hline Date Sampled & 01/14/09 & $07 / 08 / 09$ & $10 / 12 / 09$ & 03/11/09 & $09 / 03 / 09$ & $10 / 12 / 09$ & 05/04/09 & $10 / 12 / 09$ \\
\hline Program & BJC & BJC & GWPP & $\mathrm{BJC}$ & BJC & GWPP & GWPP & GWPP \\
\hline \multicolumn{9}{|l|}{ Sample Type } \\
\hline Chloroethenes ( $\mu \mathrm{g} / \mathrm{L}$ ) & & & & & & & & \\
\hline Tetrachloroethene & $<$ & $<$ & $<$ & $<$ & $<$ & $<$ & $<$ & $<$ \\
\hline Trichloroethene & $<$ & $<$ & $<$ & $<$ & $<$ & $<$ & $<$ & $<$ \\
\hline cis-1,2-Dichloroethene & $<$ & $<$ & $<$ & $<$ & $<$ & $<$ & $<$ & $<$ \\
\hline trans-1,2-Dichloroethene & $<$ & $<$ & $<$ & $<$ & $<$ & $<$ & $<$ & $<$ \\
\hline 1,1-Dichloroethene & $<$ & $<$ & $<$ & $<$ & $<$ & $<$ & $<$ & $<$ \\
\hline Chloroethanes $(\mu \mathrm{g} / \mathrm{L})$ & & & & & & & & \\
\hline 1,1,1-Trichloroethane & $<$ & $<$ & $<$ & $<$ & $<$ & $<$ & $<$ & $<$ \\
\hline 1,2-Dichloroethane & $<$ & $<$ & $<$ & $<$ & $<$ & $<$ & $<$ & $<$ \\
\hline 1,1-Dichloroethane & $<$ & $<$ & $<$ & $<$ & $<$ & $<$ & $<$ & $<$ \\
\hline Chloroethane & $<$ & $<$ & $<$ & $<$ & $<$ & $<$ & $<$ & $<$ \\
\hline Chloromethanes $(\mu \mathrm{g} / \mathrm{L})$ & & & & & & & & \\
\hline Carbon tetrachloride & $<$ & $<$ & $<$ & $<$ & $<$ & $<$ & $<$ & $<$ \\
\hline Choroform & $<$ & $<$ & $<$ & $<$ & $<$ & $<$ & $<$ & $<$ \\
\hline Chloromethane & $<$ & $<$ & $<$ & $<$ & $<$ & $<$ & $<$ & $<$ \\
\hline Miscellaneous ( $\mu \mathrm{g} / \mathrm{L})$ & & & & & & & & \\
\hline 1,1,2-Trichloro-1,2,2-trifluoroethane & & & $<$ & & & $<$ & $<$ & $<$ \\
\hline Trichlorofluoromethane & & & $<$ & 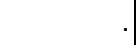 & & $<$ & $<$ & $<$ \\
\hline 1,4-Dichlorobenzene & & & $<$ & & & $<$ & $<$ & $<$ \\
\hline Benzene & $<$ & $<$ & $<$ & $<$ & $<$ & $<$ & $<$ & $<$ \\
\hline Toluene & $<$ & $<$ & $<$ & $<$ & $<$ & $<$ & $<$ & $<$ \\
\hline Total Xylene & $<$ & $<$ & $<$ & $<$ & $<$ & $<$ & $<$ & $<$ \\
\hline Acetone & $<$ & $<$ & $<$ & $<$ & $<$ & $<$ & $<$ & $<$ \\
\hline Carbon disulfide & $<$ & $<$ & $<$ & $<$ & $<$ & $<$ & $<$ & $<$ \\
\hline
\end{tabular}


APPENDIX F.2: CY 2009 MONITORING DATA FOR THE CHESTNUT RIDGE HYDROGEOLOGIC REGIME Volatile Organic Compounds

\begin{tabular}{|c|c|c|c|c|c|c|}
\hline Sampling Point & SCR2.2SP & \multicolumn{2}{|c|}{ SCR3.5SP } & SCR3.5SW & \multicolumn{2}{|c|}{ SCR4.3SP } \\
\hline Functional Area & EXP-SW & \multicolumn{2}{|c|}{ EXP-SW } & EXP-SW & \multicolumn{2}{|c|}{ EXP-SW } \\
\hline Date Sampled & $10 / 12 / 09$ & 03/11/09 & 09/03/09 & $10 / 12 / 09$ & $01 / 29 / 09$ & 07/14/09 \\
\hline Program & GWPP & BJC & BJC & GWPP & BJC & BJC \\
\hline \multicolumn{7}{|l|}{ Sample Type } \\
\hline Chloroethenes ( $\mu \mathrm{g} / \mathrm{L})$ & & & & & & \\
\hline Tetrachloroethene & $<$ & $<$ & $<$ & $<$ & $<$ & $<$ \\
\hline Trichloroethene & $<$ & $<$ & $<$ & $<$ & $<$ & $<$ \\
\hline cis-1,2-Dichloroethene & $<$ & $<$ & $<$ & $<$ & $<$ & $<$ \\
\hline trans-1,2-Dichloroethene & $<$ & $<$ & $<$ & $<$ & $<$ & $<$ \\
\hline 1,1-Dichloroethene & $<$ & $<$ & $<$ & $<$ & $<$ & $<$ \\
\hline Chloroethanes ( $\mu \mathrm{g} / \mathrm{L})$ & & & & & & \\
\hline 1,1,1-Trichloroethane & $<$ & $<$ & $<$ & $<$ & $<$ & $<$ \\
\hline 1,2-Dichloroethane & $<$ & $<$ & $<$ & $<$ & $<$ & $<$ \\
\hline 1,1-Dichloroethane & $<$ & $<$ & $<$ & $<$ & $<$ & $<$ \\
\hline Chloroethane & $<$ & $<$ & $<$ & $<$ & $<$ & $<$ \\
\hline Chloromethanes $(\mu \mathrm{g} / \mathrm{L})$ & & & & & & \\
\hline Carbon tetrachloride & $<$ & $<$ & $<$ & $<$ & $<$ & $<$ \\
\hline Choroform & $<$ & $<$ & $<$ & $<$ & $<$ & $<$ \\
\hline Chloromethane & $<$ & $<$ & $<$ & $<$ & $<$ & $1 \mathrm{~J}$ \\
\hline Miscellaneous ( $\mu \mathrm{g} / \mathrm{L})$ & & & & & & \\
\hline 1,1,2-Trichloro-1,2,2-trifluoroethane & $<$ & & & $<$ & & \\
\hline Trichlorofluoromethane & $<$ & & . & $<$ & $<$ & $<$ \\
\hline 1,4-Dichlorobenzene & $<$ & & & $<$ & $<$ & $<$ \\
\hline Benzene & $<$ & $<$ & $<$ & $<$ & $<$ & $<$ \\
\hline Toluene & $<$ & $<$ & $<$ & $<$ & $<$ & $<$ \\
\hline Total Xylene & $<$ & $<$ & $<$ & $<$ & $<$ & $<$ \\
\hline Acetone & $<$ & $<$ & $<$ & $<$ & $<$ & $<$ \\
\hline Carbon disulfide & $<$ & $<$ & $<$ & $<$ & $<$ & $<$ \\
\hline
\end{tabular}



APPENDIX F.3

RADIOLOGICAL ANALYTES 

APPENDIX F.3: CY 2009 MONITORING DATA FOR THE CHESTNUT RIDGE HYDROGEOLOGIC REGIME

Radiological Analytes: Gross Alpha and Gross Beta Activity

\begin{tabular}{|c|c|c|c|c|c|c|c|c|c|}
\hline \multirow{2}{*}{$\begin{array}{c}\text { Sampling } \\
\text { Point } \\
\end{array}$} & \multirow{2}{*}{$\begin{array}{c}\text { Functional } \\
\text { Area }\end{array}$} & \multirow{2}{*}{$\begin{array}{c}\text { Date } \\
\text { Sampled }\end{array}$} & \multirow{2}{*}{ Program } & \multicolumn{3}{|c|}{ Gross Alpha (pCi/L) } & \multicolumn{3}{|c|}{ Gross Beta (pCi/L) } \\
\hline & & & & Result & TPU & MDA & Result & TPU & MDA \\
\hline 1090 & UNCS & 03/05/09 & BJC & $<$ & . & 2.64 & $<$ & $\cdot$ & 4.16 \\
\hline 1090 & UNCS & 07/27/09 & $\mathrm{BJC}$ & $<$ & . & 2.73 & $<$ & . & 4.6 \\
\hline GW-141 & LIV & 01/29/09 & BJC & $<$ & . & 1.18 & $<$ & . & 3.14 \\
\hline GW-141 & LIV & 07/16/09 & BJC & 1.27 & 0.62 & 0.24 & 3.12 & 1.47 & 2.78 \\
\hline GW-143 & KHQ & 01/08/09 & BJC & $<$ & . & 2.25 & 14.2 & 3.23 & 3.28 \\
\hline GW-144 & $\mathrm{KHQ}$ & 01/06/09 & BJC & 2.44 & 1.51 & 2.29 & $<$ & . & 2.91 \\
\hline GW-145 & $\mathrm{KHQ}$ & 01/08/09 & $\mathrm{BJC}$ & 10.5 & 3.28 & 2.42 & 13 & 3.07 & 3.33 \\
\hline GW-161 & ECRWP & 01/14/09 & BJC & $<$ & . & 1.76 & & & \\
\hline GW-161 & ECRWP & 07/08/09 & BJC & $<$ & . & 1.38 & & & \\
\hline GW-177 & CRSP & 01/14/09 & BJC & $<$ & . & 2.41 & 4.71 & 1.9 & 3.27 \\
\hline GW-177 & CRSP & 07/09/09 & BJC & 2.46 & 1.19 & 1.49 & 4.84 & 1.8 & 3.03 \\
\hline GW-203 & UNCS & 03/05/09 & BJC & 4.34 & 2.71 & 3.73 & $<$ & . & 4.7 \\
\hline GW-203 & UNCS & 07/27/09 & BJC & $<$ & . & 1.68 & $<$ & . & 3.76 \\
\hline GW-205 & UNCS & 03/05/09 & BJC & $<$ & . & 2.7 & 59.1 & 10.3 & 3.62 \\
\hline GW-205 & UNCS & 07/27/09 & BJC & $<$ & . & 2.52 & 64.3 & 11.1 & 3.88 \\
\hline GW-217 & LIV & 01/28/09 & BJC & $<$ & . & 1.51 & $<$ & . & 2.98 \\
\hline GW-217 & LIV & 07/13/09 & BJC & $<$ & . & 1.4 & $<$ & . & 2.91 \\
\hline GW-221 & UNCS & 03/05/09 & BJC & $<$ & . & 2.01 & $<$ & . & 4.02 \\
\hline GW-221 & UNCS & 07/27/09 & BJC & $<$ & . & 3.25 & $<$ & . & 4.04 \\
\hline GW-231 & $\mathrm{KHQ}$ & 01/12/09 & BJC & $<$ & . & 1.95 & $<$ & . & 3.39 \\
\hline GW-231 Dup & $\mathrm{KHQ}$ & 01/12/09 & $\mathrm{BJC}$ & $<$ & . & 2.96 & $<$ & . & 3.39 \\
\hline GW-294 & ECRWP & 01/14/09 & $\mathrm{BJC}$ & $<$ & . & 1.85 & . & . & . \\
\hline GW-294 Dup & ECRWP & 01/14/09 & BJC & $<$ & . & 2.28 & . & . & . \\
\hline GW-294 & ECRWP & 07/08/09 & BJC & $<$ & . & 1.45 & . & . & . \\
\hline GW-294 Dup & ECRWP & 07/08/09 & BJC & $<$ & . & 1.98 & . & . & . \\
\hline GW-296 & ECRWP & 01/14/09 & BJC & $<$ & . & 1.39 & . & . & . \\
\hline GW-296 & ECRWP & 07/08/09 & BJC & $<$ & . & 1.79 & . & . & . \\
\hline GW-298 & ECRWP & 01/13/09 & BJC & $<$ & . & 1.73 & . & . & . \\
\hline GW-298 & ECRWP & 07/08/09 & BJC & $<$ & . & 2.33 & . & . & . \\
\hline GW-305 & LIV & 01/28/09 & BJC & $<$ & . & 1.58 & $<$ & . & 3.1 \\
\hline GW-305 & LIV & 07/09/09 & $\mathrm{BJC}$ & $<$ & . & 2.24 & $<$ & . & 3.15 \\
\hline GW-521 & LIV & 01/28/09 & BJC & $<$ & . & 1.91 & $<$ & . & 2.85 \\
\hline GW-521 & LIV & 07/09/09 & BJC & $<$ & . & 1.51 & $<$ & . & 2.83 \\
\hline GW-522 & LIV & 01/28/09 & $\mathrm{BJC}$ & $<$ & . & 1.46 & $<$ & . & 2.9 \\
\hline GW-522 Dup & LIV & 01/28/09 & BJC & $<$ & . & 1.66 & $<$ & . & 3.2 \\
\hline GW-522 & LIV & 07/09/09 & BJC & $<$ & . & 1.42 & $<$ & . & 3.56 \\
\hline GW-522 Dup & LIV & 07/09/09 & BJC & $<$ & . & 2.06 & $<$ & . & 4.08 \\
\hline GW-540 & LII & 02/02/09 & BJC & $<$ & . & 1.92 & $<$ & . & 3.19 \\
\hline GW-540 & LII & 07/13/09 & BJC & 2.58 & 1.16 & 1.49 & 3.72 & 1.51 & 2.79 \\
\hline GW-557 & LV & 02/02/09 & BJC & $<$ & . & 0.82 & $<$ & . & 2.85 \\
\hline GW-557 & LV & 07/14/09 & BJC & 1.45 & 0.72 & 0.85 & $<$ & . & 2.61 \\
\hline GW-560 & CDLVII & 02/02/09 & BJC & $<$ & . & 1.74 & $<$ & . & 2.93 \\
\hline GW-560 & CDLVII & 07/15/09 & BJC & $<$ & . & 1.36 & $<$ & . & 2.81 \\
\hline GW-562 & CDLVII & 02/02/09 & $\mathrm{BJC}$ & $<$ & . & 1.09 & $<$ & . & 2.86 \\
\hline GW-562 & CDLVII & 07/15/09 & BJC & $<$ & . & 1.2 & $<$ & . & 3.16 \\
\hline GW-564 & CDLVII & 02/02/09 & BJC & $<$ & . & 1.34 & $<$ & . & 3.14 \\
\hline GW-564 Dup & CDLVII & 02/02/09 & BJC & $<$ & . & 1.46 & $<$ & . & 3.02 \\
\hline GW-564 & CDLVII & 07/15/09 & BJC & $<$ & . & 1.05 & $<$ & . & 2.95 \\
\hline GW-564 Dup & CDLVII & 07/15/09 & BJC & $<$ & . & 0.83 & $<$ & . & 3.08 \\
\hline GW-709 & LII & 02/03/09 & $\mathrm{BJC}$ & 1.17 & 0.67 & 0.86 & 3.49 & 1.36 & 2.48 \\
\hline GW-709 & LII & 07/13/09 & BJC & 3.34 & 1.19 & 1.3 & $<$ & . & 3.48 \\
\hline
\end{tabular}


APPENDIX F.3: CY 2009 MONITORING DATA FOR THE CHESTNUT RIDGE HYDROGEOLOGIC REGIME

Radiological Analytes: Gross Alpha and Gross Beta Activity

\begin{tabular}{|c|c|c|c|c|c|c|c|c|c|}
\hline \multirow{2}{*}{$\begin{array}{c}\text { Sampling } \\
\text { Point }\end{array}$} & \multirow{2}{*}{$\begin{array}{c}\text { Functional } \\
\text { Area }\end{array}$} & \multirow{2}{*}{$\begin{array}{c}\text { Date } \\
\text { Sampled }\end{array}$} & \multirow{2}{*}{ Program } & \multicolumn{3}{|c|}{ Gross Alpha (pCi/L) } & \multicolumn{3}{|c|}{ Gross Beta (pCi/L) } \\
\hline & & & & Result & TPU & MDA & Result & TPU & MDA \\
\hline GW-757 & LII & 02/03/09 & $\mathrm{BJC}$ & $<$ & . & 2.86 & 12.3 & 1.99 & 3.03 \\
\hline GW-757 & LII & 07/13/09 & BJC & 4.39 & 1.54 & 1.95 & 16.7 & 2.09 & 2.82 \\
\hline GW-796 & LV & 01/29/09 & BJC & 0.83 & 0.54 & 0.77 & $<$ & . & 3.52 \\
\hline GW-796 & LV & 07/14/09 & BJC & 1.2 & 0.56 & 0.2 & 3.27 & 1.4 & 2.62 \\
\hline GW-797 & LV & 01/29/09 & BJC & $<$ & $\cdot$ & 2.06 & $<$ & . & 3.35 \\
\hline GW-797 & LV & 07/14/09 & BJC & 2.16 & 1.05 & 1.41 & $<$ & . & 2.96 \\
\hline GW-798 & CDLVII & 02/02/09 & $\mathrm{BJC}$ & $<$ & . & 1.04 & $<$ & . & 2.69 \\
\hline GW-798 & CDLVII & 07/14/09 & BJC & $<$ & . & 1.04 & $<$ & . & 2.95 \\
\hline GW-799 & LV & 01/29/09 & BJC & 1.03 & 0.61 & 0.81 & $<$ & . & 2.72 \\
\hline GW-799 & LV & 07/14/09 & BJC & $<$ & . & 1.61 & $<$ & . & 3.59 \\
\hline GW-801 & LV & 01/29/09 & BJC & 0.89 & 0.61 & 0.89 & $<$ & . & 3.5 \\
\hline GW-801 & LV & 07/13/09 & $\mathrm{BJC}$ & 1.51 & 0.66 & 0.23 & $<$ & . & 2.86 \\
\hline MCK 2.0 & EXP-SW & 03/18/09 & $\mathrm{BJC}$ & $<$ & . & 1.46 & 4.36 & 1.75 & 3.06 \\
\hline MCK 2.0 & EXP-SW & 09/03/09 & BJC & $<$ & . & 1.69 & 5.26 & 1.89 & 3.16 \\
\hline MCK 2.05 & EXP-SW & 03/18/09 & $\mathrm{BJC}$ & $<$ & . & 2.38 & 4.59 & 2.14 & 3.94 \\
\hline MCK 2.05 Dup & EXP-SW & 03/18/09 & BJC & $<$ & . & 2.01 & $<$ & . & 4.17 \\
\hline MCK 2.05 & EXP-SW & 09/03/09 & BJC & $<$ & . & 1.67 & 7.74 & 2.2 & 3.19 \\
\hline MCK 2.05 Dup & EXP-SW & 09/03/09 & $\mathrm{BJC}$ & $<$ & . & 1.57 & 6.46 & 1.96 & 2.94 \\
\hline $\mathrm{S} 17$ & EXP-SW & 10/12/09 & GWPP & $<$ & . & 2.5 & $<$ & . & 6.6 \\
\hline SCR1.25SP & EXP-SW & 03/11/09 & BJC & $<$ & . & 2 & $<$ & . & 4.26 \\
\hline SCR1.25SP & EXP-SW & 09/03/09 & $\mathrm{BJC}$ & $<$ & . & 1.64 & $<$ & . & 2.99 \\
\hline SCR1.5SW & EXP-SW & 10/12/09 & GWPP & $<$ & . & 3 & $<$ & . & 7 \\
\hline SCR2.1SP & EXP-SW & 10/12/09 & GWPP & $<$ & . & 3.4 & $<$ & . & 6.7 \\
\hline SCR2.2SP & EXP-SW & 10/12/09 & GWPP & $<$ & . & 4.2 & $<$ & . & 5.9 \\
\hline SCR3.5SP & EXP-SW & 03/11/09 & BJC & $<$ & . & 2.44 & $<$ & . & 4.52 \\
\hline SCR3.5SP & EXP-SW & 09/03/09 & BJC & $<$ & . & 1.79 & 3.18 & 1.61 & 3.04 \\
\hline SCR3.5SW & EXP-SW & 10/12/09 & GWPP & 5 & 2.9 & 3 & $<$ & . & 6.3 \\
\hline SCR4.3SP & EXP-SW & 01/29/09 & BJC & $<$ & . & 2.09 & 4.55 & 1.62 & 2.97 \\
\hline SCR4.3SP & EXP-SW & 07/14/09 & BJC & $<$ & . & 1.2 & $<$ & . & 3.16 \\
\hline UNC SW-1 & EXP-SW & 03/11/09 & $\mathrm{BJC}$ & $<$ & . & 2.64 & $<$ & . & 4.43 \\
\hline UNC SW-1 & EXP-SW & 08/19/09 & BJC & $<$ & . & 1.84 & $<$ & . & 2.74 \\
\hline
\end{tabular}


APPENDIX F.3: CY 2009 MONITORING DATA FOR THE CHESTNUT RIDGE HYDROGEOLOGIC REGIME

Radiological Analytes: Isotopic Analyses

\begin{tabular}{|c|c|c|c|c|c|c|c|c|c|c|c|c|}
\hline Sampling Point & \multicolumn{6}{|c|}{1090} & \multicolumn{6}{|c|}{ GW-203 } \\
\hline Functional Area & \multicolumn{6}{|c|}{ UNCS } & \multicolumn{6}{|c|}{ UNCS } \\
\hline Date Sampled & \multicolumn{3}{|c|}{$03 / 05 / 09$} & \multicolumn{3}{|c|}{$07 / 27 / 09$} & \multicolumn{3}{|c|}{$03 / 05 / 09$} & \multicolumn{3}{|c|}{$07 / 27 / 09$} \\
\hline Program & \multicolumn{3}{|c|}{ BJC } & \multicolumn{3}{|c|}{ BJC } & \multicolumn{3}{|c|}{ BJC } & \multicolumn{3}{|c|}{ BJC } \\
\hline \multicolumn{13}{|l|}{ Sample Type } \\
\hline Result (pCi/L) & Activity & TPU & MDA & Activity & TPU & MDA & Activity & TPU & MDA & Activity & TPU & MDA \\
\hline Gross Alpha & $<$ & & 2.64 & $<$ & & 2.73 & 4.34 & 2.71 & 3.73 & $<$ & & 1.68 \\
\hline Gross Beta & $<$ & & 4.16 & $<$ & & 4.6 & $<$ & & 4.7 & $<$ & & 3.76 \\
\hline Cesium-137 & & & & & & & & & & & & \\
\hline Cobalt-60 & & & & & & & & & & & & \\
\hline Potassium-40 & & & & & & & & & & & & \\
\hline Strontium-89/90 & $<$ & & 1.54 & $<$ & & 1.84 & $<$ & & 1.92 & $<$ & & 1.93 \\
\hline Technetium-99 & & & & & & & & & & & & \\
\hline Uranium-234 & $<$ & & 0.78 & 0.786 & 0.444 & 0.266 & 0.632 & 0.437 & 0.409 & $<$ & & 0.409 \\
\hline Uranium-235 & $<$ & & 0.603 & $<$ & & 0.313 & $<$ & & 0.313 & $<$ & & 0.382 \\
\hline Uranium-238 & $<$ & & 0.517 & 0.388 & 0.308 & 0.266 & 0.377 & 0.335 & 0.367 & $<$ & & 0.352 \\
\hline
\end{tabular}

\begin{tabular}{|c|c|c|c|c|c|c|c|c|c|c|c|c|}
\hline Sampling Point & \multicolumn{6}{|c|}{ GW-205 } & \multicolumn{6}{|c|}{ GW-221 } \\
\hline Functional Area & \multicolumn{6}{|c|}{ UNCS } & \multicolumn{6}{|c|}{ UNCS } \\
\hline Date Sampled & \multicolumn{3}{|c|}{$03 / 05 / 09$} & \multicolumn{3}{|c|}{$07 / 27 / 09$} & \multicolumn{3}{|c|}{ 03/05/09 } & \multicolumn{3}{|c|}{$07 / 27 / 09$} \\
\hline Program & \multicolumn{3}{|c|}{ BJC } & \multicolumn{3}{|c|}{ BJC } & \multicolumn{3}{|c|}{ BJC } & \multicolumn{3}{|c|}{ BJC } \\
\hline \multicolumn{13}{|l|}{ Sample Type } \\
\hline Result (pCi/L) & Activity & TPU & MDA & Activity & TPU & MDA & Activity & TPU & MDA & Activity & TPU & MDA \\
\hline Gross Alpha & $<$ & & 2.7 & $<$ & & 2.52 & $<$ & & 2.01 & $<$ & & 3.25 \\
\hline Gross Beta & 59.1 & 10.3 & 3.62 & 64.3 & 11.1 & 3.88 & $<$ & & 4.02 & $<$ & & 4.04 \\
\hline Cesium-137 & $<$ & & 7.21 & $<$ & & 7.97 & & & & & & \\
\hline Cobalt-60 & $<$ & & 8.99 & $<$ & & 10.6 & . & & & . & & \\
\hline Potassium-40 & $<$ & & 134 & $<$ & & 156 & & & & & & \\
\hline Strontium-89/90 & $<$ & & 1.61 & $<$ & & 2.3 & $<$ & & 1.61 & $<$ & & 2.16 \\
\hline Technetium-99 & $<$ & & 11.5 & $<$ & & 10.5 & & & & & & \\
\hline Uranium-234 & 0.517 & 0.396 & 0.455 & $<$ & & 0.536 & $<$ & & 0.347 & $<$ & & 0.352 \\
\hline Uranium-235 & $<$ & & 0.506 & $<$ & & 0.442 & $<$ & & 0.419 & $<$ & & 0.316 \\
\hline Uranium-238 & $<$ & & 0.551 & $<$ & & 0.381 & $<$ & & 0.386 & $<$ & & 0.317 \\
\hline
\end{tabular}

\begin{tabular}{|c|c|c|c|c|c|c|}
\hline Sampling Point & \multicolumn{6}{|c|}{ UNC SW-1 } \\
\hline Functional Area & \multicolumn{6}{|c|}{ UNCS } \\
\hline Date Sampled & \multicolumn{3}{|c|}{$03 / 11 / 09$} & \multicolumn{3}{|c|}{$08 / 19 / 09$} \\
\hline Program & \multicolumn{3}{|c|}{ BJC } & \multicolumn{3}{|c|}{ BJC } \\
\hline \multicolumn{7}{|l|}{ Sample Type } \\
\hline Result (pCi/L) & Activity & TPU & MDA & Activity & TPU & MDA \\
\hline Gross Alpha & $<$ & & 2.64 & $<$ & & 1.84 \\
\hline Gross Beta & $<$ & & 4.43 & $<$ & & 2.74 \\
\hline Cesium-137 & $<$ & & 9.99 & $<$ & & 9.25 \\
\hline Cobalt- 60 & $<$ & & 10.4 & $<$ & & 11.6 \\
\hline Potassium-40 & $<$ & & 158 & $<$ & & 162 \\
\hline Strontium-89/90 & & & & & & \\
\hline Technetium-99 & & & & & & \\
\hline Uranium-234 & & & & & & \\
\hline Uranium-235 & & & & & & \\
\hline Uranium-238 & & & & & & \\
\hline
\end{tabular}



APPENDIX G

\section{CY 2009 QUALITY ASSURANCE/QUALITY CONTROL DATA}





\section{EXPLANATION}

\section{Sampling Point:}

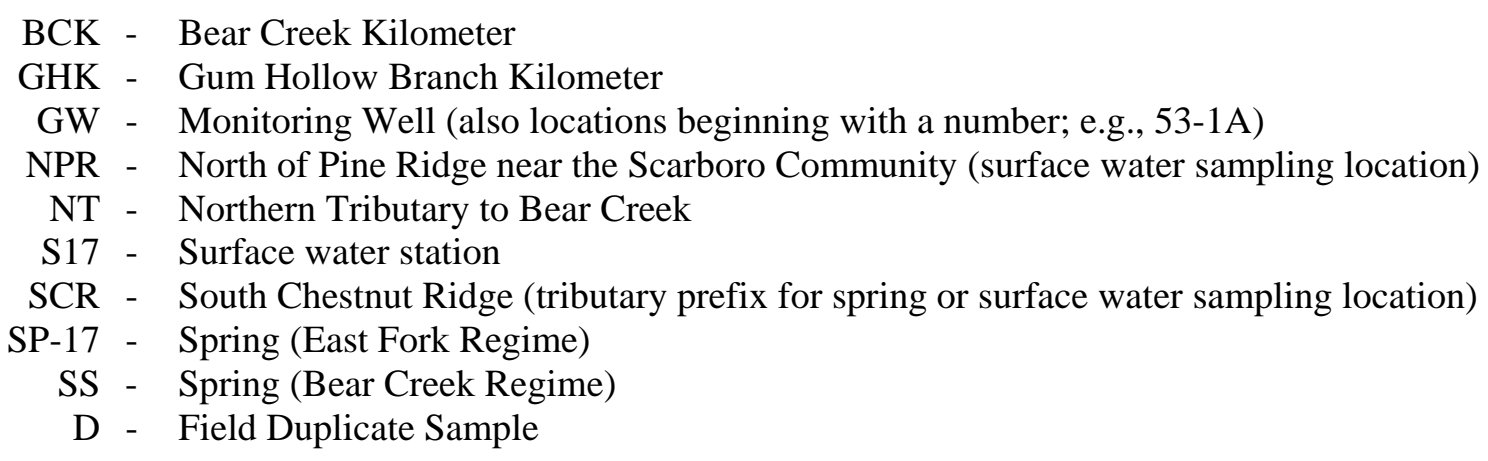

\section{Hydrogeologic Regime:}
BC - Bear Creek Hydrogeologic Regime
CR - Chestnut Ridge Hydrogeologic Regime
EF - Upper East Fork Poplar Creek Hydrogeologic Regime

\section{Notes:}

Appendix G shows the method (laboratory) blank and trip blank samples associated with each groundwater and surface water sample collected under management of the GWPP during CY 2009. Each method and trip blank was analyzed for volatile organic compounds (VOCs). None of the method blank samples contained VOCs. However, chloroform was detected $(2 \mu \mathrm{g} / \mathrm{L})$ in one trip blank sample (sample number A090900098) that was associated with well GW-508. Chloroform was not detected in the groundwater sample.

Two field blank samples were collected and analyzed for VOCs during CY 2009. These samples were collected at well GW-623 (03/03/09) in the Bear Creek Regime and well 56-3C (07/30/09) in the East Fork Regime. The field blank samples were analyzed for VOCs and acetone was detected $(9 \mu \mathrm{g} / \mathrm{L})$ in the sample collected at well 56-3C.

Two equipment rinsate samples were collected and analyzed for VOCs at Westbay wells during CY 2009: one in the Bear Creek Regime at well GW-726 (second quarter), and the other in the East Fork Regime at well GW-722 (third quarter). None of the VOCs were detected in the rinsate sample from well GW-726, and only the VOCs shown below were detected in rinsate sample from well GW-722.

\begin{tabular}{|c|c|c|c|c|c|}
\hline Well-Port & $\begin{array}{c}\text { Sample } \\
\text { Number }\end{array}$ & $\begin{array}{c}\text { Date } \\
\text { Sampled }\end{array}$ & Analyte & Result & Units \\
\hline GW-722-17 & A091820230 & $09 / 02 / 09$ & $\begin{array}{c}\text { 2-Butanone } \\
\text { Acetone } \\
\text { Tetrachloroethene }\end{array}$ & $\begin{array}{c}4 \mathrm{~J} \\
30 \\
2 \mathrm{~J}\end{array}$ & $\begin{array}{c}\mu \mathrm{g} / \mathrm{L} \\
\mu \mathrm{g} / \mathrm{L} \\
\mu \mathrm{g} / \mathrm{L}\end{array}$ \\
\hline
\end{tabular}

Of the VOCs detected, only tetrachloroethene was detected $(1 \mu \mathrm{g} / \mathrm{L})$ in the groundwater sample from the zone, and it was less than the value reported for the rinsate sample. 

APPENDIX G: CY 2009 QUALITY ASSURANCE/QUALITY CONTROL DATA

Correlation with Associated Groundwater and Surface Water Samples

\begin{tabular}{|c|c|c|c|c|c|}
\hline $\begin{array}{l}\text { Sampling } \\
\text { Point }\end{array}$ & $\begin{array}{c}\text { Hydrogeologic } \\
\text { Regime }\end{array}$ & $\begin{array}{c}\text { Date } \\
\text { Sampled }\end{array}$ & $\begin{array}{l}\text { Sample } \\
\text { Number }\end{array}$ & $\begin{array}{c}\text { Trip Blank } \\
\text { Sample Number }\end{array}$ & $\begin{array}{l}\text { Method Blank } \\
\text { Sample Number }\end{array}$ \\
\hline $55-2 A$ & $\mathrm{EF}$ & 10/27/09 & A092670158 & A092710314 & Q093280106 \\
\hline $55-2 B$ & $\mathrm{EF}$ & 10/26/09 & A092670157 & A092710315 & Q093280106 \\
\hline $55-2 C$ & $\mathrm{EF}$ & 10/26/09 & A092670156 & A092710315 & Q093280106 \\
\hline $55-3 A$ & $\mathrm{EF}$ & 05/14/09 & A090850256 & A090900085 & Q091610083 \\
\hline $55-3 A$ & $\mathrm{EF}$ & 10/20/09 & A092670155 & A092710317 & Q093200289 \\
\hline $55-3 B$ & $\mathrm{EF}$ & 05/14/09 & A090850255 & A090900085 & Q091610083 \\
\hline $55-3 B$ & $\mathrm{EF}$ & 10/21/09 & A092670154 & A092710316 & Q093230109 \\
\hline $55-3 C$ & EF & 05/13/09 & A090850254 & A090900086 & Q091610003 \\
\hline $55-3 C$ & $\mathrm{EF}$ & 10/21/09 & A092670153 & A092710316 & Q093230109 \\
\hline $56-1 A$ & $\mathrm{EF}$ & 07/28/09 & A091820243 & A091820195 & Q092320136 \\
\hline $56-1 C$ & EF & 07/28/09 & A091820242 & A091820195 & Q092320136 \\
\hline $56-1 C D$ & $\mathrm{EF}$ & 07/28/09 & A091820241 & A091820195 & Q092320136 \\
\hline $56-2 A$ & $\mathrm{EF}$ & 07/29/09 & A091820240 & A091820194 & Q092320144 \\
\hline $56-2 B$ & EF & 07/29/09 & A091820239 & A091820194 & Q092320144 \\
\hline $56-2 C$ & $\mathrm{EF}$ & 07/28/09 & A091820238 & A091820195 & Q092320136 \\
\hline $56-3 A$ & $\mathrm{EF}$ & 07/30/09 & A091820237 & A091820193 & Q092320140 \\
\hline $56-3 B$ & EF & 07/29/09 & A091820236 & A091820194 & Q092320136 \\
\hline $56-3 C$ & $\mathrm{EF}$ & 07/30/09 & A091820235 & A091820193 & Q092320140 \\
\hline $56-4 A$ & $\mathrm{EF}$ & 05/12/09 & A090850253 & & Q091610000 \\
\hline GW-014 & $\mathrm{BC}$ & 03/04/09 & A090060070 & A090060121 & Q090910118 \\
\hline GW-053 & $\mathrm{BC}$ & 03/03/09 & A090060079 & A090060122 & Q090920030 \\
\hline GW-053 D & $B C$ & 03/03/09 & A090060077 & A090060122 & Q090920030 \\
\hline GW-058 & $\mathrm{BC}$ & 02/10/09 & A090060078 & A090060117 & Q090710000 \\
\hline GW-065 & $\mathrm{BC}$ & 02/25/09 & A090060076 & A090060111 & Q090820069 \\
\hline GW-065 & $B C$ & 08/06/09 & A091820209 & A091820190 & Q092320152 \\
\hline GW-068 & $B C$ & 03/03/09 & A090060075 & A090060122 & Q090920030 \\
\hline GW-071 & $\mathrm{BC}$ & $03 / 04 / 09$ & A090060074 & A090060121 & Q090910118 \\
\hline GW-071 & $B C$ & 08/10/09 & A091820208 & A091820189 & Q092320155 \\
\hline GW-082 & $\mathrm{BC}$ & 08/10/09 & A091820207 & A091820189 & Q092320155 \\
\hline GW-098 & $\mathrm{BC}$ & $02 / 25 / 09$ & A090060071 & A090060110 & Q090840133 \\
\hline GW-100 & $B C$ & 02/19/09 & A090060089 & A090060114 & Q090820069 \\
\hline GW-101 & $\mathrm{BC}$ & 02/19/09 & A090060088 & A090060114 & Q090820069 \\
\hline GW-122 & $\mathrm{BC}$ & 02/17/09 & A090060087 & A090060116 & Q090710004 \\
\hline GW-127 & $B C$ & 02/17/09 & A090060086 & A090060116 & Q090710004 \\
\hline GW-153 & $\mathrm{EF}$ & 10/14/09 & A092670171 & A092710319 & Q093130088 \\
\hline GW-153 D & $\mathrm{EF}$ & $10 / 14 / 09$ & A092670170 & A092710319 & Q093130088 \\
\hline GW-175 & $\mathrm{CR}$ & $12 / 15 / 09$ & A093200191 & A093290070 & Q100070025 \\
\hline GW-220 & EF & 04/29/09 & A090850250 & A090900093 & Q091470000 \\
\hline GW-220 & $\mathrm{EF}$ & $10 / 14 / 09$ & A092670152 & A092710319 & Q093130088 \\
\hline GW-222 & EF & 04/30/09 & A090850249 & A090900092 & Q091470003 \\
\hline GW-222 D & $\mathrm{EF}$ & 04/30/09 & A090850248 & A090900092 & Q091470007 \\
\hline GW-225 & $\mathrm{BC}$ & $02 / 26 / 09$ & A090060085 & A090060125 & Q090840133 \\
\hline GW-229 & $B C$ & 02/26/09 & A090060084 & A090060125 & Q090840133 \\
\hline GW-236 & $B C$ & 02/23/09 & A090060083 & A090060113 & Q090820069 \\
\hline GW-240 & EF & 10/14/09 & A092670151 & A092710319 & Q093130088 \\
\hline GW-242 & $B C$ & 03/05/09 & A090060082 & A090060120 & Q090920034 \\
\hline GW-246 & $\mathrm{BC}$ & 08/05/09 & A091820206 & A091820191 & Q092320148 \\
\hline GW-251 & $\mathrm{EF}$ & 04/30/09 & A090850247 & A090900092 & Q091470007 \\
\hline
\end{tabular}


APPENDIX G: CY 2009 QUALITY ASSURANCE/QUALITY CONTROL DATA

Correlation with Associated Groundwater and Surface Water Samples

\begin{tabular}{|c|c|c|c|c|c|}
\hline $\begin{array}{l}\text { Sampling } \\
\text { Point }\end{array}$ & $\begin{array}{l}\text { Hydrogeologic } \\
\text { Regime }\end{array}$ & $\begin{array}{c}\text { Date } \\
\text { Sampled }\end{array}$ & $\begin{array}{l}\text { Sample } \\
\text { Number }\end{array}$ & $\begin{array}{c}\text { Trip Blank } \\
\text { Sample Number }\end{array}$ & $\begin{array}{l}\text { Method Blank } \\
\text { Sample Number }\end{array}$ \\
\hline GW-269 & $\overline{E F}$ & $04 / 21 / 09$ & A090850246 & A090900097 & Q091400123 \\
\hline GW-270 & EF & 04/28/09 & A090850245 & A090900095 & Q091420052 \\
\hline GW-272 & EF & 04/21/09 & A090850244 & A090900097 & Q091400117 \\
\hline GW-274 & EF & 04/21/09 & A090850243 & A090900097 & Q091400123 \\
\hline GW-274 D & EF & 04/21/09 & A090850241 & A090900097 & Q091400123 \\
\hline GW-275 & EF & 04/27/09 & A090850240 & A090900096 & Q091420052 \\
\hline GW-289 & $\mathrm{BC}$ & 08/06/09 & A091820205 & A091820190 & Q092320152 \\
\hline GW-289 D & $\mathrm{BC}$ & 08/06/09 & A091820204 & A091820190 & Q092320152 \\
\hline GW-307 & $\mathrm{BC}$ & 02/10/09 & A090060081 & A090060117 & Q090710000 \\
\hline GW-307 D & $\mathrm{BC}$ & 02/10/09 & A090060098 & A090060117 & Q090710000 \\
\hline GW-315 & $\mathrm{BC}$ & 02/17/09 & A090060080 & A090060116 & Q090710004 \\
\hline GW-322 & $\mathrm{CR}$ & 12/16/09 & A093200190 & A093290069 & Q100070025 \\
\hline GW-332 & EF & $04 / 28 / 09$ & A090850239 & A090900095 & Q091420052 \\
\hline GW-337 & EF & 04/28/09 & A090850238 & A090900095 & Q091420052 \\
\hline GW-365 & BC & 03/02/09 & A090060099 & A090060123 & Q090920030 \\
\hline GW-381 & EF & 10/19/09 & A092670150 & A092710318 & Q093200289 \\
\hline GW-383 & EF & $10 / 14 / 09$ & A092670149 & A092710319 & Q093130088 \\
\hline GW-508 & EF & $04 / 20 / 09$ & A090850235 & A090900098 & Q091400117 \\
\hline GW-601 & $\mathrm{BC}$ & $03 / 02 / 09$ & A090060096 & A090060123 & Q090920030 \\
\hline GW-615 & $\mathrm{BC}$ & 02/18/09 & A090060095 & A090060115 & Q090710004 \\
\hline GW-623 & $\mathrm{BC}$ & 03/03/09 & A090060094 & A090060122 & Q090920030 \\
\hline GW-627 & $\mathrm{BC}$ & 03/05/09 & A090060092 & A090060120 & Q090920034 \\
\hline GW-627 & $\mathrm{BC}$ & 08/06/09 & A091820201 & A091820190 & Q092320152 \\
\hline GW-629 & $\mathrm{BC}$ & 03/05/09 & A090060091 & A090060120 & Q090920034 \\
\hline GW-629 & $\mathrm{BC}$ & 09/09/09 & A092510134 & A091820182 & Q092780599 \\
\hline GW-629 & $\mathrm{BC}$ & 08/06/09 & A091820200 & A091820190 & Q092320155 \\
\hline GW-633 & EF & 04/28/09 & A090850234 & A090900094 & Q091470000 \\
\hline GW-648 & $\mathrm{BC}$ & 02/09/09 & A090060090 & A090060118 & Q090710000 \\
\hline GW-648 & $\mathrm{BC}$ & 08/05/09 & A091820199 & A091820191 & Q092320148 \\
\hline GW-648 D & $\mathrm{BC}$ & $02 / 09 / 09$ & A090060109 & A090060118 & Q090710000 \\
\hline GW-653 & BC & 03/05/09 & A090060108 & A090060120 & Q090910118 \\
\hline GW-656 & EF & 05/12/09 & A090850233 & A090900099 & Q091610003 \\
\hline GW-686 & EF & 05/13/09 & A090850232 & A090900086 & Q091610003 \\
\hline GW-690 & $\mathrm{EF}$ & 05/13/09 & A090850231 & A090900086 & Q091610003 \\
\hline GW-691 & EF & 05/12/09 & A090850230 & A090900099 & Q091610000 \\
\hline GW-691 & EF & 10/20/09 & A092670169 & A092710317 & Q093200289 \\
\hline GW-691 D & EF & $10 / 20 / 09$ & A092670168 & A092710317 & Q093200289 \\
\hline GW-692 & EF & 05/12/09 & A090850229 & A090900099 & Q091610000 \\
\hline GW-698 & EF & 04/29/09 & A090850228 & A090900093 & Q091470007 \\
\hline GW-698 & EF & 10/21/09 & A092670148 & A092710316 & Q093230109 \\
\hline GW-698 D & EF & 04/29/09 & A090850227 & A090900093 & Q091470007 \\
\hline GW-700 & $\mathrm{EF}$ & $07 / 28 / 09$ & A091820233 & A091820195 & Q092320136 \\
\hline GW-703 & BC & 02/26/09 & A090060107 & A090060124 & Q090840133 \\
\hline GW-722-14 & EF & 09/02/09 & A091820232 & A091820184 & Q092740178 \\
\hline GW-722-17 & EF & 09/02/09 & A091820231 & A091820184 & Q092740178 \\
\hline GW-722-20 & EF & 09/02/09 & A091820229 & A091820184 & Q092740178 \\
\hline GW-722-22 & EF & 09/02/09 & A091820228 & A091820184 & Q092740178 \\
\hline GW-722-33 & EF & 09/03/09 & A091820227 & A091820183 & O092740178 \\
\hline
\end{tabular}


APPENDIX G: CY 2009 QUALITY ASSURANCE/QUALITY CONTROL DATA

Correlation with Associated Groundwater and Surface Water Samples

\begin{tabular}{|c|c|c|c|c|c|}
\hline $\begin{array}{l}\text { Sampling } \\
\text { Point }\end{array}$ & $\begin{array}{l}\text { Hydrogeologic } \\
\text { Regime }\end{array}$ & $\begin{array}{c}\text { Date } \\
\text { Sampled }\end{array}$ & $\begin{array}{l}\text { Sample } \\
\text { Number }\end{array}$ & $\begin{array}{c}\text { Trip Blank } \\
\text { Sample Number }\end{array}$ & $\begin{array}{l}\text { Method Blank } \\
\text { Sample Number }\end{array}$ \\
\hline GW-724 & $B C$ & $02 / 25 / 09$ & A090060106 & A090060111 & Q090820069 \\
\hline GW-725 & $\mathrm{BC}$ & 02/25/09 & A090060105 & A090060110 & Q090840133 \\
\hline GW-726-04 & $\mathrm{BC}$ & 05/04/09 & A090850218 & A090900091 & Q091470003 \\
\hline GW-726-06 & $\mathrm{BC}$ & 05/04/09 & A090850217 & A090900090 & Q091470003 \\
\hline GW-726-09 & $\mathrm{BC}$ & 05/05/09 & A090850216 & A090900090 & Q091470003 \\
\hline GW-726-12 & $\mathrm{BC}$ & 05/05/09 & A090850215 & A090900090 & Q091470003 \\
\hline GW-726-16 & $\mathrm{BC}$ & 05/06/09 & A090850214 & A090900089 & Q091540178 \\
\hline GW-726-20 & $\mathrm{BC}$ & 05/06/09 & A090850213 & A090900089 & Q091540178 \\
\hline GW-726-23 & $\mathrm{BC}$ & 05/06/09 & A090850212 & A090900089 & Q091540178 \\
\hline GW-735 & EF & 08/26/09 & A091820226 & A091820188 & Q092670002 \\
\hline GW-738 & $\mathrm{BC}$ & 02/25/09 & A090060104 & A090060111 & Q090820069 \\
\hline GW-740 & $\mathrm{BC}$ & 02/24/09 & A090060103 & A090060112 & Q090820069 \\
\hline GW-744 & EF & 08/26/09 & A091820225 & A091820188 & Q092670002 \\
\hline GW-747 & EF & 08/31/09 & A091820224 & A091820186 & Q092720590 \\
\hline GW-750 & EF & 04/29/09 & A090850226 & A090900093 & Q091470000 \\
\hline GW-763 & EF & $10 / 14 / 09$ & A092670147 & A092710319 & Q093130088 \\
\hline GW-765 & EF & 05/07/09 & A090850225 & A090900087 & Q091540178 \\
\hline GW-769 & EF & 04/29/09 & A090850224 & A090900093 & Q091470007 \\
\hline GW-775 & EF & 08/27/09 & A091820223 & A091820187 & Q092670002 \\
\hline GW-776 & EF & 09/01/09 & A091820222 & A091820186 & Q092720590 \\
\hline GW-779 & EF & 08/31/09 & A091820221 & A091820186 & Q092720590 \\
\hline GW-781 & EF & 08/27/09 & A091820220 & A091820187 & Q092670002 \\
\hline GW-782 & EF & 08/27/09 & A091820219 & A091820187 & Q092670002 \\
\hline GW-783 & EF & 08/27/09 & A091820218 & A091820187 & Q092670002 \\
\hline GW-791 & EF & 08/27/09 & A091820217 & A091820187 & Q092670002 \\
\hline GW-816 & EF & 08/26/09 & A091820216 & A091820188 & Q092670002 \\
\hline GW-820 & EF & 04/29/09 & A090850223 & A090900093 & Q091470000 \\
\hline GW-959 & EF & 05/06/09 & A090850222 & A090900088 & Q091540178 \\
\hline GW-960 & EF & 05/07/09 & A090850220 & A090900087 & Q091540178 \\
\hline \multicolumn{6}{|c|}{ Surface water and Springs } \\
\hline BCK-04.55 & $\mathrm{BC}$ & 08/03/09 & A091820213 & A091820192 & Q092320148 \\
\hline BCK-09.40 & $\mathrm{BC}$ & 08/03/09 & A091820212 & A091820192 & Q092320148 \\
\hline BCK-09.40 D & $\mathrm{BC}$ & 08/03/09 & A091820211 & A091820192 & Q092320148 \\
\hline BCK-11.97 & $\mathrm{BC}$ & 08/03/09 & A091820210 & A091820192 & Q092320148 \\
\hline GHK2.51WSW & EF & 01/29/09 & A090060102 & A090060119 & Q090400144 \\
\hline NPR12.0SW & EF & 01/29/09 & A090060101 & A090060119 & Q090400144 \\
\hline NPR23.0SW & EF & 01/29/09 & A090060100 & A090060119 & Q090400144 \\
\hline NT-01 & $\mathrm{BC}$ & 08/03/09 & A091820198 & A091820192 & Q092320144 \\
\hline S17 & $\mathrm{CR}$ & 10/12/09 & A092670163 & A092710321 & Q093130084 \\
\hline SCR1.5SW & $\mathrm{CR}$ & 10/12/09 & A092670162 & A092710321 & Q093130084 \\
\hline SCR2.1SP & $\mathrm{CR}$ & 05/04/09 & A091200196 & A090900091 & Q091470003 \\
\hline SCR2.1SP & $\mathrm{CR}$ & 10/12/09 & A092670161 & A092710321 & Q093130084 \\
\hline SCR2.2SP & $\mathrm{CR}$ & 10/12/09 & A092670160 & A092710321 & Q093130084 \\
\hline SCR3.5SW & $\mathrm{CR}$ & 10/12/09 & A092670159 & A092710321 & Q093130084 \\
\hline SP-17 & EF & 08/03/09 & A091820215 & A091820192 & Q092320140 \\
\hline SP-17 D & EF & 08/03/09 & A091820214 & A091820192 & Q092320140 \\
\hline SS-4 & $\mathrm{BC}$ & 08/03/09 & A091820197 & A091820192 & Q092320144 \\
\hline SS-5 & $\mathrm{BC}$ & 08/03/09 & A091820196 & A091820192 & Q092320144 \\
\hline
\end{tabular}





\section{DISTRIBUTION}

\section{U.S. DEPARTMENT OF ENERGY}

J. D. Darby, DOE-EM

J. P. Donnelly, DOE-NNSA *

TENNESSEE DEPARTMENT OF

ENVIRONMENT AND CONSERVATION

DOE-ORR OVERSIGHT DIVISION

J. E. Sebastian *

J. A. Owsley

B\&W Y-12, L.L.C.

ENVIRONMENTAL COMPLIANCE DEPT.

S. M. Field

C. C. Hill

S. L. Jollay *

S. B. Jones *

E. R. Schultz

S. E. McNamara

L. O. Vaughan

B\&W Y-12, L.L.C. ANALYTICAL CHEMISTRY ORGANIZATION

M. C. Tucker-Watson $\underline{\text { BECHTEL JACOBS COMPANY LLC }}$

E. L. Berglund

M. E. Cleveland

H. K. Haase

R. H. Ketelle

J. W. Kubarewicz

L. M. Sims *

M. L. Willoughby

File - EMEF-DMC *

File - Y-12 Project PDCC *

SCIENCE APPLICATIONS

INTERNATIONAL CORPORATION

W. K. Jago

UT-BATTELLE, LLC

D. B. Watson

ELVADO ENVIRONMENTAL LLC

T. R. Harrison *

J. R. Walker*

B\&W Y-12, L.L.C.

ENGINEERING ORGANIZATION

S. B. Ahmed

S. A. Shults

Y-12 Central Files *

9114DMC-01971865.6551-RC

Y-12 Records Services (Electronic copy- OSTI)

YDCC - RC *

Note: * = receives hard copy version 
